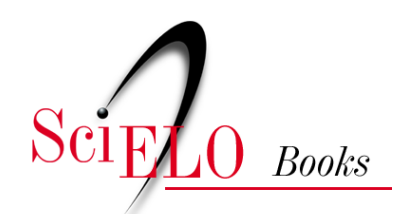

\title{
Movimentos e lutas sociais pela terra no sul do Brasil questões contemporâneas
}

\author{
João Carlos Tedesco \\ Jonas José Seminotti \\ Humberto José da Rocha \\ (orgs.)
}

TEDESCO, J.C., SEMINOTTI, J.J., and ROCHA, H.J., ed. Movimentos e lutas sociais pela terra no sul do Brasil: questões contemporâneas [online]. Chapecó: Editora UFFS, 2018, 422 p. ISBN: 978-85-6490576-4. https://doi.org/10.7476/9788564905764.

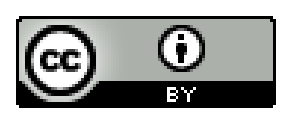

All the contents of this work, except where otherwise noted, is licensed under a Creative Commons Attribution 4.0 International license.

Todo o conteúdo deste trabalho, exceto quando houver ressalva, é publicado sob a licença Creative Commons Atribição $\underline{4.0}$.

Todo el contenido de esta obra, excepto donde se indique lo contrario, está bajo licencia de la licencia $\underline{\text { Creative Commons }}$ Reconocimento 4.0. 


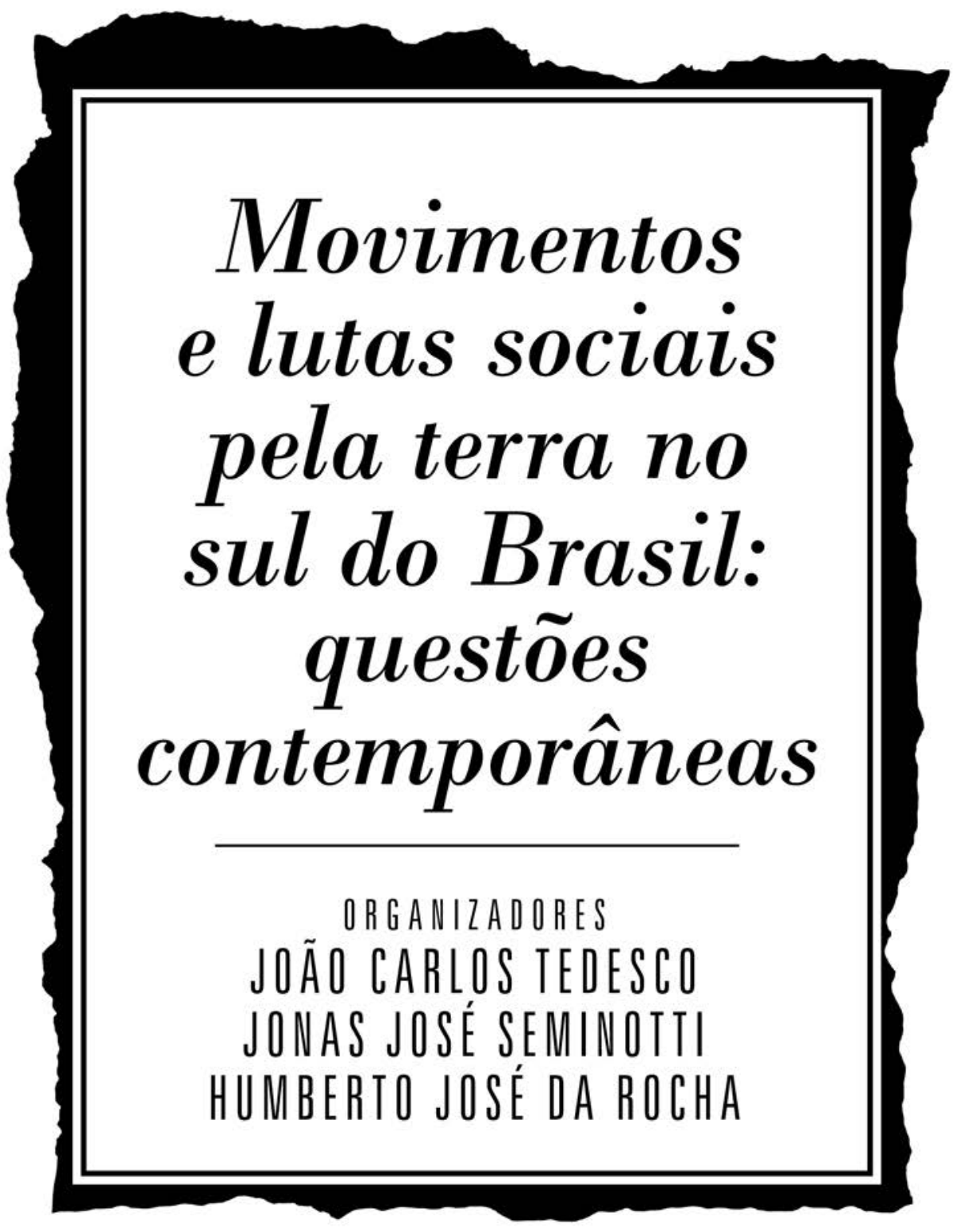




\title{
2) 20.0.
}

\author{
Reitor Jaime Giolo \\ Vice-Reitor Antônio Inácio Andrioli \\ Chefe do Gabinete do Reitor Stefani Daiana Kruetz
}

Pró-Reitor de Administração e Infraestrutura Péricles Luiz Brustolin

Pró-Reitor de Assuntos Estudantis Darlan Christiano Kroth

Pró-Reitor de Gestão de Pessoas Marcelo Recktenvald

Pró-Reitor de Extensão e Cultura Émerson Neves da Silva

Pró-Reitor de Graduação João Alfredo Braida

Pró-Reitor de Pesquisa e Pós-Graduação Joviles Vitório Trevisol

Pró-Reitor de Planejamento Charles Albino Schutz

Secretária Especial de Laboratórios Cladis Juliana Lutinski

Secretário Especial de Obras Rodrigo Emmer

Secretário Especial de Tecnologia e Informação Claunir Pavan

Procurador-Chefe em exercício Douglas Alexandre Goergen

Diretor do Campus Cerro Largo Ivann Carlos Lago

Diretora do Campus Chapecó Lísia Regina Ferreira

Diretor do Campus Erechim Anderson André Genro Alves Ribeiro

Diretora do Campus Laranjeiras do Sul Janete Stoffel

Diretor do Campus Passo Fundo Vanderlei de Oliveira Farias

Diretor do Campus Realeza Antônio Marcos Myskiw 


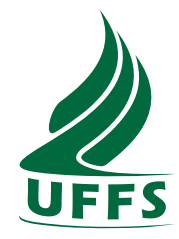

EDITORA

Diretor da Editora UFFS

\section{Valdir Prigol}

Chefe do Serviço Especial de Publicações Editoriais

Fabiane Pedroso da Silva Sulsbach

Revisora de texto

\section{Marlei Maria Diedrich}

Secretária Executiva

\section{Claudiane Brito de Almeida}

\section{Conselho Editorial}

Marlon Brandt (Presidente)

Tiago Vecchi Ricci

Gilmar Roberto Meinerz

Demétrio Alvez Paz

Paulo Afonso Hartmann

Bernardo Berenchtein

Thiago Bergles Bitencourt

Gustavo Acrani

Vanderleia Laodete Pulga

Adelita Maria Linzmeier

Rozane Marcia Triches

Antonio Marcos Myskiw

Valdir Prigol

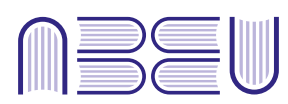

Associação Brasileira das Editoras Universitárias 


\section{REVISÃO DOS TEXTOS Autores \\ REVISÃO FINAL Marlei Maria Diedrich \\ PROJETO GRÁFICO E Mariah Carraro Smaniotto \\ DIAGRAMAÇÃO \\ CAPA Felipe Stanque Machado Junior}

DIVULGAÇÃO Diretoria de Comunicação

FORMATO DO E-BOOK ePub, mobi e PDF

\section{T257m Tedesco, João Carlos}

Movimentos e lutas sociais pela terra no sul do Brasil: questões contemporâneas. / João Carlos Tedesco, Jonas José Seminotti, Humberto José da Rocha.

Chapecó: Ed. UFFS, 2018.

422 p.: il.

$$
\begin{aligned}
\text { ISBN: } & 978-85-64905-75-7 \text { (pdf) } \\
& 978-85-64905-76-4 \text { (e-pub) } \\
& 978-85-64905-77-1 \text { (mob) }
\end{aligned}
$$

1. Movimentos sociais - Brasil. 2. Questão agrária - Brasil. 3.

Movimentos sociais rurais - Brasil - Região Sul 4. Questão agrária

- Rio Grande do Sul. 4. Educação rural. 5. Trabalhadoras rurais. 6. História social. I. Seminotti, Jonas José. II. Rocha, Humberto José da. III. Título.

CDD: 333.3181 


\section{Sumário}

\section{Apresentação}

A mobilização social rural no sul do Brasil: perspectivas de análise.. 6 João Carlos Tedesco

Jonas José Seminotti

Humberto José da Rocha

\section{Parte 1}

Representações do rural

Resgate histórico-analítico da mobilização e organização dos atingidos por barragens na bacia do rio Uruguai (1970-2015)

Humberto José da Rocha

Gerson de Lima Oliveira

Organização e atuação da Fetraf-Brasil e da Fetraf-Sul

Jairo Bolter

Jaqueline Haas

Da questão agrária à agroecologia: a narrativa da reforma agrária no

Brasil 82

Cleber José Bosetti

Movimento de mulheres camponesas, feminismo e segurança alimentar

Valdete Boni 
Parte 2

Conflitos pela terra 145

Estado, questão agrária e o desafio da luta pela terra 146 Algacir José Rigon

José Guilherme Franco Gonzaga

Vinicius Piccin Dalbianco

A disputa pela terra entre indígenas e agricultores no norte do Rio Grande do Sul: síntese de alguns elementos históricos 175 Alex Antônio Vanin

Gean Zimermann da Silva João Carlos Tedesco

Territórios e territorialidades contestadas: espaços em conflitos e disputas pela terra 230

Giovana Didoné Piovezana

Leonel Piovezana

Maria de Lourdes Bernartt

Dádiva e reciprocidade: dimensões simbólicas na manutenção e reconfiguração dos territórios quilombolas de Arvinha e Mormaça 260 Edla Eggert

Heron Lisboa Oliveira

Parte 3

Pautas e políticas para o campo 291

As demandas dos agricultores familiares na pauta da Fetraf-Brasil (2005-2015)

Catia Grisa

Jonas José Seminotti 
A educação do campo e desafios na atual conjuntura política brasileira

Willian Simões

Os assentados do Madre Terra em São Gabriel-RS respondem: que escola queremos para que nossos filhos permaneçam no campo?.. 358 Tânia Mara De Bastiani

O Pronaf e a educação do campo na perspectiva da Fetraf-Brasil.. 377 Catia Grisa

Jonas José Seminotti

Roniere dos Santos Fenner 


\title{
Apresentação A mobilização social rural no sul do Brasil: perspectivas de análise
}

\author{
João Carlos Tedesco ${ }^{1}$ \\ Jonas José Seminotti ${ }^{2}$ \\ Humberto José da Rocha ${ }^{3}$
}

A mobilização social de luta pela terra e por políticas públicas para o campo no sul do Brasil desenvolveu-se mais intensamente seguindo o histórico de resistência e luta dos povos indígenas, quilombolas e camponeses a partir da segunda metade do século XX, período marcado pelo fim da Segunda Guerra Mundial e pela bipolarização ideológica entre as duas maiores potências mundiais (Estados Unidos - capitalista e União Soviética - socialista), bem como por transformações dos paradigmas do desenvolvimento agrário brasileiro.

O Brasil, economicamente, vivia a égide da "ideologia desenvolvimentista", que correspondia a uma orientação econômica de industrialização pela iniciativa privada, porém planejada pelo Estado, que captava e orientava os recursos financeiros. O desenvolvimentismo abrangeu o período

\footnotetext{
1 Professor Adjunto da Universidade de Passo Fundo (UPF). Contato: <jctedesco@upf.br >.

2 Professor Adjunto da Universidade Federal do Rio Grande do Sul (UFRGS). Contato: <jonas.seminotti@ufrgs.br>.

3 Professor Adjunto da Universidade Federal da Fronteira Sul (UFFS). Contato: <humberto.rocha@uffs.edu.br>.
} 
de 1930-1980, com início no governo Vargas, destacando-se fortemente no governo Juscelino Kubitschek (1956-1961) e manteve sequência nos governos militares (1964-1985), que deram continuidade a essa orientação econômica. Do ponto de vista político, houve uma alteração no que diz respeito ao fluxo e refluxo dos direitos civis, políticos e sociais. O Ato Institucional $\mathrm{n}^{\circ} 5$ (AI 5), de 13 de dezembro de 1968, restringia a liberdade dos cidadãos brasileiros em quase todos os campos, levando a que a construção da cidadania não acompanhasse da mesma forma o ritmo desenvolvimentista. Porém, em 13 de outubro de 1978, o AI 5 foi revogado, e a nação brasileira começava a respirar um pouco mais livre.

Nesse contexto, em nível estrutural, considerando as duas orientações ideológicas da época (capitalismo e socialismo), tem-se o marco metodológico de predomínio do capitalismo multinacional, posição ideológica brasileira, em detrimento ao nacionalismo estatizante, representado pelas reformas de base do ex-presidente João Goulart. Interessava ao governo brasileiro o crescimento econômico global, de maneira que não viesse primeiro em benefício da sociedade brasileira, tanto que o ministro do período militar assim justificava: "Primeiro fazer o bolo crescer para depois dividi-lo".

Em 1945, final da Segunda Guerra Mundial, entrou em curso a chamada revolução verde, uma iniciativa de empresas norte-americanas que propagavam a modernização da agricultura mundial mediante a intensificação da mecanização e do uso de adubos e defensivos químicos. A partir da década de 1960, a proposta de modernização da agricultura chegou ao Brasil, instalando indústria pesada voltada para a industrialização da agricultura, com instalação de fábricas de máquinas e insumos. Já o reflexo se fez sentir, e o governo brasileiro criou a demanda para essa indústria. O resultado foi um aumento da concentração fundiária e uma rápida expansão da fronteira agrícola. A modernização prevaleceu no Centro-Sul e Nordeste, sendo que a fronteira agrícola se expandiu principalmente para o Norte (Amazônia) e Centro-Oeste (Mato Grosso e Goiás). 
A política de modernização agrícola interferiu também nas fronteiras das terras indígenas, caracterizando conflitos com os autóctones. Para resolver a questão, o governo criou o Serviço de Proteção ao Índio (SPI), mais tarde substituído pela Fundação Nacional do Índio (Funai) sem, contudo, mudar a orientação política desenvolvimentista. A ação do SPI foi, inicialmente, de natureza humanista, assumida, para proteger os índios, pelos irmãos Vilas Boas e pelo marechal Rondon. A política desenvolvimentista nacional, a partir de 1950, deu lugar a ações modernizantes, adotadas também em relação aos indígenas no sentido de tornar as áreas produtivas no limite em exportadoras de produtos. Na década de 1970, já como Funai, as ações foram norteadas a partir de projetos de integração dos índios com a sociedade via mecanização agrícola das terras e do arrendamento para os colonos.

A iniciativa dos arrendamentos agravou o problema de intrusão das terras indígenas pelos colonos, apesar de acontecer desde iniciativas colonizadoras do século XIX. Por meio desses arrendamentos avançavam além das áreas estabelecidas pelos contratos. Disso resultou em conflito entre agricultores e índios, o que aumentou a emergência do Movimento dos Agricultores Sem Terra (Master) a partir de 1961. Dentre as ações, o Master ocupou reservas indígenas como estratégia para pressionar a reforma agrária, o que gerou a reação dos índios no sentido de expulsar os intrusores.

Outro aspecto dessa opção de industrialização se reforçou na crise do petróleo em 1973, no sentido de ratificar a opção brasileira pela matriz hidrelétrica na geração de energia. Em resposta à crise, o governo passou a intensificar a instalação de usinas hidrelétricas (UHE), tanto que, para o setor elétrico, a década de 1970 foi conhecida como década ganha, pois se construíram grandes hidrelétricas, como Paulo Afonso, Três Marias, Furnas, Itaipu, Sobradinho, Tucuruí, Salto Osório e Salto Santiago, além da UHE Passo Real, elemento importante para a análise sobre o sul do Brasil. Considerando a hidroeletricidade como um processo social, partindo da primeira hidrelétrica instalada no Brasil (1883), pode-se dizer que até 
1970 e 1980 não havia um planejamento prévio para reassentamento das famílias atingidas por barragens. O remanejamento acontecia às vésperas ou quase que simultaneamente ao alagamento, conforme ocorreu na Sobradinho e Itaparica (rio São Francisco-PE), em 1970, e Tucuruí (rio Tocantins-PA) e Itaipu (rio Paraná-PR), em 1980.

Na segunda metade da década de 1970, o crescimento econômico, sustentado por empréstimos externos contraídos pelos governos militares, começou a dar sinais de crise. Não obstante ao mencionado crescimento dos índices econômicos, os reflexos tanto da modernização agrícola quanto da instalação de hidrelétricas não têm no aspecto social o mesmo desempenho que o econômico, já que as populações rurais passaram a ser gradativamente expulsas das suas terras por conta do avanço das duas iniciativas desenvolvimentistas.

Ante essa crise econômica, o governo militar já não tinha argumentos para sustentar a repressão dos direitos civis e políticos e a reação popular deflagrada. Iniciativas para a criação do Partido dos Trabalhadores (1980), o sindicalismo combativo (no campo e cidade), a orientação da Igreja Católica na linha da teologia da libertação e as organizações de classe (associações de professores, médicos, funcionários públicos, artistas) davam sinais de reação popular ante a conjuntura. Em outubro de 1978, a revogação do AI 5 significou um passo importante para a organização popular, com a volta dos exilados e a reorganização da classe política brasileira.

Nesse panorama histórico, mesmo que sucinto, é possível perceber que o desenvolvimentismo que impulsionou o campo econômico refletiu negativamente no social, já que os indicadores não incidiam necessariamente na qualidade de vida da população. A precariedade material ficou insuportável por conta das violações dos direitos humanos durante os governos militares.

As mobilizações sociais de contestação e resistência não são exclusividade do período desenvolvimentista; podem ser percebidas ao longo da história brasileira. Com olhar voltado para a formação da cidadania, 
Maria da Glória Gohn (2012) mapeou as principais lutas e movimentos sociais desde o século XIX, quando as lutas esparsas pelo território brasileiro pautavam questões como escravidão, tributos, poder público, regime político ou lutas entre categorias econômicas e pequenos camponeses até o século XX. Com o avanço da democracia e da complexidade das relações sociais, as pautas apresentaram-se mais difusas e os atores envolvidos apresentaram questões no sentido dos direitos humanos.

Gohn (2012) assinala vários movimentos: de estudantes, guerrilha (Araguaia, nordeste), comunidades eclesiais de base e pastoral da terra, sindicatos, classes (educação, saúde); lutas pela redemocratização e protestos pontuais (passagem de ônibus, indígenas, custo de vida); de Formoso e Trombas (Goiás); ligas camponesas a partir de Pernambuco desde 1950 e União dos Lavradores e Trabalhadores Agrícolas do Brasil (Ultab), fundada em São Paulo em 1954. Todos fundamentais para a compreensão do processo histórico das lutas pela terra.

Quanto à importância e à relação mútua entre as lutas e os movimentos para a compreensão do processo social, convém considerar a formação socioeconômica do sul do Brasil - Rio Grande do Sul, Santa Catarina e Paraná -, onde há traços comuns que os identificam. Um primeiro traço é o longo período de isolamento da vida política e a tardia incorporação à economia nacional. A colonização ocorreu com imigrantes oriundos das Colônias Velhas do Rio Grande do Sul no final do século XIX, chegando ao Oeste catarinense em 1930 e alcançaram o Paraná em 1950. As pequenas propriedades de agricultura familiar avançaram sobre áreas antes ocupadas por indígenas e caboclos. A economia de subsistência foi influenciada pela orientação capitalista internacional, baseada na propriedade privada da terra e no ethos do trabalho, fundamentado em valores comunitários e religiosos.

Os aspectos geográficos predominantes na região Sul eram vistos na contramão das iniciativas desenvolvimentistas dos governos brasileiros. Para além de índios e caboclos expropriados no ciclo anterior de colonização, a modernização da agricultura empreendida a partir da década de 
1960 atingiu também os pequenos agricultores familiares que se viram excluídos do processo por terem propriedades de pouca extensão e em áreas de relevo acidentado, o que dificultava a mecanização. Essa pressão tecnológica refletiu tanto na política indigenista, no sentido da "integração" ao capitalismo, como na pressão que os agricultores exerceram sobre as terras indígenas. Diante dessa situação, o fator geográfico ganhou importância pelo alto potencial à exploração hidrelétrica em razão dos vales dos rios Paraná, Iguaçu e Uruguai e seus afluentes. A conformação socioeconômica (espírito capitalista, propriedade privada da terra, ethos do trabalho, busca de riqueza) e cultural (valores comunitários e religiosos) resultante do modelo de colonização predominante nessas áreas foi outro elemento que condicionou a região a um potencial berço de movimentos de contestações. A partir desse cenário, os movimentos e as lutas sociais pela terra corresponderam tanto à modernização agrícola quanto à instalação de hidrelétricas. A iniciativa de contestações foi a partir de movimentos de pequenos agricultores da agricultura familiar sem-terra atingidos por barragens, indígenas, quilombolas e mulheres camponesas que emergiram no local a partir desse projeto modernizante intensificado na década de 1960.

O sul do Brasil pode ser tomado como palco da mobilização social em vista da estrutura mundial e conjuntura brasileira a partir da década de 1960. A expressão “mobilização social” reclama uma conotação histórica. De acordo com Charles Tilly (1977), o termo define-se como "processo pelo qual um grupo passa de um coletivo passivo de indivíduos a um grupo participativo na vida pública”. A mobilização implica que o grupo passa a ter controle sobre os recursos de cunho repressivo (armas), utilitário (dinheiro, materiais) e normativo (obrigações) que até então não controlava.

Para entender em que condições essa mobilização desponta, parte-se do conceito de polity model que Tilly (1977) desenvolve para tratar das condições de mobilização a partir do exterior do grupo que se mobiliza, considerando os elementos "governo", "população" e "outros grupos" 
concorrentes ou aliados. Resgatando a análise conjuntural apresentada anteriormente, basta assinalar que o governo brasileiro imprimia uma política desenvolvimentista que desfavorecia a maior parte da população do campo, especialmente na fronteira sul do Brasil.

No elemento "grupo", não obstante, já se realizavam conferências de trabalhadores rurais organizadas pelo $\mathrm{PCB}$, além de registros de confrontos entre posseiros e policiais militares na reivindicação de terras em alguns lugares do Sul. Esses movimentos isolados ainda não caracterizavam um grupo ou movimento coeso, porém apontavam o surgimento deles, tomando corpo e agravando-se pela crescente concentração da propriedade da terra e o esgotamento da fronteira agrícola no Rio Grande do Sul.

O cenário de restrições desenvolvimentistas e mobilizações remetem à ideia de Sidney Tarrow (2009) acerca dos “ciclos de confrontos”. Um ciclo é notabilizado por um ou mais eventos de culminância que ajudam a catalisar os elementos dispersos, porém interligando-se ao longo do processo social correspondente. $\mathrm{O}$ autor define ciclo como "uma fase de conflito acentuado que atravessa um sistema social", caracterizado por "uma rápida difusão da ação coletiva de setores mais mobilizados para outros menos mobilizados", pela "criação de quadros interpretativos de ação coletiva, novos ou transformados", pela "combinação de participação organizada e não organizada”, pela capacidade de produzir "externalidades que dão aos desafiantes ao menos uma vantagem temporária e permite que superem a fraqueza na sua base de recursos". Um ciclo de confronto "produz resultados gerais que são mais do que a soma dos resultados de um agregado de eventos desconectados", compreende um período em que as restrições e reações se acentuam de tal forma que conformam uma unidade de análise (TARROW, 2009).

Nessa perspectiva, os ciclos de confrontos podem ser vislumbrados no Brasil, especialmente no Sul, a partir do surgimento do Movimento dos Agricultores Sem Terra (Master) na década de 1960. 
A linha de raciocínio de Tilly (1977), do ponto de vista do interior do grupo, utiliza o conceito de mobilization model e elenca cinco aspectos para a análise das possibilidades de mobilização: interesse, vantagens ou desvantagens comuns que possam advir para a população em questão; organização, medida da identidade comum que unifica os indivíduos da população; mobilização, quantidade e qualidade de recursos no controle do grupo; ação coletiva, grau da ação conjunta do grupo no processo de busca de fins comuns; oportunidade, sintonia entre os interesses do grupo, da população e do estado atual do mundo em torno dele.

O Master, ao reunir desempregados, posseiros, parceiros, arrendatários, agregados e pequenos proprietários, deve ser relacionado ao perfil socioeconômico da região para assinalar a fragilidade ante a política desenvolvimentista da modernização agrícola, deixando clara a sintonia com os interesses e a identificação da mobilização com a população do campo. A modernização e o esgotamento da fronteira agrícola colocaram os pequenos agricultores num dilema: migrar para outras regiões ou para a cidade, ou, ainda, intrusar terras indígenas. O apoio do governo do Rio Grande do Sul, com base na ideia de que havia muita terra para pouco índio, passou a incentivar e legitimar a intrusão de agricultores nas reservas indígenas. Essa ação pode ser entendida como consequência da política desenvolvimentista brasileira e que, mais tarde, refletiria no surgimento de outros conflitos de luta pela terra na região.

Quanto aos outros elementos da análise de Tilly (1977) sobre o mobilization model -mobilização, ação coletiva e oportunidade -, apesar do apoio do governo do Rio Grande do Sul, a organização da luta pela terra pode ser considerada incipiente até os primeiros anos de 1960. Não se tem a pretensão de aprofundar a história do Master, mas assinalar a correspondência entre o surgimento do movimento e a conjuntura e assinalar, como ponto fundamental, a primeira ocupação, em 1962, na Fazenda Sarandi, feita pelo então fundado Master. Além de considerar um marco histórico da luta pela terra, a ocupação significa o primeiro e talvez o mais 
importante elemento constituinte do que Charles Tilly (1977) chama de "repertório" da luta pela terra. Genericamente o termo refere-se às formas como o grupo utiliza os recursos que passa a dispor (repressivos, utilitários, normativos) no contexto da mobilização. $\mathrm{O}$ autor assinala que o repertório de um grupo é conformado pelas circunstâncias do momento, que também tendem a evoluir segundo a trajetória da mobilização.

Passados mais de cinquenta anos da ocupação da fazenda, sabemos que a luta pela terra compreende desde ações de conscientização a debates acerca da questão, enfrentamentos físicos e manifestações. De qualquer forma, o que ficou marcado desde o início foi a ocupação como carro-chefe de mobilização.

O repertório de uma mobilização em determinado ciclo de confronto acontece em virtude de condições internas e externas ao grupo. Um ponto não mencionado, que também caracteriza o conjunto, é o ciclo de protestos e o respectivo repertório de mobilização, levando a que o Estado monte amplas estratégias de reação, repressivas ou facilitadoras, ou uma combinação de ambas. Na maioria das vezes, sobretudo no Brasil, na década de 1960, a mobilização social correspondeu a uma reação às políticas de governo. Todavia, a medida da repressão ou facilitação do governo ante a mobilização é um elemento crucial. Não significa que a mobilização social está condicionada à vontade do governo, mas a medida da repressão/ facilitação influencia no custo da mobilização. Nesse sentido, a tomada do governo federal pelos militares, com o consequente fim do governo Brizola e a posse de Ildo Meneghetti pelo Partido Social Democrático (PSD) no governo gaúcho, em 1963, representou o endurecimento da repressão estatal com a total ausência de assentamentos dos sem-terra de 1964 a 1979, iniciando, assim, uma nova etapa de luta pela terra na região Sul.

Tilly (1977) destaca que a comunicação e a criminalização são elementos que o Estado pode controlar de forma a reprimir ou facilitar a mobilização social. O autor deixa claro que um governo necessariamente não precisa ser compreendido como repressivo ou facilitador. Os governos, na 
maioria das vezes, combinam ambas as partes e agem de forma seletiva, segundo suas intenções. No governo Brizola, por exemplo, o que era tido como favorável aos agricultores não tinha a mesma conotação na perspectiva indígena. Já no governo Meneghetti, a repressão e a contrainformação praticamente inviabilizaram a mobilização social no período de 1964 a 1979, embora grandes madeireiros, granjeiros, industriais e comerciantes regionais tenham sido beneficiados.

No conjunto da análise é importante relacionar a narrativa histórica e os elementos teóricos para obter pistas de como aconteceu a mobilização social de luta pela terra a partir da polity model desenvolvimentista. $\mathrm{O}$ agravamento da situação, especialmente no campo econômico, fez emergir um ciclo de confronto em que a mobilização social, marcada pela formação do Master no início da década de 1960, deixa perceber que o principal recurso do repertório era a ocupação de terra. Consequentemente, o governo reage à mobilização e reprime a luta pela terra. Esse período de inanição da luta foi também de aglutinação de forças que viriam eclodir futuramente num outro ciclo de protestos, quando a luta pela terra se estabeleceu como eixo aglutinador de diferentes grupos.

A ocupação e o decreto de desapropriação da Fazenda Sarandi foram marcos importantes de luta por mostrar o poder de mobilização social. Contudo, a mudança conjuntural no Rio Grande do Sul e os "anos de chumbo" da ditadura militar colocariam à prova tal mobilização, sendo que novos elementos passaram a constituir um ciclo de confronto, de forma que uma "indústria de movimentos sociais", no sentido proposto por McCarthy e Zald (1977), pode ser percebida na época. Os autores fazem a análise na perspectiva da mobilização de recursos e acrescentam ideias que ajudam a compreender essa fase de luta pela terra. Partindo da ideia genérica de movimento social enquanto conformação de um conjunto de opiniões e crenças que buscam mudanças em alguns elementos estruturais ou distribuição de recompensas de uma determinada sociedade, os autores explicam que esse movimento social não aparece espontaneamente. 
Corresponde a uma "organização complexa e formal, que identifica suas metas com as preferências de um movimento ou mesmo de um contramovimento, e tenta implementar essas metas" (Social Movement Organization - SMO). Assim, um movimento social mobiliza recursos para organizar-se. Na sequência do raciocínio, os autores chegaram ao conceito de indústria de movimentos sociais (Social Movement Industry - SMI), quando diferentes movimentos sociais procuram identificar-se com um maior número de preferências e objetivos em relação a outros movimentos (MCCARTHY; ZALD, 1977).

Essa "indústria" (SMI) teve na própria política desenvolvimentista brasileira uma importante fornecedora de matéria-prima. A partir da segunda metade da década de 1960 começaram os trabalhos de instalação da usina hidrelétrica Passo Real, no rio Jacuí-RS, que implicaria o remanejamento populacional das famílias atingidas. Em março de 1972, o Incra deu início ao processo de desapropriação da Fazenda Annoni para reassentar parte dessas famílias, o que foi interrompido por conta da judicialização dos proprietários das terras, desencadeando um processo de luta dos atingidos. Diante disso, a Usina Passo Real forneceria outro substrato para a chamada "indústria de movimentos sociais" na fronteira sul. Além dos agricultores sem-terra, em razão da modernização agrícola, os projetos de grande escala a partir da inundação de milhares de hectares despejavam mais outra leva de agricultores que, pela natureza da perda, ficaram conhecidos como afogados do Passo Real.

A relação entre os conceitos de ciclos de protestos e SMI ajuda a compreender como a mobilização social foi ganhando unidade com o passar do tempo, apesar da repressão estatal a partir de 1964. Para avançar no entendimento de qual seria o eixo dessa unidade, o conceito de frames, elaborado por David A. Snow e Robert D. Benford (1992) a partir dos conceitos anteriores, torna-se importante. A palavra frame remete à ideia de "quadro" ou "moldura", que, metaforicamente, sugere "um esquema interpretativo que simplifica e condensa o mundo lá fora, pontuando 
seletivamente e codificando objetos, situações, eventos, experiências e sequências de ações dentro do ambiente presente ou passado". Segundo os autores, num cenário de ação coletiva, a importância de um frame está na capacidade de atribuição e articulação. Na esfera da atribuição, a referência de um frame ajuda nos diagnósticos (identificação) e prognósticos (resolução) de problemas. Já na esfera da articulação, funciona no sentido de alinhar elementos para constituir uma ordem significativa, o que seria buscado entre os grupos que demonstram uma "consciência aderente".

Assim, o conceito de frame aproxima-se do SMO por fazer referência a um grupo específico que busca atribuição e articulação no mundo social. No caso citado, o Master procurou reunir pessoas que de certa forma perderam suas terras em consequência do desenvolvimentismo, da modernização da agricultura que os excluía. $\mathrm{O}$ advento da hidrelétrica de Passo Real colocou em cena o grupo dos "afogados", que também lutava contra a perda das suas terras, mesmo que por outros motivos. Nessa luta, sessenta famílias não contempladas ou que tiveram o reconhecimento de seus direitos negados pelo Incra ocuparam a fazenda Annoni, com os "sem-terra", formando um acampamento em meados de 1970.

A “indústria dos movimentos sociais" encontra substratos em dois SMO ou frames que se aproximam por meio do que os segundos chamam de master frames (SNOW; BENFORD, 1992). O conceito de master frame funciona da mesma forma que oframe, todavia é mais genérico, catalisador e acontece em maior escala. A mudança de escala implica a variedade maior de recursos e objetivos inter-relacionados. Dessa forma, o potencial aglutinador de um master frame depende de variáveis, como capacidade de atribuição, fidelidade ou centralidade narrativa e credibilidade empírica ou comensurabilidade experimental.

Geograficamente, os caminhos dos sem-terra e dos afogados se aproximaram na antiga Fazenda Sarandi. Já na perspectiva da mobilização social, a luta pela terra corresponde ao master frame, que identifica esses dois movimentos. Observando o potencial aglutinador do master frame a partir dos 
pontos citados, pode-se afirmar que a luta pela terra seria o master frame, que identifica os afogados e os sem-terra. No tocante à atribuição, ambos identificam a modernização ou industrialização e concentração fundiária como problemas que teriam como solução a reforma agrária. No viés da articulação, o fato de ambos serem expropriados por uma política desenvolvimentista confere fidelidade e credibilidade para uma narrativa de sofrimento e luta que condiz com a realidade empírica daqueles que, por um ou outro motivo, terminaram acampados, conformando esse quadro.

Essas colocações, mesmo que tratadas sumariamente, servem para explicar o ciclo de protestos inaugurado a partir de meados de 1960, iniciando um novo master frame a partir da luta pela democracia ou contra a ditadura. No tocante ao meio rural, não obstante a influência desse quadro, a luta pela terra passou a ser o master frame que identificou os sem-terra e afogados. O predomínio do elemento terra sobre o elemento água é compreensível tanto pela credibilidade empírica, pois se trata de terra que se perdeu com a inundação pela hidrelétrica, quanto pelo fato de o master atribuir à terra, ou à sua má distribuição, a causa e solução para o problema social brasileiro. Dessa forma, o master frame influenciou no repertório dos movimentos, tornando a ocupação de terras a sua marca registrada. Essa tática que havia minguado em consequência dos "anos de chumbo" retornaria em razão de um quadro de oportunização política a partir do que a luta pela terra pode ser compreendida como um master frame, que aglutinou grupos e orientou um repertório que tinha nas ocupações a principal ação. Os anos de chumbo, que vamos considerar aqui com vistas à publicação e suspensão do Ato Institucional n 5 (AI 5), compreendem um período em que a luta pela terra sofreu forte repressão e avançou menos em termos de conquistas em comparação a outros períodos.

A retomada da luta pela terra tomou novo impulso no final de 1970, a partir de um cenário que vai ao encontro do que Sidney Tarrow (2009) define como "estrutura de oportunidades políticas" (EOP), visando compreender como as demandas de grupos são manifestadas diante de um 
cenário oportuno que deu origem a confrontos políticos. $\mathrm{O}$ autor sustenta que, num cenário de oportunização, “o confronto político surge como uma reação a mudanças nas oportunidades e restrições políticas em que os participantes reagem a uma variedade de incentivos materiais e ideológicos, partidários ou baseados no grupo, de longa duração ou episódicos" (TARROW, 2009).

No entanto, um cenário de oportunidades não significa necessariamente que confrontos políticos ocorram. Mesmo diante das demandas dos grupos, pontuais ou estruturais, há que distinguir-se "potencial de mobilização" de "ação de fato". O primeiro representa o estado de latência do confronto, ao passo que o segundo representa a mobilização efetiva que o promove. Nesse sentido, Tarrow (2009) apresenta cinco aspectos observados de forma a perceber-se como essa passagem de potencial em ação pode acontecer de maneira geral: “1) abertura do acesso à participação para novos atores; 2) evidência de realinhamento político no interior do sistema; 3) presença de aliados influentes; 4) divisões emergentes no interior da elite; 5) declínio na capacidade do estado de reprimir dissidências."

Resgatando a história do Brasil, esse quadro de oportunização corresponde ao período em que o poder de repressão do Estado foi aos poucos diminuindo em relação aos chamados anos de chumbo, auge do período militar. A revogação do AI 5 (outubro de 1978), a Lei da Anistia (agosto de 1979) e o fim do bipartidarismo (novembro de 1979) permitiram a volta dos exilados políticos ao país de origem, reforçando o ativismo das diversas causas sociais, promovendo a divisão das elites e acarretando o enfraquecimento das oligarquias, o realinhamento político e o fortalecimento da sociedade civil.

De acordo com o panorama histórico apresentado, há de considerar-se que o enfraquecimento do regime militar, não obstante as lutas pela redemocratização, passa pela dificuldade econômica do final do ciclo desenvolvimentista brasileiro (1930-1980). Os seguidos anos de crescimento e as iniciativas de modernização (agricultura e projetos de grande escala) 
sustentadas por financiamentos exteriores ficaram comprometidas em razão da crise do petróleo de 1979, que afetou o mundo inteiro, e no Brasil inaugurou um novo período econômico de crise. Dessa forma, o regime ditatorial já não contava com a pujança econômica para contrabalançar a repressão. A partir daí configurou-se um período de abertura política que ganhou espaço na participação de novos atores, ficando a repressão mais fraca.

Concentrando a discussão na luta pela terra no campo político-institucional no estado do Rio Grande do Sul, são notórios os trabalhos da Assembleia Legislativa na investigação parlamentar da Fazenda Sarandi (1979) e na questão das barragens em 1983. Há que registrar-se outro importante realinhamento político, a criação do Partido dos Trabalhadores (PT), que passou a caminhar ao lado dos movimentos sociais.

Quanto à luta pela terra propriamente dita, o norte gaúcho esboçou, no final da década de 1970, o ressurgimento das mobilizações. O ambiente de oportunização política reascendeu a questão indígena no município de Nonoai, local onde os agricultores intrusaram as terras indígenas desde 1960. O movimento indígena passou a utilizar a tática da intimidação e da expulsão das famílias de agricultores, passando a integrar-se à massa dos sem-terra, ocupando a reserva florestal da Fazenda Sarandi em meados de 1978, o que passou a ser seguido por outras famílias. Do excedente de famílias que não encontraram espaço na Fazenda Sarandi no momento, originou-se o acampamento da Encruzilhada Natalino, em 8 de dezembro de 1980, estendendo-se até 1983.

Em meio ao cenário de oportunização, foram fundados, definitivamente, dois movimentos sociais de expressão na luta pela terra, o Movimento dos Trabalhadores Rurais Sem Terra (MST) e o Movimento dos Atingidos por Barragens (MAB). As ocupações de terras realizadas nos estados de Santa Catarina, Paraná, São Paulo, Mato Grosso do Sul e, sobretudo, Rio Grande do Sul resultaram na fundação do MST durante o I Encontro nacional do MST, realizado em 1984, em Cascavel-PR. A questão dos "afogados" do Passo Real e a divulgação de que a Eletrosul pretendia 
instalar 25 hidrelétricas na bacia do Uruguai contribuíram para a criação da Comissão Regional de Barragens (CRAB), em Concórdia-SC, em 1979, que passou a responder como MAB/Região Sul a partir de 1991, quando se oficializou o MAB durante o I Congresso Nacional dos Atingidos por Barragens em Brasília.

O cenário de oportunização política permitiu a articulação de pessoas e instituições, como intelectuais, setores de universidades, políticos e alas de partidos políticos, sindicatos combativos, organizações da sociedade civil - CNBB, OAB e ABI -, segmentos das igrejas Católica e Luterana, além de organizações internacionais, de forma que a luta pela terra, embora protagonizada pelos agricultores, contou com um importante suporte material e ideológico que ajudou a conformar os repertórios dos movimentos sociais de luta pela terra. Dessa forma, a formação da CRAB e, depois, do MAB tem nos afogados do Passo Real uma importante referência de estruturação. Os atingidos pela UHE Itaipu-PR também se aproximaram do MASTRO e de certa forma ajudaram na estruturação do MST, que tem nas ações do Master Encruzilhada Natalino e Annoni importantes elementos da sua formação.

A partir da aproximação dos sem-terra e dos afogados na luta pela terra, várias ações de ocupação, tanto a propriedades quanto a órgãos públicos, foram registradas nos anos seguintes. Em qualquer movimento social é difícil uma homogeneidade e as disputas internas também foram elementos marcantes dessa articulação. De qualquer forma, a Fazenda Annoni já representava um palco de luta pela terra com repercussão internacional, onde se aglutinaram os afogados e os sem-terra, evidenciando pontos comuns entre as diferentes demandas e as diferenças de interesses.

Desde o final do processo de reassentamento na Annoni, já num ambiente político mais democrático, os movimentos sociais seguiram trajetórias próprias, estabelecendo uma identidade de luta pela terra forjada ao longo do processo. James M. Jasper (2016) conceitua "movimentos sociais" como "esforços persistentes e intencionais para promover ou obstruir 
mudanças jurídicas e sociais de longo alcance, basicamente fora dos canais institucionais sancionados pelas autoridades". A persistência, assinalada por Jasper, diferencia movimento social de eventos isolados. A intencionalidade indica que um movimento social implica cultura e estratégia para promover as mudanças sociais e jurídicas pela via não institucional, para mencionar o próprio movimento, sem esquecer as relações com partidos políticos e grupos de interesses dos quais se diferiam. O governo brasileiro imprimiu uma política desenvolvimentista desde a década de 1930, porém, na década de 1950, na Revolução Verde, tratou de modernizar a agricultura, estreitando a fronteira agrícola e promovendo conflitos entre indígenas e agricultores, depois os projetos de grande escala que expropriavam pela inundação, começando a registrar-se mobilizações, mesmo que esparsas. Essa "mobilização" deu-se a partir de ciclos de confrontos em que os repertórios correspondem à intencionalidade de resistir e promover a mudança dessa realidade.

Foi nesse processo histórico que a intencionalidade e a persistência marcaram as mobilizações desde a década de 1950, convergiram para a criação do MST, em 1982, e MAB, em 1991. É possível considerar os movimentos sociais anteriores a essas datas, porém foi a partir desses momentos que a luta pela terra passou a contar com o protagonismo e a referência de forma persistente definitivamente, reforçando suas bandeiras específicas paralelas à identificação em torno da luta pela terra.

A complexidade da questão fundiária no Brasil, intercruzada por aspectos econômicos, culturais e políticos, fez emergir outros movimentos de expressão, como o Movimento dos Pequenos Agricultores (MPA) e o Movimento de Mulheres Camponesas (MMC), oriundos da mobilização no âmbito dos movimentos anteriores, mas que construíram suas bandeiras específicas e ampliaram o master frame da luta pela terra, encontrando amparo teórico-metodológico na perspectiva dos novos movimentos sociais (NMS). Num outro estágio de desenvolvimento, esses movimentos formalizaram sua articulação em 1993, por ocasião da I Conferência da Via 
Campesina, em Mons (Bélgica). Esse movimento de abrangência internacional reúne organizações camponesas de pequenos e médios produtores, mulheres rurais, comunidades indígenas, quilombolas, sem-terra, jovens rurais e trabalhadores agrícolas migrantes nos cinco continentes. Apesar da internacionalização, a Via Campesina representa uma continuidade das lutas de 1960, 1970, 1980, especialmente no que se refere aos eventos ocorridos no norte do Rio Grande do Sul.

A história dos movimentos e as lutas sociais descritas por Maria da Glória Gohn ganham novos atores e demandas neste início de século XXI, com destaque no avanço da luta e implementação de políticas públicas na saúde, educação, crédito e habitação rural. Seguindo a concepção gramsciana de hegemonia, mesmo que o Estado tenha permanecido condicionado aos interesses do capital, houve a concessão de algumas políticas sociais para os trabalhadores, fruto das lutas e mobilizações nas últimas três décadas. O processo histórico que originou os movimentos sociais de luta pela terra ainda contabiliza tanto refluxos, divisões internas e criminalizações quanto conquistas, como a chegada do PT ao governo federal. São momentos que impõem desafios, criam esperanças e geram frustrações, levando esses movimentos sociais a permanecer em constante atualização.

Como forma de registro da parte do processo até aqui apresentado, este livro foi pensado para contemplar questões contemporâneas distintas, agrupadas em três partes: "Representações do mundo rural"; "Conflitos pela terra"; "Pautas e políticas para o campo". Cada parte é formada por quatro capítulos que apresentam diferentes questões atuais segundo essas linhas respectivas.

Na primeira parte, "As representações do mundo rural", o texto de Humberto José da Rocha e Gerson de Lima Oliveira apresenta um resgate histórico-analítico da mobilização e organização dos atingidos por barragens na bacia do rio Uruguai a partir da trajetória do movimento dos atingidos por barragens (MAB), abrangendo o período dos anos 1970, da formação do movimento social até a atualidade, de forma a distinguir 
pautas, avanços e refluxos desse movimento em relação aos estágios do processo social no que diz respeito a barragens no sul do Brasil.

No segundo trabalho desse eixo temático, Jairo Bolter e Jaqueline Haas analisam a trajetória da Federação dos Trabalhadores na Agricultura Familiar da Região Sul do Brasil (Fetraf-Sul) no processo de organização e proposição de um projeto de desenvolvimento socialmente justo e economicamente sustentável para a agricultura familiar. O estudo compreende desde o início da articulação, década de 1980, até a atualidade, quando se faz presente em 18 estados brasileiros, compondo a Federação Nacional dos Trabalhadores e Trabalhadoras na Agricultura Familiar (Fetraf-Brasil) e se constituindo numa das principais organizações sociais da agricultura familiar existente no país. ${ }^{4}$

No terceiro trabalho deste grupo, Cleber José Bosetti discute a reforma agrária brasileira segundo nuanças do terreno discursivo. Nesse sentido apresenta elementos como redistribuição fundiária, desigualdade social, desemprego, precariedade da cidadania e problemas ambientais enquanto partes da narrativa dos movimentos sociais pela reforma agrária. Centrando a análise no Movimento dos Trabalhadores Rurais Sem Terra (MST), o autor resgata esse processo, identifica as mudanças em relação aos contextos sociais de forma a chegar nos dias atuais, em que a proposição de um projeto alternativo de desenvolvimento rural tem na agroecologia uma de suas principais bandeiras discursivas.

Fechando o primeiro bloco, o trabalho de Valdete Boni aborda a questão da mulher no campo, tendo como foco o Movimento de Mulheres Camponesas (MMC). Registrando a recente criação oficial do movimento (2004), a autora apresenta os temas da segurança e soberania alimentar na perspectiva de discurso e prática do MMC por meio das ações contra as empresas de sementes transgênicas e recuperação de sementes crioulas.

4 A partir de maio de 2016 a FETRAF foi transformada na Confederação Nacional dos Trabalhadores e Trabalhadoras da Agricultura Familiar (CONTRAF-BRASIL). Seguiremos a denominação FETRAF por estarmos analisando o período que antecede esta alteração. 
De forma conjunta, o texto analisa o movimento de mulheres camponesas enquanto movimento feminista com base no debate sobre segurança e soberania alimentar.

O segundo eixo temático deste livro traz como tema "Conflitos pela terra” no sul do Brasil. O módulo é aberto por Algacir José Rigon, Vinicius Piccin Dalbianco e José Guilherme Franco Gonzaga, que apresentam um panorama da evolução da luta pela terra, tendo como ponto de referência o MST tanto pelo pioneirismo quanto pela continuidade das lutas. Nessa perspectiva, ao apresentar a evolução das estratégias e demandas do MST, o texto marca diferentes momentos de luta pela terra no sul do Brasil, que possibilita uma visão do processo social a partir do protagonismo do MST.

O trabalho de João Carlos Tedesco, Gean Zimermann da Silva e Alex Antônio Vanin apresenta a luta pela terra na perspectiva da disputa entre indígenas e agricultores no norte do Rio Grande do Sul. Os autores analisam um processo histórico em que as disputas tendem a assumir contornos favoráveis tanto para agricultores quanto para indígenas, segundo as ações de mobilização de ambos em relação aos respectivos contextos sociais. A modernização da agricultura, as orientações ideológicas e a Constituição de 1988 são elementos que parecem desequilibrar momentaneamente em favor de determinado grupo em diferentes estágios desse processo.

O trabalho de Leonel Piovezana, Giovana Didoné Piovezana e Maria de Lourdes Bernartt segue a mesma direção, porém localiza a discussão no Oeste catarinense. Tendo também a questão indígena como referência, os autores resgatam o processo de ocupação desse espaço, relacionando a outros movimentos sociais de forma a possibilitar uma compreensão expandida não só da questão indígena, mas também do processo histórico em seu conjunto, para a compreensão da trajetória conflituosa e da possibilidade da configuração de uma "terra de ninguém" para uma "terra sem males".

Fechando essa parte do livro, o texto de Heron Lisboa Oliveira e Edla Eggert mantém a linha de análise, entretanto apresenta o conflito pela terra na perspectiva das comunidades negras rurais. Localiza a discussão em 
duas comunidades remanescentes de antigos quilombolas no norte do Rio Grande do Sul. Os autores apresentam as ideias de dádiva e a reciprocidade enquanto elemento de coesão, permanência e ampliação de territórios disputados num campo que compreende múltiplos atores e interesses historicamente constituídos.

O terceiro eixo temático refere-se às "Pautas e políticas para o campo" tanto do que já foi conquistado pelas mobilizações quanto do que ainda representa demandas a serem alcançadas. Abrindo este bloco, Cátia Grisa e Jonas José Seminotti analisam as demandas da agricultura familiar a partir da pauta de reivindicações da Fetraf-Brasil entre 2005 e 2015. Abordadas em dimensão histórica, as pautas não só resgatam um processo social relativo à própria agricultura familiar, como também expressam um conjunto de demandas em termos de políticas públicas e demais ações do Estado.

Seguindo na mesma linha, o trabalho apresentado por Jonas José Seminotti, Catia Grisa e Roniere dos Santos Fenner aprofunda a discussão, concentrando a análise no Programa Nacional de Fortalecimento da Agricultura Familiar (Pronaf) e no Programa Nacional de Educação do Campo (Pronacampo). O texto permite compreender como as duas linhas representam conquistas da agricultura familiar e elementos de constituição e fortalecimento das políticas públicas para o campo.

A educação é tema também do trabalho de Tânia Mara de Bastiani. Tendo por base as concepções, tanto abordadas pelas políticas públicas de educação do campo, quanto do Movimento dos Trabalhadores Rurais Sem Terra (MST) para as escolas dos assentamentos, o texto apresenta um comparativo no que diz respeito aos conteúdos curriculares, entre a escola frequentada por crianças e adolescentes do Assentamento Madre Terra em São Gabriel-RS até o final de 2013 e a escola idealizada pelos assentados para atuar dentro do assentamento, a partir de 2014.

Por fim, o trabalho de Willian Simões traz a questão da educação do campo para além de sua constituição política institucional, uma vez que 
o autor apresenta uma síntese de conquistas e desafios, compreendendo um estado da arte sobre essa temática no sul do Brasil.

Com esse conjunto de trabalhos organizados nos três eixos temáticos, procura-se oferecer diferentes perspectivas de discussão sobre a questão rural na contemporaneidade. A complexidade dessa questão requer especificidades, concomitantemente relacionadas a contextos mais amplos, que requerem análises multidisciplinares empreendidas de forma multiescalar. Eis um cenário de pesquisa para o rural da atualidade.

\section{REFERÊNCIAS}

GOHN, Maria da Gloria. História dos movimentos e lutas sociais: a construção da cidadania dos brasileiros. 7. ed. São Paulo, SP: Loyola, 2012.

JASPER, James, M. Protesto: uma introdução aos movimentos sociais. Rio de Janeiro: Zahar, 2016.

MCCARTHY, John D.; ZALD, Mayer N. Resource mobilization and social movements: a partial theory. The American Journal of Sociology, Vol. 82, n. 6, May, 1977, p. 1212-1241.

SNOW, David A.; BENFORD, Robert D. "Master frames and cycles of protest". In: MORRIS, A.; MUELLER, C. M. (Org.). Frontiers in social movement theory. London: Yale University Press, 1992, p. 133-55.

TARROW, Sidney. O poder em movimento: movimentos sociais e confrontos políticos. Petrópolis: Vozes, 2009.

TILLY, Charles. From mobilization to revolution. Reading: Addison-Wesley, 1977. 


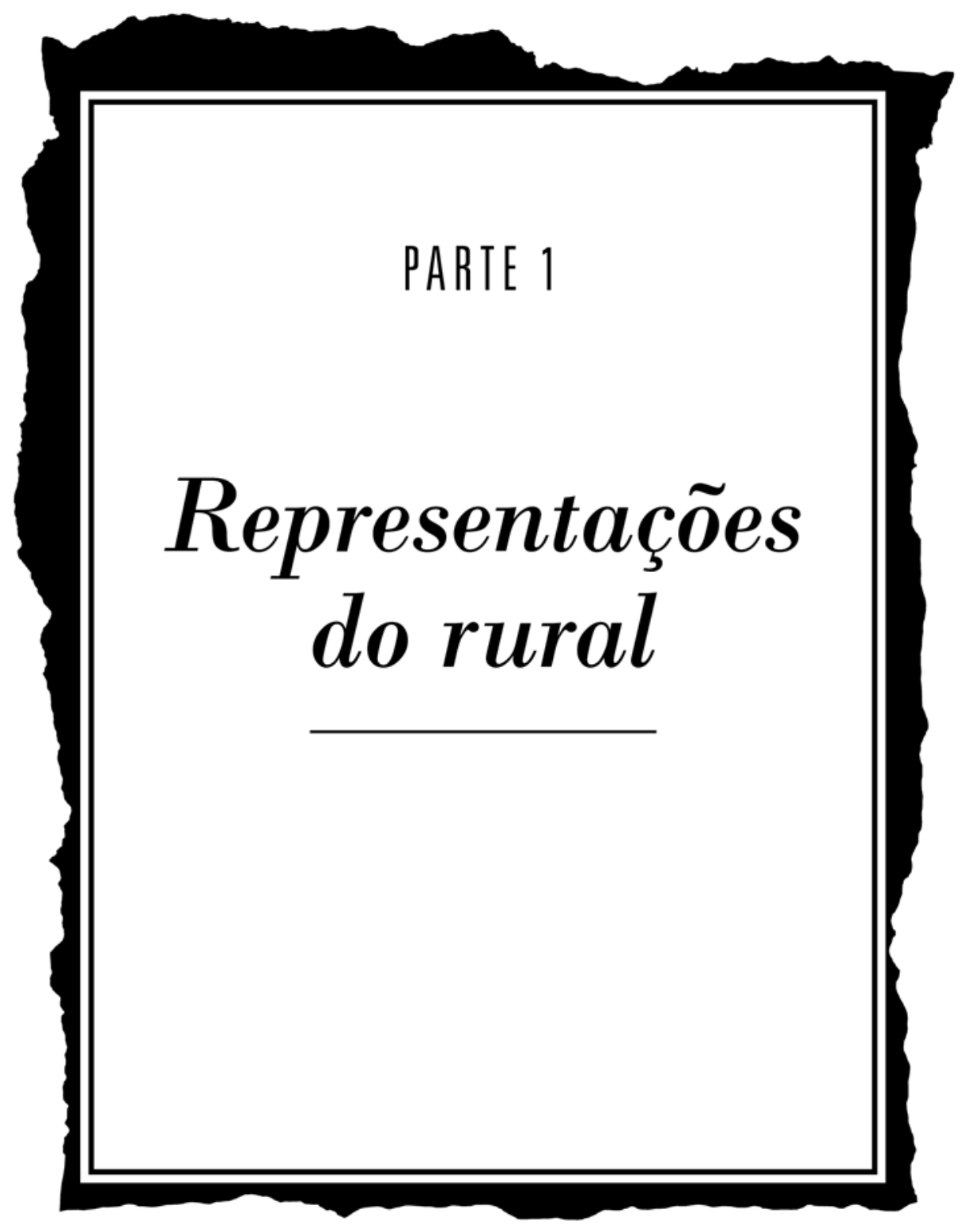




\section{Resgate histórico-analítico da mobilização e organização dos atingidos por barragens na bacia do rio Uruguai (1970-2015)}

Humberto José da Rocha ${ }^{1}$

Gerson de Lima Oliveira ${ }^{2}$

\section{A vertente contextual no berço do rio Uruguai (1970-1985)}

Considerando a hidroeletricidade um processo social no sentido de que produz efeitos e impactos concretos à sociedade, desde a primeira hidrelétrica instalada no Brasil (1883) podemos afirmar que até 1970 a 1980 não havia um planejamento prévio para reassentamento de famílias atingidas por barragens. Nesse período, o remanejamento acontecia "às vésperas da inundação" ou "quase que simultaneamente à subida das águas", como ocorrido nas hidrelétricas de Sobradinho e Itaparica (rio São Francisco-PE) em 1970, Tucuruí (rio Tocantins-PA) e Itaipu (rio Paraná-PR) em 1980 (BERGAMASCO; NORDER, 1996).

Considerando também a mobilização social diante desses impactos gerados pelas barragens identificadas em diferentes regiões do Brasil, como a usina hidrelétrica de Itá (UHE), observamos um salto qualitativo

1 Professor Adjunto da Universidade Federal da Fronteira Sul (UFFS). Contato: humberto.rocha@uffs.edu.br.

2 Professor Adjunto da Universidade Federal do Pampa (Unipampa) e pesquisador do Grupo de Pesquisa Associativismo, Contestação e Engajamento (GPACE) vinculado à Universidade Federal do Rio Grande do Sul (UFRGS). Contato: gerson.oliveira@unipampa.edu.br. 
a esse respeito. Podemos considerar como marco oficial da organização de movimento social contra as barragens o evento que reuniu, aproximadamente, 350 agricultores familiares, em Concórdia-SC, no dia 24 de abril de 1979, quando foi formalizada a Comissão Regional de Barragens (CRAB). A mobilização social baseou-se em notícias dos traumáticos processos vividos por atingidos pelas hidrelétricas instaladas em outras regiões do país. Na bacia do rio Uruguai, a UHE Passo Fundo era a única obra de grande escala instalada até então. Mesmo assim, não se aproximava em tamanho e impacto às demais hidrelétricas do Centro, Nordeste e Paraná. A notícia mais contundente foi o projeto de 22 UHEs pretendidas pela Eletrosul no rio Uruguai no trecho nacional e mais três no trecho da fronteira com a Argentina. As de Machadinho e Itá seriam as primeiras, porém, em virtude da mobilização social, a ordem, em parte, foi invertida. A mobilização caracterizou-se como uma espécie de "serviço" pelas ações pontuais, ainda sem sistematização estratégica e organizacional definidas. No início de 1980, o regime civil-militar apresentava sinais de abertura democrática, e o tema ambiental foi regulamentado regrando o processo de licenciamento. Assim, o movimento social consolidou-se em vista da instalação das UHEs Itá e Machadinho, na divisa entre Santa Catarina e Rio Grande do Sul.

Segundo Jasper, Goodwin e Polletta (2001), a dimensão emotiva é um dos principais elementos de análise das questões sociais, inerente ao fazer humano e aos grupos sociais. É, portanto, algo central na conformação das relações humanas. Nem sempre se festeja a alegria, tampouco a insatisfação; são necessariamente manifestadas diante das adversidades do cotidiano. Em relação aos atingidos por barragens, o grau de insatisfação e insegurança ante os possíveis impactos causados pela construção da barragem coloca em xeque o seu modo de viver. Essa situação, de fato, corresponde a um dos principais fatores de mobilização coletiva.

Outro elemento explicativo de mobilização e organização dos atingidos por barragens vai ao encontro da conceituação de Sidney Tarrow, que 
define como "estrutura de oportunidades políticas" (EOP). Esse conceito visa compreender como as demandas de grupo são manifestadas diante de um cenário oportuno, que dá origem a confrontos políticos. Sustenta que "o confronto político surge como uma reação a mudanças nas oportunidades e restrições políticas em que os participantes reagem a uma variedade de incentivos: materiais e ideológicos, partidários ou baseados no grupo, de longa duração ou episódicos" (TARROW, 2009, p. 38).

No entanto, em um cenário de oportunidades não significa, necessariamente, que confrontos políticos possam ocorrer. Mesmo diante das demandas dos grupos serem pontuais ou estruturais, há que distinguir-se "potencial de mobilização" de "ação de fato". O primeiro representa o estado de latência do confronto, ao passo que o segundo representa a mobilização efetiva que o promove. Nesse sentido, Tarrow apresenta cinco aspectos em que se percebe como essa passagem de potencial em ação pode acontecer: "1) abertura do acesso à participação para novos atores; 2) evidência de realinhamento político no interior do sistema; 3 ) presença de aliados influentes; 4) divisões emergentes no interior da elite; 5) declínio na capacidade do estado de reprimir dissidências" (TARROW, 2009, p. 105).

Em relação ao movimento dos atingidos por barragens (MAB), tema empírico de nossa análise, Rothman (1996) apresenta um estudo importante na perspectiva das EOPs. Sem restringir-se ao arcabouço analítico da escola norte-americana, $\mathrm{o}$ autor apresenta pontos que contribuem para o entendimento de como o MAB passou de latência para a ação de fato num cenário de oportunidades para ações efetivas. Depois de apresentar pontualmente os itens sugeridos por Tarrow (2009) e enriquecidos com apontamentos de ordem geopolítica e social específicos à bacia do Uruguai, Rothman (1996, p. 117) sintetiza a análise das oportunidades políticas da seguinte forma:

No período 1979-83 abriu-se uma estrutura de oportunidades favorável e crescente: a abertura política do regime civil-militar permitiu 
o acesso progressivo de atores antes impossibilitados de ingressar no sistema político; a fragmentação das elites enfraqueceu a posição dos grupos dominantes; a tendência ao uso de repressão pelo regime militar mostrou sinais de enfraquecimento; grupos populares - livres da tutela dos partidos 'populistas' - desenvolveram formas mais autônomas de organização; e vários movimentos populares se reforçaram na fase crescente do ciclo de protesto, dentre eles organizações coletivas que culminaram na formação do Movimento dos Trabalhadores Rurais Sem Terra (MST) e do próprio MAB.

É fundamental percebermos como esse cenário de oportunidades consiste em um dos fatores de explicação da mobilização social, que, com o tempo, culminou na criação do MAB. Além da identificação da estrutura de oportunidades quando da criação do $\mathrm{MAB}$, a análise de Rothman chama a atenção para outro fator importante: a ideia de "ciclos de protesto", que serão abordados com a denominação dada por Tarrow (2009), "ciclos de confrontos".

Os ciclos de confrontos são condicionados pelos cenários de oportunidade e restrição política. Um ciclo é notabilizado por um ou mais eventos de culminância que ajuda a catalisar os elementos dispersos, porém interligados ao longo do processo social que corresponda ao ciclo. Tarrow apresenta a definição do termo como "uma fase de conflito acentuado que atravessa um sistema social”. E, na sequência, acrescenta elementos constituintes do ciclo, como "uma rápida difusão da ação coletiva de setores mais mobilizados para outros menos mobilizados", "criação de quadros interpretativos $^{3}$ de ação coletiva, novos ou transformados", "combinação de participação organizada e não organizada", capacidade de produzir “externalidades que dão aos desafiantes ao menos uma vantagem temporária e permite que superem a fraqueza na sua base de recursos", faz com que o Estado "monte amplas estratégias de reação repressivas ou facilitadoras,

3 Para Benford e Snow (2000), o processo de enquadramento (framing process) consiste em uma "batalha interpretativa" travada pelos movimentos sociais contra seus opositores na definição do próprio conflito e da justiça/legitimidade das posições em disputa. São formas de interpretar a realidade que obedecem a determinados princípios e se confrontam na esfera pública em disputa pela "veracidade" dos processos sociais em questão. 
ou uma combinação de ambas" e, por último, um ciclo de confronto "produz resultados gerais que são mais do que a soma dos resultados de um agregado de eventos desconectados" (TARROW, 2009, p. 182).

Exemplos que combinam esses elementos podem ser identificados na Revolução Francesa de 1789 e nos movimentos de maio de 1968, ambos na França (TARROW, 2009).

A questão geográfica pode ser um fator facilitador da expansão de um ciclo, como as revoluções de 1848 na Europa ou, mesmo, transcendê-la, como a oposição à guerra do Vietnã nos Estados Unidos. O autor apresenta uma série de ciclos que podem ser melhor estudados no que se refere à condição de continuidade ou novidade na relação entre eles. É importante destacar que, ao analisar um ciclo e seus desdobramentos, é necessário atenção para não considerá-lo “apenas como um 'contágio’ da ação coletiva para grupos similares e que fazem as mesmas reivindicações a opositores equivalentes". O autor assinala como característica importante para a análise a "difusão da propensão à ação coletiva" (TARROW, 2009, p. 186).

O título do livro 1968: o ano que não terminou, do jornalista Zuenir Ventura, ilustra um exemplo da relação entre ciclos de confrontos em diferentes partes do mundo, os quais têm ou podem ter relação dentro de um mesmo ciclo. Ventura (1988) apresenta várias crônicas sobre o período ditatorial brasileiro, com recorte temporal do ano de 1968, tendo como pano de fundo, porém, um ciclo que compreende desde a França até o Brasil na luz do ciclo de confrontos notabilizado pelos movimentos de maio de 1968. Restringindo a nossa análise ao caso brasileiro, os vinte anos entre 1968 e 1988 podem ser tomados como um ciclo de confrontos, que culminou no movimento das "Diretas Já" e, consequentemente, a abertura democrática. Nesse ciclo de confrontos está a questão das barragens, tendo como recorte espacial a bacia do rio Uruguai.

O relevo ondulado e o solo pedregoso dificultam a mecanização agrícola nessa bacia. A ocupação do espaço e o modo de vida condizem com tal configuração geográfica já que os agricultores têm na unidade 
familiar a pluriatividade e a reciprocidade, bases da organização da vida social. Esses elementos fundamentam as palavras de Piran (2001) quando define o Alto Uruguai como "um lugar para a agricultura familiar". A partir da configuração geográfica e social da região foi estruturado um parque agroindustrial que, atualmente, é referência mundial em produtos derivados de suínos e aves. No entanto, paralelo a esse desenvolvimento econômico, consideraram-se os reflexos da intensificação dessa atividade no viés social sobre o qual indagamos que desde que os agricultores familiares passaram a desenvolver a suinocultura e a avicultura, através do sistema de integração com as empresas, mesmo que tenham garantido o mercado para o seu produto, isso se deu por meio da relativa perda da autonomia dos que passaram a trabalhar sob as orientações das empresas, tendo que acompanhar um ritmo de modernização de produção em vista da competitividade do mercado.

A agroindústria regional é um elemento importante para o registro histórico que se entende estar diretamente relacionado à questão hidrelétrica. Preponderante na economia a partir do final do século XIX, a crise que a suinocultura atravessou na década de 1970 refletiu de forma importante no contexto político regional. Foi deflagrada pela suposta contaminação dos suínos, a chamada "peste suína africana”, que poderia espalhar-se por todo o país. Diante dessa suspeita, a partir de setembro de 1978, as propriedades identificadas eram interditadas, e os suínos exterminados por pelotões do Exército (POLI, 1999, p. 68).

O evento que envolveu a suinocultura, principal atividade econômica, significou um duro golpe para os pequenos produtores, levantando suspeitas de que tal doença e os decorrentes abatimentos eram parte de uma estratégia das empresas interessadas em debilitar a produção autônoma de suínos no intuito de controlar o mercado na região. A partir da mediação de setores da Igreja (CPT) e do Sindicato de Trabalhadores Rurais (STR), foi feita uma intensa mobilização social que culminou com uma manifestação com mais de vinte mil pessoas na cidade de Chapecó-SC, 
em outubro de 1979, em protesto contra as condições de produção do setor e principalmente contra o que ficou conhecido como a "farsa da peste suína africana" (POLI, 1999, p. 70).

A mobilização social diante dessa questão levou, aos poucos, à diminuição dos abatimentos. Do episódio, o certo é que não ficou comprovada a existência ou o alcance da doença, mas não mudou o fato de que os abatimentos compulsórios tenham prejudicado os pequenos produtores. $\mathrm{O}$ registro desse evento é importante, pois aconteceu na mesma época em que a Eletrosul publicou um estudo do inventário hidrelétrico da bacia do rio Uruguai (outubro de 1979) prevendo a construção de 22 usinas hidrelétricas. Isso significava que grandes áreas de terra seriam inundadas na região. As construções das hidrelétricas de Machadinho e Itá seriam as primeiras a se concretizarem e, diante disso, além do problema do abatimento dos suínos, sobraria para os agricultores familiares locais a ameaça de expropriação.

O estudo realizado pela Eletrosul foi levado ao conhecimento da opinião pública pela ação de grupos que também militavam no contexto nacional da ditadura militar, como igrejas, sindicatos e universidades. No caso da bacia do rio Uruguai, segmentos da Igreja Católica, Igreja Evangélica de Confissão Luterana no Brasil (IECLB), alguns sindicatos de trabalhadores rurais e a Fundação Alto Uruguai para a Pesquisa e o Ensino Superior (Fapes) de Erechim-RS, atual Universidade Regional Integrada (URI), foram os principais mediadores nessa questão desde o plano teórico até a mobilização da população atingida.

Quando das primeiras ações na direção da organização de um movimento social coeso, há que retomarmos o cenário de oportunidade política que, se não determinava a eclosão de movimentos dessa natureza, favorecia a sua estruturação. Nesse contexto, o poder de repressão do Estado foi aos poucos diminuindo em relação ao auge do período militar. A Lei da Anistia, de agosto de 1979, permitiu a volta dos exilados políticos para o país, reforçando o ativismo nas diversas causas sociais. Em novembro do mesmo ano, o fim do bipartidarismo promoveu a divisão das elites 
acarretando o enfraquecimento das oligarquias locais. Em 1983, no Rio Grande do Sul, partidos de oposição na Assembleia Legislativa investigaram e publicaram um relatório sobre a questão das barragens, disponibilizando suas instalações para o "I Encontro estadual sobre a construção de barragens na bacia do rio Uruguai", reunindo diferentes segmentos sociais sobre a questão. Essa conjuntura política atrelada a eventos locais representou um ambiente favorável para a emergência de um movimento social ante o projeto da empresa hidrelétrica.

De acordo com McAdam, Tarrow e Tilly (2001), uma onda de protestos consumava-se a partir da combinação do surgimento de uma janela de estrutura de oportunidades políticas (EOP) com a própria capacidade de organização dos movimentos sociais, influenciada por uma série de fatores, dentre os quais os imperativos contextuais. Em suma, a organização dos atingidos por barragens na bacia do rio Uruguai foi possibilitada pela EOP, que se abriu pelo compartilhamento de uma indignação coletiva diante da ameaça da construção de barragens e pela capacidade de organização. No que diz respeito à organização coletiva, uma série de fatores foram cruciais, dentre os quais a capacidade de os atingidos se manterem mobilizados, de captarem recursos para sua organização e o papel desempenhado pelos mediadores, isto é, indivíduos e grupos que forneceram suporte material e simbólico para a incipiente mobilização dos atingidos por barragens.

Entre as ações mais expressivas dos mediadores, algumas merecem destaque: a atuação da Igreja Católica, que ocorreu por meio do recrutamento de participantes para o movimento social de setores da Igreja, como a Comissão Pastoral da Terra (CPT), a Pastoral da Juventude Rural (PJR) e o Ministério Eucarístico; as estações de rádios de Concórdia, Marcelino Ramos e Aratiba foram utilizadas; a disponibilidade de pessoal para a organização do movimento dos chamados "liberados". A IECLB serviu de canal de ligação entre os atingidos da bacia do rio Uruguai com outros locais, como Itaipu e Sobradinho, intermediou apoio financeiro na organização evangélica alemã Brot Fur die Welt (pão para o mundo), além de "liberar" 
pessoal para a organização do movimento social. A Fapes, além da pesquisa dos impactos socioeconômicos, importantes para a fundamentação da mobilização e organização em torno do problema, angariou recursos de duas ONGs: Comitê Católico Contra a Fome e Desenvolvimento (CCFD), da França, e Obra Episcopal da Igreja Católica da Alemanha para a Cooperação ao Desenvolvimento (Misereor), da Alemanha. Além dessas, foi importante a atuação do Sindicato de Trabalhadores Rurais (STR) na perspectiva de "sindicalismo combativo", uma vez que estabelecia uma ligação mais efetiva entre essas instituições e os trabalhadores rurais, bem como disponibilizava as estruturas físicas dos sindicatos para a organização do movimento social (ROTHMAN, 1996).

A evolução do movimento social aconteceu paralelamente à apresentação de novos projetos hidrelétricos por todo o Brasil. O plano 2010, elaborado pela Eletrobras, previa a construção de cerca de duzentas usinas hidrelétricas no país. Diante dessa estimativa, o movimento se articulou e, em março de 1991, na cidade de Brasília, realizou o "I Congresso Nacional dos Atingidos por Barragens", onde se oficializou o Movimento Nacional dos Atingidos por Barragens (MAB). A CRAB passou a responder pela $\mathrm{MAB} /$ Região Sul, embora continuasse organizada na estrutura apresentada anteriormente (comissões locais e regionais), a partir desse momento passou a responder pelo movimento nacional.

\section{A consolidação do movimento social: Itá e Machadinho (1985-2000)}

Na medida em que o movimento se consolidava, sua estrutura buscava adequar-se de maneira a abranger toda a bacia hidrográfica. Nesse momento o movimento social passa de uma estrutura de "serviço", com atuações pontuais a partir dos mediadores, para uma organização em 
forma de "movimento", ${ }^{4}$ sistematizando as ações e formando novos ativistas e lideranças (MORAES, 1996a; REIS, 2007). Nessa linha, em dezembro de 1983, foi instituída uma executiva regional para a liderança do movimento. Essa executiva compreendia: dois atingidos (base), dois componentes da comissão inicial (CR), um diretor de STR, um agente da CPT, além de assessores. Nesse momento, a "regional" correspondia apenas às áreas afetadas pelas duas primeiras hidrelétricas, UHE Machadinho e Itá, abrangendo apenas parte da bacia do rio Uruguai, onde era prevista a construção de 22 barragens.

Em março de 1984, a CRAB organizou um abaixo-assinado que reuniu 1.016.000 de assinaturas, deixando claro no cabeçalho do documento a sua posição de "não às barragens" (MORAES, 1996a). Em março de 1985 reuniram-se representantes de 24 municípios regionais na cidade de Erechim-RS com o objetivo de consolidar a atuação da Crab em toda a bacia. A partir dessa reunião, o movimento passou a contar com quatro comissões regionais: R1 - Machadinho e Itá; R2 - Itapiranga e Iraí; R3 Lages; R4 - Chapecó. Em 1986 foi acrescentada a R5 - Missões ou Garabi e Roncador. Com essa conformação, ampliou-se a área de atuação do Movimento na Bacia Hidrográfica, e a Crab foi legitimada como porta-voz dos atingidos. Em 23 de janeiro de 1986, através das portarias nº 86 e 87, o Ministério das Minas e Energia previu a participação de representantes do movimento em "grupos de trabalho" para a avaliação dos impactos na construção das hidrelétricas de Itá e Machadinho (MORAES, 1996a).

Em 29 de outubro de 1987, um acordo entre a CRAB e a Eletrosul (ratificando o documento PRE-692/86, de 7/10/1986) assegurava que "nenhuma obra" seria realizada "dentro dos rios sem prévia indenização ou reassentamento dos atingidos de cada barragem, Itá e Machadinho", além

4 Por "movimento social" entende-se e emprega-se a definição de Mario Diani (2000, p. 389) que compreende, genericamente, como "redes formais e informais de atores (organizações, grupos e indivíduos) engajadas em conflitos em torno de interesses materiais ou simbólicos, baseadas em identidades compartilhadas". 
de estabelecer que as famílias atingidas fossem compensadas mediante três alternativas:

terra por terra, mediante a apresentação de áreas quantas necessárias, preferencialmente na região, ou nos três Estados do sul, com características agrícolas e infraestrutura não inferiores às áreas atingidas; indenização por dinheiro com a participação dos atingidos na determinação dos preços das terras e benfeitorias;

garantia de participação em projetos de reassentamento para todos os sem-terra atingidos pelas barragens de Itá e Machadinho, em áreas dos três estados do sul, com características agrícolas e infraestrutura não inferiores às atingidas pelas barragens (MORAES, 1996a).

Os pontos desse acordo histórico podem ser percebidos nos "termos de acordo" firmados nas hidrelétricas subsequentes.

Em 1989, a Constituição estadual do Rio Grande do Sul previa a instituição de um grupo de trabalho com a participação de representantes da CRAB e de técnicos para a promoção de um "amplo debate público sobre o Projeto Energético Brasil ano 2001, suas repercussões para o Rio Grande do Sul e alternativas a sua Implantação" (MORAES, 1996a). A partir das portarias ministeriais, da Constituição estadual, da garantia de participação em grupos de trabalhos e do acordo com a Eletrosul, a CRAB firmava-se como representante legítima da causa na bacia hidrográfica do rio Uruguai.

Entre 19 e 21 de abril de 1989 ocorreu, em Goiânia-GO, o I Encontro Nacional dos Atingidos por Barragens, quando se decidiu pela organização do movimento em âmbito nacional. Em março de 1991, na cidade de Brasília, oficializou-se o Movimento dos Atingidos por Barragens (MAB) e, a partir de então, a nacionalização do movimento cujas ações se tornaram maiores e mais frequentes em todo o país. Entre 11 e 14 de março de 1997 ocorreu, em Curitiba-PR, o I Encontro Internacional de Atingidos por Barragens, envolvendo mais de vinte países. Nesse encontro, além de discussões em torno da luta contra as barragens, instituiu-se o dia 14 de março como Dia Internacional de Luta Contra as Barragens e pelos Rios, 
pela Água e pela Vida (ALMEIDA, 2004). Esse foi o processo de estruturação do $\mathrm{MAB}$ que, a partir da bacia do rio Uruguai, tomou proporções nacionais e internacionais, militando em cada nova hidrelétrica a ser instalada.

As duas primeiras hidrelétricas - Itá e Machadinho - começaram a ser instaladas em 1991 e 1996, entrando em operação em 2000 e 2001, respectivamente. Além de inaugurarem a exploração sistemática da bacia, essas duas obras representam marcos na estruturação e consolidação do MAB como movimento social antagônico. Em síntese, foi um momento de desinformação, incerteza, articulação e luta dos atingidos ante os projetos capitaneados pelo Estado brasileiro. Um aspecto importante desse período é o fato de que, a partir de 1997, o setor elétrico foi reestruturado, e esses projetos passaram a ser conduzidos pela iniciativa privada (SANTOS; NACKE, 2001; BOAMAR, 2003; ALMEIDA, 2004). Embora essa mudança tenha ocorrido no percurso da instalação, as indenizações e os reassentamentos, especialmente na de Itá, foram encaminhados ainda na gestão estatal. Porém, nas usinas subsequentes - UHE Quebra Queixo, Barra Grande, Campos Novos e Foz do Chapecó -, a mudança ficou mais evidente para os movimentos sociais. O novo cenário do setor elétrico trazia novos atores e estratégias que acentuaram a assimetria nas relações de poder inerentes à questão hidrelétrica (ROCHA, 2013). Um novo período começava para o movimento social.

\section{A privatização, os novos atores e as estratégias: Quebra Queixo, Barra Grande, Campos Novos e Foz do Chapecó (2000-2015)}

Como referimos na seção anterior, no período de instalação das duas primeiras hidrelétricas a mudança estrutural no setor elétrico mudaria drasticamente a relação entre os propositores das hidrelétricas e o movimento social. Ainda na década 1980, o neoliberalismo representava uma tendência mundial, capitaneada principalmente pelos governos Thatcher 
(Inglaterra), Reagan (Estados Unidos) e Pinochet (Chile). No Brasil, a abertura democrática e a eleição de Fernando Collor de Mello marcaram o início do processo no país. O Plano Nacional de Desestatização (PND), instituído pela Lei $\mathrm{n}^{\circ}$ 8.031, de 12 de abril de 1990, deu diretrizes básicas para a organização da economia em todos os setores. O neoliberalismo, enquanto tendência global, aconteceu de forma exemplar no Brasil, que teve o maior pacote de privatização do mundo. Entre os anos 1990 e 2002, dos $48,3 \%$ do capital estatal transferido para a esfera privada, $31 \%$ couberam ao setor de energia elétrica (GONÇALVES JR., 2007, p. 25).

$\mathrm{Na}$ esteira das privatizações, a Eletrosul, responsável pela hidreletricidade na bacia do rio Uruguai, foi dividida em duas partes: a Estatal, responsável pela transmissão de energia; a Gerasul (iniciativa privada), responsável pela geração de energia, assumindo todas as usinas hidrelétricas da Eletrosul em operação ou em projeto. Em 1998, essas hidrelétricas passariam para o controle da Tractebel Energia, uma empresa belga pertencente ao grupo GDF Suez S.A., originado na França.

O governo Fernando Henrique Cardoso sancionou a Lei no 8.987, de 13 de fevereiro de 1995, que dispõe sobre o regime de concessão e permissão da prestação de serviços públicos. Assim, ofereceu as linhas gerais para organização, tendo na Lei ${ }^{\circ}$ 9.074, de 7 de julho de 1995, as normas para a outorga e prorrogações das concessões e permissões específicas para o setor hidrelétrico. Na mesma linha, a Lei $n^{\circ} 9.427$, de 26 de dezembro de 1996, ao instituir a Agência Nacional de Energia Elétrica (Aneel), conferiu ao governo a postura de regulador do sistema hidrelétrico, visto que a agência foi criada com a finalidade de regular e fiscalizar a produção, transmissão, distribuição e comercialização da energia elétrica em conformidade com as políticas e diretrizes do governo federal.

A partir desse marco regulatório, o Estado assumiu definitivamente a condição de parceiro da iniciativa privada na instalação de hidrelétricas. No governo Lula isso foi ratificado através da Lei no 11.079, de 30 de dezembro de 2004, que estabelece as normas gerais para as parcerias 
público-privadas (PPP). Segundo a lei, os projetos de grande escala, como as hidrelétricas, passam a ser conduzidos por sociedades de propósitos específicos (SPE), que têm sua criação em razão da obra (usina) que pretendiam instalar e operar.

A primeira usina instalada integralmente com esse regulamento foi a UHE Quebra Queixo, no rio Chapecó, entre os municípios de Ipuaçu e São Domingos-SC. Embora de porte reduzido em relação às UHE Itá e Machadinho, a instalação dessa hidrelétrica assumiu os mesmos contornos dramáticos das outras. Todavia, aqueles que viam a obra como uma chance de prosperidade tiveram uma oportunidade também no que diz respeito à negociação. Segundo Baggio (2003), a UHE Quebra Queixo apresentou a mesma característica de "desinformação" que ajudou a inserir as hidrelétricas anteriores na bacia. Anteriormente, luta do MAB era contra o Estado, especialmente um Estado repressor, que negava o diálogo e expropriava os cidadãos. Nesse novo cenário de privatização, a "participação" dos atingidos seria "viabilizada" e "incentivada" pelos próprios propositores das obras.

A organização da Associação dos Atingidos pela Barragem do Quebra Queixo nos municípios de São Domingos e Ipuaçu (Asabsi) foi uma iniciativa de 16 pessoas da localidade que se uniram com o apoio dos propositores da usina para intermediar as negociações para facilitar no processo. Do ponto de vista das negociações, uma falha por parte da associação pode ser apontada: o fato de homologar na "Proposta de políticas e ações de remanejamento da população atingida pelo empreendimento" a possibilidade de reassentamento fora da região, conforme desejo manifestado pelos atingidos. O que acabou sendo acordado foi a tomada de preço e a consequente possibilidade de remanejamento populacional ampliada para o sudoeste do Paraná. Essa relativa distância do lugar de origem desmobilizou a opção por reassentamento. Já no processo de negociação, as reuniões entre atingidos e consórcio eram costumeiramente antecedidas por reuniões entre a associação e o consórcio de forma que 
as decisões já estariam tomadas a priori. Pode ser observado no processo de negociação que os casos apoiados pela associação tiveram um tratamento diferenciado por parte do consórcio em detrimento aos casos que não contavam com tal intermediação (BAGGIO, 2003, p. 64-68). Dessa forma, o papel da associação teve uma dupla função no processo. Além de favorecer a legitimidade do projeto, a associação comprometeu o protagonismo ocupado pelo MAB em casos anteriores. Através desse controle do fluxo de negociação (ROCHA, 2014), os consórcios passaram a fomentar a individualização do processo, o que consistiu numa maior inovação nas estratégias de negociação, cujo resultado foi o enfraquecimento da organização coletiva dos atingidos.

Outra hidrelétrica importante do período começou a ser instalada antes da Quebra Queixo e por sua envergadura e problemas ambientais só seria concluída posteriormente. A UHE Barra Grande foi instalada no rio Pelotas entre os municípios de Pinhal da Serra-RS e Anita Garibaldi-SC. Essa hidrelétrica ficou mundialmente conhecida pelo grave problema ambiental detectado durante a instalação. Ocorreu que o estudo de impacto ambiental e o consequente relatório de impacto ambiental (Eia-Rima) negligenciaram informações sobre uma área de 7.650 hectares de cobertura florestal primária (mata de araucária). Em estágios médios e avançados de regeneração, foi desqualificada como "capoeirão" e diminuída na extensão em que seria alagada (PROCHNOW, 2005, p. 6-7). Não obstante os problemas ambientais na perspectiva analisada por Zen (2005, p. 51), o caso de Barra Grande deu um "novo fôlego à luta pela moralização dos Estudos de Impacto Ambiental e à atuação dos órgãos ambientais oficiais que têm sido 'atropelados' pelo discurso de crescimento econômico e pela influência exercida pelo grande capital no governo Lula”. De fato, o que se viu nesse caso foi uma aproximação entre os atingidos, representados pelo MAB, organizações não governamentais (ONGs), especialmente da área ambiental, e a imprensa internacional, que passou a tratar o problema como exemplo de negligência ambiental. 
A de Barra Grande ofereceu ainda uma oportunidade de explicitar outro ponto importante desse período para o movimento social, ou seja, a chegada do Partido dos Trabalhadores (PT) ao governo federal. O cenário de oportunidade política que mencionamos nas seções anteriores compreendeu o processo em que as lutas populares se organizaram originando o PT e o MAB como braços de um mesmo corpo ideológico. Na do Alto Uruguai, as lideranças do MAB eram as mesmas que militavam no PT. Com a subida do partido ao governo, a relação entre o movimento social e o partido abriu canais de interlocução do movimento com a esfera político-estatal, porém essa relação seria tensionada. Em estudo sobre a UHE Barra Grande, Rossato (2008, p. 65) assinala que os "movimentos sociais, entre os quais o $\mathrm{MAB}$, desacreditavam a via partidária como instrumento político para a condução da nação". Isso fica evidente em casos em que as lideranças do movimento manifestam certo incômodo diante da contradição que enfrentaram ao fazer campanha política para o mesmo partido, que, muitas vezes, enquanto governo, promoveu a instalação de hidrelétricas na região. Dessa forma, o MAB distanciou-se sensivelmente do PT e passou a atuar alinhado à Via Campesina, ${ }^{5}$ da qual era membro desde 1998.

A aproximação com o campesinato reforçou a principal forma de luta do movimento dos atingidos por barragens: a "pressão popular" (MAB, 2008, p. 27). Tanto que as ações de mobilização social, como passeatas, acampamentos nas vias de acesso e ocupação de canteiros de obras das barragens, podem ser percebidas nos diferentes locais de conflito. Em resposta a esses movimentos de pressão popular, pode-se dizer que a estratégia da criminalização, que não é recente na história do Brasil, assumiu uma nova roupagem no contexto neoliberal. Essa estratégia procurou

5 A Via Campesina surge em abril de 1992 a partir de uma reunião de dirigentes camponeses de vários países em Manágua, na Nicarágua, quando da realização do Congresso da União Nacional de Agricultores e Pecuaristas. Desse encontro surge a organização internacional composta por movimentos sociais e organizações de todo o mundo. A Via Campesina coordena e visa articular os processos de mobilização social de organizações camponesas de pequenos e médios agricultores, trabalhadores agrícolas, mulheres camponesas e comunidades originárias da Ásia, África, América e Europa em nível internacional. 
enquadrar as ações do movimento social como "crimes", entre os quais "dano", "esbulho possessório", "furto simples e qualificado", "sequestro e cárcere privado", "formação de quadrilha", "incitação ao crime" e "apologia ao crime", tudo previsto no Código Penal Brasileiro (MNDH, 2006, p. 14-15). Referindo-se às ações que foram movidas contra militantes do MAB por ocasião de movimentos de resistência na bacia do rio Uruguai, o Anexo III de um relatório produzido pelo $\mathrm{MAB}$ menciona, além do que já foi relacionado, acusações de natureza criminal, como dano ao patrimônio particular, invasão de áreas de segurança nacional, descumprimento de decisão judicial, crime contra a liberdade do trabalho, ameaça aos funcionários das empresas, destruição de marcos das barragens, roubo de bens nos canteiros de obras, obstrução de vias públicas, perturbação do sossego público, extorsão, lesões corporais, constrangimento ilegal e vias de fato. Já na vara cível, o mesmo documento apresentava ações de reintegração de posse, obrigação de não fazer, interdito proibitório, cautelar inominada e de indenização (MAB, 2005).

Nesse cenário de pressão popular e consequente criminalização dos movimentos sociais é exemplar o caso da UHE Campos Novos, instalada no rio Canoas, entre os municípios catarinenses de Campos Novos e Celso Ramos. O processo de instalação dessa hidrelétrica deu-se entre 1996 e 2006, a partir do que podemos estabelecer um paralelo com os casos mencionados anteriormente, sobretudo na questão da criminalização dos movimentos sociais. Analisando esse caso de Campos Novos, Zen (2005) relata que em março de 2005 foi decretada a prisão preventiva de dez lideranças do MAB sob a justificativa de "evitar a realização de manifestações por ocasião do 14 de março, Dia Internacional de Luta Contra as Barragens e também, do 22 de março, quando se comemora o Dia Internacional da Água”, conforme relatado no início deste capítulo. O mandado de prisão foi cumprido na madrugada do dia 12 de março de 2005, quando foram presos cinco pequenos agricultores e apreendidos "dezesseis veículos [...] utilizados para o cometimento de ilícitos", segundo a Promotoria (ZEN, 2005). 
Segundo o autor, a ação policial chamou a atenção pela quantidade de efetivo e equipamentos mobilizados. Os atingidos não presos naquela ocasião o foram nos dias seguintes, quando se apresentaram; outros se tornaram foragidos da justiça. Os agricultores presos foram encaminhados para o Presídio Regional, onde ficaram 23 dias, quando tiveram as prisões revogadas após declararem que não pretendiam promover atos contra a ordem pública. Ainda segundo o autor, "para 36 atingidos processados em ações criminais, são pedidas penas que vão de um a 30 anos de prisão por participarem do movimento e nove pessoas respondem a ação onde se pede indenização de R 1 milhão de reais por danos na usina de Campos Novos", ações estendidas aos apoiadores do MAB e tipificadas conforme as categorias já relatadas. Por outro lado, o autor ressalta que 237 famílias que participaram de alguma forma de pressão popular na hidrelétrica de Campos Novos tiveram reconhecidos direitos até então negados pelos propositores da obra (ZEN, 2005).

A criminalização dos movimentos sociais na UHE Campos Novos ilustra outro aspecto do período de privatização. A pressão popular ainda tem se mostrado a mais eficaz estratégia de conquista de demandas negadas pelos consórcios. Todavia, a criminalização funciona como forma de manchar a imagem do MAB perante a opinião pública, ao passo que age individualmente estigmatizando aqueles atingidos que assumem essas estratégias de pressão. Para além da criminalização, outra estratégia semelhante é a "judicialização" da questão hidrelétrica, aspecto que trataremos utilizando como pano de fundo o caso da UHE Foz do Chapecó, que teve seu processo de instalação no rio Uruguai, entre os anos entre 2001 e 2010, nos municípios de Alpestre-RS e Águas de Chapecó-SC. Essa hidrelétrica apresentou aspectos identificados também em outros casos, conforme referidos anteriormente. Perseguindo o objetivo do nosso trabalho, trataremos da questão da judicialização da UHE Foz do Chapecó, onde se destacam ações civis individuais e ação civil pública. 
Assim, como aconteceu nas outras hidrelétricas, firmou-se um termo de acordo entre o consórcio e uma associação representante dos atingidos. Nos casos em que determinadas famílias atingidas não concordassem com os valores ofertados pelas suas propriedades, teriam o direito de mover ações civis individuais contra o consórcio para que os valores fossem revistos. Na maioria dos casos, o consórcio lançou mão do depósito judicial, depositando a quantia que entendesse ser o valor justo para a indenização, enquanto o processo seguia o trâmite normal. Nessa modalidade ocorreu um confronto envolvendo o grupo de empresas privadas e estatais, com um amplo corpo jurídico e recursos financeiros para manter a disputa judicial por longo tempo contra uma família que detinha uma pequena área de terra, única fonte de sustento - quando não arrendatários ou agregados. Isso significa que essas famílias tinham pressa na solução da questão, pois disso dependia o seu sustento. Conhecedores da realidade desses processos, as empresas lançaram mão de estratégias de postergação da questão, que, ao final, forçavam as famílias a aceitarem um acordo com o consórcio por não terem recursos, nem tempo para estender a disputa na área judicial.

Além do ingresso individual na justiça para rever suas demandas, os atingidos tinham a possibilidade da ação civil pública. Na UHE Foz do Chapecó, foi movida uma ação civil pública tendo como réus o consórcio responsável pela obra e o Instituto Brasileiro do Meio Ambiente e dos Recursos Naturais Renováveis (Ibama), enquanto órgão licenciador. A ação suscitava três demandas principais: a proposta de construção de um canal artificial lateral para favorecer a piracema, baseado no projeto da UHE Itaipu; a revisão da proposta de vazão remanescente para o trecho a jusante da barragem, principalmente na parte entre o barramento e a casa de força (Volta Grande); a supressão de 100\% da vegetação de maior porte da área a ser alagada pelo reservatório da usina hidrelétrica, já que o consórcio, com o aval do Ibama, retirou apenas parte da vegetação. A emissão da licença de operação chegou a ser suspensa por conta da ação, todavia o consórcio recorreu ao Superior Tribunal de Justiça (STJ) com o 
apoio do Ibama, da Advocacia-Geral da União (AGU) e da Agência Nacional de Energia Elétrica (Aneel).

Como resultado dessa mobilização, o relator do processo no Superior Tribunal de Justiça (STJ) baseou-se em jurisprudência para fundamentar o argumento de que "a alegação de risco ao meio ambiente, deduzida no regimental, não fragiliza, diante dos elementos contidos nos autos, a ideia de que a paralisação do projeto de construção de usinas hidrelétricas, neste momento, poderá causar grave risco de prejuízos à ordem e à economia pública”. Foi reforçado pela continuação da obra por compor "um projeto maior, envolvendo a construção de outras usinas hidrelétricas, revela-se de extrema importância para a população brasileira, que vem crescendo a cada dia", fazia-se necessário o incremento da infraestrutura. O relator decidiu pela suspensão da liminar, "sobretudo, pelo fato de o órgão ambiental competente postular, mediante argumentos técnicos fortes, a continuidade do empreendimento", além do que, do ponto de vista econômico, "a liminar ora impugnada poderá causar grave lesão aos bens juridicamente tutelados pela lei de regência, cabendo o acolhimento da pretensão deduzida pelo IBAMA" (BRASIL/STJ, 2010).

Analisando os argumentos da decisão, percebemos que os julgamentos de casos específicos são feitos a partir de uma perspectiva macro sobre uma iminente crise energética que estaria sendo prevenida por meio de um plano que não podia ter o seu conjunto "prejudicado" por casos isolados. Depois, em que pese o meio ambiente e a economia, tende a prevalecer o segundo, com base no fato de que o atual nível de degradação do primeiro não chegaria a justificar a revisão do segundo, pelo menos por enquanto. Independentemente do resultado, é digno de nota que desde o início da ação civil pública (18 de junho de 2010) até a decisão em última instância (25 de agosto de 2010) passaram-se 61 dias. Considerando a sobrecarga de trabalho do Judiciário, essa agilidade é louvável, estabelecendo um comparativo com as ações individuais movidas pelos atingidos. É desalentador constatar que enquanto a primeira percorreu todas as 
instâncias em dois meses, as anteriores chegam a ultrapassar uma década, favorecendo ao consórcio propositor da obra em detrimento das famílias atingidas. De qualquer forma, com a decisão do STJ, o Ibama emitiu a licença de operação autorizando o funcionamento de mais uma hidrelétrica na bacia do Uruguai.

Constatamos que, a partir da década de 1990 até a metade da década de 2010, a relação entre atingidos e esfera político-estatal teve uma nova configuração, principalmente em razão da entrada do capital privado internacional no ramo energético, o que colocou novos e poderosos agentes na arena. Mesmo o PT, aliado histórico do MAB desde 2003, tendo ocupado a Presidência da República, não traduziu as políticas efetivas de proteção aos atingidos por barragens, sobretudo quando do lançamento do Programa de Aceleração do Crescimento (PAC) ${ }^{6}$ durante o primeiro governo Dilma (2010-2014), que fomentou o aumento da produção hidrelétrica no país a partir da construção de novas UHEs.

\section{Crescimento e difusão do MAB até 2015}

Até aqui acompanhamos de maneira detalhada a trajetória do MAB desde sua fundação. Nesta seção, exploramos de maneira analítica os intercursos dessa trajetória, dando ênfase às condições que possibilitaram ao movimento crescer e expandir-se. De forma mais ou menos comum a outros movimentos sociais, o MAB estrutura-se, cresce e difunde-se ao longo das últimas quatro décadas a partir do desencadeamento de uma série de processos articulados entre si. Eles dizem respeito, basicamente, à capacidade de os próprios militantes manterem o movimento em constante mobilização e à sua habilidade de aproveitar fatores externos, como a abertura de oportunidades políticas e o estabelecimento de relações externas

6 Com o PAC o governo federal previa o investimento de cerca de R 83 bi na construção de novas usinas hidrelétricas até 2017, sobretudo nas regiões Sul e Norte do país. Informação disponível em: <http://www.brasil.gov.br/cop/ panorama/o-que-o-brasil-esta-fazendo/matriz-energetica/print>. Acesso em: 20 fev. 2016. 
com redes de apoio. Essas dimensões de processos se combinam ao longo do tempo e se evidenciam na trajetória do movimento.

Sobre o aproveitamento de uma EOP, vimos como o contexto de abertura política favoreceu não somente a organização dos atingidos, como também a uma série de outros movimentos sociais que se articularam entre si e criaram um campo de movimentos sociais no país a partir da década de 1980 (GOHN, 1997). A mobilização dos atingidos por barragens aproveita a abertura política para sua formação e, posteriormente, vale-se de uma série de outras oportunidades por meio das quais estabelece relações com a esfera político-estatal. Por outro lado, a consolidação do movimento é fruto da conjunção entre fatores "externos" e "internos", dentre os quais a capacidade dos atingidos de prover a sustentação de sua organização.

Ao longo da história do MAB, percebemos os seguintes mecanismos de conformação do movimento: a) mediação - capacidade de estabelecer relações com indivíduos e grupos ${ }^{7}$ que possibilitam acessar espaços institucionais e demais redes pelas quais o movimento consegue angariar recursos e/ou ter suas demandas atendidas, ainda que parcialmente; b) captação de recursos - corresponde à capacidade de os atingidos acessarem recursos materiais que provenham da sustentação do movimento, os quais podem ser conseguidos a partir da própria contribuição dos atingidos e da relação com mediadores e parceiros que contribuem com o movimento ou lhes abrem espaços para que possam alcançá-los, como instituições religiosas, centrais sindicais e instituições de ensino; c) formação de redes de apoio - diz respeito ao estabelecimento de relações com movimentos sociais, centrais sindicais, partidos políticos, organizações não governamentais (ONGs) e outras entidades com as quais o MAB forma um bloco de unidade permanente ou momentâneo para ações políticas conjuntas. Esses mecanismos têm por objetivo o fortalecimento mútuo de organizações que compartilham de um projeto político comum. O Movimento

7 O Partido dos Trabalhadores (PT) é um histórico mediador do MAB. 
dos Trabalhadores Rurais Sem Terra (MST) e demais movimentos sociais componentes da Via Campesina e eventuais parceiros de mobilizações locais são exemplos.

Essas ações, somadas ao aproveitamento das EOPs, possibilitaram ao $\mathrm{MAB}$ crescer e difundir-se ao longo das últimas décadas. Vimos nas primeiras seções o quanto a mediação de entidades vinculadas às igrejas Católica e Protestante foi importante para que a então CRAB conseguisse dar seus primeiros passos e aos poucos lograsse sustentar-se, assim como, num momento seguinte, os sindicatos de trabalhadores rurais cumpriram o mesmo papel. A partir de 1991, quando a CRAB passou a denominar-se $\mathrm{MAB}$ e atuar em todas as regiões do país, os atingidos por barragens alcançam um novo patamar de mobilização e, se por um lado, dispõem de um movimento social mais estruturado e autônomo, por outro, o novo nível de atuação exige maior capacidade de captar recursos e acessar novas redes de apoio.

Outra dimensão importante de transformação do MAB ao longo do tempo diz respeito à questão discursiva ou simbólica. Da incipiente mobilização de colonos na bacia do rio Uruguai ao movimento articulado nacionalmente e que congrega em suas fileiras uma gama de categorias sociais de atingidos, o MAB foi passando por transformações internas que se traduzem na diversificação de demandas ao longo do tempo. De um movimento que reivindicava questões pontuais, como "não às barragens" e "águas para a vida e não para a morte", o MAB passou a articular-se discursivamente em torno de questões como um novo modelo energético, representado pelo slogan "água e energia não são mercadorias". A qualificação discursiva pela qual passa o MAB é indicativa do crescimento do movimento e da inserção em novas arenas de disputas.

O confronto simbólico intensifica-se na medida em que os opositores do movimento reforçam sua criminalização. Quando a criminalização se torna latente, o movimento é desafiado a justificar suas ações perante a opinião pública. Dessa forma, o movimento é instigado a disputar a 
veracidade dos fatos com seus opositores e ambos passam a enquadrar a realidade de acordo com seus sensos de justiça, interesses e, sobretudo, a partir de sua experiência diante do fenômeno social, a construção de barragens. Como os atingidos têm uma experiência fundamentalmente negativa em relação ao acontecimento, que coloca em xeque seus modos de vida, o MAB passa a questionar a correlação direta estabelecida por seus opositores entre produção de energia e desenvolvimento econômico e social. Portanto, as transformações estruturais e discursivas pela qual passa o movimento ao longo do tempo são o resultado de processos históricos que unem a conformação de eventos conjunturais - as EOPs - com a capacidade dos atingidos de se organizarem coletivamente.

Essa transformação possibilita ao movimento atingir um raio maior de atuação, aumentando seu poder de influência política ante os atingidos e ator capaz de confrontar com maior fôlego o Estado e consórcios privados. Todavia, o crescimento e a difusão não se concretizam sem tensões internas. Refletem-se na exigência cada vez maior de que parte dos atingidos se especializa e possa confrontar discursivamente seus opositores, já que passam a influenciar esferas de decisão mais abrangentes. O crescimento e a expansão do movimento provocam também a complexificação das redes internas, o que acarreta diferenciações internas e, geralmente, distanciamento entre lideranças e militantes de base. Em relação ao MAB, isso se expressa quando o movimento funda sedes em centros urbanos, como Porto Alegre, Brasília e São Paulo, onde lideranças ligadas à direção nacional do movimento se dedicam a questões macroestruturais do movimento e à formação de alianças. Por sua vez, lideranças locais e militantes de base ficam responsáveis por organizar o movimento no plano micro.

A especialização de quadros militantes, o distanciamento e a hierarquização do movimento, todavia, acabam por configurar-se numa exigência do crescimento e da difusão da organização coletiva. À medida que o movimento amplia os horizontes, sua capacidade de ação se firma; por outro lado, sua manutenção passa a exigir maiores esforços. Trata-se de 
um paradoxo enfrentado por, praticamente, todos os movimentos sociais que logram transcender suas fronteiras originais. De acordo com o que vimos ao longo do debate proposto neste capítulo, a estruturação da mobilização e a organização dos atingidos por barragens, assim como uma série de outros movimentos sociais ao longo da história, não são possíveis somente a partir do voluntarismo de seus militantes. Somado à capacidade de mobilização e organização, é necessário que uma estrutura de oportunidades políticas esteja madura para que os movimentos sociais possam desempenhar seu papel.

Sem embargo, um movimento social solidamente articulado é capaz de resistir com maiores chances de êxito diante de um cenário adverso, tal como o MAB enfrentou durante a década de 1990 os impactos das privatizações no setor elétrico. A segunda metade da década de 2010 apresenta novos desafios ao movimento, observando a queda de aliados políticos importantes com a consolidação do golpe institucional, refletidos na impunidade após um ano do desastre de Mariana, quando em novembro de 2015 centenas de famílias foram atingidas pelo rompimento de uma barragem de mineração na cidade mineira. Entretanto, se as EOPs são cruciais na definição das possibilidades de sucesso de um movimento social, não é o único fator determinante. $\mathrm{O}$ fechamento de uma janela de oportunidades políticas impõe dificuldades importantes aos movimentos sociais, mas é justamente nesse momento que a capacidade de mobilização e coesão interna possibilita resistir para que na abertura do próximo ciclo de oportunidades possa avançar na conquista de suas demandas.

\section{REFERÊNCIAS}

ALMEIDA, Alvenir Antonio de. As usinas hidrelétricas e os atingidos da bacia do Rio Uruguai: intenções entrecruzadas. Dissertação (Mestrado) - Programa de Pós-Graduação em História da Universidade de Passo Fundo, 2004. 
BAGGIO, Elaine Regina. Aspectos sobre a reprodução socioeconômica das unidades familiares rurais atingidas pela usina hidrelétrica Quebra Queixo. Dissertação (Mestrado) - Centro de Ciências Agrárias da UFSC, 2003.

BENFORD, Robert D. Master frame. In: SNOW, David A. et al. The WileyBlackwell Encyclopedia of Social and Political Movements. Blackwell Publishing, 2013. p. 1-2.

BERGAMASCO, Sônia Maria; NORDER, Luiz Antônio Cabello. O que são reassentamentos rurais. São Paulo: Brasiliense, 1996.

BOAMAR, Paulo Fernando de Azambuja. A implantação de empreendimentos hidroelétricos: o caso da UHE de Machadinho. Dissertação (Mestrado) - Programa de Pós-Graduação em Engenharia de Produção da UFSC. Florianópolis, 2003.

BRASIL. Superior Tribunal de Justiça-STJ. Voto do relator do processo de suspensão de liminar e de sentença $n^{\circ}$ 001270. Data da Publicação: DJ $27 / 08 / 2010$.

BRITO, Sebastião Berlinck. A Celesc: da instalação aos dias atuais. In: SANTOS, Sílvio Coelho dos; REIS, Maria José (Org.). Memória do setor elétrico na região Sul. Florianópolis: UFSC, 2002. p. 167-183.

CANALI, Gilberto Valente. A definição e a importância do projeto Uruguai. In: SANTOS, Sílvio Coelho dos; REIS, Maria José (Org.). Memória do setor elétrico na região Sul. Florianópolis: UFSC, 2002. p. 111-129.

CENTRO DA MEMÓRIA da Eletricidade no Brasil. Panorama do setor de energia elétrica no Brasil. Rio de Janeiro: Centro da Memória da Eletricidade no Brasil, 1988.

. Notas sobre racionamento de energia elétrica no Brasil (1940-1980). Rio de Janeiro: Centro da Memória da Eletricidade no Brasil, 1996.

DIANI, Mario. Social movement networks virtual and real. Information, Communication \& Society, Taylor \& Francis, v. 3, p. 386-401, 2000.

ELETROSUL. Bacia hidrográfica do rio Uruguai: estudo de inventário hidroenergético. [s. 1.]: Eletrosul, CNEC, 1979.

FEARNSIDE, Philip. Impactos ambientais da barragem de Tucuruí: lições ainda não aprendidas para o desenvolvimento hidrelétrico na Amazônia. Manaus: Instituto Nacional de Pesquisas da Amazônia, 2002. 
FERRET, Luis Airton. A CEEE e sua trajetória histórica. In: SANTOS, Sílvio Coelho dos; REIS, Maria José (Org.). Memória do setor elétrico na região Sul. Florianópolis: UFSC, 2002. p. 147-166.

GERMANI, Guiomar Inez. Expropriados. Terra e água: o conflito de Itaipu. Salvador: Edufba; Ulbra, 2003.

GOHN, Maria da Glória. Teoria dos movimentos sociais: paradigmas clássicos e contemporâneos. São Paulo: Loyola, 1997.

GONÇALVES JUNIOR, Dorival. Reformas na indústria elétrica brasileira: a disputa pelas "fontes" e o controle dos excedentes. Tese (Doutorado) Programa Interunidades de Pós-Graduação em Energia da Universidade de São Paulo (EPUSP - FEA - IEE - IF/USP). São Paulo, 2007.

JASPER, James; GOODWIN, Jeff; POLLETTA, Francesca. Passionate politics. Chicago: University of Chicago Press, 2001.

LIMA, José Luiz; BARBALHO, Arnaldo Rodrigues; CARVALHO, José Marcondes Brito de. A trajetória do setor de energia elétrica na década de 1970. In: CMEB. Ciclo de palestras: a Eletrobras e a história do setor de energia elétrica no Brasil. Rio de Janeiro: Centro da Memória da Eletricidade no Brasil, 1995. p. 163-219.

LIMA, José Luiz; PENNA, João Camilo; CAMOZZATO, Izaltino. A trajetória do setor de energia elétrica na década de 1980. In: CMEB. Ciclo de palestras: a Eletrobras e a história do setor de energia elétrica no Brasil. Rio de Janeiro: Centro da Memória da Eletricidade no Brasil, 1995. p. 221-262.

MAGALHÃES, Sônia Barbosa. Lamento e dor. Uma análise socioantropológica do deslocamento compulsório provocado pela construção de barragens. Tese (Doutorado) - Programa de Pós-Graduação em Ciências Sociais da Universidade Federal do Pará em co-tutela com a École Doctorale Vivant et Sócietés da Universidade Paris, 13. Belém: UFPA, 2007.

McADAM, Doug; TARROW, Sidney; TILLY, Charles. Dynamics of Contention. New York and Cambridge: Cambridge University Press, 2001.

McCARTHY, John D.; ZALD, Mayer N. Resource mobilization and social movements: a partial theory. The American Journal of Sociology, v. 82, n. 6, p. 1212-1241, May 1977.

MORAES, Maria Stela Marcondes de. No rastro das águas: pedagogia do movimento dos atingidos pelas barragens da bacia do rio Uruguai (RS/SC) - 1978-1990. Tese (Doutorado) - Departamento de Educação, PUCRJ, 1994. 
. No rastro das águas: organização, liderança e representatividade dos atingidos por barragens. In: NAVARRO, Zander (Org.). Política, protesto e cidadania no campo: as lutas sociais dos colonos e trabalhadores rurais no Rio Grande do Sul. Porto Alegre: UFRGS, 1996.

. O movimento dos atingidos pelas barragens da bacia do rio Uruguai e a ação político-educativa dos mediadores. Revista Brasileira de Educação, n. 1, p. 80-92, 1996a.

MOVIMENTODOS ATINGIDOS PORBARRAGENS(MAB). Criminalização contra os defensores de direitos humanos na implantação de hidrelétricas na bacia do rio Uruguai. Brasília, 2005. (Relatório).

A luta dos atingidos por barragens contra as transnacionais, pelos direitos e por soberania energética. São Paulo-SP, 2008. (Cartilha).

MOVIMENTO NACIONAL DE DIREITOS HUMANOS (MNDH). A criminalização dos movimentos sociais no Brasil: relatório de casos exemplares. Organizado por Rosiana Pereira Queiroz. Brasília: MNDH; Passo Fundo: IFIBE, 2006.

OLSON, Mancur. A lógica da ação coletiva. São Paulo: Edusp, 1999.

POLI, Odilon Luiz. Leituras em movimentos sociais. Chapecó: Grifos, 1999.

PROCHNOW, Miriam. Entendendo o caso. In: PROCHNOW, Miriam (Org.). Barra Grande: a hidrelétrica que não viu a floresta. Rio do Sul: Apremavi, 2005. p. 6-8.

REIS, Maria José; BLOEMER, Neusa Maria Sens; NACKE, Aneliese. Empreendimentos pioneiros na produção de energia elétrica. In: SANTOS, Sílvio Coelho dos; REIS, Maria José (Org.). Memória do setor elétrico na região Sul. Florianópolis: UFSC, 2002. p. 31-76.

REIS, Maria José. O movimento dos atingidos por barragens: atores, estratégias de luta e conquistas. In: SEMINÁRIO NACIONAL NPMS/USC, II. Anais... Florianópolis-SC, 2007. p. 473-501.

ROCHA, Humberto José da. Relações de poder na instalação de hidrelétricas. Passo Fundo-RS: UPF, 2013.

- O controle do espaço-tempo nos processos de instalação de hidrelétricas. Tempo Social, São Paulo, v. 26, n. 1, p. 259-280, 2014. 
A criminalização dos movimentos sociais ante a instalação de uma hidrelétrica no rio Uruguai (Brasil): uma discussão entre o legal e o legítimo. Ideias, Campinas-SP, v. 8, n. 1, 2014a.

ROCHA, Humberto José da; GODOI, Emilia Pietrafesa de. Configuração social e suas implicações na negociação para a instalação da UHE Foz do Chapecó. In: REUNIÃO DE ANTROPOLOGIA DO MERCOSUL, IX. Anais... Curitiba-PR, 2011.

ROCHA, Humberto José da; TEDESCO, João Carlos. A judicialização da questão hidrelétrica no Brasil. In: CONGRESO ALAS, XXIX. Acta científica. Santiago-Chile, 2013.

ROSSATO, Alexania. A recepção de rádio e televisão por jovens do movimento dos atingidos por barragens: as representações da classe popular. Dissertação (Mestrado) - Programa de Pós-Graduação em Comunicação da UFSM. Santa Maria, 2008.

ROTHMAN, Franklin Daniel. A emergência do movimento dos atingidos pelas barragens da bacia do rio Uruguai (1979-1983). In: NAVARRO, Zander (Org.). Política, protesto e cidadania no campo: as lutas sociais dos colonos e trabalhadores rurais no Rio Grande do Sul. Porto Alegre: UFRGS, 1996.

SANTOS, Sílvio Coelho dos. A história da eletricidade no Sul. In: SANTOS, Sílvio Coelho dos; REIS, Maria José (Org.). Memória do setor elétrico na região Sul. Florianópolis: UFSC, 2002. p. 19-30.

. A Eletrobras e suas subsidiárias: projetos termo e hidrelétricos no Sul. In: SANTOS, Sílvio Coelho dos; REIS, Maria José (Org.). Memória do setor elétrico na região Sul. Florianópolis: UFSC, 2002a. p. 99-110.

SANTOS, Sílvio Coelho dos; NACKE, Aneliese. A importância estratégica do setor elétrico no cenário da região Sul. In: SANTOS, Sílvio Coelho dos; REIS, Maria José (Org.). Memória do setor elétrico na região Sul. Florianópolis: UFSC, 2002. p. 204-211.

A implantação da UHE Machadinho num cenário privatizado: um caso para reflexão. In: REIS, Maria José; BLOEMER, Neusa Maria Sens (Org.). Hidrelétricas e populações locais. Florianópolis: UFSC, 2001. p. 71-92.

SCOTT, Parry. Negociações e resistências persistentes: agricultores e a barragem de Itaparica num contexto de descaso planejado. Recife-PE: UFPE, 2009. 
SEYFERTH, Giralda. As contradições da liberdade: análise de representações sobre a identidade camponesa. Revista Brasileira de Ciências Sociais, Rio de Janeiro, v. 18, p. 78-95, 1992.

SIMON, Camilo. A revolução silenciosa: a saga da eletrificação rural cooperativada do RS. Porto Alegre: Sescoop, 2011.

SNOW, David A.; BENFORD, Robert D. Framing processes and social movements: an overview and assessment. Annual Review of Sociology, v. 26, p. 611-639, 2000.

. Master frames and cycles of protest. In: MORRIS, A.; MUELLER, C. M. (Org.). Frontiers in social movement theory. London: Yale University Press, 1992. p. 133-155.

SIMON, Camilo et al. Frame alignment processes: micromobilization, and movement participation. American Sociological Review, v. 51, n. 4, p. 464-481, 1986.

TARROW, Sidney. O poder em movimento: movimentos sociais e confrontos políticos. Petrópolis: Vozes, 2009.

TILLY, Charles. From mobilization to revolution. Reading: Addison-Wesley, 1977. VENTURA, Zuenir. 1968: o ano que não terminou. Rio de Janeiro: Nova Fronteira, 1988.

ZEN, Eduardo Luiz. Ditadura na barranca dos rios brasileiros: perseguição e criminalização de militantes da luta contra as barragens. Disponível em: $<$ www.mabnacional.org.br/artigo/ditadura-na-barranca-dos-rios-brasileirospersegui-e-criminaliza-militantes-da-luta-contra-ba>. Acesso em: 5 nov. 2009.

ZIMMERMANN, Neusa de Castro. Os desafios da organização interna de um assentamento rural. In: MEDEIROS, Leonilde et al. (Org.). Assentamentos rurais: uma visão multidisciplinar. São Paulo: Unesp, 1994. p. 205-224. 


\title{
Organização e atuação da Fetraf-Brasil e da Fetraf-Sul
}

\author{
Jairo Bolter ${ }^{1}$ \\ Jaqueline Haas ${ }^{2}$
}

\section{Considerações iniciais}

Os processos de desenvolvimento no meio rural emergiram de diferentes formas, sob diferentes contextos e situações político-organizacionais. No centro do cenário, além das ações e das políticas públicas, estão as organizações sociais e sindicais rurais. No período de 1980 a 2018, destacam-se três momentos distintos: inicialmente as organizações sociais e sindicais rurais atuavam de forma contestatória e reivindicatória - neste período as políticas se centravam em torno da compensação e eram formuladas de forma "top down"; na década de 1990 as organizações passaram a ser mais propositivas e proativas, conquistando espaços junto aos processos de formulação das políticas públicas, que passaram a incluir em seu bojo os pequenos e médios produtores rurais, em especial no quesito crédito; a partir do início da primeira década de 2000, as organizações adentraram ao processo de coformulação das políticas, das ações e dos programas públicos voltados para a agricultura familiar, que passaram a atingir e focar-se na qualidade de vida dos agricultores e suas famílias.

1 Professor Adjunto da UFRGS, Campus Litoral Norte. Doutorado em Desenvolvimento Rural. Contato: jairobolter@ufrgs.br

2 Professora Adjunta da UFRGS, Campus Litoral Norte. Doutorado em Extensão Rural. Contato: jaquelinehaas@ ufrgs.br 
O processo de reorganização social no campo, iniciado a partir da abertura política no início dos anos 1980, ganhou força e se reestruturou no âmbito da agricultura familiar, em meados da década de 1990. Os debates e as proposições no processo da Constituinte, as mobilizações contrárias à integração regional (ALCA) no início dos anos 1990 e os Gritos da Terra Brasil, iniciados em 1994, foram emblemáticos nesse sentido. Em todos esses momentos “os rurais" da Central Única dos Trabalhadores (CUT) estiveram presentes, reivindicando e propondo políticas públicas e ações para o desenvolvimento rural e disputando a organização sindical no meio rural. No final dos anos 1990, esses atores criaram uma nova organização, a Frente Sul da Agricultura Familiar, transformada, em 28 de março de 2001, em Federação dos Trabalhadores na Agricultura Familiar da Região Sul do Brasil. Em 2004 a organização expandiu-se para o território nacional, denominando-se, a partir daí, Fetraf-Brasil. Atualmente, está presente em 18 estados da Federação e constitui-se em uma das principais organizações sociais da agricultura familiar existentes no país.

O presente capítulo tem o propósito de analisar a trajetória e atuação da Federação Nacional dos Trabalhadores e Trabalhadoras na Agricultura Familiar (Fetraf-Brasil) e, de modo mais específico, da Federação dos Trabalhadores na Agricultura Familiar da Região Sul do Brasil (Fetraf-Sul). Assim sendo, o estudo realiza-se a partir de quatro métodos: revisão bibliográfica; análise de documentos e registros históricos; entrevistas; e observação participante. Além do histórico e das ações desenvolvidas pela Federação, buscamos destacar, também, o processo de atuação da organização em torno da defesa de propostas que visaram à implementação de um projeto de desenvolvimento socialmente justo e economicamente sustentável para a agricultura familiar.

A partir do panorama conjuntural político, tracejado com informações relevantes, desenvolvemos este estudo que se dividiu fundamentalmente em dois momentos: inicialmente destacamos o panorama histórico da criação e organização sindical da Fetraf-Sul, da Fetraf-Brasil e da CONTRAF; 
e, por fim, abordamos as concepções de desenvolvimento sustentável defendidas pela organização e a relação com o tema das políticas públicas.

\section{Da Federação à Confederação dos Trabalhadores da Agricultura Familiar do Brasil}

A partir do processo de redemocratização do país (1988) e da emergência de políticas específicas para a agricultura familiar, os atores e movimentos sociais do campo passaram a reestruturar-se e a reorganizar-se em diferentes e distintas frentes sociais. O principal elemento que desencadeou a reestruturação sócio-organizacional do campo e a emergência de diversas organizações sociais refere-se a divergências quanto à forma de atuação de tais organizações e de encaminhamento das ações. Segundo Bolter (2013), em grande medida, os dirigentes das diversas organizações e movimentos sociais não divergiam dos pontos e das propostas encaminhadas (as pautas das organizações sociais apresentadas para os governos no geral eram e são muito semelhantes), mas sim dos métodos de encaminhamento.

Pós-redemocratização no Brasil, a Confederação Nacional dos Trabalhadores na Agricultura (CONTAG) - principal e maior organização social do campo no Brasil - manteve-se fazendo representação sindical pouco propositiva. Discordando dos métodos de encaminhamento, surgiram outras duas organizações oriundas do campo dos rurais da CUT: o Movimento dos Pequenos Agricultores (MPA), em 1997, com um viés mais contestatório (assim como o Movimento dos Trabalhadores Sem Terra, optou por não organizar-se a partir da estrutura sindical e sim de movimento); a Federação dos Trabalhadores da Agricultura Familiar (Fetraf-Sul), surgiu, em 2001, com um viés mais propositivo e de diálogo frente aos governos (BOLTER, 2013).

Esta Fetraf-Sul foi criada com visão e objetivos diferentes do sindicalismo tradicional, representado pela CONTAG. Essas diferenças têm 
origem desde a década de 1980, quando as oposições sindicais começaram a surgir e manifestar-se no país, capitaneadas e estimuladas pela Secretaria e o Departamento dos Rurais da CUT (FAVARETO, 2001). A criação da Federação significou uma tentativa de propor uma nova forma de atuação sindical rural, com um olhar voltado para a inclusão social e econômica dos pequenos e médios produtores rurais, intitulados agricultores familiares. As políticas públicas precisavam garantir aos agricultores familiares condições viáveis para que esses pudessem se manter trabalhando e produzindo alimentos sem a interferência dos efeitos perversos do mercado globalizado, valorizando as características e as questões regionais (SEMINOTTI, 2014).

A criação da Fetraf-Sul foi concebida no final da década de 1990, quando os dirigentes e idealizadores da proposta não viam mais possibilidade de disputar e conquistar espaços importantes dentro das direções das centrais tradicionais, em especial as Federações dos Trabalhadores na Agricultura vinculadas à CONTAG (BOLTER, 2013). Segundo o autor, esses dirigentes consideravam os espaços de poder interno relevantes para construção e implementação de propostas sindicais para o meio rural, mas não visualizavam no sindicalismo tradicional espaço para atuar de forma inovadora e colocar suas ações em prática. Desse modo, idealizaram a criação da Fetraf-Sul, com abrangência nos três estados do sul do Brasil, conforme Figura 1. A Federação foi fundada em 28 de março de 2001, na cidade de Chapecó-SC, com a presença de mais de dois mil participantes, entre delegados, convidados nacionais, internacionais e observadores.

Já a Fetraf-Brasil foi criada oficialmente em 2004, observando a decisão tomada no I Encontro Nacional da Agricultura Familiar, realizado em julho do corrente ano. Durante o IV Congresso Nacional dos Trabalhadores e Trabalhadoras na Agricultura Familiar do Brasil, realizado em maio de 2016, a plenária aprovou e determinou que a Federação fosse transformada em uma Confederação, decisão que deu origem à Confederação Nacional dos Trabalhadores e Trabalhadoras da Agricultura Familiar (CONTRAF 
BRASIL). A Confederação, que reforça os ideais do novo sindicalismo, tem por objetivos principais a defesa da agricultura familiar, o desenvolvimento e soberania alimentar do país. Para tanto, atua em onze eixos centrais: garantia de acesso à terra e nela permanecer; produção e renda para a agricultura familiar; preservação do meio ambiente e da biodiversidade articulada à democratização do acesso à água e à infraestrutura hídrica; respeito à diferença e diversidade do semiárido; valorização e inclusão produtiva das mulheres agricultoras; valorização e inclusão produtiva da juventude rural; educação; habitação rural; previdência social rural; saúde; e direito à liberdade de organização sindical (FETRAF, 2016).

Figura 1: Mapa da área de abrangência de atuação da Fetraf-Sul

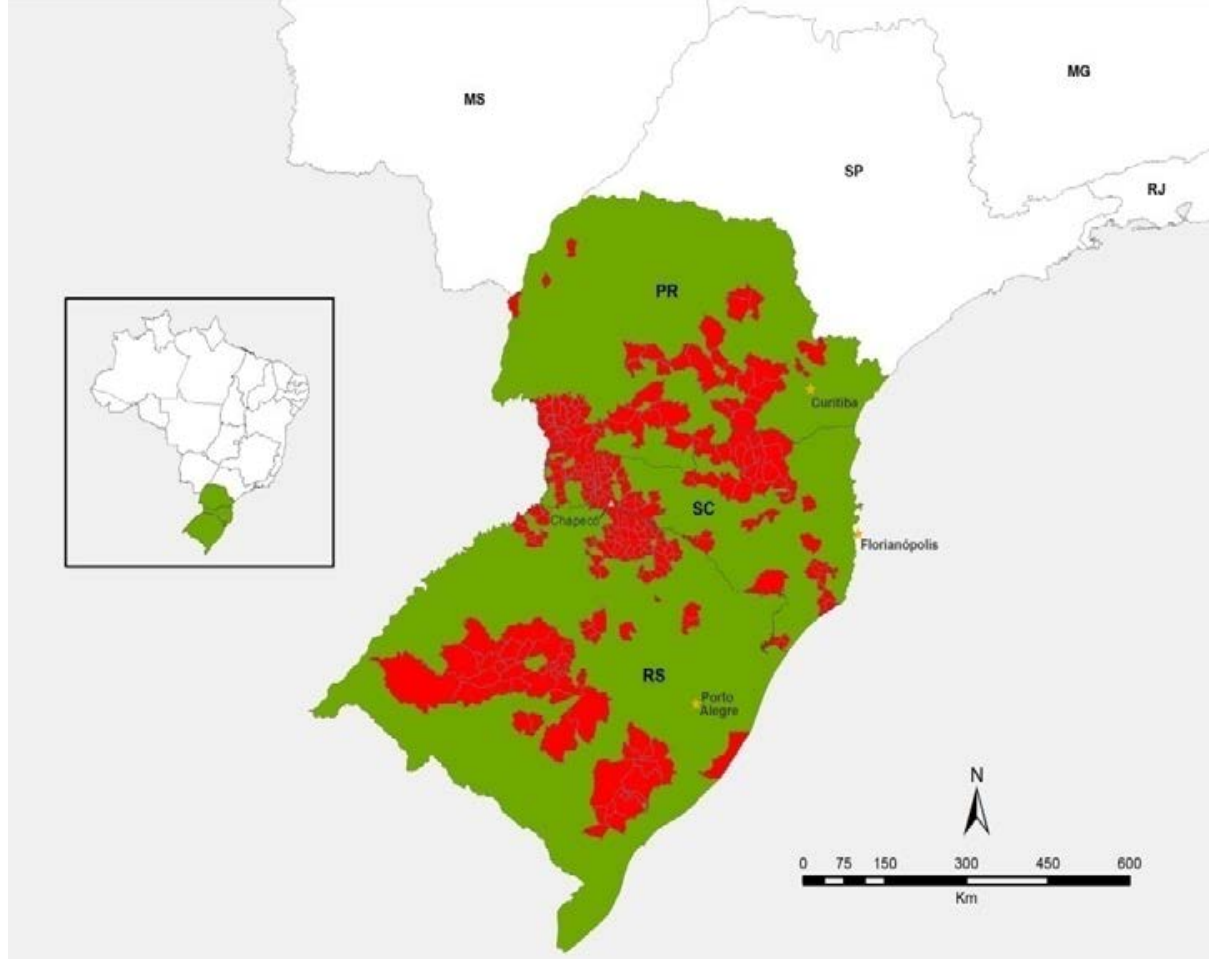


Atualmente a direção da CONTRAF é constituída por: Coordenação Geral; Coordenação da Secretaria Geral; Coordenação de Gestão e Finanças; Coordenação de Reforma Agrária; Coordenação de Mulheres; Coordenação de Políticas Sociais; Coordenação de Juventude; Coordenação de Política Agrícola; Coordenação de Formação e Educação Profissional; Coordenação de Habitação; Coordenação do Meio Ambiente; e Coordenação de Organização Sindical.

A Confederação representa as federações que, por sua vez, são ligadas aos Sindicatos de Trabalhadores Rurais (STRs), Sindicatos de Trabalhadores na Agricultura Familiar (SINTRAFs), Associação dos Agricultores Familiares (ASSAF), Associação dos Pecuaristas e Agricultores Familiares (APAFA) e Associações dos Sindicatos de Trabalhadores da Agricultura Familiar (ASSINTRAFs). Esse conjunto de organizações atua em consonância com as ações rurais da Central Única dos Trabalhadores (CUT), tendo como principais objetivos: a) articular os trabalhadores da agricultura familiar em torno dos sindicatos e fortalecer a representatividade e o poder desses sobre o Estado; b) ser um espaço representativo dos agricultores e agricultoras nas negociações com os governos nas diferentes esferas de poder; c) organizar projetos alternativos nas diversas áreas de atuação dos agricultores, tais como gestão, planejamento, meio ambiente, agroecologia, saúde, etc.; d) atuar de forma não simplesmente assistencialista; e) fortalecer e ampliar a visibilidade da categoria; f) implantar um sindicalismo novo, classista, democrático, massivo e propositivo, tendo como foco a melhoria das condições de vida dos associados; g) ser uma organização capaz de elaborar e organizar propostas e ações para apresentar junto aos governantes no momento das negociações com o Estado e com a sociedade; h) articular as propostas de projetos para além do sistema produtivo tradicional dos agricultores; i) organizar os espaços regionais, criando sindicatos regionais estruturados em novas funções e princípios, enraizados na base por meio de grupos de produção, núcleos comunitários, associações e cooperativas (BOLTER, 2013). 
Em 2016, a Confederação estava atuando, com representação sindical, em dezoito Estados, contando com aproximadamente 600 sindicatos e associações sindicais que, por sua vez, abrangiam mais de mil municípios em todo o Brasil, representando aproximadamente 500 mil agricultores (as) associados (as) (FETRAF, 2016).

\section{O funcionamento e a estrutura operacional das federações, a partir do caso da Fetraf-Sul}

A Fetraf-Sul está dividida em três níveis. O primeiro deles é o "local", em que circulam os agricultores e os dirigentes locais. Nesse nível, as ações são desenvolvidas nos municípios ou, no máximo, nas regiões (no caso das associações regionais). Os atores presentes no nível local participam de: i) audiências públicas locais; ii) sessões de câmaras de vereadores; iii) conselhos municipais e locais; iv) reuniões, debates, palestras, entre outras atividades. Dialogam constantemente com prefeitos, vereadores e outros atores sociais que compõem o campo político e institucional do processo de formulação das políticas públicas voltadas para o rural no município e região, como também desempenham, entre outras, as seguintes tarefas: i) coordenar as assembleias locais dos sindicatos e das associações dos agricultores (nas quais são dialogadas e estabelecidas as metas de ações do próximo período e também debatidos os temas a serem apresentados nas próximas pautas); i) representar o município nas discussões regionais e nacionais, nas quais buscam encaminhar as demandas oriundas das assembleias e ou regiões locais (BOLTER 2013).

Um segundo nível seria o "estadual" em que circulam o conjunto dos dirigentes sindicais locais (presidentes, coordenadores municipais ou regionais dos sindicatos e das associações) e, em certos momentos (como na assembleia estadual), dos delegados municipais. Os dirigentes sindicais atuam com o objetivo de encaminhar as demandas debatidas e apresentadas 
nos sindicatos rurais locais, nas assembleias estaduais e nas regionais da Federação. Cada "estadual" define sua forma de agir e de pautar suas demandas, visto que existem simultaneamente governos diferentes, com diferentes visões ou interpretações do contexto social nos estados. Os atores de nível "estadual" têm a missão de participar em: i) conselhos estaduais; ii) audiências públicas; iii) reuniões; iv) debates; v) dentre outras atividades em nível estadual (BOLTER, 2013).

Segundo Bolter (2003), também há o nível "Regional Sul" (nível pioneiro e que até então se mantém), no qual circulam os dirigentes regionais/ estaduais e os delegados regionais e locais (no caso das assembleias regionais sul). A direção da Regional Sul é composta de acordo com a representação dos três estados sulistas. Nesse nível são demandadas e pautadas as questões regionais do sul e nacionais. Ao agregar mais que um estado da Federação, a Fetraf-Sul confere mais força e mais respaldo aos atores sociais para negociarem com os governos estaduais e federal.

Uma das questões centrais em relação ao funcionamento e à organização da Federação diz respeito ao processo de “oxigenação" da organização sindical, ou seja, ao processo de renovação do seu quadro diretivo. A partir da sua reestruturação constante, a organização sindical tem proporcionado um rejuvenescimento das suas lideranças e, por consequência, a renovação das ações, das dinâmicas e das ideias ao longo do tempo. Ademais, proporciona que um número maior de agricultores adquira experiência no interior das organizações sindicais e possa assumir tarefas e ações fora dessas instâncias, em especial no processo político de formulação das políticas públicas, tanto nos poderes legislativos, como nos poderes executivos (BOLTER, 2013).

Os (As) dirigentes sindicais (tanto nos níveis local/municipal e regional/estadual como regional/sul), com o poder e o respaldo que lhes são conferidos por sua representatividade social, atuam e dialogam com os poderes municipais, estaduais e nacional. Além disso, concedem entrevistas (em rádios, jornais, TVs), participam de debates e discussões 
em todos os níveis públicos. Em suma, essa atuação ocorre ativamente em todo o processo político e institucional dos municípios, dos estados e do governo federal. Esses dirigentes apresentam diferentes níveis de formação e qualificação. Contudo, como são atores que circulam e precisam dialogar desde as suas bases até os mais altos escalões de governos ou de organizações parceiras, acabam adquirindo habilidades e capital simbólico e políticos importantes (BOLTER, 2013).

De modo geral, os(as) dirigentes contam com o apoio de equipes de assessoria técnica e política, estruturadas com recursos da própria organização sindical. De modo geral, os(as) assessores(as) da Fetraf são profissionais de diferentes áreas do conhecimento (agronomia, economia, desenvolvimento rural, sociologia, gestão e planejamento, técnicas agrícolas, etc.), que têm algum vínculo histórico com a organização ou com suas bases conceituais. Não raro, esses(as) assessores(as) são oriundos da própria base social local da Federação. Em geral, participam das negociações para finalizar ou programar uma determinada ação, já acordada com as lideranças sindicais. Cabe-lhes operacionalizar e sistematizar os acordos preestabelecidos no contexto em que emergem os fatos e não propor e negociar (BOLTER, 2013).

Os (As) assessores (as) são peças-chaves no processo de cogestão das políticas públicas voltadas para a agricultura familiar, visto que proporcionam à Federação uma representação qualificada e respaldada pelas lideranças das organizações sociais. Essa participação qualificada fortaleceu a organização junto ao governo e aos demais atores do processo político e institucional das políticas e programas públicos voltados para a agricultura familiar.

Cabe destacar que a Federação angariou, ao longo dos anos, um seleto grupo de apoiadores situados em espaços variados - legislativos, executivos, universidades, organizações da sociedade civil, etc. Esse leque de relações/apoio fez com que a Federação tivesse visibilidade e legitimidade política e institucional e passasse a atuar em torno de todo o "processo 
político" de formulação das políticas públicas voltadas para a agricultura familiar (BOLTER, 2013).

\section{As organizações sindicais frente a organização dos agricultores familiares}

Ao longo dos anos, a forma de atuação das organizações sociais foi sendo moldada por diferentes contextos e fatores. O Sistema Fetraf, desde o início de suas atividades, atuou tanto nos processos de contestação e reivindicação de programas e políticas públicas como nos processos de cogestão dessas ações. As lideranças, dirigentes e assessores, já no período dos rurais da CUT, defendiam uma atuação mais ativa das organizações quanto ao processo político de proposição, idealização e execução das políticas, programas e ações públicas voltadas para as categorias sociais que representam.

Um dos primeiros movimentos do Sistema Fetraf foi o estabelecimento de um processo contínuo de formação e qualificação política e administrativa do quadro de colaboradores. Esse processo foi instituído visando à formação tanto dos(as) dirigentes, dos(as) assessores(as), funcionários(as) das organizações, bem como dos(as) próprios(as) agricultores(as) ligados(as) aos sindicatos e às associações. O processo de formação perpassou as questões administrativas e institucionais das entidades e atingiu o processo de criação, gestão e planejamento de novas organizações (BOLTER, 2013).

As associações e os sindicatos de base têm sido uma ferramenta de organização e mobilização social dos pequenos e médios produtores rurais, em especial os(as) agricultores(as) familiares. As organizações de base da Federação têm assumido uma postura que vai além da oferta de informação, formação, encaminhamento de ações e organização e realização de mobilizações sociais de massa. 
Em nível local, o Sistema Fetraf tem oferecido apoio para emergência de outras organizações sociais, com o intuito de auxiliar os agricultores a obterem mais qualidade de vida e, assim, conseguirem manter-se na propriedade de forma digna e feliz. Conforme pode ser observado na Figura 2 , ao redor do sindicato emergem, muitas vezes, diversas e importantes organizações que servem de ferramentas para o encaminhamento de ações dos(as) agricultores(as). Desse modo, o sindicato passa a ser o responsável direto pela criação e gestão de muitas organizações de pequeno e médio porte existentes no meio rural brasileiro.

Figura 2: Fachada do prédio da Agricultura Familiar do município de Sarandi-RS

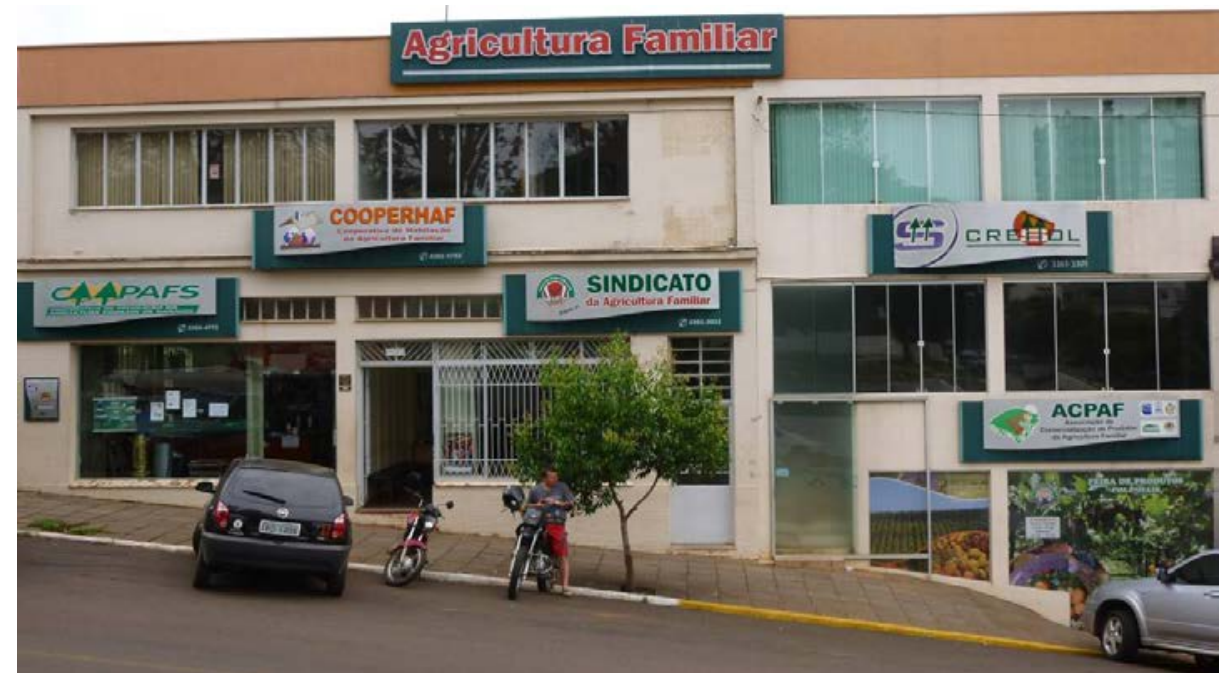

Fonte: BOLTER (2013).

É possível observar que o prédio da Agricultura Familiar abriga inúmeras organizações além do sindicato, que vão desde a organização produtiva, com a presença da Cooperativa de Produção da Agricultura Familiar (COOPAFS); a organização comercial, via Associação de Comercialização de Produtos da Agricultura Familiar (ACPAF); organização de crédito rural, por meio da Cooperativa de Crédito Solidário (CRESOL); e 
a prestação de serviços, a partir da Cooperativa de Habitação da Agricultura Familiar (COOPERHAF). Essa prática se repete frequentemente na base social do Sistema Fetraf, sendo considerada importante tanto pelos agricultores quanto pelos próprios dirigentes, pois, em um mesmo espaço físico, se agrupam organizações que visam, de maneira comum, à organização social e produtiva dos associados.

No caso da COOPAFS, especificamente, o(a) agricultor(a) encontra suporte para o planejamento e a execução de suas ações produtivas. Ele (Ela) encontra informações sobre processo produtivo a partir da equipe técnica disponível para assessorar-lhe. Além disso, a cooperativa é, de certo modo, intermediária entre empresas e agricultores, adquirindo produtos agrícolas (sementes, insumos, agrotóxicos, entre outros) de forma coletiva e comercializando-os juntos aos(às) agricultores(as) familiares. Assim, conseguem acessar os produtos necessários para garantir sua produção agrícola com um preço menor que aquele praticado nos demais mercados (BOLTER, 2013).

Já na ACPAF, o (a) agricultor (a) dispõe de um espaço de comercialização direto ao (à) consumidor (a). Além de eliminar em grande parte os (as) atravessadores (as), a associação permite que ocorra, durante as feiras, uma troca de experiência entre agricultores (as), bem como uma aproximação dos (as) agricultores (as) com os (as) consumidores (as), o que possibilita que ambos possam dialogar sobre a qualidade dos produtos e a satisfação dos clientes. No geral, nota-se que as associações de comercialização também proporcionam que os produtos produzidos pela agricultura familiar cheguem a grandes eventos, como feiras regionais, estaduais, nacionais e até internacionais (BOLTER, 2013).

A Cresol disponibiliza crédito de forma mais fácil que nos sistemas de crédito tradicional. Tanto a direção como os próprios funcionários da Cooperativa conhecem a realidade de cada um (a) dos (as) agricultores (as) filiados (as) à cooperativa. Isso permite que o (a) agricultor (a) se sinta mais seguro (a) em encaminhar e acessar uma determinada política 
ou programa de crédito rural voltado para a agricultura familiar. As cooperativas de crédito, em especial durante meados da década de 90 , foram fundamentais para que agricultores (as) familiares conseguissem acessar as políticas e os programas públicos de crédito rural disponíveis na época, em especial os recursos do Pronaf (BOLTER, 2013).

Por sua vez, a COOPERHAF proporciona que os (as) agricultores (as) familiares consigam encaminhar os projetos de financiamento para a construção e ou a reforma de suas unidades habitacionais. Com isso, conseguem acessar as políticas públicas de habitação rural que, até então, estavam distantes da realidade e da vida das famílias de agricultores e agricultoras que vivem e trabalham no campo (BOLTER, 2013).

No geral, o prédio da Agricultura Familiar, em destaque, é considerado pelo (a) agricultor (a) e sua família como uma extensão de sua propriedade e de sua casa. É um espaço importante para o(a) agricultor(a) na cidade, onde, além de encaminhar suas demandas e reivindicações no sindicato, consegue encaminhar questões relevantes para o funcionamento e a viabilidade de sua propriedade.

\section{A noção de desenvolvimento sustentável da Fetraf}

No congresso de fundação da Fetraf-Sul, foram aprovadas resoluções sobre o projeto de agricultura que a Federação seguiria. Dentre seus objetivos centrais aparece a intenção de priorizar a elaboração e implementação do Projeto Alternativo de Desenvolvimento Sustentável e Solidário (PADSS) em toda a região Sul, por meio de estudos, debates, criação, estímulo e fortalecimento de novas experiências, da disputa de políticas públicas, assim como da construção de políticas que valorizem o espaço local e o trabalho dos membros da família, diretamente envolvida no processo produtivo. 
A mudança conceitual de pequena propriedade para agricultura familiar foi também um importante momento para o movimento sindical cutista aprofundar o tema do desenvolvimento sustentável, pois junto a sua base social e política, afinal, o processo de reconhecimento da agricultura familiar significava a valorização desta categoria de trabalhadores (as) e a oportunidade de avançar nos debates sobre projeto de desenvolvimento que tinham ocorrido no decorrer da década de 1990.

A incerteza da conjuntura política e econômica do país nos anos 1990 e no início dos anos 2000 - ausência de políticas para pequena propriedade; concorrência sofrida pelas pequenas cooperativas com as grandes agroindústrias; e a descapitalização dos pequenos agricultores, entre outros aspectos - constituíam-se grandes entraves para a implementação de outro modelo de produção.

Desse modo, se por um lado o modelo de desenvolvimento proposto pelo Estado brasileiro considerava apenas as exigências da globalização, ajustando, adaptando e submetendo os diferentes contextos aos agentes econômicos que controlavam a economia e os setores produtivos, por outro, desenvolve-se a concepção entre os (as) mediadores (as) sociais e políticos de que os sistemas locais teriam poderes ilimitados, capazes de gerar o desenvolvimento a partir de uma visão territorial.

A noção de desenvolvimento expressa pelas organizações sociais da região sul do Brasil ligadas à CUT, entre elas a Fetraf-Sul, apresentava várias diretrizes que condicionavam o projeto de desenvolvimento que desejavam construir, conforme pode ser observado no Quadro 1.

Quadro 1: Diretrizes para o projeto de desenvolvimento planejado pelas organizações sociais cutistas da região Sul do Brasil

a) A dimensão endógena discutindo e construindo práticas de processos de desenvolvimento formatados a partir do local, das pessoas, dos grupos sociais, não sendo um desenvolvimento construído de cima para baixo, nem de fora para dentro. 
b) Um projeto de desenvolvimento que gere inclusão social, política, econômica e ambiental, superando as dinâmicas de exclusão historicamente construídas pelos formatos hegemônicos de desenvolvimento.

c) Um projeto de desenvolvimento que tem uma dimensão econômica, mas que não se pauta por estar como uma dimensão exclusiva ou determinante dos processos sociais. Há visivelmente na prática dessas organizações e movimentos um tensionamento na questão social e humana enquanto deve ser orientadora dos rumos do processo de desenvolvimento a gerar-se.

d) Manifestam uma luta clara contra os monopólios e oligopólios, indicando a necessidade da construção de mecanismos sociopolíticos de distribuição/desconcentração da riqueza e da renda. A construção de alternativas econômicas em nível local, organizando sociedades cooperativas marcadas por práticas socioeconômicas solidárias.

e) Essas organizações apontam para a multiculturalidade como uma prática social necessária à valorização dos diferentes grupos sociais. Constroem o resgate da cultura local e forjam a multiculturalidade em suas práticas.

f) Na democracia enquanto sistema político, as práticas políticas tradicionais, como o coronelismo, o nepotismo, o assistencialismo, são marcas da construção histórica. A principal prática indicada pelas organizações e movimentos é a participação cidadã dos atores sociais, a descentralização da política, gerando mecanismo de autonomia local a partir de processos participativos e controlados socialmente.

Fonte: ARNS; ZUNIGA; ROVER (2004), p. 34-36.

\section{Entretanto, as diretrizes não agradam a todos. Brandão (2007) critica} essa concepção meramente localista dentro do debate sobre desenvolvimento, em que ocorre a banalização de definições como "capital social", "redes", "economia solidária" e no espaço local e regional tudo pode, dependendo de sua vontade. Nesse sentido, Brandão destaca:

Essa 'endogenia exagerada' das localidades crê piamente na capacidade das vontades e iniciativas dos atores de uma comunidade empreendedora e solidária, que tem controle sobre seu destino e procura promover sua governança virtuosa lugareira. Classes sociais, oligopólios, hegemonia etc. seriam componentes, forças e características de um passado totalmente superado, ou a ser superado. O Estado pouco teria o que fazer nesse contexto de 'aprendizagem coletiva' e 'atmosfera sociopolítica', em que os atores se congregam e se aproximam de forma cooperativa (BRANDÃO, 2007, p. 12). 
A ideia de construir um modelo de desenvolvimento a partir das potencialidades locais entra em atrito com os determinantes da lógica capitalista de acumulação de capital, pois esse sistema aperfeiçoa seus instrumentos de ação, mobiliza a diversidade social e material em seu favor.

Para as organizações sociais vinculadas à CUT e defensoras da pequena propriedade, nos debates sobre a formação da agricultura familiar, a noção de desenvolvimento era ampla, ultrapassava o sentido econômico e atingia diferentes aspectos da vida dos pequenos agricultores. Picolotto (2011), nesse sentido, em sua tese destaca:

O movimento sindical, portanto, entendia que: Não há desenvolvimento no meio rural sem educação, saúde, garantias previdenciárias, salários dignos, erradicação do trabalho infantil e escravo, respeito à autodeterminação dos povos indígenas e preservação do meio ambiente. As lutas dos trabalhadores e trabalhadoras pela terra, política agrícola diferenciada, políticas sociais e direitos trabalhistas inserem-se, portanto, na construção de um projeto alternativo de desenvolvimento baseado na expansão e no fortalecimento da agricultura familiar (PICOLOTTO, 2011, p. 189).

A partir dos debates e da construção teórica sobre o tema do desenvolvimento, a Fetraf identifica dois modelos opostos de desenvolvimento: o modelo tradicional, baseado na produção de grãos, na monocultura, na dependência do mercado exportador; e a construção de experiências associativas, como cooperativas, associações, agroindústrias familiares, a diversificação da produção e a abertura de mercados locais para a comercialização.

O modelo de desenvolvimento sustentável, a partir da agricultura familiar, teria como característica a relação íntima entre trabalho e gestão, a direção do processo produtivo conduzido pelos proprietários, a ênfase na diversificação produtiva e na durabilidade dos recursos e na qualidade de vida, diferentemente do modelo patronal, que tem como característica a separação entre gestão e trabalho, a organização descentralizada e ênfase na especialização. 
No debate sobre a importância do trabalho e a gestão andarem juntos e constituírem-se com características da agricultura familiar em relação à patronal, Picolotto (2011) analisa que no modelo familiar, diferentemente dessa perspectiva de exploração patronal, são valorizadas suas características de não separação entre quem pensa e quem executa as atividades produtivas. Existe uma relação íntima entre a gestão da unidade produtiva familiar e a execução de seu processo produtivo pelos membros da família. Portanto, nesse modelo tende a ocorrer uma reversão do qualificativo negativo atribuído ao trabalho manual e aos sujeitos sociais que realizam tais trabalhos.

Apresentando-se como uma estratégia de sobrevivência das unidades familiares que buscam a sua reprodução, a noção de desenvolvimento defendida pela Fetraf só poderia ser viável através da implementação de ações na organização da produção, na organização socioeconômica, na conquista de políticas públicas e com uma boa organização interna na Federação.

Por isso, no I Congresso da Fetraf-Sul, em 2004, ocorreu a definição do que seria o "objetivo estratégico" da federação e dos seus quatro "eixos estratégicos de ação". A essa ideia que já vinha sendo debatida pelo sindicalismo cutista é agregado o qualificativo solidário, com o propósito de adicionar a esse debate o acúmulo existente no sindicalismo sobre a temática da economia solidária, que inclusive motivou a formação de uma agência no interior da CUT para tratar desse tema também no âmbito urbano: a Agência de Desenvolvimento Solidário (ADS). Nesse sentido, foram incorporados valores e práticas advindos do movimento da economia solidária e do comércio justo no programa da Fetraf-Sul, como destacado nas resoluções do II Congresso (FETRAF-SUL/CUT, 2007).

As linhas de ação apontavam, num primeiro eixo, que a Federação direcionaria suas ações para as políticas agrícolas e agrárias, mas avançaria também para outras políticas nas áreas da educação, saúde e habitação. Um segundo eixo de ação apontava para o avanço na organização socioeconômica da agricultura familiar, como elemento fundamental para 
a implantação de um desenvolvimento sustentável e solidário. Nesse ponto, buscava traçar diretrizes para que o sindicalismo, em conjunto com as organizações de crédito, as cooperativas e associações de produção, as redes de certificação solidária e as ONGs de apoio, conseguisse ter ações concretas para a realização do projeto de desenvolvimento da Federação, como produção agroecológica, agroindustrialização familiar, comercialização direta e iniciativas de econômica solidária (SEMINOTTI, 2014).

O terceiro eixo de ação focava na luta por avanços na democratização do Estado e na elaboração, disputa, negociação e implementação de políticas públicas que potencializassem a valorização da agricultura familiar como protagonista social, econômico e político (FETRAF-SUL/CUT, 2007).

$\mathrm{O}$ quarto eixo refere-se à gestão e às relações institucionais da Federação, tendo por objetivo avançar na melhoria e no aperfeiçoamento da sua gestão e organização interna e de seus sindicatos, na visibilidade da organização sindical da agricultura familiar e nas relações institucionais com organizações parceiras (FETRAF-SUL/CUT, 2007).

Em suma, a noção de desenvolvimento sustentável defendida pela Federação, bem como o planejamento de suas ações, apontava para a necessidade de construir uma agricultura mais sustentável, que considerasse os aspectos sociais e ambientais, além dos aspectos econômicos, baseada em iniciativas solidárias entre os agricultores familiares.

\section{Considerações finais}

Desde sua criação a Federação baseou-se em uma nova proposta de atuação sindical, o Novo Sindicalismo Rural, que guiou as discussões sindicais nos anos 1980 encabeçadas pelos rurais da Central Única dos Trabalhadores (CUT). Em um primeiro momento as discussões circundaram os métodos de ações e atuação sindical e posteriormente os termos organizacionais. 
As organizações sindicais rurais de base do Sistema Fetraf, desde a criação da Federação, têm ofertado suporte organizacional e institucional para criação e estruturação de diversas organizações sociais existentes no meio rural, que passaram a atuar de forma conjunta, otimizando espaços e estruturas em torno do aprimoramento e aperfeiçoamento das ações realizadas pela Federação e organizações sociais parceiras. A atuação conjunta perpassa o processo de cogestão das políticas, dos programas e das ações públicas voltadas para a agricultura familiar e se estende até a participação ativa no processo político e institucional como um todo das organizações.

Tanto no sentido de ações, como de organização, a Federação inovou se comparada às ações do sindicalismo tradicional. Do método organizativo ao método de ação e atuação, a Federação passou a compor um campo político com as demais organizações sociais de representação política dos(as) agricultores(as) familiares, que surgiram lideradas pela Fetraf. Conforme vimos no decorrer do texto, esse campo político guia suas ações atuando de forma propositiva, participando ativamente do processo de idealização, proposição e criação de políticas públicas voltadas para o meio rural, em especial para os(as) agricultores(as) familiares.

O projeto de desenvolvimento defendido pela Fetraf-Brasil e pela Fetraf-Sul apontava para um modelo de produção diversificada, para a agroindustrialização e para a comercialização em âmbito local, como alternativa à monocultura e dependência ao mercado externo. No entanto, o trabalho sociopolítico e a tentativa de o movimento sindical intervir no campo econômico emperravam pela falta de políticas públicas, em especial o crédito para investimentos e pela falta de mercado consumidor local para os produtos dos pequenos agricultores.

Por isso, o fortalecimento político do movimento sindical cutista se dá a partir do processo de reconhecimento social e político da agricultura familiar, através do qual o resultado das lutas realizadas durante os anos 1980 e 1990 culminam com a conquista de políticas públicas, em especial 
o Pronaf, que reuniu com o passar dos anos diversas linhas de crédito para investimento, custeio e infraestrutura para os (as) agricultores (as) familiares.

\section{REFERÊNCIAS}

ABRAMOVAY, Ricardo;VEIGA, JoséE. Novasinstituiçõespara odesenvolvimento rural: o caso do Programa Nacional de Fortalecimento da Agricultura Familiar (Pronaf). Brasília-DF: Ipea, 1999. (Texto para Discussão, 641).

ARNS, Carlos Eduardo; ZUNIGA, Gláucia M. F.; ROVER, Oscar. Organizações populares e desenvolvimento no Sul do Brasil. Curitiba: Gráfica Popular, 2004.

BIANCHINI, Valter. 20 do Pronaf: 1995:2015 - avanços e desafios. Brasília: MDA, 2015.

BOLTER, Jairo A. G. Interfaces e cogestão nas políticas para agricultura familiar: uma análise do Programa Nacional de Habitação Rural. Tese (Doutorado em Ciências Sociais) - UFRGS, 2013.

BRANDÃO, Carlos Antônio. Território e desenvolvimento: as múltiplas escalas entre o local e o global. Campinas-SP: Unicamp, 2007.

CADONÁ, C. V. Movimento dos pequenos agricultores - MPA: o novo nasce das estradas. Dissertação (Mestrado em Educação nas Ciências) - Unijuí, IjuíRS, 2004.

CENTRAL ÚNICA DOS TRABALHADORES (CUT). Construir a unidade na diversidade. Plataforma da CUT para o $6^{\circ}$ Congresso da Contag. Cajamar-SP: CUT, 1995.

CONFEDERAÇÃO NACIONAL dos Trabalhadores na Agricultura (Contag). Política agrícola e pequenos agricultores. Brasília-DF: Contag, 1984.

. Projeto nacional de política agrícola. Brasília-DF: Contag, 1988.

. Proposta do movimento sindical de trabalhadores rurais para as leis agrária e agrícola. Brasília-DF: Contag, 1989.

. In: CONGRESSO NACIONAL DOS TRABALHADORES RURAIS, 5․ Anais... Brasília-DF: Contag, 1991.

. In: CONGRESSO NACIONAL EXTRAORDINÁRIO DOS TRABALHADORES RURAIS, I. Anais... Brasília-DF: Contag, 1994. 
79

. $6^{\circ}$ Congresso nacional dos trabalhadores rurais (Documento base). Brasília-DF: Contag, 1995.

. Grito da terra Brasil 2008: pauta de reivindicações. Brasília-DF: Contag, Fetags e STTR, 2008.

. Grito da terra Brasil 2009. Brasília-DF: Contag, Fetags e STTR, 2009.

. Grito da terra Brasil 2010: pauta de reivindicações. Brasília-DF: Contag, 2010.

. Grito da terra Brasil - 2011. Pauta de reivindicações. Brasília-DF: Contag, Fetags e Sindicatos, 2011.

CONTI, Irio L. Organizações sociais e políticas públicas: inserção da Fetraf-Sul nas políticas públicas de segurança alimentar e nutricional. Tese (Doutorado) - UFRGS, 2016.

FAVARETO, Arilson. Agricultores, trabalhadores - estudo sobre a representação sindical dos agricultores familiares brasileiros organizados na CUT. Dissertação (Mestrado em Filosofia e Ciências Humanas) - Universidade Estadual de Campinas, Campinas-SP, 2001.

Agricultores, trabalhadores: os trinta anos do novo sindicalismo rural no Brasil. Revista Brasileira de Ciências Sociais, v. 21, n. 62, p. 27-45, 2006.

FAVARETO, A. da S.; BITTENCOURT, G. L. Agricultura e sindicalismo nos anos 90 - notas para um balanço. In: TEDESCO J. C. (Org.). Agricultura familiar. Realidades e perspectivas. 3. ed. Passo Fundo: UPF, 2001.

FEDERAÇÃO NACIONAL dos Trabalhadores e Trabalhadoras na Agricultura Familiar (Fetraf-Brasil). In: JORNADA NACIONAL DE LUTA DA AGRICULTURA FAMILIAR E REFORMA AGRÁRIA. Pauta de reivindicações. Brasília-DF: Fetraf-Brasil, 2015.

FEDERAÇÃO NACIONAL dos Trabalhadores e Trabalhadoras na Agricultura Familiar (Fetraf-Brasil). In: JORNADA NACIONAL DE LUTA DA AGRICULTURA FAMILIAR E REFORMA AGRÁRIA, XI. Pauta de reivindicações. Brasília-DF: Fetraf-Brasil, 2015.

FETRAF-SUL/CUT. Tese do II Congresso da Fetraf-Sul/CUT: consolidando a agricultura familiar. A ousadia na luta e na organização construindo um novo desenvolvimento. Chapecó: Fetraf-Sul/CUT, 2007.

. $3^{\circ}$ Congresso da Fetraf-Sul/CUT: agricultura familiar - alimento e vida para o Brasil, documento base. Chapecó: Fetraf-Sul/CUT, 2010. 
FETRAF. Fetraf cumpre deliberação aprovada em congresso e passa a ser Contraf-Brasil. 2016. Disponível em: <http://contrafbrasil.org.br/destaques>. Acesso em: 20 set. 2016.

FOUILLEUX, Ève. Entre production et institutionnalisation des idées: la réforme de la politique agricole commune. Revue française de science politique, v. 50, n. 2, p. 277-306, 2000.

. La politique agricole commune et ses réformes: une politique à lépreuve de la globalisation. Paris: L'Harmattan, 2003.

GRISA, C.; SCHNEIDER, S. Três gerações de políticas públicas para a agricultura familiar e formas de interação entre sociedade e estado no Brasil. Rev. Econ. Sociol. Rural [on-line], 2014.

GRISA, Catia. Políticas públicas para a agricultura familiar no Brasil: produção e institucionalização das ideias. Tese (Doutorado em Ciências Sociais) UFRRJ, 2012.

GRITO DA TERRA BRASIL. Pauta nacional de reivindicações. Brasília-DF: CUT/DNTR, Contag, MST, MAB, Monape, CNS, Capoib, 1994.

. Pauta nacional de reivindicações 1995. Brasília-DF: CUT, Contag, MST, MAB, CNS, Monape, Capoib, Organizações das Mulheres Trabalhadoras Rurais, 1995.

INSTITUTO BRASILEIRO de Análises Sociais e Econômicas (Ibase). Relatório Pronaf: resultados da etapa Paraná. Rio de Janeiro-RJ: Ibase, 2006.

KUJAWA, Henrique. Conflitos envolvendo indígenas e agricultores no Rio Grande do Sul: dilemas de políticas públicas contraditórias. Ciências Sociais Unisinos, v. 51, n. 1, p. 72-82, 2015.

MULLER, Pierre. Les politiques publiques. 7. ed. Paris: PUF, 2008.

ORGANIZAÇÃO DAS NAÇÕES UNIDAS para Agricultura e Alimentação (FAO)/Instituto Nacional de Colonização e Reforma Agrária (Incra). Diretrizes de política agrária e desenvolvimento sustentável para a pequena produção familiar. Brasília-DF: FAO/Incra, 1994.

. Perfil da agricultura familiar no Brasil. Brasília-DF: FAO/Incra, 1996.

PICOLOTTO, Everton L. As mãos que alimentam a nação: agricultura familiar, sindicalismo e política. Tese (Doutorado em Ciências Sociais) - UFRRJ. Rio de Janeiro-RJ, 2011. 
PICOLOTTO, Everton L.; BRANDENBURG, Alfio. Uma grande oportunidade: o sindicalismo e seus projetos de ecologização da agricultura familiar. Ambiente e Sociedade, v. XVIII, n. 3, p. 1-18, 2015.

RADAELLI, Claudio M. Logiques de pouvoirs et récits dans les politiques publiques de l'Union Européene. Revue Française de Science Politique, v. 50, n. 2, p. 255-275, 2000.

SCHNEIDER, Sergio; CAZELLA, Ademir; MATTEI, Lauro. Histórico, caracterização e dinâmica recente do Pronaf-Programa Nacional de Fortalecimento da Agricultura Familiar. In: SCHNEIDER, Sergio; SILVA, Marcelo K.; MARQUES, Paulo E. M. (Org.). Políticas públicas e participação social no Brasil rural. Porto Alegre-RS: UFRGS, 2004. p. 21-49.

SEMINOTTI, Jonas. Os agricultores familiares e a representação política do Sutraf na região Alto Uruguai do RS. Tese (Doutorado em Sociologia) Programa de Pós-Graduação em Sociologia. Curitiba-PR, 2013.

TEDESCO, João C.; KUJAWA, Henrique. Mediações em conflito na demarcação de áreas indígenas em região de colonização no norte do Rio Grande do Sul: dilemas e configurações. História: Debates e Tendências, v. 16, n. 1, p. 135-152, 2016.

WANDERLEY, Maria N. B. O mundo rural como um espaço de vida: reflexões sobre a propriedade da terra, agricultura familiar e ruralidade. Porto AlegreRS: UFRGS, 2009.

WILKINSON, John; REYDON, Bastian; SABBATO, Alberto. Dinâmica do mercado de terras na América Latina: o caso do Brasil. Santiago: FAO/ Escritório Regional, 2010. 


\title{
Da questão agrária à agroecologia: a narrativa da reforma agrária no Brasil
}

\author{
Cleber José Bosetti ${ }^{1}$
}

\section{Considerações iniciais}

A reforma agrária no Brasil tem sido um campo de disputa. Historicamente ela tem confrontado grupos sociopolíticos favoráveis a sua realização e grupos que lhe fazem oposição. As primeiras discussões da reforma agrária remontam às décadas de 1950-1960, período marcado por uma importante transição socioeconômica do país em direção à industrialização e urbanização. A precariedade desses processos foi impactante tanto no campo quanto na cidade e levou vários teóricos a levantar o problema da questão agrária brasileira. Por muito tempo o discurso da reforma agrária foi sustentado por esse problema estrutural da sociedade brasileira. Nas últimas décadas, entretanto, as mudanças socioeconômicas ocorridas na agricultura e na sociedade enfraqueceram esse argumento histórico, levando o discurso da reforma agrária a assentar-se em outro terreno discursivo.

A narrativa da reforma agrária no Brasil, produzida pelo MST, apresenta, ao longo de sua trajetória, um sentido estruturante que preconiza não só a redistribuição fundiária, mas a idealização de outra maneira de

1 Doutor em Sociologia Política pela Universidade Federal de Santa Catarina (UFSC) e professor de sociologia na Universidade do Oeste de Santa Catarina (Unoesc). Contato: cbbosetti@yahoo.com.br. 
se pensar e praticar a agricultura tendo em vista a construção de um projeto utópico de sociedade. A centralidade do problema da terra é uma espécie de suporte para resolver outros problemas presentes na sociedade, como a desigualdade social, o desemprego, a precariedade da cidadania e os problemas ambientais decorrentes do modelo de desenvolvimento rural produtivista.

Todos esses elementos fizeram parte da narrativa dos movimentos sociais que reivindicaram a reforma agrária no Brasil, especialmente a partir do surgimento do Movimento dos Trabalhadores Rurais Sem Terra (MST) na década de 1980. Entretanto, em cada conjuntura histórica, determinados elementos ganharam destaque em relação aos demais, fazendo com que o sentido da reforma agrária adquirisse especificidades pontuais em razão do ambiente político-discursivo no qual está sendo enunciado.

Por que isso ocorre? Em certo sentido, porque as condições sociais, políticas e econômicas de cada conjuntura apresentam situações objetivas que o discurso da reforma agrária precisa responder. Há demandas sociopolíticas que precisam ser satisfeitas. Noutro sentido, é preciso considerar que o campo discursivo opera numa arena de disputa com outras forças sociopolíticas que procuram deslegitimá-lo, isto é, os objetos do discurso também se modificam em virtude das perspectivas materiais, simbólicas e políticas presentes na sociedade.

Por conseguinte, a construção discursiva que procura sustentar a necessidade da reforma agrária movimenta-se nos terrenos dessas disputas. Conforme as cercas do modelo de desenvolvimento produtivista na agricultura foram construídas, a narrativa da reforma agrária buscou desenrolar os arames das contradições deixadas por ele. Assim, a historicidade dos embates foi tecida, primeiramente, com o problema dos camponeses sem-terra e explorados no campo; em seguida, incorporou o problema do desemprego e a precariedade de cidadania na sociedade brasileira; passou pela proposição do cooperativismo como alternativa para a agricultura de base familiar 
resistir enquanto forma de produção; atualmente, incluiu o discurso de um projeto alternativo de desenvolvimento rural baseado na agroecologia.

\section{Narrativa discursiva da reforma agrária}

As ações políticas dos grupos sociais e suas entidades representativas orientam-se através de várias estratégias. Uma maneira eficiente de fortalecer suas próprias capacidades de mobilização é a utilização do discurso como ferramenta de persuasão e convencimento. Através da estratégia discursiva, os grupos sociopolíticos procuram apresentar suas demandas, confrontar seus oponentes e legitimar seus projetos políticos. Compreender a ordem discursiva é, para a ciência social, uma forma de apreender a ação social, as relações políticas e de poder presentes na sociedade.

Nesse sentido, é necessário considerar que “o discurso não é definível independentemente das relações que o constituem, portanto, é, em última instância, uma prática” (LECOURT, 2008, p. 50). Essa prática é composta pela adesão dos sujeitos a determinadas condições de produção e reprodução do discurso numa dada formação social, ou seja, são as regras e as possibilidades históricas disponíveis àqueles que enunciam o discurso em virtude das perspectivas políticas que os motivam. Assim, por trás de um discurso existe um conjunto de forças econômicas, políticas, científicas e até morais que o instrumentalizam.

Um enunciado é um acontecimento único, porém está aberto à repetição, à transformação e à reativação (FOUCAULT, 1986, p. 32). Nunca será o mesmo, pois está inserido em diferentes ordens discursivas que, por sua vez, estão sempre associadas às condições históricas. Isso leva a que questões, como a da reforma agrária, sejam abordadas discursivamente com nuanças diferenciadas nas diferentes conjunturas históricas em que são enunciadas. Embora nos embates discursivos atuais acerca da reforma agrária ainda seja possível observar determinada cisão sociopolítica 
evocada no passado, os novos sujeitos, as novas demandas e outra ordem discursiva estão presentes na atualidade. Sendo assim, os discursos enunciados em torno da reforma agrária na atualidade não significam a mesma coisa que nas conjunturas anteriores, portanto, possuem singularidade.

Os discursos manifestos emergem historicamente como uma irrupção de acontecimentos ligados a sua instância, ao conjunto de acontecimentos históricos que o envolvem e lhe dão sentido (FOUCAULT, 1986). Isso significa, por mais que aparentem ser repetições e continuidades, que os discursos são acontecimentos singulares dispostos em dada formação social. Essa irrupção envolve um conjunto de relações discursivas, de sujeitos e, fundamentalmente, de interesses sociais empenhados com o objetivo de impor sua visão no mundo social.

O mundo social pode ser entendido como um conjunto de espaços construídos na base de princípios de diferenciação ou de distribuição, constituídos pelo conjunto de propriedades que nele atuam (BOURDIEU, 2005). Nesses espaços circulam os agentes, suas propriedades e posições materiais e imateriais e a intersecção dos diferentes campos da vida social. Essa configuração faz com que a vida social apresente constantes concorrências e lutas pelo direito de ocupar determinadas posições dentro desse espaço.

Nesse sentido, os discursos tornam-se parte das estratégias de fortalecimento das posições e interesses sociais em disputa. Os agentes e as instituições procuram articular discursivamente suas demandas de forma a operar uma infusão das prerrogativas de suas próprias posições aos demais. Essa operação exige a articulação discursiva, a legitimidade do discurso e a disponibilidade de capital político e científico para fazer valer seu regime de verdade em relação aos oponentes do campo discursivo.

$\mathrm{Na}$ sociedade brasileira, no passado e no presente, existe uma cisão sociopolítica entre um conjunto de agentes e organizações que defendem a realização da reforma agrária e um conjunto de agentes e organizações que buscam desconstruir sua legitimidade. Dessa forma, configura-se um campo discursivo em disputa na medida em que há uma articulação 
de grupos distintos e opostos para legitimar suas visões de mundo e seus respectivos projetos políticos.

Do ponto de vista metodológico, este capítulo procura analisar o conteúdo discursivo dos jornais e documentos de divulgação produzidos pelo movimento social dos trabalhadores rurais sem-terra desde seu período pré-formativo (1981-1984) até a atualidade. A especificidade desse tipo de documento histórico está no fato de que sua produção é intencionalmente pensada em virtude das ideias e concepções acerca da reforma agrária que seus proponentes querem apresentar. A defesa de seu projeto político e as respostas às contestações de seus adversários levam a que os discursos produzidos revelem um ambiente social no qual a reforma agrária adquire sentidos distintos.

Fundado no início da década de 1980, o Movimento dos Trabalhadores Rurais Sem Terra (MST) tem sido, sem dúvidas, a principal força sociopolítica empenhada na defesa política da reforma agrária no Brasil. A compreensão das narrativas do MST, por uma questão analítico-metodológica, pode ser dividida em quatro momentos distintos: o contexto pré-formativo oficial do MST (1981-1984); o período da transição democrática (1985-1989) em que se discutiu a Política Nacional de Reforma Agrária (PNRA); a expansão e radicalização do movimento durante a década de 1990; o período da guinada discursiva a partir da década de 2000. Embora essa divisão não seja rígida, está assentada na percepção das mudanças de ênfase no discurso em razão das disposições objetivas e subjetivas das disputas sociopolíticas enunciadas nos documentos e nas manifestações discursivas produzidas pelo MST.

\section{Terra aos camponeses sofridos: ainda temos uma questão agrária!}

A tematização da questão agrária no Brasil possui suas especificidades históricas. Diferentemente dos processos socioeconômicos que serviram de 
base para o pensamento marxista clássico acerca do tema, a dinâmica da agricultura e da sociedade brasileira seguiram outro caminho. Isso porque o processo de modernização capitalista da agricultura brasileira ocorreu de forma distinta ao modelo europeu analisado pelos teóricos marxistas. Essa distinção pode ser visualizada pelo fato da modernização da agricultura no Brasil ter sido posterior ao próprio processo de industrialização. Com isso, a estrutura fundiária e as relações de produção pré-capitalistas, típicas do período colonial, continuaram presentes no espaço rural brasileiro mesmo após a intensificação da urbanização da sociedade na década de 1960 (RANGEL, 2004).

Com o processo de modernização da agricultura em marcha a partir da década de 1960, o espaço rural brasileiro apresentava uma grande massa de camponeses vivendo em condições precárias. As raízes da pobreza rural foram diagnosticadas como decorrentes dos minifúndios, da área insuficiente de terra pertencente a uma família camponesa e da falta de acesso à terra para grande parcela do campesinato decorrente da concentração fundiária (latifúndios). Além disso, havia o problema da precariedade dos direitos trabalhistas no campo (PRADO JUNIOR, 1987).

Ainda na década de 1960, em razão das pressões sociais oriundas dos movimentos sociais, foi criado o Estatuto da Terra que, dentre outras prerrogativas, sinalizava para a realização da reforma agrária por interesse social nos latifúndios por dimensão e exploração. ${ }^{2}$ Entretanto, a política efetiva dos governos da época não priorizou a reforma agrária como solução para os problemas em questão. No período da Ditadura Militar (19641985), as soluções apresentadas, em termos de políticas para agricultura, foram o incentivo à modernização, na qual cabia à agricultura o papel de substituição das importações, de fornecer recursos cambiais através das

2 O artigo $1^{\circ}$ do Estatuto da Terra dizia: "Considera-se reforma agrária o conjunto de medidas que visem promover a melhor distribuição de terra, mediante modificações no regime de sua posse e uso, a fim de atender os princípios de justiça social e aumento de produtividade." Quanto ao latifúndio, o estatuto estabelecia que uma área de terra que excedia seiscentas vezes o módulo rural de cada região, bem como as propriedades que, não excedendo tal limite, se apresentassem inexploradas, portanto, sem cumprir sua função social (BRASIL, 1964). 
exportações, bem como de produzir alimentos e matérias-primas para o mercado interno a baixo custo, o que, em tese, favorecia o desenvolvimento industrial do país (GRAZIANO DA SILVA, 1998). Para os segmentos da agricultura patronal e seus interlocutores intelectuais, a questão agrária seria resolvida com a própria modernização, com a absorção da massa empobrecida em empregos urbanos.

O resultado desse processo foi uma modernização parcial. Com isso, muitos camponeses foram para as cidades, o desemprego aumentou nas áreas urbanas pela não absorção da mão de obra migrante pelo setor industrial e houve um crescimento da pobreza nas periferias das cidades. ${ }^{3}$ No espaço rural, uma reforma agrária ampla não foi realizada ${ }^{4}$ e as condições socioeconômicas de grande parte dos agricultores de base familiar continuaram precárias. $\mathrm{O}$ que se construiu foi um modelo de desenvolvimento rural alicerçado na lógica produtivista, tanto em termos tecnológicos quanto socioeconômicos. No final do período militar houve um novo alento. A reforma agrária voltou a ser discutida de forma ampla na sociedade, especialmente após o surgimento do MST.

No início da década de 1980, as condições socioeconômicas no espaço rural brasileiro continuavam apresentando uma característica marcante: a presença de um grande contingente de camponeses sem-terra. A presença deles contrastava com a existência visível de latifúndios improdutivos nas mais diversas regiões do país e o Estatuto da Terra de 1964, principal mecanismo legal referente às questões agrícola e agrária, previa a possibilidade da reforma agrária. Diante disso, as narrativas da reforma agrária nesse período buscavam legitimar-se nas próprias condições objetivas existentes no espaço rural. Antes mesmo de qualquer projeto político, havia a necessidade de distribuir terra para àqueles que nela trabalhavam.

3 Ver Rangel (2004).

4 Algumas experiências isoladas até foram feitas entre as décadas de 1960 e 1970. Porém, a falta de infraestrutura, de políticas agrícolas e, em alguns casos, a localização dos assentamentos em áreas de conflitos das fronteiras agrícolas resultaram no insucesso das experiências (STEDILE, 2013). 
Anteriormente à criação oficial do MST, as organizações que apoiavam os trabalhadores rurais sem-terra produziram um importante documento. Trata-se do Boletim Sem Terra (BST), produzido entre os anos de 19811984 a partir do acampamento denominado Encruzilhada Natalino, no norte do Rio Grande do Sul. Essa mobilização contou com a participação de milhares de camponeses e de segmentos da sociedade civil em prol da reforma agrária. Diante da repressão costumeira dos governos militares, o BST foi produzido com o intuito de sensibilizar a sociedade para os problemas agrários existentes na região e no país.

O Boletim foi construído com a participação de diversas entidades que na época apoiavam as reivindicações dos sem-terra. Dentre essas entidades podem ser destacadas a Comissão Pastoral da Terra (CPT), o Movimento de Justiça e Direitos Humanos (MJDH) e a Pastoral Universitária (PU) do Rio Grande do Sul (PERLI, 2006). A presença dessas entidades indica uma característica importante do movimento social dos trabalhadores rurais sem-terra na década de 1980: sua interdependência política. A participação ativa de várias entidades religiosas e sujeitos ligados a elas, especialmente a CPT, fez com que a narrativa da reforma agrária, nesse momento, apresentasse uma simbologia do imaginário religioso. Essa condição política integrada ao discurso religioso constitui-se parte das estratégias discursivas de legitimação da reforma agrária. A comparação entre os camponeses sem-terra com o sofrimento do povo bíblico foi um recurso muito utilizado para mobilizar as autoridades e, principalmente, a sociedade civil na época.

Em sua primeira edição, o BST apresenta a difícil situação dos segmentos camponeses demandantes por terra (arrendatários, posseiros, peões, meeiros, agregados) e reforça sua identidade com a terra e com o trabalho na agricultura, com o lema: "terra para quem nela trabalha" (BST, 1981). Não atendidos pelos governos e vivendo em condições precárias de vida nos acampamentos, o documento faz um apelo à comunidade para ajudar os trabalhadores que querem terra para trabalhar. 
Ao longo do ano de 1981, as demais edições do BST continuam relatando o cotidiano dos acampamentos. Destacam-se neles a organização das lideranças com base no espontaneísmo e o discurso religioso como forma de sustentação da narrativa da reforma agrária, como comprova este trecho:

Movidos pelo evangelho e pela graça de Deus, devemos não somente ouvir, mas assumir os sofrimentos e angústias, as lutas e esperanças das vítimas da injusta distribuição da posse da terra [...]. Diariamente, após as 17 horas, as famílias dos sem terra se reúnem junto à cruz, símbolo de seu sofrimento e paixão. Escorada no centro do acampamento, a cruz significa a solidariedade, o apoio dos sindicatos, entidades e igrejas na luta pela conquista da terra. Ali, os acampados rezam, recebem informações e debatem seus problemas $[\ldots] .^{5}$

Essa narrativa se explica pela forte religiosidade professada pelos próprios trabalhadores acampados que, em sua maioria, eram oriundos de comunidades rurais com forte presença da religião desde a colonização da região. Algumas entidades religiosas, como a Comissão Pastoral da Terra (CPT), auxiliavam os acampados e eram responsáveis pela própria edição do BST, o que justifica o discurso religioso ter ocupado espaço significativo no imaginário da luta pela terra durante os primeiros acampamentos. Reforçando a ideia do sofrimento do povo, a simbologia religiosa da cruz e os relatos dos momentos de oração fortaleciam a busca por apoio da população civil no momento em que a solidariedade era crucial.

Durante os primeiros acampamentos no Rio Grande do Sul, a luta dos sem-terra com o governo estadual dava-se em razão deste último não querer desapropriar os latifúndios existentes no estado. $\mathrm{O}$ governo oferecia emprego temporário e terras em outros estados, especialmente no Mato Grosso, ao passo que os camponeses queriam reforma agrária e desapropriações de latifúndios na região. O BST enfatizava a questão do

5 Boletim Sem Terra, Ano I, nº. 3, jun. 1981. 
latifúndio improdutivo com base na legislação vigente, especialmente no Estatuto da Terra, que, no artigo $4^{\circ}$, inciso V, prescrevia:

Latifúndio, o imóvel rural que: a) exceda a dimensão máxima fixada na forma do artigo $46, \S 1^{\circ}$, alínea b, desta Lei, tendo-se em vista as condições ecológicas, sistemas agrícolas regionais e o fim a que se destine; b) não excedendo o limite referido na alínea anterior, e tendo área igual ou superior à dimensão do módulo de propriedade rural, seja mantido inexplorado em relação às possibilidades físicas, econômicas e sociais do meio, com fins especulativos, ou seja, deficiente ou inadequadamente explorado, de modo a vedar-lhe a inclusão no conceito de empresa rural ${ }^{6}$.

Nesse sentido, a adesão discursiva daqueles que lutavam pela terra pautava-se na legitimidade legal. Isso se dava especialmente pelo fato de a definição de latifúndio, anterior à Constituição de 1988, possuir o elemento da dimensão baseado nos módulos rurais de cada região, ou seja, além das questões ecológicas e produtivas, o tamanho da propriedade poderia ser tomado como referência para a realização da reforma agrária. Esse aspecto parece ter mais objetividade em relação ao critério da produtividade estabelecido a partir da Constituição de 1988.

Ainda antes da criação oficial do MST, a narrativa da reforma agrária buscava sua legitimidade nos problemas eminentemente agrários, na persistência de uma questão agrária ainda não resolvida. No ano de 1983, foi divulgado um documento denominado "Campanha nacional pela reforma agrária”.

Reforma Agrária: uma solução para a crise brasileira. Uma reforma agrária no Brasil teria como resultado a solução para o desemprego e para o subemprego; a ocupação das terras que não produzem nada, o aumento da produção de alimentos e matérias primas para as indústrias, movimentando o mercado interno; a economia do

6 BRASIL (1964). 
país voltaria a crescer; as liberdades e direitos dos trabalhadores rurais seriam atendidos. ${ }^{7}$

Nota-se que a reforma agrária é invocada em nome da existência de uma "questão agrária”, o que significa uma estrutura agrária marcada por elementos pré-capitalistas que atravancam o desenvolvimento econômico e geravam pobreza no meio rural (GRAZIANO DA SILVA, 1987). O discurso da existência de uma questão agrária fundamentou as narrativas da reforma agrária nas décadas de 1950 e início da de 1960, mas foi relativamente silenciada durante a ditadura militar das décadas de 1960-1970 com a chamada modernização da agricultura. Porém, seu caráter seletivo fez com que os problemas agrários reaparecessem com força conforme os governos militares foram perdendo legitimidade.

Assim, no início da década de 1980, diante de um cenário de crise econômica e com desemprego no campo e na cidade, a reforma agrária reapareceu como uma das soluções para os problemas mais amplos de desenvolvimento econômico e social do país. Invocada em nome dos camponeses sem-terra em um espaço rural marcado por latifúndios, em consequência das péssimas condições de vida de grande parte da população rural e das possibilidades de desenvolvimento econômico geradas, nota-se que a reforma agrária ainda era reivindicada em razão do reconhecimento da existência de uma questão agrária.

\section{A distribuição da terra é indispensável à democratização!}

Em 1984 foi realizado, na cidade de Cascavel, no Estado do Paraná, o I Encontro Nacional do MST, evento que se tornou o marco oficial do nascimento desse movimento social. Além disso, esse encontro contribuiu para definir os princípios de sustentação da ideia de reforma agrária

7 Federação dos Trabalhadores da Agricultura do estado de Minas Gerais. Campanha Nacional pela Reforma Agrária, 1983. 
a ser defendida nos anos seguintes. Promovido em um contexto político de expectativas em virtude da redemocratização do país, as discussões notabilizaram-se pela afirmação de um discurso de autonomia política, embora o MST, ao longo de sua trajetória, tenha continuado com o apoio de outras organizações no plano político-discursivo e em algumas mobilizações sociais.

A concepção de reforma agrária elaborada no referido evento pode ser sintetizada nos seguintes pontos:

Reforma agrária. Podem fazer parte dos sem terra os vários segmentos rurais que não possuem a propriedade da terra ou que possuem uma quantidade inferior a 5 hectares; o movimento sem terra deve ter autonomia política; o objetivo da reforma agrária é lutar por uma sociedade igualitária, acabando com o capitalismo; o acesso à terra deve ser através da pressão e da luta; em todas as conquistas de terra, deve-se discutir formas alternativas de produção de posse e cultivo da terra [...]. ${ }^{8}$

A exclusividade de ser trabalhador rural (meeiros, posseiros, arrendatários ou minifundiário) para fazer parte do movimento ainda se justificava pela presença de um grande número de camponeses nessas condições, isto é, pelo fato de o desenvolvimento da agricultura capitalista ainda não ter expulsado esses segmentos do campo. Essa exclusividade foi suprimida em anos posteriores, pois, com a diminuição dos sujeitos mencionados no campo em virtude da modernização e do êxodo rural, os segmentos urbanos passaram a ser aceitos como integrantes do movimento dos sem-terra.

Em 1985, o cartaz do I Congresso Nacional do MST apresentava a imagem representativa da ideia dos camponeses que lutavam pela terra. 
Figura 1: I Congresso Nacional do MST

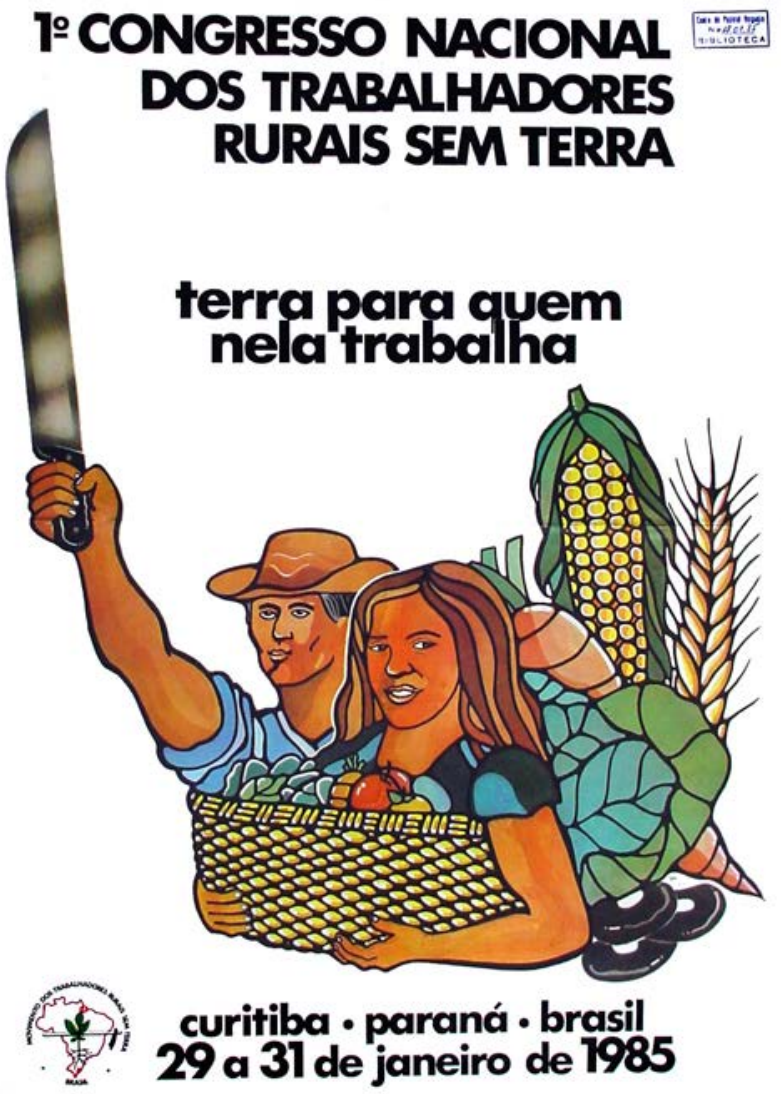

Fonte: Movimento dos Trabalhadores Sem Terra.

A presença de regimes socialistas, ainda que decadentes, como alternativa ao capitalismo inspirou o ideário socialista revolucionário nos discursos do MST no período. A narrativa socialista presente nos discursos oficiais é o sinal mais explícito da autonomia política construída pelo movimento. Nesse momento, a narrativa transcende o problema eminentemente agrário e faz da reforma agrária um caminho para chegar ao terreno de um projeto de sociedade inspirado no ideário socialista.

Porém, tal manifestação interferiu nas relações do movimento com a sociedade civil, uma vez que a ideia de socialismo havia sido negativamente 
construída no imaginário social da população brasileira, principalmente durante o período da ditadura militar. Se em anos anteriores havia uma forte presença do discurso religioso, aspecto que criava uma empatia maior com a sociedade civil, após a autonomização do movimento e a adoção do discurso socialista, a relação com a sociedade civil mudou significativamente.

Cabe também ressaltar a prescrição da defesa das formas alternativas de produção para os assentamentos rurais de reforma agrária. Essa narrativa já era enunciada, porém com uma ênfase ainda tímida em relação aos demais objetivos. Isso porque ainda não havia uma definição sobre o significado do que eram essas formas alternativas. Embora a menção de ruptura com o modelo de desenvolvimento rural vigente já estivesse sendo sinalizado, o contexto exigia maior ênfase na organização da luta para desapropriar os latifúndios e na organização dos assentamentos rurais.

A partir de 1985, durante o governo de José Sarney, foi lançado o Plano Nacional de Reforma Agrária (PNRA), resultado das discussões políticas relacionadas ao processo de democratização no qual se intensificavam as discussões políticas favoráveis e contrárias à reforma agrária no Brasil. As expectativas criadas no início logo foram perdendo força com a firme reação dos segmentos sociopolíticos contrários à realização da reforma agrária. Liderados pelas entidades patronais, como a União Democrática Ruralista (UDR), a Sociedade Rural Brasileira (SRB), a Confederação Nacional da Agricultura (CNA), entre outras, essa oposição foi caracterizada pela pressão política e pela violência de milícias armadas. As pressões trazidas por essas organizações conseguiram esvaziar a plataforma política do PNRA (CARVALHO, 1989).

O processo de transição para a Nova República foi visto pelas elites rurais como a reedição do movimento das reformas de base das décadas de 1950 e 1960, no qual a reforma agrária era contemplada como um dos carros-chefes. Assim, criaram-se rapidamente sindicatos e associações patronais que visualizavam a inevitabilidade de uma guerra no campo. Essa postura política do setor patronal se converteu rapidamente em práticas 
tradicionalmente associadas ao coronelismo, como a formação de milícias armadas e a ação paramilitar para coibir as atividades do MST no campo (BRUNO, 2003).

Diante das dificuldades políticas enfrentadas para sustentar a legitimidade da reforma agrária com o lema anterior (terra para quem nela trabalha), a prerrogativa em nome da questão agrária deslocou-se parcialmente na direção dos problemas sociais urbanos. A inflação, o alto custo dos alimentos e o desemprego urbano, em parte gerado pela concorrência e em parte pela não incorporação dos camponeses que migraram para a cidade, eram problemas reais que poderiam dar legitimidade à reforma agrária. Isso pode ser visto na Campanha Nacional pela Reforma Agrária mobilizada por vários movimentos sociais, dentre os quais o MST, no ano de 1986.

A luta pela reforma agrária. A luta pela reforma agrária não é uma luta isolada e exclusiva dos trabalhadores rurais; o interesse pela redistribuição de terra alcança também a classe trabalhadora da cidade. A falta de alimentos, as miseráveis favelas na periferia das cidades, as famílias desmembradas, os milhões de menores na rua, são só alguns dos problemas que os operários da cidade estão vivendo?

Ao tocar nos graves problemas urbanos, a narrativa da reforma agrária idealizava uma inversão histórica no movimento de migração da população brasileira do campo para a cidade. Esse movimento, produzido pela modernização da agricultura a partir da década de 1960, apresentou-se como problemático em virtude das discrepâncias na relação entre o êxodo rural gerado e a incorporação desses trabalhadores em empregos urbanos. A reforma agrária era apresentada como uma forma de regeneração para o projeto de país que estava sendo construído com todas as expectativas da democratização.

9 Campanha Nacional pela Reforma Agrária. Brasília: Contag, CPT, MST, CUT, 1986. 
Às vésperas do processo constitucional que confirmaria a redemocratização do país, o MST e demais entidades comprometidas com a causa da reforma agrária procuraram reforçar sua necessidade como uma questão crucial para a democracia e cidadania no país, como se verifica neste trecho:

A questão agrária e a constituinte: sem reforma agrária não há democracia. A próxima constituinte é a última chance. É chegado o momento de invertermos os termos da questão. A regra agora é a desapropriação, é a entrega gratuita ou não de terra a quem nela trabalha ou queira trabalhar. A reforma agrária não é apenas o exercício de uma economia baseada no trabalho familiar, não é somente mais produção, diversidade de cultura, lavoura de subsistência, ampliação do mercado interno. Reforma agrária é, antes de tudo, um passo fundamental em direção à cidadania, diante do que se vê no país, ou seja, a subordinação quase absoluta dos trabalhadores rurais, dos camponeses, dos posseiros, dos sem terra ao poder econômico e ao poder político dos que tem o monopólio da terra ${ }^{10}$.

Os discursos são produzidos socialmente dentro de uma rede discursiva e, portanto, estão conectados aos assuntos e às disputas vigentes em dado contexto. Diante das discussões da Assembleia Constituinte do ano de 1987, os movimentos sociais defensores da reforma agrária mobilizaram seus recursos políticos e discursivos para reforçar o lugar da reforma agrária dentro da Constituição que estava por vir. É importante perceber que o termo "questão agrária" continua sendo invocado, pois representa uma dimensão mais ampla do problema da terra que nesse momento também se associa à questão da cidadania.

Outro aspecto interessante ser a destacado é o fato de que, desde o contexto pré-formativo do MST até o início da década de 1990, a narrativa da reforma agrária tem como um de seus ancoradouros a necessidade de aumentar a produção de alimentos no país. Um dos reflexos da concentração fundiária e do modelo de desenvolvimento rural voltado para

10 Campanha Nacional pela Reforma Agrária. Rio de Janeiro: MST, CPT, Contag, CUT., 1986. 
a agricultura de exportação no período era a deficiente produção de alimentos para o mercado interno. De certa forma, essa reivindicação tecia uma crítica ao principal pilar que instrumentalizou as políticas de desenvolvimento rural nas décadas anteriores: a segurança alimentar ${ }^{11}$.

Se o aumento da produtividade de alimentos foi uma conquista da "revolução verde", o mesmo não aconteceu com sua distribuição. Assim, como o objetivo do modelo de desenvolvimento rural baseado na revolução verde não estava sendo efetivo no que se refere ao problema da distribuição de alimentos, a narrativa da reforma agrária encontrava ressonância nos segmentos urbanos da sociedade brasileira. A perspectiva de que a redistribuição da terra poderia significar a redistribuição de alimentos nutria uma fonte de legitimidade no discurso da reforma agrária.

Porém, nos embates surgidos no contexto constitucional, as forças sociopolíticas contrárias à reforma agrária conseguiram sobressair-se. Liderados pela UDR e demais entidades patronais, novamente a questão agrária foi vencida pelo discurso da modernização das grandes e pequenas propriedades (ARAÚJO; TEIXEIRA, 1987). Com o esvaziamento do PNRA e as derrotas na constituição de 1988, que acabou restringindo a desapropriação ao latifúndio improdutivo, os embates pela reforma agrária não tinham mais em vista as expectativas otimistas criadas em razão da redemocratização do país.

Diante disso, o MST teve que reorganizar sua plataforma política. Foi a partir desse momento que seus discursos se tornaram mais enfáticos em relação à desapropriação e às estratégias de ocupação para pressionar o Estado. A narrativa da reforma agrária adquiriu uma ênfase maior na pressão pela desapropriação. Dentro das novas regras políticas do país,

11 O pacote tecnológico da revolução verde tinha como uma de suas missões resolver o problema da segurança alimentar, ou seja, de produzir e distribuir alimentos à grande massa de "famintos" que havia no mundo (CHONCHOL, 2005). O século XX foi marcado pela preocupação com a segurança alimentar e, mesmo, com todas as mudanças empreendidas no campo técnico-produtivo, o problema da fome não foi resolvido, afinal, ele não se explica necessariamente pela falta de alimentos, mas pela má distribuição da renda que impede à massa da população adquiri-los. 
da democracia, o MST reorganizou suas ações no sentido de intensificar as pressões políticas através de ocupações de latifúndios improdutivos e de organizar ações articuladas com outras entidades sociopolíticas para dar visibilidade à necessidade de se fazer reforma agrária. De certa forma, pode-se dizer que a narrativa da reforma agrária passou a ser escrita nas ruas através das grandes mobilizações organizadas pelos movimentos sociais nesse período.

\section{Cidadania e cooperativismo: é preciso condições para quem na terra trabalha!}

Mesmo após a aprovação da Constituição de 1988 e das eleições presidenciais de 1989, a situação econômica do país continuava grave. A agricultura brasileira ressentia-se com o sucateamento de toda uma estrutura de políticas públicas criadas no período da ditadura militar, que incluía desde o crédito à assistência técnica. Com isso, a inserção do país nos mercados globais competitivos tornava-se fragilizada. Os problemas sociais já existentes no campo se intensificaram, pois a reforma agrária não havia sido feita e os direitos trabalhistas não haviam sido consolidados.

A inserção do país na globalização, em que a agricultura passou a ser regulada pelos mercados globais e instituições internacionais como a OMC (BUAINAIN, 2007), trouxe enormes dificuldades para o setor, pois estava desestruturado em termos de políticas públicas eficientes para o setor agrícola. A produção de alimentos para o mercado interno estava desestimulada, e os agricultores de base familiar enfrentavam enormes dificuldades econômicas. O êxodo rural intensificou-se, e o desemprego urbano também. Consequentemente, o discurso da reforma agrária, como condição para a cidadania, passou a enfatizar de forma incisiva a necessidade de políticas agrícolas eficientes para os segmentos da agricultura de 
base familiar, ou seja, para os assentados rurais e para os então denominados pequenos agricultores. Além de conquistar a terra era fundamental não perdê-la!

Com a ascensão de Fernando Collor de Melo à presidência em 1990, a reforma agrária sofreu outro revés. O governo com sua política neoliberal (LUNA; KLEIN, 2007) desmontou as pastas institucionais responsáveis pelos assuntos fundiários e, durante o ano de 1990, nenhum assentamento foi realizado. Diante do descaso do governo não só com a política de reforma agrária, mas com a política agrícola de um modo geral, a estratégia do MST foi estimular as grandes mobilizações populares e fortalecer a organização interna da militância.

Uma das mobilizações sociais mais significativas que relacionava a reforma agrária com a cidadania no país no início da década de 1990 foi o "Grito da terra Brasil". Organizado por um conjunto de entidades, incluindo o MST, o movimento buscava reivindicar a aplicação dos direitos sociais e trabalhistas necessários à consolidação da cidadania, sendo que a reforma agrária era o ponto de partida para as demais demandas. Isso pode ser observado no seguinte extrato:

Por um país sem fome, sem violência e com trabalho. Os trabalhadores do campo estarão novamente nas ruas. É o grito da terra Brasil por um país melhor, sem fome, sem violência e com trabalho. Assalariados, pequenos produtores, sem terra, pescadores, seringueiros, povos indígenas, atingidos por barragens, estão unidos por uma nova proposta de desenvolvimento socioeconômico para o país [...]. Por isso queremos: condições de produção e comercialização para a agricultura familiar e para a pesca artesanal; reforma agrária; demarcação de terras indígenas; cumprimento dos direitos sociais e trabalhistas; fim da violência no campo; previdência pública; preservação ambiental; política energética compatível com os interesses sociais [...]. A democratização da terra é fundamental para a geração de empregos e para elevar a produção de alimentos ${ }^{12}$ ".

12 Grito da Terra Brasil, 1995. 
A atuação propositiva dos movimentos sociais foi um aspecto marcante desse período (GHON, 2004). As mobilizações articuladas pelos movimentos sociais contribuíram para a consolidação dos direitos mencionados, bem como para a criação das políticas públicas voltadas para a agricultura familiar nos anos subsequentes. Entretanto, a reforma agrária foi um dos pontos que não avançou. Diante da imobilidade do Estado em fazê-la, o MST intensificou as táticas de ocupação como forma de pressão política.

A reforma agrária literalmente não estava na agenda política governamental no início da década de 1990 e só passou a integrá-la graças às ações pontuais e estratégicas do MST. A forte atuação do Movimento no estado de São Paulo durante a década de 1990, especialmente nas regiões do Vale do Ribeira e do Pontal do Paranapanema, foi, sem dúvida, um elemento de peso para redimensionar a visibilidade social dos problemas agrários no país (BERGAMASCO; NORDER, 1999). A ideia era aumentar a capacidade de pressionar o governo para conseguir assentar as famílias de agricultores sem-terra, agora já compostas também por trabalhadores oriundos dos centros urbanos.

O lema do MST no início da década de 1990 era "Ocupar, resistir, produzir". A ocupação era a forma de pressionar o governo a acelerar os processos; a resistência era necessária em razão da violência promovida pelo próprio Estado e pelas milícias armadas formadas pelos latifundiários; a produção era a resposta dada à sociedade de que a reforma agrária se justificava também pelo elemento produtivo, especialmente pelo impacto do preço dos alimentos para a população urbana brasileira no período.

A imagem do cartaz do II Congresso Nacional do MST reforça a ideia do período de mobilização pela reforma agrária. 
Figura 2: II Congresso Nacional do MST

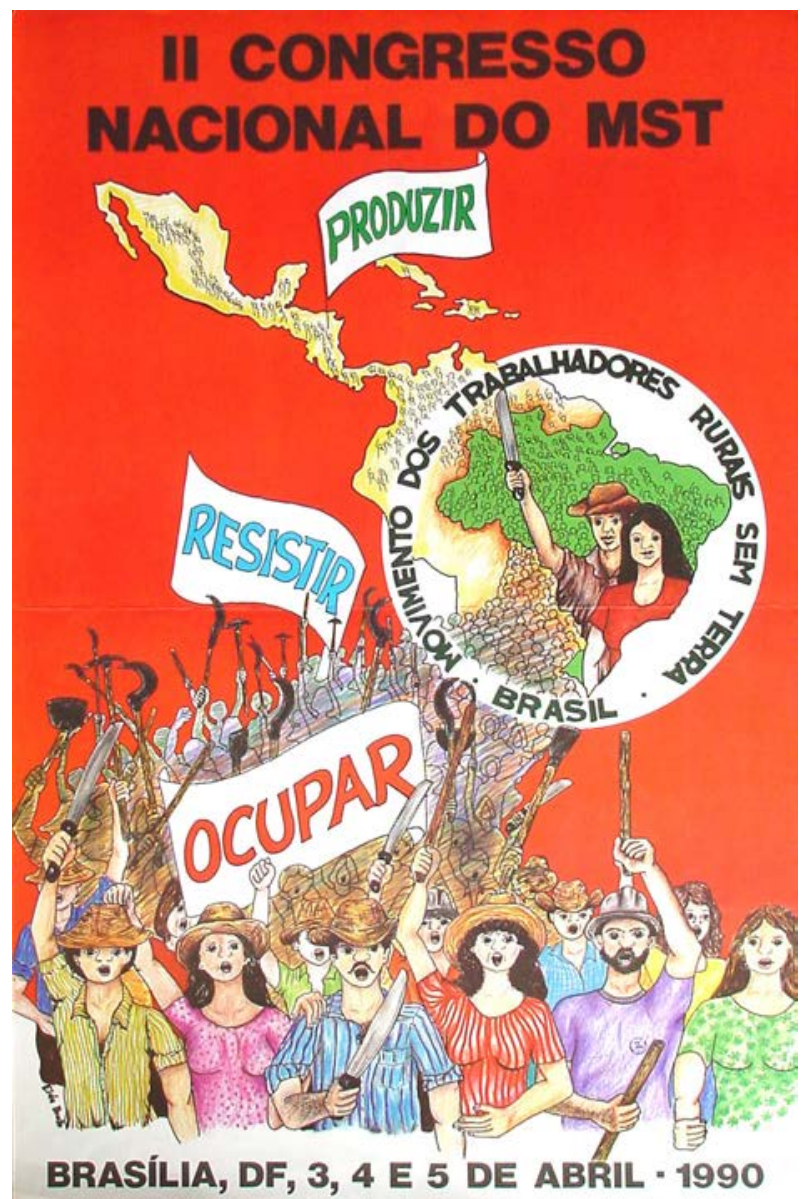

Fonte: Movimento dos Trabalhadores Sem Terra.

As dificuldades econômicas enfrentadas pelos agricultores eram, no entanto, uma realidade que demandava uma resposta. Nesse sentido, a narrativa da reforma agrária produzida pelo MST fez do cooperativismo uma de suas principais estratégias propositivas para sustentar a eficiência da produção nos assentamentos rurais. Nota-se que a busca pela legitimidade também precisa responder positivamente dentro de seu próprio campo, para os membros que participam dos movimentos de ocupação e 
para os que já foram assentados. O Jornal Sem Terra divulgava o cooperativismo nos seguintes termos:

O caráter revolucionário da reforma agrária: A reivindicação de reforma agrária, atualmente, tem um novo caráter. Ela somente adquire uma expressão revolucionária se articulada a um projeto amplo de mudança estrutural em direção ao socialismo. Mas seu caráter revolucionário não é conferido pela socialização imediata da terra, e sim pelo fato de inserir-se em um projeto anticapitalista [...]. A curta experiência realizada nos assentamentos desde 1983, sob o impacto das lutas pela terra, já conduziu ao reconhecimento explícito da importância de cooperação entre os pequenos agricultores. Isso leva à proposição geral de associação imediata dos pequenos agricultores assentados"13.

No cenário em que o modelo de socialismo soviético estava no auge de sua crise, a narrativa do MST continuava evocando o discurso socialista. Porém, esse alinhamento mantém certo pragmatismo ao afirmar que diante das experiências já existentes o caminho possível era o de estimular as formas cooperativas de produção. As propostas versam desde a produção coletiva, ainda que coexistindo com a produção individual, até a criação de bancos cooperativos para os assentados. $\mathrm{O}$ cooperativismo defendido pelo MST parece ser mais uma solução pragmática para responder à falta de políticas públicas diferenciadas para a agricultura de base familiar do que uma referência ao modelo soviético propriamente dito.

No VII Encontro Nacional do MST, em 1994, as desapropriações foram reivindicadas em regime de urgência, e a necessidade de políticas públicas para os assentamentos ganhava destaque. A pobreza no campo, nas periferias das cidades e o desemprego serviam de argumentos para dar legitimidade à luta pelas desapropriações e formação de novos assentamentos rurais. 
Reforma agrária e geração de empregos! De certa forma, pode-se afirmar que a pobreza está concentrada no eixo urbano enquanto a miséria é eminentemente rural. Pouco adianta sanear a pobreza urbana, se a miséria rural não for combatida. Novos fluxos migratórios para a cidade repetirão o caos atual. Hoje, a conquista efetiva da cidadania para grande parcela da população brasileira passa pela reforma agrária [...]. $\mathrm{O}$ assentamento de trabalhadores rurais é uma das principais formas de combate à fome e ao desemprego no país" ${ }^{14}$.

De certa forma, esse parece ter sido um dos últimos momentos em que o sentido da reforma agrária busca de forma incisiva legitimar-se em nome de uma questão agrária. Embora nos discursos do MST essa referência não tenha sido apagada, nota-se que seu peso vem sendo gradativamente reduzido. Isso pode ser atribuído ao próprio desenvolvimento histórico da agricultura produtivista nas últimas décadas, bem como às políticas públicas criadas para a agricultura familiar que, em parte, reduziram os problemas sociais existentes no campo. O fato é que durante a década de 1990 a narrativa da reforma agrária em nome da cidadania tem na resolução dos problemas urbanos um de seus principais pontos de legitimação.

No III Congresso Nacional do MST em 1995, a narrativa da reforma agrária enuncia o projeto político de promover a justiça social, da busca pelo socialismo e do cooperativismo como alternativa de desenvolvimento rural.

Reforma agrária: uma luta de todos. Nesse congresso, reafirmamos nosso ideal: fazer do Brasil um país justo e socialista. Carta aos trabalhadores do campo: Buscamos hoje caminhos alternativos para fazer produzir a terra conquistada: a valorização da produção familiar, das cooperativas, das associações e da socialização dos bens produzidos. Com eficácia, reinventamos políticas de combate à pobreza, a fome, ao desemprego [...]. Carta aos trabalhadores da cidade: com melhor distribuição de terras teremos trabalho, construiremos nossas casas, escolas, nos fixaremos no campo, contribuindo para um desenvolvimento mais justo do país. E com esse

14 Jornal dos Trabalhadores Rurais Sem Terra, a. XIII, n. 135, abr. 1994. 
desenvolvimento rural, ajudaremos a melhorar as condições de vida também na cidade" 15 .

O lema "reforma agrária para todos" é muito elucidativo. A ideia de que a reforma agrária é importante tanto para os trabalhadores do campo quanto para os da cidade retrata a narrativa cidadã da reforma agrária nesse período. O raciocínio de que a redistribuição das terras diminuiria a pressão por emprego e o custo dos alimentos na cidade era uma tentativa de amenizar o impacto de um imaginário social negativo criado em torno das ocupações de terra por parte do MST. Paralelamente, a proposição do socialismo como ideal político teve, nesse período, seu momento de maior ênfase.

A correlação entre a reforma agrária e a cidadania pode ser observada na divulgação da "Carta da terra", documento produzido ao longo de vários anos por iniciativa da ONU e um conjunto amplo de organizações com o intuito de promover uma perspectiva de desenvolvimento sustentável. Embora o lançamento oficial da carta só tenha ocorrido no ano 2000, uma versão foi divulgada, no Brasil, em 1995, com a assinatura do sociólogo Herbert de Souza (Betinho). Nessa versão, a reforma agrária é justificada em nome da cidadania.

A partir da segunda metade da década de 1990, as ações de ocupação de terras pelo MST se intensificaram e, com elas, a violência por parte dos fazendeiros e do próprio Estado, como aconteceu em Eldorado do Carajás. ${ }^{16}$ A divulgação pela mídia televisiva das ações do MST e dos casos de violência produziu efeitos políticos, como a tentativa de fazer uma reforma agrária de mercado, uma política de compra e venda de terras feitas pelo governo através de financiamentos públicos e leilões feitos pelo Instituto

15 Jornal dos Trabalhadores Rurais Sem Terra, a. XIV, n. 150, ago. 1995.

16 O assassinato de membros do MST pelas forças policiais em Eldorado do Carajás, no Estado do Pará em 1996, foi um dos momentos mais impactantes dos embates envolvendo as disputas de terra no Brasil contemporâneo. Nesse episódio, a polícia do Estado do Pará matou 19 membros do MST, que faziam uma marcha na BR 155 em prol da desapropriação da fazenda Macaxeira para reforma agrária. 
Nacional de Reforma Agrária (INCRA) (MALIN, 2002). Além disso, a criação do Ministério do Desenvolvimento Agrário (MDA) em seguida e a adoção de medidas provisórias para acelerar o processo de desapropriação pelo INCRA para a formação dos assentamentos rurais ${ }^{17}$ revelam que o problema da terra não havia sido resolvido.

Diante de todos esses eventos, durante o governo Fernando Henrique Cardoso os assentamentos rurais foram ampliados. Ainda que parte deles tenha sido feita através da chamada "reforma agrária de mercado", com vendas de terras adquiridas em leilões por parte do INCRA (SAUER, 2010), o fato é que o número de assentamentos rurais se multiplicou. E, com eles, a cobrança por resultados. Isso levou alguns estudiosos a costurar argumentos para a desconstrução da legitimidade da reforma agrária. Pensadores como Graziano (2010) e Navarro (2008) questionaram tanto o funcionamento dos assentamentos em termos de viabilidade econômica quanto a necessidade histórica de fazer reforma agrária em razão do próprio desenvolvimento da agricultura brasileira no contexto do agronegócio.

O contexto da agricultura brasileira já apresentava aspectos bem distintos em relação aos períodos anteriores. A evolução da modernização agrícola, o desenvolvimento da biotecnologia, a agricultura brasileira inserida nos mercados globais dominados por grandes empresas, a diminuição da população residente no espaço rural e o aumento gradativo da produção agrícola trouxeram novos desafios para a legitimação discursiva da reforma agrária. Esses elementos, em conjunto, enfraqueceram o argumento histórico da questão agrária e colocaram um importante desafio para os defensores da reforma agrária: como torná-la legítima? Embora os latifúndios improdutivos ainda existissem, já não possuíam mais a mesma visibilidade, o que tornou mais árdua a tarefa de justificar

17 Deve ser mencionado que nesse contexto o governo aumentou a tributação dos grandes latifúndios, o que serviu de estímulo para muitos latifundiários considerarem um bom negócio vender suas terras para o governo. Além disso, como o preço da terra ainda sofria a influência da crise do final da década de 1980 e início da de 1990, quando a falta de incentivos do Estado gerou uma queda significativa no preço, a política de aquisição de terras não teve um custo tão oneroso para os cofres do Estado. 
a necessidade de uma reforma agrária ampla no país. Contudo, um novo campo de batalha foi aberto.

\section{E agora, o que dizer?}

O cenário da agricultura brasileira a partir do final da década de 1990 pode ser considerado, em que pese algumas oscilações, como de grande expansão do agronegócio ${ }^{18}$. A agricultura de exportação foi favorecida pelas políticas macroeconômicas dos governos, e as políticas públicas que financiaram os diferentes segmentos da agricultura brasileira (patronal e familiar) receberam investimentos significativos. Com os mercados externo e interno favoráveis aos produtos agrícolas, a expansão da produção ocupou áreas que ainda não haviam sido intensamente exploradas do território brasileiro (Amazônia e Cerrado).

Ainda acerca das condições objetivas da agricultura nessa conjuntura, cabe destacar o desenvolvimento da biotecnologia. As sementes transgênicas entraram ilegalmente no país, venceram as disputas judiciais e foram legitimadas pela Comissão Técnica Nacional de Biossegurança (CTNBio) (ZANONI et al., 2011). As incertezas em relação aos impactos ambientais e humanos no uso e consumo de alimentos transgênicos, bem como a certeza do controle social e econômico exercido pelas grandes empresas do agronegócio que controlam tal tecnologia, abriram um novo campo de batalha para as organizações que defendem a reforma agrária. Afinal, a perspectiva de desenvolvimento rural estimulada pelo atual contexto político e econômico da agricultura brasileira passou a reproduzir uma nova forma de concentração fundiária.

18 Conforme Davis e Golberg (apud GRAZIANO DA SILVA, 1998, p. 65), "o agrobusiness é a soma de todas as operações envolvidas no processamento e na distribuição dos insumos agropecuários, as operações de produção na fazenda; o armazenamento e processamento dos produtos e a sua distribuição". Porém, os movimentos sociais utilizam o termo "agronegócio" em seu sentido político, ou seja, do controle econômico e social exercido pelas empresas do setor. 
A globalização econômica também trouxe consigo a globalização das mobilizações políticas e sociais. No caso das questões ligadas à agricultura, desde a Conferência Rio 92 já vinham sendo discutidas sistematicamente perspectivas de desenvolvimento rural que fossem capazes de minimizar os impactos socioambientais já criados pela agricultura produtivista ao longo do século XX e resolver problemas, como a pobreza, em diversas regiões rurais do mundo. Nesse processo cabe destacar entidades como a Via Campesina, uma importante organização internacional que defende formas alternativas de desenvolvimento rural, considerando a diversidade cultural e biológica das regiões e criticando o modelo produtivista de fazer agricultura.

No IV Congresso Nacional do MST, realizado em 2000, observa-se a reorientação discursiva na direção da crítica do modelo de desenvolvimento rural e na retomada dos temas ambientais. Embora o lema do congresso tenha sido "Por um Brasil sem latifúndio", o sentido da luta contra esse problema fundiário é ampliado. Dizer não ao latifúndio significa, além de conseguir terra para os camponeses, construir um projeto alternativo de desenvolvimento rural. Entre os principais pontos deliberados, destacam-se:

Um projeto político popular para o Brasil. Construir a unidade no campo, desenvolver novas formas de luta e fortalecer os novos movimentos sociais existentes no campo (MPA); combater o modelo das elites, que representa os produtos transgênicos, as importações de alimentos e os monopólios das multinacionais na agricultura; resgatar o debate sobre temas importantes como o meio ambiente e a biodiversidade; desenvolver um novo modelo tecnológico que seja sustentável do ponto de vista ambiental ${ }^{19}$.

A crítica ao modelo do agronegócio, incentivado pela política econômica do governo, tornou-se central na narrativa da reforma agrária a partir desse momento. Além de conquistar a terra, o grande desafio agora

19 Jornal dos Trabalhadores Rurais Sem Terra, a. XVIII, n. 203, ago. 2000. 
é viabilizar as condições para os agricultores de base familiar conseguir produzir. Por isso, justifica-se o alinhamento do MST com os movimentos da Via Campesina, com o Movimento dos Pequenos Agricultores (MPA) e com o discurso de um novo projeto de desenvolvimento rural que consiga dar autonomia aos agricultores em relação às grandes agroindústrias que controlam a tecnologia e a renda dos agricultores.

A integração à Via Campesina levou o MST a inserir outros elementos discursivos no foco de sua narrativa, dando vazão a temas já presentes, porém pouco enunciados anteriormente, como a questão ambiental e o desenvolvimento sustentável através da agroecologia. Um desses elementos é o discurso da "soberania alimentar".

A Via Campesina reivindica. Impulsionar e reativar o processo de reforma agrária para garantir a soberania alimentar, o direito de produzir e o acesso à terra; defender os camponeses, pequenos agricultores, povos indígenas nos acordos de comércio internacional; excluir a agricultura dos tratados de comércio internacional, pois a produção de alimentos não deve ser uma mercadoria manipulada pelas grandes corporações internacionais; planificar a agricultura de acordo com a realidade e as necessidades de cada país de maneira autônoma. Diante de tudo isso exigimos políticas justas de desenvolvimento rural, no acesso a recursos produtivos e na participação na tomada de decisões que afetam os pequenos e médios agricultores ${ }^{20}$ ".

O termo "soberania alimentar" tem sido usado para expressar uma contraposição ao termo "segurança alimentar", característico do modelo produtivista de desenvolvimento rural (BOSETTI, 2013). Diante do controle exercido pelas grandes empresas do agronegócio, dos impactos ambientais desse modelo para os territórios e povos que neles habitam, da mercantilização da agricultura, dos impactos ambientais e pelo fato de o modelo produtivista não ter resolvido o problema da fome em nível

20 Jornal dos Trabalhadores Rurais Sem Terra, a. XVII, n. 189, maio 1999. 
mundial, o discurso da soberania alimentar busca contrapor-se a esse modelo de desenvolvimento rural. A preocupação desloca-se da quantidade, defendida pela revolução verde nas décadas anteriores, para a qualidade e distribuição dos alimentos.

Essa enunciação vem ao encontro dos discursos produzidos por outros movimentos sociais, por ONGs e, mesmo, por conferências internacionais preocupadas com a questão da sustentabilidade, em que pese o caráter amplo e controverso em torno desse termo. $O$ fato é que a ligação com a soberania alimentar indica a aproximação da narrativa da reforma agrária com um discurso em voga, o da sustentabilidade. Assim, no cenário em questão, sem desconsiderar a presença das motivações anteriores centradas na existência de uma questão agrária, ${ }^{21}$ a narrativa da reforma agrária tem enfatizado como um de seus eixos principais as contradições do modelo produtivista de desenvolvimento rural.

O modelo de desenvolvimento rural produtivista tem apresentado uma configuração social, tecnológica e econômica insustentável em termos socioambientais. A utilização intensa de agrotóxicos, o uso de sementes transgênicas e todo o pacote mecânico-químico da chamada "revolução verde" das décadas anteriores tornaram a agricultura uma atividade altamente dependente da indústria. Contra o domínio econômico exercido pelas corporações empresariais que controlam a agricultura na atualidade, as narrativas de entidades, como o MST, procuram ressignificar o discurso da reforma agrária de modo a encontrar novas fontes de legitimidade social.

O discurso da reforma agrária segue o jogo de sua instância, pois é pronunciado a partir da sua temporalidade e das suas relações com outros

21 Embora questões cruciais, como a pobreza no meio rural, ainda sejam evocadas, afinal, parte significativa da população rural brasileira possui rendimento inferior ao salário-mínimo e ao rendimento médio dos trabalhadores brasileiros (SAMPAIO JUNIOR, 2013), essa condição tem sido comumente associada ao modelo de desenvolvimento do agronegócio. Esse, na percepção de entidades como o MST, além de causar danos ambientais e explorar o trabalho dos trabalhadores do campo, também produz o latifúndio. Em comparação com outros países e, contrariando as perspectivas otimistas em relação ao agronegócio, a pobreza no Brasil rural continua sendo uma realidade (MIRANDA; BRAULIO, 2012). Como parte dessa pobreza, está associada ao acesso à terra, e o modelo de desenvolvimento rural hegemônico caracteriza-se pela concentração fundiária. Entende-se que esse é um dos responsáveis pelos problemas sociais no campo. 
discursos. Essas relações discursivas consistem em buscar em outros discursos pontos de sustentação para fortalecer seu próprio enunciado e, dessa forma, desestabilizar seus oponentes. $\mathrm{O}$ aparecimento e fortalecimento dos discursos ambientalistas, da sustentabilidade, da biossegurança e das mudanças climáticas, por exemplo, fez desses pontos apoio para que o discurso da reforma agrária fosse reativado em sua significação histórica. Com isso, o discurso sociopolítico passou a associar o modelo da agricultura produtivista do agronegócio como responsável pelos desequilíbrios mencionados, como se pode observar no enunciado:

A batalha entre dois modelos. O agronegócio é uma agricultura sem agricultores. Praticamente as únicas pessoas que vivem nas terras no Brasil nos dias de hoje são os guardas de segurança que são responsáveis pela propriedade - os trabalhadores vivem nos subúrbios e marginalizados da propriedade. Investidores do agronegócio veem a terra como uma máquina que produz lucros, não importando o que se produza, e para ser usada até ao seu esgotamento. As suas decisões não levam em conta as pessoas que precisam e que vivem da terra. A agricultura industrial, liderada pelo agronegócio, é um pacote tecnológico. O mesmo conjunto de tecnologias é utilizado da mesma forma em todas as regiões, independentemente das diferenças locais ou as habilidades e conhecimentos dos povos ${ }^{22}$.

A forma de agricultura que funciona pela lógica do agronegócio, pelo controle exercido pelas grandes empresas sobre as atividades agropecuárias, não só concentra a terra e a renda no espaço rural, como promove práticas produtivas não sustentáveis. A intensificação do uso de agrotóxicos e a biotecnologia dos transgênicos são duas dessas práticas. Se a segunda ainda é discutida no campo acadêmico quanto aos impactos ambientais e sociais negativos, a primeira já é consensualmente vista como negativa para a saúde da população e para o meio ambiente. 
A reforma agrária como contraposição ao agronegócio foi tema de cartazes produzidos pelo MST.

Figura 3: Advertência dos movimentos sociais do campo sobre o agronegócio

Os Movimentos Sociais do Campo Advertem:

\section{O AGRONEGÓCIO GERA CÂNCER E DESTRÓI O MEIO AMBIENTE!}

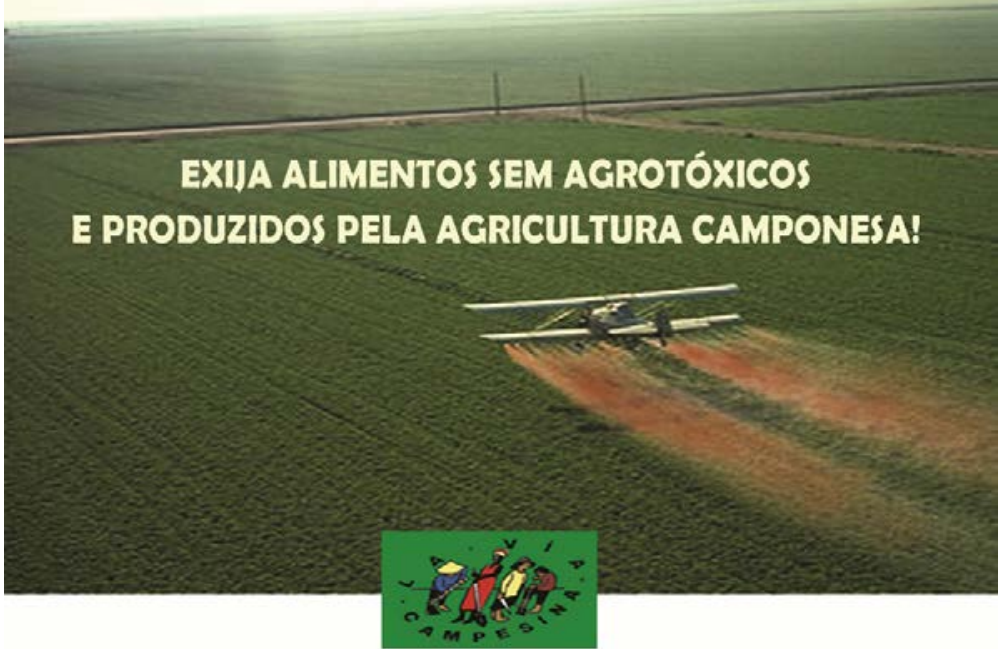

Fonte: Movimento dos Trabalhadores Sem Terra.

A difusão dos transgênicos na agricultura brasileira a partir de 1990 (PELAEZ; SCHMIDT, 2000) foi interpretada pelos segmentos que defendem a reforma agrária como mais uma das estratégias de controle político e econômico das empresas do agronegócio sobre os agricultores. Isso pode ser observado nos seguintes enunciados do MST:

Transgênicos para dominar a agricultura: A transgenia é introduzida e controlada pelo grande capital, que tem interesse em apontar o rumo da agricultura para garantir a obtenção de lucro e a apropriação do trabalho das pessoas" (março de 2008); "Adoção de cultivos transgênicos aumenta o uso de agrotóxicos: Necessidade de 
agrotóxicos casados a sementes transgênicas leva ao aumento no uso destas substâncias, que se mostram cada vez menos eficientes. Assim, ingredientes mais tóxicos voltam ao campo, agravando problemas ambientais e de saúde" (julho de 2009); "Ditadura transgênica: BASF e Embrapa licenciam nova soja transgênica. A Empresa pública trabalhando para o privado. A Empresa Brasileira de Pesquisa Agropecuária (Embrapa) é uma instituição pública brasileira vinculada ao Ministério da Agricultura, Pecuária e Abastecimento, cujos objetivos são a produção de conhecimento científico e desenvolvimento de técnicas de produção para a agricultura e a pecuária brasileira. Atualmente, a pesquisa com transgênicos está entre as suas prioridades (MST, s/d) ${ }^{23}$.

Desde a introdução das sementes transgênicas no Brasil em escala comercial, entidades, como o MST, construíram o discurso de denúncia do controle político e econômico subjacente a esse tipo de tecnologia. A associação da transgenia com o aumento do uso de agrotóxicos, opondo-se ao discurso oficial das empresas que preconizava sua redução, foi feita pelas entidades da Via Campesina desde o início da utilização dos transgênicos no Brasil.

Dessa forma, um dos alicerces da defesa da reforma agrária nas últimas décadas é a contraposição ao modelo de desenvolvimento rural hegemônico no Brasil. Essa contraposição incorpora em suas contradições diferentes formas sociais de produção, inclusive os próprios agricultores dos assentamentos de reforma agrária. Nesse sentido, a contraposição ao agronegócio possui uma conotação política que levou seus defensores a apresentar um projeto alternativo.

A migração discursiva do MST para a defesa da agroecologia teve início ainda na década de 1990, com a ampliação do diálogo com a Via Campesina, com a criação de grupos de discussão no ambiente dos fóruns sociais mundiais e com parcerias com universidades e governos de outros países. Essas mobilizações resultaram na criação de cursos de agroecologia e na

23 Disponível em: <http://www.mst.org.br >. 
adoção do discurso político agroecológico pelo movimento (DE CARLI, 2013). Oficialmente, foi a partir de seu IV Congresso Nacional, realizado em 2000, que o MST inseriu a agroecologia ${ }^{24}$ como eixo do projeto político de reforma agrária.

A crise no modelo cooperativista de produção nos assentamentos de reforma agrária inspirado no pensamento marxista ortodoxo, bem como a adesão do MST à Via Campesina, contribuiu para uma guinada discursiva na direção da agroecologia como alternativa de produção (BORSATO; CARMO, 2013). Em conjunto com as demais organizações ligadas à Via Campesina, o discurso do MST retomou o uso do termo "camponês", agora ressignificado em virtude da disputa política contra o agronegócio.

É importante ressaltar que essas mudanças discursivas não são apenas resultados de uma reflexão teórica, mas de um novo contexto das disputas sociopolíticas no campo e de outra ordem discursiva envolvendo questões ideológicas, sociais, ambientais e de saúde pública. Se em contextos anteriores a reforma agrária era defendida em nome da própria modernização do campo (fim do latifúndio improdutivo), no atual estágio de desenvolvimento da agricultura produtivista foi preciso construir outro ancoradouro, que foi encontrado nas contradições do modelo produtivista. Ou seja, na insustentabilidade econômica, social e ambiental apresentada pelo modelo hegemônico do agronegócio. Nesse sentido, a agroecologia passou a integrar o projeto político do MST porque faz parte de uma ordem discursiva presente em vários outros discursos e movimentos políticos.

Diante desses desdobramentos, o discurso da reforma agrária tem se alicerçado na proposição de outra perspectiva de desenvolvimento rural. Dessa forma, a agroecologia tem sido o ponto de encontro entre a crítica do agronegócio e um novo projeto de desenvolvimento rural.

24 A agroecologia refere-se a uma forma de se produzir na agricultura, observando um manejo dos recursos naturais que se diferencia das práticas convencionais da agricultura moderna, bem como implica um estilo de vida próprio no âmbito da relação do produtor com o mercado e com a natureza (ALTIERI, 1989, p. 30). Porém, o termo passou a ter uso político, significado como uma perspectiva de desenvolvimento rural, que se contrapõe ao da agricultura produtivista. 
A necessidade de uma transição agroecológica, para o militante, advém das características nocivas do modelo do capital na agricultura, hoje conhecido como agronegócio. É justamente nas contradições desse modelo que está nossa esperança em uma adesão crítica da sociedade como um todo para enfrentarmos a agricultura capitalista e estabelecermos novas bases de produção, fundadas na agroecologia $^{25}$.

Essas palavras enunciadas pelo líder do MST João Pedro Stedile na $14^{\text {a }}$ Jornada da agroecologia, cujo lema foi "Terra livre de transgênicos e sem agrotóxicos", expressa o entendimento de que a agroecologia é uma forma alternativa de agricultura capaz de opor-se ao modelo da agricultura produtivista. O projeto político para a agricultura defendido por entidades, como o MST, preconiza a necessidade de superação do modelo produtivista devido à sua insustentabilidade econômica, social e ambiental.

A ideia de um projeto político calcado na agroecologia também aparece no seguinte extrato:

Agroecologia como modelo ideal! Os dados nos mostram que tão concentradas quanto a terra do agronegócio, estão também a distribuição e o acesso à alimentação em nível global [...]. Esse cenário de crise alimentar pede a urgência de uma alternativa que não se limite apenas à produção, mas atente para problemas sociais estruturais. Enquanto o agronegócio destrói o meio ambiente, a agroecologia não utiliza produtos químicos, recicla totalmente seus componentes e prioriza o desenvolvimento da diversidade genética no espaço agrário. Estamos diante de uma disputa de dois modelos concorrentes de desenvolvimento. Resta à população refletir sobre a melhor maneira para produzir a alimentação necessária para os cerca de 180 milhões de brasileiros, levando em conta os aspectos econômicos, sociais, ambientais e de saúde ${ }^{26}$.

25 Disponível em: <http://www.mst.org.br/2015/07/24/defender-a-agroecologia-e-defender-novo-modelo-economico-e-politico-afirma-sem-terra.html $>$.

26 Disponível em: <http://www.mst.org.br/2015/06/17/a-agroecologia-como-modelo-ideal-de-producao-de-alimentos.html>. 
Embora o discurso da agroecologia dentro do MST apresente ênfases diferenciadas conforme a região do país (BORSATO; CARMO, 2013), ele é enunciado como parte de um novo projeto político de desenvolvimento rural. Enunciada como contraposição ao modelo produtivista, a proposição agroecológica fundamenta-se em outra forma de organização do mundo rural. No limite, a questão agrária acaba sendo incluída nessa organização, afinal, em termos políticos, o modelo agroecológico está alicerçado nas formas familiares e patronais de produção. A agroecologia passa a ser concebida discursivamente como uma possibilidade de ruptura por parte dos agricultores de base familiar, das redes de dependência impostas pelo agronegócio. A partir dessa perspectiva de autonomização, imaginam-se novas relações sociais, ambientais e de produção. Ainda que essa seja uma idealização, possui seu valor enquanto discurso político.

Em 2012, uma nova coalizão de movimentos sociais resultou no "Encontro unitário dos trabalhadores, trabalhadoras, povos, do campo, das florestas e das águas", com o lema: “terra, território e dignidade”. O documento oficial produzido reflete a perspectiva dos movimentos sociais atuais acerca da questão da terra no Brasil. Os cinco primeiros pontos do documento expressam:

1) a reforma agrária como política essencial de desenvolvimento justo, popular, solidário e sustentável, pressupondo mudança na estrutura fundiária, democratização do acesso à terra, respeito aos territórios e garantia da reprodução social dos povos do campo, das águas e das florestas; 2) a soberania territorial, que compreende o poder e a autonomia dos povos em proteger e defender livremente os bens comuns e o espaço social e de luta que ocupam e estabelecem suas relações e modos de vida, desenvolvendo diferentes culturas e formas de produção e reprodução, que marcam e dão identidade ao território; 3) a soberania alimentar como o direito dos povos a definir suas próprias políticas e estratégias sustentáveis de produção, distribuição e consumo de alimentos que garantam o direito à alimentação adequada a toda a população, respeitando suas culturas e a diversidade dos jeitos de produzir, comercializar 
e gerir estes processos; 4) a agroecologia como base para a sustentabilidade e organização social e produtiva da agricultura familiar e camponesa, em oposição ao modelo do agronegócio. A agroecologia é um modo de produzir e se relacionar na agricultura, que preserva a biodiversidade, os ecossistemas e o patrimônio genético, que produz alimentos saudáveis, livre de transgênicos e agrotóxicos, que valoriza saberes e culturas dos povos do campo, das águas e das florestas e defende a vida; 5) a centralidade da agricultura familiar e camponesa e de formas tradicionais de produção e o seu fortalecimento por meio de políticas públicas estruturantes, como fomento e crédito subsidiado e adequado as realidades; assistência técnica baseada nos princípios agroecológicos; pesquisa que reconheça e incorpore os saberes tradicionais; formação, especialmente da juventude; incentivo à cooperação, agroindustrialização e comercialização ${ }^{27}$.

Nota-se que a reforma agrária continua sendo o eixo estruturante das perspectivas políticas voltadas para o campo. A partir dela visualiza-se a construção de uma perspectiva de desenvolvimento rural que se contrapõe ao modelo produtivista vigente, por isso o reconhecimento da diversidade de categorias de trabalhadores, sua relação com o meio ambiente e o compromisso com a construção de um modelo de agricultura sustentável para a comunidade biótica. Essa reversão do modelo vigente passa pela transformação da estrutura fundiária, afinal, exige novas relações de produção, humanas e do homem com o meio ambiente.

Portanto, enquanto discurso político, a agroecologia tem ganhado cada vez mais espaço na contraposição ao agronegócio e, consequentemente, na defesa da reforma agrária. No entendimento do MST e das demais organizações que defendem a reforma agrária no Brasil na atualidade, a viabilização da agroecologia só seria possível com uma reorganização do espaço rural que, por sua vez, só parece possível com um projeto amplo de reforma agrária. Assim, a agroecologia e a reforma agrária são

27 Declaração do "Encontro nacional unitário de trabalhadores e trabalhadoras, povos do campo, das águas e das florestas", Brasília, 2012. 
complementares num projeto de crítica e contraposição ao modelo da agricultura produtivista. Ao mesmo tempo, ambas são estruturantes de um novo projeto de desenvolvimento rural.

De certa forma, visualiza-se uma ampliação do escopo de legitimidade na narrativa da reforma agrária. Partindo da questão agrária, que envolve problemas estruturais relacionados ao desenvolvimento histórico do capitalismo no campo, o discurso incluiu o problema da cidadania no Brasil e chegou às questões socioambientais mais amplas. Essa trajetória discursiva foi motivada pelas mudanças objetivas ocorridas na agricultura e na sociedade, bem como na interconexão discursiva do tempo presente, ou seja, na vinculação sócio-histórica que um discurso possui em relação ao que está sendo dito por outros discursos.

\section{Considerações finais}

Os discursos acerca da reforma agrária foram tecidos de acordo com o ambiente socioeconômico e político da sociedade brasileira. Num primeiro momento, percebe-se que a narrativa da reforma agrária centrava-se no fato de existir um grande contingente de camponeses sem-terra e que viviam em condições precárias no meio rural. A pobreza da massa camponesa contrastava com a presença do latifúndio improdutivo, com grandes extensões de terra pouco aproveitadas pelos seus proprietários. A legitimidade da reforma agrária dava-se em cima dessa contradição.

As mudanças ocorridas com a modernização da agricultura foram diminuindo parcialmente o segundo elemento dessa contradição, mas mantiveram o primeiro. Entre as décadas de 1960 e 1980, a modernização acabou sendo muito mais efetiva nas grandes propriedades do que nas pequenas. Assim, o contingente de camponeses sem-terra e em condição de pobreza era muito significativo, aspecto que impulsionou a formação do Movimento dos Trabalhadores Rurais Sem Terra no início da década 
de 1980. A existência desses camponeses, trabalhadores rurais por excelência, foi o principal elemento de legitimidade discursiva para justificar a reforma agrária nesse período. A forte presença de entidades religiosas ajudou a construir os alicerces de legitimidade durante os primeiros assentamentos, aspecto que foi gradativamente perdendo força na medida em que o MST construiu sua autonomia política.

Com a redemocratização do país em marcha a partir de meados da década de 1980, gerou-se uma expectativa de realização da reforma agrária. Aproveitando-se do ambiente político favorável, a reforma agrária foi amplamente discutida na sociedade e nos espaços institucionais do Estado. A estratégia discursiva em defesa da reforma agrária nesse momento alicerçou-se na correlação entre a questão fundiária e o desenvolvimento socioeconômico do país. Diante da crise econômica, da desigualdade social e do deficit de cidadania na sociedade brasileira, a reforma agrária era difundida como o ponto de partida para a reversão desse quadro histórico negativo pelo qual o país passava. Mesmo assim, as forças contrárias foram mais fortes e conseguiram desconstruir, tanto no âmbito político-institucional quanto no imaginário social, a necessidade histórica da reforma agrária.

Diante dessas derrotas, o MST fortaleceu seu discurso de alinhamento a então decadente alternativa socialista. Embora já presentes desde o primeiro congresso nacional de 1984, o fortalecimento da militância e o discurso socialista ganharam força no início da década de 1990. Não acreditando em soluções institucionais, a estratégia de ocupação e resistência tornou-se central. Como o país vivia uma crise agrícola sem precedentes, fruto da precária inserção nos mercados globais e da desestruturação do aparato estatal responsável pelos subsídios econômicos do setor, a narrativa da reforma agrária acrescentou aos argumentos anteriores a necessidade de resolver a crise alimentar vivida pelo país. A pobreza no campo, o desemprego, a miséria e a violência na cidade poderiam ser resolvidos com uma distribuição mais equitativa da terra. Mas isso não era suficiente; 
eram necessárias políticas agrícolas eficientes, e o MST apostava na perspectiva cooperativista como alternativa de desenvolvimento rural para os assentados rurais e pequenos proprietários familiares. Mas o cooperativismo não foi uma experiência bem-sucedida na maioria dos assentamentos.

Nesse ínterim, a agricultura produtivista, agora denominada "agronegócio", expandiu-se numa conjuntura internacional favorável e com políticas econômicas voltadas para fortalecer o setor de exportação agrícola. Esse clima de expansão produtiva fez com que muitos latifúndios improdutivos se tornassem produtivos, aspecto que acabou estimulando a concentração fundiária. Mesmo com políticas específicas para a agricultura familiar a partir de meados da década de 1990 e a inserção de parte desses segmentos no agronegócio, esse modelo de desenvolvimento reproduziu a desigualdade e a dependência dos agricultores de base familiar em relação às grandes empresas do agronegócio. Além disso, os impactos socioambientais gerados pelas novas tecnologias, como os transgênicos e o uso intensivo de agrotóxicos, abriram espaço para uma nova fonte de legitimidade da reforma agrária.

Produzir alimentos de qualidade, respeitando o meio ambiente e o equilíbrio da comunidade biótica, tem sido um discurso cada vez mais enunciado por entidades sociopolíticas em nível mundial. Diante de tal ambiente discursivo, a narrativa da reforma agrária alinhou-se a essas disposições para fortalecer seu campo de reivindicações, pois os argumentos tradicionais da questão agrária já não são mais representativos como foram outrora para fins de legitimidade política. Embora a existência de latifúndios improdutivos e de camponeses em condições de pobreza ainda faça parte da realidade do mundo rural brasileiro, as mudanças históricas e na agricultura do país fizeram com que o discurso da agroecologia fosse incorporado como fonte de legitimidade discursiva para justificar a atualidade da reforma agrária. De modo geral, essa narrativa aponta para uma nova perspectiva de desenvolvimento rural que tem como pressuposto a reforma agrária. 
Portanto, a reforma agrária, em sua dimensão político-discursiva, é significada socialmente em razão dos acontecimentos sociais que a envolvem. Um discurso é produzido dentro de um ambiente político, social e econômico e responde às demandas, pretensões e oposições impregnadas nesse ambiente. Nesse sentido é possível observar historicamente na evolução da narrativa da reforma agrária a busca para justificá-la de acordo com as prerrogativas de cada conjuntura. Em que pese as diferentes ênfases que lhe foram dadas e seu aparente recrudescimento, a persistência dessa narrativa parece significativa para a realidade social e histórica do país.

\section{REFERÊNCIAS}

ALTIERI, Miguel. Agroecologia: as bases científicas da agricultura alternativa. Rio de Janeiro: PTA/Fase, 1989.

ARAÚJO, Brancolina Ferreira; TEIXEIRA, João Gabriel. Constituinte e reforma agrária. Águas de São Pedro: ANPOCS, 1989.

BERGAMASCO, Sônia Maria; NORDER, Luís Antônio. Os impactos regionais dos assentamentos rurais em São Paulo. In: MEDEIROS, Leonilde Servolo de; LEITE, Sérgio. A formação dos assentamentos rurais no Brasil: processos sociais e políticas públicas. Porto Alegre: UFRGS, 1999. p.70-116.

BOSETTI, Cleber José. Perspectivas de desenvolvimento rural em disputa no Brasil. Tese (Doutorado em Sociologia Política) - UFSC. Florianópolis: UFSC, 2013.

BOURDIEU, Pierre. Coisas ditas. São Paulo: Brasiliense, 2004.

. O poder simbólico. Rio de Janeiro: Bertrand do Brasil, 2005.

BORSATO, Ricardo Serra; CARMO, Maristela Simões do. A construção do discurso agroecológico no Movimento dos Trabalhadores Rurais Sem Terra. Rev. Econ. Sociol. Rural, Brasília, v. 51, n. 4, Oct./Dec. 2013. Disponível em: <http://www.scielo.br/scielo>. Acesso em: 26 abr. 2016.

BRASIL. Estatuto da Terra. Brasília, 1964.

BRUNO, Regina. Nova República: a violência patronal rural como política de classe. Sociologias, Porto Alegre, n. 5, p. 284-310, jul./dez. 2003. 
BUAINAIN, Antônio Marcio. Modelo e principais instrumentos de regulação setorial: uma nota didática. In: RAMOS, Pedro et al. Dimensões do agronegócio brasileiro: políticas, instituições e perspectivas. Brasília: MDA, 2007. p. 53-102. CARVALHO, Abdias Vilar de. Transição política e democracia: um espaço para a reforma agrária? In: ENCONTRO NACIONAL DA ANPOCS, XIII. Anais. Caxambu-MG, 1989.

CHONCHOL, Jacques. A soberania alimentar. Estudos Avançados, a. 19, n. $55,2005$.

DE CARLI, Caetano. O discurso político da agroecologia no MST: o caso do assentamento 17 de Abril em Eldorado dos Carajás, Pará. Revista Crítica de Ciências Sociais [Online], n.100, p. 105-130, 2013.

FOUCAULT, Michel. A microfísica do poder. Rio de Janeiro: Graal, 1979. . A arqueologia do saber. Rio de Janeiro: Forense Universitária, 1986.

GOHN, Maria da Glória. Movimentos sociais no início do século XXI: antigos e novos atores. Petrópolis: Vozes, 2004.

GRAZIANO DA SILVA, José. A modernização dolorosa. Rio de Janeiro: Zahar, 1982.

. O que é a questão agrária. São Paulo: Brasiliense, 1987.

. A nova dinâmica da agricultura brasileira. Campinas: Unicamp, 1998.

GRAZIANO, Xico. O carma da terra no Brasil. São Paulo: Girafa, 2004.

LECOURT, Dominique. A arqueologia e o saber. In: FOUCAULT, Michel. $O$ homem e o discurso. Rio de Janeiro: Bomtempo, 2008. p. 49-70.

LUNA, Francisco Vidal; KLEIN, Herbert. O Brasil desde 1980. São Paulo: Girafa, 2007.

MALIN, Mauro. Agricultura e reforma agrária. In: LAMOUNIER, Bolívar; FIGUEREDO, Rubens (Org.). A era FHC. São Paulo: Cultura, 2002. p. 70-115.

MIRANDA, Carlos; BRÁULIO, Breno Tibúrcio. A nova cara da pobreza rural: desafios para as políticas públicas. Rio de Janeiro: Iica, 2012.

NAVARRO, Zander. "Nunca cruzaremos este rio" - a estranha associação entre o poder do atraso, a história lenta e a "sociologia militante", e o ocaso da reforma agrária no Brasil. Redes, Santa Cruz do Sul, v. 13, n. 2, p. 5-51, maio/ago. 2008. 
PELAEZ, Victor; SCHMIDT, Wilson. A difusão dos OGMs no Brasil: imposição e resistências. Estudos, Sociedade e Agricultura, n. 14, p. 5-31, abr. 2000.

PERLI, Fernando. O boletim sem terra: um lugar de sociabilidade na arregimentação do MST. In: ENCONTRO REGIONAL DE HISTÓRIA, XVIII. Anais... São Paulo: Anpuh; Unesp, 24 a 28 jul, 2006.

PRADO JÚNIOR, Caio. A questão agrária no Brasil. São Paulo: Brasiliense, 1987. RANGEL, Ignácio. Questão agrária, industrialização e crise urbana no Brasil. Porto Alegre: UFRGS, 2004.

SAMPAIO JUNIOR, Plínio de Aruda. Notas críticas sobre a atualidade e os desafios da questão agrária. In: STEDILE, João Pedro. A questão agrária no Brasil: debate sobre a situação e as perspectivas de reforma agrária na década de 2000. São Paulo: Expressão Popular, 2013. p. 85-102.

SAUER, Sérgio. Reforma agrária de mercado no Brasil: um sonho que se tornou dívida. Estudos, Sociedade e Agricultura, Rio de Janeiro, n. 1, v. 18, p. 98-126, 2010.

STEDILE, João Pedro (Org.). A questão agrária no Brasil: programas de reforma agrária (1946-2003). São Paulo: Expressão Popular, 2013.

ZANONI, Magda et al. O biorrisco e a comissão técnica nacional de biossegurança: lições de uma experiência. In: ZANONI, Magda; FERMET, Gilles (Org.). Transgênicos para quem? Agricultura, ciência e sociedade. Brasília: MDA, 2011. p. 244-276. 


\section{Movimento de mulheres camponesas, feminismo e segurança alimentar}

Valdete Boni ${ }^{1}$

\section{Considerações iniciais}

No campo dos movimentos sociais rurais no Brasil, as mulheres agricultoras ocuparam espaços de lutas. No sul do Brasil, o Movimento de Mulheres Camponesas de Santa Catarina (MMC/SC) soma três décadas de história e nesse período passou por diversos momentos diferentes em alguns aspectos, mas que somados mostram a trajetória de um movimento social rural formado apenas por mulheres. Iniciou no bojo da efervescência política dos movimentos sociais, tornou-se grande em número de participantes, atravessou um momento de diminuição na participação e, finalmente, renovou suas bandeiras de luta. Atualmente acompanha o desenrolar das políticas públicas para o campo. Entre as discussões atuais estão, principalmente, a segurança e a soberania alimentar. Esses temas são tratados como discursos e como práticas por meio das ações contra as empresas de sementes transgênicas e recuperação de sementes crioulas. Para essas mulheres, ter o controle das sementes significa não ficar na dependência das empresas multinacionais, que dominam sua produção e sua comercialização, mas também garantir alimentos saudáveis tanto para os camponeses quanto para os consumidores. Este texto tem o objetivo de

1 Doutora em Sociologia Política, professora na Universidade Federal da Fronteira Sul (UFFS) - Campus Chapecó. 
levantar apontamentos acerca do movimento de mulheres camponesas, da sua definição enquanto movimento feminista ao longo de sua história e do debate atual sobre a segurança alimentar a partir da produção.

O Movimento das Mulheres Camponesas (MMC) foi criado oficialmente em 2004. De forma isolada nos estados brasileiros, as organizações de mulheres existiam desde a década de 1980, como o Movimento de $\mathrm{Mu}$ lheres Agricultoras (MMA) em Santa Catarina, Movimento de Mulheres Trabalhadoras Rurais (MMTR) no Rio Grande do Sul e no Paraná e das extrativistas no norte e nordeste do Brasil, as quebradeiras de coco de babaçu, entre outras organizações de mulheres. Na década de 1990 esses movimentos se juntaram e, assim, criaram a Articulação Nacional de Mulheres Trabalhadoras Rurais (ANMTR), resultando, atualmente, no MMC.

A discussão a respeito do nome que teria o movimento suscita uma importante questão, o significado do termo "camponês". As antigas denominações de "agricultoras" e "trabalhadoras rurais" foram substituídas por "camponesas". Uma das justificativas do MMC foi pelo fato de o termo "camponês" englobar as diferentes atividades exercidas no campo, sejam agricultoras, assalariadas rurais, pescadoras ou extrativistas. Outra justificativa refere-se ao trabalho familiar e à produção de alimentos, conforme documento do movimento. A mulher camponesa é a que, de uma ou outra maneira, produz o alimento e garante a subsistência da família. "É a pequena agricultora, a pescadora artesanal, a quebradeira de coco, as extrativistas, arrendatárias, meeiras, ribeirinhas, posseiras, boias-frias, diaristas, parceiras, sem-terra, acampadas e assentadas, assalariadas rurais e indígenas" (MMC, 2009).

Nota-se que mesmo as camponesas nessa decisão não assumiam a influência da Via Campesina, e isso ocorreu no momento em que passaram a fazer parte dessa organização. Ao criarem o MMC, esse movimento se incorporou à Via Campesina por ocasião da IV Conferência da Via Campesina, em junho de 2004, no Brasil. A união já vinha sendo discutida e, portanto, não há como separar essa decisão, pois é uma consequência das 
articulações entre os movimentos sociais do campo para se fortalecerem diante dos desafios colocados nas últimas décadas em relação à própria existência de algumas organizações. Entretanto, o importante para este trabalho é o que o próprio MMC considera para explicar essa mudança.

$\mathrm{O} \mathrm{MMC}$ atual discute muito as questões ligadas à segurança alimentar, ao cultivo de alimentos saudáveis e ao modelo de agricultura agroecológica e, também, ao feminismo. Assim como ressignifica o conceito de campesinato, o faz também no feminismo. $O$ feminismo tratado pelas mulheres no MMC aproxima-se mais da ideologia marxista. No entanto, ganha contornos de outro movimento, o ecofeminismo, muito embora o MMC não tenha se assumido em seus discursos como um movimento ecofeminista. Assim, decidimos iniciar este texto ${ }^{2}$ expondo alguns aspectos sobre o ecofeminismo e como o movimento se articula com esse conceito, para, então, mostrar como o MMC organiza o movimento à ideia de segurança e soberania alimentar.

\section{O surgimento do $\mathrm{MMC}$}

Para falar do momento atual do MMC, é necessário resgatar um pouco de sua história, pois não há rupturas nessa trajetória; há um processo contínuo e linear de lutas que tiveram que acompanhar as mudanças ocorridas nas últimas décadas. ${ }^{3}$

O Movimento de Mulheres Camponesas em Santa Catarina nasce em 1983 com o nome de Movimento de Mulheres Agricultoras (MMA). Embora nesse momento histórico brasileiro tenham surgido outros movimentos

2 Este texto é uma síntese de parte da pesquisa empírica e teórica desenvolvida durante o Doutorado, nos anos de 2008 a 2012. Portanto, não tem a pretensão de ser muito abrangente, mas, sim, levantar alguns aspectos relevantes acerca do MMC em Santa Catarina e de um discurso que se constrói à medida que o movimento também rediscute suas práticas.

3 Para um histórico mais amplo do Movimento de Mulheres Camponesas em Santa Catarina consultar: BONI, Valdete. Três décadas do movimento de mulheres camponesas em Santa Catarina. In: BONI, Valdete et al. Mulheres camponesas e agroecologia. Curitiba: CRV, 2017. 
sociais no campo, como o Movimento dos Trabalhadores Rurais Sem Terra (MST), o Movimento de Atingidos por Barragens (MAB) e as oposições sindicais, o MMA traz uma inovação: a luta de classe e de gênero. $O$ Brasil atravessava uma crise resultante da forma como a pequena produção foi tratada ao longo da história, porém agravada principalmente pelo processo de modernização da agricultura.

Nesse contexto, pequenos produtores, assalariados rurais, trabalhadores rurais sem-terra e atingidos por barragens, com o apoio de setores progressistas das igrejas Católica e Luterana, especialmente do movimento conhecido como Teologia da Libertação, representada na Pastoral da Terra, se organizaram em movimentos para reivindicar reforma agrária, políticas agrícolas e educação para o campo.

Mesmo participando ativamente desses movimentos, as mulheres não encontraram espaço para questões especiais que as atingiam, como o reconhecimento de sua profissão, combate à violência contra as mulheres, saúde das mulheres, previdência diferenciada etc. Da mesma forma que a Igreja contribuiu na organização dos movimentos mistos, ajudou na organização das mulheres, ainda que não de forma direta. O estímulo da Igreja veio principalmente por incitá-las a participarem de comunidades. Mesmo que os espaços destinados nas comunidades fossem secundários, como catequistas e coordenadoras de grupos de família, a participação contribuiu para que saíssem do ambiente privado das casas. Dessa forma, perceberam que poderiam alcançar outros espaços públicos. Como sentiram que as demais organizações não incorporaram as questões de gênero às suas lutas, resolveram criar um movimento autônomo de mulheres.

Foi assim que, em 1983, em Nova Itaberaba, um grande grupo de agricultoras reuniu-se e criou o Movimento de Mulheres Agricultoras de Santa Catarina. Nas décadas seguintes, o MMA atua principalmente em campanhas de documentação para as trabalhadoras rurais, o que garante seu reconhecimento profissional. Paralelamente à documentação, o movimento organiza diversas caravanas a Brasília para cobrar a implementação 
das leis garantidas na Constituição de 1988, como o direito à aposentadoria das mulheres aos 55 anos e dos homens aos 60 anos, a licença-maternidade, o auxílio-doença, entre outros. A Constituição de 1988 equiparou os trabalhadores rurais aos trabalhadores urbanos no que concerne aos direitos previdenciários, com a diferença de que os rurais se tornaram segurados especiais. ${ }^{4}$ Essa condição foi garantida pela Lei $n^{\circ} 8.213 / 91$, alterada posteriormente pela Lei ${ }^{\circ} 11.718 / 08 .^{5}$

As primeiras reivindicações do MMA eram principalmente trabalhistas. No ano de 1990, com a realização da $4^{\text {a }}$ Assembleia Estadual do MMA, é possível perceber um debate de gênero tomando mais espaço, com a crítica às relações desiguais no que diz respeito ao acesso ao crédito e também à participação política. Conforme Casagrande (1991, p. 44), a $4^{\mathrm{a}}$ Assembleia foi decisiva para a definição das linhas de ação do movimento, como a educação dos filhos. As mulheres levantaram a preocupação de não dar continuidade a uma educação que reforça a divisão sexual rígida dos papéis definidos para homens e mulheres. As mulheres queriam também delegar aos filhos homens a responsabilidade na execução das tarefas domésticas, retirando esse fardo exclusivo dos ombros das filhas mulheres. Outro ponto tratado na assembleia refere-se à importância do movimento autônomo. Como é uma organização só de mulheres, trata-se do espaço onde elas detêm o poder de decisão. O mesmo não ocorria nos outros movimentos nos quais algumas militavam e se sentiam discriminadas e

4 Os segurados especiais são trabalhadores rurais que produzem em regime de economia familiar, sem utilização de mão de obra assalariada ou que a utilizam em períodos esporádicos desde que não ultrapasse o limite de 120 dias ao ano ( $\$ 80$ da lei no 11.718 de 20 de junho de 2008). Estão incluídos também nessa categoria os cônjuges, os companheiros e os filhos maiores de 16 anos que trabalham com a família em atividade rural. Também são considerados segurados especiais o pescador artesanal e o índio que exerçam atividade rural e os familiares que participam da produção (regime de economia familiar). A contribuição do segurado especial ao INSS ocorre na venda de sua produção. O valor da contribuição é de $2,3 \%$ sobre o valor bruto da comercialização de sua produção rural. Desse montante, $2 \%$ é destinado à Seguridade Social, $0,1 \%$ ao financiamento de benefícios decorrentes de riscos do trabalho e 0,2\% ao Serviço Nacional de Aprendizagem Rural (Senar). (Fonte: Ministério da Previdência Social. Disponível em: <www.mpas.gov.br>. Acesso em: $1^{\circ}$ nov. 2011).

5 A Lei no 8.213/91garantia aos trabalhadores rurais a condição de segurados especiais por um período de 15 anos. Com a organização dos trabalhadores, conseguiu-se manter essa condição e também algumas alterações na referida lei que garantem direitos importantes. Essas mudanças podem ser vistas na Lei no 11.718/08. 
sua palavra não tinha o mesmo valor que a dos homens. Paulilo e Silva (2007) mostram como as agricultoras podem encontrar no movimento de mulheres um espaço de convivência que lhes permite "desabafar as mágoas" da opressão que sentem em suas casas, o que não aconteceria se o movimento fosse misto, com a participação de homens e mulheres.

Nessa assembleia também surgiu o tema que trago neste texto: ao tratar da formação das militantes, os eixos centrais foram feminismo, violência contra as mulheres, sexualidade e afetividade, utilização de métodos contraceptivos, discriminação das mulheres, entre outros (CASAGRANDE, 1991, p. 50). É a partir daí que o movimento vem discutindo um feminismo que tenha relação com a realidade vivenciada pelas mulheres camponesas.

Ao longo das últimas três décadas, o movimento passou por três momentos principais (BONI, 2012). O primeiro, na década de 1980, diz respeito à luta pelo reconhecimento profissional como trabalhadoras rurais/ agricultoras/camponesas. O segundo, na década de 1990, é a explicitação do debate de gênero, que não havia aparecido tão forte no primeiro momento. O terceiro, especialmente a partir dos anos 2000, constitui-se de uma discussão sobre o desenvolvimento rural e a organização produtiva com base na agroecologia, na soberania e na segurança alimentar.

Este último momento é marcado também pela consolidação de uma postura mais feminista no movimento de mulheres. O próprio MMC está discutindo e definindo um feminismo camponês. Em pesquisas anteriores (BONI, 2012), chega-se a considerar esse feminismo como um ecofeminismo ${ }^{6}$, negado por muitas lideranças. Se para o MMC está claro

6 O ecofeminismo é uma teoria que faz interconexão entre ambientalismo e feminismo, fazendo uma associação entre a dominação da natureza com a dominação das mulheres. Da ecologia, o ecofeminismo resgata a preocupação com o uso da natureza e a sua destruição, tendo suas bases na ecologia profunda e na ecologia social. Já com relação ao feminismo, bebe na fonte do feminismo liberal (na luta das mulheres por direitos políticos), no feminismo socialista (na luta pela transformação da sociedade patriarcal) e no feminismo radical (que luta pela mudança do paradigma masculino pelo feminino) (Souza, 2000, p. 57). O termo "ecofeminismo" passou a ser utilizado na década de 1970 e surgiu dos diversos movimentos sociais engendrados pelas mulheres na defesa de seus direitos enquanto mulheres e na defesa do meio ambiente. Conforme Shiva e Mies (1997), mesmo que o termo tenha sido utilizado pela primeira vez por Françoise d'Eaurbonne, em 1974, só ganhou o campo mesmo com as lutas das mulheres frente aos desastres ecológicos e contra o avanço das usinas nucleares nos Estados Unidos e o movimento Chipko na Índia. 
que o movimento é feminista, não ocorre o mesmo em relação ao ecofeminismo. No entanto, apesar da negativa, concluímos que, pela leitura do ecofeminismo de algumas vertentes, a exemplo da espiritualista e da construtivista, aliada às práticas e aos discursos do movimento de mulheres camponesas, nossa hipótese estava correta. O fato de se negarem enquanto ecofeministas contradiz suas falas em encontros do movimento e também em suas publicações. A impressão que se tem é de que, para elas, o ecofeminismo é algo muito "radical", termo que foi usado por uma das lideranças em conversa durante um de nossos encontros. Talvez, do mesmo modo que as mulheres precisaram de um tempo para ressignificar o termo "camponês" e, posteriormente, o termo "feminista", uma incorporação explícita de alguma das vertentes do ecofeminismo possa ocorrer no futuro na medida em que não há contradição entre as propostas do MMC e as linhas do ecofeminismo com as quais trabalhamos. O movimento diz estar ainda definindo o que elas consideram como feminismo camponês. Este, entanto, será um debate para trabalhos futuros.

\section{Agricultura camponesa e (eco)feminista - a nova definição do MMC}

É comum ouvir, seja nos depoimentos que as militantes nos cedem, seja nos discursos dos eventos do $\mathrm{MMC}$, seja ainda em seus materiais escritos, que o MMC é um movimento camponês e feminista. Essa denominação é bastante recente; foi na $11^{\text {a }}$ assembleia do MMC em 2010 que se percebeu essa aproximação com o discurso feminista. Esse feminismo, que quase sempre vem acompanhado do termo "camponês", difere do feminismo urbano. Aproxima-se mais do feminismo marxista, mas sempre fazendo relação com a condição de mulheres camponesas, como evidenciam suas falas: 
Para nós, do Movimento das Mulheres Camponesas, o nosso feminismo vai pra além das relações de gênero: é uma proposta, é um projeto de sociedade que enfrenta a cultura patriarcal, a opressão que nós sofremos dos homens e tudo e também a luta contra o capital e a construção de um projeto de sociedade com mais igualdade, que é o nosso sonho. Continuar afirmando que um dia nós queremos uma sociedade socialista, que pra nós a sociedade socialista é uma sociedade igualitária, distribuição de renda, que todo mundo tenha terra e os direitos. Então, nós, na nossa avaliação, é trabalhar um pouco essa questão, que quando falamos de feminismo, seja o nosso feminismo (Fala de abertura do XX Encontro Estadual do MMC - Xaxim - 21 a 23 agosto de 2010).

Essa relação com o feminismo, que em seus discursos é recente, mostra também uma mudança que vem ocorrendo na agricultura. As mulheres já não se sentem intimidadas ao se assumirem como feministas, mas, da mesma forma que ressignificam o conceito de camponês, também adotam um feminismo com características particulares. E são essas características que contribuem para o que se considera como postura ecofeminista do MMC.

$\mathrm{O}$ discurso do MMC, principalmente em suas publicações, vem mesclado de valores religiosos e políticos. Ao mesmo tempo em que ressalta a importância da mulher, coloca-se responsável pela luta por um novo modelo de sociedade. $\mathrm{O}$ capitalismo não somente é agente de opressão de classe, como também contribui para a opressão de gênero. Há um misto de religiosidade com marxismo típico de sua formação nas bases da teologia da libertação. Toda ideia de preservação ambiental e das sementes e a preocupação com a alimentação fazem do MMC um movimento que não é apenas camponês e feminista como elas assumem, mas um movimento ecofeminista.

Para ecofeministas como Karen Warren (2003, p. 62), quando um problema ambiental afeta diretamente as mulheres, torna-se uma questão feminista. Segundo a autora, podemos considerar que uma questão é feminista quando pretende contribuir na compreensão de como fatos, 
crenças ou valores oprimem as mulheres, ou seja, tanto a busca de igualdade de direitos entre homens e mulheres como a produção de alimentos. São questões feministas quando pretendem demonstrar, de alguma forma, a subordinação das mulheres.

Para o MMC, essa relação com as florestas não foi tão estreita como no exemplo de Karen Warren, pois a tradição da agricultura na região sempre deixou um espaço pequeno para as florestas. A preocupação, no entanto, com a diversidade ambiental exemplifica o que a autora mostra: a falta de acesso a certas plantas se torna uma questão feminista.

Companheiras, sejam todas bem-vindas ao nosso encontro. Vamos pensar um pouco: Quem somos? Pensem comigo: O processo de nossa vida é como uma semente! Podemos dizer que nós somos uma semente. Houve uma época que a maioria das pessoas não sabiam que a união do homem e da mulher gerava a vida. Com o passar do tempo essa realidade foi mudando. As pessoas foram aprendendo que através do ovário a mulher mensalmente libera um óvulo, que é uma parte da semente. $\mathrm{O}$ homem produz o líquido seminal que contém o espermatozoide. Quando mulher e homem se relacionam sexualmente o óvulo pode ser fecundado pelo espermatozoide e se torna uma semente completa gerando uma nova vida. As plantas também se reproduzem. Na semente do milho, por exemplo, há os genes que conferem as características de uma nova planta e as diferenciações sexuais próprias da espécie, assim como nas hortaliças, frutas, entre outras. Podemos perceber que há uma relação íntima e parecida entre as mulheres, a terra e a natureza. Todas geram, cultivam e recriam a vida nas diferentes espécies. Por isso essa sensibilidade que as mulheres carregam em relação à natureza é tão visível e presente nas suas atitudes. Esta proximidade faz com que chamemos a terra, a natureza e as mulheres de mães, revelando uma dimensão do lado feminino das mesmas. (grifo nosso)

Catherine Roach (2003) analisou a relação mulher e natureza fazendo uma crítica à ideia de conceber a Terra como Mãe. As propagandas ecológicas que incitam a amar a "Mãe Terra" são, segundo ela, uma faca de dois gumes. Da mesma forma que a simbologia de mãe é voltada para 
o amor e o respeito, há a ideia de que amor de mãe é incondicional, que mãe tudo dá, a tudo renuncia em nome dos seus filhos. "La madre en la cultura patriarcal es aquella que nos provee de todas las materias, se deshace de toda nuestra basura, y satisface todas nuestras necesidades y caprichos sin ningún coste" (ROACH, 2003, p. 112).

Da mesma forma que a alimentação perdeu sua qualidade com a diminuição do cultivo de muitas espécies, também os remédios alopáticos invadiram esse espaço para tratar de problemas, como ansiedade, estresse e depressão, doenças da vida moderna. Aquela idealização de um rural sem conflitos e harmônico já ficou para trás há muito tempo na região. Tanto a diminuição do número de filhos quanto a resistência de grande parte deles em permanecer nas propriedades trouxe um ritmo de vida mais agitado, porque não somente as mulheres, mas também os homens abriram mão de parte de seu lazer para suprir a falta de mão de obra.

Esse modelo de agricultura camponesa proposto pelo MMC é sustentável, busca a agroecologia, a proteção do meio ambiente (elas tiveram formação sobre o Bioma Mata Atlântica para aprender a preservar e a recuperar áreas degradadas) e a recuperação não somente de variedades de alimentos, como também de algumas tradições que foram se perdendo com a modernização da agricultura. Quando se referem a recuperar práticas antigas, deixam claro que querem resgatar o que era bom no passado e não o que era ruim, e elas conseguiram superar, pelo menos em parte, o patriarcado.

A interface com o feminismo aparece claramente no discurso atual do MMC. Se no início houve receio em mostrar que o movimento era feminista, agora essa postura não só não é mais negada, como também é vista positivamente. A noção de feminismo vem associada ao modelo de agricultura camponesa proposta pelo movimento. É um modelo de feminismo que se adaptam às necessidades que são sentidas pelas camponesas, de luta por espaço dentro da propriedade, nas relações sociais, um feminismo que busca mais do que direitos para as mulheres: almeja 
transformações de relações que vão além das diferenças de gênero. São transformações políticas.

\section{MMC: soberania e segurança alimentar}

O termo "segurança alimentar" provém de dois termos ingleses, foodsecurity (quantidade dos alimentos) e foodsafety (qualidade dos alimentos), o que caracteriza a segurança para o consumidor. Nesse contexto, é uma discussão complexa porque não se refere somente à problemática da fome, que, sem dúvida, é a mais preocupante, mas também aos outros problemas causados pela falta de comida, excesso ou carência de nutrientes, e também à qualidade dos alimentos num momento em que, além do consumo exagerado de produtos industrializados, refrigerantes, enlatados, entre outros, com muitos corantes e conservantes, temos ainda o alto índice de agrotóxicos e insumos utilizados sem o devido acompanhamento na produção alimentar. Por esse motivo, não será possível falar em segurança alimentar de forma mais específica no âmbito deste trabalho. As colocações aqui apresentadas servem apenas para introduzir o debate sobre a produção agroecológica, a não utilização dos agrotóxicos e o resgate de sementes crioulas de hortaliças pelas camponesas do MMC, que associam essa prática a uma forma de garantia de sua soberania alimentar.

Na década de 1930, o mundo viveu um paradoxo no que diz respeito à produção de alimentos e seu consumo. Se, por um lado, vários países desenvolvidos possuíam excessos de produção, por outro, nos países em desenvolvimento, observavam-se problemas de subnutrição e de fome. Conforme Chonchol (2005, p. 33), enquanto especialistas em nutrição alertavam para a necessidade de produzir mais alimentos para suprir a carência mundial, economistas faziam o contrário, falando em diminuição da produção por causa dos excessos em alguns países. É nesse contexto 
que em 1945, através de discussões feitas no âmbito das Nações Unidas (ONU), surge a Organização para a Alimentação e Agricultura (FAO). Em 1962 a FAO cria o programa Alimentar Mundial, que tinha por objetivo sanar o problema da fome no extremo Oriente. ${ }^{7}$ Com isso, a comunidade científica apoia a iniciativa de introduzir o plantio de sementes de alto rendimento. Tem início, então, em 1965, na Ásia, a revolução verde. Segundo Chonchol (2005, p. 34), esse processo aumentou consideravelmente a produção; no entanto, as consequências sociais foram ainda maiores. Na Índia, por exemplo, antes da revolução verde, 18\% do campesinato não possuía terras; em 1970, esse número cresceu para 33\%. $\mathrm{Na}$ década seguinte, países como Etiópia, Bangladesh e também os da região conhecida como Sahel Africano ${ }^{8}$ passaram por períodos de fome. Conforme Maluf e Menezes (2000), a falta de estoques de alimentos nas décadas de 1960 e 1970 fundamentaram a ideia de que o problema da fome no mundo era a falta de alimentos suficientes para toda a população, o que reforçou o argumento de que aumentar a produtividade seria uma das soluções possíveis. Com isso, as concepções favoráveis à revolução verde ganharam mais força.

Procurava-se convencer a todos de que o flagelo da fome e da desnutrição no mundo desapareceria com o aumento significativo da produção agrícola, o que estaria assegurado com o emprego maciço de insumos químicos (fertilizantes e agrotóxicos). A produção mundial, ainda na década de setenta, se recuperou - embora não da mesma forma como prometia a Revolução Verde - e nem por isto desapareceram os males da desnutrição e da fome, que continuaram atingindo tão gravemente parcela importante da população mundial (MALUF; MENEZES, 2000, p. 1).

7 O extremo Oriente corresponde a países como China, Japão, Coreia do Sul, Coreia do Norte, Taiwan, Hong Kong, Mongólia e Macau.

8 O Sahel Africano corresponde a uma região que faz divisa com o deserto do Saara e a parte sul da África onde as terras são mais férteis. É uma faixa de transição entre o clima desértico e o clima tropical e abrange países como Mauritânia, Senegal, Mali, Burkina Faso, Níger, Chade, Nigéria, República Democrática do Congo, Camarões e Sudão. 
$\mathrm{Na}$ década de 1980, os estoques alimentares mundiais crescem. Entretanto, como isso ocorre nos países mais desenvolvidos, o problema da fome persiste. Como coloca Chonchol (2005, p. 34), “a fome não é tanto consequência de uma produção alimentar insuficiente, como da marginalização econômica de certas populações”. Assim, aumentar a produtividade dos países que já produzem estoques suficientes não resolveria o problema da fome, seria mais eficaz dar condições para que todos pudessem produzir para garantir o mínimo de autossustento interno. O problema da carência de alimentos em diversos países não é decorrente somente de problemas climáticos, mas, sobretudo, de conflitos políticos em muitas regiões. Esses conflitos se tornaram, na década de 1990, o principal motivo da necessidade de ajuda alimentar para vários países, principalmente na África.

A Via Campesina apresentou um conceito de soberania alimentar na Conferência Mundial sobre a Alimentação realizada em 1996, em Roma, pela FAO. Esse conceito ressalta a soberania alimentar como "o direito que os povos têm de definir suas próprias políticas agrícolas e alimentares sem dumping de outros países". Esse é o grande desafio, uma vez que os rumos da política agrícola dos países são decididos em cúpulas fechadas e nas bolsas de valores, locais onde não somente os agricultores, mas a maioria da população sequer conhece a dinâmica de funcionamento. Refletindo em termos de Brasil, de 1996 para cá, a política agrícola esteve ainda mais orientada para a exportação (MALUF, 2009). A preocupação maior tem sido um modo de produção que seja aceitável pelos países aos quais esses produtos serão destinados e não a garantia de qualidade de vida dos produtores e da população do país de origem. Em outras palavras, quando a produção é voltada para a exportação, a preocupação é aumentar a produtividade do que será exportado em detrimento da variedade necessária à alimentação da população interna, não garantindo alimentos saudáveis e com valores nutricionais necessários.

No Fórum Mundial sobre Soberania Alimentar realizado em Havana, Cuba, no ano de 2001, a soberania alimentar foi caracterizada como 
o direito dos povos a definir suas próprias políticas e estratégias sustentáveis de produção, distribuição e consumo de alimentos que garantam o direito à alimentação para toda a população, com base na pequena e média produção, respeitando suas próprias culturas e diversidade dos modos campeiros, pesqueiros e indígenas de produção agropecuária, de comercialização e gestão dos espaços rurais, nos quais a mulher desempenha um papel fundamental.

Para Maluf (2009, p. 19), a incorporação da noção de soberania alimentar aos princípios da Segurança Alimentar e Nutricional (SAN) apresenta uma nova visão que difere das ações para a segurança alimentar anteriormente implementadas pelos governos, já que traz à tona a discussão das grandes corporações e sua influência nas decisões que envolvem a produção de alimentos e o que é concebido como soberania pelos movimentos sociais.

\section{As mulheres e a alimentação: segurança e soberania alimentar}

Para Marta Chiappe (2006), ocorre certa confusão entre os conceitos de soberania e segurança alimentar, quase sempre utilizados como sinônimos. Por soberania alimentar deve-se entender o controle dos alimentos por parte dos camponeses; por segurança alimentar, a condição de existência de alimentos suficientes e de qualidade para que todos possam ter acesso.

Conforme León (2003, p. 218), na África subsaariana e no Caribe, as mulheres são responsáveis pela produção de 60 a $80 \%$ dos produtos básicos utilizados na alimentação, e na Ásia realizam mais de 50\% do trabalho nos cultivos de arroz. Da mesma forma, no sudeste asiático e na América Latina, as hortas cultivadas pelas mulheres aparecem entre os sistemas agrícolas mais complexos. Diante disso, a ideia de que é necessário o cultivo de transgênicos para alimentar o mundo é propagada cada vez mais. Esse discurso sai do ambiente das multinacionais e se propaga 
entre camponeses com o intuito de abandonarem os cultivos tradicionais e adotarem o sistema produtivo, que é comercializado em larga escala pelas empresas.

Essas medidas, segundo León (2003, p. 219), eliminarão as práticas de soberania alimentar concebidas pelas mulheres durante toda a história da agricultura, obrigando-as a pagar aos donos das patentes a utilização de recursos que sempre fizeram parte de sua vida.

León (2003, p. 220) diz, além disso, que a agricultura científica excluirá ainda mais as mulheres do acesso ao conhecimento e destruirá seus saberes tradicionais, continuando o processo deflagrado pela revolução verde. Temos visto, na prática, um afastamento das camponesas no conhecimento básico sobre o plantio dos alimentos e a diminuição da variedade e qualidade alimentar das famílias. No entanto, tamanha exclusão gera revolta e, consequentemente, a busca de alternativas. É o que o MMC faz ao estimular as camponesas a resgatar as práticas alimentares e de tratamento por meio de uma alimentação mais saudável, desde a maneira de produzir o alimento, das suas variedades e da forma de preparo até as ervas medicinais, alternativas para os remédios alopáticos.

Um dos grandes vilões que colocam em risco a segurança alimentar são os agrotóxicos, porque, além da contaminação dos alimentos e da água, eliminaram diversas espécies de plantas utilizadas na alimentação e no preparo de remédios.

Conforme Londres (2011), na última década, o uso de agrotóxicos no Brasil cresceu assustadoramente. Somente entre os anos 2001 e 2008 a venda subiu de pouco mais de dois bilhões de dólares para mais de sete bilhões. Assim, o Brasil atingiu a posição de maior consumidor de agrotóxicos do mundo. Em 2008 foram aplicados 986,5 mil toneladas de defensivos e em 2009 mais de um milhão de toneladas, o que significa $5,2 \mathrm{~kg}$ de agrotóxico por habitante (LONDRES, 2011, p. 19). A autora apresenta também dados da Anvisa sobre, pelo menos, dez tipos de agrotóxicos que já foram proibidos nos Estados Unidos, na União Europeia, China, entre 
outros, que continuam sendo utilizados no Brasil. Esses dados apontam que o crescimento agrícola no país foi pequeno diante do aumento exorbitante do volume das vendas de agrotóxicos.

Outra característica importante a ser levada em conta é a concentração das empresas que detêm a produção e comercialização de agrotóxicos. Em 2007, seis empresas - Bayer, Syngenta, Basf, Monsanto, Dow e DuPont - controlavam mais de $80 \%$ da venda de agrotóxicos no mundo. No Brasil essa taxa era ainda maior. Essas empresas não controlam somente os agrotóxicos ou as sementes de milho e soja, como poderia parecer mais evidente, mas também sementes de hortaliças, ou seja, as sementes de toda base de alimentação vegetal.

O que o movimento de mulheres propõe é ir em direção contrária a esse processo. É resgatar valores (sementes) e técnicas que suas mães e avós dominavam para restituir a alimentação melhor para suas famílias. É o que mostram os trechos retirados de um documentário produzido pelo $\mathrm{MMC} / \mathrm{SC}$, de acordo com a fala de uma camponesa do movimento:

Nesse projeto das sementes eu acho muito importante também o resgate que está tendo das ervas medicinais. Porque isso é uma coisa da natureza. E os nossos antepassados, eles usam muito isso, sobreviviam dos remédios caseiros, dos remédios de ervas medicinais. Mas depois, com o uso dos venenos aí que tanto tão usando, as ervas foram sendo extintas e aí então esse projeto do Movimento de Mulheres Camponesas vem trazendo pra nós, ou resgatando de volta o uso para as nossas famílias, que é muito importante a mãe fazer um chazinho, usar os remédios naturais em vez de pra cada coisinha tem que correr na farmácia ou estar comprando os remédios químicos. E isso pra nós é uma experiência muito importante e que está sendo resgatado também no projeto das sementes. Então isso vem trazer um estímulo de volta pra nós, aquilo que é da natureza. Os remédios, usando eles, utilizando e industrializando pro nosso uso e para o uso da nossa família, dos nossos filhos (Liderança do MMC explicando sobre o projeto de recuperação de sementes crioulas de hortaliças/maio de 2010). 
Conforme Shiva (2003, p. 39), a revolução verde não substituiu somente as sementes nos países do Terceiro Mundo, mas safras inteiras. A justificativa foi que determinadas variedades de sementes, por serem inferiores, produziam muito pouco. Para Shiva, as camponesas da Índia conheciam as variedades produzidas e seu valor nutritivo. Esses cultivos, no entanto, foram considerados inferiores e, além disso, muitos foram extintos pelo uso dos agrotóxicos. Da mesma forma, diversas espécies de plantas que antes eram consumidas pelos camponeses no oeste de Santa Catarina, hoje dificilmente são encontradas, porque, com a intensa utilização de agrotóxicos nas lavouras e com a diminuição de variedades cultivadas, elas também se perderam. As lideranças do MMC, ao iniciarem o resgate de sementes crioulas de hortaliças, se disseram admiradas com as variedades que as camponesas trouxeram e que eram mantidas em suas propriedades. Somente no encontro que ocorreu no ano de 2002 em Curitibanos, na Serra catarinense, as camponesas trouxeram mais de quarenta variedades de couve.

Para León e Senra (2010, p. 17), mulheres e homens vêm construindo uma ideia diferente do que é agricultura. Isso se explica, em parte, pelas condições que foram dadas ao longo da história para ambos. Dessa forma, a imagem construída pelas mulheres é de uma agricultura como fonte de alimentação e de produtos que são destinados ao sustento da família.

Ainda conforme as autoras, em diversas partes do mundo, o controle da produção pelo governo e pelas grandes empresas foi precedido por uma associação do produto oriundo das explorações familiares à má qualidade ou a problemas sanitários. Essas medidas afetaram especialmente as mulheres que tradicionalmente comercializam sua produção nos mercados locais. Uma das líderes comentou sobre as dificuldades de comercializar a produção em pequena escala. $\mathrm{O}$ objetivo principal para as mulheres que participam dos projetos do MMC é cultivar para o consumo da família, mas sempre há um excedente que pode ser comercializado. Mas como fazer isso se o mercado exige quantidade? 
Hoje, entre os produtos mais cultivados para o consumo pelos agricultores estão a mandioca, algumas espécies para horta, como radice, alface, cenoura e beterraba. Já o repolho e as diversas variedades de couve não são muito cultivados porque a ocorrência de pulgões é grande. Os insetos que atacam os cultivos são outro argumento muito utilizado para justificar o não plantio de diversos produtos, especialmente na horta. Muitos dizem que não adianta plantar "porque os pulgões, as lagartas ou mesmo os passarinhos estragam, então fica mais barato comprar".

Já no MMC o discurso é bem diferente, como mostram as falas das participantes dos encontros, das oficinas e dos cursos dos quais participamos. As camponesas mostraram uma listagem bem extensa dos alimentos que ainda cultivavam e dos que voltaram a cultivar pela iniciativa dos projetos do Movimento.

Em estudo acerca dos alimentos ainda produzidos para o consumo entre agricultores gaúchos, Menasche et al. (2007, p. 67) referem a questão do "tempo" que os agricultores alegam não possuir mais para plantar. Conforme relato de uma agricultora entrevistada pelas autoras, depois que iniciou um plantio de laranjas em maior escala, foi perdendo as sementes dos produtos que antes eram comuns na propriedade, como o feijão, o amendoim. Com a saída dos filhos da terra o trabalho se concentrou no casal e, assim, não puderam mais dedicar-se ao plantio desses alimentos.

Do mesmo modo que foi constatada uma diminuição da variedade de alimentos produzidos e consumidos pelos agricultores no oeste de Santa Catarina, Menasche et al. (2007, p. 75) mostraram que no Vale do Taquari, no Rio Grande do Sul, os agricultores familiares referiram uma mudança muito grande da alimentação de "antigamente" em relação à atual. Segundo as autoras, eles foram unânimes ao falar da intensidade dessas mudanças, relacionando a alimentação atual como sendo mais industrializada. "Em geral a produção para o autoconsumo é hoje considerada como sendo muito menor do que a realizada em época anterior. Assim, muitas respostas 
apontam no sentido de maior dependência das famílias rurais em relação à aquisição de alimentos" (MENASCHE et al., 2007, p. 75).

Em outra pesquisa realizada também no Vale do Taquari, Zanetti e Menasche (2007, p. 139) mostram que a segurança alimentar é garantida, sobretudo pelas mulheres. Como a produção de alimentos para o consumo familiar é conduzida basicamente por elas, quando deixam de produzir a variedade com a qual estavam acostumadas, o consumo desses alimentos cai na família. As mulheres mais velhas são as que ainda mantêm a tradição de produzir diversos alimentos; já as mais jovens adotaram o hábito de adquirir esses alimentos no mercado. As razões apontadas em sua pesquisa são praticamente as mesmas mencionadas pelas agricultoras entrevistadas na região Oeste de Santa Catarina.

Aqui no caso são todas trabalhadoras que trabalham para produzir alimentos. E alimentos só para nós? Alimentos para todos. Hoje, na verdade, a agricultura camponesa é responsável pela produção de quase $80 \%$ dos alimentos que vão para a mesa dos consumidores. Então, esse é o segundo elemento: ser trabalhadora pertencente a uma classe que produz pelo seu trabalho as riquezas e [...] que produz alimento para as pessoas poderem viver, nenhum ser vivo vive sem alimento. Então vejam a importância estratégica dos camponeses e das camponesas. E [...] as mulheres camponesas são lutadoras, são guerreiras, que daí é próprio da característica de quem faz parte do movimento, da luta, da militância (XX Encontro Estadual do MMC - 21 a 23 agosto de 2010).

A noção de segurança alimentar assumida como alimentação saudável pelas mulheres tem relação estreita com o ecofeminismo ou com o feminismo camponês, como elas definem. Para o MMC, esses conceitos não se dissociam, mas se complementam. Os próprios termos "agroecologia" e "feminismo" têm sido utilizados conjuntamente. A discussão é bem mais ampla, envolve um modelo de sociedade na qual tanto o modelo de produção quanto à relação entre as pessoas deve ser visto como um conjunto necessário para o alcance de uma sociedade mais justa e igualitária. Dessa 
forma, a produção de alimentos saudáveis e sem a utilização de agrotóxicos garante, por um lado, a segurança alimentar ao fornecer alimentos livres de contaminação química e, por outro, a soberania alimentar ao retirar as camponesas e os camponeses do aprisionamento das grandes empresas de sementes transgênicas e de insumos químicos. Ao produzirem alimentos livres de transgênicos e agrotóxicos, as camponesas também preservam o meio ambiente e evidenciam sua relação com o ecofeminismo.

\section{REFERÊNCIAS}

BONI, Valdete. De agricultoras a camponesas: o movimento de mulheres camponesas de Santa Catarina e suas práticas. Florianópolis, SC, 2012. Tese (Doutorado) - Universidade Federal de Santa Catarina, Centro de Filosofia e Ciências Humanas. Programa de Pós-Graduação em Sociologia Política.

- Três décadas do Movimento de Mulheres Camponesas em Santa Catarina. In: BONI, Valdete et al. Mulheres camponesas e agroecologia. Curitiba: CRV, 2017.

CASAGRANDE, Jacir L. Movimentos sociais no campo: mulheres agricultoras em Santa Catarina. Dissertação (Mestrado) - Universidade Federal de Santa Catarina. Florianópolis, 1991.

CHIAPPE, Marta. Estudio de caso sobre la cadena productiva de maíz. In: MELLO, Ruth de; RODRÍGUEZ, Graciela (Org.). Estudios de casos que destacan la dinámica de género en torno a la agricultura, el comercio y la soberanía alimentaria. Rio de Janeiro: Instituto Equit., 2006.

CHONCHOL, Jacques. A soberania alimentar. Estudos Avançados, São Paulo: USP, v. 19, n. 55, p. 33-48, 2005.

LEÓN, Irene. Mulher, vida e semente. In: CARVALHO, Horácio Martins de. Sementes: patrimônio do povo a serviço da humanidade. São Paulo, Expressão Popular, 2003. 352p. (209-227).

LEÓN, Irene; SENRA, Lidia. Las mujeres gestoras de la soberanía alimentaria. In: SENRA, Lidia et al. Las mujeres alimentan al mundo: soberanía alimentaria en defensa de la vida y del planeta. Entrepueblos, Barcelona, 2010. 
LONDRES, Flavia. Agrotóxicos no Brasil: um guia para ação em defesa da vida. Rio de Janeiro: Assessoria e Serviços a Projetos em Agricultura Alternativa, 2011. MALUF, Renato S. J. Segurança alimentar e nutricional. Petrópolis-RJ: Vozes, 2009. MALUF, Renato. S.; MENEZES, Francisco. Caderno Segurança Alimentar, 2000. Disponível em: <http://www.dhnet.org.br/direitos/sos/alimentacao/ tconferencias.html>. Acesso em: 10 jul. 2011.

MENASCHE, Renata; WAGNER, Saionara Araújo; MARQUES, Flávia Charão. Agricultura familiar à mesa. In: MENASCHE, Renata (Org.). Agricultura familiar à mesa: saberes e práticas no Vale do Taquari. Porto Alegre: UFRGS, 2007.

PAULILO, Maria Ignez Silveira. Movimento de mulheres agricultoras: terra e matrimônio. In: PAULILO, Maria Ignez S.; SCHMIDT, Wilson. Agricultura e espaço rural em Santa Catarina. Florianópolis: UFSC, 2003.

PAULILO, Maria Ignez Silveira; SILVA, Cristiane Bereta da. A luta das mulheres agricultoras: entrevista com dona Adélia Schmitz. Estudos Feministas, v. 15, n. $2,2007$.

PAULILO, Maria Ignez Silveira. El movimiento de las mujeres campesinas y el medio ambiente. Otras Miradas, v. 7, n. 1, enero/junio 2007.

$\mathrm{ROACH}$, Catherine. Ama a tu madre: sobre la relación mujer-naturaleza. In: WARREN, Karen J. Filosofías ecofeministas. España: Icaria Ecología Humana, 2003.

SHIVA, Vandana; MIES, Maria. Ecofeminismo. Lisboa: Instituto Piaget, 1997.

SHIVA, Vandana. Cosecha robada. El secuestro del suministro mundial de alimentos. Barcelona: Paidós, 2003.

SOUZA, Sandra Duarte de. Teoria, teo(a)logia e espiritualidade ecofeminista: uma análise do discurso. Mandrágora - Ecofeminismo: Tendências e Debates, A. 6, n. $6,2000$.

VIA CAMPESINA. La agricultura campesina sostenible puede alimentar al mundo, 2011. Documento de punto de vista de la vía campesina. Yakarta. Disponível em: <www.viacampesina.org $>$. Acesso em: 20 set. 2011.

ZANETTI, Cândida; MENASCHE, Renata. Segurança alimentar, substantivo feminino: mulheres agricultoras e autoconsumo. In: MENASCHE, Renata (Org.). Agricultura familiar à mesa: saberes e práticas no Vale do Taquari. Porto Alegre: UFRGS, 2007.

WARREN, Karen J. Filosofías ecofeministas: una mirada general. In: WARREN, Karen J. Filosofías ecofeministas. España: Icaria Ecología Humana, 2003. 


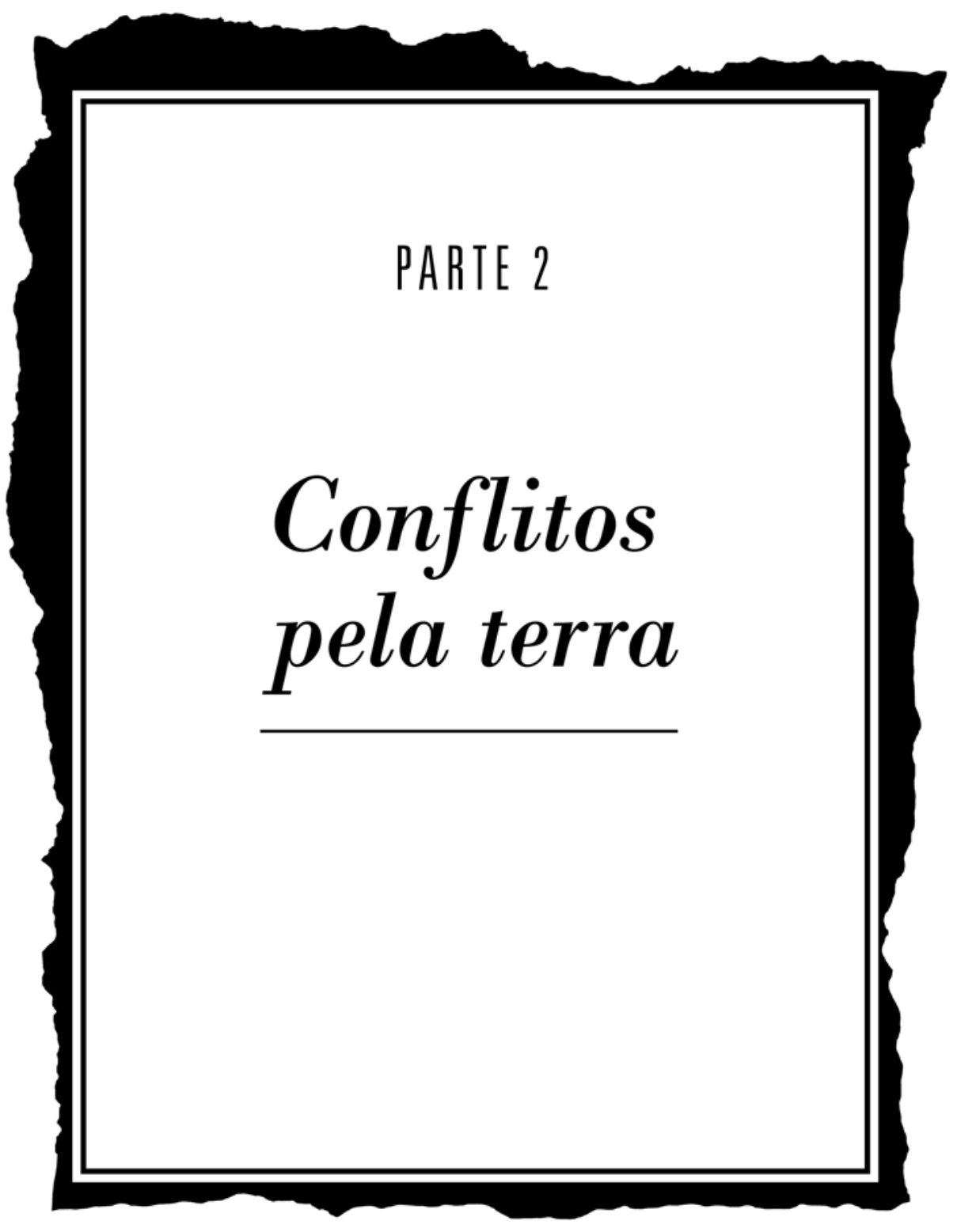




\title{
Estado, questão agrária e o desafio da luta pela terra
}

\author{
Algacir José Rigon ${ }^{1}$ \\ José Guilherme Franco Gonzaga ${ }^{2}$ \\ Vinicius Piccin Dalbianco ${ }^{3}$
}

\section{Considerações históricas e introdutórias}

A organização social tem no Estado uma estrutura burocrática capaz de manter autonomia, especialmente no seu modo executivo em relação à luta de classes. Por ser uma aparência, ficam ocultos no Estado os interesses das classes sociais, os conflitos e também a desigualdade social. $\mathrm{O}$ interesse deste estudo teórico é dar visibilidade ao movimento dos camponeses que disputam a terra como meio de vida e como esta organização, ao longo dos tempos, tem impactado no Estado e evidenciado as questões agrárias, especificamente, a partir do Movimento dos Sem Terra (MST).

O MST tem sua origem nas lutas camponesas de resistência e disputa pela terra que, de bem comum, tornou-se aos poucos propriedade privada.

Atualmente, a defesa dos 'bens comuns' é uma forte reivindicação de muitos movimentos sociais. Ela inclui elementos indispensáveis à vida - como a água e as sementes —, como 'serviços públicos', hoje desmantelados pelas políticas neoliberais, tanto no Sul como no

1 Professor da Universidade Federal do Pampa (Unipampa) — Campus Dom Pedrito. Contato: ajrigon@gmail.com.

2 Professor da Universidade Federal do Pampa (Unipampa) - Campus Dom Pedrito. Contato: joguigon@gmail.com.

3 Professor da Universidade Federal do Pampa (Unipampa) - Campus Dom Pedrito. Contato: viniciusdalbianco@unipampa.edu.br. 
Norte. Esta luta consiste em uma oposição à onda de privatizações que atingiram a maioria das redes públicas, desde as ferrovias, a energia elétrica, a água, os transportes, a telefonia, saúde e a educação e também as florestas, os rios, as terras (HOUTART, 2011, p. 7).

No Brasil, em específico, ao longo de mais de 500 anos de história, a terra que originariamente estava sob uso comum dos povos indígenas que aqui habitavam, arbitrariamente foi distribuída em capitanias hereditárias, dentre outros mecanismos adotados para que a terra tivesse seu uso por posseiros de confiança da coroa portuguesa. Como regramento oficial, constata-se a Lei das Sesmarias (estabelecida em Portugal em 1375) e, depois, a Lei de Terras, que propiciaram a concentração da maioria das terras brasileiras em mãos de poucos donos. As disputas iniciais pela terra foram com os indígenas e com os negros, sendo que os primeiros lutavam contra os bandeirantes e aqueles que avançavam sobre suas terras a fim de colonizar. Os negros, de alguma forma, faziam a disputa por sua liberdade, pela própria terra, por uma terra livre. Liderados por alguém carismático ou algum religioso (líder messiânico), provocaram guerras, campanhas, manifestações Brasil afora - Canudos (Antônio Conselheiro), Contestado (Monges Maria), Cangaço (Lampião), os quilombos, dentre outras. ${ }^{4}$

Depois desse processo inicial, os camponeses adentraram num período em que se organizaram como classe - 1950 até, ao menos, 1964. Nessa direção, surgiram as Ligas Camponesas, a União de Lavradores e Trabalhadores Agrícolas do Brasil (UTAB), o Movimento de Agricultores Sem Terra (MASTER) e movimentos autônomos, não vinculados a sindicatos. Esses movimentos todos e, em especial, seus líderes, se toparam com a ditadura que, quando não acabou com os movimentos, deixou-os com pouca expressão ou até mesmo solapando suas existências.

4 Este e outros parágrafos na sequência resultam de um apanhado de fontes diversas das quais cabe destacar: Brie, 2011; Caldart, 1997; Fernandes, 1975; Marcon, 2016; Mauro, 1999; MST, 2013; Prado Jr, 1981 entre ouros. Aponta-se ainda que há inúmeras teses, livros, artigos sobre o MST, sua história e suas lutas, por isso não se remete aqui a nenhum em específico. 
A Reforma Agrária, melhor distribuição de recursos como a terra, apesar de ser o motim e o principal motivo da organização desses camponeses, não é o único. O que se almeja, concomitantemente, é uma reforma social, é a emancipação humana em última instância. Conforme aponta Stedile (1997, p. 9), “o MST é um movimento de massas que se organiza para conquistar basicamente três objetivos: terra, implantação da Reforma Agrária e mudanças sociais em nosso país”.

O objetivo, portanto, parece não ser apenas o reconhecimento como camponês, como trabalhador, mas como pessoas, como cidadãos, como sujeitos de uma sociedade, como sujeitos da história. Em outras palavras, os problemas que anunciam, a luta que tem como conteúdo a terra, é uma luta da sociedade inteira; são problemas enfrentados pela sociedade inteira. $\mathrm{Na}$ outra ponta, significa dizer que a falta de Reforma Agrária não extingue o camponês, o pecuarista familiar, o agricultor que possui pequena quantidade de terra, a agricultura familiar, mas dificulta sua integração - política e econômica - na sociedade. A derrota dos seus representantes políticos - a exemplo do impedimento da Presidenta Dilma Rousseff - tampouco diminui sua importância ou anula suas ações. Cria desafios em maior proporção, sim, mas é a continuidade do processo histórico da luta de classes, em específico, no campo, afinal a "história de todas as sociedades até agora tem sido a história das lutas de classes" (MARX \& ENGELS, 2008, p. 8).

Considerando-se esse aspecto, mesmo a ditadura não fez com que os ideais de luta pela Reforma Agrária se apagassem ou fossem suplantados por uma "modernização" amparada no capital estrangeiro, crédito rural para as grandes empresas ou grandes propriedades, uso de agrotóxicos e mecanização. Ao contrário, todo o processo levou à insurreição massiva desses povos, que passaram a fazer ocupações em todo território brasileiro no início da década de 80 . Essas lutas, massivas no sentido de espalhadas por todo o território nacional, até internacional, e, ao mesmo tempo, isoladas (puxadas por diferentes lideranças), culminaram com a constituição 
de um movimento articulado, que viria a ser o MST. O Brasil presencia também, na saída da ditadura, década de 70 e 80, o surgimento de inúmeros novos movimentos sociais, cujas reivindicações constituíam-se de pautas amplas, como moradia (políticas de reforma urbana), saúde (daqui nasceu o SUS, por exemplo), mais participação popular (nas administrações locais) e a pauta da Reforma Agrária, que não poderia faltar. Esses movimentos carregam uma ideologia - um grupo social, um projeto político - , uma pauta ou reivindicação específica e uma determinada estrutura organizacional.

O fato incontestável que temos de analisar é que desde os anos 1970, com mais intensidade a partir dos anos 1990, produziram-se lutas sociais que diversificaram enormemente o universo que se conhecia até então. De lá pra cá, colecionamos mais derrotas que vitórias, mas o universo se ampliou consideravelmente, envolvendo desde lutas fabris até as mais variadas lutas, passando por questões culturais, étnicas e ambientais. De Seatle ao Ocuppy W. Street, dos zapatistas à luta dos sem-terra no Brasil, passando pelos piqueteiros da Argentina, por Oaxaca no México e pelas lutas altermundistas (antiglobalização) nos países centrais até os recentíssimos mal chamados "movimento dos indignados", colecionamos não só derrotas, mas também exemplos concretos do perfil das lutas de classes contemporâneas. (BRAZ, 2012, p. 480).

O MST, nessa perspectiva, configura-se como um movimento social que tem seu foco na organização dos povos do campo para que tenham seus direitos de trabalhar na terra, direitos inclusive constitucionais, garantidos. Enquanto compreensão de direito, a terra é um bem natural, da natureza; não é fruto do trabalho de alguém ou resultado da produção de alguém que envidou esforços para assim obtê-lo. É uma organização que visa preservar o direito dos povos, dos sujeitos camponeses, contra a desigualdade na distribuição dos bens naturais e distribuição de terras para aqueles que não a possuem. Um movimento que, em seu ideário, carrega um planejamento e um projeto de nação, pensada para todos e não somente 
para uma parte da população ou, então, para atender as demandas de um determinado sistema produtivo (capitalismo). A Reforma Agrária, nesse tocante, é um caminho pensado para distribuir renda e criar um mercado interno para a indústria/industrialização). A luta pela terra por meio da transformação social e contra a concentração de renda (latifúndios) trata-se de um compromisso político com a coletividade.

A pauta principal do MST é a Reforma Agrária com ações baseadas em ocupações de latifúndio (geralmente, os latifúndios improdutivos ou que não alcançam o grau de produtividade adequado), manifestação democrática de algo que não está sendo cumprido (um direito ou uma decisão judicial), a ocupação de terras griladas. Essas ações têm como base jurídica a prerrogativa constitucional da função social da propriedade prevista na Constituição Federal de 1988, que determina à União desapropriar por interesse social, para fins de Reforma Agrária, o imóvel rural que não esteja cumprindo sua função social (Art. 184). Essa condição é importante, pois reflete uma mudança de posicionamento nas disputas: os camponeses em luta a reivindicarem os seus direitos.

\section{Poderes assimétricos na disputa do Estado: questão agrária}

O Estado brasileiro, preconizado enquanto instituição interventora e reguladora da sociedade, passou a interferir substancialmente no desenvolvimento do país a partir da crise de 1929. Nesse período, a agricultura foi beneficiada com uma política de controle do preço do café por meio da compra e queima de quantidades significativas do produto. Posteriormente, o Estado teve um papel fundamental no direcionamento da economia nacional. Atuou deliberadamente na abertura econômica do país permitindo a exportação de produtos agrícolas e importação de bens de capital destinados à modernização industrial. 


\section{Entre o desenvolvimentismo e o neoliberalismo: mudanças na estrutura do Estado}

A partir de 1964, com a ditadura civil-militar, várias medidas econômicas foram adotadas com o intuito propagandeado de "desenvolver" e "modernizar" o país num processo que ficou conhecido como Modernização Conservadora, devido a alguns fatores como a manutenção concentrada da estrutura fundiária, disponibilidade seletiva de crédito e ampliação do investimento do capital internacional no país. No ambiente macro, as medidas visavam incrementar as exportações, principalmente por meio de produtos agrícolas, objetivando gerar saldos comerciais que permitissem a importação de bens de capital que seriam utilizados na industrialização do País. A crise da balança comercial, as altas taxas de juros e de inflação e a pressão social dos setores populares na década de 1980 fizeram com que a política do governo militar declinasse, dando abertura para um período de ascensão democrática no país. Esse cenário proporcionou o repensar da intervenção estatal na política e na economia nacional (DELGADO, 2004).

A crise da balança comercial, a escassez de recursos do governo, a crise de financiamento, o aumento dos juros internacionais, o aumento da inflação, os resultados negativos do modelo produtivista modernizador para o campo, bem como a pressão social pela abertura política rumo à democracia foram alguns dos elementos que proporcionaram o fim do regime militar e o início de uma nova fase na história do Brasil.

Delgado (2004) apontou que o fim do governo militar, na década de 1980, possibilitou uma "oxigenação" das organizações sociais colocadas em clandestinidade durante a década de 1960 e 1970. Constituiu-se um cenário político que possibilitou a elaboração do I Plano Nacional da Reforma Agrária em 1985, a inauguração da Nova República com a eleição do Presidente Tancredo Neves e o Governo José Sarney e a Constituição Nacional, em 1988, que respaldou o Estatuto da Terra de 1964. 
Essas mudanças no cenário político-econômico no Brasil foram estimuladas pelos resultados negativos da economia ao longo da década de 1970, quando o Brasil teve que pagar por um aumento de $283 \%$ nos juros internacionais, com a balança comercial acumulando um défice de seis bilhões de dólares. Para Delgado (2004, p. 13), esses resultados catastróficos para a economia brasileira ocasionaram uma recusa dos bancos internacionais em realizar novos empréstimos ao país. Para tanto, adotou-se uma política monetária contracionista, que elevou as taxas internas de juros e reduziu a disponibilidade de crédito. Ou seja, houve uma espécie de emissão negativa de moeda no sistema financeiro do país com o objetivo de controlar o défice orçamentário. O resultado desse esforço foi inverso.

Entre os anos de 1990 e 1992, com Fernando Collor de Melo à frente do Governo Federal, a situação agravou-se. Objetivando reduzir os gastos públicos, o governo Collor enxugou a estrutura pública. O setor agrícola sofreu duramente essas medidas, que levaram à extinção da EMBRATER em 1990, ao corte de recursos da EMBRAPA, ao fim do Instituto Brasileiro do Café e do Instituto do Açúcar e Álcool. Após a extinção do sistema nacional público de Extensão Rural, apenas os agricultores mais modernizados conseguiram pagar serviços privados de assistência técnica, com exceção de algumas iniciativas estaduais que garantiram a continuidade de convênios com empresas e Organizações Não Governamentais (ONGs) voltadas a atender agricultores familiares (ALVES; VALENTE JUNIOR, 2006).

Com o apogeu do neoliberalismo no mundo e com as mudanças governamentais do início da década de 1990, o Estado reduziu sua intervenção na economia e na sociedade. A iniciativa privada passou a intervir mais fortemente na economia, incorporando áreas que antes eram de responsabilidade parcial ou total do Estado.

A partir do ano de 2002, identifica-se um novo fortalecimento das ações do Estado, o que, na agricultura, traduz-se no aporte maior de recursos, num maior incentivo à pesquisa, em programas de incentivo a cadeias produtivas, como a dos biocombustíveis. Entretanto, não se 
alteram os condicionantes macroeconômicos da economia e a perspectiva de crescimento da produção agrícola com base no setor patronal. Com isso, a estrutura agrária concentrada não é submetida a reestruturações redistributivas, permanecendo, portanto, os condicionantes da condição marginal da agricultura familiar e camponesa.

Essas intervenções do Estado na sociedade brasileira, ao longo dos últimos 80 anos, são resultados das disputas sociais, políticas, ideológicas e econômicas que as classes sociais configuraram nas esferas do poder do Estado e da sociedade civil. O Estado passou a ter um papel diferenciado na sociedade capitalista com a nova organização social da sociedade em classes. Uma série de autores, dentre eles, Marx, Engels, Smith, Lênin, Gramsci, Poulantzas, Offe, formularam importantes conceitos e teorias sobre a natureza, o caráter e o papel do Estado na sociedade.

\section{Críticas sobre o papel do Estado}

De acordo com Smith (1983), o Estado é uma organização neutra, servidor da sociedade e da cidadania, na qual cada indivíduo tem a liberdade de opinar e participar da coordenação das políticas do Estado e deve submeter-se a essa estrutura que ajudou a construir. Engels (1987), numa perspectiva diversa à de Smith, defende que o Estado representa os interesses de uma classe específica, mesmo quando se posiciona acima do antagonismo das classes sociais. Para o autor, a autonomia do Estado fica apenas restrita a tarefas burocráticas e sua posição a favor da classe dominante se dá na esfera política e econômica. Lênin (1983), numa leitura aproximada à de Engels, identifica o Estado enquanto produto do antagonismo irreconciliável entre as classes sociais, servindo aos interesses e à dominação pela classe mais poderosa economicamente e também tendo o papel de refrear o antagonismo entre classes. Essas teorias, distintas e/ou complementares, que em muito contribuíram para o debate sobre a 
natureza, o caráter e a função do Estado, apresentam limitações para explicá-lo na atualidade, principalmente pelas características atuais do funcionamento e da dinâmica geral conflituosa a que o Estado está submetido. Coutinho (1992) considera um avanço a análise feita pela Teoria Ampliada do Estado de Gramsci, pois identifica, na socialização da participação política por meio da formação de grandes sindicatos e de partidos de massa, o surgimento de uma esfera social nova, dotada de leis e de funções relativamente autônomas e específicas, qual seja, a sociedade civil.

Portanto, o Estado, em sentido amplo, com novas determinações, comporta duas esferas principais:

a sociedade política [...] que é formada pelo conjunto de mecanismos através dos quais a classe dominante detém o monopólio legal da repressão e da violência, e que se identifica com os aparelhos de coerção sob controle das burocracias executiva e policial-militar; e a sociedade civil, formada precisamente pelo conjunto das organizações responsáveis pela elaboração e/ou difusão das ideologias, compreendendo o sistema escolar, as igrejas, os partidos políticos, os sindicatos, as organizações profissionais, a organização material da cultura (revistas, jornais, editoriais, meios de comunicação de massa), etc. (COUTINHO, 1992, p. 76-77, grifo nosso).

Segundo Coutinho (1992), ambas as esferas visam sustentar uma determinada base econômica segundo os interesses da classe social hegemônica. Entretanto, o modo como são encaminhadas as ações para preservar os interesses hegemônicos são diferentes. Na sociedade civil, busca-se exercer a hegemonia ganhando-se aliados para suas posições mediante a direção política e o consenso, enquanto que, por meio da sociedade política, as classes exercem uma ditadura ou, mais precisamente, uma dominação mediante a coerção. Um segundo ponto de diferenciação entre as esferas refere-se às distinções em sua materialidade (social-institucional) própria. Enquanto a materialidade da sociedade política se expressa nos aparelhos de Estado, os portadores materiais da sociedade civil são o que 
Gramsci chama de aparelhos privados de hegemonia, ou seja, organismos sociais coletivos voluntários e relativamente autônomos em face da sociedade política.

Gramsci (1995) vai além ao afirmar que as classes sociais que detêm o poder do Estado utilizam-se de meios para legitimar os seus interesses enquanto interesses universais da sociedade, fazendo-se valer das esferas da superestrutura, composta pelas forças política, jurídica e ideológica. Segundo o autor, a relação de poder implica a demarcação de uma linha nítida entre os lugares de dominação e de subordinação de classe. O Estado capitalista busca maquiar essa demarcação, usando a superestrutura para ocultar diferenças sociais e harmonizar posições sociais potencialmente conflituosas, alienando e distanciando as pessoas de sua identidade de classe. Dessa forma, a busca pelo controle do poder do Estado é um movimento de classe com vistas a realizar os seus interesses econômicos e políticos.

Conforme Offe (1984), o Estado coordenado por essa hegemonia burguesa desenvolve um processo seletivo na sua atuação decisória sobre a regulamentação da economia e da política, agindo como um sistema de filtro. Para o autor, o Estado busca, de um lado, consolidar estratégias conjugadas e medidas estruturais de alcance econômico e político para manter um processo de acumulação de capital. De outro lado, busca estratégias para neutralizar ou minimizar os efeitos excludentes e perversos da acumulação de capital. Neste último caso, o Estado burguês busca maquiar sua natureza e caráter de classe por meio de ações denominadas "democráticas" e de políticas públicas para apresentar-se como guardião dos interesses comuns e gerais da sociedade. Para isso, a classe dominante (burguesa) tece acordos com a classe trabalhadora a fim de manter certa correlação de entendimento e minimização dos conflitos de classe. Para o autor, o Estado burguês nunca deixou de servir ao processo de acúmulo de capital em benefício das ações para o bem-estar da população.

De acordo com Poulantzas (1977), o antagonismo das classes sociais é determinado por complexas relações de poder, que, por sua vez, agem 
constantemente na disputa do poder do Estado e configuram um aparelho destinado a intervir na dominação de uma classe sobre a outra. $\mathrm{O}$ autor concorda com Gramsci (1995) ao afirmar que tais relações de poder extrapolam a constituição da estrutura e agem sobre os meios coercitivos presentes na superestrutura. Logo, a separação entre economia (estrutura) e política (superestrutura), tão defendida pelos intelectuais liberais, serve para esconder uma dupla relação de poder que a classe burguesa dominante possui sobre o Estado.

Noutra obra de Poulantzas (1985), o autor defende a existência de um "esqueleto" material do Estado, que confere, ao bloco no poder, mesmo em conflito, uma unidade à frente do Estado. Este, no caso, capitalista, não deve ser considerado como uma instituição intrínseca, mas como a condensação de forças entre classes e frações de classe, tal como ele expressa, de maneira sempre específica, no seio do Estado (POULANTZAS, 1985). Nesse sentido,

[...] entender o Estado como condensação material de uma relação de forças, significa entendê-lo como um campo e um processo estratégico, onde se entrecruzam núcleos e redes de poder que ao mesmo tempo se articulam e apresentam contradições e decalcagens uns em relação aos outros. Emanam daí táticas movediças e contraditórias, cujo objetivo geral ou cristalização institucional se corporificam nos aparelhos estatais. (p. 157).

A teorização de Poulantzas e Gramsci colabora para a elucidação de dois fatos sobre o funcionamento e papel do Estado. Ao mesmo tempo em que são superadas suas visões instrumentais, que percebem esta instituição enquanto neutra, passiva, servindo unicamente aos interesses das classes ou frações de classes no poder, portanto, sem reconhecer sua autonomia relativa, as elaborações desses autores superam visões que concebem a autonomia do Estado quase que de forma absoluta, pois compreendem 
que a burocracia que o dirige é portadora legítima de uma vontade racionalizante da sociedade civil.

Indo ao encontro das contribuições de autores que brevemente foram abordados nesta seção, a noção norteadora presente nesta leitura da realidade identifica o Estado enquanto condensação de uma relação de forças cujas lutas e processos decorridos no seio da sociedade civil visa à constituição de hegemonias que interferem na definição das políticas de Estado. O bloco no poder do Estado desenvolve políticas de caráter seletivo, visando assegurar o entendimento comum de que os interesses universais são o propósito das ações do Estado. A extensão das políticas legitimadoras da dominação de classe por um bloco no poder também pode ser entendida enquanto produto da intensidade dos conflitos e da capacidade de exercer hegemonia pelas forças no poder. Entretanto, se existe um caráter seletivo nas políticas públicas, elas estão comprometidas em, sobretudo, assegurar a reprodução do capital e a condição de dominação pela classe mais influente economicamente, utilizando-se, para isso, não somente da capacidade de hegemonia, mas também dos instrumentos de coerção do Estado. Além disso, de acordo com Carnoy (2006), não basta o poder do Estado para uma classe tornar-se hegemônica. O poder hegemônico da classe burguesa sempre está organizado no seu exercício, em instituições específicas, em centros de poder, sendo o Estado, nesse contexto, o centro do exercício do poder mais importante. Assim, a definição e a gestão de uma política pública estão submetidas às relações de poderes estabelecidos no âmbito do Estado e das classes sociais. $\mathrm{O}$ atendimento das demandas sociais por uma política pública é reflexo da disputa do Estado e, nesse sentido, $o$ atendimento da demanda das classes sociais mais empobrecidas se torna problema para as classes dominantes. 


\section{Estado, questão agrária e política agrícola}

O Estado brasileiro coloca-se em condição de atraso na adoção de políticas agrícolas comparado a alguns países. De acordo com Corazza e Martinello Jr. (2002), na Europa, as políticas agrícolas já faziam parte das medidas governamentais durante o século XVII. Elas tinham como objetivo transformar os agricultores em empresários rurais, favorecendo a submissão dos produtos agrícolas ao mercado capitalista. Os minifúndios e latifúndios eram vistos como entraves ao desenvolvimento do capital por não serem capazes de valer-se da terra e da mão de obra de forma eficiente.

Conforme Veiga (1991), o Estado capitalista europeu passou a efetivar profundas reformas estruturais no campo a fim de aquecer a economia agrícola por meio da Reforma Agrária, do aumento da produção destinada a atender a segurança alimentar e, posteriormente, uma efetiva relação comercial entre os países. Assim, a economia europeia passa a ver a agricultura como um setor econômico importante para o crescimento econômico industrial.

Segundo Coelho (2001), no Brasil, as políticas agrícolas só começaram a tomar corpo a partir da década de 1920. Para o autor, foi a superprodução de café e a "ressaca" do comércio mundial, devido à Grande Crise de 1929, que estimularam as políticas agrícolas com os objetivos de alocar recursos, garantir renda e segurança alimentar para o país. No entanto, diferentemente da Europa, no Brasil, a intensificação das políticas agrícolas se deu sem um processo de reformulação agrária. A maioria das políticas agrícolas foi destinada à produção em grande escala segundo demandas internacionais e interesses da burguesia agrária.

Concordando com essas análises, João Pedro Stedile, da Coordenação Nacional do MST, aponta quatro momentos em que a Reforma Agrária clássica foi identificada como uma possibilidade histórica de solucionar a crise agrária nos marcos do desenvolvimento do capitalismo nacional, 
sendo que, em todas essas oportunidades, a opção da burguesia foi por um pacto ainda mais conservador.

O primeiro momento no qual a questão agrária poderia ter sido solucionada com uma Reforma Agrária foi na luta contra a escravidão. Alguns abolicionistas, como Joaquim Nabuco, defenderam com ênfase que a liberdade do povo negro deveria ser acompanhada de um processo de distribuição de terras, com o desenvolvimento de uma indústria nacional e a consequente demanda de consumo:

Não há outra solução possível para o mal crônico e profundo do povo senão uma lei agrária que estabeleça a pequena propriedade, e que vos abra um futuro, a vós e vossos filhos, pela posse e cultivo da terra. É preciso que os brasileiros possam ser proprietários de terra, e que o Estado os ajude a sê-lo.

A propriedade não tem somente direitos, tem também deveres, e o estado de pobreza entre nós, a indiferença com que todos olham para a condição do povo, não faz honra ao Estado. Eu, pois, se for eleito, não separarei mais as duas questões: a da emancipação dos escravos e a da democratização do solo. Uma é o complemento da outra. Acabar com a escravidão não nos basta; é preciso destruir a obra da escravidão. (NABUCO, 2010, p. 154).

Entretanto, tais argumentos foram derrotados pelos coronéis das terras, uma oligarquia rural que controla(va) o poder político. Com isso, a "libertação dos escravos" manteve a reprodução de uma lógica excludente, concentradora, subalternizante e racista, que, na visão de Fernandes, constitui-se em um dos padrões da sociedade brasileira.

A transição entre o regime escravocrata de exploração da força de trabalho para o primeiro momento da industrialização no Brasil intensificou a luta pela terra, dando origem aos primeiros movimentos. Esses movimentos, cuja base de representação social era formada por forte influência religiosa, tinham como lideranças representações messiânicas. Nesse contexto, a disputa pela terra era necessidade básica de sobrevivência, e as 
condições de trabalho, o desenvolvimento das forças produtivas e a correlação de forças eram extremamente desfavoráveis, mantendo-se como lutas locais e sem influência no projeto hegemônico da época.

$\mathrm{Na}$ década de 50 do século XX, iniciou-se um novo período de luta pela terra no Brasil. Condições objetivas, como a crise no comércio de commodities agrícolas, o projeto do governo federal, liderado por João Goulart, de desenvolver a agricultura para atender a demanda interna e a produção agrícola para a indústria nacional e as condições subjetivas estimuladas, principalmente, pelos movimentos de libertação e com o crescimento de organizações políticas que tinham em sua pauta a Reforma Agrária deram impulso aos movimentos de expressão nacional protagonizados por camponeses, destacando-se com maior expressão as Ligas Camponesas, a União de lavradores e trabalhadores agrícolas do Brasil (Ultabs) e Movimento dos Agricultores Sem Terra (Master), conforme identificamos no início deste texto.

As motivações econômicas e o surgimento desses movimentos influenciaram a correlação de forças de discussão sobre projetos nacionais. As disputas pelos rumos do desenvolvimento da produção agrícola, cujas relações sociais, trabalhistas, econômicas e culturais sofriam as consequências de séculos de um modelo degradador das forças naturais, produtivas e sociais provocadas pelo modelo agroexportador, colocavam-se entre os grupos que defendiam a Reforma Agrária clássica para aumentar o mercado interno e as demandas da indústria nacional de um lado e, de outro, os que defendiam um pacto entre a oligarquia rural e a burguesia industrial, apostando numa modernização conservadora da agricultura.

De acordo com Prado Jr. (1981, p. 26), “os êxitos comerciais da agricultura brasileira são essencialmente devidos a duas circunstâncias: disponibilidades relativamente abundantes de terras e de força de trabalho". Para o autor, a agricultura patronal detentora de grandes extensões de terras sempre participou ativamente sobre o domínio dos recursos econômicos 
do país e, consequentemente, foi uma força decisiva nas formulações das políticas públicas para a agricultura.

Nesse período, as definições políticas e econômicas convergem para a promoção da modernização da indústria e da agricultura. A burguesia industrial, representada por alguns políticos e intelectuais, como Delfim Neto e Roberto Campos, passou a influenciar mais fortemente as decisões do Estado, exigindo que a agricultura adotasse medidas modernizadoras e mais produtivas.

De acordo com Delgado (2004, p. 8), as posições defendidas pelo grupo formado por Delfim Neto negaram a existência de uma questão agrária ao "desconsiderar[em] a estrutura fundiária e as relações de trabalho prevalecentes no meio rural como um problema econômico relevante, visto que com essa estrutura agrária teriam sido adequadamente cumpridas as funções da agricultura no desenvolvimento econômico".

Para o autor, o modelo agrícola defendido por Delfim Neto tinha o papel de cumprir cinco funções: a) liberar mão de obra a ser utilizada no setor industrial; b) produzir quantidades suficientes de alimentos a fim de baratear o custo de vida dos trabalhadores e evitar a pressão social sobre o ajuste dos salários; c) criar mercado para os produtos da indústria; d) expandir as exportações; e) financiar parte da capitalização da economia. Os argumentos de Delfim Neto para negar uma questão agrária no Brasil são estritamente econômicos sem levar em consideração os aspectos sociais apontados por Prado Jr., que reconhecia a existência de duas vertentes principais para justificar a necessidade urgente da Reforma Agrária. A primeira diz respeito à legislação social trabalhista no Brasil, que era extremamente arcaica e não garantia condições dignas de vida para os trabalhadores. $\mathrm{A}$ segunda era a extrema concentração de terras, que possibilitava a um pequeno grupo de produtores o controle da economia agrícola do país.

O processo de industrialização do Brasil forçou a agricultura patronal a adotar relações mais comerciais e urbanas para que, gradativamente, ela se tornasse unidade de produção mais moderna e produtiva (CORAZZA; 
MARTINELLO, 2002), vinculada aos interesses do mercado internacional, de commodities, em franco crescimento pela perspectiva neoliberal adotada pelo Estado. Para Graziano da Silva (1999), esse processo provocou uma transformação da agricultura, passando de mercantil para os complexos agroindustriais, orientado pela integração vertical entre indústria - agricultura - agroindústria. De acordo com o autor,

a dinâmica da agricultura passa a estar determinada pelo padrão de acumulação industrial, centrado no desenvolvimento dos complexos agroindustriais, e a ação do Estado nesse contexto orienta-se para a modernização da agricultura, visando integrá-la ao novo circuito produtivo liderado pela indústria de insumos e processamento de matéria-prima e gerando as condições infra-estruturais necessárias à expansão do conjunto do setor (GRAZIANO DA SILVA, 1999, p. 23).

Esse novo impasse foi "resolvido" com o golpe civil-militar de $1^{\circ} \mathrm{de}$ abril de 1964. Para Fernandes (1975), a opção das elites econômicas e políticas pelo golpe militar encerrou a possibilidade de mudanças no capitalismo brasileiro por meio de reformas. O golpe definiu a opção pelo neocolonialismo, e o desenvolvimento nacional deixou de ser definitivamente um projeto das elites nacionais. O Brasil integrou-se de forma subordinada e dependente na ordem mundial.

O governo ditatorial dos militares impôs a "modernização sem reformas" e reprimiu duramente o movimento camponês. Assim, no Brasil, a burguesia industrial, ao contrário da burguesia europeia do século XVIII, aliou-se à oligarquia rural para desenvolver o capitalismo nacional, dependente dos países centrais.

A opção por um projeto de integração subordinada ao "mercado mundial" como exportador de recursos naturais e commodities agrícolas possibilitou desenvolver as forças produtivas da agricultura e criar uma pequena indústria nacional sem a criação de um mercado de massas. Esse modelo provocou um profundo êxodo rural, com a migração em massa 
de camponeses e camponesas para as grandes cidades, formando um grande exército industrial de reserva, possibilitando a redução salarial e a superexploração. Entre acumular com o desenvolvimento das forças produtivas e a criação de um mercado consumidor interno, optou-se por aumentar a taxa de forma constante e abusiva da mais-valia, fazendo com o que o Brasil tenha uma das maiores concentrações de renda do mundo.

O pacto das elites, representado no golpe civil-militar, foi escrito com o sangue de trabalhadores e trabalhadoras do campo e da cidade. A maioria das organizações sociais e políticas que defendiam projetos populares, entre eles, a Reforma Agrária, foram perseguidas e massacradas. A imposição dessa violência política e social foi fundamental para a consolidação da "revolução verde", com uso de máquinas e implementos de grande porte, insumos químicos, degradação de paisagens naturais dos biomas, etc. Isso resultou no agravamento dos problemas sociais, ambientais, econômicos, especialmente na concentração da terra, alargando a fronteira agrícola para o pantanal e a região amazônica.

A partir do golpe militar de 64, o Estado brasileiro voltou-se massivamente para atender as necessidades de uma burguesia industrial, e a agricultura passou a servir majoritariamente esse setor (PALMEIRA; LEITE, 1998). Em 1965, o Governo Federal criou o Sistema Nacional de Crédito Rural (SNCR) com o objetivo de ser o principal estimulador da política de modernização da agricultura, passando de $15 \%$ do PIB na década de 60 para 50\% do PIB na década de 70 (COELHO, 2001). De acordo com Rodrigues (1997), com a criação do SNCR, substituiu-se o CRS pelo CRO.

Durante a década de 70, o SNCR promoveu a criação do Sistema Brasileiro de Assistência Técnica e Extensão Rural (SIBRATER), da EMBRATER e da Empresa Brasileira de Pesquisa Agropecuária (EMBRAPA). Com isso, ampliou-se o sistema nacional de Extensão Rural, buscando-se superar aspectos culturais e ideológicos "tradicionais", considerados entraves no processo de modernização da agricultura (CAPORAL, 1998; MOREIRA, 1999). O enfoque desse serviço esteve voltado para o aumento 
da produtividade agrícola, com base no desenvolvimento de uma agricultura de monocultivo. Segundo Coelho (2001), na safra 1984/85, o milho e a soja corresponderiam por $82,4 \%$ da produção nacional de grãos.

Os efeitos negativos das medidas sociais e econômicas adotadas nas décadas de 1960 e 70 proporcionaram a queda do governo militar. Alguns fatores foram decisivos para esse processo: a crise da balança comercial e dos recursos do Estado; o aumento dos juros nacionais e internacionais; o aumento da inflação; a crítica aos resultados negativos das medidas modernizantes para o campo; o consequente esgotamento e a redução dos recursos para o SNCR; a pressão social por democracia e pela abertura política do país. Para Delgado (2004), o fim do governo militar possibilitou uma "oxigenação" das organizações sociais colocadas em clandestinidade durante a década de 60 e 70 e possibilitou a formulação da nova Constituição Nacional no ano de 1988.

No cenário agrícola, o crédito rural foi se extinguindo, e o patronato rural permanecia dividido. De um lado, estavam os segmentos mais atrasados, retrógrados e reacionários da burguesia agrária, organizados e representados pela Confederação Nacional da Agricultura (CNA) e, de outro, a agricultura patronal mais modernizada, que conseguia articular grandes e pequenos produtores a fim de exercerem um poder de pressão e reivindicações específicas diante do novo governo. O lançamento do Plano Nacional de Reforma Agrária (PNRA) no ano de 1985, pelo governo Sarney, resolveu essa separação. Essa ação governamental gerou a unidade do patronato rural em prol do arquivamento do PNRA. A pressão sobre o governo resultou na transformação da proposta de Reforma Agrária em apenas um capítulo do Plano Nacional de Desenvolvimento Rural (PNDR) (SILVA, 1998).

Com o PNDR, foi sepultada, mais uma vez, a possibilidade da realização de uma massiva Reforma Agrária no Brasil. A fraqueza das organizações dos trabalhadores rurais diante da gigantesca unidade da burguesia agrária minimizou a pressão social para a sustentação do PNRA. A unidade 
da burguesia agrária e a organização dos complexos agroindustriais sustentaram uma blindagem do governo contra as mudanças estruturais do país. Mais uma vez, as políticas para agricultura ficaram submetidas aos interesses do capital industrial e da burguesia agrária. Esses condicionantes possibilitaram a abertura do Estado brasileiro ao ideário do neoliberalismo como forma para reestruturação da dinâmica social e econômica do país.

\section{Desafios e perspectivas atuais}

Segundo Gonzaga (1996), o programa de Reforma Agrária no Brasil sofreu transformações durante os diferentes períodos históricos. Se na transição entre feudalismo e capitalismo o processo de desconcentração da propriedade da terra foi fundamental para o sucesso do novo modo de produção, nos países colonizados e de economia dependente, como nos mostra Fernandes (1975), Prado Júnior (1981) e outros, a desconcentração da terra não é de interesse da burguesia hegemônica.

Por isso, mesmo a "Reforma Agrária clássica" - a que tem como protagonistas as burguesias industriais e que objetivava potencializar o mercado interno por meio da democratização da propriedade da terra e transformar os camponeses em produtores e consumidores de mercadoria -, realizada em vários países, se tornou prescindível para os setores hegemônicos da "burguesia nacional".

A possibilidade de um "projeto de desenvolvimento nacional" no Brasil nunca passou de ensaios. A correlação de forças dos setores interessados em completar o longo ciclo interrompido entre colônia e nação nunca alcançou força suficiente para transformar seu programa particular na vontade e ação geral da sociedade. Os motivos que impediram essa correlação de forças favorável são variados. Uma análise mais detalhada consta nas obras dos autores citados anteriormente. 
Assim, ao longo de nossa história, a Reforma Agrária, nos momentos de crise econômica ou social, é percebida, por alguns setores, como uma possível solução. Nessas conjunturas, em que disputas de projetos de sociedade se explicitam, a questão agrária entra na pauta.

Diante desse novo contexto, a luta pela Reforma Agrária deixa de objetivar o desenvolvimento capitalista e passa a ser uma das estratégias para a superação desse modelo de produção. Em um esforço coletivo, em que a luta pela Reforma Agrária extrapola a luta pela terra e os que dela dependem diretamente, existe

um novo projeto de país que precisa ser construído com todas as forças populares, voltado para atender os interesses e necessidades do povo brasileiro. Buscando assim, com a luta pela reforma agrária popular, acumular forças, obter conquistas para os camponeses e derrotas para as oligarquias rurais, organizar e politizar nossa base social, ampliar e consolidar o apoio da sociedade à nossa luta. É dessa forma que construiremos nossa participação nas lutas de toda a classe trabalhadora para construir um processo revolucionário, que organize a sociedade e um novo modo de produção, sob os ideais do socialismo. (MST, 2013, p. 33-34).

Alexandre da Conceição, da Coordenação Nacional do MST, defende que os sem-terra façam oposição ao agronegócio que, segundo ela, se fortalece com o avanço das empresas transnacionais sobre a agricultura.

O agronegócio, que vem tomando conta dos nossos recursos naturais; que vem expulsando os indígenas e os quilombolas de suas terras; que vem impedindo e travando a Reforma Agrária; e que vem ao mesmo tempo envenenando o campo e a cidade com as altas taxas de agrotóxicos consumidos neste tipo de agricultura, uma agricultura do monocultivo, uma agricultura atrasada, com tecnologia que não gera emprego.

Essa mudança de paradigma nos objetivos da Reforma Agrária implica a reformulação da tática e do programa agrário em todo seu conjunto. Para 
Neuri Rosseto, também da Coordenação Nacional do MST, a construção da Reforma Agrária, na perspectiva do programa agrário atualmente defendido pelo Movimento, tem, pelo menos, cinco premissas:

\section{Acumular forças para a construção de novas relações sociais}

Essas novas relações sociais têm, pelo menos, três frentes:

a. enfrentar a burguesia agrária, ou seja, derrotar o latifúndio;

b. criar consensos na sociedade em torno do projeto de Reforma Agrária, de agricultura e de organização da sociedade;

c. disputar esse programa, na base social camponesa, fortalecendo a organização classista.

II. Considerar a relação entre teoria e prática, na perspectiva da formação para o programa de Reforma Agrária popular

É necessária uma relação dialética entre teoria e prática, que fazem parte de uma unidade práxis, mas não são a mesma coisa. Enquanto a teoria tem o conhecimento como fim, a prática tem o conhecimento como meio; o tempo da teoria é infinito, o da prática é imediato; o "teoricismo" pode conduzir ao desvio do idealismo, enquanto o "praticismo" pode levar ao desvio do pragmatismo.

\section{Contrapor as lutas à sociedade capitalista}

Os principais problemas da sociedade contemporânea (concentração da terra, pobreza no campo, degradação ambiental) são agravados pelo desenvolvimento do capitalismo. $\mathrm{O}$ aprofundamento das relações capitalistas pode colocar em colapso a existência humana. As lutas não podem, portanto, existir apartadas do capitalismo.

\section{Processo revolucionário}

Transformação do modo de produção e consumo; transformação das relações sociais e tomada de poder, estruturando a produção com vistas à sociedade socialista; soberania alimentar - produzir para a vida é contradizer o capitalismo.

Só há um motivo para existir 800 milhões de pessoas passando fome: a permanência da lógica capitalista. Por isso, é importante pensar em 
como envolver a população nas tomadas de decisões, seja nas escolas, nas universidades, nos assentamentos e na sociedade como um todo.

\section{Neutralizar e combater o capitalismo}

O capitalismo cria conflitos, e o controle desses conflitos é fundamental para o capitalismo perpetuar-se. Há uma crise do Estado (crise da república) implicando agravamento da crise institucional; para manter o consenso, ampliou-se o nível de coerção e repressão (prevenir a subversão) para neutralizar e combater alternativas ao capitalismo; intensificou-se a monocultura, seja na agricultura ou em outras dimensões de produção da vida, como tentativas da padronização das formas de viver.

A partir dessas premissas, o programa de Reforma Agrária, defendido pelo MST, propõe a contraposição entre a Reforma Agrária clássica e a Reforma Agrária popular, que se expressa, de forma resumida, nos seguintes pontos:

I. Distribuir a propriedade da terra é um obstáculo ao atual ciclo de acumulação capitalista. Atualmente, apenas 8\% (ALVES; ROCHA, 2010) das propriedades se viabilizam com a agricultura em larga escala. Isso demonstra a importância de compreender a produção de alimentos como estratégico e a necessidade de políticas públicas que garantam a diversificação da produção.

No programa agrário defendido pelo MST, o entendimento é de que a terra e todos os bens da natureza em nosso território precisam estar a serviço de todo o povo brasileiro, impedindo a concentração da propriedade privada, estabelecendo tamanho máximo de propriedade e eliminando o latifúndio.

II. A Reforma Agrária popular baseia-se em outro sistema agrícola fundamentado em quatro bases:

a. desenvolvimento da produção agrícola deve ser diversificado, utilizando-se de técnicas de produção agroecológica e máquinas agrícolas 
socialmente adaptadas - tendo os camponeses e as camponesas como guardiões e guardiãs da biodiversidade;

b. trabalho cooperativado com produção e apropriação coletivas, implementando as formas diversas de cooperação agrícola para desenvolver as forças produtivas e agroindústrias adequadas às relações sociais que promovam os princípios sociais apontados no programa popular;

c. escolas do e no campo, compartilhando saberes em tempos e espaços, respeitando a vida e as produções do e no campo. Todas as pessoas que vivem no meio rural têm direito à educação pública, de qualidade, em todos os níveis, assim como o desenvolvimento de sua culturae identidade social.

Na concepção do MST:

A educação não acontece no espaço e tempo que o educando e educanda frequenta a escola. O direito à educação se relaciona, também, ao acesso aos diferentes tipos de conhecimentos e de bens culturais; à formação para o trabalho e para a participação política; ao jeito de produzir e se organizar; a aprender a se alimentar de modo saudável; e à prática dos valores humanos e socialista que defendemos. (MST, 2013, s/p).

III. Relação com a propriedade da terra que rompa tanto com a lógica jurídica constitucional, privatista da sociedade capitalista, que pressupõe o direito de o proprietário fazer o que quiser com a terra, para outra lógica: a terra, na Reforma Agrária, deve cumprir uma função social - produzir alimentos, cultura, vida! A apropriação da terra para a Reforma Agrária, segundo o MST, deve respeitar e demarcar todas as áreas pertencentes ou de usufruto das comunidades indígenas, quilombolas, ribeirinhas, extrativistas e de pescadores artesanais.

IV. Reapropriação social dos bens da natureza - minério, biodiversidade, terra, água, sementes: a água e as florestas nativas são recursos da natureza e devem ser tratados como um direito de todo cidadão. 
Não podem ser considerados mercadoria nem objeto de apropriação privada.

V. Alimentos como direito e não mercadorias; enfrentar a OMC: construir a soberania alimentar, defendendo o direito de produzir seu próprio alimento. Produção de alimentos saudáveis em cada região do país, para atender todas as necessidades do povo, de acordo com seus hábitos alimentares e culturais. "Povo que não produz seu próprio alimento é um povo escravo" (José Martí).

Para alcançar a soberania alimentar, é fundamental a autonomia sobre a produção de sementes, de forma que o MST defende preservar, multiplicar e difundir as sementes crioulas, sejam as tradicionais ou melhoradas, de acordo com a diversidade do nosso clima e dos biomas, para que todos os agricultores tenham acesso a elas e, assim, se mantenha a soberania nacional da produção.

\section{Considerações finais}

O programa de Reforma Agrária passa a fazer parte de um projeto social mais amplo, envolvendo a questão ambiental, a resistência cultural, a criação de emprego, a soberania alimentar, o direito à educação e à saúde e a defesa da democracia, etc. ("Sem Reforma Agrária não há democracia!", gritavam os sem-terra em 1982). Sem esse conjunto de mudanças, a Reforma Agrária deixa de ser viável. Esse programa passa a integrar e a ser integrante de outros programas, indo para além da posse da terra.

A Reforma Agrária não é necessidade apenas dos povos, que, por meio dela, terão acesso à posse da terra, mas de outros setores da sociedade que demandam um conjunto de ações que podem ser proporcionadas a partir dela. 
Dessa forma, questões como produção, soberania alimentar e acesso a alimentos saudáveis passam a ser temas diretamente relacionados ao programa agrário.

Como síntese, existem os desafios atuais da luta pela Reforma Agrária e da luta do MST, a necessidade de possibilitar à população camponesa acesso aos bens culturais e aos demais direitos básicos, como escola, teatro, cinema, atendimento à saúde, saneamento básico. E novas relações sociais que valorizem: trabalho coletivo; divisão justa da renda; relações de gênero que levem em conta as especificidades das orientações sexuais; defesa da soberania alimentar, ou seja, a autodeterminação sobre a escolha dos próprios alimentos à imposição de interesses dos mercados ligados as grandes multinacionais; defesa das diversidades culturais e étnicas; recuperação de um futuro digno para o mundo agrário, capaz de ser acolhedor para os jovens; subordinação das tecnologias e técnicas às razões e éticas dos povos, respeitando interesses e necessidades de cada cultura. Enfim, no plano ecológico, a implementação de um projeto que seja ambientalmente sustentável. Para o MST não basta democratizar o acesso à terra, não basta tomar os meios de produção; é preciso ir além.

O capitalismo, ao transformar a terra em mercadoria, transformou todas as relações que em torno dela se estabelecem em relações hegemonizadas pelo capital. Junto à apropriação dos meios de produção, criaram uma forma (equipamentos, técnicas e tecnologias) de produzir na qual o resultado contém o processo. São indissociáveis do produto as relações sociais e a forma como foi produzido. Se o objetivo é uma nova forma de convívio social, não mais baseada no capital, além de expropriar os meios de produção, é necessário mudar a forma de produzir. A partir dessas relações sociais pretendidas, o MST aponta a agroecologia como um conjunto de relações que, ao mesmo tempo em que são de produção, são igualmente culturais e sociais. 


\section{REFERÊNCIAS}

ALVES, E.; ROCHA, D. P. Ganhar tempo é possível? In: GASQUES J. G.; VIEIRA FILHO, J. E. R.; NAVARRO, Z. (Org.). A agricultura brasileira: desempenho, desafios, perspectivas. Brasília, DF: IPEA, 2010.

BRASIL. Constituição da República Federativa do Brasil. Brasília, DF: Senado Federal: Centro Gráfico, 1988.

BRAZ, Marcelo. Capitalismo, crise e lutas de classes contemporâneas: questões e polêmicas. Serv. Soc. Soc., São Paulo, n. 111, p. 468-492, set./2012. Disponível em: <http://dx.doi.org/10.1590/S0101-66282012000300005>. Acesso em: 09 maio 2017.

CALDART, Roseli Salete. Educação em Movimento: formação de educadoras e educadores no MST. Petrópolis: Vozes, 1997.

BRIE M. Making the Common Good of Humanity concrete. Brussels: Rosa Luxembourg Foundation, 2011.

CARNOY, M. Estado e teoria política. 12. ed. São Paulo: Papirus, 2006.

COELHO, C. N. 70 Anos de Política Agrícola no Brasil. Revista de Política Agrícola. Ministério da Agricultura, Pecuária e Abastecimento. Brasília, 2001.

CORAZZA, G.; MARTINELLI, O. JR. Agricultura e Questão Agrária no pensamento Econômico. Teoria e Evidência Econômica. Passo Fundo, 2002.

COUTINHO, C. N. Gramsci: um estudo sobre o seu pensamento político. Rio de Janeiro: Campus, 1992.

DELGADO, G. C. A Questão Agrária Brasileira no Pós-Guerra e sua Configuração Contemporânea. Brasília, 2004. (Versão não publicada).

ENGELS, F. A origem da família, da propriedade privada e do estado. Rio de Janeiro: Civilização Brasileira, 1987.

FERNANDES, F. A Revolução Burguesa no Brasil. Rio de Janeiro: Zahar, 1975.

GONZAGA, J. G F. Possibilidades educativas nas ações coletivas do MST: reflexões teóricas e epistemológicas. 2006. 236 f. Dissertação (Mestrado em Educação) - Universidade Federal Fluminense, Niterói, RJ, 2006.

GRAMSCI, A. Concepção dialética da história. Rio de Janeiro: Civilização Brasileira, 1995. 
GRAZIANO DA SILVA, J. O novo rural brasileiro. Unicamp: Instituto de Economia, Série Pesquisas, 1999.

HOUTART, François. Dos Bens Comuns ao "Bem Comum da Humanidade". Bruxelas: Fundação Rosa Luxemburgo, 2011.

LÊNIN, V. I. O Estado e a Revolução. São Paulo: HUCITEC, 1983.

MARCON, Telmo. Os movimentos sociais como educadores: contribuições políticas e pedagógicas do Acampamento Natalino. Passo Fundo: UPF, 2016.

MARX, Karl \&ENGELS, Friedrich. Manifesto Comunista. São Paulo: Expressão Popular, 2008.

MAURO, G. MST: lutas e perspectivas. In: BARSOTTI, P.; PERICÁS, L. B. (Org.). América Latina: história, crise e movimento. São Paulo: Xamã, 1999.

MST. Programa Agrário do MST: Texto aprovado pela Coordenação Nacional para o VI congresso Nacional. Movimento dos Trabalhadores Rurais Sem Terra. São Paulo, 2014. Disponível em: <http://forumeja.org.br/sites/forumeja.org. br/files/Cartilha-Programa-agr\%C3\%A1 rio-do-MST-FINAL\%20(texto\%20 basico).pdf>. Acesso em: 10 fev. 2017.

MST. Programa Agrário do MST: Texto em Construção para o VI Congresso Nacional. Movimento dos Trabalhadores Rurais Sem Terra. São Paulo, 2013.

NABUCO, J. Campanha Abolicionista no Recife. Eleições de 1884. Brasília: Senado Federal, 2010.

OFFE, C. Dominação de classe e sistema político: sobre a seletividade das instituições políticas. In: OFFE, C. Problemas estruturais do Estado capitalista. Rio de Janeiro: Tempo Brasileiro, 1984. p. 140-177.

PALMEIRA, M.; LEITE, S. Debates Econômicos, Processos Sociais e Lutas Políticas. In: COSTA, L. F. C.; SANTOS, R. (Org.). Política e Reforma Agrária. Rio de Janeiro: Mauad, 1998. p. 92-165.

POULANTZAS, N. Poder político e classes sociais. São Paulo: Martins Fontes, 1977. . O Estado, o poder, o Socialismo. Rio de Janeiro: Graal, 1985.

PRADO JR., C. A questão Agrária no Brasil. São Paulo: Brasiliense, 1981.

RODRIGUES, C. M. Conceito de Seletividade de Políticas Públicas e sua Aplicação no Contexto da Política de Extensão Rural no Brasil. Cadernos de Ciência \& Tecnologia, Brasília, v. 14, n. 1, p. 113-154, 1997. 
SILVA, J. G. da S. A Nova Dinâmica da Agricultura Brasileira. Campinas, SP: UNICAMP, 1998.

SMITH, A. A riqueza das nações: investigação sobre a natureza e suas causas. São Paulo: Abril Cultural, 1983.

STEDILE, João Pedro. Prefácio - MST. In: CALDART, Roseli Salete. Educação em Movimento: formação de educadoras e educadores no MST. Petrópolis: Vozes, 1997.

VEIGA, J. E. da. O desenvolvimento agrícola: uma visão história. São Paulo: USP; HUCITEC, 1991. 


\title{
A disputa pela terra entre indígenas e agricultores no norte do Rio Grande do Sul: síntese de alguns elementos históricos
}

\author{
Alex Antônio Vanin ${ }^{1}$ \\ Gean Zimermann da Silva ${ }^{2}$ \\ João Carlos Tedesco ${ }^{3}$
}

\section{Considerações iniciais}

Os conflitos agrários e sociais envolvendo indígenas eram correntes no norte do Rio Grande do Sul, às vezes com muita intensidade. Para entender melhor os fatos, é necessário abordar, pelo menos, alguns elementos históricos que acreditamos serem as causas. ${ }^{4}$

A discussão inicia com a colonização da região Norte, ou seja, no antigo e amplo território de Passo Fundo, o qual tem hoje os municípios de Passo Fundo e Erechim como epicentros, com descendentes de imigrantes oriundos das Colônias Velhas (região de Caxias do Sul e São Leopoldo) com o incentivo do governo republicano rio-grandense na virada do século XIX para o XX, fundando novas colônias. O estado implementou um processo de modernização associado ao capital estrangeiro, como a

\footnotetext{
Graduando de História da UPF; bolsista CNPq.

2 Mestre em História Regional pela Universidade de Passo Fundo. Contato: gean.z.dasilva@gmail.com

3 Prof. do PPGH/UPF. Contato: jctedesco@upf.br

4 Sobre os conflitos agrários atuais, sugerimos ver TEDESCO, João C. (Org.). Conflitos agrários no norte do Rio Grande do Sul: indígenas e agricultores. Porto Alegre: Letra \& Vida; Passo Fundo: Imed, 2014. v. 7.
} 
construção de estradas de ferro. Para facilitar a compra de lotes, o governo estadual, por intermédio do engenheiro de terras Carlos Alberto Torres Gonçalves, responsável pela Diretoria de Terras e Colonização (DTC), demarcou 11 áreas indígenas ao norte e noroeste do Rio Grande do Sul.

Nessa área - norte do Rio Grande do Sul - concentra-se, hoje, a quase totalidade dos conflitos pela terra envolvendo indígenas e agricultores no Estado. É um espaço de histórica presença de parcialidades Kaingang, as quais interagiam, em suas territorialidades, com outros grupos do oeste de Santa Catarina, tendo Chapecó como seu epicentro. O mapa a seguir nos permite visualizar e identificar seus locais, bem como justificar o norte do estado como o espaço que delimita a intensidade da luta indígena pela terra.

Mapa 1 - Locais e denominações dos atuais conflitos indígenas no Norte do Rio Grande do Sul e Oeste de Santa Catarina
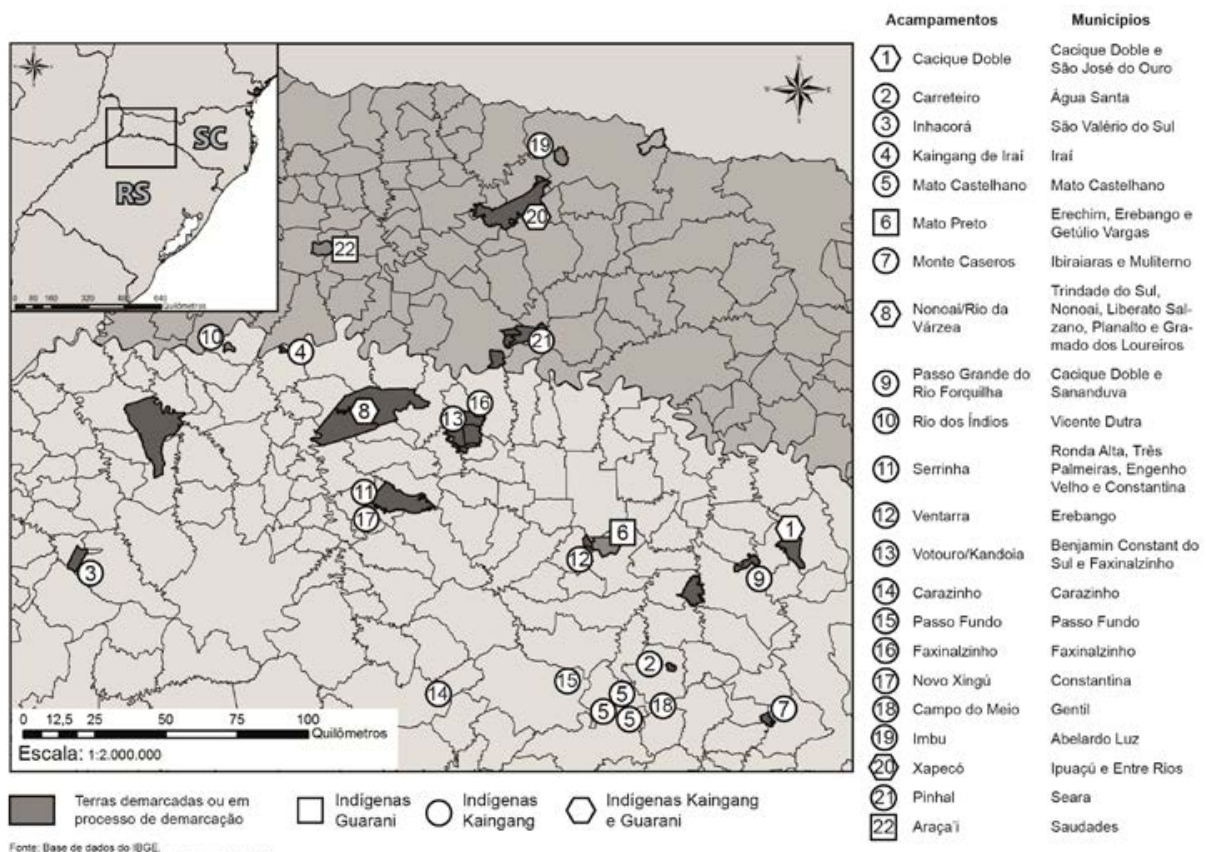

Fonte: Adaptação de Alex A. Vanin. 
Neste texto, trabalhamos o período auge das reduções das áreas indígenas, anos de 1910-1960, no qual, em razão de demarcações originais, intrusões de agricultores, ações de colonizadoras e políticas públicas, houve uma intensa subtração da área indígena. Esse processo histórico está diretamente ligado aos conflitos agrários atuais entre indígenas e agricultores. O período compreendido entre as décadas de 1940 e 1960 foi um momento em que ocorreu a modernização no meio rural, a escassez da terra foi colocada em evidência, o governo estadual necessitava de um plano de ação para os colonos, e as reservas indígenas suprimiram essa demanda através da redução de área.

O plano de ação expressou-se pelas políticas de reforma agrária, que ocasionaram reduções e extinções de áreas indígenas. Havia muitos posseiros no interior dessas áreas e, atendendo ao interesse principalmente das elites regionais onde esses territórios estavam concentrados e estabelecidos, a alternativa do território indígena demarcado passou a fazer parte da estratégia governamental.

Enfatizaremos também o que ocorreu entre as décadas 1970 e 1980. Temporalidade essa em que a Igreja Católica, através do Conselho Indigenista Missionário (CIMI) e intelectuais ligados à academia, dentre outros, visualizaram a causa indígena e a colocaram em evidência. Um marco temporal e simbólico desse período foi 1978, quando os indígenas de Nonoai expulsaram centenas de famílias de colonos que habitavam a área. Esse conflito surtiu efeito, pois a área indígena foi sendo desintrusada nos anos subsequentes, o que ocasionou conflitos entre os colonos sem-terra com os latifundiários na região de Sarandi, fato que se repetiu ao longo da década de 1980. Por fim, enfatizaremos a questão do retorno dos indígenas para as terras consideradas de ocupação tradicional após a Constituição Federal de 1988. 


\section{A política dos aldeamentos na província do Rio Grande do Sul}

A presença indígena desde o período colonial se estabeleceu questão central nos debates e impasses com diversas instituições envolvidas na exploração e ocupação do território brasileiro, entre as quais as ordens religiosas e o governo instituído. Em meio a propostas, pressões populares e frentes de expansão, a Coroa portuguesa deliberou em torno da questão primando satisfazer primeiro os interesses econômicos, intuindo controlar certos agrupamentos considerados "mansos”, ou seja, suscetíveis ao domínio português, simultaneamente combatendo e escravizando os grupos considerados "bravos", que não se submetiam à conquista.

No contexto do Brasil imperial, o tratamento ao indígena permaneceu análogo ao do período colonial. A Carta Régia de 1808 foi expressiva nessa continuidade de resoluções, pois primou pelo enfrentamento, extermínio e escravização das populações nativas. A guerra oficializada tornou-se a marca das ações do governo colonial e também nos primeiros anos da monarquia brasileira, sobretudo no empreendimento de guerras de sujeição (FRANCISCO, 2013). Essas ações começaram a alterar-se a partir de 1831, início do período regencial, quando foi decretado o fim da "guerra aos bugres”, a abolição e a libertação dos indígenas escravos.

Em razão das frentes de povoamento e na posterior colonização dos territórios indígenas e consequentes conflitos resultantes desses encontros, foi necessário criar planos de ação para que os objetivos da ocupação e colonização do Império não sofressem interferências dessas populações. Nesse sentido, em 1845, logo após a retomada da imigração europeia para o Brasil, foi encampada a política de aldeamento de indígenas, que primava pela conservação da integridade das zonas coloniais e abertura de outras nos territórios que, a partir de então, seriam "liberados" da presença indígena.

A política dos aldeamentos foi instaurada pelo Decreto $n^{\circ} 426$, de 24 de julho de 1845, nominado "Regulamento das missões", 5 que acordava

5 Coleção de leis do Império do Brasil, 1845. v. parte II. p. 86. 
os termos da regulamentação das missões de catequese e de civilização dos indígenas em todo o território nacional. Concebido como resolução acertada para pôr fim aos enfrentamentos entre parcialidades indígenas e colonos nos interiores do Brasil, o regulamento previa que os indígenas fossem estabelecidos em aldeias ou em seus já existentes toldos, ${ }^{6}$ para, assim, receberem assistência e instrução da fé católica e dos meios de se produzir riquezas (FRANCISCO, 2013).

Primando pela integração dos nativos à sociedade nacional por meio da civilização, o Regulamento das missões determinava que fossem estabelecidas aldeias oficiais nas províncias do Império. Desse modo, a administração das áreas passaria a ser independente e descentralizada do governo imperial e ficaria a cargo dos governos das províncias através do já existente Diretório Geral dos Índios. ${ }^{7}$ Apesar dessa determinação, percebeu-se que o decreto se constituiu como marco na política indigenista brasileira, uma vez que despontou certa homogeneidade quanto ao tratamento legado aos indígenas. Assim, foram determinados os parâmetros e as condições em nível nacional para a formação dos aldeamentos, como também os costumes e deveres que os nativos deveriam ser instruídos a adotar.

As aldeias das províncias ${ }^{8}$ estavam atreladas não apenas ao projeto colonizador, mas também à premissa do desenvolvimento de uma produção agrícola nacional. Por meio da inserção da agricultura nos aldeamentos como prática central, imaginavam ser possível manter coesas essas localidades, tendo o trabalho agrícola como elemento aglutinador dos grupos de indígenas nos assentamentos. Dessa forma, seria nesses espaços que os indígenas receberiam instrução acerca das técnicas de plantio e colheita produtiva, assim como serem acostumados ao trabalho regular e inseridas as bases dos costumes ocidentais (FRANCISCO, 2013).

6 Local de ocupação tradicional de determinada etnia indígena.

7 O Diretório Geral dos Índios foi um órgão criado em 1758 para o tratamento das questões atinentes àss populações indígenas brasileiras, regulando-as no espaço colonial.

8 Aldeias da província aparecem frequentemente nos registros como sinônimo de aldeamentos, por esse motivo resolvemos também empregá-las nesse sentido. 
A execução desses projetos configurava intrinsecamente à manutenção da colonização. Para auferir resultados exitosos, os aldeamentos tinham de suprir a premissa básica de sua criação: liberar as terras devolutas ocupadas até então por populações indígenas. No período pós-Revolução Farroupilha era imprescindível o retorno ao desenvolvimento e ao crescimento econômico, abalados pelo conflito. A abertura de estradas e a expansão das frentes pioneiras nas regiões desabitadas estavam interligadas à necessidade de criar-se mobilidade produtiva entre os núcleos coloniais e a província como um todo, resgatando e reacendendo a economia, com incentivo ao escoamento da produção.

A partir de meados do século XIX novas áreas foram requisitadas para a instalação de colônias, necessário para a dissipação da assoberbada lotação da colônia de São Leopoldo e adjacências. Teve início um movimento gradual no deslocamento populacional em direção ao centro-norte da província, possibilitando a abertura de estradas para melhor conduzir e distribuir o contingente de colonos.

Segundo Laroque (2007), a partir da década de 1840 foi perceptível uma determinada alteração no modo e na prática dos caingangues de se relacionarem com a figura cada vez mais permanente em seus territórios. Foram feitas importantes alianças entre os povos nativos e as frentes de ocupação e também com o governo provincial. Essa atitude perpetrada por parcialidades caingangues, à primeira vista, pode ser entendida como a derradeira submissão, o êxito das políticas de sujeição impostas pelas vias do combate. Segundo Laroque (2007), a adoção dessa política de aliança talvez tenha se configurado como uma estratégia caingangue de assegurar vantagens diante da constatação de que os combates que visavam à expulsão dos intrusos de seus territórios já não se mostravam eficazes como outrora. A prática caingangue, então, foi incorporar as negociações em seu corolário de ações, almejando, através do apoio provincial, fortalecer-se contra agrupamentos rivais e obter utensílios, roupas etc. 
A política de alianças começou a delinear-se primeiramente sob um manto do colaboracionismo e reciprocidade entre nativos e autoridades da província, criando um terreno fértil para a constituição dos aldeamentos. Em movimento gradativo, os incipientes aldeamentos que congregavam indígenas figuravam como localidades para fins de negociação, tanto na visão dos aldeados quanto na dos não aldeados (FRANCISCO, 2013; LAROQUE, 2007).

Entretanto, a adesão de grupos nativos aos projetos de aldeamento não deve ser entendida de maneira simplificada como se o indígena fosse apenas um agente passivo da situação. Inseridos nessa nova realidade, na qual a aliança com as autoridades provinciais era central, tem-se presente que a relação não se distanciava do âmbito dos conflitos. A coerção exercida pelos administradores dos aldeamentos, especialmente através da catequese levada a cabo por padres jesuítas, vinha de encontro às tradições e aos costumes caingangues de maneira a negar sua cultura, a concepção de mundo, a sociabilidade, a ligação com o território ainda fortemente relacionado aos moldes das sociedades tribais. Pelo menos, nos primórdios da organização dos aldeamentos, esse conflito interno era como entrave na consolidação do projeto de aldeamento.

Ao longo do século XIX, a presença indígena no território brasileiro condensou-se problemática. Central em discussões e debates, essa questão era permeada de conflitos acirrados, em decorrência do avanço do povoamento sobre as regiões Oeste, Norte e Sul, e a tentativa contínua de estabelecer o Estado nos moldes do capitalismo europeu, com a instauração da propriedade privada, de mercados interno e externo, que seriam alcançados pela alta produtividade de todas as regiões do país, pela expansão da sociedade nacional por todo o território. Os grupos indígenas, à margem desse processo, tinham de ceder lugar ao avanço da civilização, sendo instalados em reduzidas áreas de onde seriam integrados à sociedade. 


\section{As tentativas de formação dos primeiros aldeamentos da Província (1845-1854): o aldeamento de Nonoai}

O território norte da província de São Pedro do Sul recebeu levas de povoadores a partir da segunda década do século XIX ocupando gradativamente espaços. Instalavam-se também integrantes de expedições de exploração e de comércio de muares. A ocupação consolidou-se a partir de 1840 , sobretudo em razão do fim do conflito civil de 1845 , que reascendeu a necessidade de ser integrada essa região da província no horizonte do desenvolvimento da civilização pelas vias da ocupação.

Conforme avançava a expansão do povoamento no sul do Brasil, que se consolidava principalmente após a conquista dos campos de Guarapuava em 1810, a necessidade de integrar-se com maior êxito à província de São Pedro tornou-se intrínseca à conquista desse objetivo. Nesse sentido, o governo da província passou a abrir novas estradas, responsáveis por prover novas rotas e caminhos para o comércio, sobretudo com o noroeste missioneiro, e que também contribuíram para a fixação de assentamento de novos moradores ao norte da província, ainda majoritariamente ocupada por diversas tribos caingangues.

Francisco Ferreira da Rocha Loures, oficial paranaense, foi incumbido pelo presidente da província de São Paulo a abrir um novo caminho para as missões. Em 1845, Francisco Ferreira comandou uma tropa de expedicionários em direção à província do Paraná intuindo encontrar uma nova entrada para o território rio-grandense. Após cruzar os campos de Palmas e atravessar o rio Uruguai, estabeleceu conexão com a província de São Pedro no passo do rio Goio-En, extremo norte do Rio Grande do Sul (RODERJAN, 1991).

A passagem traçada por Ferreira Loures garantiu o acesso à província pelas adjacências dos chamados "campos de Nonoai", reduto dos indígenas da etnia caingangue. Desde meados do século XVIII, vinham sendo constantemente pressionados a se refugiarem cada vez mais para o sul 
de seus territórios, sendo o norte o limite geográfico das matas que lhes serviam de abrigo (SIMONIAN, 1981). A estrada a ser aberta reacenderia os conflitos entre indígenas e sociedade que almejava se instalar na região, o que ocasionaria simultâneos conflitos entre indígenas e colonos na região serrana.

A abertura da estrada entre Palmas e Nonoai ficou a cargo de Ferreira da Rocha. Em relação à presença indígena, era necessária a realização de negociações e acordos entre as lideranças e o encarregado da estrada, auxiliado em maior medida por nativos já aldeados nos campos de Guarapuava, como Vitorino Condá. Com a abertura de novos caminhos ao norte e a colonização de imigrante no nordeste, os projetos de aldeamento começaram a ser executados, indo ao encontro dos interesses expansionistas e povoadores do império do Brasil, amenizando a situação conflituosa que se iniciava.

O padre Penteado relata, acerca da expedição, que a desconfiança dos indígenas se fazia presente diante do encontro que se processava, pois eles, em períodos anteriores, haviam sido

[...] perseguidos a ponto de se encantonarem por esses apertados desertos, só tendo abrigo dessas escarpadas serras, sempre hostilizados, e hostilizando; parte das maneiras mais com que aliás nossos maiores os iludiram, quando aproveitando-se de sua boa-fé, e ignorância começaram a assassiná-los, roubar seus filhos, e escravizá-los, fatos esses e outros que de alguma maneira não deixa de justificar, seus bárbaros feitos, porquanto se veem as atrocidades, que para com eles praticam os civilizados quando atacam seus toldos. Ora, sendo o $1^{\circ}$ toldo pouco distante desta praça, parece que nenhuma ocasião seria mais oportuna para a catequese, que por essa; e que o Governo com alguma despesa em ferramentas e fazendas grossas mandando fazer uma visita à primeira tribo por um eclesiástico acompanhado de uma força defesa, tendo por fim agradá-los etc. [...]. ${ }^{9}$

9 Correspondência 17-06-1845. O Imparcial. Porto Alegre, n. 72, p. 1. 9 jul. 1845. Museu de Comunicação Social Hipólito da Costa. 
No início do projeto de aldeamento, padre Antônio esteve à frente da administração. Pelo relato ficou clara a intenção: pôr em prática a nova tratativa que se formava acerca dos indígenas, ou seja, reunir os índios em seus numerosos toldos, onde já se encontravam estabelecidos. Essa situação seria oportuna também para a catequese, sobretudo onde ele havia feito contato com os indígenas nos campos de Nonoai. Era premente a necessidade de controlar os nativos tanto para a manutenção da ordem nos arredores da construção da estrada quanto para a garantia de sua conclusão, facilitada mais ainda a partir do selamento de acordos e cooptação de vários indígenas no trabalho.

O presidente da Província, conde de Caxias, acolhe os pedidos de Penteado após ter tomado conhecimento das intenções e ações dele. Em razão do auxílio do presidente da Província, Penteado havia conseguido reunir mais de quatrocentos índios em torno de si, agraciando-os com roupas e terras. ${ }^{10}$

Nonoai era o toldo mais próximo da estrada a ser aberta e também o que congregava maior número de indígenas caingangues. Os grupos de indígenas estabeleciam-se no comando do cacique Nonoai, liderança já centenária, que tinha guiado o estabelecimento dos caingangues na região após a travessia do rio Uruguai na primeira década do século XIX em ritmo migratório em consequência das pressões sofridas pelo avanço português (SIMONIAN, 1981).

Em 1846, João Cypriano da Rocha Loures foi nomeado diretor do aldeamento de Nonoai para tratar da atração e da tentativa de consolidação do assentamento fixo de grupos caingangues na localidade. Em razão da sua má administração - por não realizar plantações necessárias para a autossuficiência e por dispender desmensuradamente recursos do governo para atração dos indígenas -, vê-se pressionado pelas acusações

10 Relatório de abertura da 2a legislatura do presidente da província conde de Caxias. Porto Alegre: Typ. de I. J. Lopes, $1^{\circ}$ mar. 1846. 
e pede demissão do cargo em 1847 (BRINGMANN, 2010; D’ANGELIS; VEIGA, 2013).

Com a saída de Rocha, abriu precedente para a inserção do elemento jesuítico nos aldeamentos. Os jesuítas espanhóis retornaram ao Brasil após convite do governo imperial para que atuassem junto aos indígenas, sobretudo nas províncias do Sul, que congregavam número expressivo dessas populações. A tarefa a ser concretizada era promover a civilização por meio do ensino de preceitos da cristandade, pautados na adoção do trabalho regular. A catequização dos nativos atuaria com a política dos aldeamentos, em que diretores e missionários levariam a cabo esse projeto civilizatório.

O sucesso do padre Penteado na atração dos indígenas e o estabelecimento dos missionários em conluio com a política dos aldeamentos passaram a ser vistos com bons olhos pela governança da província. A partir de 1848, a presença dos jesuítas entre os nativos tornou-se marcante especialmente com a chegada do jesuíta espanhol Bernardo Parès, interlocutor responsável por legar maior quantidade de informações acerca dos primórdios dos aldeamentos, tendo atuado não só como provedor da catequese, mas também na administração dos aldeamentos. Pela autorização do presidente da província, Parès assumiu a diretoria do aldeamento de Nonoai, que estivera sem diretor desde a saída de João Cypriano da Rocha Loures (AZEVEDO, 1984; BRINGMANN, 2010). 
Figura 1 - Retrato do padre Bernardo Parès anterior à sua chegada na província do Rio Grande do Sul

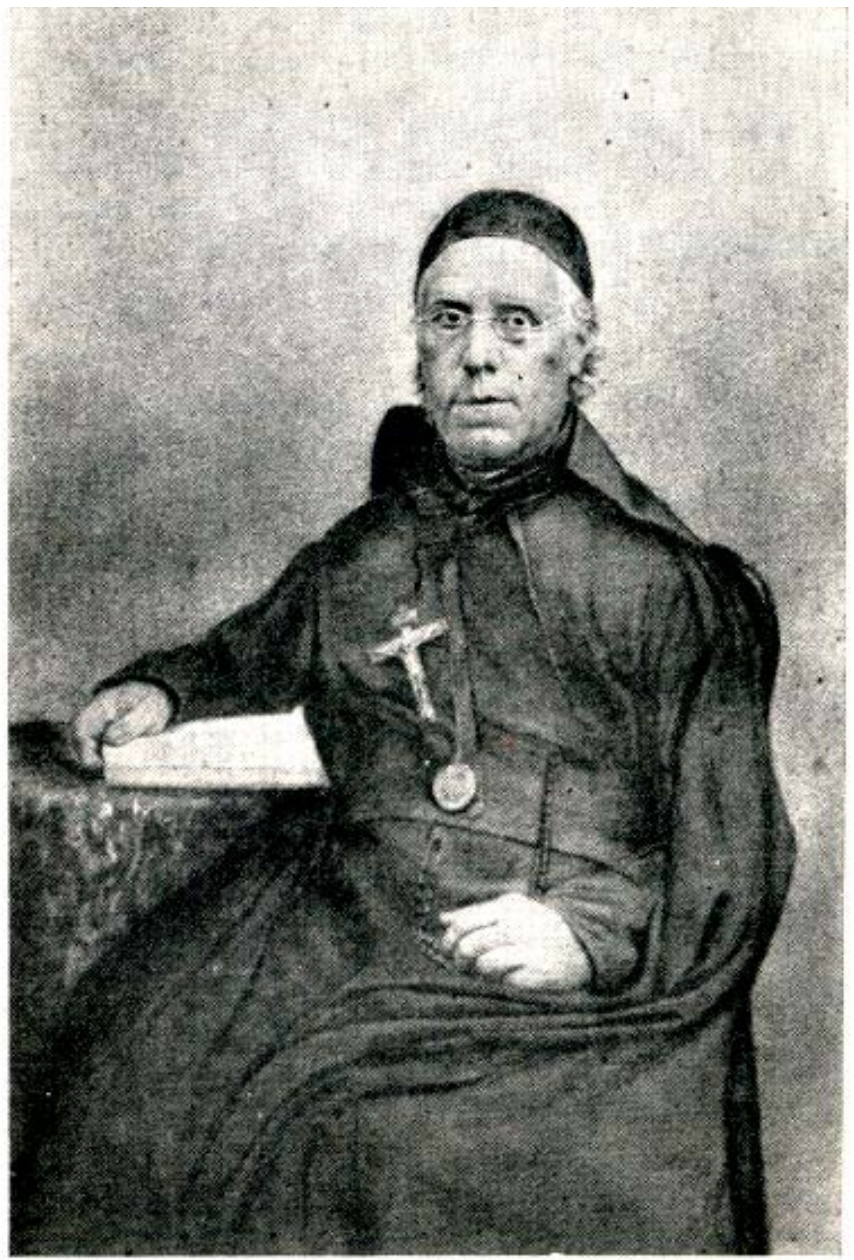

El jesuita padre Bernardo Parés, superior de

la Compañía de Jesús en Buenos Aires, en la época de Rosas. (Foto de G. Furlong.)

Fonte: Comisión de Investigaciones Histórico Eclesiásticas del Arzobispado de Buenos Aires.

Enquanto diretor do aldeamento de Nonoai, cargo que lhe permitia congregar tanto poder político quanto religioso, Parès foi capaz de disseminar a catequese nos aldeamentos com o auxílio de outros padres, como 
Luís Santiago Vilarrubia e Juliano Solanellas (AZEVEDO, 1984, p. 102). Ocupou o cargo com superioridade a muitos missionários que também estavam interessados nessa possibilidade de agirem junto aos indígenas. Comandou a distribuição de outros padres nos aldeamentos em formação na condição de provedores da catequese, uma vez que as aldeias já possuíam diretoria nomeada pela província.

Os missionários angariaram prestígio por se tornarem essenciais no sucesso da política indigenista. Com sua presença conseguiam aumentar a produtividade do trabalho dos índios e também o número de indígenas aldeados. De acordo com Parès, contabilizando as diferentes famílias indígenas no comando de vários caciques, Nonoai concentrava, em 1851, aproximadamente 470 "almas". Nessas terras também havia "de dez a doze pessoas portugueses que tem feito n'elles seus ranchos e roças". ${ }^{11}$

Mesmo com a presença dos jesuítas, alguns conflitos surgiram com relação à questão fundiária. $\mathrm{O}$ acirramento viria a agravar-se no decorrer do desenvolvimento dos aldeamentos. Eram destinadas extensas áreas de terras aos indígenas com localização privilegiada, propícias para o desenvolvimento de uma série de atividades econômicas, desde a produção agrícola, pecuária e extração da erva-mate. Essas terras eram alvo de cobiça dos não índios que se instalavam progressivamente na região.

O líder mais célebre e que serve de exemplo para suscitar a problemática do apossamento nas aldeias foi o ex-diretor João Cypriano da Rocha Loures. Depois de acusações que o levaram a renunciar o cargo de diretor do aldeamento, além de manter-se na residência reservada ao diretor da aldeia, apossou-se de quantidade de terras que seriam destinadas aos indígenas para o cultivo, o que causou tensões entre nativos, missionários e autoridades governamentais. Sobre a situação, Parès escreveu que Rocha

11 Notícia sobre o estado da catequese dos índios. Padre Bernardo Parès. Passo Fundo, 14 jan. 1851. AHRGS, lata 299, maço 1 . 
Loures teria ocupado "três léguas do dito campo, em cuja posse continua ainda depois de ter sido demitido da Diretoria". ${ }^{12}$

Segundo Márcia Motta (2007), no período pós-independência do Brasil, 1822-1850, não houve uma lei específica que regulamentasse a questão fundiária. Durante as quase três décadas, segundo a autora, prevalecia a posse como prática única e intrínseca de obter-se terras e constituir propriedades. Nesse período houve uma "vacância na lei", um cisma social na distribuição fundiária na região. Os posseiros, então, que já detinham várias propriedades, detentores de recursos e prestígio social, faziam valer seus requerimentos diante da lei, legal ou ilegalmente, conseguindo aumentar consideravelmente os domínios sem muitos entraves (BOTH, 2011).

Em 1850, apesar da Lei de Terras Nacional, a situação dos posseiros se manteve. A lei determinava que a partir da data de sua instituição o único meio de adquirir posses em território brasileiro era pela compra. Mesmo assim, a prática do apossamento continuava. Em relação à questão indígena, essa prática se desenvolvia na contramão dos objetivos de formação e consolidação das aldeias da província. Em meados do século XIX, aumentava visivelmente essa prática entre os novos contingentes populacionais que se instalavam, desde viajantes, tropeiros de outras províncias ou, mesmo, colonos imigrantes insatisfeitos com o desenvolvimento da colonização.

Rocha Loures, peça fundamental nesse processo, manteve-se ali, servindo de exemplo e incentivo à exploração e ao apossamento de terras que seriam destinadas a outros aldeamentos que possivelmente se instalariam, externando negligência e imobilismo do aparelho público em fazer valer as determinações aos grandes proprietários.

Em 1854, por determinação do presidente da província, Cansansão Sinimbú, por meio de alianças com as lideranças cacicais, foi colocada em prática a criação de um aldeamento geral, um local onde todos os indígenas podiam concentrar-se. Ali já se encontravam aldeados 635 indígenas

12 Notícia sobre o estado da catequese dos índios. Padre Bernardo Parès. Passo Fundo, 14 jan. 1851. AHRGS, lata 299, maço 1 . 
comandados por diversos caciques, como Fongue, Nicofé, Nicafim, Nonoai, Condá e Contufé. Esse somatório era fruto da aglutinação de indígenas já aldeados na localidade e contingentes incorporados do extinto aldeamento da Guarita ou outras tribos errantes atraídas para o assentamento. ${ }^{13}$

\section{A colonização e a demarcação das áreas indígenas}

O estado do Rio Grande do Sul no período em estudo foi governado por Júlio de Castilhos (1893-1898), Borges de Medeiros (1898-1908/19131928), Carlos Barbosa (1908-1913) e Getúlio Vargas (1928-1930), todos do Partido Republicano Rio-Grandense (PRR), que seguia os moldes do positivismo de August Comte.

No programa do PRR e na Constituição Estadual de 14/7/1891, as diretrizes do positivismo castilhista, para o desenvolvimento do capitalismo no Rio Grande do Sul, são basicamente: a diversificação econômica; o desenvolvimento dos meios de transporte; uma preocupação social, implícita no programa de imigração e na incorporação do proletariado à sociedade (RÜCKERT; KUJAWA, 2010b, p. 110).

É importante ressaltar que durante a Primeira República, e nessa "Babel do Novo Mundo", ${ }^{14}$ também habitavam caboclos. No processo colonizador (denominados por Torres Gonçalves de "nacionaes") foram preteridos ou não receberam o mesmo tratamento e prioridade dada aos imigrantes e/ ou descendentes. Essa forma de proceder marcou muito pelo fato de o Estado seguir a doutrina positivista na tentativa de manter a "paz" interna, em particular nas colônias públicas/particulares, para seguir com o

13 Relatório do presidente da província de São Pedro do Rio Grande do Sul, João Lins Vieira de Cansansão Sinimbú. Porto Alegre: Typ. do Mercantil, 2 out. 1854. p. 31.

14 Marcio Antônio Both da Silva é autor do livro Babel do novo mundo: povoamento e vida rural na região de matas do Rio Grande do Sul (1889-1925). A denominação "Babel” está relacionada à região norte do Rio Grande do Sul, e "novo mundo", simbolizava as colônias novas desse mesmo estado brasileiro. 
progresso. A questão que surge é o assentamento desse caboclo para evitar confrontos e atentados contra os descendentes de imigrantes. Nessa situação, o governo passou a doar ou cobrar menos preço nas terras e alojar os nacionais numa fração denominada de "fim da picada". ${ }^{15}$

Silva (2011) destaca a diferença do emprego e sentido do termo "caboclo”. Na historiografia nacional são encontradas as denominações tabaréu, caipira, sertanejo, jagunço, entre outras, e na historiografia rio-grandense é definido como nacional. De qualquer forma, a ideia corrente entre os imigrantes era de que o caboclo não tinha muita aptidão para o trabalho.

A política imigratória do governo do estado previa para os imigrantes a colonização da região Centro-Norte, a formação de colônias e, para os indígenas, $\mathrm{o}$ aldeamento nas terras demarcadas.

O positivismo no período de governança do Rio Grande do Sul (18891930) teve o papel de gerenciador da população. Com base nele, além dos descendentes de imigrantes europeus e dos grupos que já viviam na região, nessa prática de governar, incorporou os grupos na então sociedade considerada moderna.

Silva (2011) evidencia que Carlos Torres Gonçalves defendia a ideia de que os caboclos eram tão aptos ao trabalho quanto os imigrantes. $\mathrm{Na}$ prática, os nacionais não tiveram o mesmo tratamento que os imigrantes ou descendentes europeus. Carini enfatiza que "a colonização da região de matas do Alto Uruguai reproduziria o modelo e a estrutura fundiária das Colônias Velhas, baseadas na propriedade familiar e na policultura [...]” (2005, p. 141). Era uma forma de continuar com a prática da inserção de novos imigrantes no que o governo republicano rio-grandense queria.

Outra prática que o governo positivista utilizava no período, além das políticas de colonização da região, foi a construção de estradas de ferro para agilizar o transporte de mercadorias e pessoas. Nesse sentido, a

15 "Fim da picada" está relacionado à prática das colonizadoras, que abriam picadas no meio das matas e, no final, ou onde a terra era mais inóspita, designavam para quem não tinha condições de adquiri-la a um preço elevado. Desse modo, em geral, os caboclos eram assentados no final dessas picadas. 
viação férrea foi um marco histórico para a região e história rio-grandense e nacional. Na virada do século XIX para o século XX, a presença do trem representava prosperidade, tecnologia e bem-estar social.

Com a construção da estrada de ferro no Alto Uruguai (década de 1910), foi possível obter uma rápida prosperidade econômica. A ferrovia São Paulo-Rio Grande (EFSPRG) teve 12 estações no entremeio Passo Fundo e Marcelino Ramos, próximo à barranca do rio Uruguai/Pelotas, sendo Coxilha, Sertão, Estação Erechim (atual município de Estação), Erebango, Capo-Erê, Paiol Grande (atual município de Erechim), Balisa (demolida para a construção da estação Barro), Barro (atual município de Gaurama), Canavial (atual município de Viadutos), Marcelino Ramos, Estação Experimental de Trigo de Passo Fundo (atual distrito do Englert, pertencente ao município de Sertão), além da própria estação, em Passo Fundo.

Uma das colônias fundadas no norte do Rio Grande do Sul no início do século XX foi a colônia Erechim. "É importante destacar que, à frente da Diretoria de Terras e Colonização, encontrava-se Carlos Alberto Torres Gonçalves, engenheiro que projetou e acompanhou a demarcação das terras da Colônia Erechim, sendo um dos fiéis seguidores de ideias econômicas positivistas [...]" (CARON; TEDESCO, 2012, p. 224). Essa região caracterizava-se por densas florestas de araucária onde viviam habitantes indígenas e caboclos.

Os descendentes de imigrantes das Colônias Velhas, motivados pela escassez de terra, migraram para o Norte, onde começaram a formar-se as "Colônias Novas". A ocupação e formação de colônias era parte da política do Estado. Assim mesmo, as empresas colonizadoras agiam, formando colônias particulares, mistas ou não. Nessa linha de ação, o governo estadual, em 22 de dezembro de 1910, criou o $8^{\circ}$ distrito de Passo Fundo, denominado Colônia Erechim.

Nas primeiras décadas do século XX, o governo positivista rio-grandense demarcou 11 áreas indígenas, período em que houve mais conflitos com pecuaristas, agricultores, madeireiros e indígenas. 
Em 1910, o governo republicano criou o Serviço de Proteção ao Índio e Localização dos Trabalhadores Nacionais (SPILTN), que contemplava o auxílio aos indígenas e aos nacionais. Em 1918, esse órgão deixou de receber a verba destinada aos nacionais (nacionais ou caboclos), obtendo ajuda do Serviço de Povoamento. A partir daí, deixou de existir a sigla SPILTN e passou a ser Serviço de Proteção ao Índio (SPI), com o objetivo de inserir os indígenas ao meio de vida dos imigrantes e descendentes.

É importante ressaltar que as lideranças indígenas do Alto Uruguai faziam alianças com os não índios na prática de trocas de valores e de conhecimentos. Assim, "as relações entre fazendeiros e poderes públicos parecem ter favorecido invasões e demandas contra os índios. O resultado foi à necessidade de uma redefinição de limites para as aldeias Kaingang na virada do século [XIX para o XX]" (VEIGA, 1998, p. 40).

A partir dessa nova redefinição para evitar possíveis conflitos na região, o governo estadual começou a estudar uma maneira de atender todas as demandas indígenas e de migrantes do setor pastoril e agrícola. Entretanto, antes de ter uma constatação da situação dos índios na região do Alto Uruguai, as lideranças passaram a reivindicar a posse da terra com documentação oficial para poder assegurar o uso da terra considerada de ocupação tradicional em caráter imemorial. Um exemplo disso é o fato de dois caciques dos aldeamentos de Nonoai e Serrinha terem se dirigido ao Palácio Piratini, em Porto Alegre, em 1908, conforme registrado pelo jornal Correio do Povo:

O General Firmino de Paula foi ontem às 10,30 horas ao Palácio apresentar ao Dr. Presidente do Estado os dois caciques dos índios coroados, com aldeiamento na Serrinha, em Nonoai [...]. O cacique-mor Antonio Pedro de Nonoai expôs que sua tribo, vivendo nas proximidades de Serrinha, desde tempos imemoriais, na mais pacífica das posses sobre as terras que ocupam, está, há algum tempo, sendo constantemente perseguido por intrusos que pretendem desalojá-la [...]. O Dr. Carlos Barbosa respondeu-lhe que [...] na convicção de que aos ditos índios assistem direitos incontestáveis de posse sobre as terras de que lhes foram os primitivos habitantes, posse essa que 
o Governo lhes deveria assegurar [...]. Nesse sentido, o Dr. Carlos Barbosa, dirigindo-se ao Dr. Cândido Godoi, secretário das Obras Públicas e então presente, determinou-lhe que mandasse ao $\mathrm{Dr}$. $\mathrm{Au}$ gusto Pestana, com o pessoal que fosse necessário, aos aldeamentos desses índios, proceder a medição e a demarcação da zona por eles até agora ocupada (Jornal Correio do Povo, 26 de julho de 1908, apud Veiga, 1998, p. 41-43; Rückert; Kujawa, 2010, p. 118-119).

Figura 2 - Cacique Antônio Pedro do Toldo Nonoai, ao centro, acompanhado de indígenas caingangues, em reunião com o presidente do estado, Dr. Carlos Barbosa, em julho de 1911

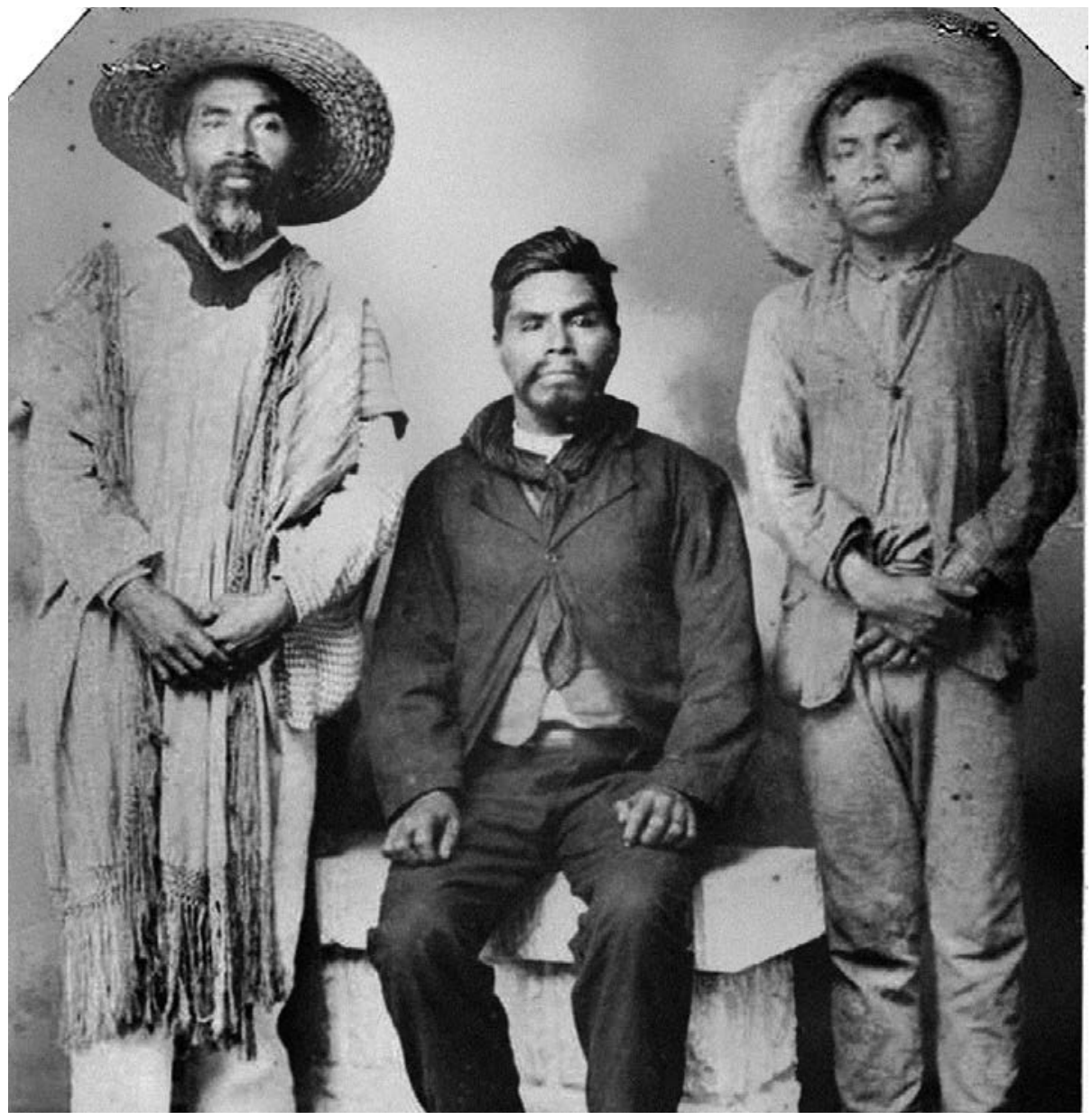

Fonte: Museu do Índio. 
A ida dos caciques à capital do Estado acelerou o processo de demarcação das terras indígenas no início do século XX, sendo que o governo estadual, do então Partido Republicano Rio-Grandense, através de atribuições do engenheiro de terras Carlos Alberto Torres Gonçalves, demarcou, como já mencionamos, 11 áreas indígenas na região do Alto Uruguai e outra próxima a Soledade, de 1910-1918.

Em 1910, Torres Gonçalves realizou um levantamento dos toldos indígenas predefinidos e os que ainda não haviam sido demarcados, chegando à constatação censitária de que havia em torno de 2.940 indígenas habitando a região nos 12 possíveis toldos.

Quadro 1 - Censo aproximado dos 12 possíveis toldos indígenas

\begin{tabular}{|c|c|c|}
\hline \multicolumn{3}{|l|}{ População aproximada } \\
\hline Toldo do Inhacorá & $2^{\circ}$ distrito do município da Palmeira & 400 hab. \\
\hline Dois toldos de Nonohay & $3^{\circ}$ distrito do município da Palmeira & 600 hab. \\
\hline Toldo do Guarita & $4^{\circ}$ distrito do município da Palmeira & 200 hab. \\
\hline Toldo do Fachinal & $2^{\circ}$ distrito do município da Lagoa Vermelha & 500 hab. \\
\hline Toldo do Caseros & $1^{\circ}$ distrito do município da Lagoa Vermelha & 100 hab. \\
\hline Toldo do Ligeiro & $3^{\circ}$ distrito do município do Passo Fundo & 500 hab. \\
\hline Toldo do Carreteiro & $3^{\circ}$ distrito do município do Passo Fundo & 80 hab. \\
\hline Toldo do Ventarra & $3^{\circ}$ distrito do município do Passo Fundo & 80 hab. \\
\hline Toldo do Erechim & $3^{\circ}$ distrito do município do Passo Fundo & 180 hab. \\
\hline Toldo do Votouro & $3^{\circ}$ distrito do município do Passo Fundo & 100 hab. \\
\hline Toldo do Lagoão & $4^{\circ}$ distrito do município do Soledade & 200 hab. \\
\hline \multicolumn{2}{|l|}{ Total } & 2.940 hab. \\
\hline
\end{tabular}

Fonte: Relatório sobre os indígenas do Rio Grande do Sul. C. Torres Gonçalves. Porto Alegre, 9 jun.1910, p. $155^{16}$.

O Quadro 2 apresenta as áreas indígenas demarcadas, entre 1910 e 1918, no norte do Rio Grande do Sul, com o intuito de abrir espaço para a colonização de novos imigrantes ou descendentes de colonos das Colônias Velhas, uma vez que o governo positivista mostrava-se preocupado com

16 Anexo ao relatório da Secretaria de Estado dos Negócios das Obras Públicas apresentado ao Exmo. Sr. Dr. Carlos Barbosa Gonçalves, presidente do Rio Grande do Sul, pelo secretário de Estado Candido José de Godoy. 10 set. 1910. Porto Alegre: Officinas Typographicas da "Livraria do Globo", p. 147-157, apud VEIGA, 1998, p. 44-45. 
a questão indígena, de possíveis e iminentes conflitos ocorrerem nessa região, caso a demarcação não fosse resolvida.

Quadro 2 - Os 11 toldos indígenas demarcados no início do século XX

\begin{tabular}{|l|l|l|l|}
\hline Área indígena & $\begin{array}{l}\text { Ano de } \\
\text { demarcação }\end{array}$ & $\begin{array}{l}\text { Área demarcada } \\
\text { em hectares (ha) }\end{array}$ & Atual município (2016) \\
\hline Faxinal (Cacique Doble) & 1910 & $5.676,33$ ha & Cacique Doble \\
\hline Carreteiro & 1911 & 600,72 ha & Água Santa \\
\hline Monte Caseiros & 1911 & $1.003,74$ ha & Ibiraiaras e Muliterno \\
\hline Inhacorá & 1911 & $5.859,00$ ha & São Valério do Sul \\
\hline Ligeiro & 1911 & $4.517,86$ ha & Charrua \\
\hline Nonohay & 1911 & $34.907,61$ ha & $\begin{array}{l}\text { Nonoai, Rio dos Índios, Gra- } \\
\text { mado dos Loureiros e Planalto }\end{array}$ \\
\hline Serrinha & 1911 & $11.950,00$ ha & $\begin{array}{l}\text { Constantina, Engenho Velho, } \\
\text { Ronda Alta e Três Palmeiras }\end{array}$ \\
\hline Ventara & 1911 & 753,25 ha & Erebango \\
\hline Guarita & 1917 & $23.183,00$ ha & $\begin{array}{l}\text { Tenente Portela, Miraguaí e } \\
\text { Redentora }\end{array}$ \\
\hline Votouro Kaingang & 1918 & $3.100,00$ ha & São Valentim \\
\hline Votouro Guarani & 1918 & 741,00 ha & Benjamin Constant do Sul \\
\hline
\end{tabular}

Fonte: RIO GRANDE DO SUL, 1997. ${ }^{17}$

Com a leva de descendentes imigrantes oriundos das Colônias Velhas para a região do planalto norte-rio-grandense na busca pelas últimas fronteiras agrícolas passíveis de ocupação, o entrechoque cultural entre índios e colonos aflorou. Até então os indígenas conseguiam de forma mais restrita manter seus costumes de habitação na região, subdividida em territórios.

Na Primeira República (1889-1930), o Rio Grande do Sul utilizou muito o capital estrangeiro, através das companhias de colonização e da viação férrea. O governo conquistava seus objetivos nas melhorias estruturais, ocupação da terra e modernização do transporte (trem) com a entrada desse capital externo. Assim, “o capital financeiro mercantil urbano esteve diretamente ligado ao negócio de terra no norte do estado, onde

17 Relatório de conclusões de grupo de trabalho criado pelo decreto no 37.118 de 30 de dezembro de 1996: Subsídios ao governo do estado relativamente à questão indígena no Rio Grande do Sul, 1997. Ver: CARINI, Joel J. Estado, índios e colonos: o conflito na reserva Serrinha/norte do Rio Grande do Sul. Passo Fundo: UPF, 2005. p. 136. 
também advinha parte do capital aplicado em outros setores produtivos" (MACHADO, 2012, p. 288).

A terra, mais do que um valor de subsistência, auferia também status de poder de capitalização. Os territórios indígenas eram considerados de domínio do Estado.

Becker (1995) analisa as moradias dos caingangues no século XX e enfatiza que as famílias viviam, de maneira semissedentária, em grupos, ou seja, em aldeias, constituindo postos centrais. A alta procura por terras na região ocasionou a intrusão de colonos, constituindo-se o princípio dos conflitos agrários envolvendo os indígenas e agricultores.

\section{O SPI, o governo do estado e a questão indígena: uma confluência de ações (1910-1940)}

Ao tratar-se da questão indígena brasileira na primeira metade do século XX, não se pode perder de vista a atuação do Serviço de Proteção aos Índios (SPI), órgão federal responsável pela tutela, assistência e contato com os diferentes povos existentes no território nacional. No estado do Rio Grande do Sul, as ações desenvolveram-se de acordo com os pressupostos teóricos a que estiveram atreladas. A intervenção junto aos indígenas processava-se de modo peculiar em relação aos outros estados brasileiros, pelos processos que se desenvolviam em torno da questão fundiária, pelo alinhamento de políticas públicas federais e estaduais e pela própria situação em que se encontravam as populações indígenas do Estado.

Na temporalidade de análise, uma série de resoluções acerca da questão fundiária provocou alterações e engendrou a base de várias mudanças e conflitos sociais no Rio Grande do Sul. No que se refere ao acesso à terra por diferentes sujeitos, determinações foram sancionadas a fim de sanar a problemática da indisponibilidade fundiária do Estado e a tensão e pressão social que se avolumavam no entorno dessa questão. 
Desde as demarcações das áreas indígenas sempre houve cooperação entre governo sul-rio-grandense e SPI, suas ações confluíram no sentido de elevar as populações indígenas a um novo "estágio de civilização". As instituições estiveram absortas nos ideais de um positivismo humanista, voltando suas concepções à interpretação da sociedade como um organismo vivo e em evolução no qual diferentes povos ocupavam diferentes estágios numa escala evolutiva.

Os povos indígenas encontravam-se, ainda, segundo esse pressuposto teórico, no mais baixo estágio da civilização, sendo necessária a sua condução para níveis superiores. A elevação seria possível apenas por meio de uma "proteção fraternal" a partir da qual os "civilizados" seriam responsáveis pelo auxílio e assistência contínuos para plena incorporação à sociedade, assimilando os valores morais ocidentais e, assim, inseri-los no sistema capitalista de produção.

Ao término das demarcações em 1918, com o reconhecimento da posse da terra pelo governo estadual para as comunidades indígenas, passou a ser conhecido como exemplo de tratamento com os indígenas. A assistência aos nativos provida através de seus órgãos de administração fundiária (Secretaria de Terras, Diretoria de Terras e Colonização) tornou-se visível nacionalmente, desenvolvida, sobretudo, nos governos do Partido Republicano Rio-Grandense (PRR), bastião dos ideais do positivismo e principal responsável pelo incentivo às políticas de modernização, técnica da produção agrícola e racionalização do uso das terras disponíveis por meio dos projetos de colonização.

Em nível nacional, até meados da década de 1930, o SPI sistematicamente atuou nas populações indígenas através da divisão administrativa do território nacional em regiões de assistência, as quais continham um ou mais estados sob a jurisdição da inspetoria subordinada ao SPI. As inspetorias proporcionavam a ação organizada e direcionada dos agentes do SPI às comunidades indígenas alocadas na região de influência, responsáveis pela localização, identificação, pacificação e assistência. Nesse 
sentido, muitas inspetorias se formaram com atuação abrangente, sobretudo nas áreas ainda não plenamente incorporadas ao sistema produtivo.

Em relatórios do SPI ao Ministério da Agricultura, é externada a notabilidade legada à povoação indígena de Passo Fundo, com destaque o papel do Estado em prover a assistência aos indígenas:

A povoação ocupa as terras do antigo Toldo do Ligeiro, uma das muitas áreas que o governo estadual garantiu ás populações indígenas, mantidas sob suas vistas protetoras. Considerando do domínio dos indios as terras por elles occupadas, independentemente de qualquer titulo oflicial e simplesmente pela prioridade de occupação, fica o Estado de Rio Grande do Sul em contraste com os outros Estados da Federação, nos quaes os indios, quando não são perseguidos como féras, são espoliados das suas terras. ${ }^{18}$

Nesse sentido, mesmo havendo a cooperação do Estado quanto à povoação, o serviço se considerava como "um complemento necessário da proteção estadual” (Rel. 1925). Na ação do SPI, a povoação recebia a assistência contínua através do fornecimento de ferramentas, sementes e estrutura para o beneficiamento da produção agrícola. A agricultura figurava como atividade central empreendida pelos indígenas, produtora de gêneros variados, como trigo, milho, arroz, feijão, dentre outros, que podiam ser beneficiados no moinho construído pelo SPI junto à usina elétrica mantida pelo trabalho indígena. ${ }^{19}$

Simultaneamente à assistência localizada na esfera do Estado, as outras dez áreas indígenas não se ausentavam de tutela; o Estado, através da DTC, mantinha regularidade na supervisão e assistência às comunidades indígenas não abrangidas pelo SPI. Ao que parece, a colaboração existente entre ambos os órgãos foi fundamental para o gerenciamento e controle das comunidades no Norte em razão da conformidade de propostas e execução de ações em torno dessa questão.

18 Relatório 1925, p. 672.

19 Relatório Ministério da Agricultura, 1929. 
Figura 3 - Indígenas reunidos próximo ao moinho e usina elétrica da povoação de Passo Fundo em 1928

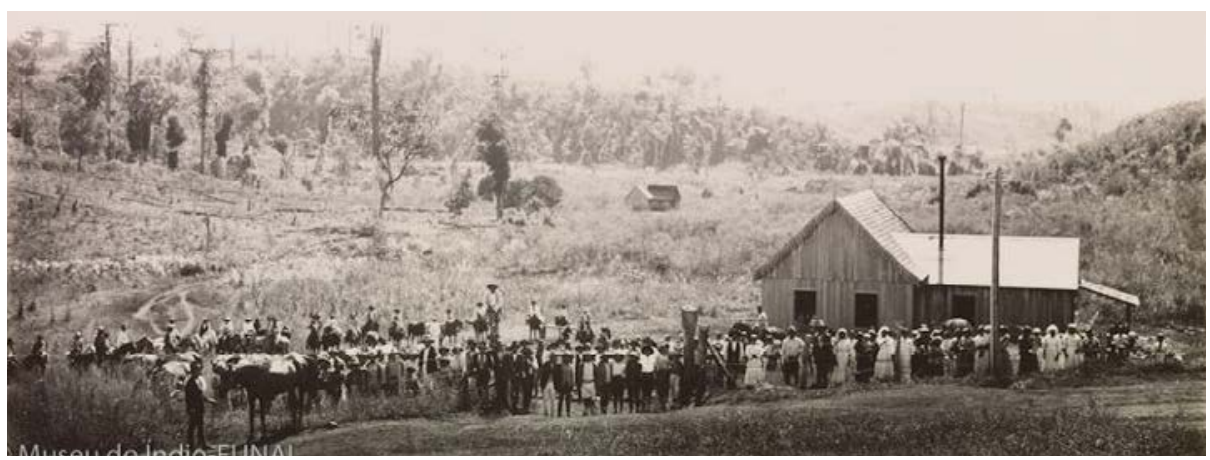

Fonte: Museu do Índio.

Dessa maneira, devido à cooperação da DTC, o SPI pôde eximir-se do dispêndio de altas quantidades de recursos e pessoal, já que eram destinados, a priori, às iniciativas e expedições das regiões centro e norte do país, detentoras de uma diversidade de comunidades indígenas que mantinham contato permanente com a sociedade nacional através da ação do SPI, sobretudo nas décadas de 1920 e 1930.

\section{O projeto de nacionalização e a ação do SPI no norte do Rio Grande do Sul}

Em 1936, o SPI, subordinado à Inspetoria Especial de Fronteiras do Ministério da Guerra, incorporou, pelo Decreto $\mathrm{n}^{\circ} 736$, de 6 de abril de 1936, nova regulamentação, alterando as diretrizes de sua ação. De acordo com esse decreto, as tratativas imediatas de contato e auxílio aos indígenas passavam à nova classificação. $\mathrm{O}$ contato com as populações nativas processaria-se unicamente por meio dos postos indígenas, unidades do SPI instaladas nas áreas indígenas, mantendo uma presença permanente de agentes responsáveis pelo gerenciamento de diversas questões que envolvessem a comunidade. Passam a existir, a partir do novo regulamento, 
duas modalidades de postos: de atração, vigilância e pacificação; e de assistência, nacionalização e educação.

Em áreas onde o SPI se fazia presente, principalmente nos sertões considerados "inexplorados" no Brasil, a descoberta de indígenas tornava-se cada vez maior. As comunidades nativas, que pouco ou nenhum contato haviam estabelecido com a sociedade nacional até então, passavam a ser centrais no corolário de ações do SPI, que desde 1930 adquiriu aspecto militarizado, empreendendo expedições de reconhecimento do território a fim de promover a consolidação da comunicação interna do país, bem como a consolidação das fronteiras do Estado nacional, sobretudo nas regiões de Mata Norte e Centro-Norte do Brasil. Nessas regiões, em linhas gerais, a atuação do SPI se desenvolveu por meio de medidas de pacificação e atração de populações hostis a fim de acostumá-los ao contato e iniciar sua integração à sociedade.

$\mathrm{Na}$ região Sul, as populações indígenas já mantinham contato de longa duração com a sociedade nacional, com destaque no século XIX, quando o contato dos nativos que habitavam as regiões da mata do Brasil meridional passou a estabelecer-se permanentemente. A partir da política de aldeamentos provinciais, muitas das concepções acerca de propriedade, trabalho e produção, bem como os valores morais impostos pela catequização via missões religiosas passaram a fazer parte dessas populações.

Os caingangues e os guaranis contatados pelo SPI em 1910 já viviam de forma sedentária, e boa parte deles estava fixada nos antigos aldeamentos onde recebia assistência do governo estadual. Na concepção do órgão federal, a população indígena sul-rio-grandense encontrava-se em avançado processo de incorporação e assimilação, que num futuro próximo e idealizado levaria ao seu desaparecimento justamente em razão da inserção e da impossibilidade de distinguir-se o indígena do trabalhador nacional. 
Nesse contexto, o SPI atuou na criação de Postos Indígenas de Nacionalização (PIN), concebidos com plano de ação explícito e alinhado às propostas de assimilação das populações indígenas encampadas nas áreas de Nonoai, Cacique Doble, Guarita e Ligeiro. A inserção dos nativos à sociedade nacional processava-se pela incorporação da lógica do sistema produtivo em prol da comunidade. De acordo com o regulamento, os PINs prezavam pelo agrupamento de comunidades indígenas que já se encontrassem sedentarizadas e passíveis de adaptação "à criação e à lavoura". 20 Cabia aos postos auxiliar os índios em todas as atividades que envolvessem a agricultura e a pecuária, sempre incentivando a adoção do método mais intensivo e técnico que os indígenas estivessem aptos a atingir. ${ }^{21}$

A ação do SPI junto aos nativos primava pelo abandono de técnicas rudimentares de cultivo da agricultura de subsistência em razão da racionalização das técnicas agrícolas, a fim de criar um sistema de produção gerador de lucro à comunidade, contariam também com estabelecimentos voltados ao beneficiamento das culturas operadas pelos próprios indígenas.

Figura 4 - Indígenas na instalação da usina-moinho - posto de Ligeiro em 1940 (observação do maquinário)
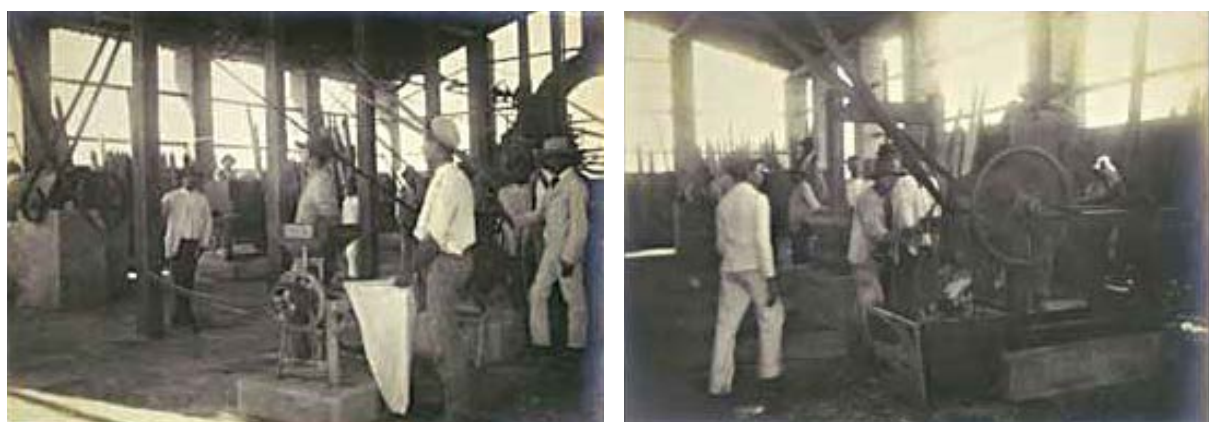

Fonte: Museu do Índio.

A nacionalização proposta pelo SPI ia além dos horizontes do produtivo. Nos postos de nacionalização seriam instaladas escolas, de educação

20 Coleção de Leis do Brasil, 1936. p. 347. v. I, art. 19.

21 Idem. 
primária, destinadas às crianças indígenas, com aulas ministradas por não índios contratados pelo encarregado do posto. Ficava ao encargo do professor enfatizar e aprofundar conteúdos de ensino da história pátria ${ }^{22}$ como meio de inserção de valores cívicos e morais voltados ao projeto de construção da identidade nacional. Dessa forma, a educação indígena se estabelecia pelo culto aos símbolos da nação, às figuras de destaque da história, ao hino e às datas nacionais.

Figura 5 - Crianças indígenas do posto de Nonoai prestando continência em frente ao palanque presidencial em desfile na cidade de Porto Alegre, 1944

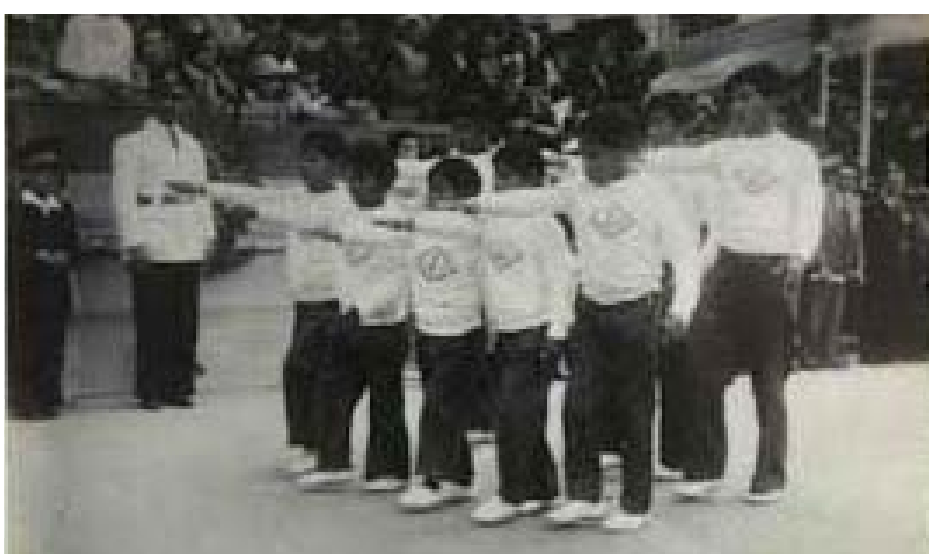

Fonte: Relatório Min. Agr. 1930-1944.

22 Coleção de Leis do Brasil, 1936. p. 347. v. I, art. 19. 
Figura 6 - Guilhermina Zeni, auxiliar educacional, acompanhada de alunos indígenas.

Fonte: Museu do Índio.

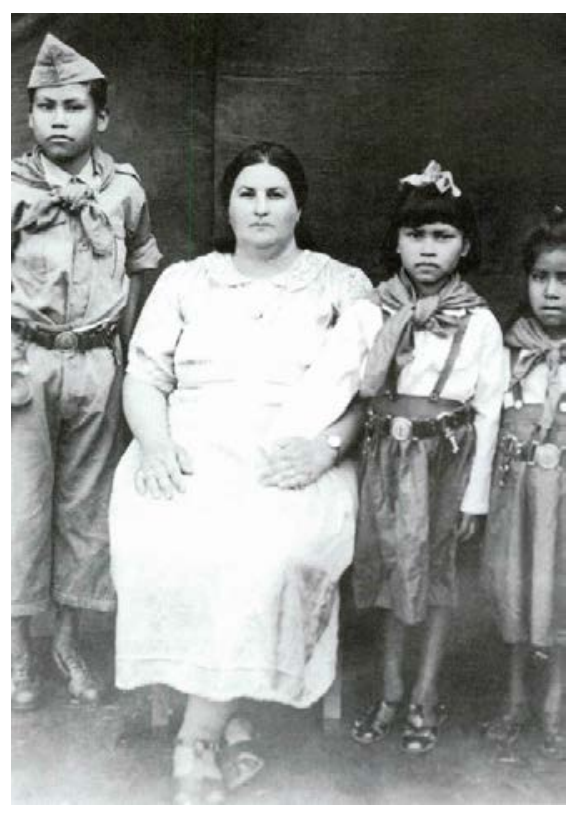

Na Figura 6, os alunos indígenas são alguns dos que se destacaram, em 1944, no posto de Cacique Doble, nos estudos de história, geografia, leitura, contabilidade e hinos patrióticos (SPI. Boletim Interno, 1944). Isso demonstra que a nacionalização do indígena figurava como uma das principais linhas de ação do SPI a partir da regulação de 1936.

Promover a interação e posterior incorporação de técnicas agrícolas e educação formal se apresentavam centrais no projeto de Construção da Identidade Nacional brasileira, que tentava consolidar-se durante o período de duração do Estado Novo. E o SPI foi o encarregado de levar esse projeto às populações indígenas em todo o território nacional. 


\section{A questão indígena e a proteção florestal no norte do RS: desencontros nas ações do SPI e da DTC}

A regulação do SPI em 1936 determinou uma série de alterações de ordem burocrática e operacional. Sua aplicação não se deu de forma homogênea ou imediata em todo o território nacional. No Rio Grande do Sul, a intervenção do SPI sob as novas diretrizes afixadas pelo regulamento passou a efetivar-se apenas no final de 1940. A partir de então as terras indígenas existentes passariam à tutela e administração do SPI, resultando numa série de desencontros entre os interesses das entidades envolvidas.

As terras indígenas foram assumidas pela administração direta do SPI, criando os PINs nas áreas de Nonoai, Guarita, Cacique Doble e Ligeiro, que já recebia assistência. A escolha dessas áreas possivelmente tenha se dado em virtude do número expressivo de habitantes cujas ações e recursos empreendidos teriam melhores condições de serem realizados, como a produção de gêneros e pecuária. Por outro lado, a criação dos postos nessas localidades poderia fazer parte de uma prévia intenção de facilitar a logística no atendimento às comunidades indígenas, cuja responsabilidade direta era do SPI, assim como a supervisão dos toldos assistidos pela DTC. Do mesmo modo, pode-se conjecturar que a distribuição dos postos criados do SPI poderia estar relacionada a intenções de agrupar as comunidades dos toldos à proteção do órgão federal. 
Mapa 2 - Serviço de Proteção aos Índios

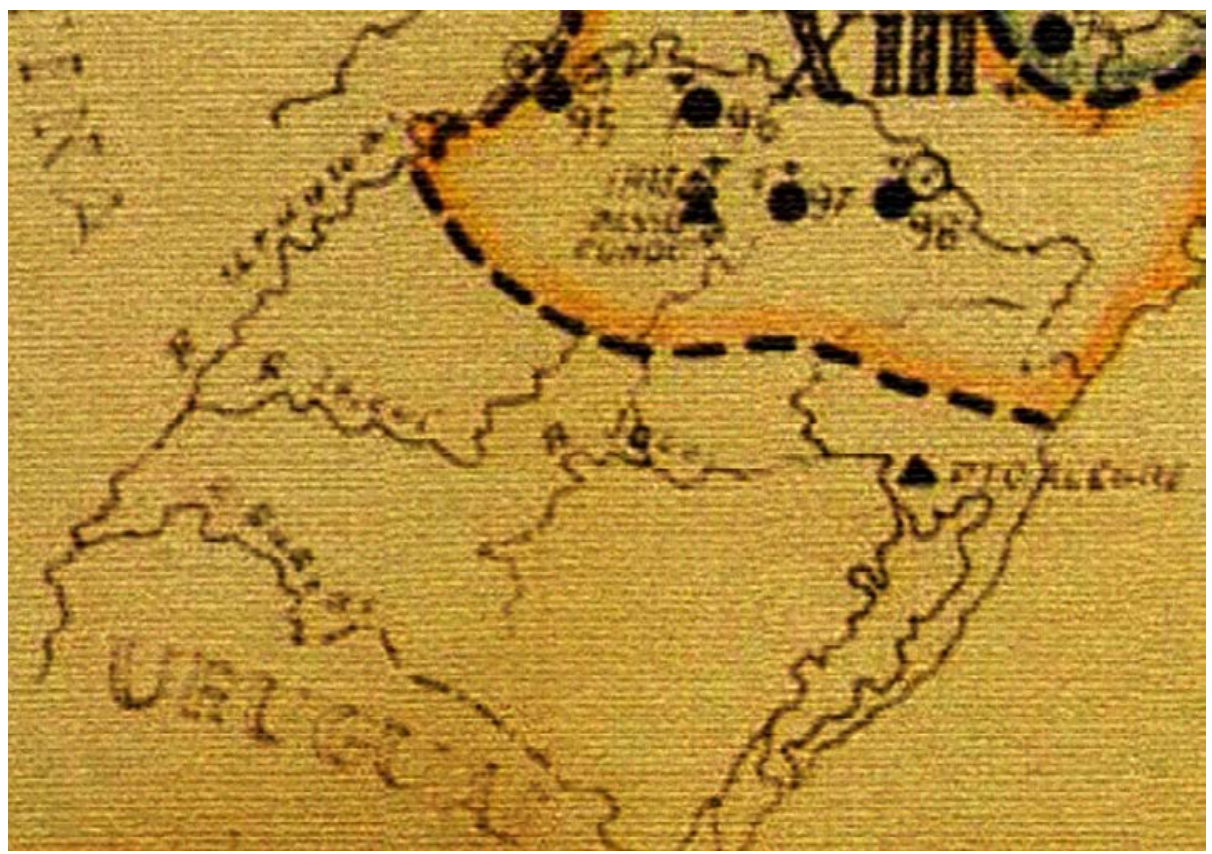

Fonte: Freire, 2011, p. 153.

O Mapa 2 apresenta a localização dos postos indígenas, no início da década de 1960. No recorte estão assinalados os quatro postos existentes no estado do Rio Grande do Sul: 95 - posto de Guarita; 96 - posto de Nonoai; 97 - posto de Ligeiro; 98 - posto de Cacique Doble.

Com a instalação dos PINs, a administração e tutela diretas dos indígenas passaram para os agentes contratados pelo SPI no exercício das funções. Diferentemente de outrora, a presença dos agentes se tornara permanente, prezando por uma contínua e engajada assistência a fim de promover a elevação e incorporação das comunidades aos horizontes produtivo, cívico etc. Desse modo, os indígenas deixaram de estar, pelo menos nos PINs, sob a assistência esporádica a que estavam submetidos enquanto tutelados pela DTC.

O desencontro entre as ações dos órgãos inicia em 1941, ano em que os PINs do SPI começavam a ser instalados no Estado, para, de fato, assumirem 
a administração das áreas indígenas. Nessa permuta administrativa, as terras cedidas ao SPI pelo Estado passaram a ser motivo de disputa com a DTC, principalmente em razão da quantidade de áreas florestadas existentes.

A problemática que envolvia a proteção florestal e a questão indígena teve início no posto indígena de Nonoai. Nos primeiros meses da administração do SPI, muita movimentação pôde ser percebida pelas correspondências e ofícios trocados entre o SPI e a DTC. O maior volume de informações em fluxo referia-se diretamente às primeiras ações do SPI junto aos indígenas, que para o governo estadual eram de extremo interesse.

O encarregado do SPI para a direção do posto foi Francisco José Vieira dos Santos, responsável pela organização inicial da comunidade e da construção de casas e estabelecimentos em benefício dos indígenas. No início da administração, dezembro de 1940, o encarregado, em correspondência ao madeireiro passo-fundense Alberto Berthier de Almeida, assinalava a possibilidade de comercializar a madeira contida na área do posto de Nonoai, dizendo que embora ainda não possuísse conhecimento de quais áreas de mata poderia destinar à exploração, tratava tal ação como breve e acertada com o extrativista. $\mathrm{O}$ encarregado também externava a intenção de auferir elevados lucros nessa prática, ${ }^{23}$ estabelecendo a venda da madeira realizada por meio de "concorrência", isto é, o preço mais alto oferecido por extrativistas interessados prevaleceria. Em adição a essa proposta, o acordo selado entre Francisco Vieira e o madeireiro Maximiliano Zambonatto, na expressiva quantia de $30 \$ 000$, era para construção de casas indígenas e estabelecimentos do posto, tornando-se ainda mais premente o interesse da DTC nas áreas subtraídas de sua administração.

Alertada pela Guarda Florestal de Iraí, ${ }^{24}$ a DTC reportou-se ao diretor da $7^{\text {a }}$ Inspetoria Regional do SPI, Paulino de Almeida, aconselhando a

23 Correspondência 26/12/1940 - enviada pelo encarregado do PIN Nonoai Francisco Vieira a Alberto Berthier de Almeida. Disponível em: Terra indígena de Serrinha: nossa história e luta pelos nossos direitos, s/n.

24 Ofício 16/12/1940 - enviado pela Guarda Florestal de Iraí à DTC. Disponível em: Terra indígena de Serrinha: nossa história e luta pelos nossos direitos, $\mathrm{s} / \mathrm{n}$. 
ordenar que o encarregado do posto de Nonoai se abstivesse do comércio das madeiras existentes na área indígena. ${ }^{25} \mathrm{Em}$ defesa à política de proteção das matas, a DTC passou abertamente a opor-se às intenções extrativistas e comercialização da madeira, uma vez que essas ações incentivariam "inevitáveis abusos", que poderiam resultar em "grande prejuízo ao patrimônio florestal". 26

Segundo Kujawa (2014), a temeridade e a insistência da DTC na destinação das terras nas áreas indígenas do Estado têm a questão florestal como central. A DTC, ao passar a administração da questão indígena ao SPI, já previa que pudesse ser instalado um conjunto de ações de cunho extrativista apoiado e direcionado pelo órgão federal. As intenções do encarregado do posto sinalizavam que os anseios da DTC se mostravam acertados. Por sua vez, confirmando as intenções do SPI, paralelamente às propostas de desenvolvimento autossuficiente das comunidades nativas por meio da agricultura indígena e beneficiamento de cereais de se concentrarem em torno de uma prática que se tornaria muito corrente nas áreas indígenas: o comércio de madeira.

A proteção florestal já se encontrava em desenvolvimento de projetos dos governos do estado. As ações da DTC em relação à questão indígena no norte do estado não podem ser compreendidas de maneira isolada de toda rede de ações que se processavam em simultâneo e partilhavam dos objetivos em comum. Nesse sentido, a assistência e a supervisão durante a primeira metade do século XX estiveram intrinsecamente relacionadas às políticas de colonização da região, em específico, e à conservação das matas, as quais figuravam como eixos centrais desse órgão por longo período.

De acordo com Gerhardt (2013, p. 129), desde as primeiras décadas do século XX, a administração pública estadual já legava importância às florestas consideradas remanescentes, que cumpririam o papel de regular o clima e, principalmente, poderiam servir de reserva de madeira do

25 Telegrama 27/02/1941 - enviado pela DTC à 7a Inspetoria Regional do SPI.

26 Ofício 27/02/1941 - Enviado pela DTC à 7a Inspetoria Regional. 
Estado. A abundância de pinheirais nas áreas indígenas também seria fator de interesse da DTC, tendo em vista a lucratividade advinda de uma possível extração e posterior comercialização das terras.

As ações da DTC estiveram em correspondência com as do SPI principalmente em prol da preservação florestal que havia sido prestada às áreas indígenas até a mudança de administração. A DTC movia-se no sentido de fazer valer determinações a seu favor e a fim da concretização de seus projetos. Sob o manto do protecionismo florestal, um dos maiores projetos da época, as áreas indígenas de Nonoai e Guarita despertavam o interesse da DTC em razão de serem extensas áreas da flora peculiar do Estado. ${ }^{27}$

Com a perda de influência e controle sobre as principais áreas indígenas e a possibilidade de perder as restantes, a DTC passou a engendrar uma proposição de revisão das extensões das áreas indígenas, alegando que seria necessário estabelecer áreas reservadas aos índios que de fato fossem passíveis de serem cultivadas em sua plenitude pelas comunidades nativas. Diante disso, por meio de cálculos, foi proposto demarcar novamente as áreas, levando em conta o número de famílias existentes, ou seja, para cada família seriam destinados 75 hectares; para indígenas solteiros seriam destinados 25 hectares; o restante, segundo a DTC, deveria ser declarado área de floresta remanescente, na qual os indígenas poderiam manter apenas atividades de caça quando permitidos. ${ }^{28}$

A pressão em torno das áreas florestadas dos postos do SPI progressivamente tomou vulto tanto na designação do governo em determinar a criação das reservas florestais quanto na pressão dos extrativistas regionais interessados em usufruir os redutos de mata nativa, sobretudo o pinheiro, abundante na região. Diante da visibilidade da situação, a direção-geral do SPI instruiu Paulino de Almeida que passasse a considerar as áreas florestais de acordo com o que já previa o regulamento

27 Ofício 18/02/1941 - enviado pela diretoria-geral da DTC à Secretaria da Agricultura, Indústria e Comércio do estado do Rio Grande do Sul enviado à $7^{\mathrm{a}}$ Inspetoria Regional.

28 Ibidem. 
de 1936, no art. 24, que indicava que nas áreas dos PINs deveriam ser criadas reservas de matas sem qualquer informação acerca de procedimentos e condições para tal. ${ }^{29}$

Segundo a direção do SPI, as áreas, pela cobiça dos madeireiros, deveriam ser preservadas, sendo necessária a proteção de "todos os pinheirais e outras essências florestais". ${ }^{30}$ Reforçava também que a derrubada de árvores deveria ser realizada e destinada unicamente em prol da construção de uso das comunidades indígenas e para instalação da administração do posto, aproveitando, de preferência, os pinheiros desvitalizados. Nesse sentido, ficava permitida a venda de pinheiros nessas condições quando excedessem à necessidade e não tivessem utilidade imediata ao posto.

Dessa forma, abria-se um primeiro precedente para a exploração irregular das áreas florestais. Às vistas da legalidade, a prática da venda de pinheiros desvitalizados se tornaria corrente em esquemas de corrupção interna de funcionários do SPI na área de atuação da $7^{\text {a }}$ Inspetoria Regional, levados ao conhecimento público apenas após a formação da CPI do índio de 1967. De fato, mormente aos esforços da DTC nas áreas indígenas da administração do SPI, a extração da madeira continuaria como prática destinada a casas e estabelecimentos do posto a partir da instalação de serrarias no interior das áreas para a extração e beneficiamento da madeira.

29 Coleção de Leis do Brasil - 1936, p. 347, v. I, art. 24.

30 Instruções 07/07/1941 - enviada pela direção-geral do SPI à 7a Inspetoria Regional Disponível em: Terra indígena de Serrinha: nossa história e luta pelos nossos direitos, s/n. 
Figuras 7 e 8 - Serraria do posto indígena de Ligeiro, em 1944
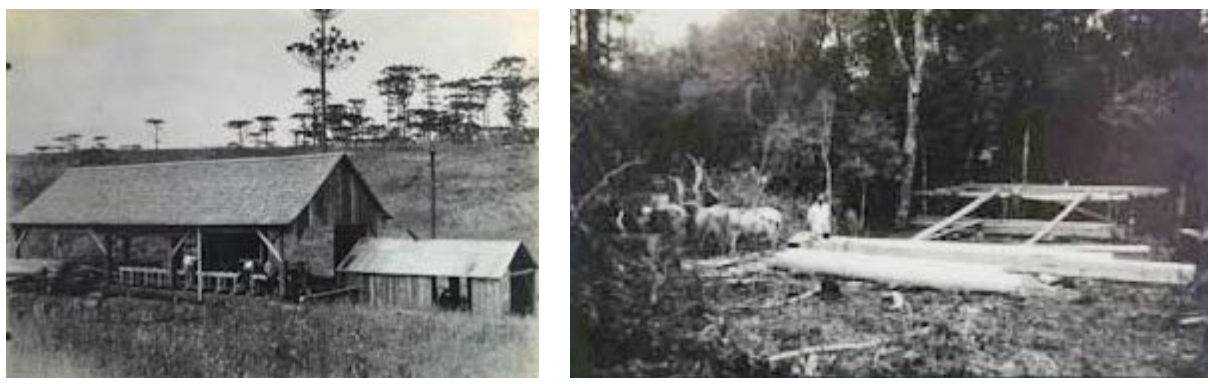

Fonte: Acervo MI / Área de extração de madeira no Posto Indígena de Nonoai, em 1942.

Das áreas anteriormente relacionadas para reservas florestais em Nonoai, Guarita e Serrinha, a subtração fundiária, na década de 1940, se processou apenas em Nonoai e Serrinha, tendo havido a homologação dessas áreas de proteção apenas em 1949. ${ }^{31}$ Com base nos cálculos supracitados, a DTC promoveu as seguintes demarcações: área de Nonoai, de 39.908 ha passou a 14.910; Serrinha, de 11.950 ha passou a 6.623 ha.

Em Nonoai a área destinada para a reserva florestal, logo a adentrar novamente à administração estadual, passou a ser severamente ocupada por colonos sem-terra. A reserva, por ser área de proteção ambiental e não ser mais de posse da comunidade indígena, entrou na classificação de terra devoluta, desocupada, pertencente ao Estado. A ocupação figurava como alternativa ao esgotamento da fronteira agrícola, situação que se acentuava e disseminava a tensão social em torno da questão fundiária, tornando-se válvula de escape para os colonos sem-terra, mesmo que passando para a ilegalidade sob o status de intrusos.

Posteriormente, o governo estadual, ciente das tensões que se propagavam no campo, encontrou nos apelos e nas ações dos intrusos nas reservas florestais a solução em curto prazo para amenizar o problema da indisponibilidade de terras. A maior parte da área da reserva florestal de Nonoai foi destinada ao loteamento para a colonização dos intrusos. O

31 Decreto nº 658 10/03/1949 do governador Walter de Sá Jobim. 


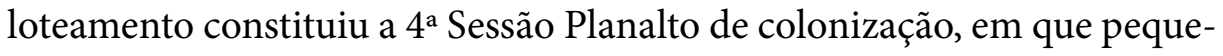
nas extensões de terra foram vendidas aos colonos.

O governo estadual, ao legalizar a situação dos intrusos, acirrou ainda mais os ânimos em torno da questão dessas áreas. Mesmo que sanasse brevemente o problema da aquisição de terras, a ação do Estado refletiria no despontar de muitos conflitos que passariam a surgir entre os colonos assentados nos limites da área indígena e os indígenas, descontentes com a ação e o descaso do governo e do SPI quanto à destinação dada às terras que outrora pertenciam à comunidade.

Desse modo, a situação das áreas indígenas na década de 1940 atingiu um patamar de intensa instabilidade. As ações do governo estadual e do SPI externaram suas contradições e alinhamentos, revelando os múltiplos interesses que se concentravam no entorno das terras pertencentes às comunidades indígenas, atrativas para o desenvolvimento tanto da extração da madeira como da colonização, ambas produzindo efeitos e alijando os indígenas que, contraditoriamente, eram os que deveriam ser os principais assistidos pela legislação indígena estadual e federal.

As reservas florestais criadas em Nonoai e Serrinha seriam as primeiras de um ciclo de reduções e posterior extinção que se processariam em 1950 e 1960 na tentativa de sanar os conflitos sociais que progressivamente avolumavam na região, colocando as populações indígenas em constante atrito na luta pela conservação de seu espaço.

\section{Intrusão e reforma agrária das/nas áreas indígenas (décadas de 1940-1960)}

Entre 1940 e meados de 1960, os problemas ligados à questão indígena continuaram, entre os quais as intrusões de agricultores no interior das reservas, a redução das áreas indígenas e a extinção de reservas. $\mathrm{Na}$ 
realidade, havia a intenção de realizar a reforma agrária nas terras indígenas, bem como integrar o índio na sociedade pelo viés produtivo e cultural.

Esse período foi muito fértil em razão de que se aglutinou um conjunto de processos históricos desenvolvidos no estado a partir de políticas públicas. Dentre esses elementos estão a colonização privada e/ou pública, a migração de agricultores e a apropriação privada da terra, os modelos de desenvolvimento e produção agrícola, as políticas nacionais de reforma agrária, principalmente no início da década de 1960, bem como a extinção de algumas reservas indígenas.

Nesse cenário conflituoso estão as ações dos governadores Meneghetti (1955-1959 e 1963-1966) e Brizola (1959-1963), principalmente em razão da intensa intrusão de agricultores no interior das reservas indígenas. Em razão de vários conflitos daí decorrentes, instalou-se na Assembleia Legislativa uma comissão parlamentar de inquérito (CPI) em 1967 para averiguar essas questões.

Como já mencionamos, esse período se caracterizou também pela extinção de reservas indígenas. No norte do Estado foram extintas Monte Caseiros, Ventarra e Serrinha. Nesse processo, os indígenas foram expulsos e foi permitida a entrada de agricultores via aquisição privada da terra.

A questão agrária no Rio Grande do Sul sempre esteve vinculada à questão indígena, com demarcações e expropriações de terras. A primeira, mais famosa, foi no início do século XX, quando ocorreu a demarcação de Nonoai e Ventarra, entre outras (Quadro 2). No tocante às expropriações, ocorreram basicamente na metade do século XX, no período de 1949-1963, com os governadores Walter Jobim, Ildo Meneghetti e Leonel de Moura Brizola. ${ }^{32}$

32 Itagiba de Moura Brizola, conhecido por Leonel Brizola, foi uma figura marcante na história do Rio Grande do Sul e do Brasil. Brizola é gaúcho de Carazinho; cedo ingressou na vida política lançado por seu $\square$ padrinho $\square$ Getúlio Vargas, sendo prefeito de Porto Alegre, deputado estadual e federal pelo Rio Grande do Sul e governador do referido, aliás, Brizola é o único político brasileiro a ser governador por dois estados diferentes: Rio Grande do Sul e Rio de Janeiro. Adotou o nome de "Leonel” porque se identificava com um líder maragato, cujo nome Leonel Rocha, na Revolução de 1923, ocorrida no Rio Grande do Sul. Acabou falecendo em 2004, aos 82 anos, vítima de parada cardíaca. 
Brizola governou o Rio Grande do Sul de 1959 a 1963 e tinha como meta a reforma agrária. Segundo Simonian (2009, p. 481), "Brizola camuflava a expropriação de toldos indígenas antes identificados e demarcados pelo estado do Rio Grande do Sul [usando] a denominação 'terras do estado"'. Nesse período Brizola criou o Instituto Gaúcho de Reforma Agrária (Igra), órgão direcionado aos Projetos de Reforma Agrária e Desenvolvimento Econômico-social (Prade), que deu apoio a um movimento social que estava tomando forma, o Movimento dos Agricultores Sem Terra (Master), semelhante ao atual Movimento dos Trabalhadores Sem Terra (MST). Na realidade, o ex-governador Brizola intensificou e legitimou a intrusão nas terras indígenas, que já vinha ocorrendo, pelo menos, desde 1949, quando o governador do estado era Walter Jobim. ${ }^{33}$ Ildo Meneghetti também entrou nesse processo. A argumentação central do ex-governador Brizola foi de que havia muita terra para pouco indígena, principalmente em Nonoai. Para Tedesco e Carini, “[...] o período que vai de 1940 até o final de 1960 deve ser considerado o mais crítico para a comunidade caingangue e guarani do norte/nordeste do Rio Grande do Sul” (2007, p. 114). Nesse período ocorreu uma nova colonização, que revela a escassez das terras devolutas do Estado na região do Alto Uruguai.

A região Centro-Norte rio-grandense, ou em todo Médio e Alto Uruguai, em suas dimensões históricas e sociais, sempre colocou frente a frente colonos, caboclos pobres, negros (descendentes de escravos) e indígenas, também tendo resquícios de uma oligarquia, a dos latifundiários, ${ }^{34}$ em menor número.

Apenas três áreas demarcadas no início do século XX não sofreram alterações: Ligeiro, Carreteiro e Guarita. As alterações eram redução das áreas indígenas em prol de uma política estadual de criação de florestas nacionais e assentamento de sem-terra. As demais tornaram-se um caso emblemático de constante redução. Conforme Carini (2005), a área de

33 Jobim desapropriou 19.998 hectares para área indígena Nonoai, para a criação de um Parque de Floresta Nacional.

34 Conflitos na antiga Fazenda Sarandi; posteriormente na Fazenda Annoni, Macali, Coqueiros, Brilhante, entre outras. 
Cacique Doble teve 22\% de área reduzida; Inhacorá, $82 \%$; Votouro Kaingang, 33\%; Votouro Guarani, 62\%, e Nonoai, 57\%. Como já observado, as áreas de Monte Caseiros, Serrinha e Ventarra foram extintas. Esse processo de redução aconteceu entre 1940 e 1960.

Nas décadas de 1950 e 1960, além de não haver mais terras disponíveis para a colonização, o ramo das madeireiras estava perdendo espaço. Essas questões levaram a que as intrusões nas áreas indígenas e nas reservas florestais se tornassem cada vez mais abundantes. As madeireiras, que não migraram para os estados de Santa Catarina e Paraná, permaneceram em solo rio-grandense, mantendo, assim, o seu empreendimento, gerando mão de obra com os mesmos colonos sem-terra e tendo a sua matéria-prima retirada em maior escala das áreas indígenas e das reservas florestais.

A intrusão de colonos em busca de terra aconteceu primordialmente em razão da modernização, uma vez que todo esse aparato industrial e populacional no campo era bem-visto e recomendado pelos governos que ficaram à frente do estado do Rio Grande do Sul, principalmente nas décadas 1950 e 1960. A economia da madeira e a presença da triticultura no horizonte dos colonos, através dos processos de modernização do campo, levaram a que as áreas indígenas ficassem à mercê de colonos em busca da terra.

Em muitos momentos, o estado, pelas atribuições de seus governantes, incentivou a prática da entrada massiva de colonos sem-terra em áreas indígenas, como as áreas de Serrinha (11.950 ha) e Ventarra (753 ha), que foram extintas no começo de 1960 como áreas indígenas, e outras sofreram retaliações, como Votouro (caingangue e guarani), Inhacorá, Cacique Doble, com porcentagem de suas terras destinadas à reforma agrária e à criação de florestas protetoras no interior dessas áreas. A área indígena de Nonoai tornou-se emblemática, pois foi demarcada em 1911 com 34.908 ha e no final da década de 1940 teve quase $50 \%$ de área reduzida em prol da criação de uma reserva florestal. Consequentemente, com o tempo, viria 
a ser destinada para amenizar o esgotamento das fronteiras agrícolas, ou para o assentamento de colonos sem-terra.

O restante das áreas indígenas pouco a pouco foi intrusado ao longo dessa primeira metade do século XX de maneira ilegal. A partir de 1940, os posseiros tornaram-se legítimos da posse perante o governo do Estado. Nesse período ocorreu um "[...] grande desenvolvimento e expansão do capitalismo, gerando muitos conflitos agrários entre grandes proprietários e pequenos posseiros, que foram obrigados a abandonar suas posses, ocupando outras áreas, geralmente indígenas" (NASCIMENTO, 2014, p. 96).

Segundo Carini, a modernização da agricultura através da produção do trigo (triticultura) agravou os conflitos:

ainda mais a disputa por terras para lavouras no Planalto Médio e médio Alto Uruguai. Esse evento, somado ao esgotamento da fronteira agrícola, à extração madeireira e ao crescimento populacional, resultante das migrações internas de colonos oriundos das terras velhas e de caboclos expropriados de suas posses ou dispensados de suas lides nas estâncias de pecuária, promoveu uma verdadeira 'corrida para dentro das reservas'. No caso da reserva de Serrinha, mesmo em áreas impróprias para o trabalho em máquinas, os colonos intrusos cultivavam o trigo como principal produto comercial, cujo plantio exigia que, a cada ano, mais mata fosse derrubada (CARINI, 2005, p. 149-150, grifo nosso).

No governo de Brizola foram realizados estudos e levantamentos agrários em latifúndios considerados improdutivos, ${ }^{35}$ os quais poderiam servir como espaços para o assentamento de colonos sem-terra. Nesse sentido, Brizola desapropriou parte da antiga fazenda Sarandi, extinguiu

35 Os latifúndios considerados improdutivos, constatados em um estudo realizado pelo governo do estado, foram: Fazenda Sarandi (24.239,00 ha); Banhado do Colégio (19.106,70 ha); Fazenda Pangaré (1.000,00 ha); Fazenda Itapuã (3.000,00 ha); Fazenda Ibirapuitã (1.300,00 ha); Fazenda Maragata (1.000,00 ha); Fazenda Capané (13.080,20 ha); Fazenda Florida (8.400,00 ha); Terras de José Medeiros (1.020,00 ha); Fazenda Mata Fome 2.450,00 ha); Rincão dos Vieiras (12.800,00 ha); Fazenda Quitéria (1.200,00 ha); Fazenda da Armada (1.650,00 ha). Nem todos esses latifúndios foram desapropriados. Destacamos a desapropriação da Fazenda Pangaré, que pertencia à esposa de Leonel Brizola e a Fazenda Sarandi que se localizava na região Norte do estado do Rio Grande do Sul. Informações disponíveis em: RIO GRANDE DO SUL, Relatório anual 1962, governador Leonel de Moura Brizola. Memorial da Assembleia Legislativa do Estado do Rio Grande do Sul, Porto Alegre. 
as áreas indígenas de Serrinha e Ventarra, entre outras ações, buscando o desenvolvimento da reforma agrária.

No final de 1950 e início de 1960, diminuiu o ritmo migratório de rio-grandenses para os estados de Santa Catarina e Paraná, porém esse processo ocorreu em maior escala durante a década de 1940 até meados de 1950. A coroação dessa prática aconteceu pelo fato de Brizola intensificar o processo que estava em curso desde 1941, durante o governo do interventor federal Osvaldo Cordeiro de Farias.

Essa migração em busca de novas terras foi proporcionada pelo esgotamento da produção econômico-social da territorialidade, pois não haveria como comportar toda demanda por uma propriedade; logo, os colonos migraram em busca de um lugar para fixar moradia. A redução das territorialidades indígenas também veio ao encontro da alta demanda por novas terras de sujeitos literalmente sem-terra (ou sem propriedade, sem moradia).

O ritmo migratório diminuiu, mas não chegou ao esperado que o governo rio-grandense necessitava. O processo de redução que começou em 1940 assolava os cofres públicos do governo estadual ainda no início da década de 1960, conforme mostra a reportagem do jornal O Nacional:

A evasão de colonos está ameaçando a estrutura agrícola do Rio Grande do Sul. Isto foi oque a reportagem deduziu de declarações que nos foram fornecidas pelo dr. Lauro Guimarães, integrante do Ministério Público e presidente do Rotary Club de Ijuí. Segundo essa fonte dezenas de caminhões com colonos deixam as barcas existentes no rio Uruguai, especialmente em Iraí, Goyoen, Monday, Tenente Portela e outros pontos existentes na divisa com Santa Catarina. Isso representa a evasão de braços preciosos às lides agro-pecuárias do Rio Grande do Sul que esses elementos a outros Estados, especialmente Santa Catarina, Paraná e sul de Mato Grosso. Os retirantes, segundo nosso informante, levam até animais para seus novos pontos de morada, oque vem, ainda, agravar mais a situação porquanto privam o Estado também desses irracionais indispensáveis. O problema já está preocupando, sendo de esperar-se 
que, em virtude do seu significado, relevante, o Estado procure dar condições satisfatórias aos colonos que é um dos esteios de nossa economia, a bem de que êle não procure outras plagas, onde a sorte lhe seja mais favoráveis (O Nacional, Passo Fundo, 01/08/1960, p. 4).

A realidade econômica era um dos pilares para ocorrer o assentamento de colonos em latifúndios desapropriados ou em áreas indígenas. A matéria do jornal O Nacional faz menção ao fato de não ter terras para os colonos a serem assentados. A quantidade considerada como de última fronteira agrícola a ser transposta levou a que um determinado grupo quisesse apoderar-se de uma gleba, pois, simbolicamente, ganharia status de valor financeiro e também valor afetivo tanto para os sem-terra quanto para os indígenas.

Com a desapropriação de parte da antiga fazenda Sarandi ${ }^{36}$, em 1961, o governo do Estado, junto ao Master, ${ }^{37}$ conseguiu assentar algumas centenas de famílias num espaço de 23 mil hectares. Entretanto, faltava território para assentar colonos que demandavam terras, fato que contribuiu para mais um passo em direção à área indígena de Nonoai em caráter de intrusão, ou seja, esses colonos legitimados pelo governo e com apoio incondicional do Master eram intrusos nessa área. "Em 1967, um grupo de jesuítas realizou um levantamento socioeconômico e cultural em três toldos do Rio Grande do Sul e constatou que no Toldo de Nonoai encontravam-se mais de 500 famílias de intrusos" (CARINI; TEDESCO, 2012, p. 38).

36 A antiga Fazenda Sarandi foi um grande latifúndio na região Noroeste do estado do Rio Grande do Sul. Esse latifúndio chegou a abranger uma área de, aproximadamente, 72.000 hectares de terra. Após aquisição dos uruguaios Mailhos e Macali em 1906, e com a destinação de glebas de terras para a colonização, esse latifúndio teve a abrangência de, aproximadamente, 25.000 hectares, sendo que a partir de 1962, essa fazenda “[...] transformou-se numa área de tensão e de conflitos sociais; nela surgiu, naquele ano, um dos primeiros acampamentos organizados pelo Movimento dos Agricultores Sem-Terra- Master - no estado" (MARCON, 1997, p. 38). 
As intrusões nas áreas indígenas foram o estopim para o desencadeamento de conflitos na região. Os movimentos sociais organizaram-se, principalmente na década de 1970, e os conflitos fundiários envolvendo pequenos proprietários, latifundiários e colonos sem-terra aconteceram por quase toda a década de 1980 .

\section{O conflito de Nonoai e a reconfiguração das terras}

A origem do conflito em Nonoai entre indígenas e agricultores intrusos ocorreu a partir de alguns grupos mediadores que aderiram à luta indígena. A Igreja Católica foi um deles, em razão de sua dimensão de ação social, sensibilizada com o que vinha ocorrendo no interior das reservas, principalmente suicídios, doenças e prostituição.

O conflito em Nonoai ocorreu em 1978; entretanto, em 1967, uma Comissão Parlamentar de Inquérito (CPI) ${ }^{38}$ foi constituída para tentar apurar as questões de expropriação de terras indígenas. A CPI tentou encontrar explicações diante do esbulho das terras indígenas, o roubo de madeiras e o iminente conflito entre indígenas e colonos sem-terra. A CPI tinha como objetivo terminar com o conflito existente: “[...] nada menos que 600 famílias de agricultores naquela área [Nonoai], para um número quase igual de famílias de silvícolas [...]. O problema social não é só do índio, como também dos chamados 'sem terra'” (RIO GRANDE DO SUL, CPI, 1968, p. 2) $)^{39}$.

A presença [...] naquele Toldo de mais de meio milhar de agricultores "sem terra", assim como a vigilância que é feita através da Brigada

38 Os cinco deputados que compuseram essa CPI foram: da bancada da Aliança Renovadora Nacional (Arena), deputados Fernando Gonçalves (presidente) e Elízio Telli; e da bancada do Movimento Democrático Brasileiro (MDB), os deputados Ivo Sprandel (vice-presidente), Darcílo Giacomazzi e Celso Testa. Também constituiu um sexto membro, o deputado Plínio Dutra (relator). Fernando Gonçalves também foi presidente do Igra, conforme atestam os jornais da época. A CPI tornou-se pública em 1968.

39 Ofício do deputado Fernando Gonçalves ao presidente da Assembleia Legislativa do Estado, Porto Alegre, 27 de abril de 1967. 
Militar, além é claro, de estar essa área em território rio-grandense, são razões para que a Assembléia Legislativa do Estado tome conhecimento dêsse grave e crônico problema, como também, adote providências para colaborar na sua solução (RIO GRANDE DO SUL, CPI, 1968, p. 2-3).

A CPI tentou deixar clara a situação do Estado, da região e dos sujeitos ao analisar dados históricos para dar o veredito final. Entendeu que "a intervenção da Assembleia Legislativa do Estado é, pois, um imperativo de justiça social, quando vivem em verdadeira 'guerra', sofrendo toda sorte de humilhações e indo até o desforço pessoal, centenas de famílias de indígenas e de agricultores 'sem terra'” (RIO GRANDE DO SUL, CPI, 1968, p. 4).

A CPI de 1968 foi um dos pontos fundamentais de luta da retomada das terras pelos indígenas em Nonoai, uma vez que contemplava e mostrava que a área estava intrusada por colonos sem título de propriedade e, portanto, na condição de intrusos e posseiros. Foi um marco na onda do esbulho das áreas indígenas. Por mais que a CPI não tenha concluído satisfatoriamente em favor dos indígenas, foi a primeira ação governamental em tentar frear as tentativas de redução das áreas pertencentes aos indígenas.

A intrusão e o roubo de madeiras em Nonoai e na reserva florestal foram os principais motivos para que se instalasse a CPI. Entretanto, a questão dos posseiros era o que mais chamava a atenção pelo fato de estarem habitando esses territórios há muitos anos. Com relação à área indígena, os posseiros ganhavam legitimidade da terra no momento em que eles eram aceitos para o trabalho de arrendamento. Essa forma de trabalhar a terra propiciou os "arranchamentos" de colonos considerados sem-terra.

A CPI tinha reconhecido a legitimidade da terra aos indígenas, mas também o reconhecimento de que o Estado havia expropriado de forma ilegítima. Embora a Comissão chegasse a um resultado em beneficio dos indígenas, não se sabia se realmente o Estado havia concordado com tal definição. "O Estado tinha um grupo dirigente e dominante contrário a 
esta política e com interesses bem claros, por mais que se apresentasse neutro e juiz das questões sociais" (NASCIMENTO, 2014, p. 133).

Outro dado relevante é sobre o "Estatuto do índio", promulgado em 1973, que assegura a posse das terras aos nativos. A Funai foi pressionada a aderir de uma vez a luta indígena. $O$ mentor desses atos em defesa das territorialidades e das comunidades indígenas foi o Conselho Indigenista Missionário (Cimi).

Os conflitos começaram a se explicitar no interior das reservas indígenas em especial a de Nonoai; colonos e madeireiros já haviam destruído grande parte da reserva florestal no interior da referida reserva. A cultura da soja, desenvolvida e incentivada pela esfera pública estatal, estava desconfigurando a paisagem. A corrupção de funcionários da Funai, os desvios de dinheiro, o não pagamento de arrendamento aos índios, o uso irracional do solo, dos rios e da vegetação em geral, além do total descontrole da esfera pública em torno das intrusões, principalmente nos anos 1974, davam do conflito que se avizinhava (CARINI; TEDESCO, 2012, p. 44-45).

É interessante relembrar que na década de 1960 muitos deputados discursavam e defendiam firmemente a desapropriação das terras e das reservas florestais em prol de uma distribuição para colonos sem-terra, alegando que essas territorialidades eram de cunho estadual, podendo reduzir, lotear e vender.

Em 1976 e 1977, os indígenas passaram por um momento de preparação, pois havia conflitos internos na reserva. Em 1977 ocorreu a troca de cacique, fundamental para desencadear o conflito, pois o novo cacique era da ala da reserva indígena mais radical, contra os posseiros e arrendatários. Os indígenas, ao praticarem o ato de ataque aos intrusos, não estavam sozinhos; havia grupos que os apoiavam, ou seja, outras comunidades indígenas da região, antropólogos, sociólogos, indigenistas, diferentes entidades (nacionais e internacionais) e demais movimentos populares. "A 'revolta' efetivamente acontece em maio de 1978, através da intimidação, 
advertência, incêndios às escolas, ataques a casas e, finalmente, expulsão [...]" (CARINI; TEDESCO, 2012, p. 46).

Figura 9 - Restos do incêndio das escolas na área de Nonoai e indígenas do aldeamento preparado para expulsar os colonos do interior de seu território

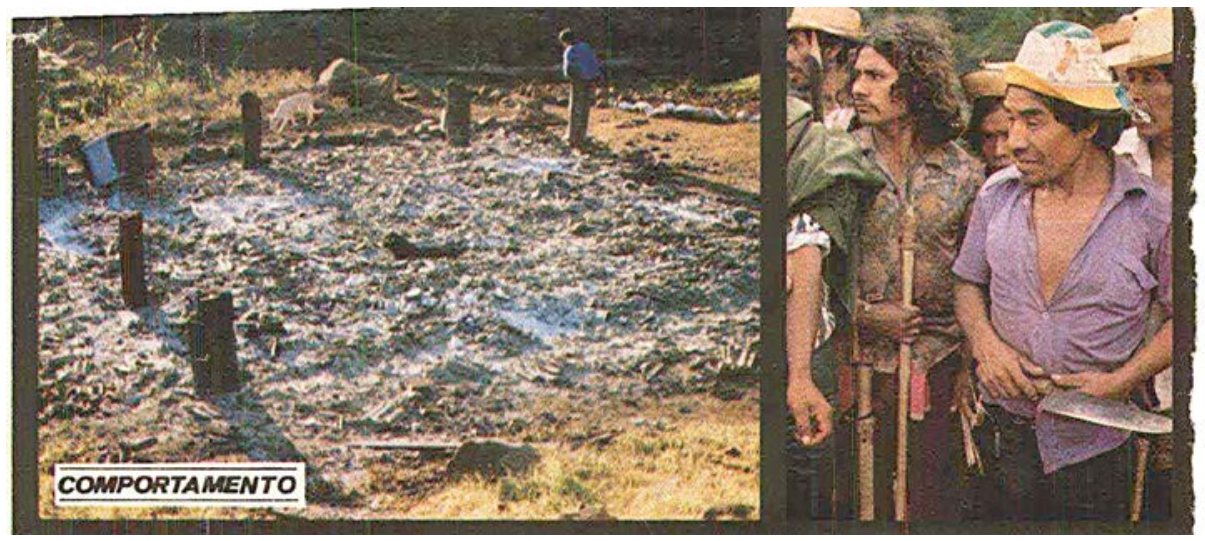

Fonte: Revista Veja, 10 de maio de 1978, p. 62 (Foto de Ricardo Chaves).

$\mathrm{O}$ ato de queimar as escolas constituídas dentro da área indígena tornou-se simbólico, pois essa ação caracterizou veementemente toda a legitimidade que o governo estadual deu aos posseiros desde o final de 1940 e que, no final de 1960, passou a ser novamente discutida.

As famílias de colonos desalojadas da área indígena dirigiram-se para três locais provisórios: uma parcela acampou no Parque de Exposições de Esteio, chamando a atenção de toda região Metropolitana de Porto Alegre; outra parte dirigiu-se para casas de parentes ou conhecidos em Sarandi e Ronda Alta; outra acampou nos arredores das áreas indígenas ou na beira das estradas. Esses três destinos mostram que os colonos sem-terra não tinham para onde ir. 
Figura 10 - Família expulsa se organizando para ir embora da área

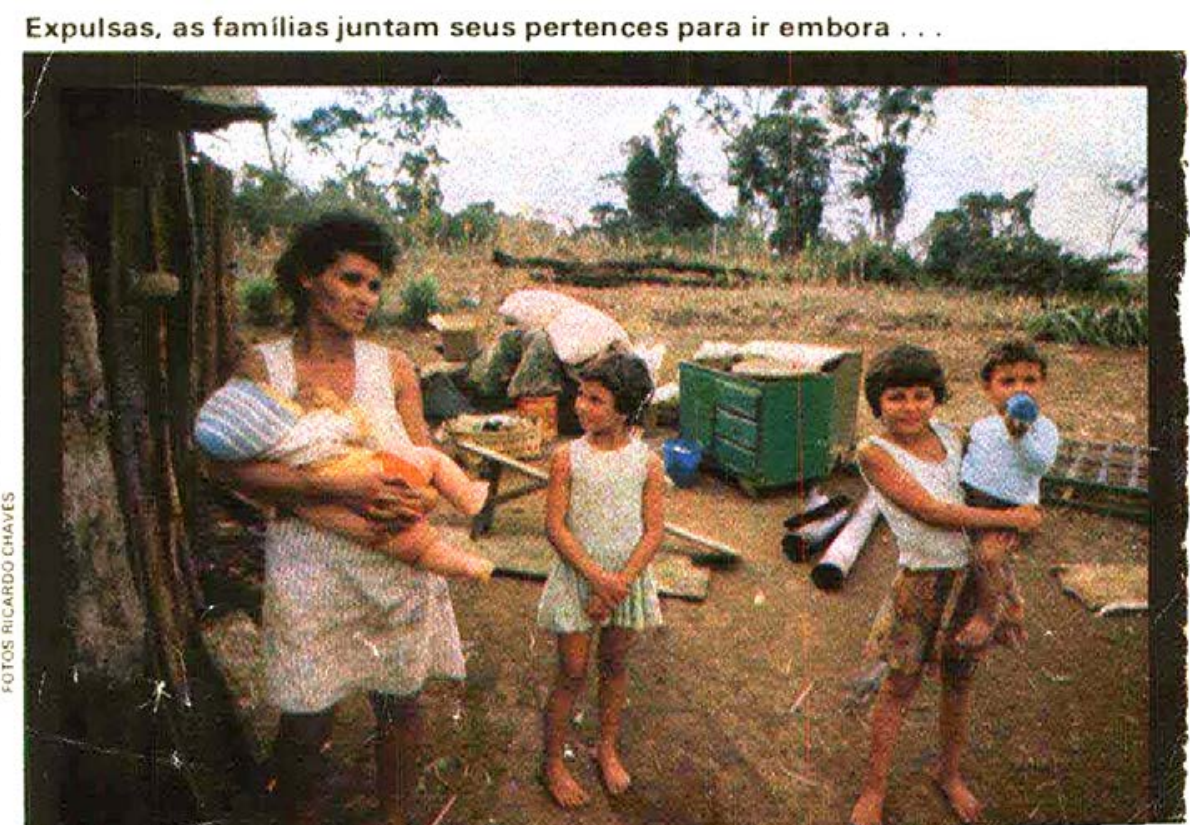

Fonte: Revista Veja, 10 de maio de 1978, p. 62. (Foto: Ricardo Chaves).

Em 1979, os colonos sem-terra iniciaram um processo de ocupação de fazendas. A primeira foi a de Macali, no mês de setembro, oriunda da antiga fazenda Sarandi. O governo estadual respondeu com aparato policial, porém logo depois recuou e preferiu resolver o impasse na base da negociação. O sucesso da ocupação (ou seja, o governo não havia retirado os colonos dessa fazenda) afetou a ocupação da fazenda Brilhante no final de setembro. Essa ação no latifúndio provocou forte reação do governo em relação aos ocupantes, tendo inúmeros confrontos com a Brigada Militar nos meses subsequentes.

A partir do conflito instaurado na área indígena de Nonoai, várias frentes de disputa por propriedades se acirraram na região. Por isso é um marco na história das lutas pela terra, porque, "além de sua tentativa de assentamentos discutiu-se a legitimidade das negociações fundiárias, reabriram-se as discussões em torno das políticas de colonização que, no 
fundo, foram marcas registradas de governos militares de até então, assim como de governo do estado" (CARINI; TEDESCO, 2012, p. 53).

O conflito de Nonoai pode ser um marco na história da região Norte em relação aos conflitos pela terra. A partir dele, é desencadeada uma série de ocupações de latifúndios considerados improdutivos na região, como fazenda Macali, fazenda Brilhante, Encruzilhada Natalino, fazenda Annoni e fazenda Coqueiros.

\section{A retomada do território indígena e os novos conflitos}

Após o conflito de Nonoai, em 1980, cresceu consideravelmente o apoio de organizações não governamentais em favor dos direitos indígenas, inclusive da própria Funai, até então apenas intelectuais das universidades e a própria Igreja (através do Cimi) demonstravam certa afeição aos indígenas desassistidos. Durante essa década, a União das Nações Indígenas (UNI) teve um papel fundamental na luta pelos direitos dos povos nativos. Os indígenas que no passado estavam em conflito uniam-se, nesse momento, pela mesma causa.

A luta pelos direitos indígenas das décadas de 1970 e 1980, através do Cimi, de intelectuais ligados à academia e ONGs, fez com que a causa indígena ganhasse força na Assembleia Constituinte do Brasil e na própria Constituição de 1988. A mudança da forma como a sociedade passou a ver os índios, a capacidade dos indígenas de fazer-se enxergar, estruturar propostas e defender seus direitos proporcionou um significativo avanço na positivação de seus direitos que estão expressos, principalmente nos artigos 231 e 232 da Constituição Federal [de 1988]. A garantia constitucional à terra que tradicionalmente ocupam deu uma grande força para $o$ movimento indígena no Rio Grande do Sul, que vinha lutando para garantir a efetiva posse das terras demarcadas, demarcar outras e recuperar os limites que tinham sido reduzidos em meados do século XX (KUJAWA, 2014). 
No pós-Constituição Federal de 1988 (CF/88), algumas áreas reduzidas e extintas conseguiram retomar a sua territorialidade, envolvendo novamente focos de conflitos. Também as 11 áreas demarcadas, das quais oito sofreram reduções, como já mencionamos, estiveram mais uma vez em litígio após a $\mathrm{CF} / 88$, fazendo com que fossem novamente estudadas para a demarcação, através da pressão do movimento indígena, da Funai e do Ministério Público.

Como o debate se alongava para o horizonte das terras de ocupação tradicional em caráter imemorial, não fez sentido a União indenizar a terra e, sim, somente as benfeitorias. No caso do Rio Grande do Sul, em que o governo concedeu e vendeu títulos de propriedade de terra nos atos de reforma agrária, levou a que as escrituras perdessem a validade e, portanto, não haveria indenização. Entretanto, para minimizar o conflito agrário e social, a Constituição estadual do Rio Grande do Sul de 1989, no art. 32, "Das ações de disposições transitórias", praticamente obrigou o Estado a indenizar os agricultores assentados irregularmente nas áreas indígenas.

Com a nova demarcação das áreas territorializadas no início do século XX, salvo Carreteiro, Guarita e Ligeiro, além da compensação de uma dívida histórica de esbulho frente aos nativos, o Estado teve de assumir o ônus financeiro em razão das indenizações dos títulos de compra dos lotes de terra, e o governo reconheceu o equívoco histórico praticado nas décadas de 1950 e 1960.

O episódio da remarcação das áreas indígenas foi mais um capítulo de anos de conflitos agrários e sociais envolvendo os mesmos sujeitos: indígenas, colonos, latifundiários e Estado.

União [realizou] a remarcação das Terras Indígenas em 1991 e inicia, através da Funai, o ajuizamento, junto ao Supremo Tribunal Federal, de ações de inconstitucionalidade, buscando anular todos os atos que, entre as décadas de 1940-60, efetivaram a redução das terras indígenas demarcadas. O Estado, por sua vez, constitui pelo Decreto 37.118 de 30/12/1996, um Grupo de Trabalho para fazer 
levantamento das terras indígenas que tinham sido colonizadas irregularmente e apontar a situação específica de cada uma e possíveis soluções (KUJAWA, 2014, p. 46).

Foi um processo desencadeado desde meados do século XIX com os primeiros aldeamentos indígenas, seguindo com a colonização e a demarcação das 11 áreas indígenas no norte do Rio Grande do Sul. A modernização do campo, a escassez da terra, a criação do Master, a reforma agrária e a redução e extinção de áreas indígenas também contribuíram para essa retomada das antigas áreas. O marco simbólico, no entanto, foi o conflito de Nonoai em 1978. O direito indígena sobre a terra somente foi atingido e ouvido com a nova luta pelos seus direitos durante a década de 1980, que teve uma vitória com o art. $231^{40}$ da CF/88 e com a remarcação das terras durante a década de 1990 e a primeira década do século XXI. Esse processo faz com que, atualmente, haja novos conflitos por novas demandas de terras indígenas não demarcadas no início do século XX, mas que, segundo os argumentos dos demandadores (indígenas), mostram a habitação em caráter tradicional imemorial. Os conflitos pela terra estão longe de serem solucionados.

\section{Considerações finais}

O início do século XX é peculiar, uma vez que o governo estadual impulsionou as políticas de colonização através das colonizadoras. O elemento que se salientou foi que a demarcação das 11 áreas indígenas já era um ato para reduzir a territorialidade das comunidades indígenas, entretanto, necessário para que eles tivessem algum direito de posse.

40 Art. 231 CF/88: "São terras tradicionalmente ocupadas pelos índios as por eles habitadas em caráter permanente, as utilizadas para as suas atividades produtivas, as imprescindíveis à preservação dos recursos ambientais necessários a seu bem-estar e as necessárias a sua reprodução física e cultural, segundo seus usos, costumes e tradições.” In: BRASIL. Constituição (1988). Constituição da República Federativa do Brasil. capítulo VIII, art. 231, § 1. Brasília: Senado, 1988. Disponível em: http://www.planalto.gov.br/ccivil_03/constituicao/constituicao.htm 
A região Centro-Norte do Rio Grande do Sul foi e continua sendo um palco de reivindicações e movimentos sociais, ou seja, a pressão por novos espaços territoriais determinou que nessa região se desencadeasse uma série de conflitos, tanto no horizonte das áreas indígenas quanto no horizonte dos latifúndios. Nela permeiam duas frentes de atuação que serviram como espaços para a reforma agrária: a área indígena de Serrinha e a antiga fazenda Sarandi.

O ex-governador Leonel Brizola estava “encurralado" em virtude da campanha eleitoral de 1958, na qual realçou sua plataforma de governo em prol da reforma agrária e, portanto, aderiu à prática de redução de terras indígenas. A Frente Agrária Gaúcha e o Movimento dos Agricultores Sem Terra travaram uma luta ideológica frente aos colonos sem-terra. Houve um equívoco histórico no período já que as áreas indígenas reduzidas e extintas foram demarcadas no início do século XX. A intrusão de colonos sem-terra nas áreas indígenas já vinha ocorrendo desde 1940, pois a demanda por novas terras, ou seja, a legitimação da posse dos colonos em áreas indígenas e de reservas florestais, feitas pelo governador Brizola, foi ao encontro dos interesses dos sem-terra.

A intrusão nas áreas indígenas foi considerada o estopim na luta pela terra no Norte do Estado, com o processo de expulsão dos colonos da área de Nonoai em 1978, realizado pelos indígenas. Os movimentos sociais organizaram-se principalmente em 1970, e os conflitos fundiários envolvendo pequenos proprietários, latifundiários e colonos sem-terra aconteceram durante praticamente toda a década de 1980. Sendo assim, aumentou o contingente de colonos sem-terra, instaurando acampamentos na busca pela terra no final de 1970 e início de 1980, ocorrendo a ocupação de latifúndios considerados improdutivos na região.

A origem do conflito em Nonoai entre indígenas e agricultores intrusos ocorreu a partir de alguns grupos mediadores que aderiram à luta indígena. Na pós-Constituição Federal de 1988, algumas áreas que foram 
reduzidas e extintas conseguiram retomar a sua territorialidade, envolvendo novos e mais focos de conflitos na região.

\section{REFERÊNCIAS}

AZEVEDO, Ferdinand. Jesuítas espanhóis no sul do Brasil (1842-1867). Pesquisas. História, São Leopoldo: Instituto Anchietano de Pesquisas, n. 47, 1984. BECKER, Ítala. O índio kaingang no Rio Grande do Sul. São Leopoldo: Unisinos, 1995.

BOTH, M. A. Babel do novo mundo: povoamento e vida rural na região de matas do Rio Grande do Sul (1889-1925). Guarapuava/Niterói: Unicentro/UFF, 2011.

BRASIL. Constituição (1988). Constituição da República Federativa do Brasil. Cap. VIII, art. 231, $₫ 1^{\circ}$. Brasília: Senado, 1988. Disponível em: $<$ http://www.planalto. gov.br/ccivil_03/constituicao/constituicao.htm>. Acesso em: 20 mar. 2017.

BRINGMANN, Sandor F. Fronteiras da inclusão e da exclusão: reflexos do contato entre caingangues e as frentes de expansão (séc. XIX). In: BOEIRA, Nelson; GOLIN, Tau (Coord.). História geral do Rio Grande do Sul - povos indígenas. Passo Fundo: Méritos, 2009. v. 5. p. 109-120.

. Índios, colonos e fazendeiros: conflitos interculturais e resistência Kaingang nas Terras Altas do Rio Grande do Sul (1829-1860). Dissertação (Mestrado em História) - Florianópolis: Universidade Federal de Santa Catarina, 2010.

CARINI, Joel J. Estado, índios e colonos: o conflito na reserva Serrinha/norte do Rio Grande do Sul. Passo Fundo: UPF, 2005.

CARINI, Joel J.; TEDESCO, João C. O conflito de Nonoai: um marco na história das lutas pela terra. In: ZARTH, Paulo A. (Org.). História do campesinato na fronteira sul. Porto Alegre/Chapecó: Letra \& Vida; Suliani/Universidade Federal da Fronteira Sul, 2012. p. 33-57.

CARON, Márcia S.; TEDESCO, João C. O estado positivista no norte do RS: a questão da propriedade da terra e a fundação da colônia Erechim (1890/1910). História Unisinos, São Leopoldo, v. 16, n. 2, p. 220-231, maio/ago. 2012.

CONSELHO DE PROTEÇÃO AOS ÍNDIOS. Coletânea de leis, atos e memórias referentes ao indígena brasileiro compilados pelo oficial administrativo Humberto de Oliveira. Rio de Janeiro: Nacional, 1947. 
D’ANGELIS, W.; VEIGA, J. Presença kaingang e penetração europeia no norte rio-grandense até o século XIX. In: TEDESCO, J. C.; KUJAWA, H. A. (Org.). Conflitos agrários no norte do Rio Grande do Sul: indígenas, negros e agricultores. Porto Alegre: Letra\&Vida; Passo Fundo: Imed, 2013. v. VI. p. 57-81.

FRANCISCO, Aline Ramos. Kaingang: uma história das interações entre nativos ocidentais durante a conquista e a colonização no sul do Planalto Meridional. Porto Alegre: PUC-RS, 2013. Tese de Doutorado em História.

GEHLEN, Ivaldo. Uma estratégia camponesa de conquista da terra e o estado: o caso da Fazenda Sarandi. Dissertação (Mestrado em Antropologia, Política e Sociologia) - Universidade Federal do Rio Grande do Sul. Porto Alegre, 1983.

GERHARDT, Marcos. História ambiental da erva-mate. Tese (Doutorado em História) - Universidade Federal de Santa Catarina. Florianópolis, 2013. Disponível em: <http://www.gerhardt.pro.br/doc/historia-ambiental-ervamate.pdf $>$. Acesso em: 10 abr. 2017.

KUJAWA, Henrique A. A política territorial indígena no Rio Grande do Sul durante o século XX. In: TEDESCO, João C. (Org.). Conflitos agrários no norte do Rio Grande do Sul: indígenas e agricultores. Porto Alegre: Letra \& Vida; Suliani; Passo Fundo: Imed, 2014. v. 7. p. 17-37.

. Conflitos territoriais envolvendo indígenas e agricultores no norte do Rio Grande do Sul: a trajetória de políticas públicas contraditórias. 2014. Tese (Doutorado em Ciências Sociais) - Universidade do Vale do Rio dos Sinos, São Leopoldo, 2014.

LAROQUE, Luís F. História dos Kaingang em seus tradicionais territórios entre os rios Inhacorá, Uruguai e Sinos. In:__ Fronteiras geográficas, étnicas e culturais envolvendo os Kaingang e suas lideranças no sul do Brasil (1889-1930). São Leopoldo: Instituto Anchietano de Pesquisas - Unisinos, 2007. p. 125-174.

MACHADO, Ironita A. P. Entre justiça e lucro: Rio Grande do Sul - 18901930. Passo Fundo: UPF, 2012.

MARCON, Telmo. Acampamento Natalino: história da luta pela reforma agrária. Passo Fundo: UPF, 1997.

NASCIMENTO, José A. M. "Muita terra para pouco índio": ocupação e apropriação dos territórios Kaingang da Serrinha/RS. São Leopoldo: Oikos, 2014.

RIO GRANDE DO SUL. Relatório anual 1962, governador Leonel de Moura Brizola. Memorial da Assembleia Legislativa do estado do Rio Grande do Sul, Porto Alegre, 1962. 
. Comissão Parlamentar de Inquérito que investiga a situação dos toldos indígenas do estado, especialmente do toldo Nonoai. Porto Alegre, 14 ago. 1968. Relatório de Conclusões de Grupo de Trabalho, criado pelo decreto $n^{o} 37.118$ de 30 de dezembro de 1996: "Subsídios ao Governo do Estado relativamente à Questão Indígena no Rio Grande do Sul”, 1997.

RODERJAN, Roselys V. Raízes e pioneiros do Planalto Médio. Passo Fundo: UPF, 1991.

RÜCKERT, Aldomar A.; KUJAWA, Henrique A. A questão territorial Mato Preto nos municípios de Getúlio Vargas, Erebango e Erechim/RS. Relatório de Perícia Fundiária. Porto Alegre: UFRGS; Passo Fundo: Imed, 2010b.

. A questão territorial Votouro/Kandóia no município de Faxinalzinho/ $R S$. Relatório de Perícia Fundiária. Porto Alegre: UFRGS; Passo Fundo: Imed, 2010a. v. 1.

SILVA, Márcio B. Babel do novo mundo: povoamento e vida rural na região de matas do Rio Grande do Sul. Guarapuava: Unicentro; Niterói: UFF, 2011.

SIMONIAN, Lígia T. L. Política/ação anti-indígena de Leonel de Moura Brizola. In: BOEIRA, Nelson; GOLIN, Tau (Org.). História geral do Rio Grande do Sul: povos indígenas. Passo Fundo: Méritos, 2009. p. 469-494. v. 5.

. Terra de posseiros: um estudo sobre as políticas de terras indígenas. Dissertação (Mestrado em Antropologia Social) - Universidade Federal do Rio de Janeiro. Rio de Janeiro, 1981.

TEDESCO, João C.; CARINI, Joel J. Conflitos agrários no norte gaúcho 19601980: o Master, indígenas e camponeses. Porto Alegre: EST Edições, 2007.

TEDESCO, João C.; CARON, Márcia S. A preocupação com os “de dentro" e a reconstituição do etos de camponês: relações interétnicas na colônia Erechim, norte do RS - 1908-1915. In: TEDESCO, João C.; NEUMANN, Rosane M. et al. (Org.). Colonos, colônias e colonizadoras: aspectos da territorialização agrária no Sul do Brasil. Porto Alegre: Suliani, 2013. v. 3. p. 144-169.

TEDESCO, João C. et al. (Org.). Conflitos Agrários no norte do Rio Grande do Sul: indígenas e agricultores. Porto Alegre: Sulilani; Passo Fundo: Imed, 2014. v. 7.

VEIGA, Juracilda. Laudo antropológico sobre o toldo Ventarra (RS). CampinasSP, dez. 1998. 


\title{
Territórios e territorialidades contestadas: espaços em conflitos e disputas pela terra
}

\author{
Giovana Didoné Piovezana ${ }^{1}$ \\ Leonel Piovezana ${ }^{2}$ \\ Maria de Lourdes Bernartt ${ }^{3}$
}

\section{Considerações iniciais}

A região Oeste do estado de Santa Catarina era conhecida, antes de 1912, como "terra de ninguém” (expressão nossa) ou, como se referiam os agricultores do Rio Grande do Sul em suas falas cotidianas, "terras do Paraná". Foi nas disputas pela limpeza da terra, realizadas por colonizadoras, bugreiros, imigrantes de matizes europeias, pelos acordos de fronteiras entre Brasil e Argentina e pela delimitação de territórios entre os estados do Paraná e Santa Catarina que esse espaço se tornou palco de conflitos e guerras sangrentas, como a guerra entre "pelados" e "peludos", então denominada "Guerra do Contestado".

Pessoas de muitas etnias e já mestiças nos processos de encontros, procedências e caminhos são, na maioria, remanescentes de indígenas, europeus, africanos, enfim, de brasileiros nas suas diferentes cores de pele

1 Mestranda em Educação pelo PPGE da Unochapecó de Chapecó (SC). Contato: giovana@unochapeco.edu.br.

2 Professor do Programa de Pós-Graduação em Educação (PPGE) da Unochapecó de Chapecó (SC). Doutor em Desenvolvimento Regional pela Unisc. Contato: leonel@unochapeco.edu.br

3 Doutorado em Educação (Unicamp). PhD em Educação (Unochapecó). Docente do Programa de Pós-Graduação em Desenvolvimento Regional (PPGDR/UTFPR Campus Pato Branco).Contato: marial@utfpr.edu.br 
e, também, de diferentes manifestações culturais. Ingênuas, na maioria, vítimas dos processos fundiários do Brasil, com referência às capitanias hereditárias, sesmarias, Leis da Terra de 1850-1854 e concessões para empresas estrangeiras em troca de serviços ou privilégios governamentais, além de racismo, xenofobia, preconceitos e intolerâncias praticados contra eles, que eram denominados, por muitos anos, de "brasileiros" (expressão nossa), sendo caboclos, indígenas, negros e pobres.

A região do Contestado, da Guerra do Contestado, "caldeirão do Brasil" (expressão nossa), por ser também o palco dos movimentos sociais, como Movimento dos Sem-Terra (MST), Movimento das Mulheres Camponesas (MMC), Movimento dos Atingidos pelas Barragens (MAB), indígenas e outros, não resolvidos, parecem esperar o acender dos pavios das bombas que passam pelas mãos de deputados, ministros e governos, armando estopim com agricultores, indígenas, afro-brasileiros, ribeirinhos e caboclos, vítimas de confronto "armado" pelo fogo a bala, pela artimanha de governos em prol de interesses do capital maior e da segurança do direito à propriedade privada, mesmo que antes expropriada.

Segundo a Fundação Nacional do Índio (Funai), vale lembrar que o reconhecimento dos índios, enquanto realidade social diferenciada, na Constituição federal de 1988, não pode estar dissociada da questão territorial, dado o papel relevante da terra para a reprodução econômica, ambiental, física e cultural deles (FUNAI, 2016). Tanto assim que o texto constitucional (art. 231, $\$ 1^{\circ}$ ) trata esse tema de forma destacada, apresentando o conceito de terras tradicionalmente ocupadas pelos índios como aquelas "por eles habitadas em caráter permanente, as utilizadas para suas atividades produtivas, as imprescindíveis à preservação dos recursos ambientais necessários a seu bem-estar e as necessárias a sua reprodução física e cultural, segundo seus usos, costumes e tradições". Terras que "são bens da União" (art. 20, inc. XI) e que são “inalienáveis e indisponíveis e os direitos sobre elas imprescritíveis” (art. 231, $₫ 4^{\circ}$ ). 
Conforme a Funai, embora os índios detenham a posse permanente e o "usufruto exclusivo das riquezas do solo, dos rios e dos lagos" (art. $231, \S 2^{\circ}$ ) existentes em suas terras, elas constituem patrimônio da União. E, como bens públicos de uso especial, as terras indígenas, além de inalienáveis e indisponíveis, não podem ser objeto de utilização de qualquer espécie por outros que não os próprios índios.

A regularização das terras indígenas por meio da demarcação é de fundamental importância para a sobrevivência física e cultural dos vários povos indígenas que vivem no Brasil. Por isso, essa tem sido a principal reivindicação dos indígenas. Sabe-se que assegurar-lhes o direito à terra significa não só assegurar sua subsistência, mas também garantir o espaço cultural necessário à atualização de suas tradições. Outro aspecto a ser mencionado e que está em evidência é o fato de que a defesa dos territórios indígenas garante a preservação de um gigantesco patrimônio biológico e de conhecimento milenar detido pelas populações indígenas.

A proteção das terras indígenas é, portanto, uma medida estratégica para o país, porque se assegura um direito dos índios, porque se garantem os meios de sua sobrevivência física e cultural e, ainda, porque se garante a proteção da biodiversidade brasileira e do conhecimento que permite o seu uso racional. A efetivação do direito territorial indígena e a preservação dessas populações em seus locais tradicionais têm sido uma garantia da integridade dos limites territoriais brasileiros (FUNAI, 2016).

Leis, falácias e enganações são constantes, e indígenas e pequenos produtores rurais são vítimas de todas as manobras e maquiavelismos, no sentido mais perverso do termo, em relação à divisão e às formas de apropriação da terra.

Nesse contexto, os questionamentos a seguir demonstram nossas inquietações diante da realidade em que vivemos e presenciamos em nosso cotidiano.

Por que é tão difícil perceber o outro, colocar-se no lugar do outro ou sentir o outro enquanto pessoa com necessidades, dor, amor, humanidade? 
Enquanto pessoa com direito à vida, com dignidade, com prazer? Por que é tão difícil perceber ou conceber a felicidade e o bem-viver do outro? Por que não se tolera o fazer com ludicidade, em harmonia com a natureza, em que os corpos se confundem com as cores e sintonias do universo? Por que a felicidade é futuro? Por que o branco é a pureza se a água e o ar são incolores e indispensáveis para a vida? Por que não se quer ver e conceber o outro, diferente em sua cultura, em seus modos de ser e de viver? Por que existe intolerância religiosa, intolerância com a pobreza, intolerância com o coletivo, intolerância com o colono, com os povos autóctones ou nativos, enfim, com o indígena, com o caboclo, se são tão necessários para a manutenção de um sistema que vive do sugar de seus sangues? Por quê, por quê, por quê?

Por que os europeus ao chegarem às Américas escravizaram pessoas? Foi porque viram nelas seres livres? Por que lhes tiraram a alma e precisou-se de um ofício papal, em 1537, para considerá-los pessoas? Por que nada foi cumprido? Por que lhes desapropriaram de tudo e de todos, até deles mesmos? Por que pintaram Deus de branco? Por que legitimamos as capitanias hereditárias como dádivas de Deus na representação do rei? De onde provieram as terras doadas pelo rei a alguns amigos privilegiados? Por que buscaram na África pessoas para serem escravas em regime de escravização? Por quê, por quê, por quê?

Por que os indígenas do Brasil têm de mendigar pela terra? A terra é dos indígenas? Por que eles precisaram de órgãos governamentais para comandá-los, administrá-los, demarcar suas terras, cuidar deles, protegê-los? O que realmente fizeram? Eles estão melhores? Quem os ensinou ou os obrigou aos arrendamentos de suas terras? Por que se criaram as reservas indígenas? Reservas? Por que algumas pessoas foram designadas de bugres? Por que motivaram a guerra entre etnias indígenas? Por que mataram milhões de pessoas indígenas nas minas, nos trabalhos forçados, nas epidemias planejadas? Por que não se comemora com homenagens aos sobreviventes da Guerra do Contestado, na qual, milhares de pessoas 
morreram? Por que eram indígenas, negros, mulatos, caboclos? Por quê, por quê, por quê?

Por que motivaram a vinda de europeus italianos e alemães para o Brasil? Por que criaram a Lei de Terras? Essa lei beneficiou a quem? Por que colonizaram o país e, após tudo dominado, demarcado, loteado, pago, forçaram o êxodo rural? Por que a cultura da dor e do desrespeito ao corpo como fonte de lazer e de felicidade? Por que quiseram e querem os povos indígenas aldeados em reservas, submissos e dependentes? Por que ainda são relativamente capazes, mesmo que a Constituição Federal brasileira de 1988 lhes garanta a cidadania? Por que indígenas e pequenos agricultores são vítimas dos processos fundiários do Brasil, do conflito armado pelas artimanhas e armas de fogo e não conseguem estabelecer as relações de poder do principal ator criador e gerenciador do conflito ou dessa guerra? Por que a luta pela terra se muitas das já reconquistadas estão arrendadas? Por que legitimamos o rico e o pobre como natural, pessoas de direitos, ricos, por que trabalharam muito? Por quê, por quê, por quê?

Continuaríamos a fazer as perguntas embora tenhamos algumas pistas das respostas. O problema está em como direcioná-las para a compreensão e percepção do outro. Os governos conhecem a dimensão do problema e parte das respostas; todavia, a conformação das forças políticas orienta votações e medidas no sentido de beneficiar os já favorecidos, que, em certa medida, são os próprios que se beneficiam ao legislar em causa própria.

Quando pensamos na dimensão biosférica, ocupamos um mesmo espaço de responsabilidade coletiva, como um grande útero. Por que então individualizar responsabilidades, rasgar a terra e demarcá-la para tão poucos?

A respeito disso, observemos a reportagem do Diário Catarinense (2011) sobre agricultores e indígenas que disputam posse de terra. Retrata ideologias e situações que persistem nos dias atuais (fev. 2016) com muita intensidade no Oeste catarinense. "Pedrozo citou que uma Comissão Parlamentar de Inquérito da Câmara dos Deputados criada em 1999 constatou que o processo de demarcação é arbitrário e concentra o poder 
nas mãos da Fundação Nacional do Índio (Funai). - A forma como o governo federal vem conduzindo a questão estimula o conflito - disse Pedrozo" (DEBONA, 2011, s. p).

A situação não mudou, e a Funai foi reestruturada geograficamente para condensar atendimentos e responsabilidades por terras indígenas, mas que, em nossa visão, enquanto pesquisadores, está de mãos amarradas, pois todas as decisões passam do poder Executivo ao Congresso Nacional. Como a maioria dos deputados está a serviço de interesses partidários e dos ruralistas, as questões relativas às demarcações de terras para indígenas são aprovadas, desaprovadas, arquivadas, enfim, deixadas de lado e, pior, jogadas para serem debatidas nos locais de disputa, confrontando e colocando indígenas e não indígenas no conflito e na guerra "armada".

O coordenador da Fundação Nacional do Índio de Chapecó, responsável por todo o Oeste de SC e parte do Paraná, Pedro Possamai, afirmou que as áreas indígenas são identificadas por estudos antropológicos que constatam se há evidências que eles moraram naquele local, como a existência de cemitérios, por exemplo. Depois, o estudo é avaliado pela Funai, encaminhado ao Ministério da Justiça, que publica uma portaria declarando área indígena. Após, é sancionado pelo governo federal. Possamai disse que reconhece o direito dos agricultores de serem indenizados. O problema é que a União não indeniza terras indígenas, pois, juridicamente, essas terras já pertenceriam à União. Os índios têm apenas a posse dessas terras, mas não são os donos. Com isso, no entendimento do administrador da Funai, caberia ao Estado, que permitiu a colonização, indenizar as terras. Possamai disse que a Assembleia Legislativa até havia aprovado um dispositivo para permitir ao Estado fazer isso, mas a lei não foi sancionada (DEBONA, 2011, s. p).

Percebemos o descaso dos governos e, ao mesmo tempo, a omissão dessa responsabilidade, uma vez que quem autorizou a posse e a venda de terras para agricultores e/ou demais formas de apropriações foi com o aval do governo. As terras são públicas e não privadas, legitimamos como 
propriedades privadas, então, são desculpas para não resolver o problema fundiário, mantendo a terra nas mãos de poucos.

O problema é antigo e começou com a colonização do Brasil. De acordo com o professor de história da Universidade Federal da Fronteira Sul (UFFS), José Carlos Radin, o problema tem origem na colonização do Brasil, quando a Coroa Portuguesa fazia grandes concessões de terras. O detalhe é que dentro dessas terras moravam populações indígenas. Em 1850, veio a Lei de Terras, que determinava a escrituração das propriedades. Os indígenas e caboclos não tinham noção de propriedade - explicou Radin. A assessoria do governo do Estado informou somente que a questão ainda está em avaliação. Enquanto isso, agricultores e índios continuam em pé de guerra (DEBONA, 2011, s. p).

Infelizmente, continua em avaliação. E novas portarias, no início de 2016, foram publicadas, anulando decisões anteriores a favor da demarcação e regularização de terras indígenas, reiniciando processos que há anos deveriam ter sido aprovados, prejudicando indígenas e agricultores da região Oeste do estado de Santa Catarina, aumentando conflitos, ódios e xenofobia. Assim, índios e agricultores continuam vítimas dos processos fundiários do Brasil, e os governos, ilesos, deixam fluir a guerra e o derramamento de sangue pela luta do que seria a vida, a mãe Terra.

\section{Situação das terras indígenas de Santa Catarina}

No Quadro 1 identificamos, conforme dados da Funai (2016), a situação das terras indígenas do estado de Santa Catarina quanto à etnia, população, localização, área de terra regularizada ou em fase de procedimentos, bem como em relação à modalidade.

Santa Catarina conta com a presença de quatro etnias indígenas: os caingangues, que formam o maior grupo populacional; os guaranis, que ainda dependem de acolhimento em terras de outros povos em virtude 
da sua tradição cultural de que terra não se vende, não se compra, não se rasga, considerando-a como mãe, sagrada; os xockleng, que também vivem em constantes conflitos pela terra e pela manutenção das que já possuem, em consequência das barragens e demais interesses econômicos na exploração; os xetá, pessoas que vivem de forma isolada em algumas terras de seus parentes ou nas periferias das cidades.

Quadro 1 - Terra indígena, etnia, UF, município, superfície, fase do procedimento, modalidade

\begin{tabular}{|c|c|c|c|c|c|c|}
\hline Terra indígena & Etnia & UF & Município & $\begin{array}{l}\text { Superfície } \\
\text { (ha) }\end{array}$ & $\begin{array}{l}\text { Fase do pro- } \\
\text { cedimento }\end{array}$ & Modalidade \\
\hline Águas Claras & $\begin{array}{l}\text { Guarani } \\
\text { Mbya }\end{array}$ & SC & Major Gercino & 165,0000 & Regularizada & $\begin{array}{l}\text { Reserva } \\
\text { Indígena }\end{array}$ \\
\hline Aldeia Kondá & Kaingang & SC & Chapecó & $2.300,0000$ & $\begin{array}{l}\text { Encaminha- } \\
\text { da RI em Re- } \\
\text { gularização }\end{array}$ & $\begin{array}{l}\text { Reserva } \\
\text { Indígena }\end{array}$ \\
\hline $\begin{array}{l}\text { Amaral/Tekoá } \\
\text { Kuriy }\end{array}$ & $\begin{array}{l}\text { Guarani } \\
\text { Mbya }\end{array}$ & SC & Biguaçu & 501,3600 & Regularizada & $\begin{array}{l}\text { Reserva } \\
\text { Indígena }\end{array}$ \\
\hline $\begin{array}{l}\text { Cachoeira dos } \\
\text { Inácios }\end{array}$ & $\begin{array}{l}\text { Guarani } \\
\text { Mbya }\end{array}$ & SC & Imaruí & 80,0000 & Regularizada & $\begin{array}{l}\text { Reserva } \\
\text { Indígena }\end{array}$ \\
\hline Cambirela & $\begin{array}{l}\text { Guarani } \\
\text { Mbya }\end{array}$ & SC & Palhoça & 0,0000 & Em estudo & $\begin{array}{l}\text { Tradicio- } \\
\text { nalmente } \\
\text { ocupada }\end{array}$ \\
\hline Canelinha & $\begin{array}{l}\text { Guarani } \\
\text { Mbya }\end{array}$ & SC & Canelinha & 207,7552 & Regularizada & $\begin{array}{l}\text { Reserva } \\
\text { Indígena }\end{array}$ \\
\hline $\begin{array}{l}\text { Guarani de } \\
\text { Araçai }\end{array}$ & Guaraní & SC & $\begin{array}{l}\text { Cunha Porã, } \\
\text { Saudades }\end{array}$ & $2.721,0000$ & Declarada & $\begin{array}{l}\text { Tradicio- } \\
\text { nalmente } \\
\text { ocupada }\end{array}$ \\
\hline Ibirama & $\begin{array}{l}\text { Xokléng, } \\
\text { Kain- } \\
\text { gang, } \\
\text { Guarani } \\
\end{array}$ & SC & $\begin{array}{l}\text { Doutor Pedri- } \\
\text { nho, Jose Boi- } \\
\text { teux, Vitor Mei- } \\
\text { reles, Itaiópolis }\end{array}$ & $14.084,8860$ & Regularizada & $\begin{array}{l}\text { Tradicio- } \\
\text { nalmente } \\
\text { ocupada }\end{array}$ \\
\hline $\begin{array}{l}\text { Ibirama La } \\
\text { Klanô }\end{array}$ & $\begin{array}{l}\text { Xokléng, } \\
\text { Kain- } \\
\text { gang, } \\
\text { Guarani }\end{array}$ & SC & $\begin{array}{l}\text { Doutor Pedri- } \\
\text { nho, Jose Boi- } \\
\text { teux, Vitor Mei- } \\
\text { reles, Itaiópolis, } \\
\text { Rio Negrinho }\end{array}$ & $37.108,0000$ & Declarada & $\begin{array}{l}\text { Tradicio- } \\
\text { nalmente } \\
\text { ocupada }\end{array}$ \\
\hline Massiambu & $\begin{array}{l}\text { Guarani } \\
\text { Mbya }\end{array}$ & SC & Palhoça & 0,0000 & Em estudo & $\begin{array}{l}\text { Tradicio- } \\
\text { nalmente } \\
\text { ocupada }\end{array}$ \\
\hline
\end{tabular}




\begin{tabular}{|c|c|c|c|c|c|c|}
\hline Terra indígena & Etnia & UF & Município & $\begin{array}{l}\text { Superfície } \\
\text { (ha) }\end{array}$ & $\begin{array}{l}\text { Fase do pro- } \\
\text { cedimento }\end{array}$ & Modalidade \\
\hline Mbiguaçu & $\begin{array}{l}\text { Guara- } \\
\text { ni Mbya, } \\
\text { Guarani } \\
\text { Nhan- } \\
\text { deva }\end{array}$ & SC & Biguaçu & 0,0000 & Em estudo & $\begin{array}{l}\text { Tradicio- } \\
\text { nalmente } \\
\text { ocupada }\end{array}$ \\
\hline Mbiguaçu & $\begin{array}{l}\text { Guara- } \\
\text { ni Mbya, } \\
\text { Guarani } \\
\text { Nhan- } \\
\text { deva } \\
\end{array}$ & SC & Biguaçu & 59,1982 & Regularizada & $\begin{array}{l}\text { Tradicio- } \\
\text { nalmente } \\
\text { ocupada }\end{array}$ \\
\hline Morro Alto & $\begin{array}{l}\text { Guarani } \\
\text { Mbya }\end{array}$ & $\mathrm{SC}$ & $\begin{array}{l}\text { São Francisco } \\
\text { do Sul }\end{array}$ & 893,0000 & Declarada & $\begin{array}{l}\text { Tradicio- } \\
\text { nalmente } \\
\text { ocupada }\end{array}$ \\
\hline $\begin{array}{l}\text { Morro da } \\
\text { Palha }\end{array}$ & $\begin{array}{l}\text { Guarani } \\
\text { Mbya }\end{array}$ & $\mathrm{SC}$ & Biguaçu & 240,3312 & Regularizada & $\begin{array}{l}\text { Reserva } \\
\text { Indígena }\end{array}$ \\
\hline $\begin{array}{l}\text { Morro dos } \\
\text { Cavalos }\end{array}$ & Guaraní & SC & Palhoça & $1.983,4901$ & Declarada & $\begin{array}{l}\text { Tradicio- } \\
\text { nalmente } \\
\text { ocupada }\end{array}$ \\
\hline Palmas & Kaingang & $\begin{array}{l}\mathrm{PR} / \\
\mathrm{SC}\end{array}$ & $\begin{array}{l}\text { Abelardo Luz, } \\
\text { Palmas }\end{array}$ & $3.800,8794$ & Regularizada & $\begin{array}{l}\text { Tradicio- } \\
\text { nalmente } \\
\text { ocupada }\end{array}$ \\
\hline Pindoty & $\begin{array}{l}\text { Guarani } \\
\text { Mbya }\end{array}$ & SC & $\begin{array}{l}\text { Araquari, Bal- } \\
\text { neário Barra } \\
\text { do Sul }\end{array}$ & $3.294,0000$ & Declarada & $\begin{array}{l}\text { Tradicio- } \\
\text { nalmente } \\
\text { ocupada }\end{array}$ \\
\hline Pinhal & Kaingang & SC & $\begin{array}{l}\text { Seara, Arvore- } \\
\text { do e Paial }\end{array}$ & 880,0761 & $\begin{array}{l}\text { Demarcada e } \\
4846,00 \text { (ha) } \\
\text { declarada }\end{array}$ & $\begin{array}{l}\text { Tradicio- } \\
\text { nalmente } \\
\text { ocupada }\end{array}$ \\
\hline Pirai & $\begin{array}{l}\text { Guarani } \\
\text { Mbya }\end{array}$ & SC & Araquari & $3.017,0000$ & Declarada & $\begin{array}{l}\text { Tradicio- } \\
\text { nalmente } \\
\text { ocupada }\end{array}$ \\
\hline $\begin{array}{l}\text { Rio dos } \\
\text { Pardos }\end{array}$ & Xokléng & SC & Porto União & 758,2614 & Regularizada & $\begin{array}{l}\text { Tradicio- } \\
\text { nalmente } \\
\text { ocupada }\end{array}$ \\
\hline Tarumã & $\begin{array}{l}\text { Guarani } \\
\text { Mbya }\end{array}$ & SC & $\begin{array}{l}\text { Araquari, Bal- } \\
\text { neário Barra } \\
\text { do Sul }\end{array}$ & $2.172,0000$ & Declarada & $\begin{array}{l}\text { Tradicio- } \\
\text { nalmente } \\
\text { ocupada }\end{array}$ \\
\hline $\begin{array}{l}\text { Toldo } \\
\text { Chimbangue }\end{array}$ & Kaingang & SC & Chapecó & 988,6625 & Homologada & $\begin{array}{l}\text { Tradicio- } \\
\text { nalmente } \\
\text { ocupada }\end{array}$ \\
\hline $\begin{array}{l}\text { Toldo Chim- } \\
\text { bangue II }\end{array}$ & Kaingang & SC & Chapecó & 954,0708 & Regularizada & $\begin{array}{l}\text { Tradicio- } \\
\text { nalmente } \\
\text { ocupada }\end{array}$ \\
\hline
\end{tabular}




\begin{tabular}{|l|l|l|l|l|l|l|}
\hline Terra indígena & Etnia & UF & Município & $\begin{array}{l}\text { Superfície } \\
\text { (ha) }\end{array}$ & $\begin{array}{l}\text { Fase do pro- } \\
\text { cedimento }\end{array}$ & Modalidade \\
\hline Toldo Imbu & Kaingang & SC & Abelardo Luz & $1.960,6934$ & $\begin{array}{l}\text { Demar- } \\
\text { cada em } \\
\text { regularização }\end{array}$ & $\begin{array}{l}\text { Tradicio- } \\
\text { nalmente } \\
\text { ocupada }\end{array}$ \\
\hline $\begin{array}{l}\text { Rio dos } \\
\text { Pardos }\end{array}$ & Xockleng & SC & Porto União & 758,26 & & \\
\hline Xapecó & $\begin{array}{l}\text { Kain- } \\
\text { gang, } \\
\text { Guarani }\end{array}$ & SC & $\begin{array}{l}\text { Ipuaçu e Entre } \\
\text { Rios }\end{array}$ & $\begin{array}{l}15.623,9581 \\
660.00\end{array}$ & $\begin{array}{l}\text { Homologada } \\
\text { Demarcada }\end{array}$ & $\begin{array}{l}\text { Tradicio- } \\
\text { nalmente } \\
\text { ocupada }\end{array}$ \\
\hline $\begin{array}{l}\text { Acampamento } \\
\text { Fraiburgo }\end{array}$ & Kaingang & SC & Fraiburgo & & Em estudo & $\begin{array}{l}\text { Tradicio- } \\
\text { nalmente } \\
\text { ocupada }\end{array}$ \\
\hline Ygua Porã & Guaraní & SC & Biguaçu & 0,0000 & & \\
\hline
\end{tabular}

Fonte: Funai (2016).

No estado de Santa Catarina, as terras indígenas existentes e reconhecidas oficialmente alcançam $0,81 \%$ do total do território $(77.709$ hectares de um total de 9.534 .618 ha do território total do Estado). Porém, os indígenas estão de posse de 36.780 ha; os outros 40.929 ha são foco de disputas administrativas ou judiciais.

Desde 1500 até a década de 1970 a população indígena brasileira decresceu acentuadamente e muitos povos foram extintos. O desaparecimento dos povos indígenas passou a ser visto como uma contingência histórica, algo a ser lamentado, porém inevitável. No entanto, este quadro começou a dar sinais de mudança nas últimas décadas do século passado. A partir de 1991, o IBGE incluiu os indígenas no censo demográfico nacional. O contingente de brasileiros que se considerava indígena cresceu $150 \%$ na década de 90 . O ritmo de crescimento foi quase seis vezes maior que o da população em geral. O percentual de indígenas em relação à população total brasileira saltou de 0,2\% em 1991 para 0,4\% em 2000, totalizando 734 mil pessoas. Houve um aumento anual de $10,8 \%$ da população, a maior taxa de crescimento dentre todas as categorias, quando a média total de crescimento foi de 1,6\% (FUNAI, 2016). 
Na cidade de Chapecó-SC, muitos bairros são habitados por descendentes indígenas, a maioria de etnia caingangue. Não são registrados na Funai e não participam ativamente das questões relativas aos indígenas e, muito menos, na luta pela terra ou pela moradia urbana, como indígena que nasce com a cidade, que é urbano e com direitos. "A atual população indígena brasileira, segundo resultados preliminares do Censo Demográfico realizado pelo IBGE em 2010, é de 817.963 indígenas, dos quais 502.783 vivem na zona rural e 315.180 habitam as zonas urbanas brasileiras. Esse censo revelou que em todos os estados da Federação, inclusive do Distrito Federal, há populações indígenas. A Funai também registra 69 referências de índios ainda não contatados, além de existirem grupos que estão requerendo o reconhecimento de sua condição indígena junto ao órgão federal indigenista. Com relação às línguas faladas, que totalizam 274, o censo demonstrou que cerca de $17,5 \%$ da população indígena não fala a língua portuguesa" (IBGE, 2010, s. p).

É importante relatar que os caingangues, habitantes da terra indígena Kondá, nasceram no centro da cidade de Chapecó; são índios urbanos que não perdem a identidade e a língua materna, falada por $100 \%$ da sua população. São obrigados a deixar o espaço urbano em 2001 para residirem no meio rural, processo que, até hoje, não está bem concebido pelos indígenas.

Esta população, em sua grande maioria, vem enfrentando uma acelerada e complexa transformação social, necessitando buscar novas respostas para a sua sobrevivência física e cultural e garantir às próximas gerações qualidade de vida. As comunidades indígenas vêm enfrentando problemas concretos, tais como invasões e degradações territoriais e ambientais, exploração sexual, aliciamento e uso de drogas, exploração de trabalho, inclusive infantil, mendicância, êxodo desordenado causando grande concentração de indígenas nas cidades. Hoje, segundo dados do censo do IBGE realizado em 2010, a população brasileira soma 190.755 .799 milhões de pessoas. Ainda segundo o censo, 817.963 mil são indígenas, representando 305 diferentes etnias. Foram registradas no país 274 línguas indígenas. 
Essa é a realidade que apontamos também nesta segunda década do século XXI. O descaso e a escravização indígena para o trabalho ainda persistem e a exploração da mão de obra infantil é uma constante, inclusive praticada pelos próprios pais indígenas, afirmando-se nos aportes da cultura. Persistem ódios e xenofobias por parte da população não indígena. Atribuímos à ignorância e ao próprio reconhecimento de si como primeiros passos para o respeito às diferenças e às pessoas nas suas culturas.

\section{Territórios contestados: descaso e desrespeito aos indígenas e agricultores do Oeste catarinense}

Para a Funai, o processo de demarcação é o meio administrativo para explicitar os limites do território tradicionalmente ocupado pelos povos indígenas. É dever da União, que busca a demarcação das terras indígenas: resgatar uma dívida histórica com os primeiros habitantes dessas terras; propiciar as condições fundamentais para a sobrevivência física e cultural desses povos; preservar a diversidade cultural brasileira, tudo isso em cumprimento ao que é determinado pelo caput do art. 231 da Constituição Federal.

Sempre que uma comunidade indígena possuir direitos sobre uma determinada área nos termos do $\$ 1^{\circ}$ do art. 231 da CF, o poder público terá a atribuição de identificá-la e delimitá-la, de realizar a demarcação física dos seus limites, de registrá-la em cartório de registro de imóveis e protegê-la. Esses atos estão vinculados ao próprio caput do art. 231 e, por isso mesmo, a União não pode deixar de promovê-los (FUNAI, 2016).

As determinações legais existentes são por si só suficientes para garantir o reconhecimento dos direitos indígenas sobre as terras tradicionalmente ocupadas pelos índios, independentemente da sua demarcação física. Porém, a ação demarcatória é fundamental e urgente enquanto ato governamental de reconhecimento, visando precisar a real extensão da posse indígena e, 
assim, assegurar a proteção dos limites demarcados e permitir o encaminhamento da questão fundiária nacional (FUNAI, 2016). "Para os povos indígenas, a terra é muito mais do que simples meio de subsistência. Ela representa o suporte da vida social e está diretamente ligada ao sistema de crenças e conhecimento. Não é apenas um recurso natural - e tão importante quanto este - é um recurso sociocultural" (RAMOS, 1995, p. 3).

No final da década de 1970, a questão indígena passou a ser tema de relevância no âmbito da sociedade civil. Paralelamente, os índios iniciaram os primeiros movimentos de organização própria em busca da defesa de seus interesses e direitos. Diversas organizações indígenas e entidades de defesa de direitos promoveram amplo debate, visando assegurar a demarcação das terras dos índios e realizar reflexão crítica sobre a política de integração. Ao mesmo tempo em que se organizavam politicamente no sentido de defender os direitos de posse das terras indígenas, passou-se a debater as bases de uma nova política indigenista, fundamentada no respeito às formas próprias de organização sociocultural dos povos indígenas (FUNAI, 2009).

$\mathrm{Na}$ sequência colocamos os passos para a demarcação de terras indígenas, cujas informações constam no site da Funai ${ }^{4}$, para a qual, ainda que o processo de regularização das terras indígenas seja conhecido como demarcação, trata-se apenas de uma das fases administrativas do processo.

As linhas mestras do processo administrativo de demarcação das terras indígenas estão definidas na Lei ${ }^{\circ}$ 6.001, de 19/12/1973, conhecida como "Estatuto do Índio", e no Decreto no 1.775, de 8/1/1996. Essa legislação atribui à Funai o papel de tomar a iniciativa, orientar e executar a demarcação dessas terras, atividade que é executada pela Diretoria de Assuntos Fundiários (DAF).

O procedimento atual para a identificação e delimitação, demarcação física, homologação e registro de terras indígenas está estabelecido e

4 As terras indígenas do Brasil. Disponível em: <http://www.funai.gov.br/indios/terras/conteudo.htm >. Acesso em: 28 dez. 2009. 
balizado no Dec. no 1.775 , de 8/1/1996, que "dispõe sobre o procedimento administrativo de demarcação das terras indígenas", definindo claramente o papel do órgão federal indigenista, as diferentes fases e subfases do processo e assegurando transparência ao procedimento por meio de sua publicidade.

O procedimento administrativo para a reserva de terras destinadas à proteção de grupos indígenas, prevista no art. 26 da Lei no 6.001/73, conta com rito diferente do aplicado às terras tradicionalmente ocupadas pelos índios, estabelecido pelo Dec. $\mathrm{n}^{\circ} 1.775 / 96$.

Aquém e além desse processo, a Fundação Nacional do Índio conta com duas outras atribuições, ditadas pelo Dec. $\mathrm{n}^{\circ} 1.775 / 96$, quanto à proteção das terras tradicionalmente ocupadas pelos indígenas: o poder de disciplinar o ingresso e trânsito de terceiros em áreas nas quais se constate a presença de índios isolados ou que estejam em grave ameaça; a extração dos possíveis não índios ocupantes das terras administrativamente reconhecidas como indígenas.

Os critérios para identificação e delimitação de uma terra indígena, realizados por um grupo de técnicos especializados, estão definidos no Dec. no 1775/96 e na Port. no 14/MJ, de 9/1/1996, que estabelece "regras sobre a elaboração do relatório circunstanciado de identificação e delimitação de Terras Indígenas".

O início do processo demarcatório se dá por meio da identificação e delimitação, quando é constituído um grupo técnico de trabalho, composto por técnicos da Funai, do Incra e/ou da Secretaria Estadual de terras da localização do imóvel. A comunidade indígena é envolvida diretamente em todas as subfases da identificação e delimitação da terra indígena a ser administrativamente reconhecida. O grupo de técnicos faz os estudos e levantamentos em campo, centros de documentação, órgãos fundiários municipais, estaduais e federais e em cartórios de registro de imóveis, para a elaboração do relatório circunstanciado de identificação e delimitação da área estudada, resultado que servirá de base a todos os passos subsequentes. 
O resumo do relatório é publicado no Diário Oficial da União e Diário Oficial do Estado federado de localização da área, sendo cópia da publicação afixada na sede municipal da comarca de situação da terra estudada.

Os estudos antropológicos e os complementares de natureza etno-histórica, sociológica, jurídica, cartográfica, ambiental e o levantamento fundiário realizados nessa fase devem caracterizar e fundamentar a terra como tradicionalmente ocupada pelos índios, conforme os preceitos constitucionais, e apresentar elementos visando à concretização das fases subsequentes à regularização total da terra. É com base nesses estudos, aprovados pelo presidente da Funai, que a área será declarada de ocupação tradicional do grupo indígena a que se refere, por ato do ministro da Justiça - portaria declaratória publicada no Diário Oficial da União - reconhecendo-se, assim, formal e objetivamente, o direito originário indígena sobre uma determinada extensão do território brasileiro.

Desde o início do processo demarcatório até noventa dias da publicação do resumo do relatório nos diários oficiais da União e do Estado, podem os interessados apresentar contestações, as quais também serão analisadas pelo pessoal técnico da Funai, podendo o seu presidente optar pelo reestudo da área proposta ou pela sua confirmação, dando-se, então, continuidade ao procedimento.

Os estudos e pareceres referentes às contestações, ao serem aprovados pela Funai, são, em seguida, encaminhados para o Ministério da Justiça, que faz a análise da proposta apresentada pelo órgão indigenista referente aos limites da terra indígena e das razões apresentadas pelos contestantes.

Após a aprovação dos estudos feitos pela Funai por parte do Ministério da Justiça, a terra é declarada de ocupação tradicional do grupo indígena especificado, indicando a superfície, o perímetro e os seus limites, sendo inclusive determinada sua demarcação física.

A demarcação física é a fase em que se materializam em campo os limites da terra indígena, conforme determinado na portaria declaratória expedida pelo Ministério da Justiça. Nessa fase, faz-se uma estimativa 
dos custos necessários à demarcação das terras declaradas, escolhe-se a modalidade de demarcação, executa-se a demarcação propriamente dita e também a fiscalização e o recebimento dos serviços executados, conforme a seguinte especificação:

I. As terras indígenas são limitadas por: acidentes naturais (rios, córregos, igarapés, lagos, orlas marítimas); estradas; linhas secas, assim denominadas, em que o limite não é definido por acidentes geográficos ou estradas.

a. Ao longo dos acidentes naturais não é executado trabalho de topografia, pois os limites já são claros e bem definidos em campo, sendo que para a elaboração dos mapas lançamos mão dos dados existentes nas cartas topográficas, com as devidas verificações em campo através de GPS de navegação.

b. Ao longo de estradas, a demarcação é feita por meio de levantamento topográfico e geodésico e implantação de marcos e placas indicativas, sendo que, geralmente, não é necessária a abertura de picadas, pois esses limites também já estão materializados em campo.

c. Ao longo das linhas secas, a demarcação é feita por meio de levantamento topográfico e geodésico e implantação de marcos e placas indicativas, sendo necessária a abertura de picadas com três metros de largura.

II. As placas indicativas são implantadas acompanhando os marcos e nos locais onde ocorrem vias de acesso à terra indígena.

III. Os marcos, confeccionados em concreto, são implantados ao longo das linhas secas num intervalo de, no máximo, um quilômetro e trazem na sua parte superior um pino de bronze com a inscrição Ministério da Justiça, Funai, número e tipo do marco, ano da demarcação e a observação "protegido por lei".

IV. O resultado final da demarcação é apresentado em mapa e memorial descritivo, elaborados dentro das normas da cartografia internacional, apresentando limites que contam com coordenadas geográficas precisas. 
V. Todos os trabalhos de demarcação são realizados de acordo com o $M a$ nual de normas técnicas para demarcação de terras indígenas, da Funai.

VI. A diretoria de assuntos fundiários (DAF) da Funai, por meio de sua coordenação-geral de demarcação (CGD), é responsável pela normatização, execução e fiscalização dos trabalhos de demarcação de terras indígenas no Brasil.

De posse do material técnico da demarcação, realiza-se a preparação da documentação para confirmação dos limites demarcados, que corresponde à homologação, o que se dá por meio da expedição de um decreto do presidente da República. O processo administrativo de regularização de uma terra indígena termina com o seu registro no Cartório Imobiliário da Comarca em que o imóvel está situado e na Secretaria de Patrimônio da União (SPU) do Ministério da Fazenda.

Quando é constatada a presença de ocupantes não índios na terra indígena, são realizados, nas fases de identificação e delimitação, levantamentos fundiários, socioeconômicos, documentais e cartoriais, bem como a avaliação das benfeitorias edificadas em tais ocupações.

Os estudos e levantamentos procedidos sobre as ocupações não indígenas são analisados e, então, julgada a boa-fé quanto à implantação, por meio da Comissão Permanente de Sindicância, instituída pela Funai, que divulga a decisão através de resolução publicada no Diário Oficial da União. O pagamento das benfeitorias derivadas das ocupações de boa-fé se dá com base em programação orçamentária disponibilizada para essa finalidade pela União.

Segundo o disposto no art. $4^{\circ}$ do Dec. no $1.775 / 96$, os ocupantes não indígenas retirados das terras indígenas têm prioridade no reassentamento fundiário feito pelo Incra, em observação à legislação pertinente.

O procedimento para a identificação e demarcação de terras indígenas tem métodos transparentes; portanto, todas as suas etapas são públicas. 
Publica-se no DOU a portaria de constituição do grupo técnico encarregado dos estudos de identificação e delimitação; o resumo do relatório caracterizando a terra indígena a ser demarcada é publicado no Diário Oficial da União e no Diário Oficial da unidade federada em que se localiza a área sob a demarcação, acompanhado de memorial descritivo e mapa da área, além de ser afixada a publicação na sede da Prefeitura Municipal onde se situa o imóvel, conforme determina o $\$ 7^{\circ}$ do art. $2^{\circ}$ do Dec. $n^{\circ} 1.775 / 96$; a portaria declaratória do $\mathrm{MJ}$ e o decreto homologatório do presidente da República são publicados no DOU.

Somado a isso, o Dec. $n^{\circ} 1.775 / 96$, no $\$ 8^{\circ}$ do art. $2^{\circ}$, assegura aos estados e municípios onde se localiza a área em demarcação e aos demais interessados manifestar-se, seja para pleitear indenizações, seja para demonstrar vícios, totais ou parciais, do relatório, pelo período que vai do início da demarcação até noventa dias após a mencionada publicação, o que, por assegurar transparência ao processo e permitir o contestatório, levou o atual governo a revogar o Dec. no 22, de 4/2/1991, substituindo-o pelo Dec. $\mathrm{n}^{\circ}$ 1.775/96.

A demarcação administrativa é apenas a primeira medida que visa à proteção das terras indígenas. Concluído esse processo, são necessárias outras ações, visando tanto prevenir como sanar as situações de exploração econômica indevida e a reintegração de posse de territórios pelos índios. Além disso, existem as questões que envolvem a proteção dos bens culturais e que se referem à valorização da identidade étnica, sem o que não é possível assegurar a cidadania para os índios.

É necessário, depois de demarcadas e garantidas as terras, assegurar, para cada povo ou comunidade que habite uma terra indígena, um processo próprio de desenvolvimento, adequado à realidade e ao anseio desse povo ou comunidade. Quanto ao dever do Estado, ele tem a função de facilitar, fomentar e possibilitar que essa escolha se torne uma realidade, constituindo, assim, o grande desafio que a Funai, hoje, tem pela frente. 
Nesse sentido, uma das necessidades referentes à reestruturação do órgão indigenista é justamente essa. Ou seja, viabilizar a substituição do velho modelo de indigenismo, caracterizado pelo paternalismo e clientelismo, por meio dos quais os índios são tratados como uma realidade genérica (índio genérico) e em vias de desaparecimento, por um novo indigenismo em que as diferentes realidades sejam contempladas por diferentes formas de planejamento e experiências indigenistas.

Assim, as ações do órgão indigenista voltadas a assegurar os direitos dos índios estão sendo repensadas no sentido de que sua concepção, planejamento e execução tenham em vista sociedades diferenciadas da nacional, bem como diferentes entre si, pois na questão da especificidade dos programas e projetos destinados a esses povos e comunidades é vital a concretização de políticas regionalizadas.

Outro desafio é assegurar a participação das populações indígenas, sem o que é inviável garantir a manutenção dos territórios já regularizados, pois só por meio de um processo de conscientização a respeito de seus direitos e por intermédio de medidas de caráter preventivo é que serão criados os meios para que possam ser evitadas novas invasões e explorações indevidas de suas terras (FUNAI, 2009).

Assim, o reconhecimento dos limites das terras dos índios não inviabiliza o desenvolvimento do meio rural. Sobre isso existem dados segundo os quais "as terras indígenas não obstaculizam a expansão das atividades agrícolas ou pecuárias, uma vez que as terras indígenas constituem parte menor do estoque de terras que poderiam ser destinadas a programas governamentais de colonização e/ou reforma agrária” (OLIVEIRA, 1987, p. 29).

\section{Terras indígenas no Oeste de Santa Catarina}

A maior área destinada aos povos indígenas do estado de Santa Catarina está localizada no Oeste, região conhecida como o "maior celeiro 
alimentício e agroindustrial do Brasil". As terras indígenas são de uso coletivo e destinam-se à manutenção da sobrevivência física e cultural de seus povos, diferentemente das terras destinadas ao mercado de capitais. No Brasil, os territórios indígenas pertencem à União, e a justificativa para não pagar a terra para agricultores ou proprietários não indígenas está neste fator: o governo não pode pagar a terra que já é deles; então, só promete pagar pelas benfeitorias.

No Quadro 2 apresentamos a situação das terras indígenas do Oeste do estado de Santa Catarina em levantamento feito em 2016.

Quadro 2 - Situação das terras indígenas do Oeste do estado de Santa Catarina em 2016

\begin{tabular}{|l|l|}
\hline $\begin{array}{l}\text { Terra In- } \\
\text { dígena } \\
\text { Xapecó } \\
\text { (cain- } \\
\text { gangue e } \\
\text { guarani) }\end{array}$ & $\begin{array}{l}\text { A Terra Indígena Xapecó é classificada na categoria terra indígena (TI), por } \\
\text { já estar com situação jurídica homologada e registrada no cartório de regis- } \\
\text { tro de imóveis em 29/10/1991. É assegurada pelo Decreto 297, publicado em } \\
\text { 30/10/1991. Está jurisdicionada à Coordenação Regional Interior Sul de Cha- } \\
\text { pecó-SC. Localizada na faixa de fronteira, possui uma extensão territorial ho- } \\
\text { mologada de 15.623,95 (ha) e mais 660,00 (ha) demarcada. Residem nessa ter- } \\
\text { ra 5.293 indígenas caingangues, oficialmente reconhecidos, e mais, aproxima- } \\
\text { damente, 1.100 agregados às comunidades de 16 aldeias e 145 indígenas gua- } \\
\text { rani, conforme dados da Funai de Chapecó (2016). A TI Xapecó abrange parte } \\
\text { dos municípios de Entre Rios-SC, com 10.517 ha, e de Ipuaçu-SC com 26.139 } \\
\text { ha. A maior porção territorial está localizada no município de Ipuaçu. }\end{array}$ \\
\hline $\begin{array}{l}\text { Toldo } \\
\text { Imbu }\end{array}$ & $\begin{array}{l}\text { Enquadrada também na categoria TI, com situação jurídica declarada em } \\
19 / 4 / 2007, \text { com portaria publicada em 20/4/2007, sob a administração regio- } \\
\text { nal da Funai de Chapecó-SC e DSEI - Funasa: Sul-Sudeste (Rio de Janeiro, } \\
\text { São Paulo, Santa Catarina, Rio Grande do Sul), possui uma extensão de área } \\
\text { de 1.906,69 ha e população de 139 pessoas (FUNAI - Chapecó, 2016). Está } \\
\text { localizada na faixa de fronteira, no município de Abelardo Luz-SC. A situação } \\
\text { em fevereiro de 2016 é de terra demarcada em regularização. }\end{array}$ \\
\hline $\begin{array}{l}\text { Com situação jurídica atual em regularização, ainda pelo documento de des- } \\
\text { Indígena } \\
\text { Kondá }\end{array}$ & $\begin{array}{l}\text { Interior Sul de Chapecó-SC. } \\
\text { Possui extensão da área de 2.300 ha e uma população de 786 indígenas cain- } \\
\text { gangue, todos falantes do idioma (FUNAI - Chapecó, 2016). Está localizada } \\
\text { na faixa de fronteira no município de Chapecó-SC. }\end{array}$ \\
\hline
\end{tabular}




\begin{tabular}{|c|c|}
\hline $\begin{array}{l}\text { TI Toldo } \\
\text { Pinhal }\end{array}$ & $\begin{array}{l}\text { Com nome de Pinhal, é declarada TI em 19/4/2007 e passa a ser denominada } \\
\text { Toldo Pinhal, pela Portaria 795, publicada em 20/4/2007. Pertence à Funai, ju- } \\
\text { risdição da Regional Interior Sul de Chapecó-SC. Com } 880 \text { ha demarcados e } \\
\text { 3.966,00 ha declarados e com portaria de demarcação anulada, possui exten- } \\
\text { são total de } 4.846,00 \text { ha, com uma população de } 138 \text { pessoas, conforme dados } \\
\text { da Funai - Chapecó (2016). Localiza-se na faixa de fronteira, no município } \\
\text { de Arvoredo-SC, que possui área de } 9.071 \text { ha, no município de Paial-SC, com } \\
\text { área de } 8.576 \text { ha, e no município de Seara-SC, com área de } 31.254 \text { ha. }\end{array}$ \\
\hline $\begin{array}{l}\text { Terra Indí- } \\
\text { gena Toldo } \\
\text { Chimban- } \\
\text { gue }\end{array}$ & $\begin{array}{l}\text { Com nome anterior à homologação de Chimbangue, passa à categoria de TI } \\
\text { (terra indígena), conforme REG, CRI e SPU de 29/10/1991 e pelo documento } \\
\text { decreto } 315 \text { publicação em 30/10/1991 no DOU. Pertence à Funai, jurisdição } \\
\text { da Regional Interior Sul de Chapecó-SC. Com extensão da área de } 988,66 \text { ha } \\
\text { homologada e mais uma área de 954,07 ha regularizada, é habitada por 553 } \\
\text { pessoas (FUNAI - Chapecó, 2016). Localiza-se na faixa de fronteira no mu- } \\
\text { nicípio de Chapecó-SC, na antes denominada Comunidade de sede Trentin. }\end{array}$ \\
\hline $\begin{array}{l}\text { TI Gua- } \\
\text { rani do } \\
\text { Araçaí }\end{array}$ & $\begin{array}{l}\text { Terra indígena guarani. Situação declarada, com área de } 2.721 \text { ha e localiza- } \\
\text { da nos municípios de Saudades e Cunha Porã-SC. Possui população de } 121 \\
\text { pessoas que aguardam pela posse, residindo na TI Toldo Chimbangue de } \\
\text { Chapecó-SC. }\end{array}$ \\
\hline $\begin{array}{l}\text { Acampa- } \\
\text { mento } \\
\text { Fraiburgo }\end{array}$ & $\begin{array}{l}\text { Área em estudo no município de Fraiburgo-SC, com sessenta indígenas cain- } \\
\text { gangue acampados no aguardo da delimitação. }\end{array}$ \\
\hline TI Palmas & $\begin{array}{l}\text { A Terra Indígena Palmas é habitada por oitocentas pessoas da etnia caingan- } \\
\text { gue. Está localizada nos municípios de Abelardo Luz-SC e Palmas-PR e possui } \\
\text { área de } 3.800,8794 \text { ha. Está regularizada e é tradicionalmente ocupada. Perten- } \\
\text { ce à Funai, jurisdição da Regional Interior Sul de Chapecó-SC. }\end{array}$ \\
\hline $\begin{array}{l}\text { TI Rio dos } \\
\text { Pardos }\end{array}$ & $\begin{array}{l}\text { A Terra Indígena Rio dos Pardos é habitada por } 48 \text { pessoas da etnia Xokleng. } \\
\text { Localizada no município de Porto União-SC, está homologada e regulariza- } \\
\text { da e possui 758,26 ha. Pertence à Funai, jurisdição da Regional Interior Sul de } \\
\text { Chapecó-SC. }\end{array}$ \\
\hline
\end{tabular}

Fonte: Funai - Chapecó (2016) e Piovezana (2016).

As terras indígenas constituem unidades políticas e territoriais dotadas de apenas um cacique ou líder político máximo. Entretanto, na estrutura política é regra que cada aldeia tenha um representante na liderança política constituída. Para Fernandes (2003), as iniciativas de concentração populacionais já empreendidas ignoraram a autonomia política relativa de cada aldeia, o que gerou situações de degradação social, política e econômica. Ademais, é dado etnográfico consolidado que o relacionamento entre as aldeias de uma mesma terra indígena seja constitutivo da dinâmica 
social. Essa dinâmica continua operante, mesmo nos contextos em que a concentração populacional foi objeto de política indigenista oficial.

Historicamente, o órgão indigenista federal, o Serviço de Proteção ao Índio (SPI), posteriormente Fundação Nacional do Índio (Funai), foi e é o responsável pela implantação de um sistema de lavouras coletivas nas terras indígenas. Esse sistema resultou na criação de um novo tipo de espaço coletivo, mas que não resistiu ao sistema de exploração dos moldes rurais do Brasil e, no início de 2016, ainda se encontrava com as terras concentradas nas mãos de algumas lideranças indígenas ou de famílias tradicionais ligadas e implicadas a produtores não indígenas do entorno. Tal situação tem ocasionado o êxodo da terra indígena para as aldeias, formando, assim, comunidades concentradas de agricultores sem terra e sem voz, que se sujeitam como trabalhadores boias-frias ou semiescravos nas lavouras de soja, milho e nas colheitas de frutas e poda da erva-mate da região Sul do Brasil. Não atendendo ao mínimo necessário para a manutenção de suas famílias, são aliciados ou obrigados a trabalhos nas agroindústrias da região. Somados com haitianos, são mais de cinco mil trabalhadores.

Inúmeras críticas já foram elaboradas a respeito dessas lavouras. É comum ouvir dos indígenas manifestações de insatisfação com relação a esse sistema produtivo; muitos são contrários ao uso intensivo de insumos agrícolas (necessários para a produção em grande escala), à dependência de sementes compradas, aos gastos excessivos com equipamentos e combustíveis e, principalmente, à gestão não participativa dos recursos gerados pelas lavouras coletivas. As críticas de analistas antropólogos, sociólogos e historiadores, entre eles Sílvio Coelho dos Santos, Ricardo Cid Fernandes, Vilmar D’Angelis e Vilson Cabral Júnior, às lavouras coletivas podem ser sintetizadas da seguinte forma: na maioria dos casos, as unidades sociais indígenas foram transformadas em unidades produtivas, ignorando-se a dinâmica tradicional de produção e socialização em nome das exigências dos mercados regionais, sem que isso resultasse, no entanto, em benefício para as comunidades. 
Apesar dessas considerações, os caingangues das unidades indígenas manifestaram, embora de forma não consensual, seu interesse na implantação de uma lavoura coletiva, chamada genericamente de "lavoura comunitária".

$\mathrm{O}$ que existe e se propaga nas terras indígenas é a reprodução das formas de produção tipicamente capitalistas com formas não tipicamente capitalistas, inclusive nas produções coletivas: a cooperativa é administrada por particulares que exploram o uso da terra em forma de parcerias. $\mathrm{O}$ proprietário indígena cede a terra e o seu trabalho; a cooperativa cede os maquinários e os defensivos agrícolas, cobrando em produção a sua parte.

Ressalta-se que esse modelo tem comprometido as formas tradicionais de usos da terra e, como consequência, a descapitalização do patrimônio cultural e das apropriações de saberes próprios de produção. No momento, processam-se os arrendamentos das terras para produtores da região por algumas famílias indígenas mais tradicionais, que se apropriaram de forma indevida de grandes áreas de terras mecanizadas, expulsando para os núcleos das aldeias muitas famílias caingangues.

[...] não é apenas indígena a terra onde se encontra edificada a casa, a maloca ou a taba indígena, como não é apenas indígena a terra onde se encontra a roça do índio. Não. A posse indígena é mais ampla, e terá que obedecer aos usos, costumes e tradições tribais, vale dizer o órgão federal de assistência ao índio, para poder afirmar a posse indígena sobre determinado trato de terra, primeiro que tudo, terá que mandar proceder ao levantamento destes usos, costumes e tradições tribais a fim de coletar elementos fáticos capazes de mostrar essa posse indígena no solo, e será de posse indígena toda a área que sirva ao índio ou ao grupo indígena para caça, para pesca, para coleta de frutos naturais, como aquela utilizada com roças, roçados, cemitério, habitação, realização de cultos tribais etc., hábitos que são índios e que, como tais, terão que ser conservados para preservação da subsistência do próprio grupo tribal. A posse indígena, pois, em síntese, se exerce sobre toda a área necessária à realização não somente das atividades economicamente úteis ao grupo tribal, como sobre aquela que lhe é propícia à realização dos seus cultos religiosos. (PONTES JUNIOR; BELTRÃO, 2005, p. 86). 
Todas as iniciativas nos moldes de produção das terras indígenas são advindas das necessidades e das políticas de produção dos granjeiros e investidores não indígenas da região. A maioria dos indígenas caingangue são vítimas desse processo, submetem-se por não terem outras opções de sobrevivência e, principalmente, por não terem a efetiva participação e regularização da Funai, órgão oficial do governo.

Segundo as lideranças caingangues do Sul do Brasil, terra é para a sobrevivência, e deve-se tirar dela o necessário para viver bem. Entretanto, todo esse processo de exploração independe deles. Essas lideranças afirmam que mais de $85 \%$ dos indígenas sobrevivem trabalhando como diaristas e do pouco que conseguem coletar na natureza: caça, pesca e matéria-prima para o artesanato.

A definição de áreas de conservação dentro dos limites da área de implantação da reserva é justificada pela forte relação dos índios com os elementos da natureza.

O modo de ocupação das terras do Sul do Brasil, mais intensamente da parte ocidental, está associada à intensa exploração madeireira, que tornou raras as áreas de floresta e, por isso, valiosas, principalmente pela sua biodiversidade. As áreas indígenas remanescentes foram exploradas pelo uso intensivo das grandes áreas mecanizáveis, inclusive com sinais de esgotamento do solo e instalação de processos erosivos. Algumas áreas protegidas por lei, como os remanescentes florestais das calhas dos rios Chapecó, Uruguai, Monte Alegre, Irani, Passo Fundo e outros, resistiram ao desmatamento não pela restrição legal, mas, provavelmente, pela declividade, pedregosidade e difícil acesso ao terreno.

Os indígenas aldeados e os não aldeados, denominados de bugres, por não se submeterem aos ditames da sociedade não indígena, embora partilhando da mesma identidade étnica, vivenciaram no pós-contato com os colonizadores, a partir do século XVIII, experiências diferenciadas de dizimação, subordinação, discriminação e condições de vida. Enquanto outra parte dessa população foi confinada em reservas indígenas, outra 
ficou à mercê de grupos da sociedade que a envolvia, sofrendo toda a forma de violência.

Diferentemente das formas tradicionais de uso das terras relatadas pelas pessoas mais velhas das comunidades indígenas caingangues, atualmente a terra não é só sinônimo de disputas com as populações não indígenas, mas também de disputas internas, necessitando de reforma agrária em terras indígenas. É um processo que vem se agravando desde os tempos do Serviço de Proteção ao Índio (SPI) e início da administração da Funai, também tida como latifundiária das terras indígenas.

Em razão da falta de condições para financiar suas roças e, mesmo, da falta de orientação para o cultivo, a maioria de homens e mulheres procura trabalho fora das TIs como diaristas, contratados temporários nas colheitas, limpezas de granjas, na poda da erva-mate e em trabalhos nas agroindústrias da região. Essa é a situação a que estão expostos para poderem alimentar-se no dia a dia, pois, na agricultura, exigem-se esperas, e não haveria possibilidade de sanar as necessidades mínimas de sobrevivência.

Reafirmamos o que diz Haesbaert (1999): a territorialidade realiza-se como possibilidade de recriação, pelos próprios grupos, de territórios originais que atendam não só as aspirações de reprodução material, mas também a expressão das especificidades culturais que efetivamente mobilizam os grupos sociais.

Para os indígenas, a territorialidade é poder social, é o meio pelo qual espaço e sociedade indígena se conectam, se inter-relacionam com as pessoas e coisas da vida presente, do passado e do futuro. É a ação da sociedade dual, sociocosmológica, responsável pela persistência e manutenção da identidade caingangue em territórios esfacelados pela ação política governamental e de outras territorialidades. 


\section{Considerações finais}

Indígenas caingangues, xockleng, guarani, xetá e agricultores não indígenas do estado de Santa Catarina são vítimas dos processos fundiários brasileiros. Agricultores, donos de suas terras, adquiridas com o suor de seus trabalhos, legalizadas pelo governo, são enganados, traiçoeiramente, como invasores, ilegais e desprovidos de direitos sobre a terra a não ser pelas benfeitorias, também prejudicadas pelas indecisões de permanência que perdura de década em década.

Nisso tudo, o conflito e a guerra armada são constantes, e os clamores de dor e de isolamento são ouvidos dos dois lados, desassistidos e colocados frente a frente, vítimas do desrespeito e até da morte precoce, enfim, da violência. Essa situação persiste há muitos anos.

Reconhecemos o direito aos indígenas e também aos agricultores não indígenas e percebemos nitidamente o quanto essas pessoas são vítimas de manobras politiqueiras, ludibriados pelas autoridades legais e de interesses econômicos deste país.

Nos dias 24 e 25 de março de 2014, no Plenarinho da Assembleia Legislativa do Estado de Santa Catarina (Alesc-SC), em evento intitulado "Terras indígenas e crescimento econômico: tempos de dúvidas e desafios", participantes do IV Seminário Interuniversitário reuniram-se para debater e sistematizar, de forma conjunta, informações e conhecimentos acerca da realidade vivida pelos povos indígenas em Santa Catarina e manifestaram apoio incondicional às lutas dos xokleng/laklãnõ, caingangue e guarani pelo reconhecimento e homologação de suas terras.

Os participantes expressaram a preocupação ambiental que envolve a responsabilidade social da ciência com a sociedade da qual fazem parte e que os sustenta.

Evidenciaram que, longe de constituírem-se em empecilhos ao desenvolvimento e ao progresso, como muitas vezes é divulgado pelas mídias e autoridades, observa-se o consenso na comunidade científica de que, nas 
áreas ocupadas pelas populações indígenas, há maior preservação de recursos naturais e ocupação controlada do território, ao contrário do que acontece, infelizmente, nas áreas ocupadas pela população não indígena. Manifestaram, assim, a preocupação com tentativas de alteração do texto constitucional, oriundas dos diversos poderes que compõem o Estado, e reiteram a necessidade premente de que o Estado e os representantes do povo brasileiro garantam os direitos constitucionais dos povos indígenas, constantes, sobretudo, nos art. 231 e 232 da Constituição Federal e no art. 192 da Constituição do estado de Santa Catarina, ainda que limitados em relação ao reparo histórico que o Brasil deve aos seus povos originários. Esses direitos devem ser garantidos pelos governos e pelo Estado de maneira firme e inequívoca, evitando provocar violências.

Manifestaram também apoio às lutas dos xokleng/laklãnõ, caingangue e guarani pelo reconhecimento e homologação de suas terras e manifestaram repúdio à violência simbólica, diuturnamente perpetrada por setores da imprensa, por particulares e por quaisquer forças que recorram a inverdades históricas e a preconceitos étnicos. E, nesse sentido, solicitaram que os governos federal e estadual acionem os mecanismos necessários para garantir que as mídias respeitem suas atribuições constitucionais, especialmente aquelas referentes à divulgação de informações fidedignas, bem como imparcialidade no que tange à veiculação das diferentes visões dos atores envolvidos nos processos demarcatórios e outros a eles relacionados.

Com efeito, esperamos que as cruzes fincadas nos caminhos das terras em conflitos não sejam manchadas pelo sangue de pessoas e voltem a ser a manifestação do abrir os braços para acolher numa terra sem males.

\section{REFERÊNCIAS}

BRASIL, Constituição 1988. Constituição da República Federativa do Brasil: texto constitucional promulgado em 5 de outubro de 1988. 
. Decreto n. 3.156 de 27 de agosto de 1999. Dispõe sobre as condições para a prestação de assistência à saúde dos povos indígenas, no âmbito do Sistema Único de Saúde, pelo Ministério da Saúde. Diário Oficial da União, ed. extra. Brasília: I (165-A), p. 37-38, 28 ago. 1999b.

. MINISTÉRIO DO DESENVOLVIMENTO AGRÁRIO. Secretaria de Desenvolvimento Territorial (SDT). Orientações para a indicação, elaboração e trâmite de projetos territoriais em 2007 e 2008. Disponível em: <www.mda.gov. br/sdt>. Acesso em: 20 mar. 2008.

Instituto Brasileiro de Geografia e Estatística. Estatísticas cadastrais municipais. Disponível em: <www.ibge.gov.br>. Acesso em: 20 mar. 2008.

CEOM. Cadernos do Centro de Organização da Memória Sócio-Cultural do Oeste de Santa Catarina. Chapecó: Unoesc, 1992.

D’ANGELIS, Wilmar da Rocha. Viry e revolta de Vaiton: Palmas 1843. Luta Indígena. Xanxerê-SC: Cimi Regional Sul, 1983.

Toldo Chimbangue: história e luta kaingang em Santa Catarina. Chapecó: Conselho Indigenista Missionário - Regional Sul, 1984.

DEBONA, Darci. Agricultores e indígenas disputam posse de terra. Disponível em: $\quad<$ http://dc.clicrbs.com.br/sc/noticias/noticia/2011/03/agricultores-eindigenas-disputam-posse-de-terras-3254026.html>. Acesso em: 8 fev. 2016.

FERNANDES, Ricardo Cid. Autoridade política kaingang: um estudo sobre a construção da legitimidade política entre os kaingang de Palmas/Paraná. Florianópolis, 1998, 201p. Dissertação (Mestrado em Antropologia) Universidade Federal de Santa Catarina, 1998.

Impactos da UHE Quebra-Queixo sobre a terra indígena Xapecó. Florianópolis: Laudo Antropológico, 2001.

- Laudo antropológico: reestudo dos limites da terra indígena toldo Pinhal. Florianópolis, 2003. Disponível em: $<$ http://pib.socioambiental.org/pt/ povo/kaingang/288>. Acesso em: 30 dez. 2009.

FERNANDES, Ricardo Cid; ALMEIDA, Ledson Kurtz; SACCHI, Angela Célia. Casa e ritual: um estudo sobre os papéis de gênero na construção da sociabilidade kaingang. Disponível em: <http://www.naya.org.ar/articulos/ etnias03.htm>. Argentina, 2000. Acesso em: 10 nov. 2006.

FUNAI. População em terra indígena. Brasília, 2006. 
. Disponível em: <http://www.funai.gov.br/indios/terras/conteudo. htm>. Acesso em: 28 dez. 2009.

. Disponível em: <http://www.funai.gov.br/indios/terras/conteudo. htm>. Acesso em: 8 fev. 2016.

HAESBAERT, Rogério. Identidades territoriais. In: ROSENDAHL, Zeny; CORREA, Roberto L. (Org.). Manifestações da cultura no espaço. Rio de Janeiro: UERJ, 1999. (Série Geografia Cultural).

. Des-caminhos e perspectivas do território. In: SPÓSITO, Eliseu Savério; RIBAS, Alexandre Domingos; SAQUET, Marcos Aurélio (Org.). Território e desenvolvimento: diferentes abordagens. Francisco Beltrão: Unioeste, 2004. p. 87-119.

$O$ mito da desterritorialização: do fim dos territórios à multiterritorialidade. Rio de Janeiro: Bertrand do Brasil, 2004a. 400 p.

INSTITUTO SOCIOAMBIENTAL. Agenda socioambiental 2009. Instituto Socioambiental, 2008. Disponível em: <http://www.socioambiental.org/pib/ portugues/quonqua/ondeestao/locext.html>. Acesso em: 28 ago. 2009.

PIOVEZANA, Leonel. Educação e cultura na terra indígena Xapecó. 2000. Dissertação (Mestrado em Desenvolvimento Regional) - Unisc-RS, 2000.

RAMOS, Alcida Rita. Sociedades indígenas. 5. ed. São Paulo: Ática, 1995. (Série Princípios).

SANTOS, Sílvio Coelho dos et al. Projeto Uruguai. Os barramentos e os índios. Florianópolis: UFSC, 1978.

. A integração do índio na sociedade regional. Florianópolis: Imprensa Universitária, UFSC, 1970.

. Nova história de Santa Catarina. Florianópolis: Do Autor, 1974.

. Educação e sociedades tribais. Porto Alegre: Movimento, 1975.

. O homem indio-sobrevivente do sul: antropologia visual. Florianópolis: UFSC; Caxias do Sul: Universidade de Caxias do Sul, 1978.

. As hidrelétricas, os índios e o direito. In: REIS, Maria José; BLOEMER, Neusa M. S. (Org.). Hidrelétricas e populações locais. Florianópolis: Cidade Futura; UFSC, 2001.

. Índios e brancos no sul do Brasil: a dramática experiência dos xokleng. Florianópolis: Edeine, 1973. 
et al. (Coord.). Estudo etnográfico da usina hidrelétrica Machadinho: projeto 145/98: relatório final. Florianópolis: UFSC/Fapeu/Nepi, 1998. 


\title{
Dádiva e reciprocidade: dimensões simbólicas na manutenção e reconfiguração dos territórios quilombolas de Arvinha e Mormaça
}

\author{
Edla Eggert ${ }^{1}$ \\ Heron Lisboa Oliveira ${ }^{2}$
}

\section{Considerações iniciais}

Historicamente as comunidades negras rurais se constituíram especialmente pela relação com a terra. Relação que ocorreu de forma conflituosa num processo de luta e resistência com as demais formas de discriminação e destituição dos direitos dos negros pós-abolição. Passados mais de cem anos da oficialização da abolição, os negros, em situação de vida rural, tiveram o direito à territorialidade reconhecida pela Constituição Federal de 1988, art. 68, do "Ato das disposições constitucionais transitórias" (BRASIL, 1988).

A partir daí inicia-se um movimento em todo o país pela identificação dessas comunidades e a busca pelo seu reconhecimento. Para elas, o território tem um valor simbólico não mensurado; é parte de um imaginário fantasiado de cultura que foge aos olhos da ciência e só a vivência e a pertença a esse território saberão explicar. As comunidades são remanescentes

1 Doutora em Teologia; pesquisadora $1 \mathrm{D}$ do CNPq e professora do Programa de Pós-Graduação em Educação da Pontifícia Universidade Católica (PUCRS). Contato: eggert@gmail.com

2 Doutor em Educação pela Unisinos; professor Titular do Instituto Federal de Educação do RS (IFRS) Campus Sertão. Contato: heron.lisboa@sertao.ifrs.edu.br 
dos antigos quilombos Arvinha e Mormaça, reconhecidas pela Fundação Cultural Palmares, originárias da descendência das escravas Cezarina de Miranda e Firmina Vieira, respectivamente.

Arvinha e Mormaça localizam-se no norte do Rio Grande do Sul na mesorregião do Planalto Médio, com áreas nos municípios de Sertão e Coxilha (Figura 1), tendo referência com maior expressão o município de Passo Fundo - polo regional em diversos setores. Além de semelhanças nas trajetórias de formação, luta e resistência - laços que as congregam —, as comunidades têm proximidades territoriais, a $16 \mathrm{~km}$ por estrada intermunicipal, que liga esses dois municípios; Arvinha possui a maior parte do território distribuída na zona rural de Sertão (em torno de 85\%).

Figura 1 - Municípios de Sertão e Coxilha (norte do RS) - espaço de presença das duas comunidades quilombolas

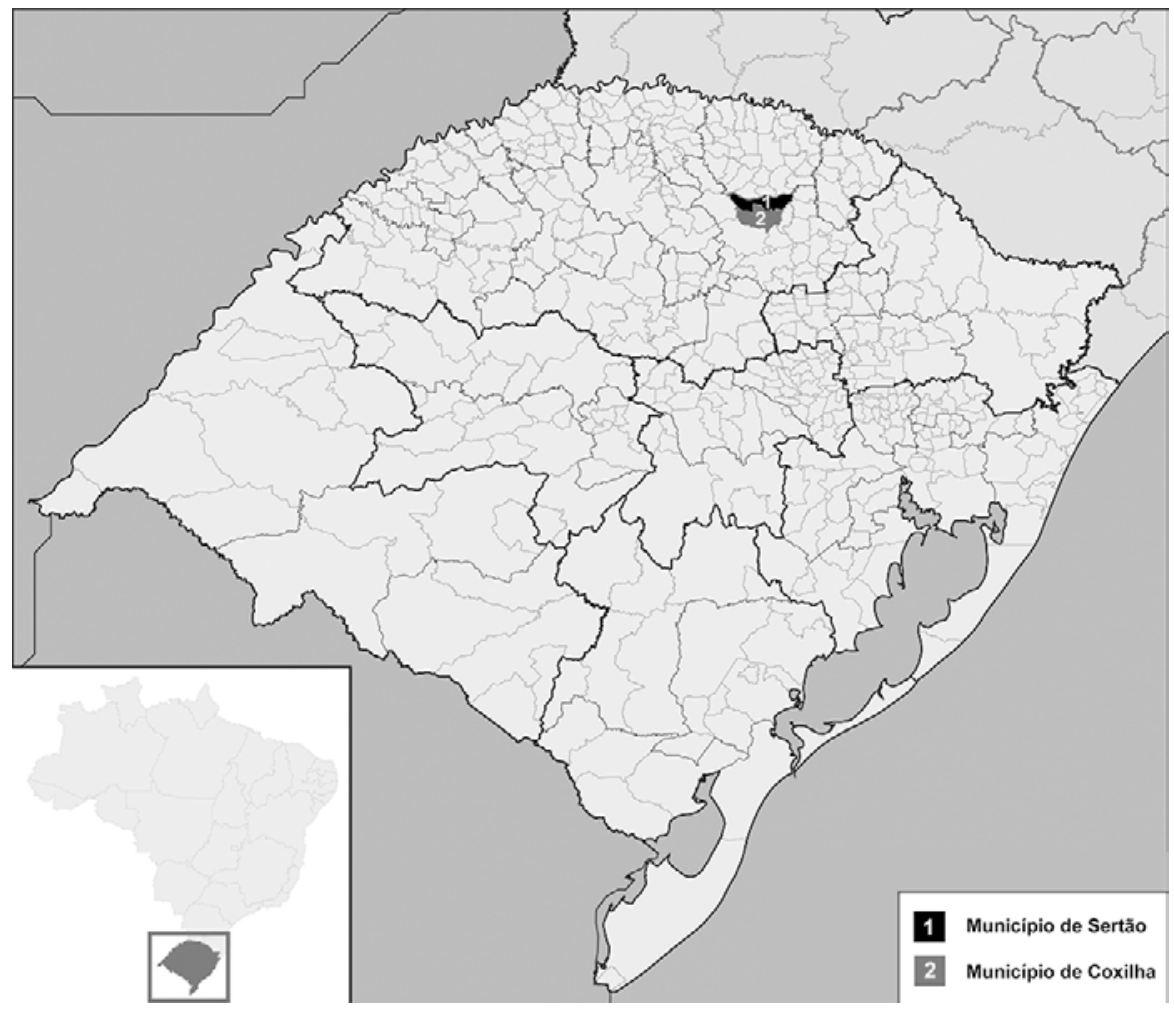


A discussão gira em torno do território e da territorialidade que constituem a questão importante desde há muito tempo, especialmente nessas três últimas décadas, para as comunidades negras que descendem de quilombos. Há busca de afirmação, primeiramente, em garantir o reduzido espaço físico a que hoje estão submetidas, guardando suas fronteiras; segundo, agregar outros que anteriormente já lhes pertenciam como condição de sobrevivência e reprodução dos grupos; terceiro, a longa espera na tramitação dos processos de regularização e titulação dos territórios no âmbito administrativo, especialmente na esfera política. Agregadas a essas intenções, perpassando a territorialidade, estão ações de dádiva e reciprocidade, secularmente praticadas entre moradores como possibilidades colaborativas - mesmo que não intencionais - para a manutenção e luta na retomada.

A dádiva e a reciprocidade ensejam o objeto da escrita. Essas práticas têm significado, entre outras, da possibilidade de manter as comunidades "unas" para a permanência e ampliação de seus territórios - um sentimento comum do grupo. Utilizam estratégias variadas de luta, porém o sentimento tem forte apelo de aproximação, ensejado por atos de dar e receber.

No entanto, esse território (Figura 2) constitui campo de disputas entre diversos atores. Com suas razões históricas e de ocupação, as comunidades remanescentes de Arvinha e Mormaça lutam, por um lado, pela permanência e anexações; por outro, famílias agricultoras, segunda e terceira gerações de colonizadores europeus que migraram para a região a partir de 1907, decorrentes de um processo de colonização pública e também privada, comprovam ter trabalhado essas terras, construído suas residências e instalações nas propriedades, adquirido máquinas e equipamentos, melhorado o processo produtivo e colaborado com a produção nacional de alimentos e com a própria arrecadação de impostos que revertem para a melhoria das comunidades regionais. É referida também a possibilidade da sobrevivência e reprodução de suas famílias. Suas ocupações são as lides com a terra na profissão de agricultores e agricultoras. 
O texto fundamenta-se em pesquisas a partir de 2008. Metodologicamente, lança-se mão da observação participante, de entrevistas com lideranças e moradores quilombolas, agricultores vizinhos e moradores da região. Utilizam-se referenciais bibliográficos que trabalham a história regional, a colonização do norte gaúcho, a formação das comunidades quilombolas, a migração de agricultores e discussões sobre dádiva e reciprocidade entre diversos povos, especialmente entre moradores quilombolas.

Figura 2 - Mapa localizando as comunidades rurais e a sede do município de Sertão-RS

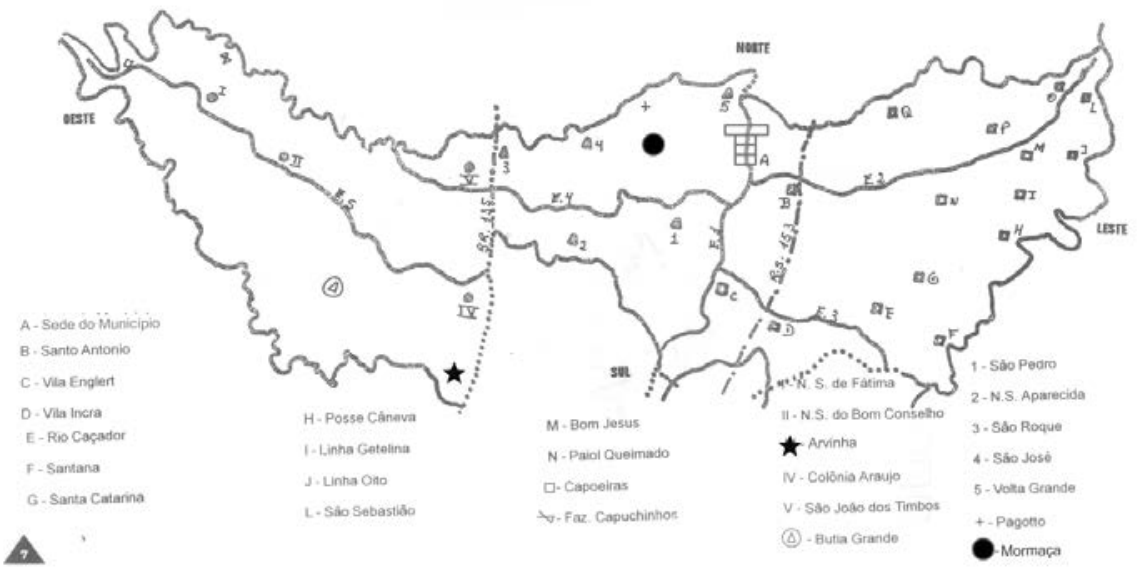

Fonte: Misturini, Olavo S.; Oliveira, Iris M. (1986).

\section{Território: configuração do espaço de sobrevivência}

O conceito de que território se refere a um espaço qualquer, geralmente marcado e defendido, espaço de sobrevivência de um grupo ou pessoa, há muito vem se ampliando na possibilidade de abarcar uma série de ocorrências que se passam em seu interior. Termo originário do latim 
territorium (terra), figurava nos tratados de agrimensura significando "pedaço de terra apropriada".

O território, então, não se reduz a uma entidade jurídica. Segundo Saquet (2007), o território resulta das relações sociedade/natureza, sendo condição para a reprodução social, campo de forças historicamente determinadas. $\mathrm{O}$ autor entende que:

As forças sociais efetivam o território, o processo social, no (e com o) espaço geográfico, centrado na territorialidade cotidiana dos indivíduos e emanado dela, em diferentes centralidades, temporalidades e territorialidades, que condicionam nossa vida cotidiana. Formam-se territórios heterogêneos e sobrepostos fundados em desigualdades e diferenças. Cristalizam-se territorialidades e interesses predominantemente econômicos e/ou políticos e/ou culturais que dão certa forma e determinados conteúdos ao território e aos territórios (SAQUET, 2007, p. 127-128).

Assim, tem-se a compreensão de que território não se resume a espaços predeterminados, uma área de campo, uma praça ou uma rua; tem de despertar um sentido, levar consigo um significado de apropriação, um sentimento. Por isso, o sentido do pertencimento, "eu sou daqui", e de apropriação, "isto é meu", "esta é a minha terra", "este é meu domínio", muito presente no campesinato e também entre os moradores de Arvinha e Mormaça (campesinato quilombola), vem ao encontro da percepção de Haesbaert (2004, p. 4): "Portanto, todo território é, ao mesmo tempo e obrigatoriamente, em diferentes combinações, funcional e simbólico, pois exercemos domínio sobre o espaço tanto para realizar 'funções' quanto para produzir 'significados"'.

Essas comunidades no viver de seus cotidianos experienciam o território como um lugar habitado, constituindo-se, assim, um lugar de "ocorrência de sentido”. Na visão de Milton Santos, o território só faz sentido como espaço usado: "O território só se torna um conceito utilizável para a análise social quando o consideramos a partir de seu uso, a partir do 
momento em que o pensamos justamente com aqueles atores que dele se utilizam" (SANTOS, 2000, p. 22).

Nos contatos com os remanescentes, ficou muito claro o intento dos quilombolas de Arvinha e Mormaça na conquista da terra e na possibilidade de viver nela em liberdade. Segundo Freire, "a liberdade, que é uma conquista, e não uma doação, exige uma permanente busca. Busca permanente que só existe no ato responsável de quem a faz. Ninguém tem liberdade para ser livre: pelo contrário, luta por ela precisamente por que não a tem" (2005, p. 37).

Rubert e Moura Mello (2011) demonstram que, no caso das comunidades remanescentes de quilombos localizadas no Rio Grande do Sul, a territorialização negra teve um caráter multifacetado. Independentemente da forma pela qual se teve acesso à terra, deve-se tratar a territorialização étnica a partir dessa ênfase recente da historiografia da escravidão, segundo a qual as ações dos escravos - o que se poderia chamar de "resistência" - tiveram um caráter multifacetado.

Assim como as diversas comunidades remanescentes de quilombos espalhadas pelo Brasil, a origem de Arvinha e Mormaça não remonta à fuga ou à insurgência de escravos. Esse caráter histórico de resistência apresenta-se por meio da descendência matrifocal das escravas Cezarina e Firmina na luta pela construção e manutenção daqueles territórios. Isso não significa que os antecedentes do grupo não tenham se deparado com uma série de arbitrariedades. Diante de situações adversas, distintas, é possível que algumas estratégias fossem acionadas, como socorrer-se com indivíduos dotados de maior capital, estabelecer relações amistosas com o senhorio, formalizar as posses e saquear os rebanhos dos estancieiros, entre outras.

No entanto, esse território do qual se fala constitui relação conflitante, campo de disputa: num fronte, as comunidades remanescentes de Arvinha e Mormaça lutam pela permanência e anexações; noutro, as famílias agricultoras lutam pela manutenção de suas propriedades. 
O grupo de agricultores organizados em forma de associação tem trabalhado no sentido de defender as suas propriedades, buscado apoio junto aos órgãos públicos (prefeituras), agentes públicos, sindicatos rurais (especialmente os patronais), sociedade local e políticos (vereadores, prefeitos e deputados) identificados com o setor ruralista empresarial. Em contraposição a outros realizados, contrataram novo "laudo histórico" que apura "aquelas terras não terem sido ocupadas por negros escravos e ex-escravos". Vivencia-se um impasse, uma situação de conflito.

Em Arvinha e Mormaça, a ocorrência de relações parentais entre quase a totalidade dos membros em cada comunidade levou a que se concretizassem valores morais regidos por determinados códigos. A condição de ser parente, compadre, amigo e vizinho era determinante na interação, o que torna o vínculo primordial na compreensão da dinâmica social das comunidades.

Observando a relação estabelecida entre os remanescentes de Mormaça com os "vizinhos" eurodescendentes, a maioria italianos, tem-se novamente uma perspectiva do contraste. Tomando o sistema de mercado visto pelos dois grupos, expressa-se uma dualidade, em que o sistema de mercado pressupõe uma razão utilitária, isto é, o que move a ação é o interesse econômico. O mercado é um dos recursos interessantes de que se pode lançar mão para análise da forma como cada grupo o pratica. Nesse prisma, o cálculo torna-se relevante, pois é a partir dele que se avalia a ação do agente como prejudicial ou vantajosa. Em termos econômicos, lucrativa. Dessa angulação, o morador quilombola com sua família sentencia: "Nossa produção é pequena, mas não é só por causa da área. Produzimo um pouco de tudo, coisas de horta, tempero, o milho, a mandioca, a aveia, o trigo, o leite, o porco gordo pra banha e a carne e outras poucas coisas. Eles plantam só o soja, nem engordam porco!” (N. R. 65, set. 2012).

A justificativa do agricultor quilombola de que em suas atividades produz um pouco de várias coisas e que "os outros, só soja”, não é somente uma crítica pela não concordância; expressa, sim, uma racionalidade mercantil do contraste, pela qual seu vizinho busca otimizar a ocupação 
daquele espaço de terra especializando-se naquele cultivo, acelerando a produção por área, atendendo às demandas do mercado e, em consequência, tendo maiores ganhos individuais (lucro).

O morador quilombola, ao expor sua lógica e dos seus, deseja demonstrar que há outros condicionantes que não somente a relação mercantil quando rejeita o plantio para o mercado. Nesse momento se estabelece no grupo o princípio da dádiva que se sobrepõe ao cálculo utilitário como uma incorporação da terra-território. A finalidade da exploração mercantil do plantador de soja é a venda de sua produção, ao passo que para o remanescente a comercialização não é fator principal, já que se comercializa o excedente, se houver, depois da partilha entre seu grupo.

Ieda Ramos (2009), em pesquisa que desenvolveu na comunidade quilombola Cambará, no interior do município de Cachoeira do Sul-RS, bem observou essa prática:

O sistema de dádiva se constitui como a perspectiva de que os bens circulem com o objetivo de fortalecer os vínculos. Ou seja, quando o produto oferecido ou serviço prestado não tiver um fim em si mesmo, mas visa criar, consolidar e alimentar relações interpessoais. Em oposição ao modelo de intercâmbio, a dádiva recusa a equivalência e, por conseguinte, rejeita o cálculo, instrumento que baliza a relação mercantil (RAMOS, 2009, p. 62).

Os "vínculos fortalecidos" que a pesquisadora detectou em seu trabalho, para N. R., morador da Mormaça, mesmo que na subliminaridade de sua proposta, trata-se da ocorrência de um processo educativo envolvendo os mais próximos, com perspectiva de ampliar-se aos demais. $\mathrm{Na}$ relação diária configura-se um processo de ensinar e aprender, considerando sua visão de utilização dos recursos naturais, a produção de diversos produtos úteis de consumo imediato e para todos. Essa visão prática que "perpassa" as gerações, constituindo essa outra forma de produção não mercantilista, mas pela qual todos se beneficiam, parece ser mais 
afetiva. Para ele, "produzir soja e não engordar porco" é ação de alguém que não está integrado àquele meio natural-cultural; preocupa-se com o lucro, quando precisar tempero ou um pé de alface, vai até o mercado na cidade e compra, transmite outra lógica de mercado aos seus.

Precisamente nessas demonstrações de apego a tudo que é parte daquele cotidiano, que é valoroso e diz respeito a todos, se renovam laços que, igualmente, vão dando configuração ao território. O território é um espaço de convivência e nele se dão as relações sociais que na memória dos mais antigos traçam um comparativo entre o anterior e o atual nesse lugar materializado nas moradias de antepassados, marcos, divisas identificadas por elementos da natureza. $\mathrm{O}$ ato de rememorar traz consigo concepções do justo e injusto, acontecimentos significativos, histórias, causos recontados associando lugares a pessoas nessa memória coletiva, perceptíveis em Mormaça e Arvinha (Figura 3).

Figura 3 - Território multifacetado - "o homem e o menino" - duas gerações restevando palha de trigo em espaço outrora quilombola (Mormaça)

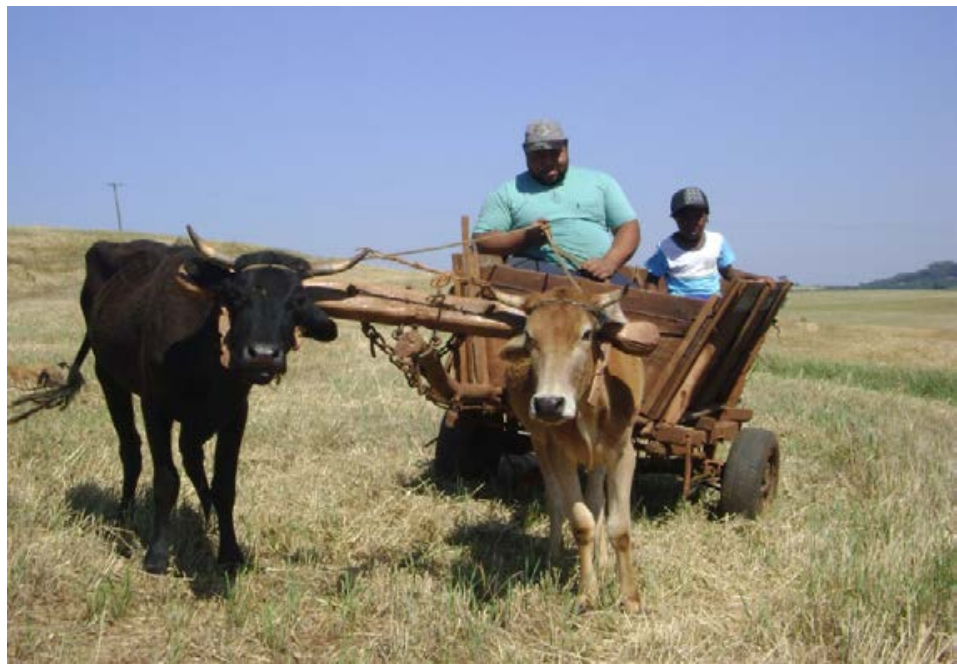

Fonte: Arquivo de pesquisa (2010).

Próximo de um dos núcleos familiares do "tronco Quirino de Miranda" em Arvinha, o morador N. C. e sua esposa, I. R. C., relatam no 
quadro atual da paisagem outra configuração que identifica o cotidiano daqueles moradores. “Toda essa terra aí agora é dos Bianchini de Tapejara [município que fica a uns $80 \mathrm{~km}$, na mesma região, a empresa possui ali uma área de 170 hectares], faz uns quinze anos plantaram eucalipto, cresceu, já cortaram. Agora tão plantando de novo outra floresta de eucalipto. Antes tinha grama que se ia, uns capão de mato, uns banhado, era muita terra. Agora só se vê eucalipto pra poste e lenha” (N. C., 64, e I. R. C., 59, set. 2012).

A lembrança nítida em suas memórias de uma "era” não tão distante mostra a alteração do ambiente que, possivelmente, seus antepassados conheciam e utilizavam como espaço de sobrevivência em cultivos, criações ou, quando ainda jovens, contemplavam aquela exuberância "pintada" como natural. É uma denúncia inscrita na terra do avanço sobre o território da comunidade. Uma possível expropriação da terra de seus legítimos donos, alterando aquele espaço de vivência e de sociabilidade.

Figura 4 - Ambiente natural alterado - plantação do exótico eucalipto em território de "antanho" quilombola (Arvinha)

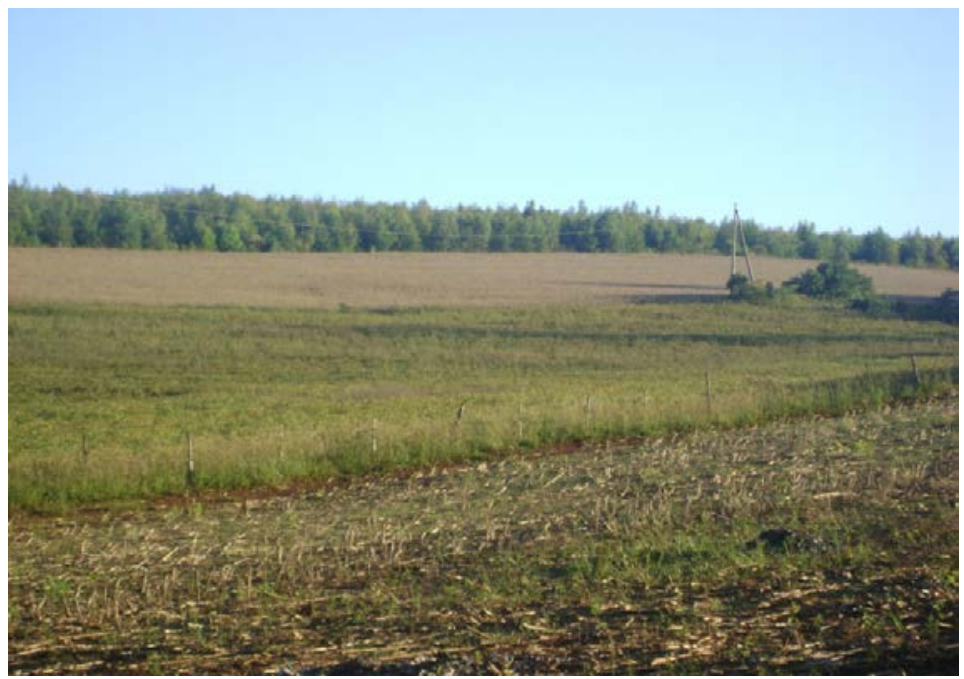


Especificamente a respeito dessa área, que corresponde a quase 50\% do território de Arvinha, delimitada pelo Incra e publicada no DOU em setembro de 2009 (386 ha), a liderança M. T. informou, em outubro de 2013, assim como o próprio morador quilombola, que a empresa interessa vender a área para a União com essa finalidade: "não coloca dificuldades" (N. C., 66, mar. 2014). Depreende-se disso a possibilidade da negociação e não ser um processo "traumático", considerando não haver necessidade de "desintrusão".

A alteração da conformação territorial com a vinda de outros grupos e a usurpação de áreas-território praticada por empresas colonizadoras com o aval do Estado no passado e também por médios e grandes produtores da região modificaram não só a geografia-paisagem do ambiente, mas também impediram formas sociais alternativas de organização do espaço. "A perda dos territórios implicou a devastação de árvores e pomares, hortas etc. Mas o importante a notar é que a ênfase dada por alguns moradores ao fato de a região ter outra configuração quando os domínios pertenciam exclusivamente ao grupo revela uma inconformidade não apenas com o esbulho de terras, mas com a alteração espacial de um território-vida, outrora conservado e abundante em alimentos e animais" (RAMOS, 2009, p. 64).

Infere-se, portanto, que não somente ocorreu uma mudança física na paisagem, o que já representa um grande dano a essa terra/território, mas que desencadeia um processo mais profundo. E isso afetará, certamente, a constituição identitária dos habitantes daquelas comunidades, $o$ desintegrar-se do "território-vida", ou seja, a compreensão de um território repleto de espaços, de aprendizagens, de trocas, de acompanhamento e de experimentação. 


\section{A privatização das áreas comuns e as assimetrias}

A exploração mais intensiva das áreas rurais no Brasil no sentido da transformação das paisagens e biomas ocorre a partir da metade da década de 1960 e 1970 nas regiões Sul e Sudeste. As demais serão incorporadas mais tarde, considerando que agricultores dessas duas regiões migram para "abrir fronteiras" agrícolas no Centro-Oeste, Norte e Nordeste brasileiros nos idos de 1980-1990.

A nova utilização das terras com a abertura de grandes áreas decorreu principalmente pelo financiamento público promovido pelos governos militares por intermédio de agentes financeiros estatais, aliado, entre outros fatos, à compra de uma tecnologia não apropriada e cara, levando à dependência externa ainda maior, promovendo aumento da dívida externa brasileira.

As populações campesinas e urbanas também foram atingidas por esse impacto. Contingentes de trabalhadores e trabalhadoras rurais evadiram-se dos campos e de suas atividades tradicionais, deixando suas terras a caminho das cidades, que, sem estrutura para acomodá-los, nem postos suficientes de trabalho, os levou a aumentar "bolsões populacionais" nas periferias.

As comunidades rurais integradas à natureza que historicamente viviam ocupando áreas mais extensas também foram afetadas, como as indígenas e quilombolas. Viram seus espaços invadidos, usurpados, povos ameaçados de morte e mortos, lideranças assassinadas, modificando sua história e cultura, afetando profundamente sua sobrevivência e continuidade das gerações.

As comunidades remanescentes de Arvinha e Mormaça da mesma maneira e pelos mesmos motivos viram alteradas as condições que há dezenas de anos permaneciam imutáveis. Espaços há muito utilizados, terras com plantios e criações, fontes de água e reservatórios naturais, riachos, passagens, "carreiros" abertos naturalmente pelo constante transitar foram, num curto espaço de tempo, interrompidos e cerceados de uso. Máquinas 
derrubaram, aterraram, impuseram as cercas, marcaram divisas, descaracterizaram continuidades e provocaram desaprendizagens e ocultamentos. Interromperam uma história de mais de 150 anos.

O cercamento é "um dos impeditivos da liberdade de ir e vir", limita acessos, comunicação, processos de troca, relações e dádivas proporcionadas pela natureza, assim como a utilização das riquezas naturais, $o$ conhecimento e as experiências que se davam por meio de formas não escolares de ensinar e aprender. A partir da delimitação desses espaços comuns, agora em domínio privado, os remanescentes passam à obediência das normas dos agricultores brancos, oficializados pelo Estado, o que os tornam dependentes e vulneráveis. Em decorrência da "tomada" dos domínios comuns, essas comunidades viram a exaustão dos recursos naturais e o seu comprometimento com o meio, o que é comprovado pelo risco da sobrevivência e das suas continuidades.

Essa realidade não foi percebida somente nas comunidades discutidas. Pesquisas em outras regiões brasileiras verificam esse repetir e, como declara Ramos (2009), isso "serve para pintar o mesmo quadro". Cunha (2010), ao estudar a expansão capitalista no sertão norte mineiro a partir de 1970, enfatiza:

Neste processo de modernização, a região teve grande parte de seu território desmatado para abrigar esta nova forma de exploração capitalista. Assim, expressiva parcela de populações rurais sertanejas foi expulsa de suas terras, uma vez que ocupavam áreas consideradas devolutas concedidas pelo Estado a grupos empresariais. $\mathrm{O}$ cercamento dos campos, [...] não tardou a se fazer, contando, inclusive, com o apoio formal do Estado, privatizando grande parte das terras devolutas, com contratos de concessão por vinte anos para empresas de plantação de eucalipto, como os efetuados pela Ruralminas durante o regime ditatorial sob tutela militar, em Minas Gerais (CUNHA, 2010, p. 6, apud GONÇALVES, 2004, p. 222). 
Percebe-se que nessa nova divisão territorial desdobra-se a perda da identidade do grupo e também do conhecimento acumulado no decorrer dos tempos:

As consequências da modernização no campo são o desaparecimento e/ou encurralamento das 'gentes sertanejas' e das identidades locais ocasionado pela perda de seus territórios, pelo cercamento dos territórios coletivos e pelo desequilíbrio ambiental em decorrência das atividades capitalistas; a perda do conhecimento acumulado por essas populações sobre o ambiente e a pauperização dessas populações que permanecem nas áreas rurais e que lutam por criarem novas estratégias de sobrevivência, ou daquelas que se transferiram para as áreas urbanas e que habitam as periferias das cidades (CUNHA, 2010, p. 7).

Ramos (2009), na comunidade remanescente de Cambará, no município de Cachoeira do Sul-RS, assim percebe: "Até mesmo a fruição dos bens existentes no interior de diminutas parcelas de terras hoje pertencentes à comunidade é ameaçada pelos impactos causados pelo avanço das cercas. Estou diante de um processo de colonização de dádivas, de bens naturais que deveriam ser usufruídos tranquilamente sem restrições e impedimentos" (p. 65).

Essa nova configuração do espaço rural vem aumentar o distanciamento entre populações. Trouxe, de um lado, vantagens para a velha elite rural, com o seu reaparelhamento territorial e o surgimento da nova classe rural brasileira, representada pela imigração europeia que inaugura esse novo modelo produtivo agrário baseado no mercado; de outro, perdas de autonomia, do conhecimento acumulado, bem como do espaço de sobrevivência e continuidade a grupos mais vulneráveis e desprotegidos, como indígenas e remanescentes quilombolas, condições essas avalizadas pelo Estado brasileiro (Figura 5). 
Figura 5 - "Cercamentos" impedindo acesso a espaços comuns
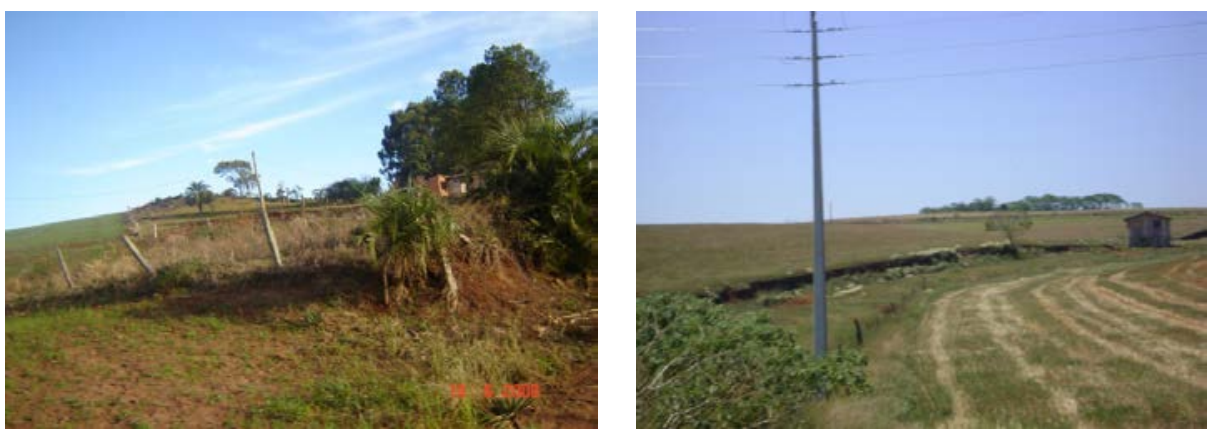

Fonte: Arquivo de pesquisa (2008/2011).

Assim, em decorrência dessas transformações, as comunidades remanescentes que passaram pelo processo de expropriação estão sujeitas a um novo processo de "colonização histórica" que está se repetindo nessas primeiras décadas do século XXI.

\section{Dádivas e reciprocidade: simbologia de coesão comunitária}

A reciprocidade constitui resposta ao ato da dádiva - ação de dar de forma generosa e gratuita, de receber e retribuir, formando um processo de solidariedade e ajuda mútua e fortalecendo a confiança e os laços de amizade, pois no ato de dar ocorre mais que uma mera troca; existe todo um simbolismo presente que reforça os valores humanos. Mauss (1974) considera que o fato de presentear alguma coisa a alguém é dar algo de si, “o vínculo pelas coisas é um vínculo pela alma”.

Para as comunidades Arvinha e Mormaça, o modo de se relacionarem em seus cotidianos pelo princípio da dádiva constituiu-se e constitui-se prática que possibilitou coesão entre os membros desses grupos, permitindo-lhes uma travessia iniciada no "ajuntamento de pessoas", criando aglomerações e, posteriormente, passando à formação de uma comunidade, 
quando hoje, em período recente, a Constituição brasileira vem reconhecê-los como remanescentes de escravos e ex-escravos.

Tal fato revestiu-se de maior importância aos remanescentes da Mormaça. Essa comunidade conseguiu resistir à opressão e espoliação, especialmente nesses últimos setenta anos (se considerarmos que a partir de 1950, a modernização da agricultura tornou desenfreada a busca por novas áreas e seus territórios foram os primeiros a sofrer esse ataque ganancioso do capital, com riscos eminentes de verem seus espaços findos), por relacionar entre os seus o princípio da dádiva. A consolidação de laços de solidariedade, a partir dessa racionalidade, permitiu a resistência diante da ameaça de outros grupos as suas continuidades.

Por outro lado, se os membros da comunidade fossem movidos por uma razão utilitária, essa resistência estaria impossibilitada de concretizar-se. É possível que esses laços, que as relações baseadas no princípio da dádiva, iniciados pela identificação étnica, que não depende somente da cor da pele, mas de aprendizagens e experiências repetidas no passado, além de uma convivência comum consolidada nas alianças de parentesco, venham contemporaneamente exprimir a identidade da comunidade negra de Mormaça, concretizados na etnicidade, no parentesco e na dádiva.

Para Mauss (1974), a dádiva não se restringe a "simplesmente regalos", está representada numa maior amplitude, segundo a qual "eles (os Polinésios), não trocam exclusivamente bens e riquezas ou coisas úteis economicamente. São, antes de tudo, amabilidades, banquetes, ritos, serviços militares, mulheres, crianças, danças, festas e feiras" (MAUSS, 1974, p. 191). Essas prestações e contraprestações se estabelecem de uma forma sobretudo voluntária, por meio de presentes, embora no fundo sejam rigorosamente obrigatórias, o que ele chama de "prestações totais". Quem as assume não são somente indivíduos; são coletividades que se obrigam mutuamente, trocam e contratam; as pessoas presentes ao contrato são pessoas morais (clãs, tribos, famílias). 
A circulação da dádiva se dá entre amigos, entre vizinhos, entre parentes na forma de presentes, de serviços e de hospitalidade, ao passo que na sociedade moderna vai circular também entre desconhecidos, em doações de sangue, de órgãos, filantropia, doações humanitárias, benevolência e outras formas. A dádiva baseia-se na dívida, que pode ser positiva ou negativa. Não é uma noção contábil, é um estado no qual cada um considera que, em termos gerais, recebe mais do que dá (SILVEIRA, 2010, p. 24).

Assim, tem-se que reciprocidade não é um ato humano preexistente, dado. Ela é construída no processo de relação social, seja em comunidades abertas, seja em comunidades fechadas. A reciprocidade provém da amizade, das relações de parentesco e do compadrio. De acordo com Silveira (2010), a demonstração material pode estar representada pela troca de presentes, prestação de serviços, ajuda mútua, consolo, ato de ensinar e demais formas de expressar uma amizade emocional, a qual se caracteriza pela forte troca afetiva entre os membros, além de trocas materiais comuns na sociedade fechada.

Nas comunidades rurais brasileiras, mesmo nas que um morador vive distante do outro, a reciprocidade nas relações de vizinhança ocorre na forma de compadrio, com um vizinho apadrinhando o filho do outro, por exemplo, e essa trama vai se materializando na forma de amizade, presentes, oferendas de festas ou troca de serviços. Entretanto, nessas relações também ocorre amizade institucional ou instrumental, como aquela que se caracteriza pela possibilidade de o indivíduo ascender socialmente por meio das trocas de recursos materiais e apoios. Por sua vez, numa situação de assimetria (desigualdade e desequilíbrio) entre os membros, o clientelismo pode se tornar uma amizade de patrono-cliente, geralmente mais comum nos grupos abertos. 


\section{Dádiva e reciprocidade cultivadas em Arvinha e Mormaça}

Dentre os diversos encontros com moradores de Arvinha e Mormaça, um se destacou mais descontraído e "democrático", uma vez que já se estava mais conhecido. No início, apresentado como "pesquisador", as coisas não fluíram com naturalidade, às vezes ficávamos mais restritos às lideranças e aos moradores mais antigos. Porém, nesse dia, um encontro mais "festivo" ocorreu. As pessoas gostam de falar da alegria, do que lhes dá prazer, do que lhes faz bem e lhes dá sentido. Procurou-se tratar de dádiva, de reciprocidade, de doação, de ajuda mútua e, para aquelas comunidades, se não houvesse dádiva e reciprocidade em suas tramas de sociabilidade, provavelmente suas continuidades estariam ainda mais comprometidas.

A respeito da cristalização dessa sociabilidade que se configura na identidade étnica das comunidades, Mauss afirma: “[...] as sociedades progrediram na medida em que elas mesmas, seus subgrupos e seus indivíduos, souberam estabilizar suas relações de dar, receber e, enfim, retribuir [...]; [...] esse é um dos segredos permanentes de sua sabedoria e de sua solidariedade" (1974, p. 313). Mesmo com o pouco que possuem, o ato da doação representa muito mais por seu sentido do que propriamente pelo bem ou ação em questão. Mulheres e homens relataram suas práticas de convivência e doação no seu núcleo familiar, no núcleo ampliado pelas relações de parentesco e com a comunidade num todo.

A prestação de dádivas em Arvinha e Mormaça assenta-se principalmente no emprego da força de trabalho, demonstrando, nesse princípio de ação, quão imbricadas são suas dívidas para com o território. A preferência por dar a força de trabalho ao outro em vez de vendê-la é constatada ainda nos "puxirões", 3 que fazem em épocas determinadas

3 "Puxirão" é conhecido por mobilização coletiva para lograr um fim, baseando-se na ajuda mútua prestada gratuitamente. É uma expressão usada originalmente para o trabalho no campo ou na construção civil de casas populares, em que todos são beneficiários e, concomitantemente, prestam auxílio, num sistema de rodízio e sem hierarquia. Atualmente, por extensão de sentido, se utiliza o termo "mutirão" que pode designar qualquer iniciativa coletiva 
nas atividades agrícolas, com necessidade de maior número de trabalhadores na execução, como em plantios, colheitas e roçadas. Essas atividades rurais, assim como em algumas no meio urbano, principalmente as expostas ao tempo, exigem que se realizem em condições ideais de trabalho e rendimento.

Nesses "puxirões" ou mutirões se envolvem quase todos os membros das famílias, inclusive crianças e jovens, atendendo aos adultos com ferramentas e água, agrupando-se para trabalharem. As mulheres talvez sejam as que maiores compromissos assumem. Mesmo antes do dia marcado para o puxirão organizam a casa, os lugares das refeições, providenciam a comida, ajudam no trabalho agrícola e, ainda, ao final das tarefas, voltam a reorganizar aqueles espaços, desempenhando uma verdadeira multiplicidade de jornadas. ${ }^{4}$

Atualmente essas atividades reduziram bastante em consequência da diminuição territorial das comunidades, principalmente de Mormaça. Uma das moradoras mais antigas e que participou dessas atividades, dona Teresa, tem clara lembrança desse tempo:

Naquela época se plantava milho, feijão e trigo. No verão, no sol de janero, tinha que arrancá o feijão e deixá secá no tempo. Quando secava tinha que "maiá" de uma vez, antes da chuva. Por abril dobrava o milho, pra secar melhor e não dá caruncho, depois, nas colheita, fazia as bandera e tinha que trilhar. Nóis não tinha trilhadera, pagava "pros de fora". O trigo dava trabalho, cortava com uma foicinha, tinha que se agacha, "doía as cadera" e tinha que trilhá

para a execução de um serviço não remunerado, como um mutirão para a pintura da escola do bairro, limpeza de um parque. Outros nomes são conhecidos na área rural do Brasil, como putirão, putirum, pixurum, punxirum, ademão, adjunto, bandeira, batalhão.

4 Jornada de trabalho da mulher. O processo de emancipação das mulheres tem avançado significativamente no último século e início do novo pelo protagonismo das ações e dos embates que realiza em seu cotidiano de espaços públicos e privados. Os meios de comunicação disponíveis através da melhoria tecnológica aproximaram informações antes restritas a grupos, dando conta dos direitos universais, entre os quais liberdade e democracia. As organizações criadas possibilitaram mobilizações em defesa de seus direitos e de todo ser humano. E nesse tocante seu espaço no mercado de trabalho, a inserção no mundo profissional e a conquista de novos espaços na sociedade, vem sendo alcançados. 
logo, não podia pegar chuva no tempo. Hoje quase não faz mais nada, não tem roça grande, só uns cantinho (T. T., 79, maio 2014).

A respeito dos dias de puxirões retribuídos às outras famílias, é importante lembrar que não se remunerava ninguém, apenas se registrava quais pessoas vieram ajudar para depois "devolver em serviço". Dona Teresa relembra algumas "passadas", com alegria:

Era necessário, aqui em casa nóis era em três, e na safra, você sabe, tem que colher ligero senão apodrece no tempo, e os bicho come, então tinha que pedir ajuda aos vizinho e, depois ajudá lá também. Então vinha bastante gente, mas tinha vez que todo mundo tava se vendo com a colheita, então vinha menos gente. O que acontecia era uma grande "confraternização" na hora do almoço. Todo mundo sentava numa sombra ou nas varanda das casa, nóis trazia uns panelão com comida, prosa contando novidade, discussão da colheita, era alegre. Descansavam e depois voltavam ao trabalho. Era uma festa! (T. T., 79 - maio 2014).

Percebe-se que nas "alegres lembranças" da moradora (Figura 6) ${ }^{5}$ há uma trama de trocas cotidianas que sustenta a liberdade festiva, que faz acontecer o momento quilombola com efervescência. É precisamente nesses momentos, quando os grupos se agregam de modo festivo e intencionam a retomada de um território de pertencimento, que se verifica a entrega celebrativa que havia sido costurada em décadas de trocas intensas. 
Figura 6 - Dona Teresa "ao pé do fogo" quando trazia as lembranças dos "puxirões"

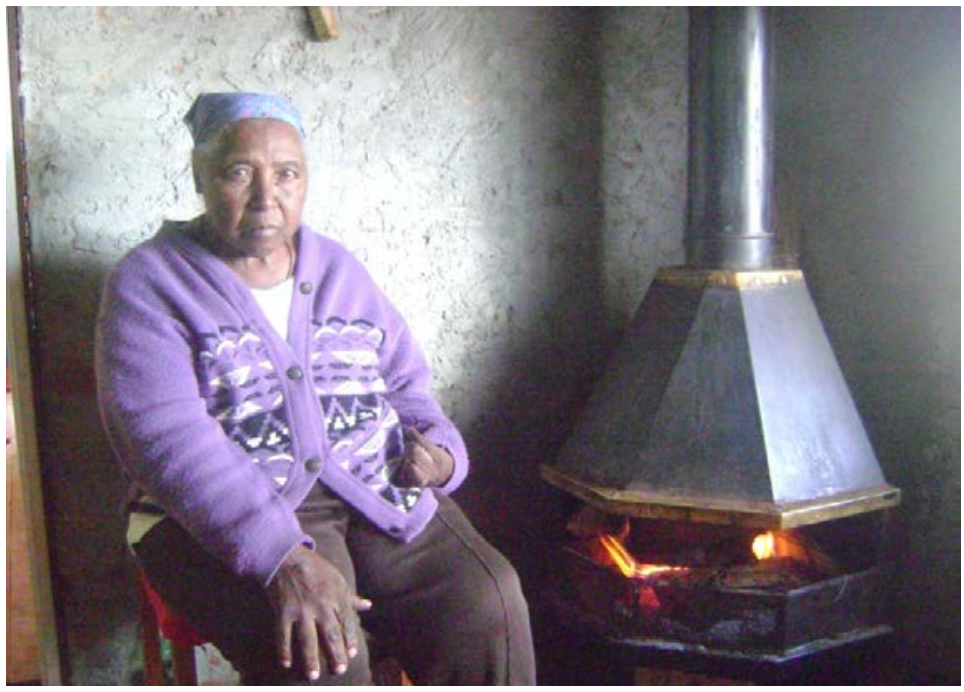

Fonte: Arquivo de pesquisa (2014).

O sentido de "comunidade", que raramente se ratifica na forma escrita, é confirmado por meio da circulação de coisas pelo território (SILVEIRA, 2010). A confraternização demonstra que as relações de proximidade se constituem nas mais importantes formas de sociabilidade, tanto de parentesco como de amizade. No entanto, as diferentes comunidades, no caso Mormaça e Arvinha, apresentam distintas maneiras de manter as sociabilidades, o interconhecimento, o preservar atos de reciprocidade e a intensidade da vida comunitária.

As dádivas prestadas e retribuídas em Mormaça e Arvinha representam também aquilo que a terra dá; são os frutos do trabalho ou a própria mão de obra. A produção agrícola não visa somente ao consumo próprio, mas à possibilidade de presentear a sobra, o excedente, ou seja, "o consumo festivo" 6 daquilo que é produzido e, assim, ocorrem as trocas. Como a produção se dava em pequenas áreas, os alimentos trocados mais intensamente eram leite, ovos, algumas carnes, verduras, legumes, frutas e ervas.

6 Termo utilizado por $\operatorname{Ramos}(2009$, p. 68) ao descrever a prestação de dádivas que ocorriam/ocorrem na comunidade quilombola de Cambará, no município de Cachoeira do Sul, no Rio Grande do Sul. 
Mauss (1974, p. 250), ao estudar sociedades arcaicas (haïda e tlingit), duas tribos do noroeste americano, detecta: "Restarem importantes vestígios da antiga prestação total. [...] trocam-se presentes a propósito de tudo, de cada 'serviço'; e tudo se retribui posteriormente ou na mesma hora para ser redistribuído imediatamente".

Práticas de obrigações recíprocas, mesmo não estando coagidas por um contrato formal de trabalho ou por promessa de uma remuneração salarial, mas motivadas por uma cultura de endividamento mútuo, são efetivadas no interior dessas relações. Nesse recorte, semelhante ao presenciado por Ramos (2009), na comunidade Cambará, foi apresentada, em Mormaça, uma cena em que três famílias conjuntamente convergem em torno da dádiva.

Na propriedade de seu N. R., 65, e dona L. R. A., 66, por não serem “mais tão moços", o morador vizinho, V. R., 36, está refazendo as cercas para delimitá-la, prepara os palanques, abre as covas, espicha e grampeia os arames. Ao mesmo tempo J. P., 16, todas as manhãs vem cuidar dos animais, tirar o leite, soltar as duas vacas e separar os terneiros para o casal. Essa obrigação (dívida?) com relação ao casal provém, dentre outros fatores, por benzerem e fabricarem remédios caseiros (utilizam das plantas as raízes, cascas, galhos e folhas), ofertando seus dons, curando diversos males daqueles moradores, crianças e adultos e outros de fora da comunidade. Dons de benzimentos que remontam à terra e às ervas (RAMOS, 2009, p. 68). Encerra, então, a dádiva um princípio educativo - são atos de ensinar e aprender relações humanas espontâneas.

\section{Relações simétricas e assimétricas de Arvinha e Mormaça com o entorno}

Entre os moradores das comunidades de Arvinha e Mormaça as ações são orientadas por uma racionalidade específica, que, articuladas, 
configuram um sistema de dádiva. Percebe-se, porém, diferenças nas relações sociais estabelecidas por membros do grupo - a dádiva não está presente da mesma forma. Ocorrem regimes de ação diferenciados entre os que pertencem à comunidade e os que não pertencem. Nas caminhadas realizadas e na "parada pro mate", com frequência se ouvia a expressão "os de dentro" e "os de fora". Inicialmente, entendeu-se que os de fora fossem remanescentes, que não habitavam, não conviviam na comunidade. Mas não era isso. Os de fora estão na fronteira do território, são os moradores vizinhos, "são os italianos", também são os representantes de agentes públicos e privados. Na Mormaça, os lindeiros são pequenos agricultores, que cultivam soja, milho, trigo e pastagens. E produzem leite e frangos de corte. Na Arvinha são produtores empresariais (médias e grandes propriedades), trabalham com monoculturas, soja, milho, trigo e reflorestamento.

Essa diferença de interações com seus vizinhos demarca uma fronteira, no entanto, num primeiro momento, não se distingue uma relação amistosa de uma conflituosa. Posteriormente, são apontados traços de um distanciamento quando em determinados momentos a colaboração se faz necessária. Existe uma relação entre o "nós" e o "eles", com um limite bem definido. Esse marco delimitador para as trocas entre a comunidade e "os italianos" corresponde a interesses recíprocos e ocorre enquanto há uma contrapartida de ambos os lados. Pode-se chamar isso de "relações assimétricas de reciprocidade".

As relações assimétricas estabelecidas pelas comunidades negras da Arvinha e Mormaça com as populações brancas de seu entorno estão bem caracterizadas no processo de troca baseado na contraprestação. $\mathrm{O}$ território negro é virtualmente todo o espaço de reciprocidade positiva (simétrica) que gera dívidas afetivas. Seu exterior é o da reciprocidade pela metade, que gera o poder patronal e dependências clientelistas (RAMOS, 2009, p. 70).

L. R., moradora na comunidade Mormaça com sua família e presidenta da Associação de Remanescentes, ainda nos primeiros contatos em 
2008, já expunha essa relação unilateral mediada pelo capital, racismo e poder. Recentemente, reforça: ${ }^{7}$

As coisa tem se tornado difícil, ainda que os mais velho tem a aposentadoria de agricultor e as família recebe a "bolsa família". Nóis que semo novo saímo pra trabalhar fora, fui pra Sertão cuidá de uma idosa, as outras também vão trabalhá e voltam pra casa, o "J." é pedreiro e assim vai. Diminuiu o trabalho na lavoura depois que "comecemo" a lutar pela nossa terra desde 2004/5 e porque a nossa terra diminuiu. Depois os vizinho agricultor não deram mais serviço "pra nóis", não arrendam, não deixam plantar em parceria. Os novo foram procurá serviço fora daqui, longe; foi pras colheita de maçã em Vacaria, Bom Jesus e na Serra. Vão em Veranópolis, Flores da Cunha e Caxias na safra da uva, outros vão carregar frango nos caminhão em aviário aqui perto e outros na cidade por dia, quando chove para (L. R., 35, out. 2012).

Nesse recorte, manifestações primárias na relação de reciprocidade, as trocas, não mais se configuram, não há uma noção de equivalência buscando a justiça, mas uma assimetria e relações de poder em favor dos brancos. As relações entre patrões e empregados perpetuam-se em modalidades de relações assimétricas de reciprocidade. Há, de certa forma, um "confronto" de interesses individuais e de diferenças sociais que determinam uma estrutura de dominação, bem caracterizada no relato da liderança.

Para melhor elucidar, descrevem-se algumas "ofertas" de trabalhos para os negros e "brancos pobres" na informalidade. Nas relações de trabalho, em que se buscava a mão de obra quilombola, agricultores produtores de frango os contratavam para fazer o carregamento de frangos de corte que iriam aos frigoríficos para abate. Esses trabalhadores se deslocavam a pé ou na carroceria de caminhão até as propriedades onde iniciavam o trabalho em torno "da meia-noite".

7 Utilizamos novamente a fala da liderança, pois a mesma propõe reflexões importantes sobre as relações dos moradores quilombolas com moradores do entorno. 
Nóis chegava - onze, meia-noite - começava a carregá; ali por duas hora da madrugada tinha um sanduíche de lanche e um suco, mais o serviço não parava, uns comia, os outro trabalhava. Ia até por cinco e meia, às veiz seis da manhã. No final nóis levava de pagamento quatro ou cinco frango, não levava dinheiro (E . M. 56, trabalhador da Mormaça, out. 2012).

O estabelecimento de relações trabalhistas injustas demonstra assimetrias caracterizadas por interesses conflitantes, como foi possível constatar em relatos acerca da contratação de força de trabalho barata. Na região da comunidade da Arvinha, município de Coxilha, algumas empresas agrícolas são produtoras de sementes e possuem grandes estruturas para armazenagem de grãos, nas quais, em determinadas épocas, é necessário bastante mão de obra, seja para a "quebra do pendão" do milho semente, para o "arranquio de inços" em lavouras de soja-semente ou para descarregamento, carregamento e movimentação de grãos.

Em análise, caracteriza-se por "trabalho exclusivamente braçal" uma atividade desvalorizada, sem uma formação profissional ${ }^{8}$ mais elaborada, que aparentemente não agrega conhecimento pelo fato de ser repetitivo. Mas, sem dúvida, nessas atividades há saberes/experiências e conhecimentos invisibilizados.

Eggert (2011), numa pesquisa sobre os processos educativos do fazer artesanal, explicita as razões de muitos conhecimentos e experiências populares - já numa condição de quase desaparecimento - constituírem conhecimentos invisibilizados, a exemplo dos trabalhos de produção artesanal, no caso da pesquisa com mulheres artesãs. A pesquisadora tenta quebrar esse preconceito em relação ao trabalho manual no campo

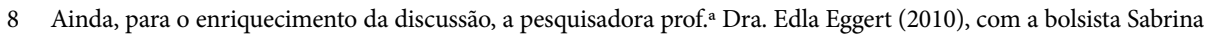
Forati Linhar (Unibic/Unisinos) e um grupo de mulheres artesãs de um atelier de tecelagem no município de Alvorada, desenvolveu pesquisa através de uma oficina de estudos no início do ano de 2010, com o tema "Fios, tramas, saberes, artesanato: o trabalho invisibilizado e precário de mulheres em um atelier de tecelagem". Entre os objetivos, buscou identificar o que e como as tecelãs compreendem o que produzem, e a partir disso analisar a percepção do trabalho que realizam como arte, técnica e conhecimento. Ainda, relacionar a experiência de tecer com a experiência dos conhecimentos invisibilizados das mulheres ao longo da história. 
pedagógico, com a contribuição do referencial teórico que tem por base a pesquisa sobre as manualidades. Segundo a autora,

o trabalho manual e o tema da violência contra as mulheres são assuntos que a academia tem, ao longo dos séculos, deixado nas margens. Desde a experiência da produção do conhecimento grego o trabalho manual foi relegado aos escravos e escravas e às próprias mulheres, mesmo aquelas pertencentes aos 'cidadãos' (EGGERT, 2008, p. 2, apud BRUN; EGGERT, 2011, p. 36).

Voltando à discussão de assimetrias noutra atividade, agora nas lavouras, o trabalho é ao relento, ${ }^{9}$ com precária ou nenhuma utilização de equipamento básico de proteção à saúde. Caso conhecido aconteceu em 2007, no município de Coxilha, quando uma empresa produtora de sementes pertencente a um grupo internacional foi condenada a ressarcir trabalhadores por não oferecer condições mínimas de trabalho, equipamentos de proteção individual, insalubridade, descanso obrigatório, transporte seguro, entre outros. Nas cerealistas submetem-se a um trabalho pesado e de péssima qualidade para a saúde. Para a liderança, “[...] são atividades que outros trabalhadores não querem fazer, restando então aos quilombolas [...]” (L. R., 35, maio 2012).

Considerando não possuírem contrato de trabalho permanente, esses homens e essas mulheres não recebem nenhuma garantia de trabalho em outras épocas; não lhes são recolhidos direitos trabalhistas para uma previdência futura e, ainda, por serem "diaristas", teoricamente trabalhadores autônomos, favorecem exclusivamente aos empresários, que não têm outras obrigações, aumentando seus lucros - características de relação de reciprocidade assimétrica.

Por outro lado, há relações diferenciadas. Um fato de reciprocidade simétrica com a vizinhança do entorno (embora numa ocorrência de

9 Expressão utilizada no meio rural brasileiro, mas no sul do Brasil e aqui no estado (RS) é frequentemente evocado quando se trabalha nas atividades rurais pecuárias e agrícolas sob o sol, chuva ou garoa, neblina, vento e outros fatores do intemperismo, ou seja, "ao relento". 
relação de poder desigual) demonstra isso: um agricultor, cujas terras devem ser desapropriadas pelo Estado por estarem localizadas dentro da área demarcada como território quilombola, presta serviços agrícolas com suas máquinas mediante pagamento na propriedade do casal de moradores N. R. e L. R. A. (Figura $7^{10}$ ).

É o único que vem fazê pra nóis! Na hora de plantá pasto de inverno, aveia ou trigo, e o milho no verão. Também vem o I.S. Os otro, nem bola, não ajudam a gente; às veis, só cumprimenta (casal $\mathrm{N}$. R., 65, out. 2012).

Figura 7 - Reciprocidade simétrica com o entorno

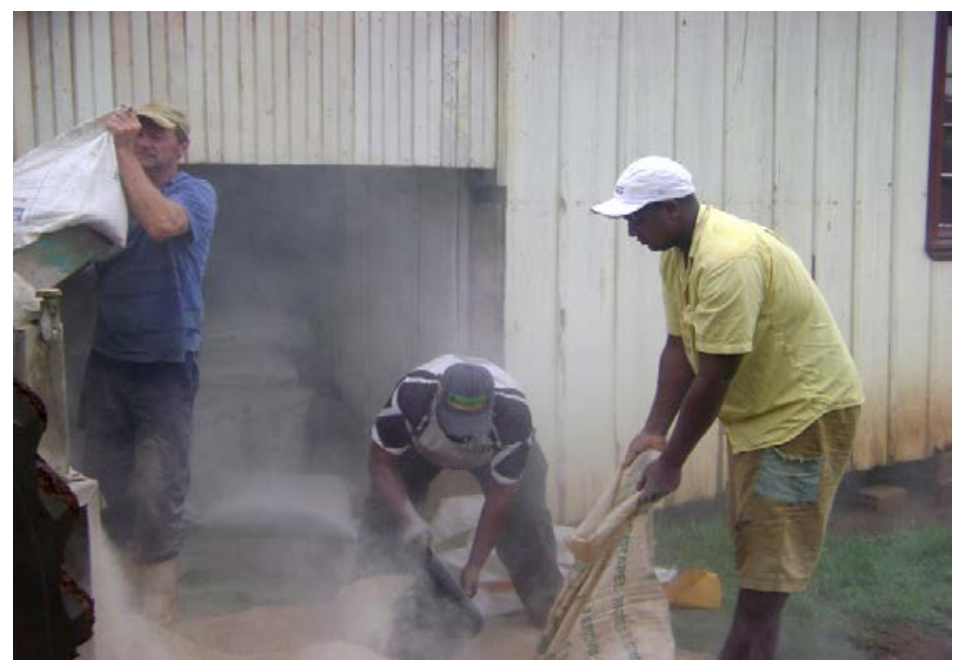

Fonte: Arquivo de pesquisa (2014).

Alguns escritos se referem a uma "proteção condescendente" (SILVEIRA, 2010), caracterizada por "supremacia" baseada em reciprocidade, que possibilita um padrão de relações raciais em que lindeiros/vizinhos (agricultores, fazendeiros e comerciantes) simultaneamente se apresentam como "protetores e guardiões" de uma moralidade local, condição que, para essa realidade, parece não aplicar-se.

10 Agricultor prestando serviço ao morador quilombola na moagem de grãos, em Mormaça, 2012. 
As comunidades de Arvinha e Mormaça, como potências, contam com uma pluralidade de princípios de ação, ou seja, as lógicas que embasam as práticas de seus membros são múltiplas, variando conforme as circunstâncias. Dizer isso não é ignorar as especificidades das suas relações sociais ou, como se poderia pensar, atribuir ao comportamento individual uma volatilidade exagerada (RAMOS, 2009).

Resulta que a singularidade dessas duas comunidades não reside em um exótico modo de relacionar-se próprio de imagens estereotipadas, atribuídas às sociedades chamadas "arcaicas". A sua particularidade advém da compreensão das racionalidades que acionam os distintos princípios de ação que constroem um arranjo social diferenciado. A variação dos modos de agir em Mormaça e Arvinha demarca uma fronteira simbólica, que delimita diferentes modelos de justiça.

\section{Considerações finais}

Ao finalizar este capítulo, convém a retomada de algumas possibilidades. As comunidades quilombolas de Arvinha e Mormaça, originárias de assentamentos de escravos e ex-escravos fugidos ou libertos que formaram suas descendências em terras próximas de seus senhores, constituem evidências inequívocas da existência de escravos nessa região. Como ocorreu em diversos outros quilombos pelo Brasil, os negros, quando fugidos, procuravam lugares de difícil acesso para não serem encontrados, mas não distantes das regiões do poder do senhorio, até porque, próximo dali, havia outro senhor, também escravista, que a qualquer momento poderia capturá-los e entregá-los aos seus donos.

Parece clara a existência da escrava Cezarina de Miranda, inclusive protegida e citada em documentos pessoais do coronel Francisco de Barros Miranda, que se acostou com seus cinco filhos em terras que estavam em poderio do coronel. Na mesma linha, a escrava liberta Firmina Vieira, 
mãe de Francisca Vieira, a Chica Mormaça, matriarca da comunidade remanescente de Mormaça, vem com sua família constituir seu grupamento numa encosta pedregosa, à época protegida região com densas florestas, especialmente araucárias, margeada por sangas e pequenos rios, na segunda metade do século XIX, hoje único espaço de sobrevivência de seus descendentes. Esse local também convergia para a propriedade de seu senhor, Amâncio de Oliveira.

Daquele período até a atualidade há continuidade, entre os grupos diversos, dos laços que promovem essa aproximação. Dentre eles, o parentesco, a amizade, o compadrio, mas muito arraigada uma constante troca de presentes, bondades, horas de trabalho, apoio nas reivindicações comunitárias, que se conhece como dádiva e reciprocidade - dar e receber —, embora "receber não seja uma obrigatoriedade" (MAUSS, 1974, p. 313). Trabalhou-se no sentido de também identificar essas subjetividades como estratégias não intencionais para a manutenção e retomada de antigos territórios como espaço não somente de sobrevivência comunitária, mas congregador de uma etnicidade, identidade cultural de seus habitantes reconhecida juridicamente.

Ações de dádiva e reciprocidade presentes em diversos grupos étnicos, desde grupos tribais até no cotidiano de muitas pessoas, tem possibilitado a Arvinha e Mormaça a manutenção dos territórios atuais. Porém, mais significante, provocou em seus moradores um sentimento de luta para ampliá-los às antigas fronteiras ocupadas por ascendentes. Tem como base sua historicidade, a legislação que reconhece a constituição das comunidades e o direito ao território e a unicidade como fator de empoderamento.

Em contraponto a essa busca das comunidades remanescentes, deve-se considerar a presença de outros grupos - as famílias agricultoras ativas nesse processo - que ocupam áreas referidas nos termos de delimitação geográfica, das áreas quilombolas expedidas pela União desde 2010. Esses agricultores familiares, na maioria, chegam à região no início do século XX e vêm ocupar áreas por meio de uma política desenvolvida pelo 
estado do Rio Grande do Sul, que promove sua medição, loteia e vende e, ainda, transfere a empresários colonizadores para comercializarem lotes. Os agricultores também ocupam áreas sem documentação.

Finalizando, identifica-se constante movimentação entre os moradores de Arvinha e Mormaça em ações de dádiva e reciprocidade, simbolizadas por atos de dar e receber, especialmente como "força motriz" para a conquista de espaço/território, que compreendem como direito dos grupos, e os agricultores defendendo áreas que legitimamente adquiriram - como argumentam.

\section{REFERÊNCIAS}

CUNHA, Maria das Graças Campolina. Entre cercas: permanências e transformações no espaço rural do sertão norte mineiro. In: ENCONTRO NACIONAL DOS GEÓGRAFOS, XVI. Anais... Porto Alegre, 2010.

EGGERT, Edla (Org.). Processos educativos do fazer artesanal de mulheres do Rio Grande do Sul. Santa Cruz do Sul: Edunisc, 2011.

FREIRE, Paulo. Pedagogia do oprimido. 42. ed. Rio de Janeiro: Paz e Terra, 2005. HAESBAERT Rogério. Dos múltiplos territórios à multiterritorialidade. Porto Alegre, 2004. Disponível em: <http://www.uff.br/observatoriojovem/sites/default/ files/documentos/conferencerogeriohaesbaert.pdf >. Acesso em: 15 nov. 2012.

MAUSS, Marcel. Ensaio sobre a dádiva: forma e razão da troca em sociedades arcaicas. In: MAUS, M. Sociologia e Antropologia. São Paulo: Edusp, 1974. v. 2. p. 49-209.

MOURA MELLO, Marcelo. Raízes e rotas da terra. Formação de um território negro no sul do Brasil. Memória americana, No 19-1, Ciudad Autónoma de Buenos Aires, ene./jun, 2011.

OLIVEIRA, Heron Lisboa. Comunidades remanescentes dos quilombos de Arvinha e Mormaça - processos educativos na manutenção e recuperação do território. Tese (Doutorado em Educação) - Universidade do Vale do Rio dos Sinos, São Leopoldo-RS, 2014. 
RAMOS, Ieda C. Alves. O lugar do parentesco na aliança entre um laudo antropológico e um território quilombola: análise a partir do processo de regularização fundiária do Quilombo Cambará. Dissertação (Mestrado em Desenvolvimento Rural) - UFRGS, Porto Alegre, 2009.

SABOURIN, Eric. Marcel Mauss: da dádiva à questão da reciprocidade. Revista Brasileira de Ciências Sociais, v. 23, n. 66, p. 131-138, fev. 2008. Disponível em: $<$ http://www.scielo.br/pdf/rbcsoc/v23n66/08.pdf >. Acesso em: 5 ago. 2013>. Acesso em: 20 maio 2016.

SANTOS, Milton. Território e sociedade. São Paulo: Fundação Perseu Abramo, 2000.

SAQUET, Marcos A. Abordagens e concepções de território. São Paulo: Expressão Popular, 2007.

SILVEIRA, Luciana Conceição Lemos da. Relações de reciprocidade quilombola: Peixoto dos Botinhas e Cantão das Lombas - município de Viamão/RS. Dissertação (Mestrado em Desenvolvimento Rural) - UFRGS, Porto Alegre, 2010. 


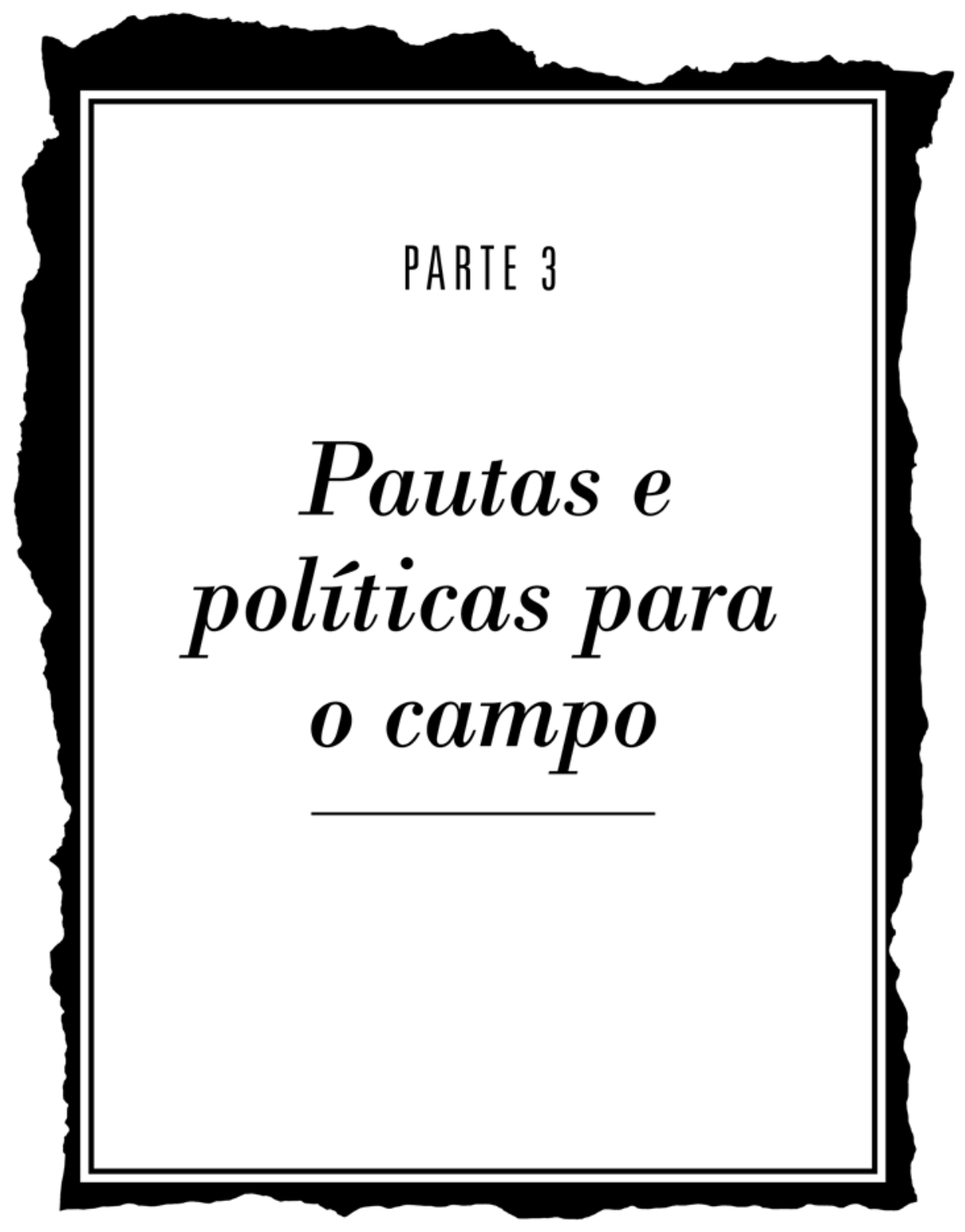




\title{
As demandas dos agricultores familiares na pauta da Fetraf-Brasil (2005-2015)
}

\author{
Catia Grisa ${ }^{1}$ \\ Jonas José Seminotti ${ }^{2}$
}

\section{Considerações iniciais}

Este capítulo tem por objetivo analisar as demandas dos agricultores familiares que entraram na pauta de reivindicações da Fetraf-Brasil ${ }^{3}$ entre 2005 e 2015. Esclarecemos que a partir de maio de 2016 a Fetraf foi transformada na Confederação Nacional dos Trabalhadores e Trabalhadoras da Agricultura Familiar (CONTRAF BRASIL). Seguiremos a denominação Fetraf por estarmos analisando o período entre 2005-2015.

Seguindo a experiência de outras organizações sindicais da agricultura familiar ${ }^{4}$, essas pautas de reivindicações expressam o conjunto de demandas em termos de políticas públicas e de demais ações do Estado. Conforme

1 Professora Adjunta da UFRGS, Campus Litoral Norte. Programa de Pós-Graduação em Desenvolvimento Rural (PGDR/UFRGS). Doutorado em Ciências Sociais. Contato: catiagrisa@yahoo.com.br

2 Professor Adjunto da UFRGS, Campus Litoral Norte. Doutorado em Sociologia. Contato: jonas.seminotti@ufrgs.br

3 Durante o IV Congresso Nacional dos Trabalhadores e Trabalhadoras na Agricultura Familiar do Brasil, realizado em maio de 2016, a plenária aprovou e determinou que a Federação fosse transformada em uma Confederação, decisão essa que deu origem a Confederação Nacional dos Trabalhadores e Trabalhadoras da Agricultura Familiar (CONTRAF BRASIL).

4 Aqui nos referimos principalmente à Confederação dos Trabalhadores na Agricultura (Contag)) e o Departamento Nacional dos Trabalhadores Rurais da Central Única dos Trabalhadores (DNTR/CUT) que desde o processo da constituinte e, de forma mais acentuada, desde o início dos Gritos da Terra Brasil (1994) constroem proposições e demandas de políticas públicas, sistematizadas em um único documento, cujo conteúdo é negociado com o Governo Federal (CONTI, 2016; SEMINOTTI, 2013; PICOLOTTO, 2011; FAVARETO, 2006). 
Conti (2016) e Bolter (2013), a construção de tais pautas envolve quatro momentos distintos e complementares: a) reuniões sindicais nos municípios e regiões para identificar as demandas centrais; b) sistematização das propostas por estados, diferenciando aquelas a serem apresentadas aos governos estaduais daquelas ao governo federal; c) consolidação das demandas oriundas dos estados em uma pauta nacional; d) realização de mobilizações sociais estaduais e nacionais, concomitantes à apresentação e negociação entre organização sindical e governos federal e estaduais (em suas diferenças organizações e estruturas institucionais). Essas mobilizações foram denominadas de Jornada Nacional de Luta pela Agricultura Familiar e Reforma Agrária.

De acordo com Conti (2016), tal denominação iniciou com a Fetraf-Sul, que criou a Jornada de Luta da Agricultura Familiar para diferenciar-se dos Gritos da Terra Brasil organizados pela Contag. Em 2008, já em um contexto de nacionalização da Fetraf, as jornadas passaram a denominar-se Jornada Nacional de Luta da Agricultura Familiar e, em 2010, Jornada Nacional de Luta pela Agricultura Familiar e Reforma Agrária. Segundo o autor, "o processo de nacionalização da pauta, iniciado com a criação da Fetraf-Brasil e consolidado em $2009^{5}$, traz consigo a incorporação de novos temas em seus repertórios de ação. [...] O próprio nome [nova denominação das Jornadas a partir de 2010] já expressa a diversidade de sujeitos e temas que passaram a integrar a agenda política da Fetraf-Brasil" (CONTI, 2016, p. 146). As jornadas são realizadas nos primeiros meses de cada ano (geralmente abril e maio), antecedendo o anúncio dos Planos Safra da Agricultura Familiar', que é um espaço institucional

5 De acordo com Conti (2016) e Picolotto (2011), até 2009, as pautas de reivindicações da Fetraf-Brasil refletiam fundamentalmente as demandas da Fetraf-Sul, sendo que, a partir deste ano, temas e demandas de outras regiões passaram a ganhar espaço, incorporando reivindicações de todas as federações estaduais filiadas.

6 Os Planos Safra da Agricultura Familiar tiveram início em 2003, expressando o planejamento anual das políticas do Ministério do Desenvolvimento Agrário (MDA) para a agricultura familiar. Construído em diálogo com as principais organizações sindicais dos trabalhadores rurais e movimentos sociais rurais, considerando as suas pautas de reivindicações, o Plano Safra da Agricultura Familiar anuncia as inovações, as condições e os recursos para as políticas públicas para a agricultura familiar para o próximo ano agrícola. 
extremamente importante (não o único) para as organizações da agricultura familiar interferirem nas políticas públicas. A apresentação da Pauta de Reivindicações da IV Jornada Nacional de Luta da Agricultura Familiar (2008) ilustra o processo de construção e de organização das demandas da organização sindical:

\begin{abstract}
A FETRAF-BRASIL/CUT e suas organizações de base realizarão a IV Jornada Nacional de Luta da Agricultura Familiar no próximo mês de maio com o objetivo de avançar nas conquistas para a categoria. É neste sentido que apresentam nesta pauta de reivindicações suas proposições, fruto de um intenso processo de discussão e elaboração coletiva das diversas instâncias organizativas. Estas ideias emergiram da prática cotidiana e das dificuldades concretas que os Agricultores e Agricultoras Familiares, Assentados e Assentadas de Reforma Agrária enfrentam no dia-a-dia, todas elas direcionadas na perspectiva de fortalecer a construção do projeto de desenvolvimento sustentável e solidário no campo brasileiro. (FETRAF-BRASIL, 2008).
\end{abstract}

Ao analisar as pautas de reivindicações procuramos mapear o conjunto de temas que entrou na agenda da Fetraf-Brasil, sua temporalidade e possíveis alterações ao longo dos anos. ${ }^{7}$ Buscaremos explicitar as pautas que a organização sindical da agricultura familiar mobilizou ou, em sentido inverso, os temas que cobraram sua atenção. Compreendemos que as pautas expressam um conjunto de ideias e representações de mundo da organização sindical (FOUILLEUX, 2003; MULLER, 2008) que, em interação, negociação e conflitos com as ideias de outros atores políticos (demais organizações da agricultura familiar, da sociedade civil e da agricultura patronal, representações governamentais, acadêmicos, mídia etc.) influenciam na construção e nas mudanças das políticas públicas (GRISA, 2012). Ainda que esta dimensão (influência na construção e mudanças das políticas públicas) não tenha sido contemplada neste capítulo (o que se

7 Tal exercício foi realizado com base em pesquisa documental. Foram resgatadas todas as pautas de reivindicações da organização sindical do período 2005 a 2015, sendo seus conteúdos analisados por meio do software NVivo. 
buscará ilustrar em políticas específicas em capítulos seguintes), o exercício realizado auxilia a reconstruir as ideias e as representações de mundo que balizaram o "repertório de ação" (TILLY, 2006) da Fetraf-Brasil.

Além destas considerações iniciais, o capítulo contempla mais três seções. A primeira analisa as argumentações ou as narrativas construídas pela organização sindical na sustentação e na defesa do conjunto das políticas públicas para a agricultura familiar. Posteriormente, são elencadas as principais questões e temas abordados pela Fetraf-Brasil no período de 2005 a 2015. Por fim são apresentadas algumas reflexões sobre o conjunto das demandas realizadas.

\section{Narrativas nas pautas de reivindicações}

Todas as pautas de reivindicações iniciam com uma apresentação que, geralmente, consiste em uma breve análise sobre as conquistas já angariadas em termos de políticas públicas, os momentos conjunturais vivenciados (eleições presidenciais, política econômica, crises, eventos etc.) e os desafios enfrentados pela categoria social. Posteriormente apresentam-se as demandas organizadas por eixos, relativas a cada política pública ou temática.

Este momento inicial comumente envolve a construção de uma narrativa (RADAELLI, 2000) que afirma o papel e a importância da agricultura familiar no desenvolvimento do país, na geração de empregos e na promoção da segurança alimentar e nutricional; os avanços obtidos nas políticas públicas até então; e também a necessidade de mudanças nos programas públicos existentes e a criação de novas ações para que a agricultura familiar possa continuar "cumprindo suas funções". ${ }^{8}$ A apresentação

8 As narrativas podem ser compreendidas como argumentações, consideradas “verdades", que tentam influenciar o decurso de uma política pública. Segundo Radaelli (2000), as narrativas se expressam amiúde como histórias causais, contendo um início, meio e fim. O poder destas narrativas está justamente em construir uma ordem temporal (ou sequencialidade) para os dramas, muito mais do que a exatidão ou falsidade dos fatos e relações. 


\section{da "Pauta de Reivindicações da Agricultura Familiar" de 2005 é ilustrativa} deste processo de construção de uma narrativa ao falar da importância da agricultura familiar, do reconhecimento pelo governo federal e da necessidade de prezar pelo diálogo e participação das organizações sociais na construção das políticas públicas:

A agricultura de base familiar tem sido para muitas pessoas (trabalhadores/as) a principal e mais importante atividade, geradora de trabalho, renda, alimentos e dignidade. Esse tipo de agricultura, modo de vida, é responsável pela produção de grande parte dos alimentos que vão à mesa dos brasileiros. Leite, carne suína, feijão, milho, mandioca, arroz, banana, aves e ovos são alguns produtos que a agricultura familiar responde com um percentual produtivo significante, em alguns itens chega a $80 \%$ como no caso do leite. Dentro deste cenário, a agricultura familiar adquiriu grande importância social e econômica, sendo responsável por um processo de geração de postos de trabalho, renda, garantia do equilíbrio dos ecossistemas, produção agrícola nacional construindo uma política de segurança alimentar e soberania alimentar, sendo estas as necessidades centrais da sociedade brasileira no atual momento. Esse fato é facilmente perceptível através dos últimos dados econômicos que apontam que a agricultura familiar é responsável diretamente por $10,1 \%$ da riqueza nacional (PIB), sendo reconhecida nacionalmente pela sua representação econômica no contexto nacional. A diversidade é um ponto em que a agricultura familiar se diferencia no contexto de produção agrícola, principalmente por que é voltada para subsistência familiar, contribuindo assim de forma decisiva para a sustentabilidade e segurança alimentar local e regional. [...] Com essa tamanha responsabilidade atribuída à agricultura familiar é preciso que as pessoas envolvidas, entidades, governos e demais organizações da sociedade tenham a clareza acerca de seu papel e consigam articular os interesse e vontades dos agricultores familiares entre si e com o todo da sociedade. Intensos debates e de mobilizações dos agricultores familiares e suas organizações têm possibilitado avançar em alguns pontos que sempre foram reivindicações, especialmente para os assuntos ligados ao crédito. Essa postura tem provocado maior reconhecimento social para a agricultura familiar, especialmente por parte do Governo Federal. 
A esfera federal tem demonstrado e apostado na agricultura familiar como um ótimo instrumento de desenvolvimento sustentável e vem investindo gradativamente em políticas e ações. Porém, é necessário que os governos estejam em constante diálogo com as organizações representativas da agricultura familiar para verificar as reais necessidades. Adequando ou readequando políticas públicas federais, tornando-as eficazes e com resultados práticos para esse público. (FETRAF-BRASIL, 2005, p. 2 e 3).

Similarmente, mas reagindo à conjuntura internacional e nacional emergida a partir de 2008, as pautas de reivindicações de 2009 e 2010 evidenciaram a existência no Brasil e no mundo de quatro crises (econômica, alimentar, ambiental e energética), "que afetam o nosso planeta e que preocupam os governos, as instituições e a sociedade, [e que] cada vez mais destacam a agricultura familiar como um dos componentes vitais na busca de soluções estratégicas e duradouras" (FETRAF-BRASIL, 2010, p. 2). Nesse sentido,

A Fetraf-Brasil/CUT se dispõe a colocar as suas energias e capacidades para contribuir na construção de um Brasil e um planeta mais humano, mais sustentável, mais solidário e mais efetivamente democrático. Para isso, se faz necessário avançar na criação, aperfeiçoamento e implementação de políticas públicas direcionadas ao campo brasileiro, afirmando a agricultura familiar e a reforma agrária como componentes estratégicos desse novo desenvolvimento, menos concentrado social e economicamente, mais harmonioso com o meio ambiente e mais alicerçado local e regionalmente (FETRAF-BRASIL, 2010, p. 2).

O documento destaca a importância da agricultura familiar na produção de alimentos, no valor bruto da produção nacional, na eficiência produtiva por hectare, na geração de empregos e na manutenção da "cultura, das tradições e da paisagem rural, garantindo a preservação das diversidades locais e territoriais" (FETRAF-BRASIL, 2010, p. 2). Seguindo na construção da narrativa, a Federação anuncia a demanda por políticas 
públicas, as quais permitiriam "reafirmar o papel estratégico da agricultura familiar na construção do país como nação soberana, com estabilidade na produção de alimentos, com garantia da preservação ambiental, potencializando maior estabilidade política e econômica e um futuro com sustentabilidade e dignidade de vida para todos" (FETRAF-BRASIL, 2010, p. 3).

Nas pautas de reivindicações de 2011, 2012, 2013 e 2014, a Fetraf-Brasil procura fazer um balanço dos Governos Lula e Dilma e avalia que:

[...] a agricultura familiar conquistou espaço por sua importância econômica, e por seu papel de vetora de desenvolvimento em harmonia ambiental e sustentabilidade social; e reconhecimento do Estado e Governos, pelo processo organizativo sindical dos trabalhadores e trabalhadoras do setor, estabelecendo interlocução com a sociedade no amadurecimento de soluções para o abastecimento e segurança alimentar, desenvolvimento regional e local de pequenos e médios municípios com instrumentos de distribuição de renda e promoção de qualidade de vida com sustentabilidade.

[...] vive um momento crucial e estratégico no processo de seu papel como sujeito e protagonista do desenvolvimento do Brasil Rural. Graças à luta e participação das suas organizações de representação, entre as quais nos incluímos (FETRAF-BRASIL, 2012, p. 2).

No entanto, a organização sindical observa que "mesmo buscando desempenhar essa complexa multifuncionalidade de funções sociais, [a agricultura familiar] está distante de ser reconhecida pela sociedade e pelo governo como real protagonista de uma estratégia de desenvolvimento que garanta segurança alimentar, sustentabilidade ambiental, equidade social e valorização das diversidades culturais" (FETRAF-BRASIL, 2013, p. 2). Para romper com este processo, a Federação passa a reivindicar um "Programa de Aceleração do Crescimento (PAC)" da Agricultura Familiar",

9 O PAC da agricultura familiar é uma analogia ao Programa de Aceleração do Crescimento (PAC) estabelecido pelo governo federal a partir de 2007. O PAC significou a retomada do planejamento e execução de grandes obras de infraestrutura social, urbana, logística e energética no país, em uma tentativa de dar impulso ao desenvolvimento econômico. 
"compreendido mais que um Plano de Investimentos como um Projeto de Desenvolvimento, abrangendo a diversidade de aspectos e de realidades desse sujeito social que têm um papel fundamental na produção de alimentos e na preservação do meio ambiente, das águas e da biodiversidade" (FETRAF-BRASIL, 2014, p. 2). Inicialmente vinculado mais a questões de infraestrutura, logo o PAC tornou-se a expressão de uma reivindicação pelo fortalecimento e pela atuação articulada de um amplo conjunto de políticas para a agricultura familiar em diversas áreas, como produção, educação, saúde, cultura, lazer e infraestruturas.

$\mathrm{O} P A C$ da Agricultura Familiar é direcionado à infraestrutura locais/ regionais de armazenamento, centrais de distribuição, qualificação dos serviços de inspeção municipais das agroindústrias familiares. Esta política não inclui crédito individual de investimento que as linhas do Pronaf já contemplam, mas o apoio a projetos comunitários, municipais e regionais de infraestrutura, geração de pesquisa e incentivos à transição e consolidação de sistemas diversificados e agroecológicos, focados na produção de alimentos e com apoio a formação de infraestrutura de consórcios regionais de suporte técnico às agroindustriais familiares e cooperativadas. O PAC deverá contemplar ações no âmbito da comunicação no meio rural, educação, saúde, cultura e lazer, enfim, fazer uma grande revolução no conceito das políticas públicas para a agricultura familiar brasileira de maneira que possamos continuar sendo o celeiro de alimentos para garantir a soberania e a segurança alimentar da nossa população e em outras nações (FETRAF-BRASIL, 2013, p. 3).

Entendemos que o fortalecimento e a valorização da agricultura familiar e, consequentemente, do fortalecimento da segurança e soberania alimentar do país e a garantia da sustentabilidade socioambiental passa pelo avanço articulado de um conjunto de políticas e ações no campo econômico, social, ambiental, cultural, na valorização da autonomia das mulheres agricultoras, na valorização e autonomia da juventude rural - o que chamamos de Projeto de Desenvolvimento ou PAC da Agricultura Familiar (FETRAF-BRASIL, 2014, p. 2). 
Mesmo que as pautas de reivindicações continuem contendo seções específicas, organizadas em eixos estratégicos com subdivisões específicas relativas aos programas (produção e garantia de renda, acesso à terra, questão ambiental etc.), observa-se, a partir de 2011, a demanda pela construção de um projeto coeso e articulado de desenvolvimento para a agricultura familiar brasileira. A analogia ao Programa de Aceleração do Crescimento não era trivial, exigindo ações articuladas e coesas do Estado para que colocassem a agricultura familiar como elemento central em um projeto de desenvolvimento do país, dadas suas contribuições para a segurança alimentar e nutricional e para a sustentabilidade. Construiu-se uma narrativa que afirmava que o cumprimento da "multiplicidade de funções sociais" da agricultura familiar perpassava obrigatoriamente pela implementação do PAC da Agricultura Familiar.

\section{Políticas e ações de apoio à produção e renda da agricultura familiar}

Uma das principais questões nas pautas de reivindicações da Fetraf-Brasil diz respeito a ações de apoio à produção da agricultura familiar. Nesse escopo, algumas demandas são destacadas: a) ampliação e aperfeiçoamento do Programa Nacional de Fortalecimento da Agricultura Familiar (Pronaf) e de suas linhas (notadamente Pronaf Sistêmico/Sustentável, Jovem, Mulher, Floresta, Mais Alimentos, Habitação e Agroecologia); b) renegociação das dívidas da agricultura familiar; c) fortalecimento e modificações no Seguro da Agricultura Familiar (SEAF) e no Programa de Garantia de Preços da Agricultura Familiar (PGPAF) no sentido de incluir novos produtos, rever custos de produtos, incluir agricultores que não acessam o Pronaf, e garantir maior renda para os agricultores familiares; d) fortalecimento e "desburocratização" do Programa de Aquisição de Alimentação (PAA); e) formulação e definição de uma política de garantia 
de preços mínimos para a agricultura familiar; f) retomada de estoques reguladores; g) participação da agricultura familiar na alimentação escolar; h) elevação das tarifas de importação dos produtos agrícolas que concorrem com os produtos da agricultura familiar brasileira; i) estruturação e ampliação da Companhia Nacional de Abastecimento (Conab); j) garantia e ampliação da Assistência Técnica e Extensão Rural (ATER) pública e mudanças nos marcos legais da relação entre Estado e organizações da sociedade civil de modo a garantir parcerias na execução da $\operatorname{ATER}^{10} ; 1$ ) investimentos em pesquisa e experimentação para a agricultura familiar, com ênfase na produção agroecológica e na convivência com o semiárido, e ampliação dos recursos para a Embrapa e outros órgãos públicos de pesquisa destinados à agricultura familiar; $\mathrm{m}$ ) fortalecimento e ampliação das agroindústrias familiares, sendo fundamental para isto a implementação do Sistema Unificado de Atenção à Sanidade Agropecuária (SUASA) e a estruturação dos Sistemas de Inspeção Municipais (SIM) em termos de infraestrutura e recursos humanos; $n$ ) intervenção do Estado no mercado de insumos, seja por meio da criação de empresas estatais no setor, seja por meio do controle de preços, ou ainda subsídios para a agricultura familiar na aquisição dos insumos ${ }^{11}$; o) mudanças normativas e fortalecimento do cooperativismo da agricultura familiar (FETRAF-BRASIL, 2015; 2014; 2013; 2012; 2011; 2010; 2009; 2008; 2007; 2006; 2005).

$\mathrm{O}$ fortalecimento produtivo da agricultura familiar via apoio das políticas públicas é uma das principais preocupações da Fetraf-Brasil. Por

10 Salienta-se que, no bojo dos debates sobre a criação da Agência Nacional de Assistência Técnica e Extensão Rural (ANATER) e da ampliação do público beneficiário para os médios produtores rurais, a Fetraf-Brasil reivindicou ATER exclusiva para a "agricultura familiar, assentados da reforma agrária, e demais públicos especiais como indígenas, ribeirinhos, extrativistas, quilombolas, pescadores e agricultores, visando atingir a sua universalização no menor prazo possível” e orientada pelos princípios da Política Nacional de Assistência Técnica e Extensão Rural (PNATER), visando atuação sistêmica, produção sustentável e "produção de alimentos sadios e a preservação ambiental" (FETRAF-BRASIL, 2015, p. 8).

11 Chama a atenção que, desde 2012, esta é uma questão que perdeu espaço nas pautas de reivindicações da Fetraf-Brasil, não sendo mais mencionada. Inversamente, as pautas de 2014 e 2015 demandam a criação de um programa de educação ambiental que, dentre outros elementos, promova a "redução dos insumos químicos" (FETRAF-BRASIL, 2015; 2014). 
mais que a Federação tenha ampliado suas bandeiras de luta (discutidas na sequência), ela "se dedica mais [...] às questões produtivas, talvez por serem as imediatas, perceptíveis e mobilizadoras das famílias" (TONDIN, 2015, p. 15). Nesse sentido, ganham centralidade na agenda programas como o Pronaf, as compras institucionais, o seguro agrícola e as demandas por melhorias nos preços. O Pronaf destaca-se entre as reivindicações devido à importância simbólica, política e econômica do Programa e a sua forte incidência entre a base social da organização sindical. Com efeito, como salientam Conti (2016) e Picolotto (2011), a prevalência dessa preocupação com a dimensão produtiva da agricultura familiar responde às características de grande parte de sua base social, ou seja, agricultores que, em geral, possuem terra (ainda que reivindiquem maior acesso), estão inseridos nos mercados, necessitam capital de giro e que demandam melhorias para sua estruturação econômica.

\section{Políticas e conflitos agrários}

Ainda que o tema da reforma agrária tenha oscilado ao longo da trajetória do sindicalismo dos trabalhadores rurais, apresentando-se a partir do final dos anos 1990 de maneira mais enfraquecida na agenda diante da prevalência das demandas da agricultura familiar (PICOLOTTO, 2011; FAVARETO, 2006) ${ }^{12}$, a pauta do acesso à terra e suas problemáticas decorrentes sempre estiveram presentes nas demandas da Fetraf-Brasil, que, em 2014, na sua Pauta de Reivindicações afirmou:

O acesso à terra é uma condição fundamental para a produção de alimentos que garanta a segurança e a soberania alimentar. Para a agricultura familiar, a terra representa a sua condição de sobrevivência, porque, além de espaço de trabalho, é também espaço de

12 Picolotto (2011) destaca que o reconhecimento político e institucional da agricultura familiar e a ascensão e prevalência do Movimento dos Trabalhadores Rurais Sem Terra na pauta da reforma agrária contribuíram para o sindicalismo cutista deixar "em segundo plano" esta temática. 
vivência. Neste sentido, a concentração fundiária, a internacionalização das terras, as dificuldades de acesso para quem nela vive e trabalha ou nela quer viver e trabalhar, os conflitos existentes em torno do acesso à terra ou de nela permanecer, as inseguranças jurídicas em relação à posse da terra são desafios fundamentais colocados para o futuro da agricultura familiar (FETRAF-BRASIL, 2014, p. 5).

Em uma leitura de todas as pautas de reivindicações, podemos observar que a Fetraf-Brasil cobrou a aplicação de todos os recursos previstos para o II Plano Nacional de Reforma Agrária, considerando o passivo de 2004 e as metas de 2005. E reconheceu:

Lamentavelmente, nestes dez anos de governos Lula e Dilma, através do MDA/INCRA pouco se avançou numa reforma agrária que pudesse reorganizar o espaço agrário, foram apenas ações periféricas e limitadas, evitando conflitos sociais, focados em áreas públicas, locais de baixo custo e de áreas de floresta. O Crédito Fundiário não se firmou como uma política importante de acesso à terra (FETRAF-BRASIL, 2013, p. 4).

Em 2015, demandou a elaboração de um "novo Plano Nacional de Reforma Agrária, com participação efetiva da sociedade e, particularmente, dos movimentos e organizações interessadas na efetivação da reforma agrária, para ser implementado a partir de 2016" (FETRAF-BRASIL, 2015, p. 2).

De forma mais particular, as principais questões e reivindicações pautadas pela organização sindical, desde 2005, foram: a) atualização dos índices de produtividade utilizados nos processos de desapropriação para fins de reforma agrária; b) desapropriação de todas as áreas ocupadas e/ ou negociadas pelas federações estaduais; c) infraestrutura e consolidação dos assentamentos de reforma agrária, sendo fundamental neste processo a constituição de comissões entre o INCRA, comunidades locais e suas representações; d) fortalecimento, aperfeiçoamento e "desburocratização" do crédito fundiário; e) expropriação para fins de reforma agrária de todas as áreas onde se verifica a presença de trabalho escravo e produção de 
plantas psicotrópicas; f) reestruturação e fortalecimento do Instituto Nacional de Colonização e Reforma Agrária (INCRA) e suas superintendências regionais, "com gestores e servidores comprometidos com a reforma agrária”; g) agilidade nos julgamentos e punição rigorosa para os mandantes e executores de crimes contra lideranças, militantes e trabalhadores da reforma agrária; h) identificação das áreas públicas e devolutas para fins de reforma agrária; i) garantia de qualidade, quantidade e regularidades das cestas básicas fornecidas pelo Ministério do Desenvolvimento Social/ Conab e INCRA às famílias acampadas; j) revogação da norma que impede vistorias em áreas ocupadas, o que emperra a reforma agrária no país; 1) estabelecimento de limite máximo da propriedade da terra associado à sua função social e regulamentação do próprio dispositivo da Constituição de 1988 que trata da temática; m) criação de um Programa Nacional de Regularização Fundiária para a Agricultura Familiar; n) proibição de comercialização das terras brasileiras para estrangeiros, sendo afirmada “posição contrária à estrangeirização de terras, contrária aos processos de concentração de terras em poucas empresas, com um modelo baseado nos monocultivos, provocando sérios riscos à soberania nacional" (FETRAF-BRASIL, 2014, p.6); o) "suspensão imediata dos processos de criação de áreas indígenas em terras antropisadas (com títulos legais e legítimos) por agricultores familiares há décadas". ${ }^{13}$

Sobre este último ponto, reivindicaram que "seja considerada pelo Ministério da Justiça e Governo Federal a possibilidade de criação de reservas indígenas previstas pelo Estatuto do Índio, mantendo os agricultores em suas terras e, ao mesmo tempo, garantindo as comunidades tradicionais indígenas e quilombolas o direito à terra", e "constituição de uma mesa de negociação com a participação dos diversos órgãos governamentais

13 É importante mencionar que as letras " $n$ " e "o" são pautas recentes na agenda da Fetraf-Brasil, notadamente a partir de 2011. Trata-se de questões igualmente recentes no debate político, acadêmico e da sociedade brasileira. O tema da estrangeirização da propriedade terra tem despertado atenção de movimentos sociais, acadêmicos e gestores públicos em âmbito nacional e internacional principalmente a partir de 2010. 
(estaduais e federal), representantes dos agricultores para debater alternativas aos conflitos agrários, com a efetividade e agilidade nos processos acordados" (FETRAF-BRASIL, 2015, p. 4). De forma mais explícita, a Fetraf-Brasil (2014, p. 8) afirma: "Reconhecemos o histórico e sagrado direito à terra por parte das nações indígenas e dos remanescentes de quilombos. Mas queremos que a sociedade e o governo reconheçam, em igualdade de condições, os direitos não menos sagrados, de milhares de famílias agricultoras ameaçadas de expulsão de suas terras."

Nessa temática, percebemos a defesa pelo acesso à terra (em suas diferentes estratégias, como desapropriação, crédito fundiário e regularização fundiária), pela soberania nacional e pelo direito à terra pelos agricultores familiares (pequenos proprietários de terra). Kujawa e Tedesco (2017, p. 239) observam que, ao longo de sua trajetória e conjuntamente com outros movimentos sociais e setores da igreja, a Fetraf procurou contrapor-se "ao modelo de desenvolvimento com base no latifúndio e defender a permanência dos agricultores familiares em suas terras e para a ampliação de políticas públicas que melhorassem suas condições econômicas e sociais". Isso conferia certa unidade entre a Fetraf e os diferentes movimentos sociais do campo, fazendo com que programaticamente a organização sindical se identificasse e fosse identificada como defensora igualmente dos direitos dos indígenas. No entanto, os conflitos entre agricultores familiares e indígenas ocorridos no Rio Grande do Sul e as revindicações apresentadas reconfiguraram a atuação dos movimentos sociais do campo e da própria Fetraf-Brasil e colocaram em campos de luta distintos atores que, anteriormente, compartilhavam um "sistema de crença” similar (KUJAWA e TEDESCO, 2017). A Fetraf precisou rever, ressignificar e esclarecer sua defesa histórica pelo acesso à terra diante da disputa entre agricultores familiares e indígenas. 


\section{Políticas e ações ambientais}

A questão ambiental e o papel da agricultura familiar nessa temática também fazem parte do rol de demandas abordadas pela Fetraf-Brasil. Nas pautas de reivindicações de 2012 e 2014, ela salientou os problemas ambientais decorrentes da modernização da agricultura e destacou a atuação, de certo modo contraditória, da agricultura familiar neste processo:

A modernização conversadora implementada em nosso país, de uma forma mais expressiva, a partir das décadas de 60 e 70 produziu, na lógica de Revolução Verde, além de outros problemas sociais, econômicos e culturais, uma devastação sem tamanho do grande patrimônio ambiental e da biodiversidade de nosso país. Em muitas regiões, a agricultura familiar, iludida pelas artimanhas da moderna tecnologia também foi envolvida nesse processo da destruição ambiental. No entanto, o setor que mais rapidamente pode responder na construção de um desenvolvimento sustentável, com preservação e recuperação da biodiversidade, das florestas e das águas, é a agricultura familiar. Mas, para isso, precisa de um forte apoio das políticas públicas (FETRAF-BRASIL, 2012, p. 6).

Dentre essas políticas públicas, a Fetraf-Brasil reivindicou: a) construção de uma "política de incentivos às boas práticas ambientais na recuperação, preservação e diversificação prestadas pela agricultura familiar, incluindo uma política de compensação financeira por essas práticas desenvolvidas" (2007, p. 12), sendo, em alguns momentos, mais explícita quanto à construção de uma política ou programa nacional para "remuneração pelos serviços ambientais prestados pela agricultura familiar, incluindo a preservação de florestas, a preservação de nascentes e de rios, e a preservação da biodiversidade" (2015, p. 10); b) criação de áreas livres de transgênicos e livres de agrotóxicos, contudo, em anos recentes, esta questão saiu da pauta para dar lugar à demanda de estabelecimento de um programa nacional para redução do uso de agrotóxicos (2014); c) implementação das diretrizes e propostas do Protocolo de Kioto adaptadas às 
realidades dos sistemas de produção da agricultura familiar; d) alterações no Código Florestal, todavia considerando as "históricas diferenças entre a agricultura familiar e o agronegócio empresarial” $(2009, \text { p.13) })^{14}$; e) criação de um programa nacional de agroecologia, com ações relacionadas ao crédito e aos mercados institucionais, qualificação dos serviços de ATER, educação direcionada para esta forma de agricultura nas escolas técnicas e universidades, campanhas publicitárias de incentivo ao consumo, dentre outros; f) ações de educação ambiental, perpassando temáticas como o uso racional da água, redução dos insumos químicos, preservação e recuperação de fontes e mananciais, erradicação de queimadas, utilização de sementes nativas e crioulas, e manejo agroflorestal sustentável; g) recursos para recuperação do passivo e preservação ambiental nos assentamentos de reforma agrária, comunidades tradicionais e agricultura familiar.

Como comentam Picolotto e Brandenburg (2015) a partir de análise da Fetraf-Sul, as preocupações com o modelo de agricultura e as tecnologias usadas na agricultura permearam a trajetória da organização sindical, manifestando-se de forma mais explícita no Projeto Alternativo de Desenvolvimento Rural Sustentável, construído em 1998 no âmbito do Projeto CUT/CONTAG. A partir dos anos 2000, como expresso anteriormente, as contribuições decorrentes de um projeto alternativo de desenvolvimento foram ganhando materialidade em reivindicações mais específicas. Nesse processo, a questão ambiental passa a ser vista como "uma grande oportunidade" a ser aproveitada pela agricultura familiar, seja via pagamento por serviços ambientais, seja via produção de alimentos coloniais e agroecológicos. Neste último caso, "a forma de produzir da agricultura familiar se diferenciaria tanto por ser produzida de forma ambientalmente correta, quanto por resgatar positivamente elementos culturais do grupo social dos colonos." (PICOLOTTO; BRANDENBURG, 2015, p. 13). A questão ambiental passa a ser interpretada como estratégia de produção e de renda.

14 É importante destacar que este foi um debate situado entre os anos de 2009 e 2012, período em que ocorreram mudanças no Código Florestal brasileiro. 
Assim, novas questões foram somando-se na agenda da Fetraf-Brasil, articuladas em torno da produção.

\section{Ações e políticas educacionais}

Avançando nas reivindicações em torno do rural como um espaço de vida, como define Wanderley (2009), a Fetraf-Brasil também sempre tem se manifestado em relação a ações e políticas educacionais. Nesse sentido, a Organização sindical afirmou que a educação pública é estratégica e determinante para o desenvolvimento sustentável e que "qualquer transformação mais expressiva na sociedade e em setores sociais específicos, que buscam valorização de sua identidade e auto-estima, tem na educação um dos seus mais fortes alicerces" (FETRAF-BRASIL, 2005, p. 10). Ressaltou também que a "educação se constitui na base para o fortalecimento e para a valorização da agricultura familiar, além de ser fator determinante na construção de um novo projeto de desenvolvimento." (FETRAF-BRASIL, 2014, p. 22).

Dentre as principais reivindicações ao longo dos dez anos da Fetraf-Brasil destacam-se: a) reestruturação curricular escolar que considere a realidade do campo (tempo, local, costumes, valores, cotidiano e linguagem) e da agricultura familiar, conjuntamente com manutenção e valorização das escolas do campo; b) valorização e fortalecimento das iniciativas de educação popular e criação de novas escolas semelhantes às Escolas Família Agrícola; c) ampliação dos programas de educação de jovens e adultos, com valorização da pedagogia da alternância; d) qualificação dos educadores e educadoras do meio rural; e) acesso ao ensino superior; f) recursos e ações para cursos de pós-graduação em programas de interesse da agricultura familiar e do desenvolvimento sustentável (FETRAF-BRASIL, 2005-2015).

Sobre as reivindicações relativas ao ensino superior, cabe salientar a demanda por descentralização das universidades públicas, sendo que logo este tema foi ilustrado com a demanda pela criação da Universidade Federal 
da Mesorregião Grande Fronteira do Mercosul, atualmente denominada Universidade Federal da Fronteira Sul, e de "extensões universitárias e criação novas universidades com vistas a garantir a universidade onde $o$ jovem vive e tem suas raízes culturais, valorizando as especificidades de cada região" (FETRAF-BRASIl, 2015, p. 16). Ainda em relação ao ensino universitário, as pautas mais recentes (2015 e 2014) demandam cursos de extensão universitários nos temas de desenvolvimento rural, cooperativismo, meio ambiente e engenharia de alimentos, "todos enfatizando o papel e a importância da mulher, do jovem e da agricultura familiar"; fortalecimento das políticas de bolsas e cotas, "garantindo cada vez mais a inclusão dos povos indígenas, dos quilombolas, negros e agricultores historicamente excluídos"; garantia de financiamento (Fundo de Financiamento Estudantil) para jovens agricultores portadores de Declaração de Aptidão ao Pronaf (DAP), especialmente aqueles em extrema pobreza e beneficiários de programas de transferência de renda (para estes últimos o financiamento deveria ser a fundo perdido); e transporte universitário.

Nessas reivindicações fica clara a defesa de uma educação que promova o acesso e atenda e fortaleça a identidade dos agricultores familiares e de outros grupos sociais do campo. Reivindicam-se mecanismos que promovam o acesso à educação básica, ao ensino superior e à pós-graduação pelos agricultores familiares, e que esta educação seja dialógica com as especificidades dos modos de vida da agricultura familiar e promova o fortalecimento da categoria social. Como observa Tondin (2015, 2013), há uma defesa da educação do campo e de uma formação sindical e classista orientada por um projeto político que valorize e potencialize a categoria social.

\section{Ações relativas à saúde}

Também no âmbito da construção do rural como um espaço de vida, o tema da saúde igualmente é recorrente nas pautas de reivindicações da 
Fetraf-Brasil. Esse é um tema histórico na atuação do sindicalismo rural, sendo que, inicialmente (décadas de 1960-70), esteve pautado na defesa de convênios para a prestação de assistência médica e de saúde, resumindo a atuação sindical, em diversas situações, em práticas assistenciais (FAVARETO, 2006). Ao longo do tempo, esse tema foi ganhando novos contornos, menos voltados para a prestação de serviços e mais pela defesa da saúde pública, do atendimento às especificidades da agricultura familiar e da medicina preventiva. O tema da saúde foi deixando de ser setorial para interagir com dimensões relativas ao meio ambiente, à produção agrícola e à segurança alimentar e nutricional.

Nessa perspectiva, dentre as principais demandas da Fetraf-Brasil destacam-se: a) ampliação do Programa Saúde da Família, qualificando-o com a atuação multidisciplinar dos profissionais, e fortalecimento do Programa de Agentes Comunitários de Saúde; b) criação de programas de tratamento alternativo e preventivo (homeopatia, plantas medicinais) dentro do Sistema Único de Saúde (SUS) e específicos para a agricultura familiar, procurando atender suas particularidades (contaminação por agrotóxicos, câncer de pele, doenças na coluna etc.); c) estabelecimento de um programa de distribuição gratuita de protetores solares para prevenção ao câncer de pele; d) efetivação de uma política de saúde bucal para a agricultura familiar, de modo especial para as mulheres e crianças; e) construção de um convênio entre o Ministério da Saúde e a Fetraf-Brasil para "implementar um projeto piloto de plantio, colheita e industrialização de plantas medicinais" (2009; 2008; 2007); f) participação da Fetraf no Conselho Nacional de Saúde (2009; 2008; 2007; 2006); g) criação de Centros de Referência de Saúde do Trabalhador com foco na agricultura familiar (2015; 2014); h) implementação de uma campanha de conscientização sobre "os males causados à saúde do trabalhador e trabalhadora pelo uso de agrotóxicos na produção convencional e no plantio do tabaco e as doenças causadas em decorrência do trabalho nestas culturas" (FETRAF-BRASIL, 2015, p. 14). 


\section{Habitação rural}

Avançando para além da agricultura, a habitação rural também é tema assíduo nas pautas de reivindicações da organização sindical, ganhando fôlego no sindicalismo da agricultura familiar a partir do Governo Lula em 2003. ${ }^{15}$ Em 2010, a Fetraf-Brasil afirmou a importância da habitação rural para a reprodução social da agricultura familiar e destacou a "conquista" da criação do Programa Nacional de Habitação Rural (PNHR) como parte integrante do Programa Minha Casa, Minha Vida:

Saímos da velha e retrógrada visão de que à agricultura familiar basta investimentos em produtividade, para um princípio de investimentos em qualidade de vida, significando reprodução socioeconômica das famílias, promoção da seguridade alimentar, sustentabilidade ambiental e cultural das comunidades. Isso corresponde a agregar os componentes de valorização social, cultural e tecnológica das populações que vivem e trabalham na agricultura familiar. Nesse mesmo contexto se insere a habitação rural. A moradia não se resume na casa em si, mas significa também organização, cooperação, relações e direitos sociais, organização econômica produtiva, organização sindical, etc. Além disso, a habitação rural torna-se a conjugação da agricultura familiar, habitação e comércio local, sendo um marco no desenvolvimento econômico regional do país. A implementação das moradias se dá nos pequenos municípios, o que gera renda, empregos e dinâmica econômica, além de contribuir com a permanência das famílias em seus locais de origem. A habitação rural é fruto da luta de toda a sociedade. A criação do Programa de Habitação para a Agricultura Familiar é uma conquista para aqueles que antes ficavam à margem da política habitacional no país. Entretanto, se faz necessário a efetiva implementação desta política, com menos burocracia e maior efetividade (FETRAF-BRASIL, 2010, p. 9).

15 Bolter (2013) analisa o modo como o tema da habitação rural entrou na agenda da Fetraf-Sul, suas repercussões em termos de políticas públicas (Programa Estadual de Habitação Rural no Rio Grande do Sul e Programa Nacional de Habitação Rural), e a atuação da organização sindical na cogestão de programas públicos junto com o Estado e as mudanças na organização sindical ao fazer cogestão da política pública. 
Ao longo desses dez anos (2005-2015), a Fetraf-Brasil pautou a ampliação das fontes e melhores condições de financiamento para a habitação rural e, de modo mais específico, para a agricultura familiar. Algumas demandas ilustram o exposto: garantia de acesso, desburocratização e aceleração aos mecanismos de crédito destinados para os programas habitacionais rurais (2007); "participação de novos agentes financeiros, principalmente cooperativas de crédito rural, para operacionalização dos programas de habitação rural no âmbito da política pública a ser definida para o setor" (2008, p. 15); "garantia de recurso complementar do Ministério da Saúde ao PNHR para implantação de saneamento nas unidades habitacionais" (2015, p. 15).

Ademais, cabe registrar como demandas da Federação no âmbito da habitação: a) consolidação de uma política permanente de habitação para a agricultura familiar que "atenda as necessidades básicas das famílias na construção de um ambiente saudável e de bem-estar em consonância com as diversas realidades sociais, culturais, ambientais e econômicas presentes no meio rural brasileiro" (2009, p.17); b) "criação de um setor específico dentro da Caixa para assuntos da agricultura familiar, com a criação do departamento de habitação rural, com técnicos que conheçam a realidade da agricultura familiar" (2010, p. 10) ${ }^{16}$.

Como comenta Conti (2016), a política de habitação rural tem sido uma das prioridades na agenda e no plano operacional da Fetraf-Brasil, precedida apenas pelas políticas de crédito e de renda. Mais do que ficar no âmbito das reivindicações, a Federação passou a ser uma das principais executoras do Programa Nacional de Habitação Rural por meio da Cooperativa de Habitação dos Agricultores Familiares (COOPERHAF). Nesse sentido, em diálogo e em cogestão com o Estado, a Fetraf-Brasil participou do processo de construção (via pautas de reivindicações e

16 Griza, Kato e Zimmermann (2014) evidenciam a influência dos movimentos sociais e sindicais da agricultura familiar, dentre elas a Fetraf-Brasil, na criação da Superintendência de Habitação Rural dentro da Caixa Econômica Federal. 
outros espaços de participação) e de implementação da política pública, compreendendo a habitação em uma perspectiva que contempla o planejamento e a execução da obra, a organização social dos agricultores, a organização e o planejamento das propriedades, o cuidado com o meio ambiente e o convívio social (BOLTER, 2012). A casa é compreendida de uma maneira mais ampla que a estruturação física, permeando também um modo de vida e de organização social.

\section{Previdência e assistência social}

A previdência e a assistência social também são temas permanentes nas pautas de reivindicações da Federação, que assim se manifestou:

A conquista dos direitos previdenciários, consagrados na Constituição Federal de 1988 e na legislação previdenciária de 1991, representou um dos grandes avanços sociais, econômicos e de conquista de cidadania, de forma muito especial para agricultores e agricultoras familiares. No entanto, o sistema previdenciário para a agricultura familiar necessita ainda de importantes aperfeiçoamentos para que, efetivamente, os princípios constitucionais da seguridade social sejam concretizados, como a igualdade de direitos entre homens e mulheres e entre as populações urbanas e as rurais, assim como o princípio da equidade social (FETRAF-BRASIL, 2014, p. 18).

Dentre esses aperfeiçoamentos e demandas, destacam-se: a) manutenção dos agricultores e agricultoras familiares (segurados especiais) no Regime Geral da Previdência Social, como prevê a Constituição Federal de 1988 e as leis n. 8.212 e n. 8.213, mantendo a idade de 55 anos para as agricultoras e 60 anos para os agricultores; b) humanização no atendimento, especialmente às pessoas mais simples, bem como uniformização dos procedimentos para concessão de benefícios aos segurados especiais; c) criação e ampliação de mecanismos que evitem e impeçam a enorme quantidade de indeferimentos evidentemente injustos e injustificados que 
ocorrem, de forma mais comum, na concessão de aposentadorias por idade e por invalidez e nos auxílios-doença e, de forma mais expressiva ainda, na concessão de benefícios às mulheres agricultoras; $d$ ) garantia da manutenção da qualidade de segurados especiais para quem possui agroindústria familiar sem empregados permanentes, independente do formato jurídico pelo qual a agroindústria foi constituída; e) revisão e aperfeiçoamento da Classificação Internacional de Doenças (CID), visando o reconhecimento das doenças ocupacionais na atividade agrícola, para efeitos no acesso aos benefícios por doença, invalidez e acidente de trabalho; f) garantia de que os agricultores familiares (segurados especiais) que contribuem com mais de um salário-mínimo tenham direito a benefícios em valor proporcional à sua contribuição; g) fiscalização maior nos adquirentes da produção rural, especialmente nas grandes agroindústrias, nas grandes cooperativas e grandes empresas que, muitas vezes, descontam o percentual da contribuição previdenciária dos agricultores familiares e grandes produtores rurais e não efetuam o devido recolhimento junto à Receita Federal; h) estabelecimento de um bloco de notas específico da agricultura familiar em todo território nacional; i) ampliação para seis meses da licença e do salário-maternidade para as agricultoras familiares; $\mathrm{j}$ ) mais recentemente, "reconhecimento da Declaração de Aptidão ao Pronaf como prova plena para comprovação do tempo de atividade rural, visto que atualmente é dos mecanismos mais usados pelos trabalhadores para acessar essa política pública" (FETRAF-BRASIL, 2015, p. 13).

Como menciona Conti (2016), a previdência social é uma pauta histórica da Fetraf e do sindicalismo cutista. As ações e reivindicações sempre estiveram voltadas para esse acesso e pela sua manutenção e ampliação no sentido de universalizar os benefícios a todos os idosos e pessoas que ainda não foram incluídos no Regime Geral da Previdência Social ou que encontram empecilhos burocráticos nesse processo. Junto com esta pauta histórica, cresceram em anos recentes as reivindicações por políticas sociais. O depoimento de uma dirigente para Conti (2016, p. 143) 
é emblemático nesse sentido: "Precisamos de políticas sociais, além de melhorar a infraestrutura no campo. Esse é um dos grandes desafios que estamos pautando no início desse governo, juntar as novas pautas com as que a gente não conseguiu avançar durante os últimos anos."

Todavia, em que pese a preocupação com políticas sociais, a inclusão das famílias mais pobres da agricultura familiar ainda é pouco presente nas pautas de reivindicações da Fetraf (CONTI, 2016). São raras as menções à pobreza (tendo sido mais acentuada na Pauta de Reivindicações de 2011, no contexto do lançamento do Plano Brasil Sem Miséria), geralmente relacionadas com elementos que podem incrementar a pobreza (como insuficiência de terra, preços baixos dos produtos agrícolas, dificuldades de comercialização...) e não com demandas de políticas públicas para a inclusão produtiva e social das famílias pobres ou em extrema pobreza da agricultura familiar.

\section{Políticas e ações para a juventude rural}

Barcelos (2014) destaca que, desde o início da organização sindical, o tema da juventude já esteve presente na sua estrutura organizacional. Desde 2005, as federações estaduais possuem secretarias de juventude que fazem parte da executiva da Fetraf-Brasil. Acompanhando essa estrutura organizacional, reivindicações relativas à juventude rural estiveram presentes desde as primeiras pautas de reivindicações da Federação, no entanto expressas principalmente em torno do Pronaf Jovem. A partir de 2007 essa temática passou a ser objeto de uma seção específica e foi ganhando maior espaço. Nesse sentido, a organização sindical assim se manifestou:

A juventude da agricultura familiar, em função da realidade social na qual está inserida, requer uma atenção especial do poder público a fim de buscar reverter a atual tendência de êxodo rural e dos problemas de sucessão nas propriedades. Compreendemos que 
um conjunto de políticas públicas quando integradas e articuladas podem contribuir em muito para enfrentar esses problemas e construir condições para o bem viver da juventude da agricultura familiar (FETRAF-BRASIL, 2007, p. 16).

Em 2014 a interpretação da Fetraf-Brasil permanecia similar, acentuando a problemática da sucessão nas propriedades da agricultura familiar:

A Juventude da Agricultura Familiar vivencia um momento histórico estratégico para a intervenção das políticas públicas no sentido de criar as condições objetivas para a construção da sua dignidade, do efetivo direito à opção de vida, da continuidade da agricultura familiar e de um redirecionamento rumo a um desenvolvimento sustentável. Se o necessário não for feito neste próximo período, muito provavelmente daqui a 10 (dez) anos essa oportunidade fará parte do passado. A questão da sucessão nas propriedades familiares é de extremo interesse das famílias e dos jovens, mas não somente deles. É um interesse da Sociedade, do Estado e dos Governos. Políticas públicas integradas e articuladas a outras ações e atitudes que necessitam ser promovidas em nível local pelas famílias, pelas organizações sociais e pela sociedade, são fundamentais para enfrentar problemas e construir condições que transformem o espaço rural e a atividade agrícola numa opção de vida e trabalho para a juventude. A implementação e a articulação de um conjunto de políticas públicas específicas (diferenciadas) que estimulem a juventude a permanecer na atividade agrícola e no espaço rural é uma condição fundamental para a construção de um desenvolvimento rural sustentável, solidário e com gente (FETRAF-BRASIL, 2014, p. 15).

Dentre as principais reivindicações relacionadas à temática da juventude rural manifestas no período 2005-2015, destacam-se: a) mudanças no Pronaf Jovem e no crédito fundiário; b) ações de valorização cultural do espaço rural como espaço comunitário de vida, com acesso a múltiplas possibilidades de trabalho, renda, cultura, lazer, informação, comunicação etc.; c) criação do Programa Nacional Bolsa Jovem para agricultura familiar, como incentivo ao jovem para implementação, na propriedade, de um 
projeto produtivo, tendo como público os(as) jovens da agricultura familiar de 18 a 29 anos, que obrigatoriamente estivesse estudando, no valor de um salário-mínimo. d) acesso da juventude rural ao ensino fundamental, médio, profissionalizante e universitário, adequados à agricultura familiar e suas especificidades; e) construção de um Plano Nacional de Sucessão na Agricultura Familiar com objetivo de incentivar os jovens a permanecerem no meio rural, articulando acesso à terra, à moradia, ao crédito (investimento e custeio), a ATER, aos serviços de infraestrutura (energia, internet e telefonia), à cultura e ao lazer (FETRAF-BRASIL, 2015; 2014; 2013).

Observa-se, desse modo, que, ao longo dos anos, o tema da juventude rural foi ganhando novos contornos. As reivindicações para esse grupo social perpassam dimensões produtivas, de infraestrutura (acesso à terra), educacionais, culturais, de comunicação e inclusão digital e, a partir de 2014, reivindicações mais expressivas em torno da promoção da sucessão na Agricultura Familiar, o que implica a construção de políticas públicas intersetoriais e multidimensionais.

\section{Políticas para as mulheres rurais}

De forma similar à juventude rural, o tema das mulheres também sempre esteve presente nas pautas de reivindicações da Fetraf-Brasil, ainda que inicialmente relacionado fundamentalmente a demandas de aperfeiçoamentos no Pronaf Mulher. A partir de 2011 a temática das mulheres começou a ganhar mais espaço e, desde 2012, passou a contar com uma seção específica. Em 2013, a Federação afirmou a invisibilidade do trabalho feminino na contemporaneidade, inclusive nas políticas públicas:

O trabalho da mulher na produção familiar é entendido geralmente como um simples prolongamento das atividades domésticas. $\hat{E}$ a chamada "invisibilidade do trabalho feminino", que significa a sua não-valorização econômica. Ou seja, nesta visão, a mulher 
desempenha apenas um trabalho reprodutivo, que apenas visa manter a força de trabalho na unidade familiar. Apesar de a agricultura familiar caracterizar-se como uma atividade que envolve todos os membros da família, ainda é forte a visão da gratuidade do trabalho da mulher, pelo qual ela apenas "ajuda" o homem, a quem se atribui o papel de responsável pelo provimento da família. Em geral, a mulher é ainda vista como dependente do marido, inclusive nas políticas públicas mais recentes. (FETRAF-BRASIL, 2013, p. 11).

Visando contrapor-se à invisibilidade e promover a inclusão socioprodutiva das mulheres rurais, a Fetraf-Brasil pontuou um conjunto de demandas, sendo algumas delas: a) ampliação do salário-maternidade de quatro para seis meses a todas as trabalhadoras rurais; b) cumprimento da idade de 55 anos para o acesso ao benefício da previdência rural, pois "para $20 \%$ das mulheres rurais a idade real da aposentadoria só acontece após os 60 anos de idade. [...] A burocracia do INSS, a subjetividade ainda presente na definição dos direitos e a falta de documentação que provocam essa discriminação das mulheres agricultoras" (2014, p. 16); c) atuação do Programa Nacional de Documentação da Trabalhadora Rural na promoção do acesso e na legalização da documentação das mulheres rurais; d) capacitação, formação e qualificação para as mulheres agricultoras familiares "a partir de temas e ações específicas na garantia de uma alimentação saudável, saúde preventiva e alternativa, sexualidade, agricultura agroecológica, elevação da autoestima, fim da violência contra a mulher e preservação do meio ambiente" (2014, p. 17); e) chamadas públicas e projetos específicos de incentivo à produção orgânica e ecológica às mulheres agricultoras familiares; f) "criação de um programa de incentivo e valorização da organização produtiva das mulheres do campo para a produção e comercialização dos produtos aos programas institucionais como o PNAE e o PAA especialmente, facilitando e desburocratizando o acesso"; g) criação de um programa de saúde preventiva para as mulheres da agricultura familiar; h) melhorias no atendimento do SUS aos exames 
periódicos necessários à saúde da mulher; e i) "criação e implementação efetiva de políticas públicas de proteção às mulheres da agricultura familiar vítimas de violência" (2015, p. 17).

Da mesma forma que no tema da juventude rural, observamos aqui intensificação do debate em torno das mulheres rurais e ampliação das reivindicações em pauta, em uma perspectiva intersetorial e de reconhecimento político.

\section{Política territorial e infraestrutura rural}

Infraestrutura para as áreas rurais e, de modo particular, para a agricultura familiar também é uma das demandas da Fetraf-Brasil, expressa notadamente em infraestrutura para os assentamentos de reforma agrária, para o fortalecimento da agricultura familiar e para a agroindustrialização. Cabe destacar que, até 2011, tal discussão se encontrava também articulada com a política territorial (Programa Nacional de Desenvolvimento Sustentável dos Territórios Rurais - Pronat), destacando-se como demandas: a) ampliação do número de territórios em regiões de agricultura familiar; b) estabelecimento de um plano orçamentário para cada território; c) garantia de participação da Fetraf e Sintraf nos conselhos/comitês estaduais e municipais, respectivamente; d) fortalecimento do Conselho Nacional de Desenvolvimento Rural Sustentável (CONDRAF); e) mais recursos para os territórios, maior "alinhamento de todos os ministérios na execução das políticas”, e redução dos valores exigidos como contrapartida nos projetos territoriais.

A partir de 2012, demandas relacionadas com as políticas territoriais não foram mais mencionadas (acompanhando o próprio arrefecimento das referidas políticas) e, em 2014, a infraestrutura para produção voltou a ter uma seção específica. As reivindicações concernem principalmente à qualificação da energia elétrica nas áreas rurais (modernização dos 
equipamentos e maior carga elétrica) e, especificadamente, "garantia de R\$ 100 milhões para estradas e pontes do estado do Pará, considerando que a SR27 já possui os Projetos Técnicos de Engenharia prontos neste montante, considerando que os assentamentos estão em situação de abandono e com impossibilidade de escoamento da produção" (FETRAF-BRASIL, 2015, p. 10). Essas demandas, alinhadas ao PAC da Agricultura Familiar, faziam parte de um conjunto de ações para dar impulso ao desenvolvimento rural e da categoria social.

\section{Ações de apoio à produção de biocombustíveis}

A produção de biocombustíveis é uma temática um pouco oscilante na pauta de reivindicações da Fetraf-Brasil, seja pela sua presença/ausência, seja pela expressividade ganha nos documentos, acompanhando, em certa medida, a dinâmica da política pública relacionada com o tema (Programa Nacional de Produção e Uso de Biocombustíveis). Em 2006, a demanda consistia em garantir a participação da agricultura familiar em todas as etapas da cadeia produtiva, uma vez que a Federação não considerava a inclusão da agricultura familiar apenas como repassadora de matéria-prima, mas entendia que essa produção deveria respeitar a diversidade da agricultura familiar.

Nos anos de 2007, 2008, 2009 e 2011 o tema dos biocombustíveis mostrou-se mais expressivo, cujas demandas contemplavam: a) criação de uma linha dentro do Pronaf para financiar a produção, industrialização e comercialização de oleaginosas; b) recursos para investimentos, infraestrutura e capacitação/ATER para fortalecer a cadeia produtiva do biodiesel na agricultura familiar e reforma agrária; c) fortalecimento, estruturação e capacitação para as cooperativas da agricultura familiar vinculadas ao Programa Nacional de Produção e Uso de Biocombustíveis (PNPB); d) criação de uma cota específica para a agricultura familiar dentro do PNPB, 
na aquisição do biodiesel por parte do Governo Federal, associado a um programa de fomento e construção de pequenas e médias usinas de biodiesel nas comunidades rurais.

Em 2012 e 2013, o tema não apareceu nas pautas de reivindicações, retornando em 2014 e 2015, mas com demandas bem específicas em relação ao Programa Nacional de Produção e Uso de Biodiesel: aumentar o percentual de mistura de biodiesel no diesel; e aumentar o "fator multiplicador de 1.2 para 1.8 quando se tratar de aquisição de matéria prima de cooperativas da agricultura familiar, por parte das empresas que detém o selo de combustível social" (FETRAF-BRASIL, 2015, p.10).

Essa oscilação e arrefecimento do tema na pauta de reivindicações provavelmente reflete os acordos e desacordos da organização sindical em relação ao Programa. Flexor et al. (2011) apontam, por exemplo, que a Fetraf reconhecia o esforço do PNPB de incluir os agricultores familiares, contudo discordava da inserção marginal da categoria social (fornecedora de matéria prima) e da centralidade que a soja acabou angariando no Programa. Similarmente, em um evento realizado em 2012, diversos movimentos sociais, entre eles a Fetraf-Brasil, assinaram um documento intitulado "Agrocombustíveis e o desenvolvimento social baseado na efetivação dos direitos humanos"', no qual apontavam os limites para a segurança alimentar e nutricional. E, além disso, que

o programa não tem sido a política inclusiva que foi proposta, mas tem fortalecido a cadeia produtiva da soja, principal matéria-prima de produção do biodiesel. [...] o diálogo com o governo tem sido insuficiente, não havendo avanços para estruturar a cadeia produtiva para agricultores familiares, que não dispõem de investimentos para o beneficiamento das oleaginosas, diversificação da produção e adequação regional do programa.

17 Disponível em: <https://www.cptne2.org.br/index.php/publicacoes/noticias/9-especiais/especial-agrocombustiveis/3676-movimentos-sociais-apontam-desafios-e-prioridades-diante-do-avan\%C3\%A7o-dos-agrocombust\%C3\%ADveis>. Acesso em: 20 abr. 2018. 
Tais desacordos podem ter repercutido nas pautas de reivindicações.

\section{Representação sindical}

Em 2009 o tema da representação sindical também entrou na agenda da Fetraf-Brasil, ganhando maior expressividade a partir da pauta de reivindicações de 2012 e, em 2014, a Federação explicitamente afirmou:

A organização sindical da agricultura familiar é amplamente reconhecida e legitimada pela sociedade nacional e internacional, pelo poder legislativo desde a constituição federal até normas infraconstitucionais (Lei 11.326/06 - a Lei da Agricultura Familiar), pelo poder judiciário com decisões favoráveis nas mais diversas instâncias e pela quase totalidade dos órgãos do poder executivo, desde o espaço nacional até os municípios. O único Ministério que ainda coloca empecilhos no reconhecimento da agricultura familiar como categoria econômica e, no consequente reconhecimento da sua organização de representação sindical é o Ministério do Trabalho e Emprego. A FETRAF-BRASIL/CUT, as FETRAFs Estaduais e os SINTRAFs têm assento nos mais diversos Conselhos Institucionais, firmam parcerias e convênios de cooperação, porém ainda não conseguem o direito de registro para fins de arquivo no Ministério do Trabalho (FETRAF-BRASIL, 2014, p. 4).

Diante desse cenário, a organização sindical demandou: a) reconhecimento público e oficialmente pelo Ministério do Trabalho e Emprego da "categoria profissional da Agricultura Familiar e, por meio da sua Secretaria de Relações Sindicais, desentrave todos os processos de Registro Sindical de Sintrafs - Sindicatos de Trabalhadores e Trabalhadoras na Agricultura Familiar que foram sumariamente arquivados, assim como aqueles requerimentos que estão em andamento e dê agilidade na análise e na divulgação do Registro Sindical destes sindicatos"; b) "o fim da criminalização das organizações da sociedade civil e, de modo particular, as organizações que exercem o papel de representação sindical" (FETRAF-BRASIL, 2015, p. 2). 
Nesse contexto, é importante citar que, em maio de 2015, o Ministério do Trabalho reconheceu a agricultura familiar como categoria e, em 2016, a Fetraf-Brasil passou a denominar-se Confederação Nacional dos Trabalhadores e Trabalhadoras da Agricultura Familiar, na expectativa de ser legalmente reconhecida como Confederação representativa dos agricultores familiares.

\section{Acesso à água}

Em 2012 o tema dos recursos hídricos também entrou na agenda da Fetraf-Brasil, que afirmou:

Em todas as regiões do país, a água é insumo indispensável tanto para o consumo humano, como para a produção de alimentos e consumo dos animais. O problema da seca, que tem sido historicamente uma realidade estrutural no Nordeste Brasileiro, já está afetando outras regiões, como é o caso de vários territórios da região Sul. A falta da água, de forma mais permanente ou em alguns momentos do ano, tem trazido prejuízos de grande envergadura a toda sociedade, pois os agricultores perdem safras, os consumidores amargam o aumento de preços, dificultando o processo de desenvolvimento destes territórios que sofrem com a estiagem (FETRAF-BRASIL, 2012, p. 6).

Dentre as principais reivindicações, destacam-se: a) “a massificação de processos que garantam a democratização do acesso à água com a construção de sistemas simplificados de abastecimento de água em comunidades rurais", com perfuração, recuperação e instalação de poços e elevação de adutoras (caixas elevadas) para abastecimento das comunidades, por meios de ramais, em distribuição por gravidade, considerando a recuperação e conservação das fontes de nascentes, garantindo água pra consumo humano e animal; b) criação do Pronaf Mais Água, com valor de até R \$ 50 mil reais para a aquisição de equipamentos para soluções de água; c) criação 
de um programa que possibilite captação de água para irrigação, por meio de crédito e tecnologia "de alcance familiar e ao nível das comunidades"; d) agilidade e recursos na implementação do Programa Água para Todos; e) criação de um Plano Nacional de Convivência com o Semiárido; e,f) garantia de abastecimento de água potável nas comunidades atingidas pelas secas, por meio de carros-pipa, perfuração de poços, construção de barragens subterrâneas, cisternas de placas, dessalinizadores e pequenos açudes (FETRAF-BRASIL, 2015; 2014; 2013; 2012).

Ainda que recente e marginal nas prioridades da agenda da Fetraf, o tema da água ilustra avanços no debate sobre segurança alimentar e nutricional no âmbito da organização sindical (CONTI, 2016). A Federação passou a explicitar que os alimentos e a água são um direito humano e, nessa perspectiva, reconhece a necessidade de preservação e recuperação das águas e suas reivindicações concentram-se na democratização do acesso na infraestrutura hídrica.

\section{Reflexões sobre os temas em destaque nas pautas de reivindicações da Fetraf-Brasil}

Ao longo dos anos, como mencionado anteriormente, novas ideias, interpretações e temas entraram ou ganharam mais espaço na agenda da Fetraf-Brasil, somando-se a pautas já tradicionais. Crédito, seguro, iniciativas de apoio à comercialização, assistência técnica e extensão rural, pesquisa agropecuária, ações de apoio aos assentamentos de reforma agrária e previdência social são exemplos de temas mais consolidados, os quais trazem aprendizados e acúmulos desde a conformação do DNTR/CUT e da Fetraf-Sul (CONTI, 2016; SEMINOTTI, 2013; BOLTER, 2013; GRISA, 2012; PICOLOTTO, 2011; FAVARETO, 2006). Geralmente são questões marcadas "com um viés mais econômico e de política agrícola" (CONTI, 
2016), historicamente presentes e ainda centrais nas bandeiras de luta da organização sindical.

A essas temáticas, uma diversidade de temas e atores sociais foi somando-se ao longo dos anos, fruto de elementos conjunturais, do reconhecimento de grupos sociais presentes na agricultura familiar, de sistemas produtivos que vieram à tona, e da compreensão do desenvolvimento em uma perspectiva ampla, que compreende o rural como um espaço e modo de vida. Para Conti (2016), a participação da Fetraf-Brasil em espaços como o Conselho Nacional de Segurança Alimentar e Nutricional (CONSEA) e o Conselho Nacional de Desenvolvimento Rural Sustentável e Solidário contribui para estas incorporações. Juventude rural, mulheres, agroecologia, plantas medicinais, serviços ambientais, acesso à água, estrangeirização da propriedade da terra, conflitos fundiários, biocombustíveis, habitação, ensino superior, energia elétrica, assistência social e liberdade de organização e representação sindical são alguns de temas e atores que ganharam espaço nas pautas de reivindicações.

No entanto, as pautas da Fetraf-Brasil também podem ser marcadas pelas ideias ausentes ou omissas, como os agricultores familiares em maior vulnerabilidade social e a diversidade de formas familiares de produção e de relacionamento com a terra (extrativistas, quilombolas, quebradeiras de coco babaçu, faxinalenses etc.). Conti (2016, p. 148) é enfático ao afirmar que as pautas mencionam "discretamente as famílias mais pobres que acessam programas como o Brasil Sem Miséria, nem fazem referências à diversidade dos povos e comunidades tradicionais, o que dá um indicativo de que estes são invisíveis na organização sindical e na composição de suas pautas." Da mesma forma, atividades não agrícolas, artesanato, turismo rural e estratégias relacionadas com a cultura das comunidades rurais (danças, músicas, rituais, receitas etc.) ainda encontram pouca correspondência nas pautas de reivindicações e bandeiras de lutas da Fetraf-Brasil. Tais ausências devem-se ao perfil da maioria dos agricultores que compõe sua base social que, como já mencionado, caracterizam-se pelo acesso à 
terra (ainda que com limitações), inserção nos mercados, centralidade da produção agrícola (não raro, grãos, suínos, aves, fumo e leite) e certa estruturação econômica (CONTI, 2016; PICOLOTTO, 2011). ${ }^{18}$

Apesar da incorporação de novos temas e questões ao longo dos anos, é importante mencionar que eles não são simétricos no que concerne à atenção conferida e às ações desenvolvidas pela organização sindical. Como já reconhecido igualmente por Conti (2016), Tondin (2015) e Picolotto (2011), os temas vinculados à "produção e renda para a agricultura familiar" destacam-se ao longo da trajetória, refletindo as próprias características da sua base social como mencionado anteriormente. A habitação rural, em função da própria estrutura organizacional da Fetraf-Brasil com a Cooperhaf, também apresenta espaço importante na agenda e nas ações da organização sindical. Os demais temas e questões ganham intensidades diferenciadas dependendo da conjuntura política e das janelas de oportunidades construídas pela Fetraf-Brasil.

Em que pesem tais diferenciações, é incontestável a importância da Fetraf-Brasil (em conjunto com demais organizações sindicais e movimentos sociais) na construção das políticas para a agricultura familiar e o desenvolvimento rural ao longo dos últimos 20 anos, seja por meio das pautas de reivindicações, seja participando em outros espaços políticos e institucionais. Diversos estudos analisaram e relataram como as ideias e "interpretações de mundo" da organização sindical contribuíram na criação ou em mudanças de diversas políticas públicas, a exemplo do Programa Nacional de Fortalecimento da Agricultura Familiar (Pronaf), Programa de Aquisição de Alimentos (PAA), políticas para juventude, políticas educacionais etc. As narrativas, os argumentos e as reivindicações da Fetraf-Brasil contribuíram para o fortalecimento da agricultura familiar e para o reconhecimento das diversas dimensões necessárias para o desenvolvimento rural.

18 Também é importante considerar que a grande maioria dos grupos sociais mencionados (extrativistas, quilombolas, quebradeiras de coco babaçu, faxinalenses etc.) já possuem suas próprias organizações sociais. 


\section{REFERÊNCIAS}

BARCELOS, Sergio B. A formulação das políticas públicas para a juventude rural no Brasil: atores e fluxos políticos nesse processo social. Tese (Tese de Doutorado em Ciências Sociais) - Programa de Pós-Graduação de Ciências Sociais em Desenvolvimento, Agricultura e Sociedade/UFRRJ, 2014.

BOLTER, Jairo. A. G. Interfaces e cogestão nas políticas para agricultura familiar: uma análise do Programa Nacional de Habitação Rural. Tese (Tese de Doutorado em Desenvolvimento Rural) - Programa de Pós-Graduação em Desenvolvimento Rural/UFRGS, 2013.

CONTI, Irio L. Organizações sociais e políticas públicas: inserção da Fetraf-Sul nas políticas públicas de segurança alimentar e nutricional. Tese. Programa de Pós-Graduação em Desenvolvimento Rural (PGDR-UFRGS). 2016.

FAVARETO, Arilson. Agricultores, trabalhadores: os trinta anos do novo sindicalismo rural no Brasil. Revista Brasileira de Ciências Sociais, v. 21, n.62, 2006.

FEDERAÇÃO NACIONAL DOS TRABALHADORES E TRABALHADORAS NA AGRICULTURA FAMILIAR (FETRAF-Brasil). XI Jornada Nacional de Luta da Agricultura Familiar e Reforma Agrária. Pauta de Reivindicações. Brasília-DF: FETRAF-Brasil, 2015.

. X Jornada Nacional de Luta da Agricultura Familiar e Reforma Agrária. Pauta de Reivindicações. Brasília-DF: FETRAF-Brasil, 2014.

. IX Jornada Nacional de Luta da Agricultura Familiar e Reforma Agrária. Pauta de Reivindicações. Brasília-DF: FETRAF-Brasil, 2013.

- VIII Jornada Nacional de Luta da Agricultura Familiar e Reforma Agrária. Pauta de Reivindicações. Brasília (DF): FETRAF-Brasil, 2012.

. Pauta de reivindicações da VII Jornada nacional de luta da agricultura familiar. Brasília-DF: FETRAF-Brasil, 2011.

- VI Jornada Nacional de Luta da Agricultura Familiar e Reforma Agrária. Pauta de Reivindicações. Brasília-DF: Fetraf-Brasil, 2010.

$V$ Jornada Nacional de Luta da Agricultura Familiar e Reforma Agrária. Pauta de Reivindicações. Brasília-DF: FETRAF-Brasil, 2009.

. Pauta de reivindicações da IV Jornada nacional de luta da agricultura familiar. Brasília-DF: FETRAF-Brasil, 2008. 
. Pauta de reivindicações da III Jornada nacional de luta da agricultura familiar. Brasília-DF: FETRAF-Brasil, 2007.

- Pauta de Reivindicações da Agricultura Familiar. Brasília-DF: FETRAF-Brasil, 2006.

Pauta de Reivindicações da Agricultura Familiar. Brasília-DF: FETRAF-Brasil, 2005.

FLEXOR, Georges et al. Dilemas institucionais na promoção dos biocombustíveis: o caso do Programa Nacional de Produção e Uso de Biodiesel no Brasil. Cadernos do Desenvolvimento, ano. 5, n. 8, 2011.

FOUILLEUX, Ève. La politique agricole commune et ses réformes: une politique à l'épreuve de la globalisation. Paris: L'Harmattan, 2003.

GRISA, Catia. Políticas públicas para a agricultura familiar no Brasil: produção e institucionalização das ideias. Tese (Tese de Doutorado em Ciências Sociais) - Programa de Pós-Graduação de Ciências Sociais em Desenvolvimento, Agricultura e Sociedade/UFRRJ, 2012.

GRISA, C.; KATO, K.; ZIMMERMANN, S. A. Projeto Repensando o conceito de ruralidade no Brasil: implicações para as políticas públicas. O rural nas políticas públicas do Brasil Contemporâneo. 2014 (relatório de pesquisa).

KUJAWA, Henrique A.; TEDESCO, João C. Mediações e representações em conflito na luta pela terra entre indígenas e agricultores no norte do Rio Grande do Sul, Brasil. Grifos, n. 42, 2017.

MULLER, Pierre. Les politiques publiques. 7. ed. Paris: PUF, 2008.

PICOLOTTO, Everton L. As mãos que alimentam a nação: agricultura familiar, sindicalismo e política. Tese (Doutorado de Ciências Sociais em Desenvolvimento, Agricultura e Sociedade) - Programa de Pós-Graduação de Ciências Sociais em Desenvolvimento, Agricultura e Sociedade (CPDA/ UFRRJ). Rio de Janeiro-RJ, 2011.

PICOLOTTO, Everton L.; BRANDENBURG, Alfio. Uma grande oportunidade: o sindicalismo e seus projetos de ecologização da agricultura familiar. Ambiente e Sociedade, V. XVIII, n. 3, p. 1-18, 2015.

SEMINOTTI, Jonas. Os agricultores familiares e a representação política do Sutraf na região Alto Uruguai do RS. Tese (Doutorado em Sociologia) Programa de Pós-Graduação em Sociologia. Curitiba-PR, 2013. 
RADAELLI, Claudio M. Logiques de pouvoirs et récits dans les politiques publiques de l'Union Européene. Revue française de science politique, v. 50, n. 2, p. 255-275, 2000.

TONDIN, Celso F. A educação na pauta de lutas da Fetraf-Sul/CUT. In: $37^{\circ}$ Reunião Nacional da ANPED, Florianópolis: UFSC/ANPED, 2015.

. Políticas públicas de educação para os/as agricultores/as familiares: um diálogo entre a Fetraf-Sul/CUT e o Estado. Tese (Doutorado em Psicologia) Programa de Pós-Graduação em Psicologia/PUC-RS. Porto Alegre-RS, 2013.

WANDERLEY, Maria N.B. O mundo rural como um espaço de vida: reflexões sobre a propriedade da terra, agricultura familiar e ruralidade. Porto AlegreRS: UFRGS, 2009. 


\title{
A educação do campo e desafios na atual conjuntura política brasileira
}

\author{
Willian Simões ${ }^{19}$
}

\section{Considerações iniciais}

Em 2018, a educação do campo faz vinte anos de sua emergência enquanto conceito que expressa e articula um conjunto de lutas pelo direito ao acesso e à permanência na escola pública, gratuita e emancipatória do/ no campo. E também como um processo de escolarização que respeita e considera, nos processos educativos, os saberes e fazeres dos territórios e territorialidades daqueles que têm como espaço de vida o espaço rural brasileiro.

Nessa trajetória, no contexto da questão agrária brasileira, a educação do campo compreende uma pedagogia de luta. Isso porque no campo, em tensão com o agro-hidro-negócio, há camponeses e agricultores familiares produtores de alimentos (orgânicos, agroecológicos, sem veneno), há comunidades tradicionais com conhecimentos igualmente tradicionais (indígenas, quilombolas, pescadores artesanais, ilhéus e ribeirinhos, faxinalenses, entre outros) que expressam relações políticas, culturais, sociais e com suas naturezas externas diferenciadas das relações de hegemonia

19 Doutor em Geografia, pela Universidade Federal do Paraná (UFPR). Professor da área de ensino de geografia na Universidade Federal da Fronteira Sul (UFFS - Campus Chapecó, em Santa Catarina). Membro do Núcleo de Estudos Território, Ambiente e Paisagem (Netap), na UFFS, e do Coletivo de Estudos sobre Conflitos pelo Território e pela Terra (Enconttra) na UFPR. Trabalha, atualmente, com os temas: Educação geográfica e formação de professores; Questão agrária, juventude rural e educação do campo. 
capitalista. São esses sujeitos em permanente tensão a partir de seus territórios, ampliando cada vez mais práticas alternativas de vida ao modelo de desenvolvimento econômico, que estiveram/estão engajados na construção do movimento por uma educação do campo.

Neste capítulo, a partir de uma revisão bibliográfica, procuramos destacar que o caminho trilhado foi sendo marcado pelo engajamento político cada vez maior de movimentos sociais e sindicais populares, por professores e pesquisadores da educação básica e do ensino superior, envolvidos, de alguma forma, no eixo das lutas por terra, território e educação no país. São coletivos que acreditam que uma educação pública, gratuita e emancipatória no campo é direito de todos e dever do Estado. Foi sendo marcado, também, pela criação e implementação de programas e políticas públicas, pela elaboração de um aporte teórico-jurídico estatal que passou a reconhecer a existência e as demandas desse movimento por uma educação do campo, pela composição de grupos de estudos e pesquisas nas instituições de ensino superior ${ }^{20}$, pela organização e atuação de articulações e comitês em diferentes escalas e com diferentes interesses etc.

Entretanto, é preciso salientar que tudo isso não vem ocorrendo sem conflito, sem a convivência com as contradições presentes no tecido social capitalista em que estamos inseridos, sem as disputas no campo político intelectual e das políticas públicas. Continua fazendo parte da realidade nas comunidades rurais: o fechamento de escolas por motivos econômicos; a existência de uma rede de transporte escolar; a convivência com infraestrutura precária nos estabelecimentos de ensino (sem laboratórios, pátio de esportes, salas de professores, entre outros); a falta de professores e concursos públicos, com planos de carreira e formação inicial e continuada adequada para as mais diferentes áreas do conhecimento e que tenham o campo como espaço de vida, entre outros.

20 Sobre a produção do conhecimento no campo intelectual da Educação do Campo, ver: SOUZA, Maria Antônia de. Educação e Movimentos Sociais do Campo: a produção do conhecimento no período de 1987 a 2015. 2. ed. Curitiba: UFPR, 2016. 
A situação política e econômica do país é delicada neste momento de sua história, podendo ser vista como o tempo de um golpe parlamentar-jurídico-midiático (SINGER et al., 2016). Indicativos, como a proposta de reforma do ensino médio, a opção pelas parcerias, sobretudo com setores do poder privado para contribuir na elaboração e implementação de políticas, são indicativos de que estamos vivenciando a hegemonia de interesses empresariais/neoliberais no campo educacional, como afirma Simões (2017, p. 47):

Os discursos e ações por parte do governo federal e seus apoiadores nesse cenário já apontam para mudanças dos rumos das políticas públicas, sobretudo aquelas que foram criadas para garantir o mínimo de seguridade social e trabalhista; em aparatos jurídicos e institucionais tanto para proteger o tecido corrupto da política quanto para dar maior seguridade jurídica aos investidores de setores empresariais e financeiros; de realinhamento do Brasil na ordem geopolítica global, que envolve maior abertura ao capital internacional para usos e abusos, sobretudo dos/nos territórios do trabalho e da natureza (produção de energia, mineração, terras agricultáveis, potencial das florestas, entre outros).

Se o lugar da educação do campo já não era de destaque no âmbito das políticas públicas educacionais, nesse cenário as tensões já estão sendo muito mais acirradas. Soma-se a isso a atuação de um dos movimentos mais conservadores deste país, o Escola sem Partido, que em nome de uma suposta neutralidade científica, por exemplo, compreende os jovens estudantes como sujeitos passivos, o professor como sujeito opressor-manipulador e que todo e qualquer ato pedagógico que permita a confrontação de conhecimentos e modos de enxergar a realidade precisa ser criminalizado (RAMOS, 2017, p. 84).

Considerando esses aspectos históricos, debruçamo-nos neste texto, a partir de um diálogo interdisciplinar, para reafirmar especificidades que marcam a trajetória da educação do campo, com destaque para seu 
conceito, os sujeitos que por ela lutam e contribuem na construção de sua concepção, algumas das conquistas e das tensões no campo político da política pública, assim como os desafios que emergem na história do presente, frente às concepções de educação defendidas por representações da "ordem e do progresso" que protagonizam seus projetos a partir do lema "ponte para o futuro".

O texto tem como objetivo, também, servir de base para que estudos locais e/ou regionais possam refletir sobre a trajetória da educação do campo e seu papel como força motriz de outra perspectiva de escolarização dos sujeitos do campo, a atuação dos movimentos sociais e sindicais que carregam essa bandeira, seus limites e desafios no campo político das políticas públicas, as marcas e as práticas da educação rural que ainda persistem, entre outros.

\section{Sobre o conceito de educação do campo}

O conceito de educação do campo nasce no Brasil a partir das lutas pela reforma agrária e por um campo com vida. É a partir dos acampamentos e assentamentos, no seio dos enfrentamentos com o latifúndio e o agronegócio, sobretudo do Movimento dos Trabalhadores Rurais Sem Terra (MST), que ainda no final da década de 1990 conquista visibilidade de modo emblemático o direito à escola pública no campo ${ }^{21}$. Demanda que vai se estendendo a outros movimentos sociais e às entidades coletivas da agricultura familiar, assim como à diversidade de povos e comunidades tradicionais existentes no país. ${ }^{22}$ Por isso, podemos afirmar que

21 Um marco desse período foi a realização, em 1997, do I Encontro Nacional dos Educadores e Educadoras das Reforma Agrária (Enera), pelo Movimento dos Trabalhadores Rurais Sem Terra (MST).

22 A literatura vem trabalhando com o conceito de "sujeitos do campo", a exemplo: o Movimento dos Atingidos por Barragens (MAB), o Movimento das Mulheres Camponesas (MMC), o Movimento dos Pequenos Agricultores (MPA), o MST, os coletivos da Agricultura Familiar, como a Federação dos Trabalhadores da Agricultura Familiar (Fetraf), também os coletivos dos povos e comunidades tradicionais (indígenas, quilombolas, pescadores, ilhéus e ribeirinhos, faxinalenses, seringueiros etc.). 
há um estreito laço entre questão agrária e educação do campo, em que os sujeitos do campo na luta por terra, território e dignidade, também se movimentam na luta pela escola.

Nesse contexto, ainda durante a realização da I Conferência Nacional por uma Educação do Campo, em 1998, era denunciado de modo mais sistemático o abandono do Estado em relação à oferta de escolarização nos espaços rurais do Brasil. Denunciava-se, também, que as escolas e os conhecimentos, ancorados em uma lógica urbano-industrial-capitalista, não consideravam como uma de suas referências pedagógicas os elementos da cultura e da identidade dos camponeses/agricultores. Em síntese, os movimentos sociais alertavam sobre a ausência de escolas ou de sua existência precária, o longo e tortuoso percurso percorrido nos transportes escolares por parte dos estudantes em diferentes partes do país, os preconceitos com os modos de vida dos camponeses, a existência de percursos formativos que pouco contribuíam/contribuem para ampliar as possibilidades de permanência e de trabalho do jovem no campo. ${ }^{23}$ Essas são algumas das marcas do que já vem sendo chamado de "Educação Rural".

Na visão de Ghedini (2015, p. 161), foi logo nessa primeira conferência que os movimentos sociais e sindicais populares do campo (MSPdoC) passaram a formular a especificidade de seu projeto de educação, que, para a autora, se expressa em três eixos:

a) o projeto histórico-político dos camponeses, que sustenta o projeto político-social de desenvolvimento do campo, no qual a luta pela terra é central, assim como a especificidade do lutar e de seus sujeitos; b) as condições para produzir e reproduzir-se na terra que "se fazem" numa mediação entre coletivos dos MSPdoC e suas organizações e as políticas públicas em diferentes esferas; c) o projeto educativo que se concretiza em projetos de educação e escola no âmbito específico dos MSPdoC e nas escolas públicas, universidades e outras instituições.

23 Ver o texto base da I Conferência Nacional por uma Educação Básica do Campo, realizada em Luziânia-GO, em 1998. Disponível em: <http://unesdoc.unesco.org/images/0014/001497/149798porb.pdf>. Acesso em: 5 maio 2017. 
Porém, de acordo com Caldart (2012), foi em 2004, durante a II Conferência Nacional por uma Educação do Campo, que nasceu o lema "Educação do Campo: direito nosso, dever do Estado!", que passou a expressar um entendimento comum sobre o significado da educação do campo para as lutas sociais.

A luta pelo acesso dos trabalhadores do campo à educação é específica, necessária e justa, deve se dar no âmbito do espaço público, e o Estado deve ser pressionado para formular políticas que a garantam massivamente, levando à universalização real e não apenas princípio abstrato. Em meio aos debates, às vezes acirrados, ficou reafirmada a posição originária de vínculo da Educação do Campo com o polo do trabalho, o que significa assumir confronto de projetos, e desde os interesses da agricultura camponesa. (CALDART, 2012, p. 260).

Nesse sentido, podemos compreender que o conceito de educação do campo, para além das lutas contra o latifúndio improdutivo presente na sua origem, carrega consigo os enfrentamentos necessários com vistas à produção de alternativas ao desenvolvimento conservador da agricultura capitalista. Entre essas alternativas, podemos citar a agroecologia e a agricultura orgânica, a agricultura familiar/camponesa que ousa r-existir ${ }^{24}$ às formas de integração à lógica do agronegócio e constroem experiências cooperadas de circuitos solidários de economia. Carrega consigo o enfrentamento aos processos mais complexos de manipulação e mercantilização da natureza, assim como as ações dos agroestrategistas que visam manipular legislações para legalizar impactos ambientais ou para desterritorializar suas terras, tradicionalmente ocupadas, os povos e comunidades

24 Aqui nos inspiramos na compreensão de r-existência de Porto-Gonçalves (2006, p. 165). Para o autor, "mais do que resistência, que significa reagir a uma ação anterior e, assim, sempre uma ação reflexa, temos r-existência, é dizer, uma forma de existir, uma determinada matriz de racionalidade que age nas circunstâncias, inclusive reage, a parti de topoi, enfim, de um lugar próprio, tanto geográfico como epistêmico. Na verdade age entre duas lógicas”. Destaca ainda, que "nessas resistências, r-existência, as epistêmes e o território (onde a questão da terra tem um lugar central) ganham uma enorme importância não só pelo lugar que a ordem moderno-colonial nos destinou na divisão internacional do trabalho, como também pelo significado da natureza para a reprodução de qualquer sociedade". 
tradicionais deste país. ${ }^{25}$ Dessa forma, concordamos com a compreensão de Ribeiro (2010, p. 189):

Os movimentos sociais populares rurais/do campo que, nas suas lutas, propõe-se a romper com séculos de políticas de expropriação/ proletarização e dominação do campesinato brasileiro, inserem a educação do campo em um projeto popular de sociedade, no qual a emancipação humana é o horizonte para o qual se orienta a sua caminhada.

O conceito de educação do campo foi se fortalecendo por compreender uma luta que está para além do acesso à escolarização, porque envolve outra perspectiva societária. E, nesse sentido, envolve pensar percursos formativos que tenham como premissa um conjunto de princípios e diretrizes que orientem o trabalho político-pedagógico de forma a contribuir para ampliação da capacidade de emancipação humana, que tenha o trabalho, a luta, o território e as territorialidades específicas do campesinato também como parte estruturante do ensinar e do aprender.

Na visão de Caldart (2012, p. 262-263), a "Educação do Campo, como prática social ainda em processo de constituição histórica", tem entre suas características o reconhecimento dos saberes e dos fazeres de seus sujeitos históricos, tais como "formas de trabalho, raízes e produções culturais, formas de luta, de resistência, de organização, de compreensão política, de modo de vida", cuja unidade está na superação das "relações sociais capitalistas". Assim, concordamos com a compreensão de que, ao ocupar a escola, os sujeitos coletivos dos movimentos sociais e sindicais populares potencializam as capacidades de transformação, "repolitizam a escola e o direito ao conhecimento" em que não só disputam acesso aos conhecimentos científicos, mas também reivindicam que seus saberes e experiências sejam reconhecidos como válidos, alternativos, às lógicas que excluem e os consideram atrasados que precisam ser superados, pois "conferem 
outros significados ao conhecimento e a suas instituições como espaços de copresenças" (ARROYO, 2012, p. 230).

Podemos compreender, dessa forma, que a educação do campo enquanto conceito, no seio das lutas por terra, território e dignidade no campo, sintetiza uma perspectiva educacional que denuncia toda e qualquer ausência ou negligência de acesso e permanência dos sujeitos do campo à escola pública, ao ensino superior, assim como os preconceitos aos saberes e as experiências do campesinato nos processos de escolarização, seus territórios e territorialidades. Anuncia uma bandeira articuladora objetivando fortalecer o enfrentamento às desigualdades sociais nos campos e cidades, a concentração de terras e os processos de destruição e mercantilização da natureza, apontando alternativas de produção, modos de vida e de relações diferenciadas com a natureza. Coloca-se como alternativa, ao propor uma escola diferenciada aos sujeitos que têm no campo seu espaço de vida. Uma escola com um projeto político-pedagógico que atenda, também, seus interesses, seus saberes e experiências, sua pedagogia da luta contra a lógica capitalista excludente e produtora de desigualdades sociais, um projeto que tenha o trabalho como princípio educativo capaz de produzir matrizes técnicas, científicas e tecnológicas. ${ }^{26}$

\section{A organicidade de coletivos que lutam por uma educação do campo}

Não há educação do campo sem a participação dos movimentos sociais e sindicais populares que desde sua origem estão a ela ligados e pela qual lutam. Podemos compreender que sem essa participação, com o tempo, tudo volta ao "mais do mesmo", ou seja, à Educação Rural como política pública educacional latifundiária de gabinete, uma política que,

26 Não por acaso, podemos afirmar que estão entre as diretrizes e/ou horizontes da Educação do Campo a Educação Popular (PALUDO, 2006); ter o trabalho como princípio educativo (PISTRAK, 1981; SHULGIN, 2013) ou estruturar-se a partir da Pedagogia Socialista (FREITAS; CALDART, 2017). 
por tradição, pensa o campo sem gente. Nesses casos, por exemplo, a partir de um olhar economicista em que educação é vista como despesa, fecham-se as escolas no campo e nucleariza-se o atendimento escolar nas sedes dos municípios, sem consultar a comunidade ou promover qualquer adequação que considere o acolhimento dos sujeitos do campo nas escolas nucleadas. Nesse processo de des-re-territorialização diária que começa com esse deslocamento, termina com a produção de invisibilidade dos saberes e das práticas do campesinato e com processos formativos que mais têm contribuído para expulsar a juventude do campo do que ofertar-lhe alternativas de permanência.

O trabalho de Antônio (2013), ao tratar do movimento Por uma Educação do Campo como sendo "de base política e pedagógica", sustenta e reforça essa compreensão. Segundo o autor, o movimento tem essa base porque os sujeitos coletivos envolvidos reivindicam uma educação alternativa ao mesmo tempo em que procuram ocupar seu espaço mais amplo nos processos educativos/formativos. Constroem "referências culturais e políticas para a intervenção de pessoas e dos sujeitos sociais na realidade" (p. 16); assim, também, não aceitam o papel de coadjuvante nos processos de elaboração de políticas ou programas educacionais, colocando-se como construtores, como sujeitos que reivindicam e se querem ativos nas proposições.

No movimento por uma educação do campo em contraposição à Educação Rural, a ação coletiva se faz presente, por exemplo, na criação das articulações (em escala estadual e/ou nacional), na realização de "conferências, seminários, audiências públicas com agentes do Estado, manifestações públicas, experiências educativas de mobilização de comunidades, assentamentos e acampamentos com escolas do campo, entre outras formas" (ANTÔNIO, 2013, p. 64). É na ação coletiva que se reúnem movimentos sociais e sindicais populares, professores e pesquisadores universitários, assim como, quando possível, membros do poder público, na disputa pela garantia do direito à educação pública, gratuita e 
emancipatória (da educação básica ao ensino superior) desde a perspectiva da educação do campo.

A diversidade de representações que passaram a compor esse movimento pode ser observada no trabalho de Ghedini (2015), ao ressaltar a organicidade dos movimentos sociais e sindicais que contribuíram para a produção da educação do campo no país. A autora lembra que durante a II Conferência Nacional por uma Educação do Campo, realizada em 2004, houve uma recomposição de forças que se manifestaram até mesmo nas cores das bandeiras.

Verde com o Movimento Sindical contaguiano, azul com as EFAs e CFRs representadas pelos Centros Familiares de Formação por Alternância (CEFFAs) e vermelho com os movimentos sociais populares filiados à Via Campesina, com uma representação mais significativa do MST. Acresciam-se Universidades, Organizações Não Governamentais (ONGs), Secretarias Estaduais e Municipais de Educação e outros órgãos de gestão pública, além de educadores e educandos de comunidades camponesas, ribeirinhas, pesqueiras e extrativistas, de assalariados rurais, quilombolas, povos indígenas, entre outros (GHEDINI, 2015, p. 168-169).

O Fórum Nacional de Educação do Campo (Fonec), por exemplo, reúne, hoje, diferentes representações dessas entidades coletivas e tem atuado organicamente em escala nacional nas disputas necessárias para que a educação do campo seja reconhecida e componha parte das agendas de políticas públicas e programas educacionais (nacionais, estaduais e municipais). Esse fórum se entende como

espaço de elaboração e direção política sobre a atuação em todos os espaços e territórios conquistados e a conquistar, espaço de articulação das lutas dos trabalhadores do campo pelo direito à educação de qualidade social, materializando ações de disputa de formulação de políticas públicas que participem da composição da política educacional brasileira [...] a luta deve ser por educação pública, mas afirmando o campo e a luta pelo acesso à terra e pelas condições de 
permanência nela, porque o direito à educação somente lá chegou pela luta dos camponeses/as (FONEC, 2012; 2015).

É a organicidade dessas entidades coletivas, a exemplo do Fonec, também das articulações e da atuação dos movimentos sociais e sindicais populares em outras escalas (estaduais, municipais), que se vai disputando os espaços-tempos e materializando a educação do campo nas experiências pedagógicas das escolas públicas e no campo político das políticas públicas educacionais. Nunca de forma harmônica, sempre na disputa com os conhecimentos e práticas acumuladas da Educação Rural e que coexistem na atualidade. Na continuidade deste texto, destacaremos alguns referenciais que marcaram e ainda marcam o campo político das políticas públicas no Brasil.

\section{No campo político das políticas públicas educacionais: conquistas e conflitos...}

A noção de campo político adotada neste texto inspira-se em Bourdieu (2007, p. 163-164), como sendo "campo de forças e como campo das lutas que têm em vista transformar a relação de forças que confere a este campo a sua estrutura". Para o pensador, esse campo é "o lugar em que se geram, na concorrência entre os agentes que nele se acham envolvidos, produtos políticos, problemas, programas, análises, comentários, conceitos, acontecimentos”. A política pública, nesse sentido, pode ser compreendida como o conjunto de "ações ou propostas - promovidas principalmente pelos governos - de regulação dos múltiplos problemas e contradições que afrontam as sociedades contemporâneas” (ROMANO, 2009, p. 13).

A partir dessa compreensão, ainda que pareça óbvio, é preciso demarcar mais uma vez que o processo de inserção da educação do campo nas políticas públicas educacionais não se dá sem disputa, sem confronto com atores e perspectivas hegemônicas (de educação, de escola, de 
conhecimento, de campo e de sujeitos do campo, por exemplo) que se encontram enraizadas no âmbito do Estado brasileiro.

Em 1998, no confronto com as forças neoliberais que naquele momento se fortaleciam dentro do governo federal, nasceu, nessa escala de atuação do Estado, uma experiência emblemática de educação do campo: o Programa Nacional de Educação na Reforma Agrária (Pronera). Um programa que ficou conhecido por atender demandas educativas que emergiam dos acampados e assentados que viviam o árduo contexto das lutas por reforma agrária no país nesse período que, segundo Santos (2012, p. 629), envolveu atender "alfabetização, anos iniciais e finais do ensino fundamental e ensino médio na modalidade de educação de jovens e adultos (EJA), ensino médio profissional, ensino superior e pós-graduação”. A II Pesquisa Nacional de Educação na Reforma Agrária (Pnera) constatou que entre 1998 e 2011 "foram realizados cerca de 320 cursos do Pronera por meio de 82 instituições de ensino", projetando experiências escolares em, aproximadamente, "880 municípios, em todas as unidades da federação" (PNERA, 2015, p. 22-23).

O Pronera é emblemático não só porque veio ao longo de todo esse tempo procurando atender demandas de escolarização dos sujeitos da reforma agrária, mas, sobretudo, pela defesa de princípios educacionais outros não comuns no âmbito do Estado capitalista. Santos (2012, p. 631) ressalta que o programa:

instituiu possibilidades de ressignificação do conteúdo e da metodologia dos processos de educação formal, por meio dos princípios básicos da participação e da multiplicação. A participação se materializa pelo fato de que a indicação das demandas é feita pelas comunidades das áreas de Reforma Agrária e suas organizações, que, em conjunto com os demais parceiros, decidirão sobre a elaboração, o acompanhamento e a avaliação dos projetos. Já a multiplicação se realiza porque a educação dos assentamentos visa à ampliação não só do número de pessoas alfabetizadas e formadas em diferentes níveis de ensino, mas também garantir educadores, 
profissionais, técnicos, agentes mobilizadores e articuladores de políticas públicas para as áreas de Reforma Agrária.

Soma-se a esses princípios a possibilidade de outras formas de organizar o espaço-tempo dos percursos formativos, considerando a existência de um tempo-escola e também um tempo-comunidade, procurando fortalecer "a indissociabilidade entre os conhecimentos sistematizados no ambiente escolar e/ou acadêmico e os conhecimentos presentes e historicamente construídos pelos camponeses”. Assim, também cabe ressaltar a preocupação com a permanência dos sujeitos na escolarização, uma vez que o financiamento dos cursos procurava contemplar "transporte, hospedagem, alimentação e material didático-pedagógico" (SANTOS, 2012, p. 632).

Outras experiências escolares de educação do campo foram se fazendo presentes e ganharam visibilidade nesses últimos 15 anos, a exemplo das ações educacionais nas Escolas Famílias Agrícolas (EFAs) e/ou Casas Familiares Rurais (CFRs), algumas experiências contando com convênios envolvendo secretarias de estado ou municipais de Educação. Lembra Begnami (2011) que as EFAs já estão inseridas no Brasil desenvolvendo experiências alternativas de educação desde a década de 1960 e que entre os princípios político-pedagógicos dessas escolas estão “a associação das famílias com a responsabilidade da gestão político administrativa, a Pedagogia da Alternância como uma metodologia pertinente e apropriada, a formação integral e emancipadora e o desenvolvimento sustentável e solidário” (p. 28).

Esses princípios permitem-nos evidenciar não somente uma escola que tem a pretensão de atender especificidades territoriais dos sujeitos do campo, mas manter articulados os processos de ensinar e aprender na escola com as dinâmicas e os processos da vida camponesa. Podemos compreender que o reconhecimento desses princípios por parte do Estado por meio de legislações e até mesmo o estabelecimento de parcerias visando ao fomento de ações educacionais mostram um processo, ainda que tímido, de ocupação do campo político das políticas públicas. 
Na experiência das EFAs e das CFRs, por exemplo, o destaque sempre foi a pedagogia da alternância, muito embora nunca tenham chamado para si a responsabilidade de sua criação ou seu monopólio (BEGNAMI, 2011; QUEIROZ, 2013; CALVÓ; GIMONET, 2013). Nessa perspectiva pedagógica, como mencionamos, a marca está em um processo formativo que procura articular os espaços-tempos da formação escolar - o acesso aos conhecimentos científicos presentes na cultura escolar - e os espaços-tempos da vida, com destaque para as relações de trabalho no campo. É preciso salientar que a literatura consultada reforça a compreensão de que essa articulação não ocorre de forma homogênea entre as escolas. Conforme Queiróz (2013, p. 137), podemos encontrar "uma grande variedade de experiências e de teorias que vão desde uma simples Alternância, entre tempos e espaços, sem nenhuma preocupação de ligação, de interação e de sintonia até uma bem elaborada integração" que, com base em Calvó e Gimonet (2013), podemos denominar de alternância real ou interativa.

A literatura consultada permite-nos evidenciar que as experiências educativas em alternância estão espalhadas em todo o país. Segundo Begnami (2011, p. 28), há, pelo menos, "148 Centros Educativos presentes em 16 estados” ligados à União Nacional das Escolas Famílias Agrícolas do Brasil (Unefab). Já ligadas às Associações Regionais das Casas Familiares Rurais (Arcafar), a exemplo da Arcafar-Sul, contabilizava-se, nesta última década, a presença de aproximadamente "73 centros educativos" situados "nos três estados do sul do Brasil", assim como da Arcafar nordeste e norte com cerca de "47 centros educativos, com abrangência nos Estados do Amazonas, Maranhão e Pará”. Destaca Queiróz (2013, p. 147) que pesquisa realizada em 2007 pelo Ministério da Educação (MEC) havia encontrado cerca de 265 unidades educativas trabalhando com o regime de Alternância. $\mathrm{O}$ autor reforça que as experiências formativas do Pronera também usam/usaram como referência essa perspectiva metodológica em diferentes níveis de ensino. 
Onde as lutas sociais por uma educação do campo encontraram fissuras em governos que procuraram acolher demandas das classes populares, experiências alternativas de educação voltadas aos sujeitos do campo se fizeram presentes, assim também programas de formação continuada de professores, elaboração de material de apoio pedagógico etc. É preciso salientar, também, que a história vem sendo marcada pela elaboração de um aporte teórico-jurídico, a exemplo das Diretrizes Operacionais para a Educação Básica nas Escolas do Campo em 2002, suas complementações realizadas em 2006 e 2008, assim como o Decreto presidencial $\mathrm{n}^{\circ}$ $7.352 / 2010$, que passou a reconhecer a educação do campo e o Pronera como política pública.

Foram criados, sobretudo a partir de 2005, cursos de licenciatura em Educação do Campo em diferentes universidades brasileiras, preocupados com a formação inicial de professores que viessem atender as demandas formativas dos sujeitos do campo. Não sem tensões, os cursos foram sendo implementados e, a partir de 2007, passaram a ser financiados pelo Programa de Apoio à Formação Superior em Licenciatura em Educação do Campo (Procampo) (GHEDINI, 2015). Alguns desses cursos passaram a ser institucionalizados nas universidades ofertantes. Porém, a inserção dos egressos na carreira do magistério ainda vem passando por diferentes desafios, um dos quais se refere à formação inicial por área do conhecimento e a contratação disciplinarizada por parte do poder público.

Entre conquistas da educação do campo, como já afirmamos, muitas tensões se fizeram presentes. A criação do Programa Escola Ativa por parte do governo federal, por exemplo, posteriormente denominado Escola da Terra, ${ }^{27}$ pode ser considerado um exemplo emblemático. $\mathrm{O}$ programa visava atender algumas demandas, sobretudo formativas, das escolas multisseriadas existentes no país. Entretanto, ao alinhar-se com princípios neoliberais de educação, privilegiando principalmente a relação

27 Ver detalhes em: <http://portal.mec.gov.br/par/194-secretarias-112877938/secad-educacao-continuada-223369541/18725-escola-da-terra $>$. Acesso em: 9 jun. 2017. 
custo/benefício, sem tocar com muito sucesso em outras dimensões fundamentais para qualificar a escolarização dos sujeitos do campo (como a infraestrutura das escolas, a valorização do trabalho docente, entre outros), suas ações conflituavam com a perspectiva de educação do campo defendida historicamente.

Outros exemplos emblemáticos das tensões podem ser encontrados no Programa Nacional de Educação do Campo (Pronacampo), criado pelo governo federal, em 2012, com objetivo de apoiar técnica e financeiramente os estados, os municípios e o Distrito Federal no desenvolvimento de políticas e/ou programas de Educação do Campo. Não por acaso, como bem lembrou Ghedini (2015), seu lançamento foi realizado pela senadora Kátia Abreu, que naquele momento presidia a Confederação Nacional da Agricultura (CNA), uma organização hegemonicamente dominada pelos interesses dos grandes latifundiários do agronegócio.

Nesse contexto, cabe salientar que parte significativa de recursos públicos do Pronacampo voltados para o Pronatec Campo, por exemplo, objetivando promover a formação profissional e tecnológica dos sujeitos do campo, foram deslocados para o Serviço Nacional de Aprendizagem Rural (Senar), que tem um perfil pedagógico mais voltado para o empreendedorismo rural a partir de uma lógica empresarial (PRONACAMPO, 2012) e, por essa, dentre outras razões, conflitua diretamente com os princípios e sujeitos originários da educação do campo. ${ }^{28}$

Evidencia-se com esses casos a coexistência de forças destoantes dentro de um mesmo governo, disputando espaço na gestão de políticas/

28 Destaca Caldart (2015, p. 21) que: "programas e políticas que têm sido identificadas como 'Educação do Campo, como o Programa Nacional de Educação do Campo (Pronacampo), lançado pelo governo federal em 2012, por exemplo, são frutos de lutas, mas têm assumido a concepção de 'educação rural', adequada às tendências do desenvolvimento capitalista neoliberal, agora também para o campo. Estão muito longe do que deveria ser a garantia pelo Estado de um sistema público e universal de educação para a população trabalhadora do campo. O agronegócio cada vez mais incide nas escolas existentes, aproveitando a abertura geral da política à entrada de empresas na educação pública, através de materiais didáticos e paradidáticos, projetos de formação de professores, atividades diretas com os estudantes. Mas sua lógica produtiva não precisa da universalização da educação básica, muito menos que o Estado invista em um sistema público de educação do campo e supere a precariedade física da maioria das escolas ainda existentes". 
programas e na distribuição dos recursos públicos. Concordamos com a compreensão de que houve:

avanço do agronegócio no campo brasileiro e, ao mesmo tempo, do avanço de suas forças no espaço do Estado através de suas agremiações que detém, como uma de suas principais características, a multiorganização. Esta forma de avanço e disputa já foi vivida na década de 1980 quando, simultaneamente, se criam o MST, a UDR e trava-se uma forte disputa destes dois campos no debate e criação do PNERA, por exemplo. Vive-se um período em que, mesmo que algumas propostas e ações dos MSP tenham avançado, eles, enquanto espaço social, estão em descenso, também não é a sua proposta que se apresenta como projeto para o campo brasileiro, mas a nova proposta é o agronegócio. Percebe-se também um alinhamento dos governos brasileiros, hoje, explicitamente, ao modelo do agronegócio e, com muito mais vigor e convicção do que fizeram os governos do final da década de 1990 (GHEDINI, 2015, p. 177).

A questão que queremos focar nessa parte final do texto trata justamente desse momento mais atual da história política do Brasil em que forças de ordem empresarial-financeira-neoliberal dominam o campo político das políticas educacionais, mudando os rumos das ações governamentais e excluindo totalmente as possibilidades de considerar as demandas oriundas das classes mais populares deste país. Os reformistas de plantão que atuam hoje dentro do MEC não querem dialogar com as entidades coletivas dos trabalhadores. Em seus documentos recentes, caso da Base Nacional Comum Curricular (BNCC), o debate sobre educação do campo já foi invisibilizada. Destacamos ainda mais duas medidas que confrontarão diretamente no campo educacional com o movimento da educação do campo e seus princípios: a reforma do ensino médio e o movimento Escola Sem Partido. 


\section{Desafios da educação do campo na atual conjuntura política brasileira: elementos para fomentar o debate}

A opção do atual governo federal pela linha empresarial de educação, evidente desde suas parcerias, ações de exclusão e de silenciamento das entidades coletivas dos trabalhadores e de pesquisadores em educação, não deixa margem para disputas nas políticas ou nos programas propostos. A proposta de reforma do ensino médio, o desmantelamento do Fórum Nacional de Educação (FNE) e a reorganização e publicação a partir de seus interesses de forma unilateral da terceira versão da BNCC são indicativos dessa supremacia em que educação ganha status de mercadoria. Nesse cenário, as tensões se acirram. Não por acaso ganha destaque o lema "Educação é direito e não mercadoria", proposto pelo Fonec como forma de denunciar que nesse cenário sombrio da atualidade há ameaças de fim de políticas públicas importantes.

$\mathrm{Na}$ atual reforma do ensino médio, com base na Lei $\mathrm{n}^{\circ} 13.415 / 2017$, certamente a ampliação da carga horária de escolarização ou da criação de escolas de tempo integral - que serão escolas de referência, não oportunizada para todos - atingirá em cheio a juventude camponesa que tem papel estruturante no trabalho familiar e, por questões ligadas ao modo de vida no campo, poderá não acessar esse direito de forma plena. ${ }^{29} \mathrm{~A}$ redução de carga horária para o trabalho com o total dos componentes curriculares e o fatiamento do currículo em itinerários formativos elevarão as possibilidades

29 Na legislação aprovada, os sistemas de ensino deverão ampliar de forma progressiva, no ensino médio, a carga horária de trabalho de efetivo escolar que hoje é de 800 horas anuais distribuídos por 200 dias letivos, para 1.400 horas. Precisará já nos próximos cinco ampliar para, no mínimo, 1.000 horas/ano. Com o "dever" de ampliação dessa carga horária e, dependendo das realidades vividas pelos sujeitos da escola, o contraturno será inevitável? Será o fim da oferta de E. M. em apenas um turno (matutino e/ou vespertino)? Como os sistemas de ensino garantirão o aumento gradativo da carga horária como prevê a atual legislação, sem impulsionar um inchaço do ensino médio noturno (este sim, com previsão de alguma margem de adequação às condições do estudante) ou sem excluir aquele que, por algum motivo, não pode permanecer o dia todo na escola (seja qualquer dia da semana), mas também não pode estudar no período noturno? E as condições objetivas — laboratórios, professores qualificados e bem remunerados, quadras de esportes, materiais de apoio pedagógico, formação continuada, entre outros - serão garantidas pelos governos? Os recursos propostos para descentralização do governo federal aos governos estaduais darão conta dessa demanda? 
de vocacionalização dos currículos escolares, quebrando o princípio de uma formação comum para todos. ${ }^{30}$ Pois, qual será o itinerário formativo a ser seguido por aqueles que vivem da agricultura ou da pecuária familiar? Análises preliminares já nos permitem afirmar que tal fato contribuirá para o fortalecimento da dicotomia formação intelectual e formação para o trabalho (agora entendida de forma hegemônica como sendo formação para o mercado de trabalho), assim como poderá criar mecanismos que dificultarão ainda mais o acesso dos sujeitos do campo ao ensino superior.

Nessa reforma, ampliaram-se, ainda, as possibilidades de relação público-privada. A formação técnico-profissional, além de aligeirada e apartada de uma formação intelectual mais robusta, poderá fincar seu pé mais profundamente nas lógicas empresariais de educação. Nesses casos, por que não uma formação empreendedora com vistas a contribuir cada vez mais para adaptação/integração à lógica do agronegócio, marcado pelo uso de agroquímicos e maquinários? A agricultura familiar e camponesa, nesse sentido, será o "agronegocinho", a única saída para o desenvolvimento rural? Qual seria o itinerário técnico profissional oferecido aos jovens do ensino médio numa região marcada pelo processo amplo de integração da agricultura familiar à lógica do agronegócio de aves, suínos e leite? Qual será o lugar das propostas formativas já existentes ou que poderão vir a existir envolvendo a perspectiva agroecológica e orgânica de produção e vida no campo?

Nesse sentido, podemos compreender a existência de um primeiro conjunto de desafios perpassado pela necessidade de oferta de um ensino médio que venha atender às demandas da agricultura familiar e camponesa que historicamente procurou r-existir à lógica do agronegócio. Não

30 Em algum momento de sua trajetória no ensino médio, os estudantes terão que tomar um rumo a ser ofertado pelos sistemas de ensino no que vem sendo chamado de "itinerários formativos": as áreas do conhecimento (I - Linguagens e suas Tecnologias; II — Matemática e suas tecnologias; III - Ciências da natureza e suas tecnologias; IV — Ciências humanas e sociais aplicadas; V — Formação Técnica e Profissional). Na perspectiva da vocacionalização dos currículos, "a área a ser trilhada e os conhecimentos nela implicados são dispostos e tratados pelos sistemas de ensino, de acordo com seu valor de aplicação, funcionando como uma ideologia que tende a articular melhor o sistema de ensino ao mercado de trabalho em uma economia com alto desemprego", conforme já mencionado por Sacristán (2013, p. 33). Os sinais apontam que isso ocorrerá, sobretudo, a partir das relações que os sistemas de ensino estabelecerão com seus parceiros. 
se trata apenas de resistir no sentido de não aceitar, mas de lutar e trabalhar pela recriação, ancorados nos aportes teórico-jurídicos que já fazem parte do campo político das políticas públicas e com base nos princípios político-pedagógicos já defendidos pela educação do campo ao longo de sua trajetória no país. Uma luta que é coletiva dos sujeitos do campo e suas entidades. Trata-se do movimento permanente de ocupação da escola, algo que já está presente há algum tempo no cenário educacional brasileiro.

É preciso salientar que a educação do campo está para além das discussões que envolvem o currículo, a organização do trabalho pedagógico na escola. Começa pelas adversidades enfrentadas pelos sujeitos do campo para inserir-se no processo de escolarização, como a falta de escolas no campo, as condições de deslocamento comunidade-escola, as relações de preconceito e os efeitos da tradição urbanocêntrica que tem como premissa, ainda, o campo como espaço do atraso ou apenas como espaço-mercadoria, desconsiderando o campo como espaço de vida (com cultura, identidade, trabalho, entre outros). Soma-se a isso uma perspectiva diferenciada de ciência e escola, sua articulação com a vida no campo, com os saberes e os fazeres dos camponeses, com a organização coletiva (movimentos sociais e sindicais), com alternativas ao desenvolvimento capitalista a partir do trabalho familiar e comunitário, nas cooperativas, na economia solidária, nas práticas de produção de alimento saudável.

E tudo isso, nesse momento da história política brasileira, se choca com perspectivas de educação cujos defensores compreendem que as escolas foram tomadas por ideólogos e doutrinadores ligados a determinados partidos políticos que usufruem da atenção, do carisma e da "audiência cativa" dos estudantes para fins político-partidários, para manipular opiniões ou, como eles mesmos afirmam, para "fazer a cabeça" de alunos e pais. Trata-se do movimento "Escola Sem Partido".

Para esse movimento, como consta em sua própria página na internet, um professor é doutrinador "quando adota ou indica livros, publicações e autores identificados com determinada corrente ideológica”. Assim, na 
visão dos adeptos desse movimento, nenhuma indicação ou uso de qualquer literatura deve ser parte do trabalho pedagógico escolar, uma vez que todos eles estão ancorados em visões distintas de mundo, em tendências políticas, científicas e pedagógicas diferentes. O professor seria doutrinador também quando incita "seus alunos a participar de manifestações, atos públicos e passeatas" ou permite que outras pessoas ocupem tempo de sua aula para esses fins.

Considerando essa postura, partilhamos a compreensão de Frigotto (2017, p. 29) para quem o movimento "Escola Sem Partido expressa o epílogo de um processo que quer estatuir uma lei que define o que é ciência e conhecimento válidos e que os professores só podem seguir a cartilha das conclusões e interpretações da ciência oficial" e, por isso, seus adeptos manipulam "até mesmo o sentido liberal de política, induzindo a ideia de que a escola no Brasil estaria comandada por um partido político e seus profissionais e os alunos são seres idiotas manipulados”. Dessa forma, a questão piora, pois:

partindo do princípio da passividade do educando - o que já é violento, pois lhe retira a condição de sujeito para transformá-lo em objeto - e de um suposto poder opressor do professor, criminaliza-se aquilo que é inerente ao processo educativo, ao ato pedagógico: confrontar ideias e compreensões sobre um mesmo assunto, debater, ajudar na elaboração do pensamento autônomo e fecundo mediada pelo conhecimento sistematizado (RAMOS, 2017, p. 84).

É na criminalização dos princípios e das diretrizes presentes nos processos formativos propostos pelos coletivos que historicamente lutaram e se dispuseram a desenvolver práticas de educação do campo no país que o movimento Escola Sem Partido pode dar um passo importante no seu projeto. Nesse caso, a opção pela educação popular ou por uma pedagogia socialista, por exemplo, poderá ser tomada como sendo o uso da escola para doutrinação ou formação de guerrilheiros, visando à instalação do comunismo no Brasil. 
Os conhecimentos e as práticas da agroecologia ou o diálogo com conhecimentos tradicionais do campesinato também poderão ser vistos como obstáculos aos projetos de desenvolvimento no campo e, por isso, precisam ser superados pelas técnicas e pelos conhecimentos do agronegócio (que, segundo propaganda veiculada pela televisão, "carrega o Brasil nas costas"). Nesse mesmo sentido, a opção em considerar a existência de uma pedagogia da luta ou a pedagogia do movimento abrirá caminhos para que professores sejam acusados de crimes ideológicos.

Na educação do campo - é necessário reforçar —, a formação-escolarização com base nos conhecimentos científicos historicamente construídos pela humanidade e presentes na cultura escolar não está deslocada da vida e dos interesses dos sujeitos do campo no processo de escolarização. Incluem-se o diálogo e a participação efetiva de suas entidades coletivas e dos sujeitos do campo, assim como aspectos marcantes de seus cenários de luta por terra, território e dignidade, como já afirmamos.

Dessa forma, concordamos com a compreensão de que "educação e política não são processos idênticos, mas compõe uma unidade" (RAMOS, 2017, p. 81). Como destaca a autora, "a educação, necessariamente e sempre, será guiada por alguma filosofia, por uma concepção de mundo, mesmo que esses não sejam explicitados nos respectivos projetos político-pedagógicos ou que seus sujeitos não tenham plena consciência dos mesmos". Ainda ressalta que:

uma das contradições virtuosas próprias à educação escolar é exatamente o fato de que o acesso ao conhecimento sistematizado pela classe trabalhadora possibilita a essa classe compreender o mundo e ampliar sua capacidade de transformá-lo, primeiramente no plano mais imediato de suas vidas e, mediatamente, por meio de sua organização coletiva. Assim, o sentido político do conhecimento está no fato de que o acesso a ele, pelos dominados, é força material na luta social (RAMOS, 2017, p. 81). 
O trabalho político-pedagógico da escola, dessa forma, não é político-partidário como o movimento Escola Sem Partido afirma, mas é de quem, ancorado na intencionalidade de ampliar a capacidade humana de conhecer e agir sobre o mundo, organiza o processo formativo com base em conhecimentos, saberes e experiências produzidas e dispostas pela humanidade ao longo de sua trajetória. Distorcer essa compreensão pode elevar as condições de criminalização da Educação do Campo em todo o país, pois podemos compreender que o movimento em questão, supostamente "sem partido", funciona como "a antítese do sentido da escola a qual, por sua vez, se transformaria num tribunal ideológico que legitimaria e naturalizaria a violência” (RAMOS, 2017, p. 85).

Podemos afirmar que a educação do campo tem, no cenário político atual do país, a parte mais sombria de seu caminho no "labirinto do capital" (FRIGOTTO; CIAVATA, 2016). O latifúndio e o agronegócio, antagonistas da acirrada e conflituosa questão agrária brasileira no campo educacional, tomam formas perversas de disputa pela escola em nome dos valores morais, éticos e estéticos, de uma perspectiva societária ancorada nos pressupostos da lógica urbano-industrial-financeira neoliberal, marcada por ampla desigualdade social (concentração de terra e renda), exploração destrutiva do trabalho e da natureza, práticas de racismo e preconceito que potencializam a exclusão social (territorial, gênero, geracional, étnico-racial, entre outros) etc. Para Frigotto e Ciavata (2016, p. 29),

tanto no plano da produção crítica teórica, social e educacional, quanto no plano socioeconômico, político e cultural, o tempo histórico que vivemos hoje, no mundo e no Brasil, é de profunda regressão social. Com efeito, fica sempre mais evidente que o sistema capitalista aprofunda cada vez mais uma crise estrutural e não sabe e nem tem meios de resolvê-la. Uma crise que já não é mais cíclica e, por isso, como mostra o pensador húngaro István Mészáros, diversa e profundamente mais destrutiva das demais crises por quatro características básicas: seu caráter atinge a universalidade das esferas da sociedade; não se atém a uma parte do mundo ou a um país, mas é 
global no sentido literal do termo; sua escala no tempo é extensa e contínua; e é uma crise que se expressa de forma gradual, mas pode assumir caráter dramático (Mészáros, 2011, p.2) senão trágico, pelas guerras fomentadas para apropriação dos recursos energéticos e o deslocamento em massa das populações dos países do Oriente Médio.

No Brasil, o caráter trágico desse momento histórico vem sendo marcado, entre outros aspectos, pelas profundas transformações defendidas no campo político das políticas públicas sociais pelos reformistas, que retomam possibilidades de exploração do trabalho cuja legislação já ordenava superar ainda na primeira metade do século passado. Assim, também, pode ser vista a existência de mais de 14 milhões de desempregados no país. No campo educacional, as possibilidades de precarização e de mercantilização/privatização da educação podem contribuir para aprofundar ainda mais o apartheid social já existente, criando uma escola para ricos, que terão elevadas suas chances de ascensão social, e uma escola para pobres, que terá como meta central formar mão de obra barata para a execução de trabalho simples. Destaca Caldart (2015, p. 14) que:

sem combater o rumo neoliberal da política educacional brasileira (que não é só do nosso país, e aqui assume o caráter dependente) não há mais como avançar nas conquistas específicas da EdoC. Tivemos no último período conquistas significativas, mas agora, mantida a tendência dominante da lógica, "batemos no teto", no sentido de avançar no acesso e podemos retroceder muito do ponto de vista da qualidade social pela ofensiva da educação rural como educação corporativa e pela eliminação de experiências alternativas que fiquem fora do padrão estabelecido pela gestão empresarial do sistema. Por outro lado, continuar essa luta específica, pressionando o sistema com as demandas dos trabalhadores superexplorados e os que tendem a uma maior marginalização da política pública, ajuda no combate geral à medida que mostra mais escancaradamente as contradições da lógica e os efeitos das opções que estão sendo feitas pelos governos atuais.

Considerando essa compreensão, a autora aponta sete desafios prioritários: manter e fortalecer a luta comum pela educação do campo, resultado de 
"uma associação real de organizações ou grupos" que dialogam e cooperam; garantir a participação dos sujeitos do campo e suas organizações coletivas na condução das práticas ou no diálogo de saberes; dar continuidade e fortalecer a elaboração de um aporte teórico que contribua na sustentação da perspectiva de educação do campo; combater permanentemente a lógica do agronegócio, a propagação de seu triunfalismo como sendo o único projeto viável para o campo brasileiro; denunciar as práticas bancárias de educação, as reformas empresariais em curso e seus desdobramentos sobre a sociedade; "radicalizar as lutas coletivas pelo acesso das famílias trabalhadoras do campo à educação escolar pública (e de gestão pública)".

É com o intuito de desafiar-nos a fortalecer as lutas por uma educação do campo, na perspectiva que aqui defendemos, na relação com os sujeitos e organizações que desde sua origem estiveram/estão presentes, que propusemos retomar neste texto algumas questões para quem tem buscado estudar e conhecer um pouco mais sobre o tema. Desafiarmo-nos, como propõe Caldart (2015), implica reafirmar sim as especificidades da educação do campo e compreendê-la em suas conquistas e nas disputas. As disputas no campo político das políticas públicas exige clareza de alguns fatos que aqui destacamos. São disputas que não acontecem apenas no âmbito dos ministérios e secretariais, mas estão presentes cotidianamente na escola, porque se trata de discutirmos a sociedade que temos e a sociedade que queremos. Não por acaso, as lutas continuam.

\section{Considerações finais}

Finalizamos o texto, mas as questões suscitadas continuam em nossas pautas de trabalho. Objetivamos reforçar alguns referenciais que sustentam a educação do campo como alternativa à educação rural e também como forma de contribuir nos embates que já estão presentes nas arenas do campo intelectual e da política pública educacional no Brasil. A necessidade 
permanente de reafirmarmos essas especificidades eleva-se no cenário político vivido pelo país na atualidade, em que os rumos das políticas estão ancorados em pressupostos empresariais-financeiros-neoliberais.

A proposta de reforma do ensino médio e o movimento Escola Sem Partido podem ser considerados duas ameaças que contribuem tanto para precarizar processos de escolarização e do trabalho docente daqueles que vivem no campo e que necessitam da escola pública e nela acreditam, assim como na criminalização das entidades coletivas e suas representações que fazem a defesa da educação do campo como alternativa credível à lógica hegemônica de educação, que, ainda hoje, tem falido no seu projeto de universalização. Somado o avanço cada vez mais violento do capital no campo, dos projetos de desenvolvimento capitalista que culminam na morte de trabalhadores, na degradação do trabalho, na desterritorialização de povos e comunidades tradicionais, nos impactos ambientais, entre outros, temos uma parte do tempero amargo do retrocesso que persiste no cenário atual do país.

No entanto, é na resistência coletiva que podemos fortalecer e até construir novas bases de sustentação da educação do campo, seus princípios e diretrizes. Evangelista e Shiroma (2007, p. 533) destacam “o fato de que há uma capacidade de organização do magistério público que parece causar temor aos órgãos governamentais internacionais", de constituir-se "obstáculo" das reformas. O cenário atual, nesse sentido, tem sido muito pedagógico para unir lutas e bandeiras, para retomar e reforçar especificidades, de fortalecer projetos formativos que apontem para outra perspectiva societária, para ecoar em alto e bom som que a educação do campo re-existe na história.

\section{REFERÊNCIAS}

ALMEIDA, Alfredo Wagner Berno de. Agroestratégias e desterritorialização: direitos territoriais e étnicos na mira dos estrategistas do agronegócio. In: ALMEIDA, Alfredo Wagner Berno de et al. Capitalismo globalizado e recursos territoriais: fronteiras da acumulação no Brasil contemporâneo. Rio de Janeiro: Lamparina, 2010. 
ANTÔNIO, Clésio Acilino. Educação do Campo: um movimento popular de base política e pedagógica. Cascavel: Edunioeste, 2013.

ARROYO, Miguel G. Outros sujeitos, outras pedagogias. Petrópolis-RJ: Vozes, 2012.

BEGNAMI, Marinalva Jardim Franca. Os Ceffas e a Educação do Campo. In: Revista da Formação por Alternância, Brasília: União Nacional das Escolas Famílias Agrícolas do Brasil, v. 6, n. 1, 2011.

BOURDIEU, Pierre. O poder simbólico. Rio de Janeiro: Bertrand Brasil, 2007.

CALDART, Roseli Salete. Educação do Campo. In: CALDART, Roseli Salete et al. Dicionário da Educação do Campo. Rio de Janeiro; São Paulo: Escola Politécnica de Saúde Joaquim Venâncio; Expressão Popular, 2012.

CALDART, Roseli Salete. Sobre a especificidade da Educação do Campo e os desafios do momento atual. Porto Alegre, 2015. (mimeografado).

FÓRUM NACIONAL de Educação do Campo - FONEC. Manifesto à sociedade brasileira. Brasília, 2012. Disponível em: <http://www.gepec.ufscar. $\mathrm{br} /$ publicacoes/documentos/forum-nacional-de-educacao-do-campomanifesto-a.pdf/view>. Acesso em: 7 jun. 2017.

FÓRUM NACIONAL de Educação do Campo - FONEC. Documento Final. III Seminário Nacional, Brasília-DF, 26, 27 e 28 ago. 2015. Disponível em: <https://seminarionacionallecampo2015.files.wordpress.com/2015/09/ documento-final-fonec-2015.pdf>. Acesso em: 25 maio 2017.

FRIGOTTO, Gaudêncio. A gênese das teses do Escola sem Partido: esfinge e ovo da serpente que ameaçam a sociedade e a educação. In: FRIGOTTO, Gaudêncio (Org.). Escola "sem" partido: esfinge que ameaça a educação e a sociedade brasileira. Rio de Janeiro: UERJ, LPP, 2017.

FRIGOTTO, Gaudêncio; CIAVATTA, Maria (Org.). Teoria e educação no labirinto do capital. 4 ed. São Paulo: Expressão Popular, 2016.

FREITAS, Luiz Carlos de; CALDART, Roseli Salete (Org.). A construção da pedagogia socialista: escritos selecionados. São Paulo: Expressão Popular, 2017.

GHEDINI, Cecília Maria. A produção da Educação do Campo no Brasil: das referências históricas à institucionalização. Jundiaí: Paco, 2017.

PALUDO, Conceição. Da raiz/herança da educação popular à pedagogia do Movimento e a Educação no e do Campo: um olhar para a trajetória da educação no MST. Reunião anual da ANPED, 30, Caxambu, 2007. 
PISTRAK, M. Fundamentos da Escola do Trabalho. São Paulo: Expressão Popular, 2000.

PNERA. Relatório da II Pesquisa Nacional sobre a Educação na Reforma Agrária. Brasília, junho de 2015. Disponível em: <http://www.ipea.gov.br/portal/index. php?option=com_content\&view=article\&id=25640>. Acesso em: 7 jun. 2017. PRONACAMPO. Programa Nacional de Educação do Campo. Brasília: Ministério da Educação, mar. 2012.

PUIG-CALVÓ, Pedro; GIMONET, Jean-Claude. Aprendizagens e relações humanas na Formação por Alternância. In: BEGNAMI, João Batista; BURGHGRAVE, Thierry de (Org.). Pedagogia da alternância e sustentabilidade. Orizona: Unefab, 2013.

QUEIRÓZ, João Batista Pereira de. O estado da arte da Alternância no Brasil. In: BEGNAMI, João Batista; BURGHGRAVE, Thierry de (Org.). Pedagogia da alternância e sustentabilidade. Orizona: Unefab, 2013.

RAMOS, Marise Nogueira. Escola sem Partido: a criminalização do trabalho pedagógico. In: FRIGOTTO, Gaudêncio (Org.). Escola "sem" partido: esfinge que ameaça a educação e a sociedade brasileira. Rio de Janeiro: UERJ, LPP, 2017.

SACRISTÁN, José Gimeno. O que significa o currículo? In: SACRISTÁN, José Gimeno (Org.). Saberes e incertezas sobre o currículo. Porto Alegre: Penso, 2013.

SANTOS, Clarice Aparecida dos. Programa Nacional de Educação na Reforma Agrária (PRONERA). In: CALDART, Roseli Salete et al. Dicionário da Educação do Campo. Rio de Janeiro; São Paulo: Escola Politécnica de Saúde Joaquim Venâncio; Expressão Popular, 2012.

PORTO-GONÇALVES, Carlos Walter. A reinvenção dos territórios: a experiência latino-americana e caribenha. In: Los desafíos de las emancipaciones en un contexto militarizado. Buenos Aires: Clacso, 2006. Disponível em: $<$ http://bibliotecavirtual.clacso.org.ar/clacso/gt/20101019090853/6Goncalves. pdf $>$. Acesso em: 12 maio 2017.

RIBEIRO, Marlene. Movimento camponês, trabalho e educação: liberdade, autonomia, emancipação: princípios/fins da formação. São Paulo: Expressão Popular, 2010.

ROMANO, Jorge Osvaldo. Políticas nas políticas: um olhar sobre a agricultura brasileira. Rio de Janeiro: Mauad X, 2009; Seropédica-RJ: Edur, 2009.

SHULGIN, Viktor N. Rumo ao politecnismo. São Paulo: Expressão Popular, 2013. 


\section{Os assentados do Madre Terra em São Gabriel-RS respondem: que escola queremos para que nossos filhos permaneçam no campo?}

Tânia Mara De Bastianỉ ${ }^{31}$

\section{Considerações iniciais}

Marcelo tem sete anos, acorda às 4h30 e, após tomar café e comer algo, percorre $2 \mathrm{Km}$, a pé e na companhia do irmão mais velho, de nove anos, para embarcar no transporte escolar que os conduzirá até a escola. O ônibus passa no ponto às $5 \mathrm{~h} 30$ e chega até o local de destino às $8 \mathrm{~h}$. Ele retorna às $16 \mathrm{~h} 15 \mathrm{~min}$ e demora o mesmo tempo para chegar até o assentamento em que residem. São 5 horas diárias dentro do ônibus. Pela distância e pelas dificuldades de acesso, em grande parte pelas estradas de chão batido, Marcelo e o irmão fazem este percurso nas terças, quintas e sábados.

Marcelo e seu irmão são personagens fictícios, mas representam crianças e adolescentes do assentamento Madre Terra, ou melhor, a realidade vivenciada por elas até o final de 2013. O Madre Terra é um dos sete assentamentos da cidade de São Gabriel-RS que se consolidaram, através de muita luta e resistência, a partir de 2008. Do mesmo modo que os demais, ele foi formado carecendo de elementos básicos, como água, luz, estradas, demarcação dos lotes, saúde e escola.

31 Graduada em Filosofia, especialista em Educação Ambiental e mestre em Educação pela Universidade Federal de Santa Maria (UFSM). Doutoranda em História na linha de Pesquisa "Trabalho e Movimentos Sociais", da Universidade Estadual do Oeste do Paraná (Unioeste). Contato: taniamaradb@hotmail.com. 
Durante o ano de 2013, como parte do trabalho de campo para o desenvolvimento da dissertação intitulada "Rompendo as cercas da educação burguesa: a luta pela construção de uma escola no assentamento Madre Terra, São Gabriel-RS” (2014), acompanhamos, além da realidade escolar das crianças e dos adolescentes do Madre Terra que, naquele momento, frequentavam a Escola Municipal de Ensino Fundamental José Ernesto Annoni, ainda o processo de luta da comunidade para a conquista de uma escola dentro do assentamento. Na ocasião, conversamos tanto com a direção e professores da Annoni a fim de compreender a organização política-pedagógica da escola, quanto com uma adolescente do Madre Terra, pais e mães do assentamento que possuíam filhos na escola a fim de entender suas concepções sobre a escola que até então era a frequentada pelos seus filhos. Além disso, também procuramos saber sobre suas expectativas diante da escola que estava sendo construída dentro do assentamento e com previsão de início de funcionamento para o ano letivo de 2014.

Este capítulo é um recorte da dissertação mencionada e tem por objetivo traçar um comparativo no que diz respeito aos conteúdos curriculares, entre a escola frequentada pelas crianças e pelos adolescentes do Madre Terra até o final de 2013 (Annoni) e a escola idealizada pelos assentados para atuar dentro do assentamento (em construção em 2013), a fim de responder ao seguinte questionamento: A Annoni é um modelo a ser seguido pela escola do assentamento? Para responder ao questionamento, além de nos basearmos nas concepções abordadas tanto pelas políticas públicas de educação do campo quanto pelo Movimento dos Trabalhadores Rurais Sem Terra (MST) para as escolas dos assentamentos, utilizamos um questionário com questões abertas e fechadas aos assentados do Madre Terra e de entrevistas com algumas professoras da escola Annoni. Todos os nomes utilizados são fictícios, o que preserva a identidade dos participantes da pesquisa. 


\section{Escola Municipal de Ensino Fundamental José Ernesto Annoni}

Até o final de 2013, crianças e adolescentes do assentamento Madre Terra frequentaram a Escola Municipal de Ensino Fundamental José Ernesto Annoni. Ela é uma escola do campo e está situada no interior de São Gabriel-RS, numa localidade denominada Catuçaba, comunidade rural Cerrito. Para traçar as características agrárias do local onde está inserida, devemos pensar um pouco sobre a formação do município. São Gabriel faz parte da Mesorregião Sudoeste e Microrregião Campanha Central do Estado do Rio Grande do Sul (RS), e sua sede político-administrativa está situada a uma distância de $320 \mathrm{Km}$ da capital, Porto Alegre (PoA). Possui uma população total de 60.425 mil habitantes e uma área de $5023.821 \mathrm{Km}^{2}$ (IBGE, 2010). A formação de São Gabriel-RS envolve a disputa de terras de parte do atual estado do RS entre Portugal e Espanha no século XVIII, o que ocasionou, em 1750, a assinatura do Tratado de Madri. Através desse tratado as duas coroas entraram em um acordo: Portugal deveria ceder a Colônia do Sacramento, hoje Uruguai, à Espanha e, em contrapartida, receberia a região dos Sete Povos das Missões (redução de São Francisco de Borja, de São Nicolau, São Miguel Arcanjo, São Lourenço Mártir, São João Batista, São Luiz Gonzaga e Santo Ângelo Custódio), hoje municípios localizados no noroeste do RS.

Nesse processo, os indígenas guaranis deveriam passar para o outro lado do rio Uruguai, ou seja, deixar o território português (Sete Povos das Missões) e passar a habitar o espanhol (Colônia do Sacramento). Com a resistência a deixar seu local de origem, eclode, entre os anos de $1754 \mathrm{e}$ 1756, o que ficou conhecido como Guerras Guaraníticas. Elas ocasionaram a mortandade de cerca de 1.500 indígenas. Sepé Tiaraju, o principal líder das Guerras, cai por solo na Batalha de Caiboaté, em 1756, território onde hoje é o município de São Gabriel-RS. Para tentar solucionar os conflitos gerados com as Guerras Guaraníticas, é assinado, em 1777, o Tratado de Santo Ildefonso. Após a assinatura, a região dos Sete Povos das Missões 
passa aos domínios espanhóis. Além disso, são estabelecidas zonas de campos neutrais, ou seja, espaços de transição entre o território luso e o castelhano. Portugal, que estava descontente com a nova divisão territorial que reduzia suas possessões na região fronteiriça, passa a fazer concessão de Sesmarias e, portanto, a formar estâncias nos campos neutrais. A porção de terra que hoje pertence ao município de São Gabriel-RS vinha sendo incorporada pelo Império Português através dessa prática. Como reação, a Espanha funda, em 1800, o povoado de São Gabriel.

Pelos conflitos e pelas disputas territoriais que não cessaram após a assinatura do Tratado de Santo Ildefonso, Portugal entra em guerra com a Espanha que, por sua vez, tem apoio da França, em 1801. Nessa disputa, o povoado de São Gabriel foi destruído, e a população remanescente submetida ao domínio português. Além disso, Portugal conquista e incorpora os Sete Povos das Missões. Ao sul, ficava um local de boas pastagens e de gado não domesticado, hoje conhecido como Fronteira Oeste e Campanha Gaúcha, mesorregião Sudoeste do Rio Grande do Sul. Para ocupar rapidamente essas terras, os portugueses passam a fundar estâncias e a conceder sesmarias a um pequeno grupo de estancieiros, em sua maioria militares. Porém, tanto as estâncias como as sesmarias não eram estabelecidas

[...] em um espaço vazio de sujeitos; a região fronteiriça era o espaço de reprodução social originário das comunidades indígenas do grupo étnico Pampeano, cujos subgrupos mais conhecidos eram Charruas e Minuanos. Também, ali se encontravam homens pobres livres de diferentes matizes, oriundos do movimento das frentes de colonização portuguesa e espanhola na bacia platina (SANTOS, A., 2012, p. 40).

Outra forma de ocupação das terras da mesorregião sudoeste do Rio Grande do Sul se dava pelas posses que se classificavam como ocupações simples, usurpações ou compras a preços irrisórios. Todas essas formas de acesso à terra foram feitas por uma parcela minoritária da sociedade no 
intuito, inicialmente, de proteger a terra de outros países que pudessem vir a ocupá-las, principalmente a Espanha, e, também, para a prática da pecuária. Portanto, a ocupação das terras por poucos deixando à margem a maioria da população já que, conforme Santos (2012), aquele não era um espaço vazio, ajuda-nos a compreender por que a Fronteira Oeste e a Campanha Gaúcha são formadas por grandes latifúndios, que, atualmente, dão espaço ao agronegócio.

Em meio às grandes propriedades rurais a escola Annoni foi construída. Ela recebe o mesmo nome do antigo dono da também antiga fazenda Annoni, localizada em Pontão, norte do estado do RS. Essa propriedade foi significativa na história do Movimento dos Trabalhadores Rurais Sem Terra (MST), pois foi a primeira ocupação, realizada em 29 de outubro de 1985, de uma área rural depois da criação do movimento. Segundo Fernandes (1999), mil e quinhentas famílias ocuparam nove mil e quinhentos hectares da fazenda Annoni. Processo que se estendeu por anos e através do qual Roseli Nunes perdeu a vida, em março de 1987, deixando três filhos, entre eles a primeira criança nascida em acampamento do MST. Portanto, a escola, mesmo que talvez esta não seja a intenção das pessoas que a constituem, marca uma posição, ou seja, ao homenagear em seu nome alguém que simboliza os princípios do agronegócio, ela toma um lado, se posiciona e deixa a entender que aquele espaço não diz respeito aos assentados que, por sua vez, defendem valores diversos aos simbolizados pelo nome.

A Annoni é considerada uma escola do campo não apenas pela sua localização, mas também porque atende aos alunos que residem no meio rural. Em 2013, quando estive na escola, ela atendia, além das crianças e dos adolescentes do Madre Terra, os filhos dos peões das grandes estâncias que formam o município. Pela configuração do local em grandes propriedades rurais, a escola fica distante da casa dos alunos, que dependem de transporte escolar. Os professores, em sua maioria, residem no centro 
urbano do município que fica a $65 \mathrm{~km}$ da escola. Nesse contexto, chegar até a escola é o primeiro desafio de alunos e professores.

Independentemente das características agrárias do local onde estão inseridas, as escolas do campo seguem um conjunto de princípios e procedimentos, tais como o artigo 28 da Lei 9.394/96 - Lei de Diretrizes e Bases da Educação Nacional (LDB), as Diretrizes Operacionais para a Educação Básica nas Escolas do Campo (Resolução CNE/CEB 1 de 2002) e a Política de Educação do campo (Decreto 7.352/02). No que diz respeito aos conteúdos curriculares, que é o recorte deste capítulo, tais políticas públicas preveem que as escolas do campo compreendam conteúdos contextualizados com a realidade dos alunos. Nesse contexto, a LDB prevê para a oferta de educação básica à população rural "conteúdos curriculares e metodologias apropriadas às reais necessidades e interesses dos alunos da zona rural" (LDB, Art. 28, inciso I). Nesse sentido, as Diretrizes Operacionais para a Educação Básica nas Escolas do Campo determinam que "as propostas pedagógicas das escolas do campo, [...], contemplarão a diversidade do campo em todos os seus aspectos: sociais, culturais, políticos, econômicos, de gênero, geração e etnia" (Resolução CNE/CEB 1 de 2002, Art. $5^{\circ}$ ) e a Política de Educação do campo coloca como um dos princípios da educação do campo a "valorização da identidade da escola do campo por meio de projetos pedagógicos com conteúdos curriculares e metodologias adequadas às reais necessidades dos alunos do campo" (Decreto 7.352/02, Art. 2º, inciso IV). Além disso, prevê:

Os recursos didáticos, pedagógicos, tecnológicos, culturais e literários destinados à educação do campo deverão atender às especificidades e apresentar conteúdos relacionados aos conhecimentos das populações do campo, considerando os saberes próprios das comunidades, em diálogo com os saberes acadêmicos e a construção de propostas de educação no campo contextualizadas (Decreto 7.352/02, Art. 6º. 
Quando fomos até a escola Annoni, tivemos contato com a lista de conteúdos elaborados para serem seguidos pelos professores e constatamos que os assuntos não contextualizavam a vida do campo. Assim, uma das questões direcionadas aos professores foi a respeito da diferenciação entre os conteúdos abordados nas escolas urbanas e os da Annoni. Segundo a professora Denise (2013),

[...] com certeza os conteúdos são os mesmos que estão na cidade, pois às vezes a gente conversa nas reuniões com as colegas e tem tópicos que são bem conhecidos delas que a gente tá sabendo também...

A professora Marta (2013) justifica que:

[...] não pode trabalhar muito diferente, porque muitos vão e voltam, aquela coisa de alunos transferidos, então eles têm que estar mais ou menos em conjunto [...] principalmente estes assentados, eles passam para lá e para cá e a gente tem que dar mais ou menos a mesma coisa para não ter problema para eles.

Apenas uma das respostas diferiu das demais. A professora Larissa (2013) afirmou:

[...] nós temos listagem de conteúdos diferenciados, nós temos material didático também, não sei se vocês viram os livros de Escola do Campo que estão chegando? [...] tá chegando material riquíssimo que, às vezes, nem os próprios profissionais conhecem ainda, aí tudo vai do interesse do profissional de conhecer o que está chegando, de perguntar [...] livros didáticos destinados, especificados para a Escola do Campo estão chegando já na escola [...] e o ano retrasado eu fiz um curso da escola ativa todo destinado para atividades da Escola do Campo, foram 180 horas de curso.

A única entrevistada que afirmou que a escola tem listagem e material didático diferenciado afirma, também, com certa preocupação, em momento paralelo à entrevista, que os livros estariam encaixotados na 
biblioteca, e os alunos raramente a frequentam. Importante ressaltar ainda que, apesar de afirmar que os conteúdos da Annoni são os mesmos das escolas urbanas, a professora Marta (2013) justifica que é devido ao fato do grupo de alunos não ser sempre o mesmo, já que eles transitam entre o urbano o rural e que trabalhar os mesmos conteúdos seria, portanto, na visão da professora, algo em benefício dos alunos que podem a qualquer momento deixar o rural e residir no urbano.

Após ouvir os relatos que afirmaram que os conteúdos curriculares trabalhados na Annoni são os mesmos das escolas urbanas, perguntamos o que pensavam sobre a questão, ou seja, se acreditavam que os conteúdos deveriam ser diferenciados. A maioria das entrevistadas respondeu com orgulho e satisfação que "não". Isso demonstra o desconhecimento quanto às políticas públicas para a educação do campo que, conforme vimos, preveem que as escolas do campo compreendam conteúdos contextualizados com a realidade dos alunos.

Além disso, o afastamento da escola Annoni em relação ao meio rural pode-se observar por um dos projetos de Educação Ambiental desenvolvido. Através dos relatos, foi exposto que entre os projetos existem a construção da horta e do jardim desenvolvido por alguns professores e o da compostagem para a horta caseira em parceria com a Associação Rio-Grandense de Empreendimentos de Assistência Técnica e Extensão Rural (Emater), os quais parecem adequados à realidade dos alunos. Porém, um dos projetos desenvolvidos há vários meses, através da modalidade de extensão pela Universidade Federal do Pampa (Unipampa) de São Gabriel, aborda a questão ambiental ensinando crianças do meio rural a separar o lixo e a saber identificar onde descartar os resíduos pela cor da lixeira. Esse projeto não parece adequado, já que muitas famílias, e esse é o caso do assentamento, queimam o lixo, pois a prefeitura não dispõe de caminhões de coleta que cheguem até a localidade onde residem. Assim, o projeto de extensão está focado em alunos urbanos e não em crianças do meio rural, com as quais seria muito mais proveitoso discutir as questões 
referentes ao meio ambiente de outra forma, abordando o uso de agrotóxicos, por exemplo. Isso mostra que nem os conteúdos, nem os projetos desenvolvidos na escola levam em consideração a realidade em que estão inseridos. A falta de alcance dos objetivos do projeto desenvolvido pela Unipampa foi constatada no trajeto do ônibus, ida e volta, realizado pelos alunos, pois eles atiravam as embalagens de comida pela janela não se importando com o meio ambiente.

Sobre o afastamento da escola Annoni de conteúdos que abranjam a vida no campo, três mães do Madre Terra confirmaram essa situação. Segundo Maria (2013),

[...] eles trabalham muita coisa da cidade e as crianças como são do interior deveriam saber um pouco mais de agricultura, por exemplo, lá tem uma horta na escola que foi o (nome de um assentado) que estava fazendo trabalho comunitário que construiu, eu acho que deveria ser trabalhado mais esta questão de horta, de plantação, claro, alguma coisa da cidade que eles também precisam saber, né?

Para Frida (2013), outra mãe do assentamento, “a Annoni não tem nenhum interesse em manter as crianças no campo, não é voltada para o campo e não tem nenhuma política social”. Já Fátima (2013), além de afirmar o afastamento da escola com conteúdos relacionados ao meio rural, ainda observa que ela está mais voltada à reprodução da lógica do agronegócio, bem comum, conforme vimos, na região de São Gabriel-RS. Segundo Fátima, a Annoni

não tem uma proposta para quem quer ficar aqui fora, [...] ali eles não têm pedagogia nenhuma voltada para suprir esta necessidade de aprendizado, de ensinamento, de cultura que estas crianças têm que ter, porque não é mais como antigamente que eles nasciam, se criavam e não conheciam nada, quando iam para a cidade eram uns "bichinho" [...], não tem um projeto para se desenvolverem, mas tudo para voltar para fora e ser tratorista do fazendeiro, ser aguador, ser... entendeu? Eles estudam para ser empregados, não para ter o canto deles, para trabalhar fazendo aquilo ali para eles, 
voltam para trabalhar de peão e a mulher é como a gente diz, a alternativa da mulher é casar e ter filhos, ficar em casa.

No entanto, até que ponto é culpa dos indivíduos que constituem a Annoni a não adequação ao meio onde a escola está inserida? Onde se formaram esses professores? Compreendemos que os conhecimentos adquiridos nas universidades não abrangem a gama de espaços que o profissional poderá ter pela frente, como o próprio nome sugere é uma formação, ou uma "forma” em que todos devem sair iguais e isso significa alguns conhecimentos básicos. Qual a proposta pedagógica da Secretaria de Educação para essa escola? Como e o que é trabalhada na formação continuada? Cabe às autoridades promover situações de avaliação do projeto da escola e aos próprios professores, posteriormente, conhecer o local onde estão inseridos, mas muitas vezes isso não ocorre, por falta de tempo ou por compreenderem que não seja necessário, por exemplo. Hoje existe o Programa de Apoio à Formação Superior em Licenciatura em Educação do Campo (Procampo), mas é recente, existe desde 2009. Já os profissionais que atuam em escolas do meio rural hoje, em geral, e na Annoni, em particular, não tiveram formação acadêmica que abranja o campo em suas especificidades.

\section{A escola que tínhamos é a que queremos?}

Os moradores do Madre Terra esperam que o módulo escolar construído no assentamento assuma conteúdos contextualizados com a realidade do campo, sendo, portanto, diferente da escola frequentada pelos alunos até o final do ano letivo de 2013. Questionados sobre isso, 76,19\% dos participantes responderam que não é um modelo aplicável à escola do assentamento; 9,52\% afirmam que sim; e 14,28\% não sabem.

Ângela (2013) acredita que na escola do assentamento as crianças "vão ter um ensino adequado para elas, entendeu? Não um ensino no meio 
assim, no meio da burguesia, não; um ensino da terra, um ensino daqui de dentro, da raiz delas". Na mesma perspectiva, Neli (2013) afirma que a escola deve "falar sobre plantação, colheita, estimular a criança a lidar com a terra, lidar com planta, como eu te disse aquela hora, gente do nosso meio, que eles vão educar nossos filhos dentro do nosso meio de vida”. Para Alcione (2013), o módulo escolar tem de ser:

diferente no modo de ensinar, tanto no modo de educar, quanto sem discriminação... Eu tenho um modelo de escola assim: uma escola em que, além de tu ensinar português, matemática, tem que ensinar outras coisas para as crianças também, tipo música, teatro, alguma coisa que desenvolva, [...] sou super de apoio de ir lá na escola fazer horta, ensinar as crianças a mexer com a terra, tocar violão, brincar, levar as crianças para fora, pro meio do mato, para buscar outros conhecimentos. O meu ponto de vista é este.

As expectativas dos pais quanto aos conteúdos curriculares da escola do assentamento são condizentes com as propostas pelo MST. No decorrer da sua existência e amadurecimento, este movimento social começou a perceber que a luta pela Reforma Agrária deveria estar associada à educação pública de qualidade. Com isso, "a escola passou a ser vista como uma questão também política, quer dizer, como parte da estratégia de luta pela Reforma Agrária, vinculada às preocupações gerais do Movimento com a formação de seus sujeitos" (CALDART, 2003, p. 63). Nessa proposta, defendem a existência de uma Escola Básica do Campo, cujos princípios diferem da Escola Rural tradicional, até então presente no meio rural, isto é, aquela entendida como a escola "para" o campo ou "no" campo, uma escola pensada para o meio rural sem levar em conta os anseios e as necessidades de seus habitantes. Ao contrário desta, a escola proposta pelo MST deve estar orientada para a Reforma Agrária, ou melhor, ela deve formar sujeitos que amem a terra e que se oponham ao modelo latifundiário exportador, que valorizem a Agroecologia e produzam alimentos saudáveis, contribuindo para a Soberania Alimentar. Para tanto, é necessário associar 
a Reforma Agrária com a Escola, pois a terra sozinha não é suficiente para "libertar o trabalhador da exploração. E só a escola também não é capaz de libertar o Sem-Terra da exploração, do latifúndio. Entendemos que a Reforma Agrária é a junção destas duas conquistas: ter acesso à terra e ter acesso à escola, ao conhecimento, à educação" (CALDART, 1997, p. 25).

A escola orientada para a Reforma Agrária auxilia na permanência dos agricultores no campo, pois seu ensino está ligado à resolução dos problemas do assentamento, ajudando-o a dar certo. Ou seja, ela deve fornecer "capacidade técnica e científica para enfrentar as exigências de um modelo e produção mais empresarial e competitivo. Para isso os três pilares fundamentais da escola dos assentamentos devem ser: o trabalho agropecuário, o conhecimento científico e o amor pela luta" (MST, 1992, p. 40). Os três pilares fundamentais da escola dos assentamentos estão interligados, uma vez que, ao se ter um trabalho agropecuário voltado para a produção de alimentos saudáveis e a soberania alimentar sobre base familiar, se valoriza ao mesmo tempo o amor pela luta, a luta pela terra, pelo chão que se passa a cultivar. Tudo isso não pode deixar de associar-se ao conhecimento científico que, por sua vez, contribui para a resolução de problemas do assentamento e isso se dá quando, por exemplo, se sabe contar, medir, ler e interpretar, orientar-se pelo sol ou definir o melhor solo para cada alimento. Ou, de uma forma geral, quando se compreende que seu sistema de produção é uma forma de resistência diante da agricultura agroexportadora. E, portanto, cada participante é sujeito que impulsiona a transformação social.

Acreditamos que, assim como o MST, muitos pais esperam que a escola do assentamento assuma conteúdos contextualizados com a realidade do campo, de ser agricultor, pois muitos deles (76,19\% dos que responderam ao questionário) desejam que os filhos continuem na terra, ao passo que apenas $23,8 \%$ dos participantes deram outras sugestões. Entre os motivos atribuídos está a crença de que o campo é um lugar melhor para viver, como relatado por Dalila (2013), a única adolescente com quem 
conversamos. Ela afirma que a vida no meio rural "é mais saudável, a vida é melhor, por mais que de vez em quando dê uma sequinha, uma enchurradinha (risos), mas igual é melhor a vida no campo". Nesse sentido, Neli (2013) afirma que "a terra é uma coisa sadia, é uma coisa mais educativa, enquanto tá capinando não tá pensando tanta bobagem, tanta malvadeza, tá pensando em coisa boa, plantar, colher". Outro motivo atribuído pelas mães para que seus filhos continuem na terra está no fato deles ficarem longe da violência que, no entender delas, o meio urbano proporciona. Segundo Maria (2013), no campo:

é outra qualidade de vida, é outro ensinamento, é outra educação que a gente dá para nossos filhos, porque nós somos pobres, nós não temos como viver em uma classe média e hoje até uma classe média tem problema no meio, né? Com droga, violência, com tudo, mas na vila é pior.

Seguindo na mesma linha de pensamento de Maria, Tiele (2013) afirma que prefere que seus filhos permaneçam no campo, pois "na cidade é muita droga, muito roubo e aqui pelo menos eu sei que não tem risco, no campo é longe de tudo, da violência, né? Aqui a gente mesmo controla a violência, agora na cidade é mais complicado".

Na perspectiva dos pais, se a escola do assentamento assumir conteúdos contextualizados com a realidade do campo, será um dos pilares de permanência dos jovens no assentamento, porém, não o único. É o que afirma Frida (2013):

A escola aqui, ela é um pilar da vida no campo, pois a pessoa que quer viver no campo tem que viver integralmente no campo, é ruim viver no campo e ter que sair para suprir suas necessidades básicas, tipo saúde, educação, cultura, lazer, isto o campo deveria proporcionar e a escola é um pilar, ainda mais com uma educação voltada para a terra. 
Assim como Frida, Fátima (2013) também acredita que a escola é um dos pilares de fazer com que os jovens permaneçam no assentamento. Segundo ela,

a escola, ficando aqui, vai ser muito bom, se ela for até o nono ano, depois pode-se brigar para vir o ensino médio, [...] por que não pode amanhã ou depois vir um curso técnico para cá? Voltado pro que a gente quer? Aqui teria que ter, até para segurar essa gurizada tudo aí... senão vão tudo embora, conforme vão terminando e fechando um ciclo aqui vão acabar indo embora (2013).

O fechamento de um ciclo e a saída do assentamento para estudar na cidade é o caso da adolescente com quem conversamos:

Eu vou sair daqui, porque eu preciso estudar, eu vou sair, porque eu não tenho mais como estudar aqui, porque se tivesse escola aqui eu ia permanecer aqui e pensar em ajudar a escola aqui, mas como não tem estudo, normalmente a agente vai procurar sair para fora, né? até depender de amigo ou parente para poder morar e tal (DALILA, 2013).

A preocupação com a saída dos jovens do assentamento também foi constatada na fala de Vânia (2013), segundo a qual se deve tomar alguma providência:

Se nós como assentados não se unir para segurar esta juventude aqui com nós, nós vamos ficar só os véio aqui dentro, porque a juventude vai "rapar" para fora, porque não tem uma comunidade de verdade, não tem onde se divertir, não tem como ficar, então é neste sentido que nós temos que começar a pensar alguma coisa para segurar esta juventude junto com nós aqui.

Nenhum assentado com quem conversamos discorda da importância da escola para o assentamento, pois $100 \%$ deles responderam que a construção do módulo escolar no Madre Terra é fundamental. Quanto à contribuição da escola para a permanência no campo, 95,23\% declararam 
que é necessária para esse fim; 4,76\% não sabem, mas ninguém negou que é importante para a permanência no meio rural.

Segundo Maria (2013), “o pai e a mãe quer dar estudo para o seu filho, pelo menos para ter um técnico agrícola, alguma coisa assim, neste sentido, né? não ser que nem nós, morrer no cabo da enxada”. Porém, em vários relatos, percebemos a vontade que os pais têm de que seus filhos estudem, não para melhorar a vida do assentamento, mas para realizarem outras atividades fora, tal como defendido por Ângela (2013):

o que eu puder dar de ensino para eles, seja o que eles quiserem ser, eu gostaria que o (nome do filho) fosse agrônomo, o que eu queria ser, mas sei lá... veterinário, mas o que eu puder dar de estudo para ele, para ele ser alguma coisa na vida, dependendo conforme for, se ele tocar sair daqui para estudar e ser alguém na vida... se depender de mim eles ficam aqui, agora tudo depende como vai a escola.

O casal Gilson e Dara (2013) seguem nessa mesma linha de pensamento de que, se estudar, se deve sair do campo. Segundo ele, "a ideia que a gente tem é que eles estudem, se formem em alguma coisa e arrumem um emprego, trabalhem, porque a gente... já chega a gente que não tem estudo, né? Se ficassem em casa, na terra, claro que trabalhando certo, dá alguma coisa, mas não é futuro". Ela segue na mesma opinião do marido e afirma que "se a gente tiver condições de dar uma faculdade para eles, se eles quiser ser outra coisa na vida, eu acho que é melhor, porque... uma que lidar com lavoura hoje em dia não tá muito bom e se tem outro meio de trabalhar é melhor".

Esses pensamentos de estudar para sair do campo, proferidos por Ângela e pelo casal Gilson e Dara, acabam ferindo as propostas do MST para as escolas do assentamento que priorizam, conforme vimos, a junção entre escola e reforma agrária, porém, diante das dificuldades e da falta de infraestrutura em que se encontra o Madre Terra, não podemos dizer 
que os assentados estão equivocados, pois compreendemos que os pais querem o melhor para seus filhos.

Diante disso, constatamos que a escola frequentada até o final de 2013 não corresponde aos anseios dos assentados e, portanto, a Annoni não é um modelo a ser seguido pela escola do assentamento. Acreditamos, assim como desejam os assentados com quem conversamos, que a escola do assentamento é um dos meios para a permanência dos jovens no campo, mas se não estiver associada à resolução de outros problemas de que o assentamento Madre Terra necessita, a saída será inevitável.

\section{Considerações finais}

No início de 2018, faz mais de quatro anos que Marcelo e seu irmão - nossos personagens fictícios que representam crianças e adolescentes do Madre Terra - não precisam mais percorrer 5 horas dentro do ônibus escolar para ir e voltar da escola, pois a escola do assentamento iniciou suas atividades. Entretanto, desde 2014, quando do início de seu funcionamento, batizada pela comunidade do Madre Terra como "Semente Libertária", houve duas tentativas de fechá-la, ambas no início de anos letivos, uma em 2015 e outra em 2017. No entanto, a organização da comunidade pela defesa da escola vem prevalecendo e ela continua em atividade. A manifestação da comunidade escolar é um dos elementos a serem considerados pelo órgão normativo do respectivo sistema de ensino antes da realização do fechamento de uma escola do campo. Conforme a LDB:

O fechamento de escolas do campo, indígenas e quilombolas será precedido de manifestação do órgão normativo do respectivo sistema de ensino, que considerará a justificativa apresentada pela Secretaria de Educação, a análise do diagnóstico do impacto da ação e a manifestação da comunidade escolar (LDB, Art. 28, parágrafo único). 
No início de abril de 2018 (período em que finalizamos este capítulo), assim como outras escolas estaduais, a escola do assentamento passava por um novo problema que afetou o início das aulas, previsto ainda para o dia 26 de fevereiro de 2018: a falta de transporte escolar. Apesar de a escola estar em funcionamento, Marcelo e seu irmão ainda dependem do transporte escolar, pois moram a $5 \mathrm{~km}$ dela. Além disso, seus professores, com exceção de uma, residem no centro urbano do município e também dependem do ônibus para chegar até o assentamento, distante $80 \mathrm{~km}$ de suas casas.

Durante o ano letivo de 2017, os estudantes das escolas estaduais utilizavam o mesmo ônibus da rede municipal, mas alegando que o Estado paga pouco pelo serviço, a prefeitura de São Gabriel-RS desfez a parceria em novembro de 2017. A falta de transporte impossibilitou que a escola do assentamento Madre Terra, assim como muitas outras, iniciasse o ano letivo na data prevista. Segundo informações apresentadas no "Jornal do Almoço” de 19 de março de 2018, o Ministério Público entrou com uma ação para agilizar a questão do transporte, e a Secretaria Estadual de Educação comprometeu-se a fazer um contrato emergencial para atender aos estudantes de São Gabriel, sendo que a expectativa é de normalização do transporte em 30 dias.

Esperamos que neste momento a questão do transporte escolar dos alunos de escolas estaduais esteja resolvida definitivamente e que as aulas no assentamento Madre Terra ocorram normalmente. As expectativas geradas ainda antes da consolidação da escola, principalmente no que diz respeito aos conteúdos curriculares, é algo que será necessário acompanhar. Pretendemos retornar futuramente ao local de pesquisa e verificar se o que se desejava se tornou realidade.

\section{REFERENNCIAS}

BASTIANI, Tânia Mara De. Rompendo as cercas da educação burguesa: a luta pela construção de uma escola no assentamento Madre Terra, São Gabriel-RS. 
2014. 166 f. Dissertação (Mestrado em Educação) - Universidade Federal de Santa Maria. Santa Maria, 2014.

BRASIL. Lei de Diretrizes e Bases da Educação Nacional. Lei nº 9394, de 20 de dezembro de 1996. Estabelece as diretrizes e bases da educação nacional. Brasília, 1996.

. Resolução CNE/CEB $n^{\circ} 01$, de 3 de abril de 2002 - Institui Diretrizes Operacionais para a Educação Básica nas Escolas do Campo. Brasília, 2002. . Decreto $n^{\circ} 7.352$, de 4 de novembro de 2010. Dispõe sobre a política de educação do campo e o Programa Nacional de Educação na Reforma Agrária (PRONERA). Brasília: 2010.

CALDART, Roseli Salete. Educação em movimento: Formação de educadores e educadoras no MST. Petrópolis-RJ: Vozes, 1997.

. Escola do Campo em Movimento. Currículo sem Fronteiras, v. 3, n. 1, p. 60-81, jan./jun. 2003.

IBGE - INSTITUTO BRASILEIRO GEOGRAFIA E ESTATÍSTICA. Censo 2010/Dados preliminares. Rio de Janeiro: IBGE, 2010. Disponível em: <www. ibge.gov.br>. Acesso em: 22 maio 2013.

MST. Boletim da Educação $n^{\circ} 1$ - publicado em agosto de 1992. Como deve ser uma escola de assentamento. In: ITERRA. Caderno de Educação no $13-$ Dossiê MST Escola. Documentos e Estudos 1990-2001. Setor de Educação do MST, 2005.

SANTOS, Anderson L. M. dos. O emergir de um novo território camponês: conquistas e transformações nos domínios do latifúndio - o caso de São Gabriel-RS. 2012. 200 f. Dissertação (Mestrado em Geografia) — Universidade Federal de Santa Maria. Santa Maria, 2012.

\section{FONTES ORAIS ${ }^{32}$}

ALCIONE, 2013. Entrevista concedida a Tânia Mara De Bastiani em novembro de 2013, no Assentamento Madre Terra, São Gabriel-RS.

32 As fontes orais são alguns dos participantes do questionário aplicado para a elaboração da dissertação "Rompendo as cercas da educação burguesa: a luta pela construção de uma escola no assentamento Madre Terra, São Gabriel-RS”. 
ÂNGELA, 2013. Entrevista concedida a Tânia Mara De Bastiani em novembro de 2013, no Assentamento Madre Terra, São Gabriel-RS.

DALILA, 2013. Entrevista concedida a Tânia Mara De Bastiani em novembro de 2013, no Assentamento Madre Terra, São Gabriel-RS.

DENISE, 2013. Entrevista concedida a Tânia Mara De Bastiani em junho de 2013, na Escola Municipal de Ensino Fundamental Ernesto José Annoni, São Gabriel-RS.

FÁTIMA, 2013. Entrevista concedida a Tânia Mara De Bastiani em novembro de 2013, no Assentamento Madre Terra, São Gabriel-RS.

FRIDA, 2013. Entrevista concedida a Tânia Mara De Bastiani em novembro de 2013, no Assentamento Madre Terra, São Gabriel-RS.

GILSON, 2013; DARA, 2013. Entrevista concedida a Tânia Mara De Bastiani em novembro de 2013, no Assentamento Madre Terra, São Gabriel-RS.

LARISSA, 2013. Entrevista concedida a Tânia Mara De Bastiani em junho de 2013, na Escola Municipal de Ensino Fundamental Ernesto José Annoni, São Gabriel-RS.

MARIA, 2013. Entrevista concedida a Tânia Mara De Bastiani em novembro de 2013, no Assentamento Madre Terra, São Gabriel-RS.

MARTA, 2013. Entrevista concedida a Tânia Mara De Bastiani em junho de 2013, na Escola Municipal de Ensino Fundamental Ernesto José Annoni, São Gabriel-RS.

NELI, 2013. Entrevista concedida a Tânia Mara De Bastiani em novembro de 2013, no Assentamento Madre Terra, São Gabriel-RS.

TIELI, 2013. Entrevista concedida a Tânia Mara De Bastiani em novembro de 2013, no Assentamento Madre Terra, São Gabriel-RS.

VÂNIA, 2013. Entrevista concedida a Tânia Mara De Bastiani em novembro de 2013, no Assentamento Madre Terra, São Gabriel-RS. 


\title{
O Pronaf e a educação do campo na perspectiva da Fetraf-Brasil
}

\author{
Catia Grisa ${ }^{33}$ \\ Jonas José Seminotti ${ }^{34}$ \\ Roniere dos Santos Fenner ${ }^{35}$
}

\section{Considerações iniciais}

O Programa Nacional de Fortalecimento da Agricultura Familiar (Pronaf) e o Programa Nacional de Educação do Campo (Pronacampo) são duas das principais políticas públicas vigentes na agricultura familiar. O objetivo do presente capítulo é compreender o Pronaf e o Pronacampo sob a perspectiva da Fetraf-Brasil ${ }^{36}$, as lutas desenvolvidas, a organização sindical, os efeitos para os agricultores familiares e a transversalidade entre essas políticas na perspectiva do desenvolvimento rural.

Um traço fundamental do desenvolvimento rural sustentável é a articulação entre o social, o econômico e o ambiental. Ou seja, conceber políticas públicas que promovam o desenvolvimento no campo requer

33 Professora Adjunta da UFRGS, Campus Litoral Norte. Programa de Pós-Graduação em Desenvolvimento Rural (PGDR/UFRGS). Doutorado em Ciências Sociais. Contato: catiagrisa@yahoo.com.br

34 Professor Adjunto da UFRGS, Campus Litoral Norte. Doutorado em Sociologia. Contato: jonas.seminotti@ufrgs.br

35 Professor Adjunto da UFRGS, Campus Litoral Norte. Doutorado em Educação nas Ciências. Contato: roniere.fenner@ufrgs.br

36 Durante o IV Congresso Nacional dos Trabalhadores e Trabalhadoras na Agricultura Familiar do Brasil, realizado em maio de 2016, a plenária aprovou e determinou que a Federação fosse transformada em uma Confederação, decisão essa que deu origem a Confederação Nacional dos Trabalhadores e Trabalhadoras da Agricultura Familiar (CONTRAF BRASIL). Trabalhamos como o termo FETRAF por estarmos analisando o período que antecede 2016. 
seguir não apenas a dimensão econômica, prática comum dos defensores do livre mercado. Nessa perspectiva, Van Der Ploeg (2000) defende a ideia de que é necessária uma reconfiguração do modelo de desenvolvimento do campo, envolvendo terra, trabalho, natureza, ecossistemas, plantas e animais, artesanatos, mercados, relações com as cidades, relações sociais e políticas públicas.

A Fetraf-Brasil, junto a outros movimentos sociais do campo, tem organizado os (as) trabalhadores (as) a fim de lutar pela terra, pela permanência nela, por direitos sociais e por políticas públicas, a exemplo da educação do campo e do crédito, com base no respeito à diversidade e à realidade dos sujeitos do campo, como diversos autores têm elaborado. (ARROYO, 2009; CALDART, 2003, 2008; FERNANDES; KOLLING; MOLINA, 2009; MUNARIM; 2008; SOUZA, 2010).

O tema da educação e a demanda por política de crédito, articulados ao tema do desenvolvimento, estiveram presentes na pauta do sindicalismo da agricultura familiar desde os anos 1980, nos cursos de formação de lideranças nas comunidades rurais em meio ao processo das oposições sindicais e nos encontros do Movimento de Mulheres Trabalhadoras Rurais, com a atuação da Escola Sul e do Departamento Rural da CUT.

Fruto de grandes mobilizações das organizações da agricultura familiar, de mudanças paradigmáticas nos estudos rurais e de negociações na agenda pública, o Pronaf foi um marco do reconhecimento político e institucional da agricultura familiar. A amplitude dos recursos disponibilizados, o formato, os critérios de acesso do público beneficiário e as mudanças ocorridas no Programa sempre foram influenciados pelas reivindicações dos movimentos sociais e sindicais da agricultura familiar, dentre eles a Fetraf.

No entanto, se o Pronaf passa a existir como política pública a partir de 1996, a compreensão, por parte do Estado, sobre a importância da educação do campo como uma política pública específica aos povos do campo, só veio a concretizar-se em 2010, com a criação da política de educação 
do campo e o Programa Nacional de Educação na Reforma Agrária (Pronera $)^{37}$. Para efeitos do Decreto 7.352/2010, entende-se por populações do campo: os agricultores familiares, os extrativistas, os pescadores artesanais, os ribeirinhos, os assentados e acampados da reforma agrária, os trabalhadores assalariados rurais, os quilombolas, os caiçaras, os povos da floresta, os caboclos e outros que produzam suas condições materiais de existência a partir do trabalho no meio rural.

A transversalidade entre a educação e as demais políticas públicas esteve presente em diferentes momentos e documentos produzidos pela Fetraf-Brasil mas ficou expresso de forma mais direta a partir da elaboração do projeto alternativo de desenvolvimento para a agricultura familiar numa postura contra-hegemônica ao modelo neoliberal vigente nos anos 1990 no Brasil, quando houve uma forte onda de privatizações e a diminuição do papel do Estado se apresentava como um projeto político, não só para o setor agropecuário, mas também para toda a sociedade.

Passaremos a analisar a especificidade do Pronaf e posteriormente do Pronacampo para, através da perspectiva do desenvolvimento, compreendermos a articulação existente entre ambos a partir da atuação da Fetraf-Brasil.

\section{O Pronaf, seu desempenho, mudanças e atuação da Fetraf}

Em 2016 comemoramos 20 anos da publicação do Decreto $n^{\circ} 1.946$ de 28 de junho de 1996, que criou o Programa Nacional de Fortalecimento da Agricultura Familiar (Pronaf). Fruto de grandes mobilizações das organizações da agricultura familiar (nomeadamente os Gritos da Terra Brasil), de mudanças paradigmáticas nos estudos rurais e de negociações na agenda pública (GRISA, 2012; SANTOS, 2011; PICOLOTTO, 2011;

37 Decreto $\mathrm{n}^{\circ}$ 7.352, de 4 de novembro de 2010, Art. $1^{\circ}$ - Consiste em um conjunto articulado de ações de apoio aos sistemas de ensino para a implementação da política de educação do campo. 
SCHNEIDER, CAZELA e MATTEI, 2004), este programa foi um marco do reconhecimento político e institucional da agricultura familiar no Brasil. A partir de então - e na continuidade da atuação dos movimentos sociais e sindicais da agricultura familiar - tanto o Programa quanto a categoria social fortaleceram-se mutuamente (GRISA, 2012; SANTOS, 2011). Atualmente, o Pronaf é a política agrícola mais importante para a agricultura familiar, seja em virtude da amplitude dos recursos aplicados ( $\mathrm{R} \$ 21$ bilhões de reais em 2015), seja em função da capilaridade da política pública, chegando a mais de $97 \%$ dos municípios brasileiros (BRASIL, MDA, 2015).

Em toda a sua trajetória, o formato e as mudanças ocorridas no Programa sempre foram bastante influenciados pelas reivindicações dos movimentos sociais e sindicais da agricultura familiar, em um processo de "cooperação conflituosa"38 (CONTI, 2016; ABERS, SERAFIM e TATAGIBA, 2014; BOLTER, 2013; GIUGNI e PASSY, 1998). Com efeito, a própria construção do Programa e seus contornos iniciais resultam de mobilizações sociais e foram construídos em diálogos e negociações com a Confederação Nacional dos Trabalhadores na Agricultura (CONTAG) e outros movimentos sociais ${ }^{39}$ (CONTI, 2016; BIANCHINI, 2015; GRISA, 2012; SANTOS, 2011; PICOLOTTO, 2011). Para ilustrar, mencionam-se os critérios que conformaram inicialmente o público beneficiário (Resolução $\mathrm{n}^{\circ} 2.191$ de 24 de agosto de 1995 do Conselho Monetário Nacional), que são frutos de discussões do movimento sindical desde o início dos anos 1990 e foram amadurecidos na Comissão Técnica do Pequeno Produtor

38 Segundo Giugni e Passy (1998), cooperação conflituosa é uma das formas que as relações entre Estado e Sociedade podem assumir, sendo as demais oposição, protesto e consenso. No primeiro caso, trata-se de uma relação que contempla conflito e cooperação da parte dos movimentos sociais na construção de suas demandas. No caso brasileiro, desde o início dos anos 2000, organizações sindicais da agricultura familiar e outras organizações da sociedade civil adentraram para dentro do Estado, seja via atuação na estrutura institucional, seja na construção, formulação e implementação de políticas públicas, em um processo de cogestão. Neste processo, em que pesem o diálogo e a colaboração, também permanecem as relações desiguais na distribuição de poder entre Estado e sociedade, sendo o primeiro prevalecente.

39 É relevante lembrar que, neste momento, a CONTAG estava filiada à Central Única dos Trabalhadores (CUT) e, deste modo, os contaguianos e os rurais da CUT participaram das negociações na construção do Pronaf. 
(Portarias MAARA no 692 de 30/11/1993 e nº 42 de 24/01/1994), conformada no Ministério da Agricultura, do Abastecimento e da Reforma Agrária (MAARA) ${ }^{40}$ em 1994, com a participação da CONTAG, para elaborar "Propostas e recomendações de política agrícola diferenciada para o pequeno produtor rural" (BRASIL, MAARA/CONTAG, 1994). Cabe salientar como inovações deste documento, dentre outros elementos, as propostas de criação de um "Programa Especial de Crédito para os Pequenos Produtores Rurais", com encargos financeiros, prazos, carências e formas de pagamentos específicos; e a proposição de uma definição de pequeno produtor, posteriormente adotada no Pronaf. ${ }^{41}$

Outro exemplo da influência marcante das organizações da agricultura familiar na configuração do Programa refere-se à criação do Pronafinho em 1997. Conforme Abramovay e Piketty (2005, p. 62), "criou-se uma nova linha de crédito no interior do Pronaf voltada a agricultores bem próximos da linha de pobreza, ou seja, em média, um terço do nível de renda bruta dos primeiros beneficiários do Programa." Tratava-se de um público mais próximo aos "periféricos", segundo classificações dos Relatórios FAO/INCRA (FAO/INCRA, 1996, 1994), diferindo das concepções originais do Pronaf. Esta linha emergiu de reivindicações de agricultores familiares que viriam a constituir, em dezembro de 1997, em Brasília, o Movimento dos Pequenos Agricultores (MPA). Ambos, o movimento social e o Pronafinho, resultaram das mobilizações realizadas no início de 1996 associadas à estiagem que assolava o Rio Grande do Sul (PICOLOTTO),

40 Em 1996, o MAARA passou a denominar-se Ministério da Agricultura e do Abastecimento e foi criado também o Ministério Extraordinário de Política Fundiária. Em 1999, este passou a denominar-se Ministério do Desenvolvimento Agrário (MDA) e aquele, em 2001, recebeu a denominação de Ministério da Agricultura, Pecuária e Abastecimento (MAPA).

41 Ilustrando a cooperação conflituosa, destaca-se que, embora a definição dos beneficiários do Pronaf tenha ocorrido em diálogo com a Contag, também houve pressão política da Confederação Nacional da Agricultura (CNA), e o Estado acabou contemplando igualmente as demandas da organização sindical patronal de que fossem incorporados como beneficiários também os estabelecimentos com até dois empregados permanentes (GRISA, 2012; SANTOS, 2011). Para Abramovay e Veiga (1999), esta admissão teve duas consequências importantes: permitiu o acesso ao PRONAF de agricultores familiares que, provavelmente, teriam maiores possibilidades de garantias reais de pagamento dos financiamentos aos bancos (ou seja, agricultores mais capitalizados), o que, por conseguinte, favoreceu a participação do sindicalismo patronal na execução local do PRONAF. 
2011; BIANCHINI, 2010: CADONÁ, 2004). Essas mobilizações revelaram-se espaços profícuos para a discussão e demanda de políticas públicas mais adequadas às especificidades de segmentos da agricultura familiar e, ao mesmo tempo, para apontar a necessidade de estabelecer outro movimento social que não se organizaria a partir da estrutura sindical, dadas as críticas que esses atores apresentavam à atuação da CONTAG e da CUT.

Dando ênfase às pressões, às negociações e aos diálogos ocorridos entre Estado e organizações da agricultura familiar na execução do Pronaf, esta seção analisa alguns elementos do desempenho histórico do Programa e a influência da Fetraf-Brasil em mudanças importantes ocorridas. Para esta reflexão, além de dados do Banco Central do Brasil sobre a execução do Pronaf, realizamos análise documental das pautas de reivindicações e outros documentos da organização sindical. Os documentos oriundos das Jornadas Nacionais de Luta da Agricultura Familiar e Reforma Agrária (Pautas de Reivindicações) são particularmente importantes nesse sentido, pois envolvem amplo processo de participação da base social da Fetraf-Brasil e compreendem um repertório de ação de construção, mobilização, negociação e execução de agendas e políticas públicas de interesse da categoria (CONTI, 2016).

\section{Distribuição regional do acesso ao Pronaf e características socioeconômicas dos agricultores familiares beneficiários}

Desde o início do Pronaf, um questionamento recorrente nos estudos rurais refere-se à distribuição desigual dos recursos entre as regiões brasileiras (AQUINO e SCHNEIDER, 2015; GRISA, WESZ Jr. e BUCHEITZ, 2014; DELGADO, LEITE e WESZ Jr., 2010; AQUINO e SCHNEIDER, 2010; MATTEI, 2006, 2005; SCHNEIDER, CAZELLA e MATTEI, 2004; BELIK, 2000; ABRAMOVAY e VEIGA, 1999). No entanto, como evidenciado no gráfico a seguir, essa desigualdade permanece um desafio importante no 
Pronaf. De acordo com os dados, no ano 2000, quase 60\% dos recursos foram para o Sul do Brasil, seguido pelo Sudeste e, em terceiro lugar, o Nordeste - embora esta região concentre 50\% dos agricultores familiares brasileiros (IBGE, 2009). Em 2006, a região Sul reduziu sua participação para $40,75 \%$, e o Nordeste incrementou para $26,05 \%$. No entanto, a partir de 2008, a região Sul retomou sua participação nos recursos totais do Programa e, desde 2009, tem situado-se próximo a 50\%. Em 2015, a região Sudeste respondeu por $19,22 \%$ dos recursos totais, a região Nordeste $14,10 \%$, Centro-Oeste 7,83\% e Norte 7,29\%.

Gráfico 1: Distribuição (\%) dos recursos do Pronaf entre as regiões brasileiras (1999 a 2015)

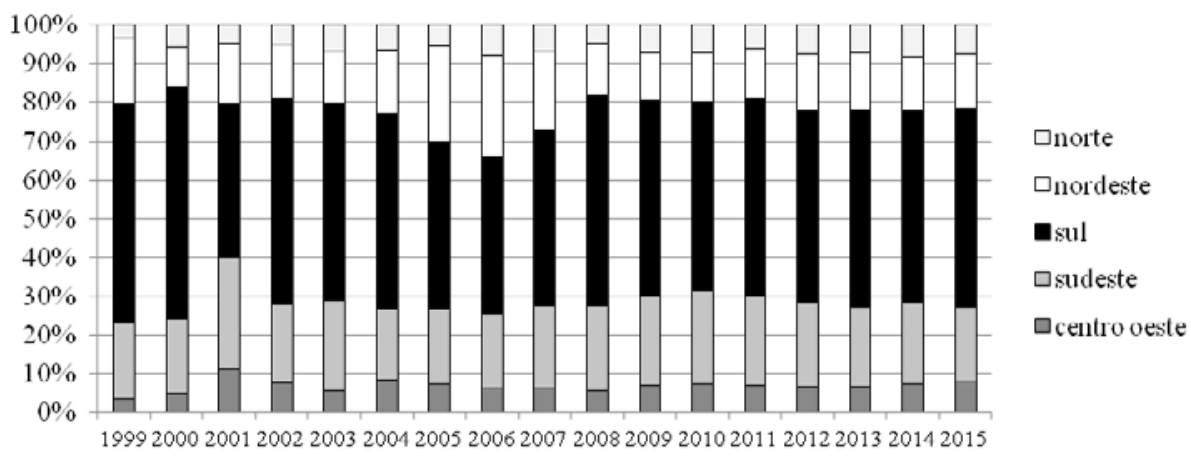

Fonte: Banco Central do Brasil (elaborado pelos autores).

Em relação aos contratos (Gráfico 2), chama a atenção que, no início dos anos 2000, a região Sul também era prevalecente (62\% no ano 2000), seguida pela região Nordeste (18,99\%) e Sudeste (11,44\%). Em 2006, a relação Sul e Nordeste praticamente se inverteu, sendo os percentuais, respectivamente, $22,11 \%$ e $60,20 \%$. Em 2015, os percentuais foram: $44,52 \%$ no Nordeste; $30,38 \%$ no Sul; $16,08 \%$ no Sudeste; $5,59 \%$ no Norte; e 3,43\% no Centro-Oeste. 
Gráfico 2: Distribuição (\%) dos contratos do Pronaf entre as regiões brasileiras (1999 a 2015)

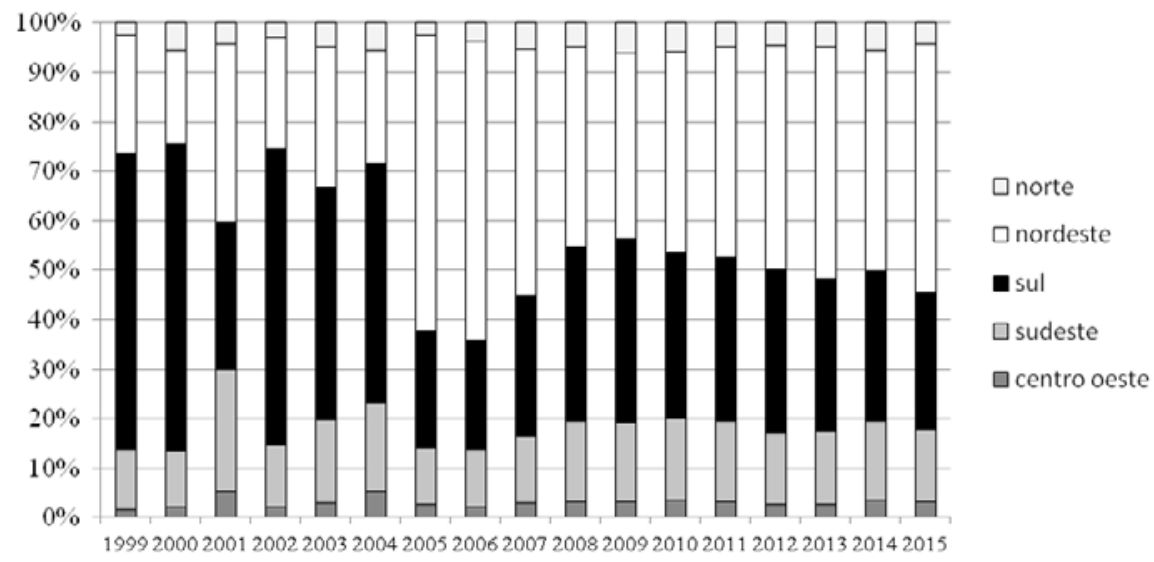

Fonte: Banco Central do Brasil (elaborado pelos autores).

Ao analisarmos os valores médios dos contratos (Gráfico 3), notamos que quase todas as regiões brasileiras apresentaram elevação expressiva dos contratos médios a partir de 2008. A região Centro-Oeste foi a mais emblemática nesse sentido, alcançando em 2015 o valor médio de R \$31.498,38 por contrato. Destoando deste cenário, destaca-se o Nordeste, cuja elevação foi menos expressiva, alcançando apenas o valor médio de $\mathrm{R} \$ 3.586,44$ por contrato em 2015. Ainda em termos comparativos, salientamos que na região Sul o valor médio situou-se em $\mathrm{R} \$ 23.623,50$ no mesmo ano.

Gráfico 3: Valores médios dos contratos $(\mathrm{R} \$)$ do Pronaf entre as regiões brasileiras (1999 a 2015)

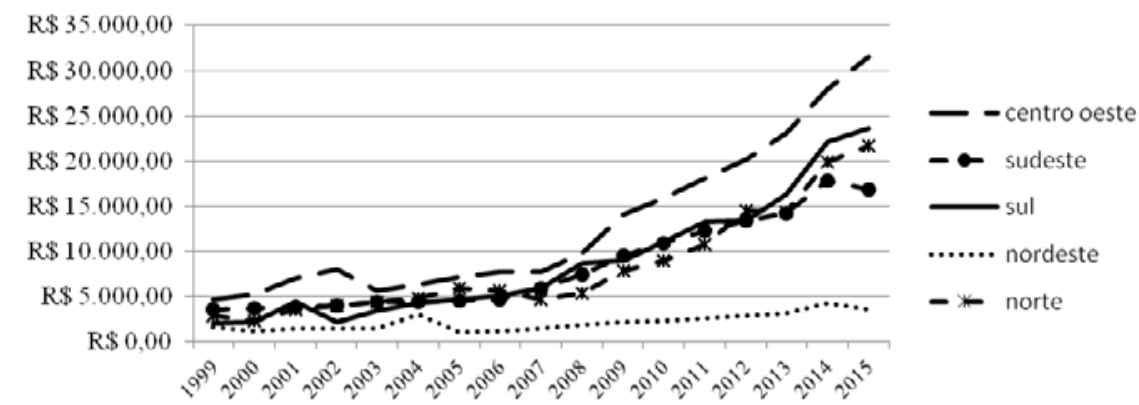


Se, como mencionado, a distribuição desigual do Pronaf entre as regiões brasileiras é frequentemente questionada pelos estudos rurais, não encontramos equivalência nas reivindicações da Fetraf-Brasil. Esta não é uma questão que perpassa as pautas de reivindicações da Fetraf-Brasil, provavelmente em decorrência de sua base sindical ainda concentrar-se na região Sul do Brasil, embora os movimentos crescentes de participação das demais regiões.

Outro questionamento recorrente nos estudos rurais refere-se à concentração dos recursos no público mais capitalizado da agricultura familiar. Como mencionam Aquino e Schneider (2015, p. 62), "nos seus primeiros 18 anos de vida, a política de crédito do Pronaf se transformou em uma fonte de financiamento público importante para diversos segmentos da agricultura brasileira. No entanto, sua versão recente se apoia numa lógica evolucionista que elege os agricultores familiares de maiores níveis de renda como seu público preferencial". Os mesmos autores apontam que, em 2011, os Grupos A e A/C ${ }^{42}$ receberam apenas 4,7\% dos recursos do Programa; de forma similar, o Grupo B - que representava 55\% da agricultura familiar brasileira - respondeu por apenas $6 \%$ do montante dos recursos do Programa; já o Grupo Variável (que contempla os antigos C, D e E, e representava $26 \%$ dos agricultores familiares brasileiros) recebeu 89,3\% dos recursos do Pronaf. Apesar de diversas mudanças normativas realizadas visando incorporar a diversidade socioeconômica dos agricultores familiares (AQUINO e SCHNEIDER, 2015; GRISA, WESZ Jr. e BUCHWEITZ, 2014; MATTEI, 2011), o Programa ainda encontra limitações em contemplar os segmentos mais vulneráveis economicamente.

42 O Grupo A refere-se aos assentados da reforma agrária; o Grupo A/C corresponde aos egressos do Grupo A; o Grupo B contempla agricultores familiares com renda bruta anual familiar de até R 20 mil, sem a presença de trabalho contratado permanente; e o Grupo Variável diz respeito aos agricultores familiares com renda bruta anual familiar de R\$ 20 mil até R\$ 360 mil, desde que ao menos 50\% da renda seja oriunda da atividade agropecuária, podendo manter empregados permanentes em um número menor que a quantidade de pessoas da própria família ocupada no estabelecimento. 
Nesse aspecto, é importante mencionar que a Fetraf-Brasil também propôs e reivindicou algumas alterações institucionais no Pronaf no sentido de ampliar a participação da diversidade socioeconômica dos agricultores familiares. Por exemplo, na Pauta de Reivindicações de 2005 propôs novos limites de renda para fins de enquadramento, novos limites de valores financiados, e novas taxas de juros, todos diferenciados de acordo com os Grupos do Pronaf; na Pauta de Reivindicações de 2006 solicitou a renegociação de dívidas dos agricultores pronafianos, com bônus diferenciados segundo os Grupos do Pronaf; e, na Pauta de Reivindicações 2007/2008, demandou o estabelecimento de juro zero nas modalidades de A até C, e juros de $2 \%$ para o Grupo D e $4 \%$ para o Grupo E (FETRAF-BRASIL, 2007; 2006; 2005). Todavia, não são frequentes demandas explícitas em relação a uma maior participação e inserção do público mais vulnerável da agricultura familiar ou da diversidade de formas familiares de produção e relacionamentos com a terra (extrativistas, quilombolas, indígenas, quebradeiras de coco babaçu, faxinalenses, catadoras de mangaba etc.).

\section{As atividades produtivas financiadas pelo Pronaf}

Os estudos rurais também têm apontado para as dificuldades do Pronaf em fortalecer um modelo de produção distinto daquele fomentado durante a modernização da agricultura. De acordo com Grisa, Wesz Jr. e Bucheitz (2014), milho, soja e café foram os principais produtos financiados pelo crédito de custeio no período de 1999 a 2012, contemplados com $68 \%$ dos recursos da modalidade. Em 2012, mais de 70\% dos recursos de custeio agrícola foram aplicados nesses três cultivos, que geralmente estão associados à monocultura, às escalas de produção, à utilização de insumos modernos e à dependência de grandes empresas do sistema agroalimentar (GRISA, WESZ Jr. e BUCHEITEZ 2014; AQUINO E SCHNEIDER, 2010; TOLEDO, 2009; IBASE, 2006; GAZOLA e SCHNEIDER, 2005). 
Visando minimizar este caráter produtivista do Pronaf, diversas linhas de financiamento foram criadas, como o Pronaf Agroecologia, Floresta e $\mathrm{Eco}^{43}$, cuja emergência está associada principalmente às demandas de organizações agroecológicas (GRISA, 2012; ALMEIDA, 2009; WEID, 2006a; 2006b; 2010). No entanto, logo reivindicações da Fetraf-Brasil somaram-se nesse sentido, ainda que na ausência de críticas à concentração dos financiamentos na produção de commodities. ${ }^{44}$

Dentre as reivindicações da Fetraf-Brasil na construção das "linhas verdes” do Pronaf (BRASIL, MDA, 2011) destacam-se: rebate de 50\% do financiamento do Pronaf Agrofloresta, quando o investimento destinar-se à preservação permanente com árvores nativas e frutíferas, recuperação de matas ciliares e preservação de nascentes (FETRAF-BRASIL, 2005); ampliação dos recursos para o Pronaf Agroecologia, com juro zero e rebate de $20 \%$ dos contratos (FETRAF-BRASIL, 2007); criação de uma normatização técnica específica para os cultivos agroecológicos, que seja aceita pelo sistema bancário de crédito e pelo seguro agrícola, garantindo o uso de sementes crioulas e outros insumos agroecológicos para produção;

43 Conforme definições do Manual do Crédito rural, o Pronaf Agroecologia contempla beneficiários que apresentem projeto técnico ou proposta simplificada para sistemas de produção de base agroecológica ou em transição para sistemas de base agroecológica, ou ainda sistemas orgânicos de produção. A taxa de juros é de 2,5\% a.a., sendo a assistência técnica obrigatória. O Pronaf Floresta financia atividades de agricultores familiares enquadráveis no Pronaf que apresentem projetos técnicos para sistemas agroflorestais, exploração extrativista ecologicamente sustentável, plano de manejo e manejo florestal, recomposição e manutenção de áreas de preservação permanente e reserva legal e recuperação de áreas degradadas, enriquecimento de áreas que já apresentam cobertura florestal diversificada, com plantio de uma ou mais espécies florestais, nativa do bioma. Os limites de financiamento são de até $\mathrm{R} \$ 27.500,00$, com taxas de juros de 2,5\% a.a. O Projeto Eco destina-se a agricultores familiares que apresentem projeto técnico para pequenos aproveitamentos hidroenergéticos; tecnologias de energia renovável, como uso da energia solar, da biomassa eólica, miniusinas de biocombustíveis e a substituição de tecnologia de combustível fóssil por renovável nos equipamentos e máquinas agrícolas; tecnologias ambientais, como estação de tratamento de água, de dejetos e efluentes, compostagem e reciclagem; projetos de adequação ambiental; adequação ou regularização das unidades familiares de produção à legislação ambiental; implantação de viveiros de mudas de essências florestais e frutíferas fiscalizadas ou certificadas; silvicultura geradora de produtos madeireiros e não madeireiro. O valor financiado pode chegar a $\mathrm{R} \$ 165.000,00$, com taxas de juros de, no máximo, 5,5\% a.a.. Nota sobre Pronaf Agroecologia, Floresta e Eco.

44 É importante destacar que, embora representantes da agricultura familiar questionassem o modelo de produção agrícola vigente durante as décadas de 1980/90 (CONTAG, 1994; 1984; CUT, 1995), essa dimensão foi minimizada durante o processo de negociação e de construção do Pronaf. A elaboração de uma primeira política diferenciada para a agricultura familiar e reivindicações de outras demandas imediatas prevaleceram na pauta das organizações sindicais da agricultura familiar, as quais buscavam com estas conquistas fortalecer os movimentos sociais e sindicais rurais (GRISA, 2012). 
incentivo a regiões agroecológicas por meio da criação de uma linha de crédito específica para a constituição de regiões livres de agrotóxicos e livre de Organismos Geneticamente Modificados, com rebate de 30\% no valor dos recursos recebidos individualmente, mais incentivos para investimentos coletivos na mesma proporção de rebate (FETRAF-BRASIL, 2009); criação de um Programa Nacional de Agroecologia que articule um conjunto de políticas públicas (inclusive o crédito rural), viabilizando sistemas de produção que impactem menos o meio ambiente e a saúde humana (FETRAF-BRASIL, 2009; 2011); garantia de R 2 bilhões de reais/ano para o Pronaf Agroecologia, Agrofloresta e Eco (FETRAF-BRASIL, 2013); criação de um programa desbancarizado de financiamento da agricultura familiar, tanto para investimento como para custeio, particularmente para a produção agroecológica ou em transição, para a inclusão produtiva das mulheres e da juventude; criação de uma linha de crédito do Pronaf para a produção orgânica e de base agroecológica, para dar conta do Plano Nacional de Produção Orgânica e Agroecológica (Planapo) (FETRAF-BRASIL, 2015). ${ }^{45}$

Apesar das reivindicações da Fetraf-Brasil, de outros movimentos sociais da agricultura familiar e de organizações agroecológicas, a participação das linhas Agroecologia, Floresta e Eco no Pronaf é ainda bastante tímida. Dados de Sambuiche et al. (2012) indicam que, entre as safras 2004/2005 e 2010/2011, foram realizados 16.418 contratos do Pronaf Floresta; 981 do Pronaf Agroecologia e 3.268 do Pronaf Eco. Segundo informações do Banco Central do Brasil, em 2015 foram realizados 1.530 contratos do Pronaf Floresta, 61 do Pronaf Agroecologia (localizados nas regiões sul, sudeste e nordeste) e 992 do Pronaf Eco. Trata-se de números modestos

45 Ao analisar o processo de incorporação da dimensão ambiental no sindicalismo da Fetraf no Sul do país, Picolotto e Brandenburg (2015) observaram que as interpretações sobre a questão ambiental sofreram transformações ao longo dos últimos 30-40 anos. "Se em um primeiro momento tendia a ser associado com as consequências negativas da modernização da agricultura, no período mais recente o tema ambiental vem sendo colocado no centro do projeto de agricultura do sindicalismo e passa a fomentar uma possível positivação do modelo de produzir da agricultura familiar" (PICOLOTTO e BRANDENBURG, 2015, p. 17). Pagamentos por serviços ambientais e agroecologia passaram a ser noções e demandas acionadas pela FETRAF Sul. 
dada a magnitude do Programa. Observa-se, desse modo, a dificuldade do Pronaf se "esverdear" (WEID, 2010) e promover o desenvolvimento rural sustentável.

Se notamos atuação da Fetraf-Brasil na promoção dessas "linhas verdes", podemos destacar protagonismo ainda maior da organização sindical na construção da linha Pronaf Sustentável ${ }^{46}$. Em termos gerais, o Pronaf Sustentável articula a assistência técnica ao crédito rural para o conjunto das atividades do estabelecimento. Por meio de chamadas públicas de Assistência Técnica e Extensão Rural (ATER) são contratados grupos de técnicos para atuarem em uma região específica, os quais realizam diagnóstico e planejamento comunitário participativo, fazem diagnóstico das unidades de produção (considerando o histórico e composição da família, fontes de renda, atividades desenvolvidas, condições ambientais da propriedade, acesso aos mercados etc.), georreferenciam os estabelecimentos rurais, planejam as atividades a serem desenvolvidas com o crédito rural, elaboram e enviam o projeto de financiamento ao agente financeiro, monitoram e fornecem orientação técnica. Realizado por meio de um aplicativo denominado “Sig@ Livre Sustentável”, este trabalho também considera os passivos ambientais dos estabelecimentos, cuja readequação é incorporada no planejamento das atividades. Esta nova concepção e forma de atuação do Pronaf possibilitam uma articulação maior entre o crédito e a assistência técnica, permitem atendimento mais próximo das particularidades de cada região e dos estabelecimentos, e proporcionam a construção de um plano de desenvolvimento da unidade produtiva familiar que considera

46 Em 12 de junho de 2009, por meio do Decreto n. 6.882, foi instituído o "Programa de Desenvolvimento Sustentável da Unidade de Produção Familiar", o "PRONAF Sustentável”. O Plano Safra da Agricultura Familiar 2008/2009 já anunciava o início da implementação de "um novo modelo de PRONAF" - o "PRONAF Sistêmico". Em 2009 esta nova modalidade do PRONAF foi institucionalizada com o nome de "PRONAF Sustentável". Este foi criado com o objetivo de "[...] planejar, orientar, coordenar e monitorar a implantação dos financiamentos de agricultores familiares e assentados da reforma agrária, com enfoque sistêmico, no âmbito das modalidades de crédito rural do PRONAF"' (BRASIL, Presidência da República, 2009). Considera-se enfoque sistêmico “[...] a capacidade de observar a propriedade rural como um todo, suas interfaces e potencialidades, permitindo que cada componente ou parte do conjunto que compõe o objetivo global do projeto de financiamento pelo PRONAF seja adequadamente definido, monitorado e avaliado, levando em conta fatores sociais, econômicos e ambientais." (Brasil, Presidência da República, 2009). 
as condições produtivas, sociais, econômicas, culturais e ambientais do estabelecimento em curto e longo prazo.

É fato que o financiamento para o conjunto das atividades do estabelecimento, e não apenas para um único produto, é uma reivindicação antiga das organizações sindicais da agricultura familiar (CONTAG, 1995; 1991; 1989; 1988; BRASIL-MAARA/CONTAG, 1994; Grito da Terra Brasil, 1995; 1994). Conforme expresso no II Grito da Terra Brasil (1995, p.08), reclamava-se a "concessão de crédito aos agricultores em regime de economia familiar, de forma global para a unidade produtiva, de modo a permitir o planejamento integrado da propriedade." No entanto, a FETRAF-Brasil tornou-se protagonista na reivindicação e na proposição de novos formatos institucionais no interior do Pronaf que contemplassem o conjunto das atividades produtivas de forma sistêmica. ${ }^{47}$

Na pauta de reivindicações de 2006, ainda de forma preliminar, a organização sindical demandou "transformar o Pronaf em um programa de desenvolvimento rural sustentável, tornando-o uma política pública permanente, que financie além da produção, o processamento, a organização dos agricultores, capital de giro e comercialização; instituição de contrato único para o conjunto dos produtos da propriedade familiar" (FETRAF-Brasil, 2006). Já em 2007, na III Jornada Nacional de Luta da Agricultura Familiar, a Fetraf-Brasil verbalizou a demanda pela criação de um Pronaf Sistêmico, o qual "[...] precisa articular o financiamento de um conjunto de ações na área da organização, produção, agroindustrialização, logística de infra-estrutura e comercialização. Portanto, um programa que integra e articula o conjunto dos fatores que envolvem a agricultura familiar, mas tendo foco e prioridade a produção de alimentos para o consumo humano

47 Se a demanda por um crédito sistêmico reemergiu principalmente a partir da atuação da Fetraf, a Contag não tardou a se manifestar. Nas pautas de reivindicações dos anos seguintes (CONTAG, 2008b; 2009; 2010; 2011), esta Confederação também passou a cobrar a criação e implementação do PRONAF Sustentável. Conforme expresso em documento, reivindicou "Criar no PRONAF a modalidade de Financiamento Integral da Unidade Familiar de Produção, destinando recursos para implantar 05 (cinco) projetos-piloto por unidade federativa, em 2009, sob coordenação do MSTTR.” (CONTAG, 2008b, p.02). 
e a produção de auto-sustentação da família." (FETRAF-BRASIL, 2007, p. 03). Compunha essa reivindicação a criação de um Grupo de Trabalho para a formatação técnica, jurídica e financeira deste Programa, com implantação de projetos-pilotos no ano agrícola 2007/2008 e massificação no ano seguinte.

Em 2012, notícias veiculadas pelo MDA anunciavam que cerca de cinco mil unidades familiares de produção estavam sendo beneficiadas pela linha (BRASIL, Ministério do Desenvolvimento Agrário, 2012). Tratava-se de experiências pontuais, em algumas regiões brasileiras, o que representava um percentual extremamente baixo em relação ao tamanho da agricultura familiar no país. Diante desse contexto, a Fetraf-Brasil passou a demandar mudanças no Pronaf sustentável e, de forma mais expressiva, "a implementação efetiva, desburocratizada e massiva do Pronaf Sustentável, com mecanismos que estimulem e garantam a diversificação produtiva e a transição agroecológica", conforme expresso nas pautas de reivindicação de 2015, 2014, 2013, 2011 e 2010 (FETRAF-BRASIL, 2015; $2014 ; 2013 ; 2011 ; 2010)$.

\section{A educação do campo como política pública para a agricultura familiar}

O refrão da música de Gilvan Santos “não vou sair do campo pra poder ir pra escola, educação do campo é direito e não esmola" pode expressar o sentido da luta que os movimentos sociais do campo vêm travando por uma educação que dialogue com a realidade dos povos do campo e com um projeto de desenvolvimento sustentável, socialmente justo, capaz de proporcionar a permanência do jovem no meio rural. Com esse propósito, a educação, incluída como parte essencial em um projeto de desenvolvimento, não é um fim em si mesma, mas uma ferramenta estratégica 
no processo de formação e tomada de consciência dos sujeitos que vivem no campo.

A Fetraf-Sul elaborou e aprovou, no II congresso, em 2007, o Projeto Alternativo de Desenvolvimento Rural Sustentável e Solidário (PADRSS), apontando para a necessidade da reforma agrária, o fortalecimento da agricultura familiar e a criação de políticas públicas na saúde, educação, habitação e crédito, entre outras ações do Estado, com o objetivo de criar as condições para a permanência dos agricultores familiares no meio rural.

O projeto de desenvolvimento sustentável e solidário tem como uma de suas preocupações centrais constituir relações harmônicas entre o ser humano e a natureza, e relações harmônicas entre os próprios seres humanos. Essas passam pela justiça social, pela distribuição da renda, da terra, pela realocação da riqueza no mundo, pela equidade no acesso aos fatores de produção, aos fatores de sobrevivência e aos serviços básicos necessários a uma vida digna (FETRAF-SUL, 2007, p. 14).

O terceiro eixo do projeto dizia respeito "à luta por avanços na democratização do Estado e na elaboração, disputa, negociação e implementação de políticas públicas que potencializem a valorização da agricultura familiar como protagonista social, econômico e político" (FETRAF-SUL, 2007, p. 35).

Sendo assim, de forma articulada, a criação da Educação do Campo como política pública específica para os povos do campo é resultado de uma construção coletiva que tem a participação de vários movimentos sociais do campo e, entre eles, está a Fetraf. Articulados, a Federação, a Via Campesina, o MST, a CONTAG, o movimento Indígena e Quilombola, entre outros, se valem de suas experiências educacionais e compreendem que a escola deve cumprir um papel fundamental no desenvolvimento socioeconômico do campo, tendo como consequência o estímulo à permanência no meio rural. A partir desse entendimento, passaremos a analisar o processo de criação da Educação do Campo como política pública, a 
mudança conceitual e paradigmática entre a educação rural e a educação do campo, as diretrizes e as perspectivas do Programa Nacional de Educação do Campo (Pronacampo).

\section{Da Educação Rural à Educação do Campo}

Em relação à educação como política pública, a Constituição de 1988, artigo 205, estabeleceu que a educação é um direito de todos e dever do Estado e da família e será promovida e incentivada com colaboração da sociedade, visando ao pleno desenvolvimento da pessoa, seu preparo para o exercício da cidadania e sua qualificação para o trabalho.

Em se tratando da educação no meio rural, salientamos que ela foi historicamente marginalizada, criando uma fronteira entre o rural e o urbano, segregando e inferiorizando culturalmente a identidade dos sujeitos do campo (quilombolas, indígenas, pequenos agricultores, seringueiros e pescadores, que normalmente viviam em espaços marginais onde lhes era negado o direito de acesso às mais diferentes políticas públicas.

A educação rural não foi nem sequer mencionada nos textos constitucionais até 1891 (BRASIL 2002). De acordo com Leite (1999), a educação rural no Brasil, por motivos socioculturais, sempre foi relegada a planos inferiores, e teve por retaguarda ideológica o elitismo acentuado do processo educacional, aqui instalado pelos jesuítas e a interpretação político-ideológica da oligarquia agrária conhecida popularmente na expressão: "gente da roça não carece de estudos. Isso é coisa de gente da cidade". (Anônimo apud LEITE, 1999, p. 14).

Até as primeiras décadas do século XX a educação era privilégio de poucos, sobretudo no meio rural. De acordo com o Grupo Permanente de Trabalho de Educação do Campo (GPTE) ${ }^{48}$, daquilo que seria um projeto

48 O GPTE foi instituído pelo Ministério da Educação em 03/06/2003, a partir do diagnóstico "Perfil da Educação no Campo", elaborado pelo Instituto Nacional de Estudos e Pesquisas Educacionais Anísio Teixeira (INEP), referente ao sistema de ensino formal no meio rural e procurou levantar instrumentos para a construção de uma política pú- 
educacional para o campo, o Estado brasileiro omitiu-se: (a) na formulação de diretrizes políticas e pedagógicas específicas que regulamentassem como a escola do campo deveria funcionar e se organizar; (b) na dotação financeira que possibilitasse a institucionalização e a manutenção de uma escola com qualidade em todos os níveis de ensino; (c) na implementação de uma política efetiva de formação inicial e continuada e de valorização da carreira docente no campo (BRASIL, 2005, p. 7).

A educação no meio rural não se constituiu historicamente em um espaço prioritário para uma ação planejada e institucionalizada do Estado Brasileiro. Isso privou a população do campo, especialmente a classe trabalhadora, de ter acesso às políticas e serviços públicos em geral. Esse fato contribuiu para o acelerado processo de êxodo rural, registrado a partir da década de 1950, acentuando-se ainda mais com a modernização agrícola e a industrialização urbana.

Nesse cenário de modernização agrícola, a partir do desenvolvimento urbano industrial, a educação rural não foi priorizada pelo Estado e os agricultores familiares enfrentaram o processo de destituição de sua identidade. Leite (1999) afirma que a educação rural vem capitulando programas educacionais via Ministério e Conselhos de Educação sem, contudo, estabelecer uma filosofia e/ou uma política específica para a escolaridade nas regiões rurais.

Compartilhamos de Arroyo, Caldart e Molina (2004a) quando afirmam que historicamente a escola no meio rural foi tratada como resíduo do sistema educacional brasileiro e à população do campo foi negado o acesso a uma educação sistêmica, ou seja, relacionada ao seu contexto sociocultural.

Se por um lado, no início da década de 1960, a perspectiva de uma educação popular com Paulo Freire ganhava força por estabelecer uma pedagogia voltada para as classes populares, por outro, com o golpe militar, em 1964, a política educacional passou a sofrer um processo de mudanças. 
Canais de participação e representação popular foram fechados, impedindo a manifestação e atuação de educadores comprometidos com projetos educacionais a partir de uma visão histórico-crítica.

Nas décadas de 1970 e 1980, ainda sob a tutela dos governos militares, ocorreu a utilização do processo escolar como meio de controle político-ideológico e cultural, principalmente da classe operária, tanto do campo quanto da cidade, por meio da profissionalização e do currículo escolar mínimo desprovido de um conteúdo crítico-reflexivo.

As reações ao autoritarismo praticado pelo regime militar, seja no campo político com a luta pela redemocratização, quanto no campo educacional, por mudanças no sistema de ensino, abriram novas perspectivas para a educação. Experiências de educação popular passaram a existir em diferentes regiões do Brasil a partir do início dos anos 1980, conquistando espaço na Constituição de 1988, culminando com a criação da Lei de Diretrizes e Bases da Educação (LDB 9394/96) que propõe, no artigo 28, diretrizes sobre a educação para a população do meio rural:

Na oferta da educação básica para a população rural, os sistemas de ensino promoverão as adaptações necessárias a sua adequação às peculiaridades da vida rural e de cada região, especialmente: I conteúdos curriculares e metodologias apropriadas às reais necessidades e interesses dos alunos da zona rural; II — organização escolar própria, incluindo adequação do calendário escolar às fases do ciclo agrícola e às condições climáticas; III — adequação à natureza do trabalho na zona rural. (BRASIL/MEC, LDB 9.394/96, art. 28).

Desse modo, a LDB promoveu a desvinculação da escola rural dos meios e da performance escolar urbana, exigindo um planejamento ligado à realidade do campo. No entanto, alguns problemas relacionados à escola no meio rural ainda eram visíveis durante a década de 1990, conforme menciona Leite: 
1. Quanto à clientela da escola rural: a condição do aluno como trabalhador rural; distâncias entre locais de moradia/trabalho/escola; heterogeneidade de idade e grau de intelectualidade; baixas condições aquisitivas do alunado; acesso precário a informações gerais. 2. Quanto à participação da comunidade no processo escolar: um certo distanciamento dos pais em relação à escola, embora as famílias tenham a escolaridade como valor sócio-moral; 3 . Quanto à ação didático-pedagógica: currículo vistas à realidade urbana; estruturação didático-metodológica deficiente; salas multisseriadas; calendário escolar em dissonância com a sazonalidade da produção; ausência de orientação técnica e acompanhamento pedagógico; ausência de material de apoio escolar tanto para professores quanto para alunos; [...] (1999, p. 55-56).

Diante dessa problemática, Arroyo, Caldart e Molina (2004b) afirmam que, nas últimas décadas do século XX, assistimos a uma instigante presença dos sujeitos do campo na cena política e cultural do País, como os movimentos sociais do campo. Tais sujeitos denunciam o silenciamento e o esquecimento por parte dos órgãos governamentais e lutam por uma escola do campo que não seja apenas um arremedo da escola urbana, mas, sim, uma escola que esteja atenta aos seus sujeitos específicos.

É salutar considerar que na luta pela redemocratização, nos anos 1980 e 1990, a educação, baseada nos princípios populares de Paulo Freire, constituiu-se uma estratégia para a emancipação e a cidadania dos sujeitos que viviam no campo. Nesse sentido, as experiências educacionais desenvolvidas em acampamentos e assentamentos de reforma agrária, a partir do início da década de 1980, buscavam articular os saberes populares e as experiências cotidianas com aspectos da conjuntura social, política e econômica do país.

No interior do debate, acerca da identidade da educação escolar rural, Silva e Costa (2006) diferenciam o paradigma da educação rural do paradigma da educação no campo. Segundo as autoras, o paradigma da educação rural apoia-se em uma visão tradicional do espaço rural no País e não se propõe a fazer as inter-relações emergentes da sociedade brasileira, 
nem incorporar as demandas trazidas à sociedade por movimentos sociais e sindicais que exigem a valorização das especificidades do meio rural. Esse modelo de educação rural torna-se um instrumento de reprodução e expansão de uma estrutura agrária concentradora. Os trabalhadores rurais e suas técnicas são vistos como improdutivos, excluídos, e seus territórios não existem porque não são entendidos como territórios de vida.

O paradigma da educação do campo concebe o campo como espaço de vida e resistência, onde camponeses lutam por acesso à terra e pela oportunidade de permanecer nela. Concebe a diversidade dos sujeitos sociais - agricultores familiares, assentados, ribeirinhos, caiçaras, extrativistas, pescadores, indígenas, remanescentes de quilombos, enfim, todos os povos do campo brasileiro. Reconhece a importância da agricultura familiar ao reconhecer a diversidade do campo brasileiro. Além disso, no processo de redemocratização do Brasil, fortaleceram-se as lutas e a organização dos diferentes tipos de movimentos sociais, dentre eles, os organizados no campo, cujas agendas de reivindicações previam a extensão de direitos, como a educação.

\section{A Educação do Campo como direito}

A conquista da educação do campo nos anos 2000, tendo o protagonismo dos movimentos sociais do campo, foi antecedida pela compreensão de que um projeto alternativo de desenvolvimento só poderia ter êxito se as pessoas estivessem como seu elemento central. Portanto, o embasamento teórico foi importante no processo de organização social e político desenvolvido entre os agricultores familiares nas décadas 1980 e 1990, e o tema da educação precede do entendimento, compartilhado por Paulo Freire, que a educação por si só não transforma a sociedade, mas igualmente a sociedade só se transforma com a presença da educação. Ou seja, falar de educação é falar de emancipação e cidadania. 
Nesse sentido, a conquista de direitos políticos, como o direito ao voto, com a redemocratização do Brasil, na década de 1980, impõe-se como limite à construção cidadã dos trabalhadores tanto do campo quanto da cidade, pois o exercício do voto não resultou necessariamente da existência de governos atentos aos problemas básicos da população, isto é, a conquista do direito político não significou a garantia dos direitos civis e sociais.

Nessa mesma direção, o cientista político e historiador José Murilo de Carvalho, ao desenvolver sobre o tema cidadania, faz referência à evolução histórica da cidadania no Brasil e de suas perspectivas enfatizando que o cidadão pleno seria aquele portador dos direitos civis, políticos e sociais, classificando-os da seguinte forma:

Direitos civis são os direitos fundamentais à vida, à liberdade, à propriedade, à igualdade perante a lei. Eles se desdobram na garantia de ir e vir, de escolher o trabalho, de manifestar o pensamento, de organizar-se.... Sua pedra de toque é a liberdade individual. É possível haver direitos civis sem direitos políticos. Estes se referem à participação do cidadão no governo da sociedade. Seu exercício é limitado a parcela da população e consiste na capacidade da fazer demonstrações políticas, de organizar partidos, de votar, de ser votado. Se puder haver direitos civis sem direitos políticos, o contrário não é viável. $\mathrm{E}$ os direitos sociais garantem a participação na riqueza coletiva, eles incluem o direito à educação, ao trabalho, ao salário justo, à saúde, à aposentadoria. A ideia central em que se baseiam é a da justiça social (CARVALHO, 2008, p. 9).

Tornou-se um discurso recorrente no Brasil entre os movimentos sociais, bem como no meio acadêmico, que educação e cidadania andam juntas, e a história tem mostrado que a ausência de uma educação libertadora tem efeito devastador para a formação sociopolítica das classes subalternas, que ficam refém da manipulação midiática patrocinada por veículos de comunicação de massa. Compartilhamos do pensamento de Guido (2007) ao afirmar: "quando se insiste no mote Educação e Cidadania é porque a sociedade ainda carece desses fatores vitais, em particular 
no espaço rural essa carência se torna ainda mais evidente uma vez que a educação oferecida historicamente esteve pautada em conteúdos voltados para o contexto urbano".

Contrapondo a concepção de uma educação tecnicista, formadora de mão de obra para o mercado de trabalho sem uma formação teórico-crítica, os movimentos ${ }^{49}$ sociais do campo têm desempenhado um papel fundamental na luta por uma educação que dialogue com o desenvolvimento sustentável das regiões onde os povos estejam inseridos socialmente.

\section{O Projeto Terra Solidária (PTS)}

A construção da proposta da Educação do Campo já nos anos 2000 recebeu a significativa contribuição de experiências educacionais desenvolvidas entre os movimentos sociais do campo nas décadas anteriores. Podemos destacar a proposta pedagógica de Paulo Freire desenvolvida através das experiências de educação popular a partir dos anos de 1960, a pedagogia da terra, desenvolvida em acampamentos e assentamentos da reforma agrária na década de 80 e 90.

Uma das principais contribuições do sindicalismo da agricultura familiar na perspectiva da educação do campo se deu com o Projeto Terra Solidária (PTS), criado em 1999 pelo Fórum Sul dos Rurais da CUT (que antecedeu a Fetraf-Sul/CUT), em parceria com a Escola Sindical Sul e o Departamento e Estudos Socioeconômicos Rurais (DESER), e executado até 2006 com recursos públicos, especificamente do Fundo de Amparo ao Trabalhador no âmbito do Plano Nacional de Formação Profissional, por meio de parceria com os governos federal e dos três estados da região Sul.

49 O movimento "Por uma educação do campo" é um coletivo nacional constituído por diferentes movimentos sociais do campo que debatem e discutem uma proposta de educação para a população do campo que prime pelas suas especificidades culturais, sociais e econômicas. Suas proposições estão representadas aqui pelos textos de Arroyo, Caldart, Molina (2004) e Fernandes, Cerioli, Caldart (2004). 
A base legal do projeto Terra Solidária foi a Lei de Diretrizes e Bases (LDB), que prevê a criação de formas alternativas de acesso à educação básica, contemplando, por meio da educação de jovens e adultos, aqueles que não a completaram na idade própria e respeitando características, interesses, condições de vida e de trabalho deles, o que inclui as peculiaridades do meio rural (BRASIL, 1996).

A partir da realidade das famílias agricultoras e com a participação delas no processo educacional, o projeto Terra Solidária ${ }^{50}$ buscava repensar o modelo de sindicalismo rural, estimulando o desenvolvimento sustentável solidário e agroecológico, a geração de trabalho e renda e a consolidação da agricultura familiar e suas formas organizativas (FETRAF-SUL/ CUT; ESCOLA SINDICAL SUL; DESER, 2001, 2002).

Denominada "currículo integrado", a proposta curricular envolvia a formação fundamental e a qualificação profissional, que estavam integradas em um processo de ação-reflexão-ação de modo a articular as dimensões da prática social, do mundo do trabalho e do conhecimento acumulado pela humanidade.

A história do desenvolvimento agrário no Brasil e a construção de um projeto de desenvolvimento sustentável e solidário formavam o eixo articulador do currículo do PTS. A ação pedagógica se efetivava através da docência dos diferentes conhecimentos por um/a único/a educador/a que buscava fazer relações entre diferentes áreas a fim de garantir a integralidade do conhecimento e potencializar o fazer político-pedagógico em busca da construção de uma práxis emancipatória (FETRAF-SUL/CUT; ESCOLA SINDICAL SUL; DESER, 2001).

O PTS orientava-se pelos princípios da Política Nacional de Formação da CUT, assim definidos: "classista e de massas" (a capacitação dos

50 O PTS tem a duração de 900 horas, desenvolvidas em 18 meses, sendo composto por "curso básico" (atividades realizadas em físico comum a todos - "sala de aula") e "oficinas pedagógicas" (atividades que envolvem famílias, comunidades, instituições e sociedade civil, com o objetivo de geração de emprego e renda na perspectiva do desenvolvimento sustentável e solidário). A certificação dos participantes se dá em nível de Ensino Fundamental com a terminalidade de "agente de desenvolvimento (FETRAF-SUL/CUT; ESCOLA SINDICAL SUL; DESER, 2001). 
trabalhadores para a organização e a ação sindical, fruto da consciência de classe); "indelegável” (a formação é uma política permanente da CUT e sua formulação, execução e sustentação financeira é de responsabilidade dela); "democrática, plural e unitária" (a formação deve estimular o debate entre as diversas correntes de opinião e buscar uma ação unificada e fortalecedora da "identidade do ser cutista"); "unificada e descentralizada" (a formação deve ser uma política unificada em termos de concepção, mas descentralizada no sentido de considerar as especificidades regionais); e "integralidade do ser humano" (o trabalhador é "um ser com múltiplas dimensões" e as práticas educativas devem considerá-las). (FETRAF-SUL/ CUT; ESCOLA SINDICAL SUL; DESER, 2001, p. 192).

A partir do entendimento da Fetraf-Sul, no período entre 2003 a 2006, durante o primeiro mandato do governo Lula, ocorreram avanços na conquista de políticas públicas voltadas ao fortalecimento da agricultura familiar: políticas agrícolas, habitacional, previdência social, de saúde e de educação. Sobre esta última, a organização sindical atuava na execução de projetos próprios ("Terra Solidária”, "Consórcio Social da Juventude Rural - Sementes da Terra" e "Mulher") e na discussão de políticas públicas de Educação do Campo.

A Fetraf-Sul apresentava um conjunto de medidas para avançar nas "mudanças estruturais", entre elas: aumento dos investimentos nas políticas sociais, a fim de "aprofundar a inclusão social" e "diminuir a pobreza"; e aprofundamento dos canais de participação popular na definição das políticas públicas. Diante desse cenário, os movimentos sociais precisariam assumir uma postura não "do contra", mas propositiva, num "patamar superior de disputa", pois o contexto político oportunizava o avanço na implementação de um conjunto de políticas públicas, entre elas a de educação, de mudança do "atual padrão hegemônico de desenvolvimento rural". 


\section{Diretrizes da Educação do Campo}

É recorrente no debate educacional que a educação se constituiu uma ação estratégica para a emancipação e a cidadania dos sujeitos que vivem ou trabalham no campo e que pode colaborar para o desenvolvimento sustentável. É possível considerar a riqueza de saberes que essa população rural produz nas suas experiências cotidianas e que a agenda de trabalho para discutir e subsidiar a construção de uma política de Educação do Campo incorpore o respeito à diversidade cultural. O campo é, acima de tudo, espaço de cultura singular, rico e diverso. Assim, é importante a superação da dicotomia entre o rural e o urbano (ARROYO, CALDART e MOLINA, 2004c).

Com o propósito de desenvolver ações educacionais específicas para as populações do campo, em 20 de março de 2012 foi criado o Programa Nacional de Educação do Campo - Pronacampo ${ }^{51}$. O Art. $1^{\circ}$ define que a política de educação do campo destina-se à ampliação e qualificação da oferta de educação básica e superior às populações do campo e será desenvolvida pela União em regime de colaboração com os Estados, o Distrito Federal e os Municípios, de acordo com as diretrizes e metas estabelecidas no Plano Nacional de Educação e o disposto neste Decreto.

51 O Pronacampo foi construído por um Grupo de Trabalho coordenado pelo MEC/SECADI, formado pelo Conselho dos Secretários Estaduais de Educação (CONSED, União dos Dirigentes Municipais de Educação (UNDIME), Confederação Nacional dos Trabalhadores da Agricultura (CONTAG), Movimento dos Trabalhadores e Trabalhadoras Sem Terra (MST), Federação dos Trabalhadores da Agricultura Familiar (FETRAF), Rede de Educação do Semi-Árido Brasileiro (RESAB), Universidade de Brasília (UNB) e Universidade Federal de Minas Gerais (UFMG), atendendo a demandas dos sistemas de ensino e dos movimentos sociais. $\$ 1^{\circ}$ Para os efeitos deste Decreto, entende-se por: I - populações do campo: os agricultores familiares, os extrativistas, os pescadores artesanais, os ribeirinhos, os assentados e acampados da reforma agrária, os trabalhadores assalariados rurais, os quilombolas, os caiçaras, os povos da floresta, os caboclos e outros que produzam suas condições materiais de existência a partir do trabalho no meio rural; e II - escola do campo: aquela situada em área rural, conforme definida pela Fundação Instituto Brasileiro de Geografia e Estatística (IBGE), ou aquela situada em área urbana, desde que atenda predominantemente a populações do campo. $\$ 2^{\circ}$ Serão consideradas do campo as turmas anexas vinculadas a escolas com sede em área urbana, que funcionem nas condições especificadas no inciso II do $\$ 10$. $\$ 3^{\circ}$ As escolas do campo e as turmas anexas deverão elaborar seu projeto político pedagógico, na forma estabelecida pelo Conselho Nacional de Educação. $\$ 4^{\circ}$ A educação do campo concretizar-se-á mediante a oferta de formação inicial e continuada de profissionais da educação, a garantia de condições de infraestrutura e transporte escolar, bem como de materiais e livros didáticos, equipamentos, laboratórios, biblioteca e áreas de lazer e desporto adequados ao projeto político pedagógico e em conformidade com a realidade local e a diversidade das populações do campo. 
Um dos pilares do Pronacampo (2012) refere-se aos princípios pedagógicos e a identidade da escola do campo, que estão assim definidos no art. $2^{\circ}$ do Programa:

a. Respeito à diversidade do campo em seus aspectos sociais, culturais, ambientais, políticos, econômicos, de gênero, geracional e de raça e etnia.

b. Incentivo à formulação de projetos político-pedagógicos específicos para as escolas do campo, estimulando o desenvolvimento das unidades escolares como espaços públicos de investigação e articulação de experiências e estudos direcionados para o desenvolvimento social, economicamente justo e ambientalmente sustentável, em articulação com o mundo do trabalho.

c. Desenvolvimento de políticas de formação de profissionais da educação para o atendimento da especificidade das escolas do campo, considerando-se as condições concretas da produção e reprodução social da vida no campo.

d. Valorização da identidade da escola do campo por meio de projetos pedagógicos com conteúdos curriculares e metodologias adequadas às reais necessidades dos alunos do campo, bem como flexibilidade na organização escolar, incluindo adequação do calendário escolar às fases do ciclo agrícola e às condições climáticas.

e. Controle social da qualidade da educação escolar, mediante a efetiva participação da comunidade e dos movimentos sociais do campo.

A partir da perspectiva de que o campo é território de produção de vida, de relações sociais, entre homem e a natureza, entre rural e urbano, faz-se necessária uma concepção teórica assentada em fundamentos filosóficos, históricos e sociológicos que permitam articular o pensar e o fazer pedagógico, com a construção de alternativas de desenvolvimento sustentável das comunidades do campo. Trata-se de criar alternativas de organização curricular e do trabalho docente que viabilizem uma alternativa educacional-formativa no que se refere aos anos finais do ensino 
fundamental e ao ensino médio, respondendo às orientações básicas propostas pelo Edital 02/2012 SECADI/SESU/SETEC - MEC:

a. O curso considera a perspectiva da interdisciplinaridade, que se caracteriza como uma estratégia de integração metodológica, seja para fins tecnológicos, epistemológicos ou pedagógicos, podendo gerar novos campos de conhecimento ou procedimentos inovadores para responder a novas necessidades sociais.

b. Organizar os componentes curriculares em áreas do conhecimento de forma interdisciplinar, de modo que os estudantes possam vivenciar na prática de sua formação a lógica do trabalho pedagógico para o qual estão sendo preparados.

c. Organizar metodologicamente o currículo por alternância entre Tempo/Espaço e Universidade e Tempo/Espaço Comunidade, a fim de permitir o necessário diálogo entre saberes técnico-tecnológicos e saberes das tradições culturais oriundos das experiências de vida no campo.

A educação do campo tem a missão de resgatar os valores camponeses do respeito à diversidade, constitutivo dos processos sociopolíticos, ecológicos e culturais. É nesse sentido que a transformação paradigmática deve estabelecer-se como princípio fundante da transformação. Sabe-se que a educação, efetivamente, não é o único caminho para a transformação social, mas talvez, hoje, seja o mais importante deles. Sobretudo deve ser educação no sentido amplo do processo de formação humana, que constrói referências culturais, políticas, sociais e ecológicas, possibilitando que as pessoas se tornem sujeitos sociais na realidade e não sujeitos à realidade. Assim, "A Educação do Campo compreende os processos culturais; as estratégias de socialização; as relações de trabalho vividas pelos sujeitos do campo em suas lutas cotidianas para manter esta identidade, como elementos essenciais de seu processo formativo" (MOLINA et al., 2009, p. 18). 
Nesse sentido, Caldart (2015) destaca que a Educação do Campo surgiu com o objetivo principal de associar lutas de diferentes sujeitos com interesses sociais comuns, no movimento entre a luta por direitos feita diretamente por quem se percebe excluído deles e a luta comum entre diferentes sujeitos, inclusive aqueles que já têm atendido esse direito por políticas que garantam o acesso e a qualidade social da educação.

O tratamento público da Educação do Campo é o tema abordado por Arroyo (2011), ao reconhecer que a trajetória dos movimentos sociais do campo avança na consciência de uma educação como direito público, que se contrapõe a uma educação rural que reproduz o uso privado do que é público e atrela a educação ao mercado. Seu texto é propositivo e instigador para pensarmos que o reconhecimento da Educação do Campo como política pública implica o reconhecimento das potencialidades de desenvolvimento do campo, construído a partir da luta camponesa, com toda sua especificidade, singularidade, mas também com sua diversidade e suas tensões.

O Pronacampo é o reconhecimento por parte do Estado de sua responsabilidade em criar e implementar mecanismos que garantam a manutenção e o desenvolvimento da educação do campo com o objetivo de superar as defasagens históricas de acesso à educação escolar pelas populações do campo, visando: I - reduzir os indicadores de analfabetismo com a oferta de políticas de educação de jovens e adultos, nas localidades onde vivem e trabalham, respeitando suas especificidades quanto aos horários e calendário escolar; II - fomentar educação básica na modalidade Educação de Jovens e Adultos, integrando qualificação social e profissional ao ensino fundamental; III - garantir o fornecimento de energia elétrica, água potável e saneamento básico, bem como outras condições necessárias ao funcionamento das escolas do campo; IV - contribuir para a inclusão digital por meio da ampliação do acesso a computadores, a conexão à rede mundial de computadores e a outras tecnologias digitais, beneficiando a comunidade escolar e a população próxima às escolas do campo. 
Considerando que a Educação do Campo se constrói no próprio campo, o Projeto Político da Educação do Campo precisa ser construído com as novas relações entre os sujeitos da educação e aqueles que vivem no campo (seus conhecimentos e saberes) e dos novos pactos entre Estado, escola e sociedade.

\section{A transversalidade entre Educação do Campo e Pronaf a partir da Fetraf-Brasil}

Tratar do tema da educação na perspectiva do desenvolvimento é uma construção que perpassa as fronteiras da escola e atinge a dimensão do trabalho e da emancipação dos sujeitos do desenvolvimento, nesse caso, dos agricultores familiares. Paulo Freire (2000) já destacava que se a educação sozinha não transforma a sociedade, sem ela tampouco a sociedade muda. Nessa direção, a escola é um instrumento fundamental na construção de um novo modelo de desenvolvimento para o campo.

A trajetória de lutas pelo direito às políticas públicas e o reconhecimento da agricultura familiar a partir de meados dos anos 1990 foram elementos importantes na construção da cidadania entre os agricultores familiares e na construção de propostas no campo educacional.

Desenvolveu-se, desse modo, na Fetraf-Brasil, a ideia que a educação/formação é uma das estratégias para a construção de um modelo de desenvolvimento, alternativo, sustentável e solidário. Essa concepção estende-se à educação escolar, o que evidencia que a escola deve atuar no sentido de promover e preservar a cultura camponesa, contribuindo para a reversão da tendência de esvaziamento do meio rural.

O programa Terra Solidária foi um dos programas educacionais da FETRAF que visava à formação integral dos agricultores familiares, conjugando a certificação em ensino fundamental, a qualificação 
profissional, a formação sindical e a formação para a cidadania. (FETRAF-SUL/CUT, 2007).

A transversalidade entre educação e outras políticas podem ser identificadas através das ações da organização sindical (FETRAF-SUL/CUT, 2010, p. 20) para o período 2010 a 2015 descritas da seguinte forma:

a. assistência técnica: luta pela constituição de uma política nacional "permanente e consistente", que considere a agricultura familiar como “condição estratégica” para o desenvolvimento sustentável, solidário e democrático, que se efetive por meio de instrumentos de estímulo, de fomento, de regulação e de proteção, ou seja, o Estado deve garantir “[...] um conjunto articulado de políticas públicas direcionadas para a agricultura familiar, que garantam renda, cidadania, dignidade e qualidade de vida, com destaque particular para a juventude e para as mulheres."

b. educação e capacitação profissional: "políticas estratégicas", fundamentos da transformação social e na vida das famílias agricultoras, que lutam pela "valorização de sua identidade" e por um "novo projeto de desenvolvimento". A proposta central de educação da entidade dirigida ao Estado é repetida do II Congresso, ou seja, a educação novamente é associada ao projeto de desenvolvimento, porém dessa vez se explicita também como elemento de construção da cidadania. A organização sindical reitera o dever do Estado de garantir educação de qualidade e entende que as suas experiências na elaboração e na implementação de uma educação que contemple a realidade da população rural e da agricultura familiar, como é o caso do Projeto Terra Solidária, sejam assimiladas pelo Estado como política pública.

O documento descreve ainda: formação na temática ambiental; formação para a atuação no controle social das políticas de saúde e na formulação de políticas dessa área para a população do campo; celebração de convênios com escolas agrotécnicas para "avançar no ensino médio profissionalizante"; "participação incisiva” na construção da "Universidade 
Federal da Mesorregião Grande Fronteira do Mercosul”; realização de parcerias com instituições de ensino superior para desenvolver cursos de pós-graduação lato sensu; intervenção em espaços públicos de discussão para proposição e disputa de políticas públicas de educação do campo; construção de um instituto de formação da Fetraf-Sul voltado à educação e à qualificação profissional da agricultura familiar.

Nessa perspectiva, a Federação já definia em seu estatuto, artigo 5, inciso VI, dentre suas finalidades fundamentais: "fortalecer a relação do sindicalismo cutista com os movimentos sociais, cooperativas que tenham por base da sua ação a valorização e fortalecimento da agricultura familiar e a construção de um desenvolvimento sustentável e solidário, visando a unificação e ampliação das forças e a conquista de políticas públicas.” (FETRAF, 2001a, p. 04)

A educação do campo e o tema do desenvolvimento, articulados com o crédito, avançaram de forma conjunta entre as demandas da Fetraf-Brasil para os jovens, como público prioritário visando sua permanência no meio rural.

O Pronaf ${ }^{52}$ jovem é um exemplo da articulação entre a educação e o crédito, demanda da Fetraf-Brasil assim definida: que a União assumisse a responsabilidade dos riscos referentes aos recursos aplicados no Pronaf Jovem (FETRAF-BRASIL, 2005); eliminação da exigência de que o jovem tenha concluído ou esteja cursando o último ano em centros familiares de formação por alternância, ou em escolas técnicas agrícolas de nível médio ou que tenha participado de curso de formação profissional (Fetraf-Brasil, 2006); garantia de programas de capacitação para jovens para que possam

52 São beneficiários do Pronaf Jovem aqueles jovens com idade entre 16 e 29 anos, enquadráveis no Pronaf, e que tenham concluído ou estejam cursando o último ano em centros familiares rurais de formação por alternância; tenham concluído ou estejam cursando o último ano em escolas técnicas agrícolas de nível médio, ou, ainda, há mais de um ano, curso de Ciências Agrárias ou Veterinária em instituições de ensino superior; tenham orientação e acompanhamento de empresa de assistência técnica e extensão rural reconhecida pelo MDA e pela instituição financeira; e tenham participado de cursos de formação do Programa Nacional de Acesso ao Ensino Técnico e Emprego (Pronatec) ou do Programa Nacional de Educação no Campo. Esses jovens são contemplados com crédito de investimento no limite de até $\mathrm{R} \$ 16.500,00$, com taxa efetiva de juros de 2,5\% a.a., e prazo de pagamento de até 10 anos, incluídos até três anos de carência. 
acessar com qualidade o Pronaf (FETRAF-BRASIL, 2007); juro zero para o Pronaf Jovem (Fetraf-Brasil, 2008); criação de um programa de inclusão socioprodutiva da juventude da Agricultura Familiar, que articule a capacitação profissional, o acesso à terra (reforma agrária e crédito fundiário), ao crédito (Pronaf Jovem), à cultura, ao lazer e à inclusão digital, ao acompanhamento técnico (ATER) e às políticas de apoio à preservação da ecobiodiversidade, dentre outras (FETRAF-BRASIL, 2012); a construção de um Plano Nacional de Sucessão na Agricultura Familiar com o objetivo de incentivar os jovens a permanecerem no meio rural, articulando acesso à terra (crédito fundiário), à moradia, ao crédito de produção (custeio e investimento), à assistência técnica e extensão rural e aos serviços de infraestrutura (energia, internet e telefonia) (FETRAF-BRASIL, 2014).

No campo das políticas públicas de educação, diante da histórica omissão do Estado brasileiro no que tange à criação de políticas específicas para o campo, observamos a insuficiente proposição dos governos que historicamente pensaram a educação no meio rural, seguindo diretrizes de uma educação urbana, desvinculada da realidade dos sujeitos do campo.

Contrapondo a histórica concepção educacional do Estado brasileiro, o II congresso da Fetraf-Sul, em 2007, foi um marco para a definição do papel da educação no âmbito da agricultura familiar. A entidade mostrou-se habilitada para contribuir com a construção de uma educação voltada para a realidade das famílias agricultoras. Por um lado, criticou o modelo da "escola rural" por seu atrelamento à lógica da escola urbana e pelo compromisso com o projeto de desenvolvimento capitalista e, por outro, propôs a Educação do Campo, cujo projeto político-pedagógico valoriza a cultura camponesa e fortalece um projeto transformador.

Nessa direção, o Projeto Terra Solidária contempla a necessária articulação da educação e da formação para a construção de um projeto de desenvolvimento alternativo ao do agronegócio, o que exige a correlata formulação de uma metodologia de educação de jovens e adultos que considere a realidade do meio rural, especificamente das famílias agricultoras. 
Assim, o PTS propõe-se a ser não apenas uma metodologia de educação para as famílias agricultoras, mas para o meio rural, pois agrega à concepção de educação/formação a concepção de um projeto de sociedade e de desenvolvimento sustentável e solidário, de base agroecológica e com enfoque territorial.

Em uma análise mais específica da atuação da Fetraf-Brasil em relação ao Pronaf, as reivindicações situam-se predominantemente no âmbito da ampliação dos recursos disponíveis e aperfeiçoamentos em termos institucionais para ampliar a participação principalmente dos jovens e das mulheres rurais; de alterações para que o programa atue de forma sistêmica, considerando o conjunto das atividades e características das unidades produtivas; da promoção da agroecologia; e da articulação do Pronaf com outras políticas públicas na construção do desenvolvimento rural e na potencialização do próprio programa.

Nesse sentido, além da dimensão econômica, a Fetraf-Brasil pontua a existência de outras dimensões da vida das famílias agricultoras. Por isso, reivindica que as políticas públicas considerem não apenas a dimensão da produção econômica, mas que pressionem o Estado para o atendimento de outras dimensões - cultural, de relações comunitárias, da história. E, nesse sentido, a educação do campo assume um papel estratégico e articulador dessas diferentes dimensões.

Não se evidenciam demandas por maior participação dos agricultores familiares em maior vulnerabilidade social ou de grupos sociais que compõem a diversidade da categoria social. Essas ausências provavelmente estão relacionadas com as características da base social da Fetraf-Brasil, a qual, segundo Conti (2016) e Picolotto (2011), contempla uma agricultura familiar mais consolidada, que possui terra, produz e encontra-se articulada com o mercado, geralmente inserida em processos produtivos com algum grau de integração com agroindústrias ou cooperativas, necessitando de políticas públicas que auxiliem a melhorar as condições produtivas e a qualidade de vida. 
Também é salutar pontuar que a participação dos/as agricultores/as familiares na discussão e na luta por políticas públicas ainda está muito centrada na questão econômica, talvez por serem as mais urgentes, perceptíveis e mobilizadoras. Assim, parece que a educação se coloca como o algo a mais, o que falta para garantir a permanência das famílias no meio rural, especialmente dos jovens, que são aqueles que podem garantir a sucessão, a reprodução da cultura e da vida nesse meio.

Como evidenciado, a construção das políticas públicas resulta da interação entre Estado e organizações sociais e sindicais da agricultura familiar, em um processo que perpassa protestos, reivindicações e proposições, cooperação e diálogos. Sendo assim, a construção e as mudanças na política pública não decorrem apenas de ideias e de interesses dos gestores públicos, mas das negociações e pressões entre gestores públicos e representações da agricultura familiar.

\section{REFERENCIAS}

ABERS, Rebecca; SERAFIM, Lizandra; TATAGIBA, Luciana. Repertórios de integração estado-sociedade em um estado heterogêneo: a experiência na era Lula. Dados, v. 57, n. 2, 2014.

ABRAMOVAY, Ricardo; PIKETTY, Marie-Gabrielle. Política de crédito do Programa Nacional de Fortalecimento da Agricultura Familiar (PRONAF): resultados e limites da experiência brasileira nos anos 90. Cadernos de ciência \& tecnologia, v. 22, n. .1, p. 53-66, jan./abr. 2005.

ABRAMOVAY, Ricardo; VEIGA, José E. Novas instituições para o desenvolvimento rural: o caso do Programa Nacional de Fortalecimento da Agricultura Familiar (PRONAF). Brasília/DF: IPEA, 1999. (Texto para Discussão, 641).

ALMEIDA, Silvio G. Construção e desafios do campo agroecológico brasileiro. Agriculturas, v. 6, número especial, p. 67-84, 2009.

AQUINO, Joacir; SCHNEIDER, Sergio. O Pronaf e o desenvolvimento rural brasileiro: avanços, contradições e desafios para o futuro. In: GRISA, Catia; 
SCHNEIDER, S. Políticas públicas de desenvolvimento rural no Brasil. Porto Alegre-RS: UFRGS, 2015.

. 12 anos da política de crédito do PRONAF no Brasil (1996-2008): uma reflexão crítica. In: Congresso Latinoamericano de Sociologia Rural, 8, 2010, Porto de Galinhas, Anais... Porto de Galinhas-PE: ALASRU, 2010.

ARROYO, Miguel Gonzalez. A educação básica e o movimento social do campo. In: ARROYO, Miguel Gonzalez; CALDART, Roseli Salete; MOLINA, Mônica Castagna. Por uma educação do campo. Petrópolis: Vozes, 2004.

. Educação do campo: o que temos a aprender. Presença Pedagógica, Belo Horizonte, v. 15, n. 90, p. 36-41, nov./dez. 2009.

BELIK, Walter. PRONAF: avaliação da operacionalização do programa. In: CAMPANHOLA, Clayton; GRAZIANO DA SILVA, José. O novo rural brasileiro: políticas públicas. Jaguariúna-SP: EMBRAPA Meio Ambiente, 2000. p. 93-115.

BIANCHINI, Valter. 20 do pronaf: 1995:2015: avanços e desafios. Brasília: MDA, 2015.

. O Programa Nacional de Fortalecimento da Agricultura Familiar PRONAF e a sustentabilidade da agricultura no Vale do Ribeira - Paraná. Tese (Doutorado em Meio Ambiente e Desenvolvimento) - Programa de PósGraduação em Meio Ambiente e Desenvolvimento (MADE/UFPR). Curitiba (PR), 2010.

BOLTER, Jairo. A.G. Interfaces e cogestão nas políticas para agricultura familiar: uma análise do Programa Nacional de Habitação Rural. Tese (Tese de Doutorado em Ciências Sociais) - Programa de Pós-Graduação em Desenvolvimento Rural/UFRGS, 2013.

BRASIL, MINISTÉRIO DO DESENVOLVIMENTO AGRÁRIO. Plano safra da agricultura familiar 2011/2012: alimentos saudáveis para o campo e para a cidade. Brasília (DF): MDA, 2016.

Crédito leva desenvolvimento ao meio rural. Entrevista João Guadagnin. 2015. Disponível em: <www.mda.gov.br>. Acesso em: 27 ago. 2016. . MDA publica metodologia do PRONAF Sustentável para orientar agricultores. Notícias. 20/01/2012. 2012. Disponível em: <www.mda.gov.br>. Acesso em: 19 mar. 2012. 
. Plano safra da agricultura familiar 2011/2012: a agricultura familiar alimenta o Brasil que cresce. Brasília (DF): MDA, 2011.

BRASIL. PRESIDÊNCIA DA REPÚBLICA. Decreto $n^{\circ} .6 .882$ de 12 de junho de 2009. Institui, no âmbito do Ministério do Desenvolvimento Agrário, o Programa de Desenvolvimento Sustentável da Unidade de Produção Familiar - PRONAF Sustentável e dá outras providências. Brasil, 2009. Disponível em: $<$ http://www.planalto.gov.br/ccivil_03/_Ato2007-2010/2009/Decreto/D6882. htm>. Acesso em: 03 out. 2011.

BRASIL. Lei no 9394, de 20 de dezembro de 1996. Estabelece as diretrizes e bases da educação nacional. Brasília, 1996. Disponível em: <http://portal.mec. gov.br/arquivos/pdf/ldb.pdf>. Acesso em: 10 mar. 2015.

. Lei $n^{\circ}$ 13.005, de 25 de junho de 2014. Aprova o Plano Nacional de Educação (PNE) e dá outras providências. Brasília, 2014. Disponível em: <http://www.planalto.gov.br/ccivil_03/_Ato2011-2014/2014/Lei/L13005. htm>. Acesso em: 20 mar. 2015.

BRASIL-MINISTÉRIO DA AGRICULTURA, DO ABASTECIMENTO E DA REFORMA AGRÁRIA(MAARA)/CONFEDERAÇÃO NACIONAL DOS TRABALHADORES NA AGRICULTURA(CONTAG). Propostas $e$ recomendações de política agrícola diferenciada para o pequeno produtor rural. Brasília (DF): MAARA/CONTAG, 1994.

BURIGO, Fabio L.; CAPELLESSO, Adinor J.; CAZELLA, Ademir A. Evolução do Pronaf crédito no período 1996-2013: redimensionando o acesso pelos cadastros de pessoa física. In: $53^{\circ}$ Congresso da Sociedade Brasileira de Economia, Administração e Sociologia Rural. João Pessoa, 2015.

BRANDÃO, Carlos Rodrigues. Da escola rural de emergência à escola de ação comunitária. In: ARROYO, Miguel Gonzalez (Org.) Da Escola Carente à Escola Possível. 6. ed. São Paulo-SP: Loyola, 2003.

BRASIL. Lei no 9394/96. Lei de Diretrizes e Bases da Educação Nacional: Nova LDB. Rio de Janeiro: Qualithmark, 1997.

BRASIL. Constituição Federal de 1988. Disponível em: <http://www.planalto. gov.br>. Acesso em: $20 \mathrm{dez} .2005$.

BRASIL. Lei $n^{\circ}$ 5692/71. Lei de Diretrizes e Bases da Educação Nacional. Disponível em: <http://www.pedagogiaemfoco.br>. Acesso em: 20 dez. 2005.

BRASIL. Ministério da Educação. Diretrizes operacionais para a educação básica nas escolas do campo. Brasília, DF, 2002. 
BRASIL. Ministério da Educação. Grupo Permanente de Trabalho de Educação do Campo. Referência para uma política nacional de Educação do Campo. Caderno de subsídios, Brasília-DF, 2005.

CALDART, Roseli Salete. A escola do campo em movimento. Currículo sem Fronteiras [S. 1.], v. 3, n. 1, p. 60-81, jan./jun. 2003. Disponível em: $<$ http:// www.curriculosemfronteiras.org/vol3iss1articles/roseli2.pdf $>$. Acesso em: 15 mar. 2015.

. Sobre Educação do Campo: campo, política pública e educação. Brasília: NEAD, 2008. (Coleção por uma educação do campo, 7).

CONFEDERAÇÃO NACIONAL DOS TRABALHADORES NA AGRICULTURA (CONTAG). Grito da Terra Brasil - 2011: pauta de reivindicações. Brasília-DF: CONTAG, FETAGs e Sindicatos, 2011.

. Grito da Terra Brasil 2010: pauta de reivindicações. Brasília-DF: CONTAG, 2010.

. Grito da Terra Brasil 2009: pauta de reivindicações. Brasília-DF: CONTAG, FETAGs e STTR, 2009.

. Grito da Terra Brasil 2008: pauta de reivindicações. Brasília-DF: CONTAG, FETAGs e STTR, 2008.

. $6^{\circ}$ Congresso nacional dos trabalhadores rurais (Documento base). Brasília-DF: CONTAG, 1995.

. Anais I Congresso nacional extraordinário dos trabalhadores rurais. Brasília-DF: CONTAG, 1994.

. Anais $5^{\circ}$ Congresso nacional dos trabalhadores rurais. Brasília-DF: CONTAG, 1991.

. Proposta do movimento sindical de trabalhadores rurais para as leis agrária e agrícola. Brasília-DF: CONTAG, 1989.

. Projeto Nacional de Política Agrícola. Brasília-DF: CONTAG, 1988.

. Política agrícola e pequenos agricultores. Brasília-DF: CONTAG, 1984.

CONSELHO NACIONAL DE EDUCAÇÃO. Resolução CNE/CEB $n^{\circ} 1$, de 3 de abril de 2002. Institui Diretrizes Operacionais para a Educação Básica nas Escolas do 37ª Reunião Nacional da ANPEd - 04 a 08 de outubro de 2015, UFSC - Florianópolis Campo. Brasília, 2002. Disponível em: < http://portal. mec.gov.br/cne/arquivos/pdf/CEB012002.pdf >. Acesso em: 15 mar. 2015. 
. Resolução CNE/CEB $n^{\circ} 2$, de 28 de abril de 2008. Estabelece diretrizes complementares, normas e princípios para o desenvolvimento de políticas públicas de atendimento da Educação Básica do Campo. Brasília, 2008. Disponível em: <http://portal.mec.gov.br/cne/arquivos/pdf/2008/rceb002_08. pdf $>$. Acesso em: 13 mar. 2015.

CONTI, Irio L. Organizações sociais e políticas públicas: inserção da Fetraf-Sul nas políticas públicas de segurança alimentar e nutricional. Tese. Programa de Pós-Graduação em Desenvolvimento Rural (PGDR-UFRGS). 2016.

DELGADO, Nelson G.; LEITE, Sergio.; WESZ JUNIOR, Valdemar. Produção agrícola. Nota técnica. Rio de Janeiro-RJ, 2010.

FERNANDES, Bernardo Mançano; CERIOLI, Paulo Ricardo; CALDART, Roseli Salete (Org.). Por uma educação básica do campo. Texto-base da Conferência Nacional Por Uma Educação Básica do Campo. Brasília: UnB, 1998.

FETRAF-SUL/CUT. Consolidando a agricultura familiar. A ousadia na luta e na organização construindo um novo desenvolvimento. Tese do II Congresso da Fetraf-Sul/CUT. Chapecó: Fetraf-Sul/CUT, 2007.

. $3^{\circ}$ Congresso da Fetraf-Sul/CUT. Agricultura familiar: alimento e vida para o Brasil. Documento-base. Chapecó: Fetraf-Sul/CUT, 2010.

FETRAF-SUL/CUT; ESCOLA SINDICAL SUL; DESER. Terra Solidária: projeto político-pedagógico. Chapecó: Fetraf-Sul/CUT, 2001.

Sistematização e avaliação do Projeto Terra Solidária. Chapecó: FetrafSul/CUT, 2002.

FREIRE, Paulo. Conscientização: teoria e prática da libertação - uma introdução ao pensamento de Paulo Freire. 3. ed. São Paulo: Moraes, 1980.

FAVARETO, A. da S. BITTENCOURT G. L. Agricultura e Sindicalismo nos anos 90 - notas para um balanço. In: TEDESCO J. C. (Org.) Agricultura Familiar. Realidades e Perspectivas. 3. ed. Passo Fundo-RS: Brasília-DF, 2001.

FOUILLEUX, Ève. La politique agricole commune et ses réformes: une politique à l'épreuve de la globalisation. Paris: L'Harmattan, 2003.

. Entre production et institutionnalisation des idées: la réforme de la politique agricole commune. Revue française de science politique, v. 50, n. 2, p. 277-306, 2000. 
FETRAF. Fetraf Cumpre Deliberação Aprovada em Congresso e passa a ser CONTRAF BRASIL. 2016. Disponível em: http://contrafbrasil.org.br/ destaques. Acesso em: 20 set. 2016.

FETRAF-SUL/CUT. Estatutos sociais. Chapecó: FETRAF-SUL, 2001a.

FERNANDES, Bernardo M; CERIOLI, Paulo Ricardo; CALDART, Roseli Salete. Primeira Conferência Nacional Por uma educação básica do campo: texto preparatório. In: ARROYO, Miguel Gonzalez; CALDART, Roseli Salete; MOLINA, Mônica Castagna. Por uma educação do campo. Petrópolis: Vozes, 2004.

GAZOLLA, Marcio; SCHNEIDER, Sergio. As duas "caras" do PRONAF: produtivismo ou fortalecimento da produção para autoconsumo? In: Congresso brasileiro de economia, administração e sociologia rural, 43, 2005, Ribeirão Preto (SP), Anais... Ribeirão Preto/SP: SOBER, 2005.

GIUGNI, Marco; PASSY, Florence. Contentious politics in complex societies: New social movemensts between conflict and cooperation. In: GIUGNI, M.; McADAM, D.; TILLY, C. From contention to democracy. Lanham: Rowman \& Littlefield Publishers, 1998.

GRISA, Catia. Políticas públicas para a agricultura familiar no Brasil: produção e institucionalização das ideias. Tese (Tese de Doutorado em Ciências Sociais) - Programa de Pós-Graduação de Ciências Sociais em Desenvolvimento, Agricultura e Sociedade/UFRRJ, 2012.

GRISA, C.; KATO, K.; ZIMMERMANN, S.A. Projeto Repensando o conceito de ruralidade no Brasil: implicações para as políticas públicas. O rural nas políticas públicas do Brasil Contemporâneo. 2014 (relatório de pesquisa).

. Projeto Repensando o conceito de ruralidade no Brasil: implicações para as políticas públicas. O rural nas políticas públicas do Brasil Contemporâneo. 2014 (relatório de pesquisa).

GRISA, Catia; WESZ JR., Valdemar; BUCHWEITZ, Vitor D. Revisitando o Pronaf: velhos questionamentos, novas interpretações. Revista de Economia e Sociologia Rural, v. 52, n. 2, 2014.

GRISA, C.; SCHNEIDER, S. Três gerações de políticas públicas para a agricultura familiar e formas de interação entre sociedade e estado no Brasil. Rev. Econ. Sociol. Rural [online]. 2014. 
GUIDO, Humberto. Filosofia da Educação: entre o anti-moderno e o ultramoderno. In: HENZ, Celso Ilgo e ROSSATO, Ricardo (Org.). Educação humanizadora na sociedade globalizada. Santa Maria-RS: Biblos, 2007.

INSTITUTO BRASILEIRO DE ANÁLISES SOCIAIS E ECONÔMICAS (IBASE). Relatório PRONAF: resultados da etapa Paraná. Rio de Janeiro-RJ: IBASE, 2006.

INSTITUTO BRASILEIRO DE GEOGRAFIA E ESTATÍSTICA. Censo agropecuário 2006. Rio de Janeiro-RJ: 2009.

LEITE, Sérgio Celani. Escola rural: urbanização e políticas educacionais. São Paulo: Cortez, 1999.

MATTEI, Lauro. Evolução do crédito do PRONAF para as categorias de agricultores A e A/C entre 2000 e 2010. In: Congresso da Sociedade Brasileira de Economia, Administração e Sociologia Rural, 49, 2011, Belo Horizonte (MG), Anais... Belo Horizonte (MG): SOBER, 2011.

. PRONAF 10 anos: mapa da produção acadêmica. Brasília (DF): MDA, 2006.

. Impactos do PRONAF: análise de indicadores. Brasília (DF): MDA/ NEAD, 2005.

MOLINA, Mônica Castagna. Cultivando princípios, conceitos e práticas. Presença Pedagógica, Belo Horizonte, v. 15, n. 88, p. 30-36, jul./ago. 2009.

MULLER, Pierre. Les politiques publiques. 7. ed. Paris: PUF, 2008.

MUNARIM. Antônio. Trajetória do movimento nacional de educação do campo no Brasil. Educação, Santa Maria, v. 33, n. 1, jan./abr. 2008. Disponível em: $<$ http://coralx.ufsm.br/revce/revce/2008/01/a4.htm>. Acesso em: 1º mar. 2015.

ORGANIZAÇÃO DAS NAÇÕES UNIDAS PARA AGRICULTURA E ALIMENTAÇÃO (FAO)/INSTITUTO NACIONAL DE COLONIZAÇÃO E REFORMA AGRÁRIA (INCRA). Perfil da agricultura familiar no Brasil. Brasília (DF): FAO/INCRA, 1996.

. Diretrizes de política agrária e desenvolvimento sustentável para a pequena produção familiar. Brasília (DF): FAO/INCRA, 1994.

PICOLOTTO, Everton L. As mãos que alimentam a nação: agricultura familiar, sindicalismo e política. Tese (Doutorado de Ciências Sociais em Desenvolvimento, Agricultura e Sociedade) - Programa de Pós-Graduação 
de Ciências Sociais em Desenvolvimento, Agricultura e Sociedade (CPDA/ UFRRJ). Rio de Janeiro-RJ, 2011.

PRONACAMPO - PROGRAMA NACIONAL DE EDUCAÇÃO DO CAMPO. Ministério da Educação, 2012. Disponível em: <http://portal.mec. gov.br/programa-saude-da-escola/194-secretarias-112877938/secad-educacaocontinuada-223369541/18720-pronacampo >. Acesso em: 13 mar. 2015.

SAUER, Sergio. Demanda mundial por terras: "land grabbing" ou oportunidade de negócios no Brasil? Revista de Estudos e Pesquisas sobre as Américas. Brasília, CEPPAC/ UnB, 2011.

SOUZA, Maria Antônia de. Educação do Campo: propostas e práticas pedagógicas do MST. 2. ed. Petrópolis-RJ: Vozes, 2012.

SEMINOTTI, Jonas. Os agricultores familiares e a representação política do Sutraf na região Alto Uruguai do RS. Tese (Doutorado em Sociologia) Programa de Pós-Graduação em Sociologia. Curitiba (PR), 2013.

SANTOS, Franciele Soares dos. Educação do campo e educação urbana: aproximações e rupturas. Educere et Educare Revista de Educação, Cascavel, v. 1, n. 1, p. 69-72, jan./jun. 2006.

SOUZA, Maria Antônia de. Educação e movimentos sociais do campo: a produção do conhecimento no período de 1987-2007. Curitiba: UFPR, 2010.

SCHNEIDER, Sergio; CAZELLA, Ademir; MATTEI, Lauro. Histórico, caracterização e dinâmica recente do Pronaf-Programa Nacional de Fortalecimento da Agricultura Familiar. In: SCHNEIDER, Sergio; SILVA, Marcelo K.; MARQUES, Paulo E.M. (Orgs.) Políticas públicas e participação social no Brasil rural. Porto Alegre-RS: UFRGS, 2004. p. 21-49.

SILVA, Lourdes Helena e COSTA, Vânia Aparecida. Educação Rural. Revista Presença Pedagógica, v. 12, n. 69 mai./ju. 2006.

SOUZA, Paulo M. et al.; Análise da evolução do valor dos financiamentos do Pronaf-crédito (1999 a 2010): número, valor médio e localização geográfica dos contratos. Revista Brasileira de Economia, Sociologia e Administração Rural, v. 51, n.2, 2013.

VAN DER PLOEG, Jan Douwe ET AL. Rural development: from practices and policies towards theory. Sociologia Ruralis, v. 40 n. 4, p. 391-408, out/2000.

WEID, Jean M. Agricultura familiar: sustentando o insustentável. Agriculturas, v.7, n.2, p. 07, 2010. 
. Construindo políticas públicas em apoio à agroecologia. Agriculturas, v.3, n.1, p.04-06, 2006a.

- A transição agroecológica das políticas de crédito voltadas para a agricultura familiar. Agriculturas, v. 3, n. 1, p. 18-20, 2006 b.

WANDERLEY, Maria N. B. O mundo rural como um espaço de vida: reflexões sobre a propriedade da terra, agricultura familiar e ruralidade. Porto AlegreRS: UFRGS, 2009. 